Hof 


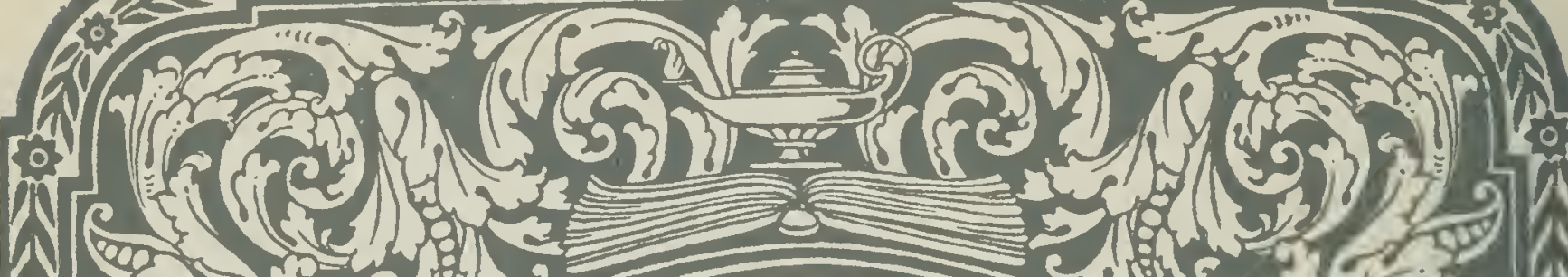

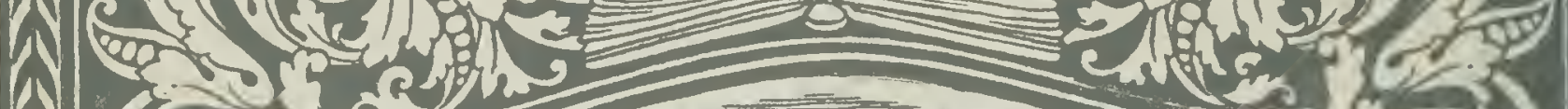

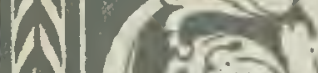
$\sqrt{(1+3)}$ $\sqrt{3}$

(

N $(1,3)$

1,10

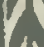

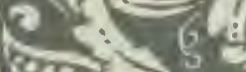

$(-2,1)$

$\left(i_{-\infty}^{2}\right)$

$\therefore \theta^{2}=\frac{200}{200}$

V

N

$\sqrt{1}$

/

c 2.

लor -5
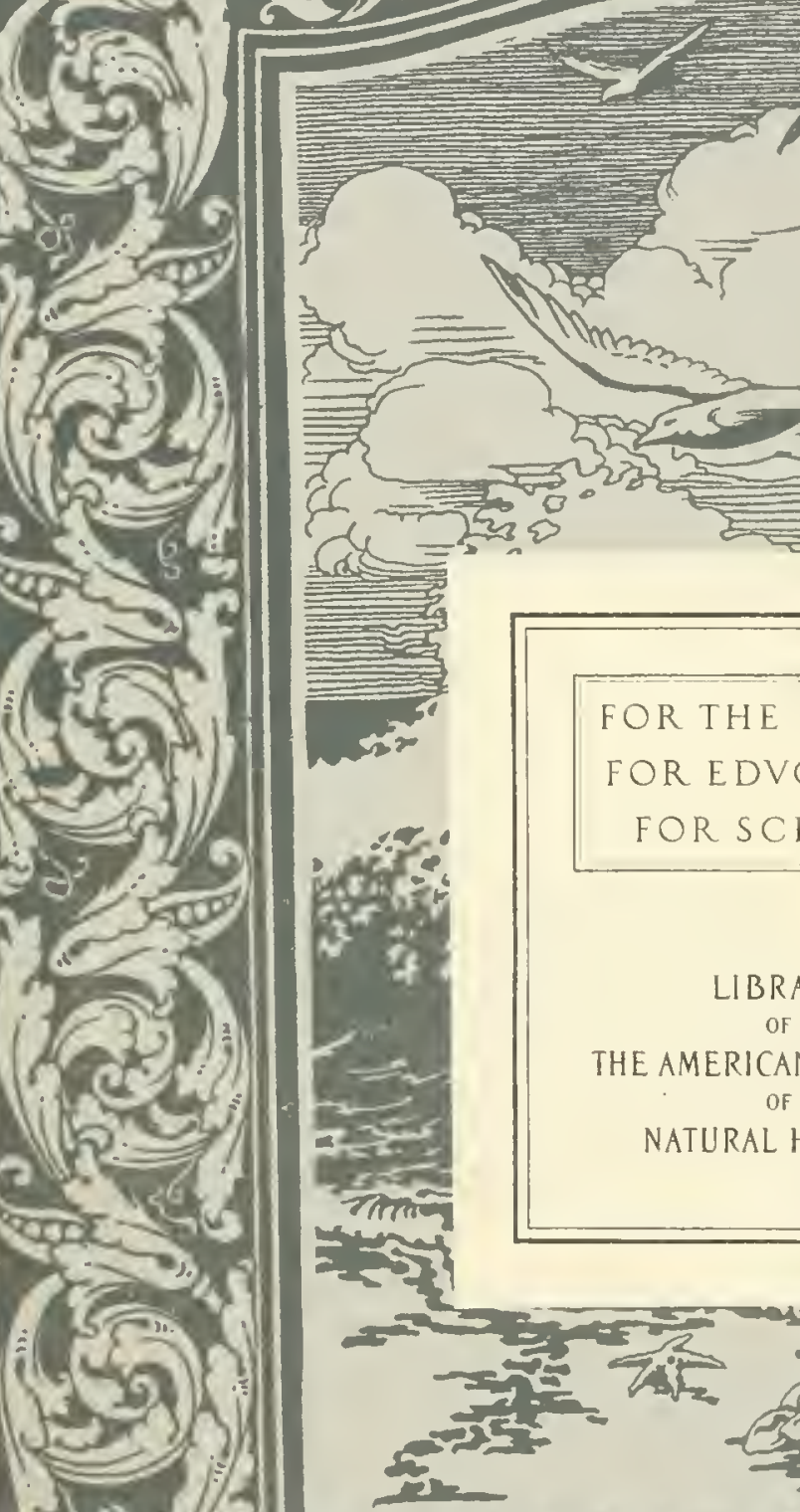
1

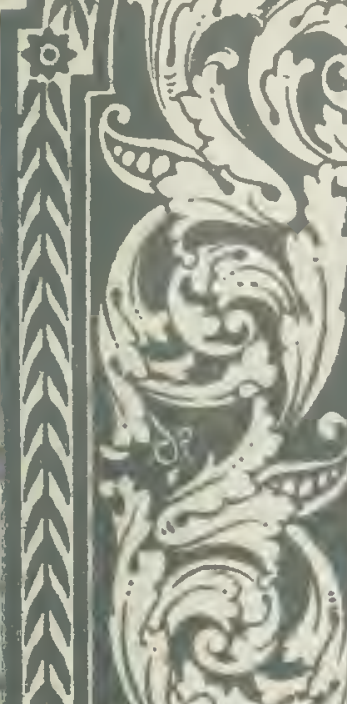

N $(8,2)$

W $\frac{2}{60}:-54$

$1 \sqrt{60-250}$

N $\mathrm{C}$ हल

Ni $(13+0)$

$(3-\sqrt{3})$

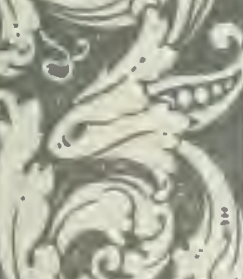

c $(2)$,

कox -56

हित्म

$(2-5)$

(2)

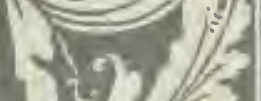

(.) 2

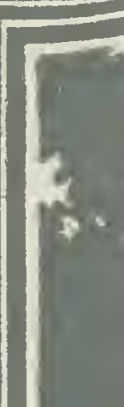

$i$

(4)

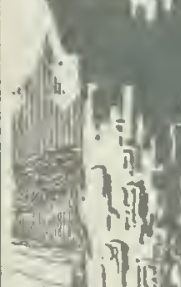

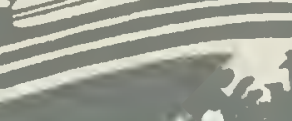

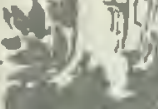$$
\text { Avy }
$$

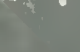

(1)

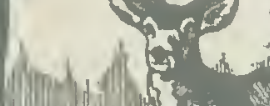

$$
\therefore<
$$
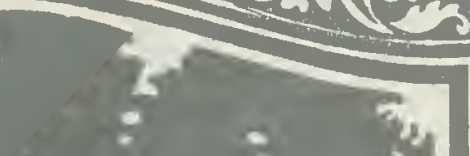

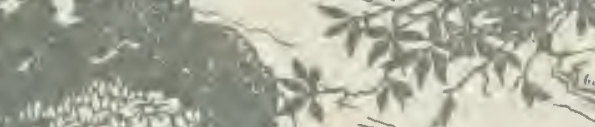

पing

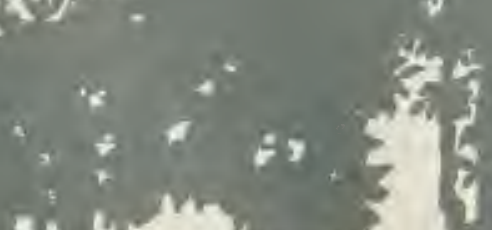

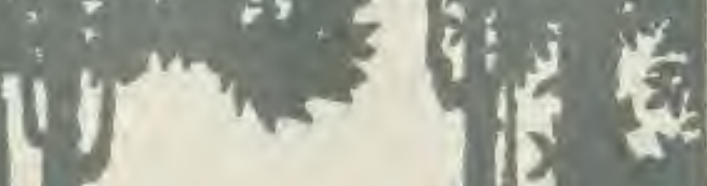
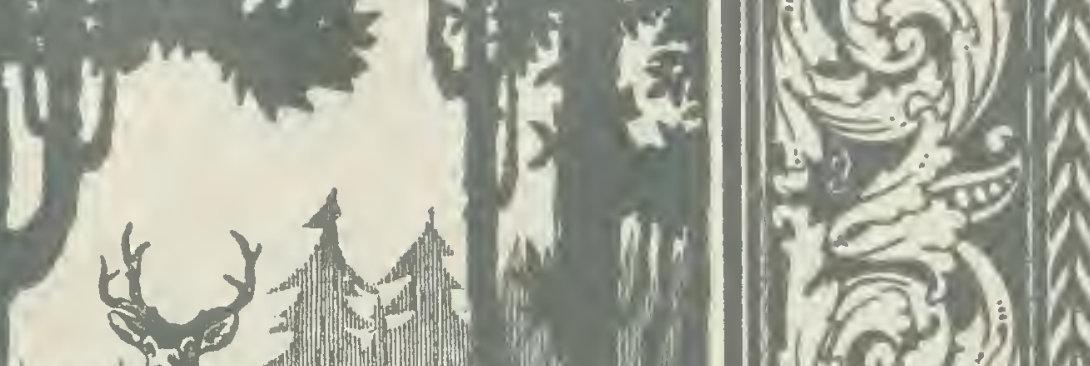

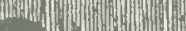
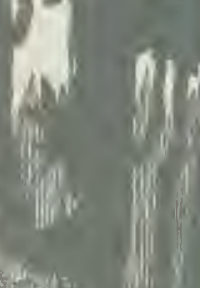

:

a.te-390

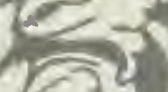

(a)

(a)

$\exists$ (n)

(2)
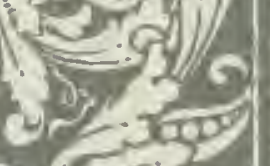

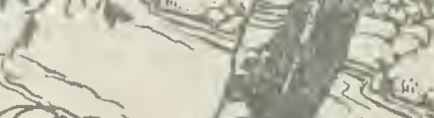

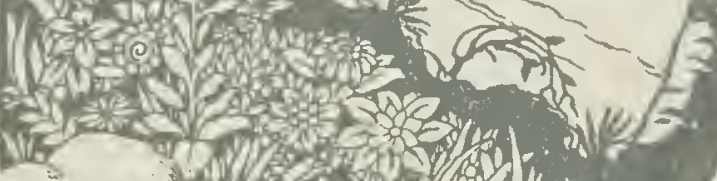

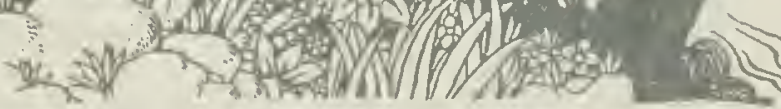

axt

a.

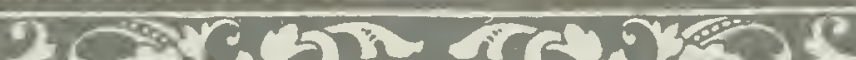

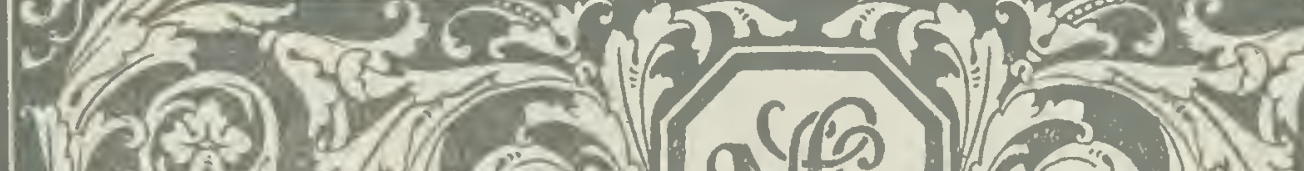
(3)

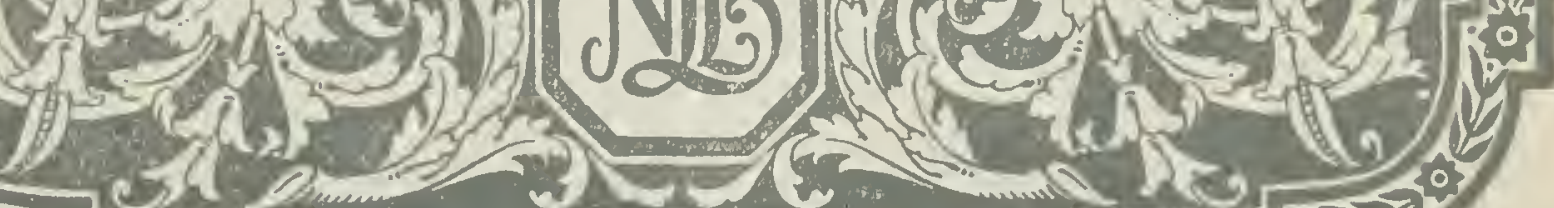
was 





\title{
Birds of America
}

\author{
EHITUR-IX-CHIEF \\ T. Gilbert Pearson \\ Presudent of the Nibtwnal Assocsation of Audubin Soctetu's \\ CONILLTING EDITOR \\ John Burroughs
}

CuNTRIBUTING EDIORS

Edward H. Forbush

state Ornathologint, Massachusctes

William I. Fintes

Naturalist, Authers, and Lectures

Maniging Editor

George Gladden
Herbert h. Job

Economic Ornitholngist

L. Nelson Nichols

Member Linnman Sorsety.

Assoclate Editor

J. Ellis Burdick

Associate Nember of Amormati

Ornuthologists' Union

ARIISIS

R. I. Brasher R. Bruce Horsfall Henry Thurston

The University Society Inc.

New lork

I 923

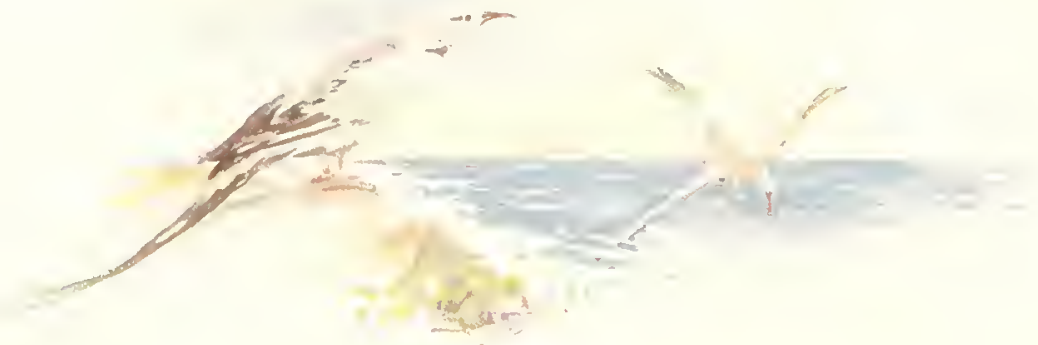


Copyright, 1917, by

The University Society Inc.

Manufactured in the U. S. A. 


\section{ADVISORY BOARD}

Artilir A. Allen. Ph.l).,

Assistant Professor of (Irnithology, Cornell Universitr.

Glover Murrill Allen, Ph.i.,

Secretary, Boston Society of Natural History

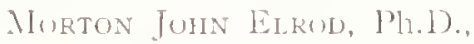

Professor of Biology, University of Montana

WAITER KENDRICK FISHER, I'T.D.

Associate Professor of Zoology, Leland Stanford Lnversity

G. Clyoe Fisher, Ph.1).

American Mluseum of Natural Ilistory

IIARRY S. I IATIAWAY,

Naturalist, Rhode Island

LrNDs Joxes, Ph.D.,

Assmiate Professor of Animal Eeology, wherlin Colluge

Orin Grant Libisy, Pli.D.

Secretary, State Historical Society, North Ditkota

Silas 1 . Lottridie, Pli.Ml,

Naturalist, Author, and Lecturer

J. Walker MCSPADDEN, Author and Lecturer

HOWARD TAYLOR MIIDDLETON,

Wild Life Photographer

George Henry Perkiss, Ph.D. State Geologist, Vermont

Albert Porter,

Editor and Lexieographer

S. F. Rathbun,

Naturalist, Washington

PALL M. REA, A.MI.,

Dircetor, Cleveland, (Mhio, Museum of Natural History

R. IV. ShufELdt, M.D.,

Author and Wild Life Photographer

HARRIET B. THORNBER,

Secretary, Arizona Audubon Society

IV. Clyde Todd,

Carnegie Museum, Pittsburgh

R. W. WiLliaMs,

United States Department of Agriculture 



\section{CONTENTS}

PAC

PREFACE . . . . . . . . . . . . . . . . .

IXTRUDTCTION . . . . . . . . . . . . . . . .

ORDER of DIVING BIRDS - . . . . . . . . . . . . .

Grebes

LooNs

Alks, Murres, and Plifins . . . . . . . . . . Ib

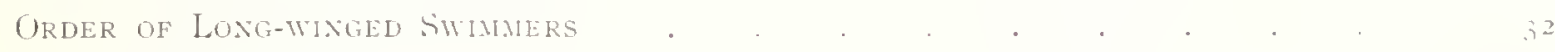

SKUAS AND JAEGers . . . . . . . . . . . . . . . 32

Glils . . . . . . . . . . . . . . 3

TERNS . . . . . . . . . . . . . . . . . . . . $5+$

SkMMIERS . . . . . . . . . . . . . . .

Order uf Ttbe-Nosed Swimers

Albatrosses . . . . . . . . . . . 75

Fulmars, Shearwaters, hNit I'Etrels . . . . . . . So

Order of Tutipaliated Swimers . . . . . . . . . . . SS

TROPIC-BIRDS . . . . . . . . . . . $8 S$

Gaxnets . . . . . . . . . . . . . . . . 90

DARTERS . . . . . . . . . . . . . . . . . . 93

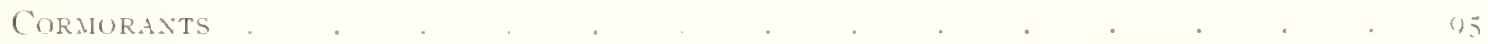

Pelictiss . . . . . . . . . . IOI

MAN-O'-WAR-BIRDS. . . . . . . TOO

Order of Lamelltrostral Simimalers. . . . . . . . . . Tol)

Mergansers . . . . . . . . . . . IOQ

Ducks . . . . . . . . . . . . . . . . .

GeEsE . . . . . . . . . . . . . . . . . . . . . .

SiYAS . . . . . . IOH

Order of Lamellikostral Graldatures (Flaningoes). . . . . . . ioc)

Order of Herons, Storks, Ibises, Ets . . . . . . . . iti

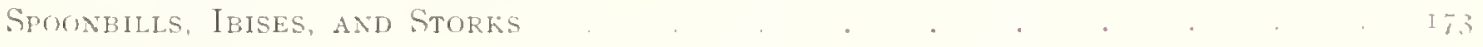

HERON FAMILY . . . . . . . . . . . . . . . . 
Order of Marsh-dWellers

Cranes and Colrtans . . . . . . . . . . . 197

Rails, Galintules, and Coots . . . . 202

Order of Shore Birds

Phalaropes

Avocets and Stilts

Snipes, Sandpipers, Etc.

Plovers

Strf-birds and TuRnstones

Oyster-Catchers 


\section{PREFACE}

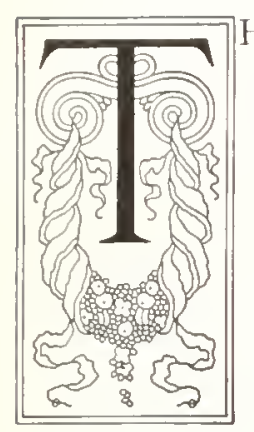

HE actual and urgent need for this book is apparent to the large and steadily increasing number of persons who are intelligently interested in American ornithology. This neerl is due to the fact that in all the literature of that subject there is no single work which presents a complete review of what is known to-day about American hirds.

The task of preparing a comprehensive aceount of the bird life of a continent is far too great to be accomplished in a natural lifetime by any individual working alone; and until recently there has been no systematic coöperation between students of our native birds. It is inevitable, therefore, that continued study of the subject, aided by such coöperation, should have revealed many errors of commission and onission in the labors of Wilson, Audubon, Bonaparte, and the other earlier students of this difficult and complex science. Nevertheless, it is clear that the work of these men lain the foundation of American ornithology; for their labors not only furnished much material of scientific value, but encouraged interest in and sympathy for birds, and thereby inspired further study of these beautiful and useful forms of animate life.

The ornithological pioneers mentioned recorded not only tcchnical deseriptions of birds, but were at much pains to present observitions calculated to give the reader ideas about bird personality. Later writers have confined thenselves generally to one or the other of these aspeets of bird life - or to regional ornithology. Douhtless the development of these two schools has been due to the rcalization of the enormousness of the task of presenting both technical descriptions, and accurate as well as readable characterizations of the hundreds of species which occur on this continent. In the case of the technical student, however, it discloses also the fact that one who is intent upon gathering purely " scientific " data about birds - that is, statistics and details concerning their size, color, distribution, nidification, and so on - is likely to overlook, or at least to pay little heed to habits or characteristics which have no classificatory value.

Yet it is these very characteristics, rather than the purely scientific data, which make the strongest appeal to the imagination and the sympathies of the great majority of persons who are interested in birds. Indeed, it may be doubted whether any account of a bird, however accurate and detailed it is in its presentation of merely physical facts, is actually complete if it omits or curtails reference to traits which reveal the human and rsthetic significance of that bird's natural life. Surely, the cleverness and the fine courage which a mother bird displays in concealing and protecting her eggs, are as significant as are their mere number and color.

It is the purpose of this work to present accurately and sympathetically both of these phases of bird life, that is, the physical and the moral. The utmost pains have been taken to present a precise description of the external physical appearance of each bird selected for scparate treatment. The size of the bird may be considered the basic fact in its identification, and this is restricted (except in a few instances) to the average length, because that is the dimension most clearly discernible in the living bird.

The color of the bird is even more important than its size, as a means of identification, and especial care has been taken in this particular. The most accurate and detailed descriptions of the coloration of American birds are those which are included in Robert Ridgway's [vii ] 
monumental work, The Birds of North and Middle America, of which seven parts have been issued by the United States National Museum. These descriptions, however, are expressed in terminology much of which is comprehensible only to the trained and essentially scientific ornithologist. Therefore, in order to employ this material in the present work, it became necessary to substitute common words for the technical terms; but in doing this great care was taken to reproduce the exact meaning of the original text. By this expedicnt there has been presented in plain language a vast amount of scientifically accurate descriptive material which, in its original form, would be comprehensible for the lay reader only by the constant use of an unabridged dictionary. Similar changes have been made, when they were necessary, in using Ridgway's text for the paragraphs on the distribution of species, and in the sections which characterize the generic groups. The descriptions of birds not included in Parts I to VII of The Birds of North and Middle America, have been written by R. I. Brasher. Special identification or "field" marks have been italicised.

Although this precise and fairly complete physical description is essential for the purposes of scientific ornithology, and often is needed by the layman to supplement or corroborate his own observation, what Mr. Burroughs calls "the human significance of our feathered neighbors " is undoubtedly that which chiefly interests the very large and increasing army of bird lovers. This human significance is reflected in natural or acquired traits which, singly or combined, often give a bird a very definite personality. To the observer who learns to detect and understand these traits, the study of birds becomes far more than a mere science devoted to the collection and classification of physical facts. For once he has adopted this point of view, he begins to see something very like distinct character and personality in the bird world; and observing the manifestations of stch traces of individuality becomes to him infinitely more interesting and significant than the mere noting of the size, contour, and plumage peculiarities of a bird, or its occurrence here, there, or elsewhere at this or that time of the year.

The characterizations, or life histories, of the species which receive separate treatment in the following pages, were prepared with especial regard for portraying their interesting and distinctive traits. In most instances this treatment reveals characteristics which serve to differentiate the species with much definiteness. It is, of course, true that individnal differences may occur even within the species. For example, an individual bird may display what clearly seems to be unusual confidence in man, or uncommon cleverness in concealing its nest or protecting its young. And it is frequently remarked that a certain bird may be a much more accomplished singer than are the others of his species in the same vicinity. Nevertheless there is a general similarity between the habits and temperament of birds of the same species, and therefore a description of these habits will be found to apply to the average individual bird of the species concerned.

To the technical descriptive matter of especial interest to the systematic ornithologist, and the popular characterizations intended particularly for the non-scientific student of birds, has been added - wherever it is called for - much very important and interesting matter concerning the actual usefulness of birds. This subject of conomic ornithology has been carefully investigated by the United States Bureat of Biological Survey, whose experts have gathered and compiled a great mass of statistics and other data concerning the food habits of birds, the object being to convey precise information as to which are the useful and which are the harmful species. It would be difficult to overstate the value of this work if its results were generally understood, for these researches demonstrate beyond peradventure the enormous usefuness of the birds in destroying insect pests which, but for this check of their natural rate of increase, would ruin every year many millions of dollars worth of crops, and threaten with defoliation and death many kinds of trees.

The Bureau of Biological Survey endeavors to disseminate this information as widely as possible, and in order to assist in this good work the data gathered by its experts have been freely used in the following pages. This has been done not only because of the obvious 



\section{Eggs of American Birds}

PLATE No. I
I. Laughing Gull
2. Least Tern
3. Water-Turkey
4. Black Skimmer
5. Common Tern
6. Great Auk
7. Loon
8. Black Tern
9. Murre 


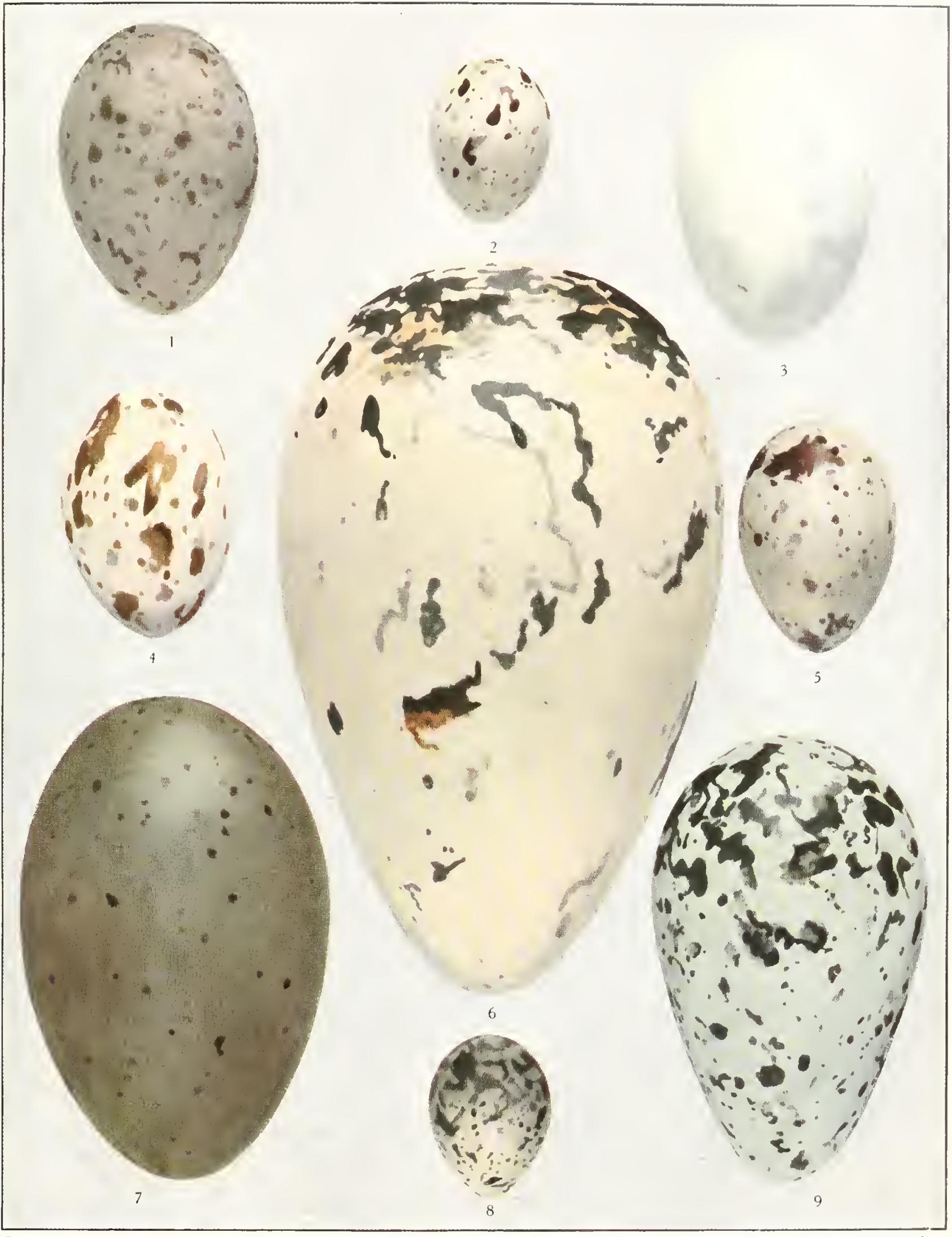

EGG' OF AMERICAN IIRDS

(Plate Number One) 

value and interest of the information thus conveyed, but because the reports and bulletins in which it is contained are likely within a few years to become mavailable through the exhaustion of the comparatively small supply printed. This, indeed, has already happenerl in the case of many of the most valuable bulletins, which are now unobtainable except in the larger pulblic libraries and other repositories for such documents, and therefore have only very restricted circulation. Possessors of Birds of America will therefore have permanent access to the best of this very valuable material.

Finally, some explanation of the general form in which this work is presented may not come amiss in this connection. In their arrangement most ornithologies follow the evnlutionary plan of proceeding from the lowest to the highest forms which, in the case of the birds, means from the Diving Birds which are considered by the scientists the lowest forms, to the Thrushes which are ranked as the highest. This is the order in which the birds are arranged in the Check-List of the American Ornithologists' Union, and the one which has been followed in these pages.

The Cheek-list of the American Ornithologists' Union includes the names of about twelve hundred lirds to which systematic ornithologists accord full specific or "sub-specific" rank. This sub-specific distinction is often based upon very inconsiderable plumage differences of little or no interest or significance to the lay student of birds, while the character of the bird remains unchanged. In other words, a Robin is a Robin, whether he has white tips to the outer tail-feathers, as in the common Robin, or whether he lacks these spots, as in the Western Robin. Birds of America discusses about one thousand birds. It practically covers every species and subspecies with which a student of birds is likely to come in contact in North America.

The publishers wish to thank Mr. T. Gilbert Pearson, who, in addition to his services as Editor-in-chief, has given freely of the photographs and material assembled by the National Association of Audubon Societies; Mr. Herbert K. Job, for his photographs and helpful suggestions; Mr. Edward H. Forbush, for his advice, and, through him, the Massachusetts Board of Agriculture for ornithological literature printed by them; Mr. William L. Finley and Mr. H. T. Bohlman for pictures supplied; Dr. Jonathan Dwight, Jr., for valuable suggestions and criticisms, and permission to quote from The Auk; Dr. R. WV. Shufeldt for critical suggestions: Mr. C. Walter short for his interest and practical advice on manufacturing details; Mr.H.J. Vredenburgh for his careful supervision of the photo-engraving; Dr. Frank M. Chapman for permission to quote from his books; Mrs. Florence Merrian Bailey for permission to quote fron her book, Handbook of 11 estern Birds of the Lnited States; Mrs. Mabel Osgood Wright, for permission to quote from her book Birderaft; Mr. John Burroughs for permission to quote from his Works; Mr. C. William Beebe for photographs; Elizabeth Torrey and John W. Seabury for permission to quote from the Works of Bradford Torrey; Mr. Winthrop Parkhurst for permission to quote from the Horks of II. E. Parkhurst; Mr. William Ieon Dawson for permission to quote from Birds of Ohio, Birds of II ashington, and Birds of Califomia; Mrs. Olive Thorne Miller for permission to quote from The Children's Book of Birds and A Bird Loier in the H'est; Mr. F. Schuyler Mathews for quotations from his Field Book of 11 ild Birds and their Music; Mr. Ralph Hoffman for quotations from his Guide to the Birds of New England and Eastem New Vork; Mr. Walter H. Rich for permission to quote from his Feathered Game of the Northcast; Mr. H. T. Middleton, Mr. Silas A. Lottridge, Mr. A. A. Allen, and all others who have so generously contributed of their best in photographic studies; the United Fruit Company for the use of paintings for reproduction on the title pages; and the Hercules Powder Co., for quotations from Game Farming for Profit and Pleasure.

The following publishers have courteously granted these permissions: D. Appleton \& Co. for quotations from the fForks of Frank M. Chapman; Houghton Mifflin Co. for "To an Oriole " by Edgar A. Fawcett, quotations from The Children's Book of Birds and A Bird Lover in the II'est by Olive Thorne Niller, quotations from Handbook of Birds of the If estern 
Initcd States by Florence Merrian Bailey, quotations from the Wrorks of John Burroughs, quotations from the Works of Bradford Torrey, and quotations from Guide to the Birds of Ncw England and Eastern New Y'ork by Ralph Hoffman; The John Lane Co. for quotations from Birds by' Sea and Land by John Maclair Boarston; the Macmillan Co. for quotations from the IVorks of Mabel Osgood Wright; Elizabeth C. T. Miller for quotations from Birds of Ohio by William Leon Dawson; G. P. Putnam's Sons for quotations from Ficld Book of Wild Birds and their Music by F. Schuyler Mathews: T. Y. Crowell Co., for quotation from Feathered Game of the Northeast by Walter H. Rich; and Charles Seribner's Sons for quotations from the Works of $\mathrm{H}$. E. Parkhurst.

To the United States Department of Agriculture and the members of the Biological Survey, to the New York State Museum and its director Dr. John M. Clarke, and to the American Nuseum of Natural History and its director Dr. Frederic A. Lucas and the nembers of its seientific staff are due special thanks for the material and pietures supplied by them.

The careful workmanship of The J. B. Lyon Company of Albany, the Phoenix Engraving Company, of New York City, and the Zeese-Irilkinson Company, of New York City, have made possible the mechanical perfection of these volumes.

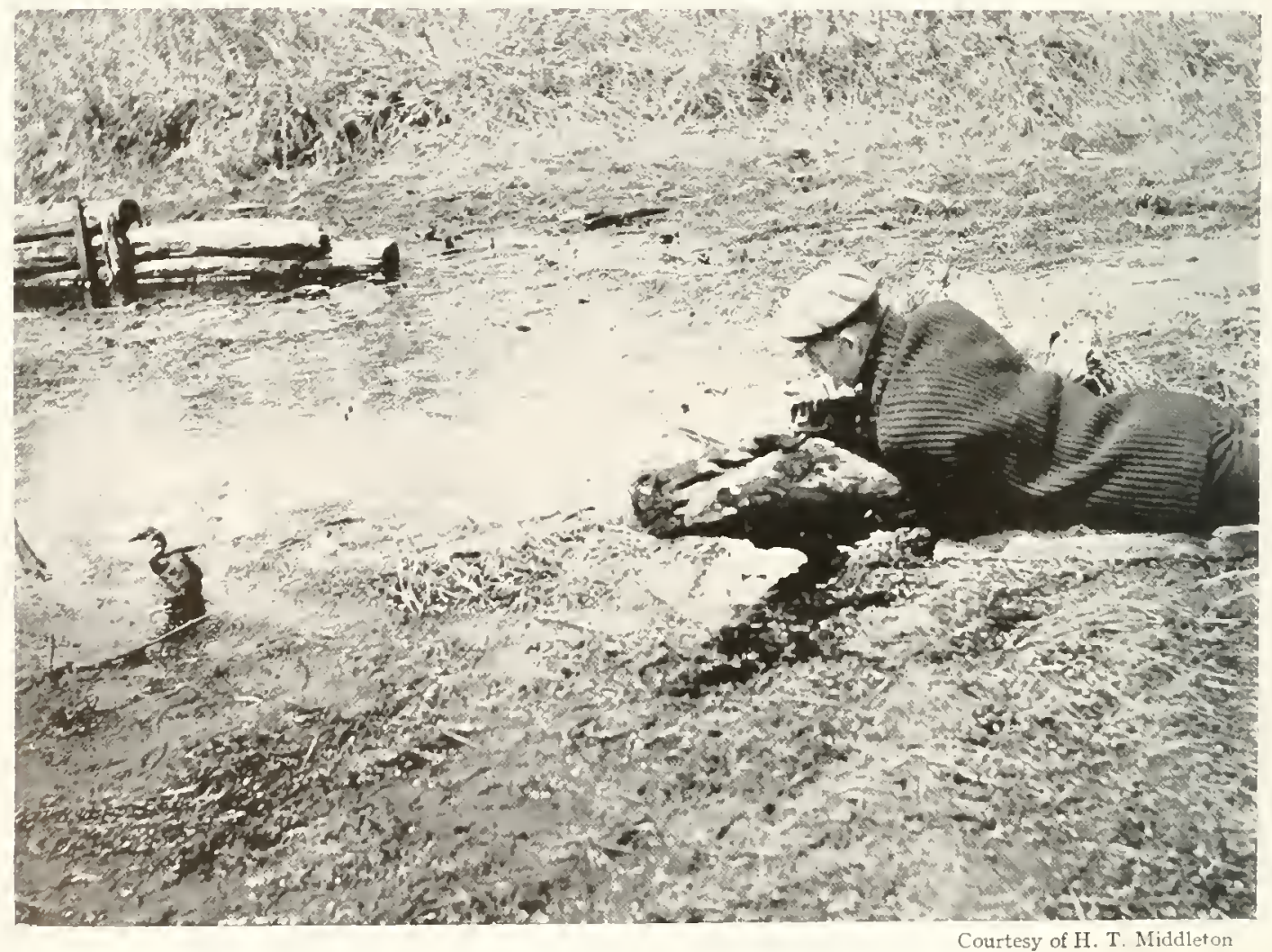

WILD-LIFE PHOTOGRAPHER SNAPPING A PIED-EILLED GREBE IN A POND 


\title{
INTRODUCTION
}

\author{
By T. Gilbert l'earson, B. S.
}

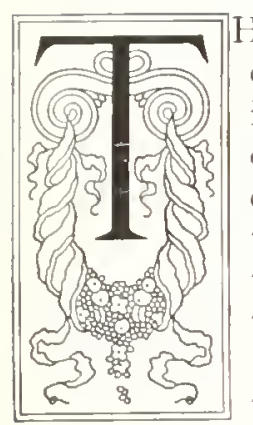

HERE is to-day in the Lnited States a very wide interest in the conservation of wild birds. This is manifester in the great interest which the public shows in proposed legislative enactments for bird-protection, in the propagation of various game-birds on private and public properties, in the huilding and erection of innumerable boxes for the convenience of nesting birds, and in the constantly increasing financial support given to the National Association of Audubon Societics, and its many affiliated state and local hird protection clubs throughout the country.

A lively euriosity has spread among all classes of thinking people as to the names of the hirds they see, what they feed on, and something of their coming and going, with the result that the demand for bird books has become very great. No publisher of general literature would to-day deem his list of books adequate without one or more standard works on some phase of ornithology. Literary magazines constantly are publishing articles on the hahits of birds, the migration of hirds, the economic value of birds, the asthetic interest in bird life.

There have been recorded in North America eight hundred distinct species of wild birds, and four hundred additional subspecies, or climatic varieties. This refers to the territory lying north of the Rio Grande - and not to Middle America, which inchdes Mexico and Central America. Naturally the individuals of some of these species are far more numerous than are others. For example, during historic times there probably never were more than a few thousand specimens of the California Vulture, while such common species as the Robin and the Mourning Dove run into the millions.

Some birds are extremely rare, for example only one specimen of the Scaled Petrel has ever been taken in North America, and that was in Livingston county, New York, although the natural habitat of all Petrels is on the open seas.

No one state contains all these varions forms of bird-life. From the latest available information the following list shows the number of birds that have been recorded in the various states of the Union:

Alabama, 275; Arizona, 37 ; Arkansas, 255; California, 541; Colorado, t03; Connecticut, 334; Delaware, 229; District of Columbia, 293; Florida, 362; Idaho, 210; Illinois, 390; Indiana, 321 ; Iowa, 356; Kansas, 370; Kentucky, 228; Louisiana, 323; Maine, 327 ; Maryland, 200; Massachusetts, 360 ; Michigan, 320 ; Ninnesota, 304; Missouri, $383 ;$ Nebraska, 418; Nevada, 250: New Mampshire, 283; New Jersey, 358; New Mexico, 314; New York, 412; North Carolina, 331; North Dakota, 338; Ohio, 330; Oregon, 328; Pennsylvania, 300 ; Rhode Island, 203; South Carolina, 337; Tennessee, 223; Texas, 546; Utah, 21 t; Termont, 255; Virginia, 302; Washington, 372; West Virginia, 240; Wisconsin, 357; Wyoming, 288. For the remaining five states no list of birds has been published.

Among the twelve hundred species and subspecies there are a considerable number that are exotic and are never seen in this country save on rare occasions when blown far by storms they wander to our shores. Among this class may be mentioned such species as the Scarlet Ibis from South America, the Mew Gull from northern Europe, the Giant Fulmar of the southern oceans, and the Lapwing, Rook, and Wheatear from the old world. 
Birds vary greatly in the extent of their natural range and here again comparison may be made between the California Vulture and the Robin; the one ranging in suitable localities from southern Florida to Alaska, the other being restricted to the California mountains. The bird of greatest range in the world is the Arctic Tern, which in the northern summer haunts the North American coastline from Maine to the Arctic seas, and during our winter feeds along the shores of the Antarctic continent. Most birds have a much more restricted range and but few are found in every state. Some species occur only along the Pacific coast, others only in the northeastern States and Canada, and still others are confined to the south Atlantic and Gulf States.

The earlier legislative enactments for bird-protection in the United States dealt almost entirely with game-birds. So persistently was this class of birds shot, trapped, and netted after the coming of the Europeans, that it soon became apparent that restrictive measures must be taken if some of the more poptlar game-birds were to be preserved for posterity. These laws at first were quite amateurish, but as a result of experience they later were established along certain definite lines, viz., first, those setting aside certain seasons of the year when the birds cottld be killed, the idea of this being to afford them protection during the period of inctbation and caring for the young; second, forbidding certain methods of capture as for example "fire lighting" at night, netting, and shooting into flocks with large swivel guns; and, third, limiting the number that might be taken in a day or season.

It was fotnd that the ordinary civil officers cotild not, or would not, enforce the game laws satisfactorily, hence there soon developed a plan of employing special state officers known as game wardens whose specific duty it was to see that the laws protecting birds and game were observed. In order to raise funds for the employing of these officers and also to increase the restrictions on gunners the custom arose of requiring hunters' license fees of all who desired to kill these State assets. These fees run from one dollar to three dollars for a resident of the State and from five to seventy-five dollars for a non-resident of the State. This hunting license fund in some of the larger States at times amounts to $\$ 200,000$ or more annually.

It was not until about the middle eighties that public attention was drawn strongly to the desirability of preserving that group of birds usually referred to as " non-game birds." By a campaign of education the Audubon Society, first formed at that time, began to educate the public sentiment on the subject with the result that the law usually known as the Audthon Law and which has for its purpose the protection of this large group of birds, has been enacted in the Legislatures of all the States with the exception of six. By the enactment of the Federal Migratory Bird Law on March 4, igr3, a provision protecting these birds was created which covers the United States. On December Io, I9I6, a treaty between this country and Great Britain was ratified, which extends protection to non-game birds in the Dominion of Canada.

The best place to study wild birds is on a Bird Reservation for here the birds have greatly lost their fear of man, and primitive conditions, so far as the birds are concerned, have thus largely been restored. In one of the protected sea-bird colonies of North Carolina I have photographed Royal Terns standing unafraid on the sands not twelve feet distant. They had become so accustomed to the warden in charge that they had regained their confidence in man. At Lake Worth I saw a man feed Scaup Ducks that swam to within two yards of his boat. In thousands of door-yards throughout the conntry wild birds, won by kind treatment, now take their food or drink within a few feet of their human protectors. This is because the door-yards have been made little bird reservations. I havea number of friends who regularly feed Chickadees in winter as the birds perch on their outstretched handis. It is astonishing how quickly wild creatures respond to a little reasonable treatment, as may readily be learned by any householder who will try the experiment. With a little patience any teacher may instruct her pupils in the simple art of making the birds feel at home in the vicinity of the school-house. 



\section{Eggs of American Birds}

\section{PLATE No. 2}

I. Whip-poor-will

2. Nighthawk

3. Yellow-billed Cuckoo

4. Eelted Kingfisher

5. Least Bittern

6. Sora

7. Bob-white

8. Red Phalarope

9. Wilson's Phalarope

I0. Spotted Sandpiper

II. Wiison's Plover

12. California Quail

I3. Semipalmated Sandpiper

14. Killdeer

I5. Florida Gallinule

I6. Sparrow Hawk

I 7. Ruffed Grouse

I8. Wilson's Snipe

I9. Woodcock

20. Sharp-shinned Hawk

2I. White Ibis

22. Little Blue Heron

23. Clapper Rail

24. White-faced Glossy Ibis 


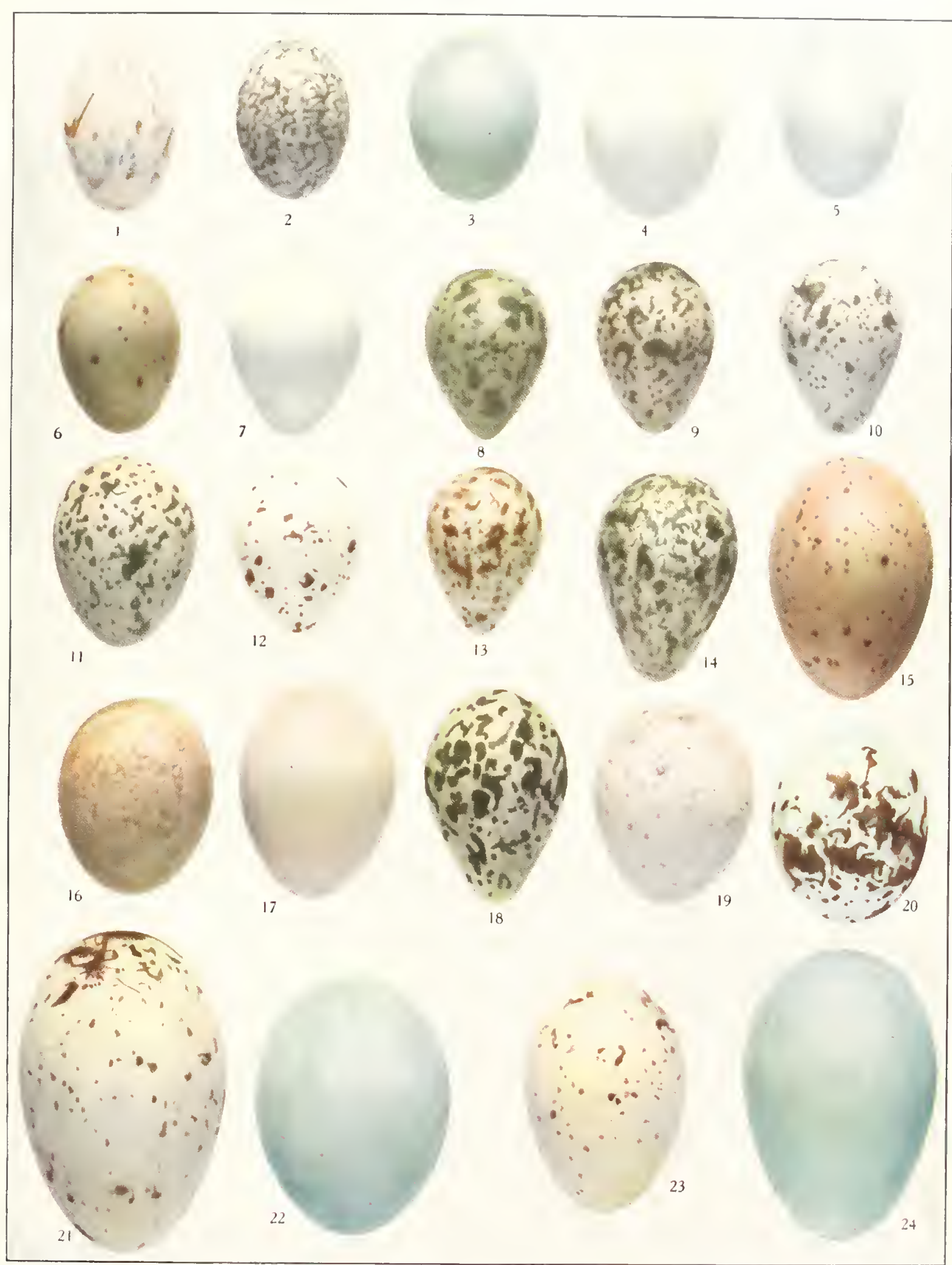

LGGS OF AMERICAN BIRDS

(Plate Number Tru) 

There are some kinds of birds that, as far as we know their history, have always huilt their nests in the holes of trees. Woodpeckers have strong chisel-shaped bills and are able to excavate nesting cavities, but there are others that do not possess such powers. These must depend on finding the ahandoned hole of some Wondpecker, or the natural hollow of some tree. It not infrequently happens that such birds are obliged to seareh far and wide for a hole in which they can make their abode. It is the custom of those who take care of lanns and city parks to chop away and remove all dead limbs or trees that may die. As there are very few Woodpeckers that ever attempt to dig a nesting hole in living trees, such work of the axeman means that when the season comes for the rearing of young, all mated Woodpeckers must move on to where more natural conditions await them. This results in an abnormal reduction of the number of holes for the use of the weaker billed hole-nesting species which must now seek for the few available hollows and knot-holes. But even these places are often taken away from them for along comes the tree doctor, who on the pretext of aiding to preserve the trees, fills up the natural openings with cement and the birds are literally left out in the cold. It is plain to see, therefore, that one reason why many birds do not remain in our towns through the spring months, is due to the absence of places where they may lay their eggs and rear their young.

To overcome this difficulty the Audubon Society several years ago began to advocate the building and erection of suitable nesting boxes, and to-day the practice is gaining wide usage. More people every year are putting such boxes upon poles or nailing then to trees about their homes, and city authorities in some instances now include bird-boxes among the annual expenditures in the care of their parks. Some of the boxes that may be purchased are very ornate and make beautiful additions even to the most carefully kept estates. One may buy these boxes at prices varying from thirtyfive cents to thirty-five dollars each. It is

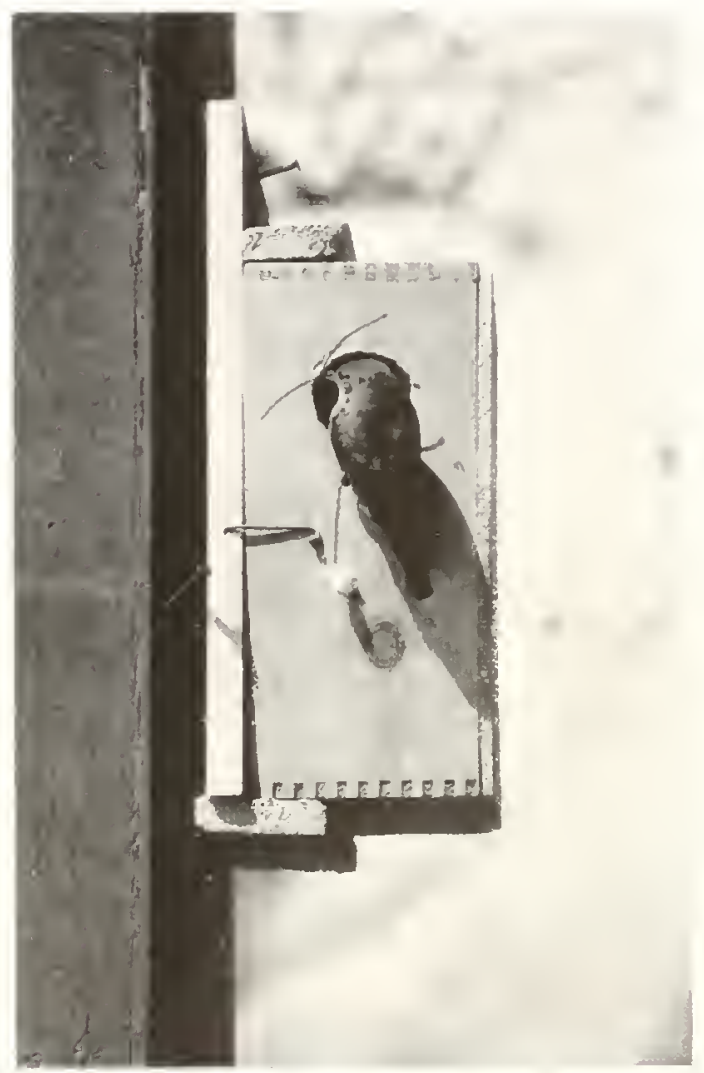

Photo by A. A. Aller

HOUSE WREN

Building its nest in a nesting box on a porch

not necessary, however, to buy the boxes to be put up for birds. Equally useful ones may readily be made in the Manual Training Department of the school, or in the basement or wood-shed at home. If one does not know how to begin one may buy a bird-box, or write to the Audubon Society for a free circular of directions, and construet similar ones for himself. People sometimes make the mistake of thinking it is absolutely necessary that such boxes should ennform strietly to certain set dimensions. Remenber, however, that the cavities in trees and stumps which the birds naturally use, show a wide variety of size, shape and location. A large, commodions, many-roomed, and well painted Martin house, makes a pleasing appearance on the landscape, but it may not be attractive to the Martins. As a buy I built up a colony of more than fifteen pairs of these birds by the simple device of rudely partitioning a couple of soap boxes. The openings of the different rooms were neither uniform in size or shape, but were such as an untrained boy would eut out with a hatchet. A dozen 
gourds each with a large hole in the side completed the tenements for this well contented Martin community.

There are a few simple rules on the making and placing of bird-boxes that should be observed.

I. In the case of all nest-boxes, except those designed for Martins, the opening should be several inches above the floor, thus conforming to the general plan of the Woodpecker's hole, or the natural cavity in a tree.

2. As a rule nest-boxes should be erected on poles from ten to thirty feet from the ground, or fastened to the sides of trees where limbs do not interfere with the outlook. The main exception to this rule is in the case of Wrens, where the boxes or gourds intended for their use may be nailed or wired in fruit trees or about out-buildings.

3. Martin houses should be erected on poles at least twenty feet high and placed well out in the open, not less than one hundred feet from buildings or large trees.

4. All boxes should be taken down after the nesting season and the old nesting material removed.

Much may be done to bring the birds about the home by placing food where they may readily get it. The majority of land-birds that pass the winter in Canada or the colder parts of the United States, feed mainly on seeds. Cracked corn, wheat, rice, sunflower seed, and bird-seed which may be purchased readily in any town, are therefore exceedingly attractive articles of diet. Bread crumbs are enjoyed by many species. Food should not be thrown out on the snow unless there is a crust or the snow has been well trampled down. Usually it should be placed on boards. Various feeding devices have been made of such character as to prevent the food being covered or washed away by snow or rain. Suet tied to the limbs of trees on the lawn will give comfort and nourishment to many a Chickadee, Nuthatch, and Downy Woodpecker. To make a bird sanctuary, therefore, nesting sites and food are among the first requirements. There appears to be no reason why town and city parks everywhere should not be made into places of great attraction for the wild birds.

At Meriden, New Hampshire, there is a tract of land containing thirty-two acres of field and woods, which is dedicated to the comfort and happiness of wild birds. It is owned by the Meriden Bird Club. The entire community takes an interest in its maintenance, and here birds are fed and nesting places provided. It is in the widest sense a "community sanctuary." There are now a number of these coöperative bird-havens established and cared for in much the same manner. One is in Cincinnati, another in Ithaca, New York, and still another at Greenwich, Connecticut.

The best equipped of this elass of community bird-refuges, as distinguished from private estates, or Audubon Society, State, or Federal bird-reservations, is Birdcraft Sanctuary, located in Fairfield, Connecticut. This tract of ten acres was presented to the Connecticut Audubon Society in June, I914. A cat-proof fence surrounds the entire place. That it may not look aggressive, it is set well inside the picturesque old wall. Stone gate-posts and a rustic gate greet the visitor at the entrance on the highway. There is a bungalow for the caretaker and a tool and workshop of corresponding style. Several rustic shelters and many seats are about. The various springs on the place were assembled into a pond. Trails were cut through the brush and the turf grass, and a charming bit of old orchard on the hill-top, was restored for the benefit of worm-pulling Robins. Stone basins were constructed for bird-baths, houses are put up for all sorts of birds, from Wren boxes, von Berlepsch model, Flicker boxes and Owl boxes, to a Martin hotel; and lastly, the natural growth has been supplemented by planting pines, spruce, and hemlocks for windbreakers, and mountain ash, mulberries, sweet cherries, flowering shrubs, and vines for berries. Not only were all these things done, but there has been built and equipped a small museum of Natural History, which for good taste and usefulness one would need to travel far to find its equal.

The interest in this subject is growing every day, in fact, America is to-day planning new homes for her birds - homes where they may live with unrestricted freedom, where 
food and lodging in abundance, and of the best, will be supplied, where bathing-pools will be at their service, where blossoning trees will welcome them in the spring, and fields of grain in the fall, quiet places where these privileges will bring to the birds nutch joy and con tentment. Throughout this country there should be a eoncerted effort to convert the cemeteries, city parks, and estates into sanctuaries for the bird-iffe of this land.

With a little trouble, seasoned with good judgment, one may soon have birds feeding on a tray within a few yards of the window or even on the window sill. Alundant npportunity is thus given for photographing birds under the hest possille conditions for successful results. With every possible convenience at hand one may get hetter pietures of lirds on a feeding tray than one could ever hope to do in a state of wild Nature.

Photographing birds then is an excellent oceupation, for the merest novice may hope for success. It is a good thing to do this too fron the standpoint of the bird's well heing. I have never known a bird photographer who was not a bird lover; for to know the hirds is to protect them.

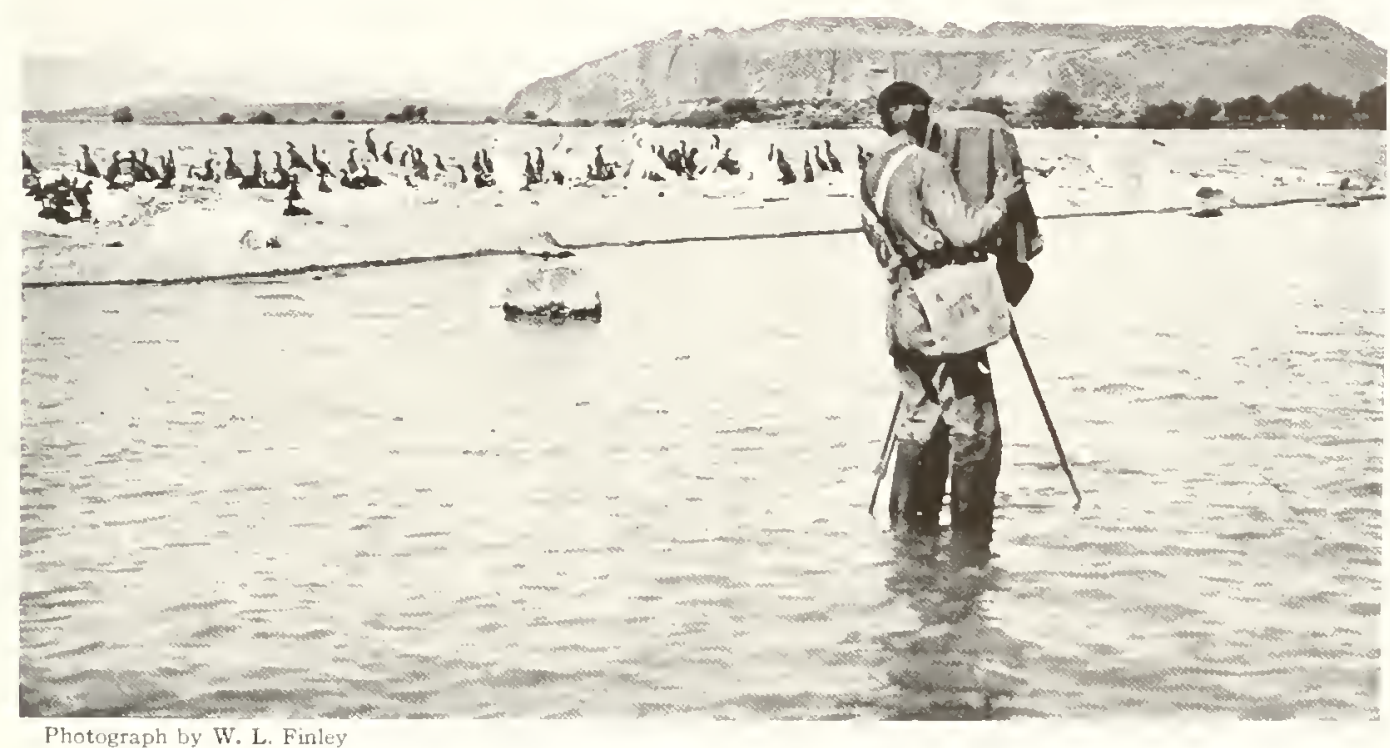

H. T. Bohlman Photographing a COLONy of White pelicans and CORMorants IN tule lake, NORTHERN CALIFORNIA

Present operations in the United States, in the line of bird-reservations, grew out of the distinct need of preserving certain classes of birds from becoming extinet. The birds that we may distinctly call farm-land birds, such as the native Sparrows, the Warblers, Wrens, Orioles, and many other common insectivorous birds, have increased in America since the advent of white man.

It is chiefly the birds that could be commercialized, either for their flesh, or their feathers that have suffered great diminution in numbers in North America as a result of man's activities. An important effort to preserve this class of birds is now being carried on in the United States by the establishment of bird-reservations. Reservation work began in I002, under the National Association of Audubon Societies. This is the best organized and most liberally financed bird protective organization in the world, and has been in active operation for many years.

One of the States that early adopted the Audubon Law was Florida. On the Atlantic coast of that state, in Indian River, there is an island of about four acres, where two thousand 
Brown Pelicans have been coming, from the time whereof the menory of man runneth not to the contrary, to lay their eggs and rear their young. About the time this law was enacted long quills became very popular in the millinery trade. Some of us found that the millinery stores in large cities were selling feathers taken from the Bush Turkey, the Albatross, the Brown Pelican, and also from the old Turkey Buzzard of the South. Certain people tried to secure the repeal of the Florida law, so that the Pelicans might be killed for their feathers.

This caused the question to rise: Would it be possible to get the government of the United States to take hold of that island in some way? A man who kills a bird would rather be haled before a local magistrate where the jury probably would be composed of friends and neighbors, who themselves had hilled birds. In such a case it was a simple matter

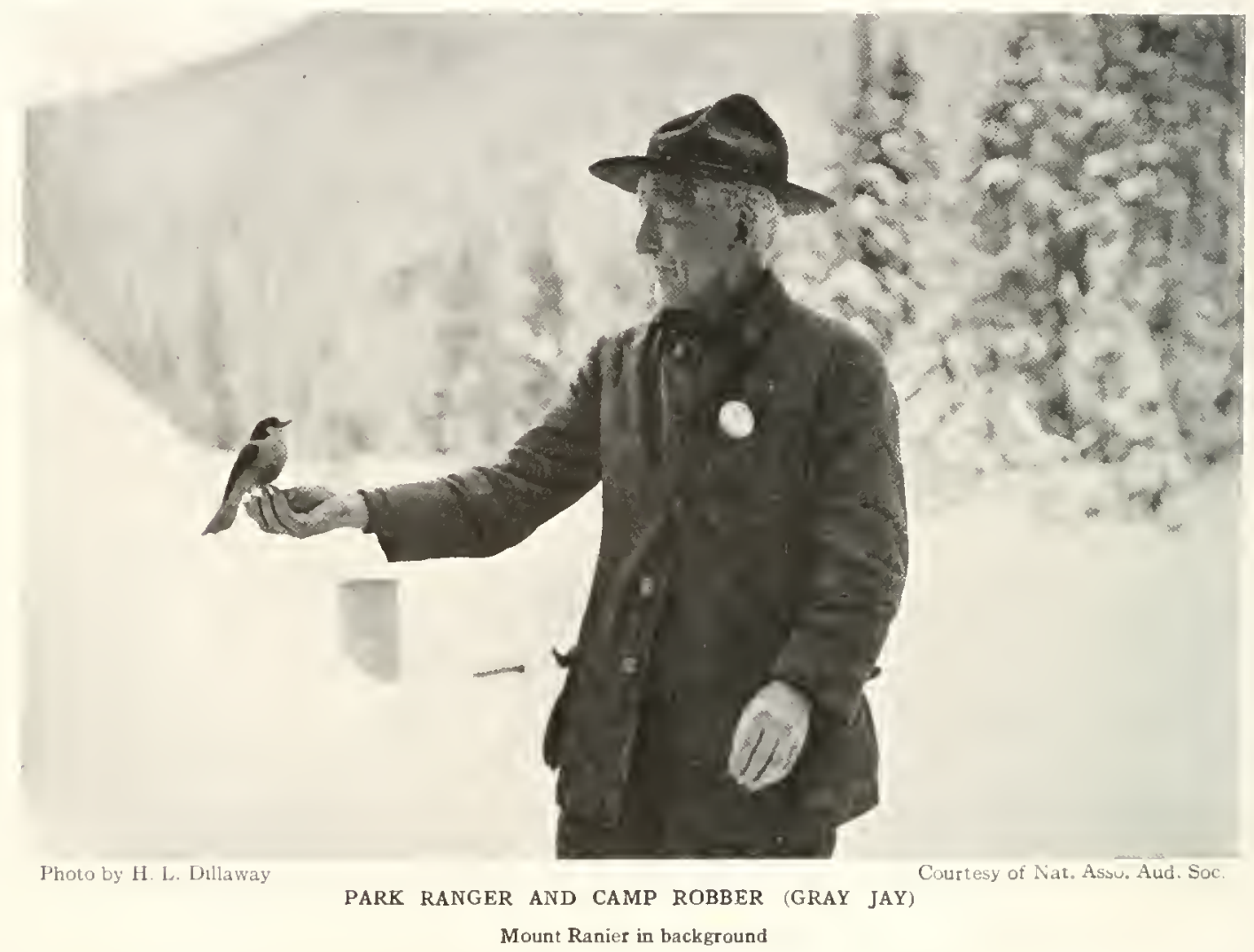

to leave the plough for a day and stand trial. But in a Federal court it is a different proposition. Here a man may have to travel half way across the state to attend court, and must appear before a jury composed of strangers - a situation to be dreaded.

There did not seem to be any way whereby this Federal control could be secured until the matter was finally taken up with President Roosevelt, who said, "If the land office will recommend that this land is not good for agricultural purposes we will make it a bird-reserve under the care of the Department of Agriculture, provided the Audubon Society will agree to hire a man to act as guardian on the island." In a very short time the matter was arranged, and the President declared the island a bird-sanctuary in perpetuity - a breeding place for wild birds for all time. He took a short cut in doing this for there was no specific law giving the executive such authority. Along the coast of Florida were found nine other small islands suitable for this purpose, and Mr. Roosevelt made them all Federal bird-reservations.

Later inquiry was made about places suitable for sanctuaries for other birds, for, bear in mind, many large birds over extended areas were threatened with extirpation to supply 
the demand for the market. Sea Gulls along the coast, Terns, Grebes, 1)ucks, Geese, and others in the West were in imminent danger from this cause. So the National Assuciation of Audubon Societies beyan to look for breeding places of Ducks and other birds in the ITest. Examination was made in rarious parts of the country and many more bird reservations were the result. When President Roosevelt went out of office, we had thirty-eight bird reserves. President Taft took an interest in the subject and also segregated quite a number. One of the largest of these bird-sanctuaries is the delta of the Yukon, which is as larere as the State of Connecticut.

One bird reserve was created in the western group of the Hawaiian Islands, including the Laysan Island. 'This, ly the way, was raided in the summer of ior 5 ly Japanese feather hunters. The Pribilof Islands were also made a reserve, as well as the Aleutian Chain. There are to-day seventy United States bird-reserves in all. At first the Government made no appropriation to protect and guard these birds. Therefore, it became the dity of the Audubon Society to ask for aid from its members and friends who were willing to give money for an idea - people willing to provide funds to protect Egrets in Florida or Cormorants and Gulls on the Three-Arch Rocks in Oregon, whether or not they could ever hope to see personally the sanctuaries. After the lapse of six years, the Government made a small grant for the purpose, although, to-day, the Audubon Society owns and operates the patrol latnches on the Government reserves, and still helps to pay the salaries of some of the wardens. The Government is appropriating more money each year to this work, and the gentlemen of the Biological Survey who have the work in charge are exercising every means at their command to successfully protect the birds.

President Wilson made the Panama Canal Zone a bird-reserve in 1913. There are many bird-reserves which the Audubon Society is protecting that are not on Government territory. These are cared for

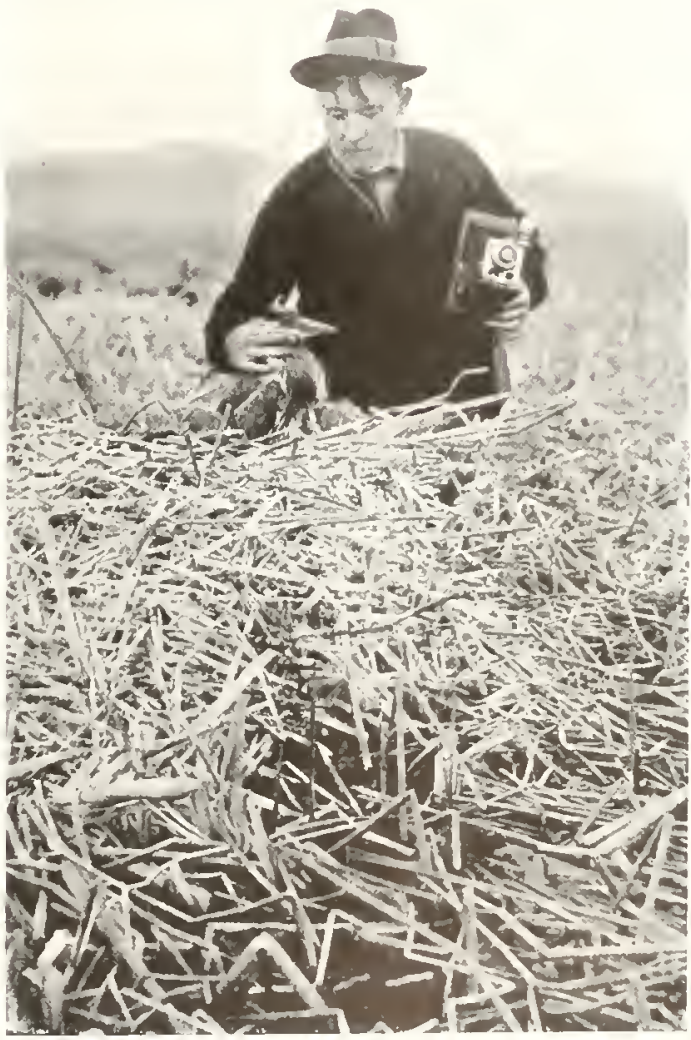

T. GILBERT PEARSON PHOTOGRAPHING YOUNG HERONS

In the marshes of Klamath Lake, Oregon by the Society's paid agents. 'The islands along the coast of Maine are great breeding places for sea-fowl of varions kinds. There are forty-two islands where they nest, and there are sixteen Audubon wardens in service there in summer. The Society also has wardens guarding islands along the coasts of Connecticut, New York, New Jersey, and North Carolina. There are still others in Florida and Louisiana. Hbout sixty important colonies of water-birds are protected by the Audubon society in the southern states. Ithas been able to buy some and to lease others. In some cases merely the consent of the owners is obtained. The result is that certain water-birds on the Atlantic coast, such as Herring Gulls and several species of Terns, have come back in great numbers. 
The Audubon Society is trying to guard the Egrets in the South and we know of about twenty thousand of these birds left in the United States. Two of the Society's agents, while on guard, have been shot and killed by plume-hunters, and the colonies have been raided and the plumes sent to New York.

In North Anerica the great nursery for wild Ducks and Geese is the region between the Great Lakes and Hudson Bay on the east and the Rocky Mountains on the west. There are three great flights of Duchs and Geese in autumn from that section of the country. Those heading for the Atlantic Seaboard chiefly cross the States diagonally, reaching the Atlantic Coast about Maryland. In a reactionary migratory movenent, many of them go back along the coast at least to Long Island and swing back and forth, according to weather conditions. The other end of this movement goes down the coast. There is also a great flight down the Mississippi Valley. Under the migratory bird laws, the Mississippi, between Memphis and St. Paul, is a reservation. In the sunken ground of Arkansas there are two large bird-reserves, and on one of these many Ducks find a refuge. This was a famous place for market hunters in days gone by. Nore than 300,000 Ducks were taken there in one year. Another larger series of bird-reservations is situated in the State of Louisiana. These include 234,000 acres of marsh-land, where numbers of Ducks and Geese now find a safe refuge. These reservations were made by the private purchase of Charles Willis Ward, E. A. McIlhenny, Mrs. Russell Sage, and the Rockefeller Foundation.

This widespread interest in birds both on the part of the Government and private individuals has had happy results. Not only are our birds protected, but unusual opportunity has been given to study them. The advance in field work, coupled with the constant improvement of photography, has obtained results little short of astounding.

When the present work on Birds of America was projected, some months ago, we of the editorial board hegan as a first move, to take stock of the situation. We felt that the time was at last ripe for a new book on the subject that should be a final repository of all this vast treasure of scattered information. Patient field ornithologists, on the one hand, and laboratory naturalists, on the other, had given us wonderfully rich material which only arvaited assembling. The task even ten years ago would have proved far more difficult. What was clearly needed, was to make a thorough canvass of the field and produce a work at once popular and scientific, and at the same time comprehensive - a record of our wild birds prepared in such form as to meet the needs of both the laymen and the trained naturalist. Ornithologists all over the country heartily endorsed the project; indeed we have seldom seen a work which aroused more enthusiasm in the doing than Birds of America. The official check list of the American Ornithologists' Union has been followed for classification, and we have included not only our common living birds as found to-day, but also many rarer forms and some recently extinct, such as the Passenger Pigeon. We have tried, in a word, to present a complete picture and story of our feathered wild bird life. 


\title{
ORDER OF DIVING BIRDS
}

\author{
Order Pygopodes
}

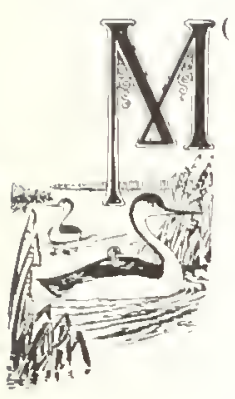

(OST aquatic of all our birds are the Diving Birds. Not only are their bodies made so that they can propel thennselves on land only with difficulty, but their food consists entirely of fish and other aquatic animals. Their flesh is coarse and unpalatable. They are the lowest form of bird life and are the most closely allied to the reptiles, from which birds are supposed to have originated. Birds of this order spend nearly their entire time in the water. They nest on the ground or on rocks. The young are covered with down when hatched, and as soon as this natal down is dry they are able to take to the water.

The scientific name given to this order, Pygopodes, is from two Greel words meaning "rump " and "foot," and refers to the position of the legs in relation to the rest of the body - a characteristic peculiar to this order. The tibia or drumstick is huried beneath the skin and feathers, brinsing the heel joint close to the tail. The birds, therufore, sit or stand in an almost perpendicular position, and walk with great difficulty and awkwardness. The toes are either wel,bed or broadly lobed. Both body and neck are elongated, giving a boat-shaped appearance to the bird. The bill is horny and pointed and has no pouch; it can be opened very wide. The wings are very short, scarcely reaching the base of the tail. The latter is never long, and sometimes it is so rudimentary as to make the bird appear tailless. The plumage is dense, and there is no sexual variation in color. The body is almost entirely encased in a layer of fat.

According to the development of the tail, the Diving Birds are divided into two suborders: the first is the Colymbi, and contains the one family of Grebes; and the second is the Cepphi, and contains two families, the Loons and the Auks, Murres, and Puffins.

\section{G R E B E S}

\section{Order Pigopodes; suborder Colymbi; family Colmbide}

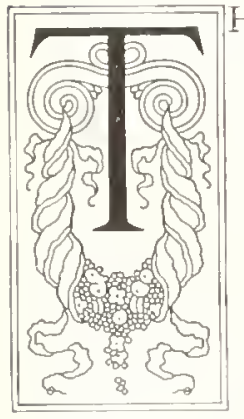

HE Grebes are much less pronounced, and consequently less interesting bird characters, than are the Loons, though both families have some of the same physical characteristics, notably shill in the water and clumsiness on land. They are smaller than the loons and are more likely to be found in inland bodies of fresh water, though their migrations take them to the sea where they are by no means entirely out of their element. Like the Loons, when pursued the Grehes try to escape by diving and swimming under water, where they propel themselves by their feet; and generally they show decided disinclination to take to their wings, though they are swift and strong flyers. Grebes undoubtedly dive with remarkahle quickness, but, as in the case of the loons (and for the same reasons), their cleverness in this operation has been much exaggerated, as at any reasonable distance they are quite unable to dodge a rifle bullet, especially if it be propelled by smoheless powder.

Grebes have feet which are lobate, that is, each toe has one or more separate metnbranes which are joined only at the base. The toes are flattened and the nails short and round. The shanks are so flattened as to be nearly blade-like. The bill, which is coneshaped, is about the length of the head. 'The head is generally ruffed or crested, at least in the breeding season, and the neck long. The wings are short and the tail is invisible. The plumage is compact, smooth, and rather hair-like; when well dressed by the bird it is absolutely waterproof, and, therefore, Grebes, though water hirds, are never wet. The 
extreme posterior pusition of the legs causes the birds to sit up like Penguins. On land they sometimes progress on their bellies after the manner of seals. In flight the feet are extended backward and serve as a rudder, as the tail would in another bird.

A dense, matted, raft-like structure, made of rushes and the like, and often floating, but usually anchored to some aquatic plant, forms the nest of these strange birds. On this platform are laid from two to nine eggs of dull white or greenish-white. The nest is always damp and the eggs sometimes are hatched when they actually are partly covered with water. "When out of the shell," says one observer, " the young has not far to walk; he looks for a few moments over the edge of his water-drenched cradle and down he goes with the expertness of an old diver." Grebes usually are gregarious. When incubation of the full number of eggs has actually begun, the sitting bird upon leaving the nest (unless she is frightened away) completely conceals the eggs with moss and rushes.

Few birds have suffered more from the millinery trade than have the Grebes, whose dense and beautiful breast plumage has been much used for decorating hats. Legislation of various kinds curbs this barbaric practice in many parts of the country.

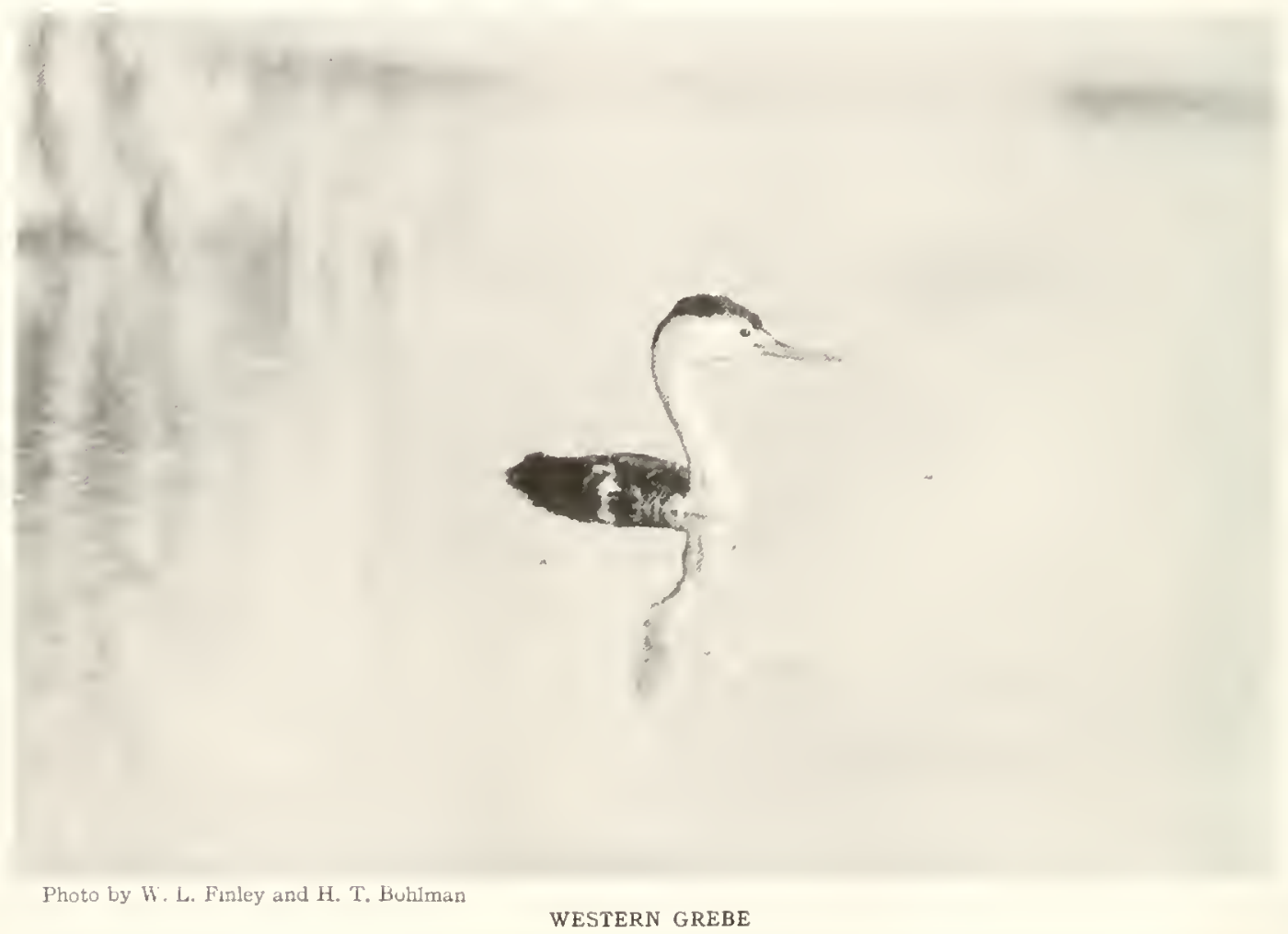

The most remarkable point about the food liabits of Grebes is that the stomachs almost invariably contain a considerable mass of feathers. Feathers are fed to the young, and there is no question that they play some essential though unknown part in the digestive economy. As they are finely ground in the gizzards it is probable that finally they are digested and the available nutriment assimilated. Feathers constituted practically 66 per cent. of the contents of the 57 Horned Grebe's stomachs examined. However, it is not likely that they furnish a very large percentage of the nourishment needed by the birds. As the nutritive value of the feathers is unknown, this part of the stomach contents is ignored. The other items of food are assigned roo per cent., and the percentages are given on that basis. Various beetles, chiefly aquatic, compose 23.3 per cent. of the food; other insects (including aquatic bugs, caddis and chironomid larva, dragon-fly nymphs, etc.), nearly i 2 per cent.; fishes, 27.8 per cent.; crawfish 20.7 per cent.; and other crustacea I 3.8 per cent. A little other animal matter is taken, including snails and spiders, and a small quantity of vegetable food was found in two stomachs. 
It has been clained that Grebes live exclusively on fish and do mischief in tish hatcheries. The results obtained by stomach examination show that they do not depend wholly or even chiefly upon fish. On the contrary, they eat a large number of criwfishes, which often severely damage crops, and consume numbers of aquatic insects which devour small fishes and the food of such fishes.

\section{WESTERN GREBE}

\section{Echmophorus occidentalis (Larrence)}

Other Names.- Western Dabchick: Swan Grebe. General Description.- Length. 2t to 21 irrches. Color above, brownish-black; helow, satiny-white. Flead with short crest on top but nune on wiles: bill, slender; neck nearly the length of the body.

Color.-Ancuts: Forehead, dark ash: crest and narrow line down back of neck, sooty-blackish shading on upper parts into brownish-hlack; the reathers of back with grayish margins: primaries, dusky-brown, white at hase; secondaries. white, some dark on outer webs: sides of hearl, chin, throat, and entire under parts, pure satiny-white: bill, yellowih-olive; feet, dull olive, yellowish on webs: outer edge and soles of feet, blackish: iris, orange, pink, or carmine with a white ring; a narrow bare space from bill to eve, lavender.

For years, the lake region of southern Gregon was the most profitable field in the llest for the plume hunter. The Westem Grebe was the greatest sufferer. This liver of glistening-white breast and silvery-gray hack was songlit not without reasun. The Grebe hunters call the skin of this bird fur rather than feathers, because it is so tough it can be scraped annl handled like a hicle, and because the thick warm plumage seemin more like the fur of a mammal than the skin of a bird. These skins, when prepared and placed on the market in the form of coats and cajes. brought the prices of the most expensive furs.

formerly there were immense colonies of ITestern Crebes living along the north shore of Tule, or Rhett, Lake, Lower Klamath Lake, and Nlalheur Lake. I'lune hunters, however, sought out these bie colonies and shot great numbers of the lirds during the nesting season. leaving the egrgs to spoil and the young to starve to death. This decreand the numbers so rapidiy that within a few seasons the bird were exterminated in places.

Malheur Lake is a large hody of shallow water surrounded on all sides by great stretehes of tules. The whole border is a veritable jungle. an almost endless area of floating tule islands between which is a network of channels. Here is the typical home of the IVestern Grebe. In the edge of the tules, the Grelse gathere tule stems and other vegetation, making a floating raft
Nest and Eggs.- Nesi. I mutted itructure of tule item, yrass. and water-plants, wh a slight depresion in the center: afloat on the water: whilally lightly iastenerl to the liviner reels so that 11 will mowe m! and down but not be carricel away from its jostion. Exos: sometimes 3 lut usually + or 5 . vale hluish-ereen but tansed a light brown from contact with the decommued vegetalile matter of the nest.

Distribution.- Western North America; breed irom British Columbia, suthern Saskatchewan, suthern Alberta, and southern Manitoba south to northern Califurnia, Ltaln, and northern North B)akota: winters from suthern British Columbia and California southward to central Mexico: casual east to Nebraskic. Kansas, II isconsin. Minnesota, and Qnehec

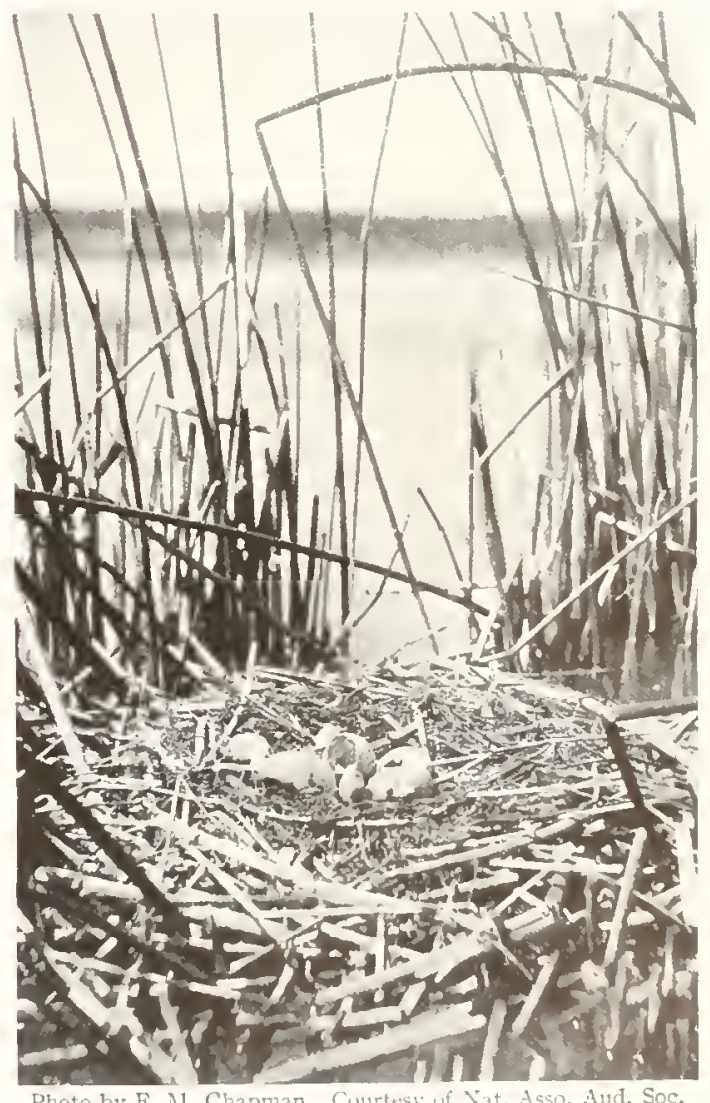

Photo by F. .1. Chapman Cuurtesy uf Nat. Asso. Aud. Soc. TWO WESTERN GREBES JUST HATCHED 
which is anchored. Around the edges of one of these islands, which was two acres in extent, we found between forty and fifty nests. The usual number of eggs was four or five.

On several occasions, we watched a Grebe chich cut his way out of the shell and liberate himself. After he gets his bill througl in one place, he goes at the task like clockwork. He turns himself a little and begins hannering in a new place and keeps this up until he has made a complete revolution in his shell. The end or cap of the egg. cut clear around, drops off, and the youngster kicks himself out into the sunshine. It doesn't take his coat long to dry.
The Grebe parents have an interesting way of taking their young with thenl. The chicks ride on the back of the mother or father just under the wing-coverts with the head sticking out. Sometimes one may see an old Grebe carrying two or three young on his back. At the slightest alarm, the old bird raises the feathers and covers the chicks completely. One can readily tell when a Grebe has chicks on his back, even if not visible, hecause he alpears to swin higher in the water. Normally, the body is almost submerged. An old Grebe not only swims, but dives readily, keeping the young in place on his back.

William L. Finley.

\title{
HOLBCELL'S GREBE
}

\section{Colymbus holbœlli (Reinhardt)}

\author{
1. O. $[$. Sumber 2 Siee Color l'late 1
}

Other Names.-American Red-necked Grehe; Rednecked Grebe: Holbrell's Diver.

General Description.- I.ength, 19 inches. IN SemMER: Glossy greenish-black above, and silvery-white below. IN Winter: Grayish-brown above, and grayish-white below. Neck shorter than body; bill, nearly as lung as head; crest lacking or inconspicuous. Iargest of the Grebes.

Color.- ADUITS iN SUMMER: Cromen back of neck. and upter parts, ghassy arecnish-hlack, darker mo head, more brownish on back where the feathers are edged with grayish; wing-coverts and primaries, dusky-brown: secondaries, white with brown tips anrl black shafts: a broud arca includin! chin, throat, and sides of head. siliery-tray, lightening along juncture witl black of crown: rest of neck and upper part of breast. deep hrownish-ruious: under parts, silvery-white sharled along sirles with pale ash, each feather with a rlark shait line and terminal spot, producing a dappled effect; bill, dusky, yellow below and at base; iris, carmine with a white ring. AntLTS IN MNTER, ANn YouxG: Crown, neck all around, and upper parts, grayish-brown, the feathers of back with lighter edges; sides of head and throat, whitish, under parts, grayish-white, the mottling of summer pltumage obsolete; bill, obscured but showing some pale yellow below: iris, as in summer.

Nest and Eggs.- Nest: Attached to live rushes: constructed of reeds, decayed vegetable matter, grass. and mud. Eritis: 3 to 5, dull white, usually soiled with brownish.

Distribution.- North America at large, eastern Siberia, and southwest to Japan; breeds from northwestern Alaska across British America to northern Ungava, south to northern Washington. Montana, and southwestern Minnesota: common throughont the United States in winter: sousth to southern California, southern Colorado, the Ohin valley and North Carolina: castal in Georgia and Greenland.
Some frebes colonize in breeding, as do the Western and Eared Grebes. In Holbrel]'s Grehe, however, we have the one large species of North Amcrica which is distinctly a lover of personal solitude. Its breeding grounds, or perhaps more properly waters, are the sloughs and marshes of the northwest States and Canadian provinces. Here, in the deep bogs, it places its soggy semifloating pile of decaying vegetation anid the areas of reerls or canes growing from the water. One can seldom see the brooding bircl on the nest. On being approached she hastily pulls débris over the three or four dirty-white eggs, conpletely covering them, then slips into the water and lives, showing herself no more until the intruder has surely vanished.

During the breeding searon these Grehes are very noisy. The male (prolably it is he) swims into the open water of the lakes, if such there be. and emits the most astonishing succession of yells and wailings, which probably are the happy expression of the torrent of his tender enotions, though to our ears ther may rather resemble cries of distress. I ater in the season he gets bravely 
ores such manfestations of wealiness, anul is silent enough for anyone. Then he is usually seen "by his honesone," (nut un some budy of water", frepuently on the oetan, well off the beach. where he can exercise to fine advantage his really great powers of diving.

Holbchll's Grebes are hardy hirds, and often winter as far to the north as they can himl orem water, and are frequent in winter along our North Itlantic coast. They have a fatal tendency to linger too late in the northern lakes, and thus they get caush in the ice, or driven to fly south. cannot find open water, and fall exhatsed on the land or into snow bankis. This is notably the case in the month of March, when they migrate morth earlier than is safe. Since they cannot ri e on wing except from water. as their wings are small, many of them perish out of their element. It is a commun nowrrence for farmers and others to pick them un in fields or roads. helplessly waddling about on legs set too far" aft" to make them handy ahome. Put in the water there is no bird more swift and liwile. better able to talie care of itself, more able in the puranit of the mall fry which comstitute its mormal pres.

IIELERT K, Jor.

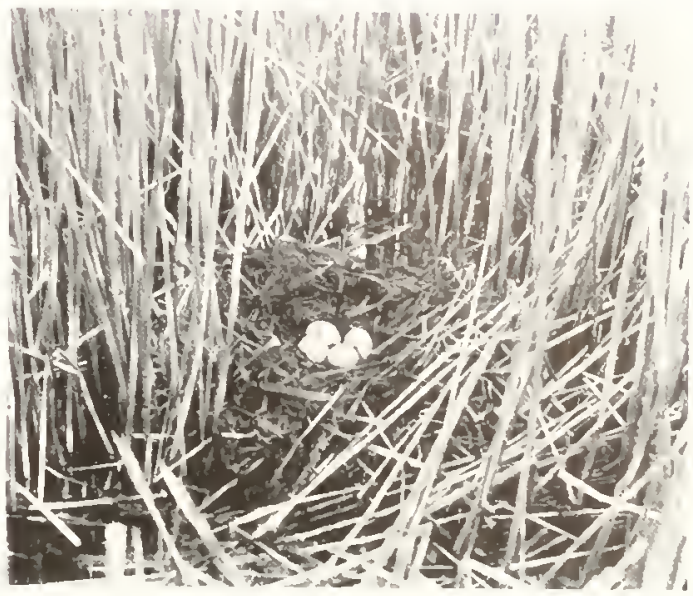

Photo by H. K. Job

NEST OF HOLBCELL'S GREBE

\section{HORNED GREBE}

\section{Colymbus auritus Limnäs}

1. O L. Number 3 hee Color I'late I

Other Names.-Hell-diver: Mater-witch; Devil diver; Pink-eyed Inver; Dipuer.

General Description,- Length, 14 inclies. Culor above, crayish-brown or dusky-gray; helow, white. In summer, adults have crests or ruffi on cheeks and iniles of head.

Color.-Avelts in Summer: Crown, chin, throat and crest, ulossy uromish-hlack: a stripe from bill through eve and above it, widening behind to nape, broinish-gellow: upper parts, graysh-brown: feathers. [ralep-edged; primaries, duky-brown; sicondurics, white neck all around (except for dusky stripe behind), sicles, and tanks, rich brownish-rufous: rest of under barts, alky-white; bill, ducky tipperl with yellow; iris, carmine with white ring; feet, ducky outcile, yellow in-irle. Mults In Winter, And Youns: Ruff, obsolete;

lorned cirebes are commonly linown as "Hell-divets" or "Water-witches," because of their fateility in disapuearing and the mbstery as t) where they so. This species often mystilies the hunter by sinking slow?y backward until nearly out of sight or by diving and disappearing altogether, until the novice is ready to make oath fureheat, crown to level of eves, a narrow strip down back of neck and upper part, lniky-gray; feathers of back with lighter edges: wings, as in smmmer: chin. throat, and sides of head. nure silky-white: front of neck and lower abdomen, washed with gray ; bill, dusky. rellowish or blukh-white luelow

Nest and Eggs.- Nest: A buoyant platform of dead reeds, grass, and regetation. Egrs: 3 to 7 , white.

Distribution. - Northern lart of northern hemisphere: breeds from the lower Yukon across British America to southern Ungava and the Magdalen Islands. south to southern British Columhia, across United States on abut the parallel $5^{\circ}$ to Maine: winters from southern British Columbia, southern Ontario, and Maine south to the Gulf coast and Florida; casual in Greenland.

that the hird has committed suicide for fear of his deadly marksmanship; lut the Grebe merely submerges and swim heneath the surface until among the water plants, where it remains secure with its beak just protruding monoticed above the water, or hidden by some overhanging leaf. When wounded it sometimes dives 
and swims along under water to the cover of overhanging vegetation on the bank, when it creeps ashore unseen and hides anid the verdant cover.

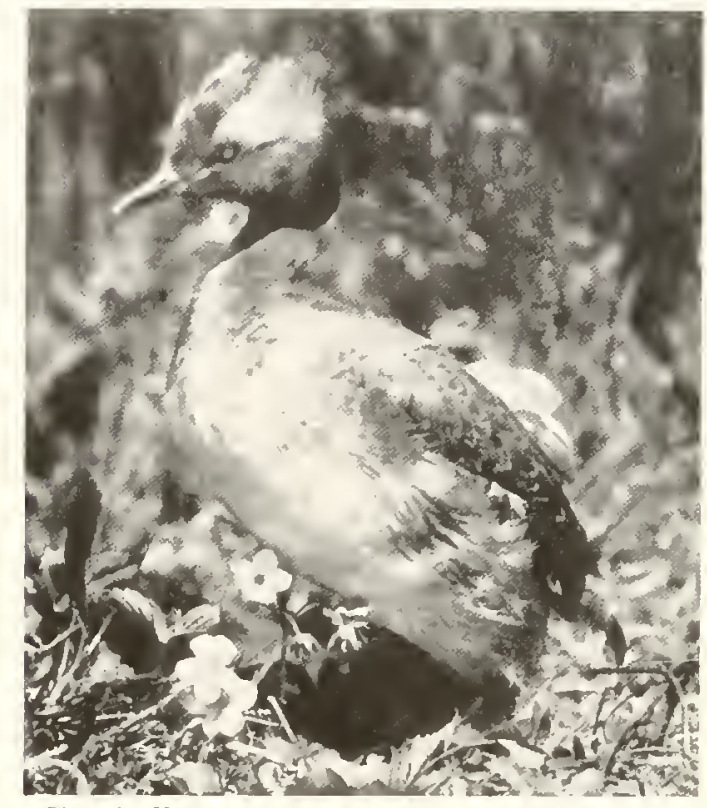

Photo by H. K. Job Courtesy of Outing Pub. Co. HORNED GREBE (Spring Plumage)
This Grebe is one of the quickest of divers, often escaping a charge of slot by its activity in going under. When alarmed it lies very low in the water, and, if it can get its head and neck beneath the surface before the shot reaches the spot, its vital parts are likely to escape unharmed. It frequents sma!l ponds and little streams with grassy banks, but where much persecuted by gumners secks the larger lakes or the sea for greater safety. Ordinarily in swimming under water it does not appear to use its wings, but probably all diving birds utilize their wing power when in pursuit of elusive prey. Mr. (C. IV. Vibert of South Windsor, Connecticut, kept a bird of this species that was seen to raise its wings slightly when swimming beneath the surface.

When storms prevail at sea in fall and winter flocks of Grebes often are driven into the ponds of the interior. At such times they may be seen asleep on the water in the daytime with the head drawn down on the back and the bill thrust into the feathers of the shoulder or breast, keeping their place head to the wind by a sort of automatic paddling. Sometimes a sleepy bird uses only one foot and so swings about in a circle.

Edward Howe Forbusi.

\section{EARED GREBE}

\section{Colymbus nigricollis californicus (Hecrmann)}

\section{A. O. U. Number 4}

Other Names.-American Eared Grebe: Eared Diver.

General Description.- Length, 12 to 14 inches. Color above, dusky: helow, white. In smmer adults have lomy, fan-shaped car-tufts of fuc feathers.

Color.-Abulas in SUMMer: Ear-tufts, yoldenbroa'n: croan, chin, throat, and ncck all around, black: upper parts, dusky; primaries, lltsky ; secondaries, white, dusky at base; sides, deep purplish-brown with a wash of the same color across breast and on uncler tailcoverts; under parts, silky white: ablomen, tinged with gray; bill, black: feet, olive, dusky outsirle and on soles; iris, red; eyelids, orange. Anults $1 \mathrm{~N}$ WINTFR: No ear tufts; crown and narrow hand on hack of neck and upper parts, grayish-clusky; chin, throat, and sides of head, white; under parts, silvery-white; sides and flanks, tinged with gray.

Nest and Eggs.- Nest: A Hoating platform of reeds and vegetation, on shallow lagoons, ponds, or lakes. EGGS: + to 6, soiled white.

Distribution.- Western Nortli America; breeds from Central British Columbia, Great Slave Lake, Saskatchewan, and Manitoha south to southern California. northern Arizona, northern Nebraska, and northern Iowa; winters from central California southward to Cape San Lucas and Guatemala; east to Kansas in migration; casual in Missouri, Indiana, and Ontario. ()ut on the main part of Malheur Lake in southeastern Oregon. We came upon a colony of Eared Grebes. Thene hirds were nesting well out in the open water. I comted one hundred and sixty-five nests scattered over an arca of two or three acres. Some homes were but a few feet alpart. The nest itself was a very interest- ing structure. It was built entirely of water weeds, commonly called milfoil. which grew in the shallow water. The nest consisted of the long slender runners yulled together from a distance of several feet around. It looked to me as if these weeds when piled together. would sink. On the contrary, I found the nest quite 
buoyant. Long red stents, kept alive by the water. often extended to the botton. In a few cases, I found the birds had collected picee of dry tule stems as a sort of lining to their platform nests. Firom a distance, the nest colony presented a line of blood-red against a background of green tules.

When we approached the Fared Grebe colony, paid no attention to this. I watehed one burl an she pritled up the stems out of the water and from the lining of the nest covering her exgs completely, so when we came near, there was not an egg in sight. I do not know whether this habit develops more from the idea of protecting the eggs from cnemies, or from the idea of keeping them warm when the mother is away. The

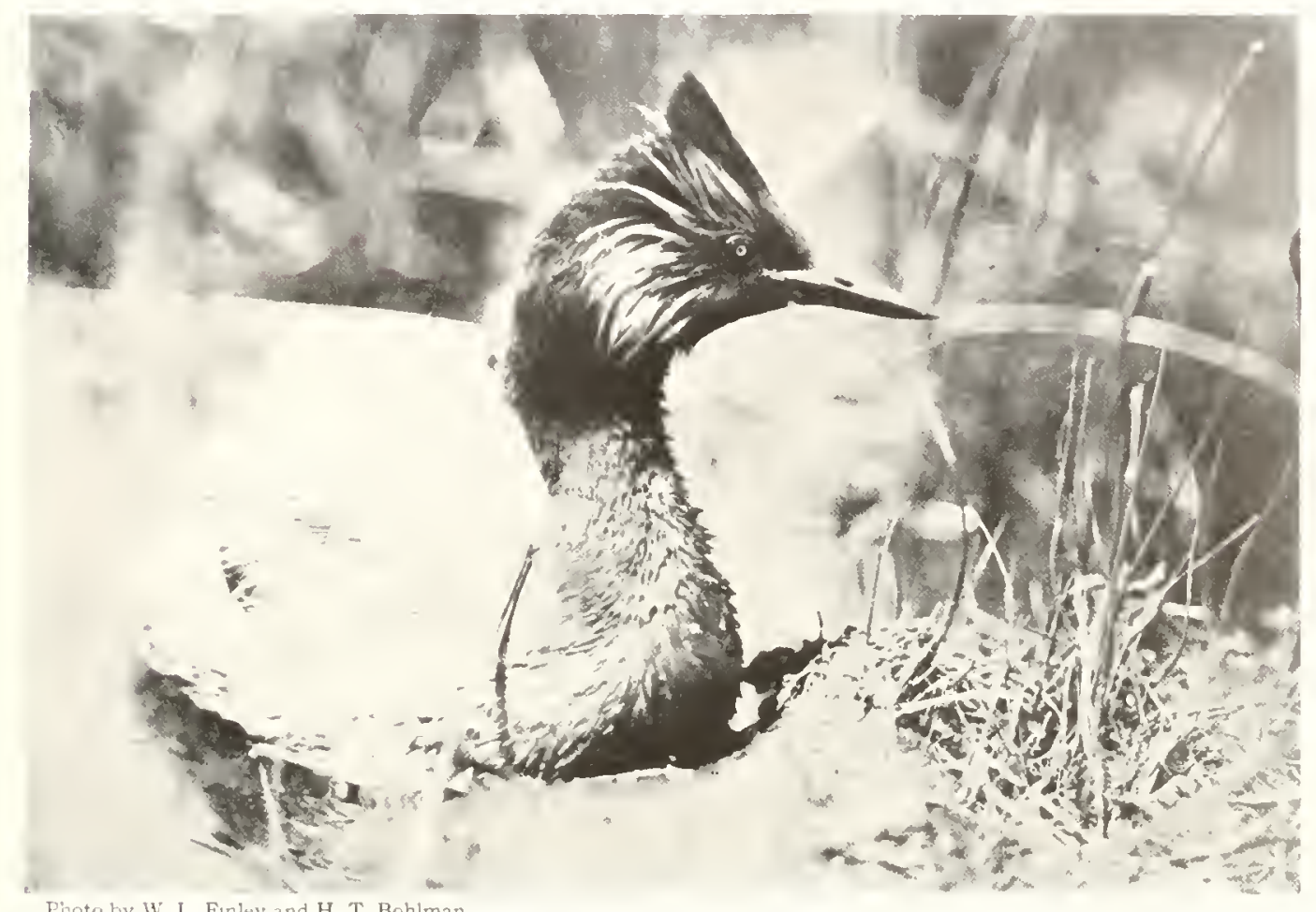

Fioto by W. L. Finley and H. T. Bohlman EARED GREBE (Spring Plumage)

Though a water-hird, it is never wet

everything was bustle and hurry. The birds were trying to cover their eggs before leaving. It seemed to be a habit in this colony to cover the eggs, while the ITestern Grebe on the same lake eggs often lie partly in the water. The sun, I think, helps a grood deal in hatching the eggs rluring the day, the bird keeping a more careful vigil at night.
W'tlliail L. Finley.

\section{PIED-BILLED GREBE}

\section{Podilymbus podiceps (Limiens)}

A. O. U. Number o see Color Flate I

Other Names.-Hell-diver; Devil-diver: Waterwitch: Dahchick: American Dahchick: Pied-liflerl Dabchick: Dipper: Dicdapper; Didapper: Divedapper; Carolina Grebe: Thick-billed Grebe.

General Description.-Length. 13 inches. Color above, brownith-black; below, lighter brown and white. Bill, chort and thick: 110 crests.
Color.-Ant'lts: Crown, back of head, and neck. grayish-black streaked with lighter; upper parts, hrownish-black; sides of head and neck, brownish-gray; chin and throat. hlack; primaries atid sicondarits, chocolatehearn: bolon. pale lwatnish-ash, thickly mottled with dusky on sides: lower abdomen, mostly dusky: bill, whitish, dusky on ridge and tip aith a black oncircling 
band a little forward of the center; feet, greenishdusky outside, leaden-gray inside; iris, brown; eyelids, whitish. ADults IN Winter: General coloration on head and upper parts more brownish than in summer: the feathers of back with paler edges; neck, breast, and sides, light brown mottled with dusky; under parts, pure silky white; lower abdomen, grayish.

Nest and Eggs.- NEST: A floating structure of dead grass, reeds, mud, and vegetable matter, unattached or fastened to living rushes. EgGs: 6 to 9, white, sometimes tinged with greenish.

Distribution.- North and Soutl America; breeds from liritish Columbia, southern Mackenzie, southern Keewatin, Quebec, and New Brunswick southward to Chile and Argentina; winters from Washington, Texas, Mississippi, and the Potomac valley southward.
The Pied-billed Grebe is the nost widely distributed of the Aneriean Grebes and in the United States is the only one that breeds over most of the region east of the $\mathrm{Nississippi.} \mathrm{It}$ appointed Hawk has gone his way. As a diver it has few equals in the bird world. Many times, especially in the days when muzzle-loading shotguns were still in rogue, I have seen it

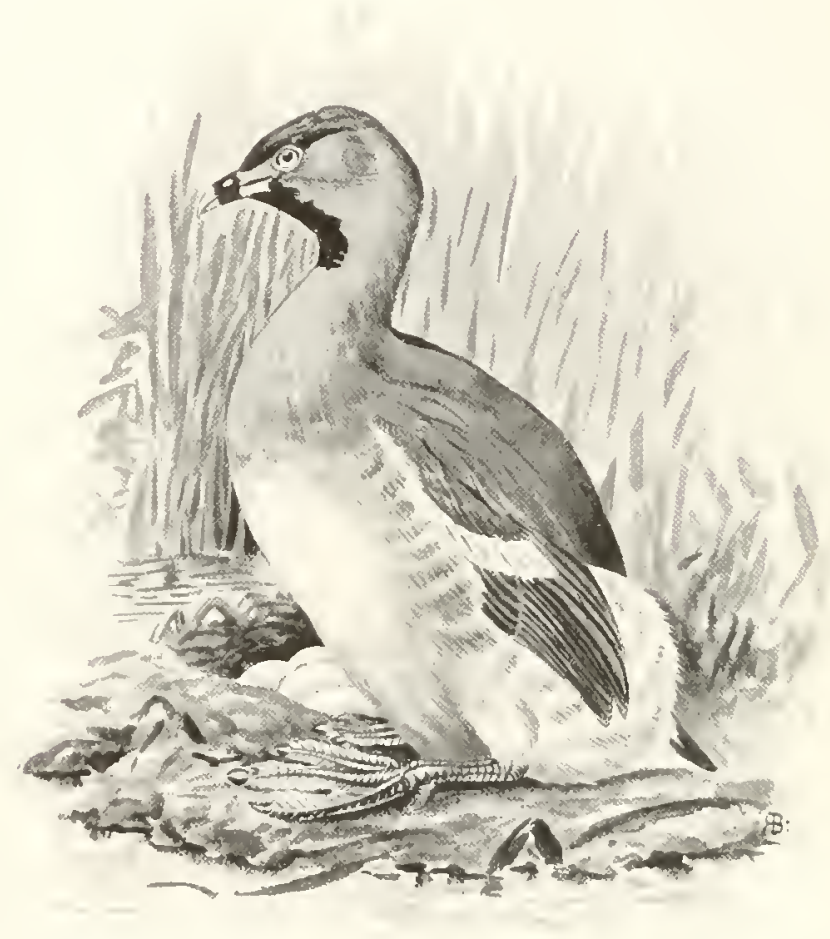

Dratwing by R. I. Brasher

PIED-BILLED GREBE (4 nat. size)

A more accomplished swimmer than any Duck

is at home in the water to an astonishing degree, in fact " Water-witch" is one of the favorite local names by which it is known. it is a more accomplished swimmer than any Duck of which I have knowledge, for it possesses the wonderful faculty of lowering its body in the water to any desired stage of subnersion, and this it can do either while swimming or while remaining stationary, as may suit its fancy. At times only the bill and eyes will appear above the surface, and in this attitude it can remain apparently without distress until the bewildered hunter or the dis- dive at the flash of discharge and be safely beneath the surface before the death-seeking shot came over the water. "Hell-diver," by the way, is another name applied to Grebes as well as to I.oons.

The remarkable nest made by this species is quite in keeping with its other unusual and secretive characteristics. It is made of decaying vegetation brought up from the botton of the shallow pond where it breeds. This unattractive mass is usually piled on a platform of green stems of water plants, which, because of their 

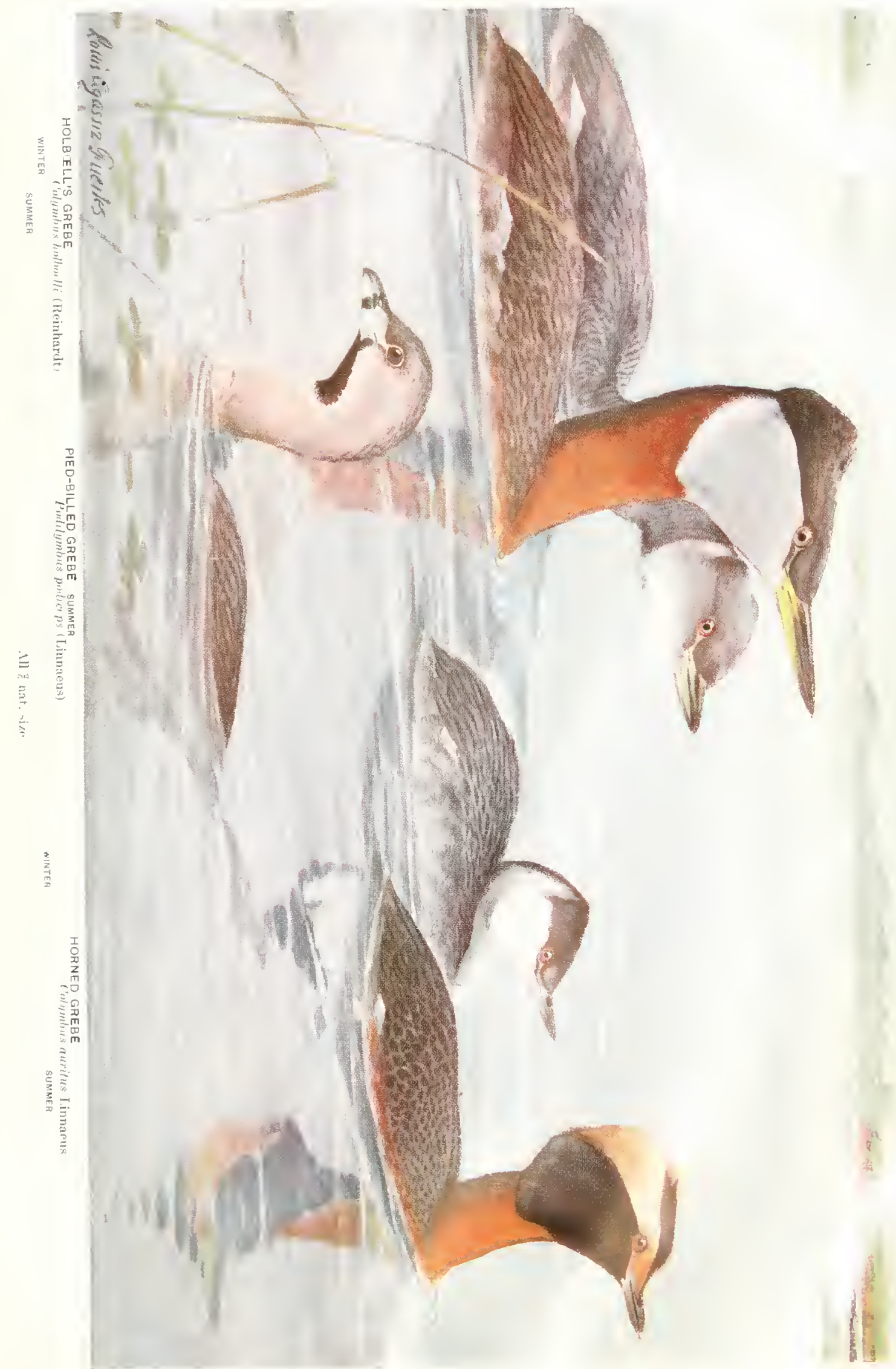
fresh condition, will readily float and are of sufficient busancy to bear the weight ot the nest. the eggs, and the lirooding bird. In Florida, where I have examined perhass tifty of their nests. I never found more than six egge in any one of them, but observers farther north speak of hindins as many as eight and nine. In colur they are dull white. unspotted, but smetintes tingerl with greenish. and always soiled or stained.

Ihen leaving its nent the cirelye pulls the water-soaked material well oxer the exsso, so that usua!ly they are completely hidelen from riem. While in this condition anyone not acquainted with the nesting labits of the bird would surely pass it by amnoticed, never dreaminer that in that little mass of Hoating, rotting water-plants the cherished treasures of a wild hiret hay conceated.

Audubon said that the ford of the l'ierl-billed Grebe " consi-ts of small fry, plant-sereds, aquatic insects, and snails; atong with thes they swallow gratul." Nayne writes: "During the hreeding -tason. the foon consicts mainly of tecones." They shoutd never be shot, for they are worse than useless for fond. They certainly do no harm, and an ever-increasing class of fird-students take much pleasure in spying upon their interesting moventents.

They have many enemies, among which may be mentioned minks, tish, frogs, snakes, and muskrats. lirds of prey undoubtedly take their share. (1) day with much lahor I climbed an enormous pine tree to a nent of the Bald Fagle around which the old hirds were circling. Lpon reaching it after a prolonged and heart-loreaking effort I foumd it to contain nnly one ohject - a P'iedbilled Grehe, with its feathers still dimp and the hood spots on its head hut halt drierl.

T. GILPERT I'LAKSON

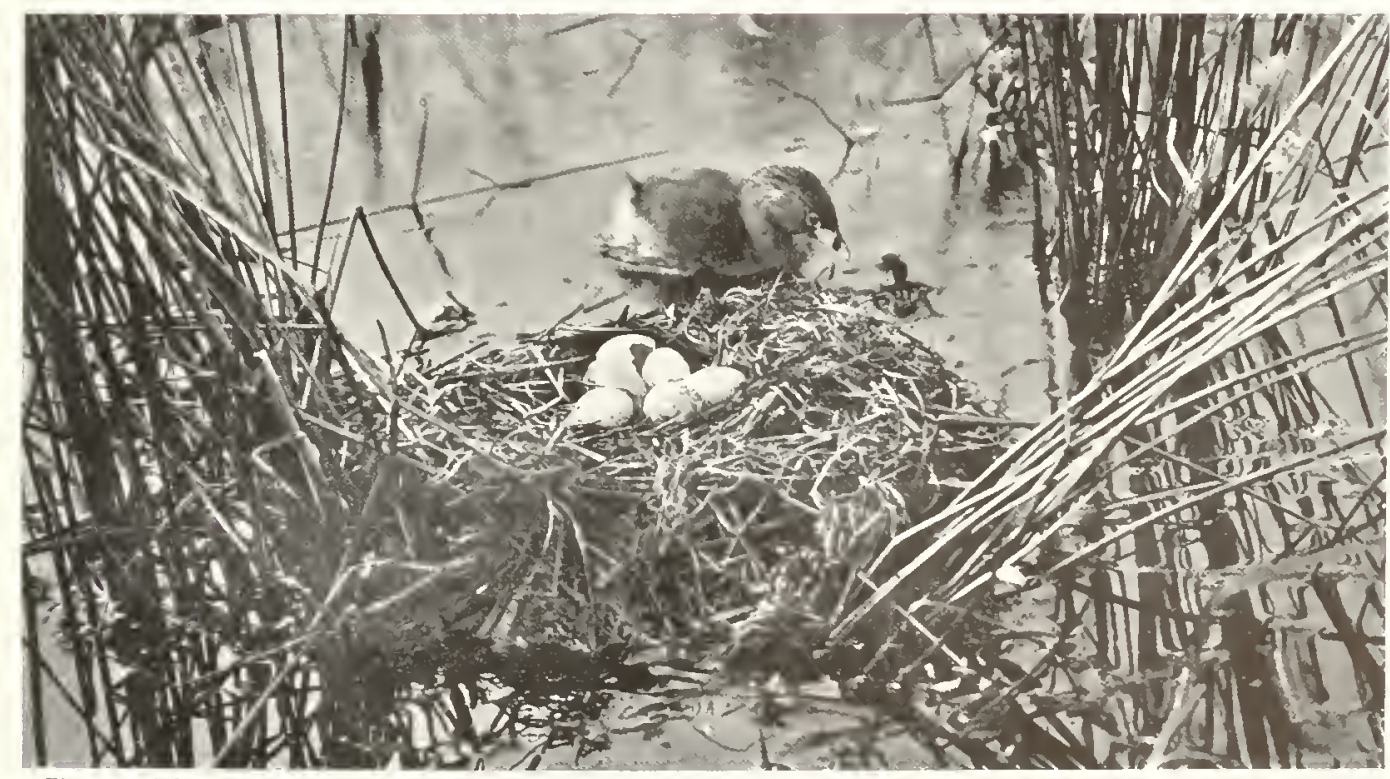

PIED-BILLED GREBE

Swimming up to its newly hatched young that has struggled from the pest 


\section{LOONS}

\section{Order Pygopodes; suborder Cepplit; family Gaviida}

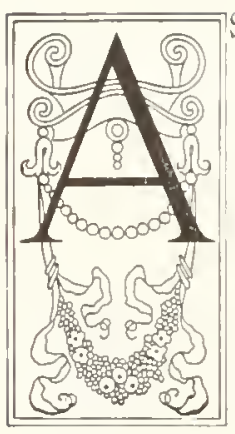

S a family the Loons of the present seem to be very much the same kind of birds as were those of which we have fossil remains in strata representing what the geologists call the Miocene Epoch of the Tertiary Period. They are birds of considerable size, and are famous especially for their skill and swiftness in swimming and diving and for their weird and unearthly cries. Their quickness in diving to escape danger is truly astonishing, and has, naturally enough, furnished occasion for frequent exaggeration, also excuses for much bad shooting by gunners who assert that they held true, but the Loon "dodged the shot." "They have a peculiar faculty of sinking gradually in the water without apparent effort and with little or no rippling of the surface of the water.

$$
\text { Summer Winter }
$$

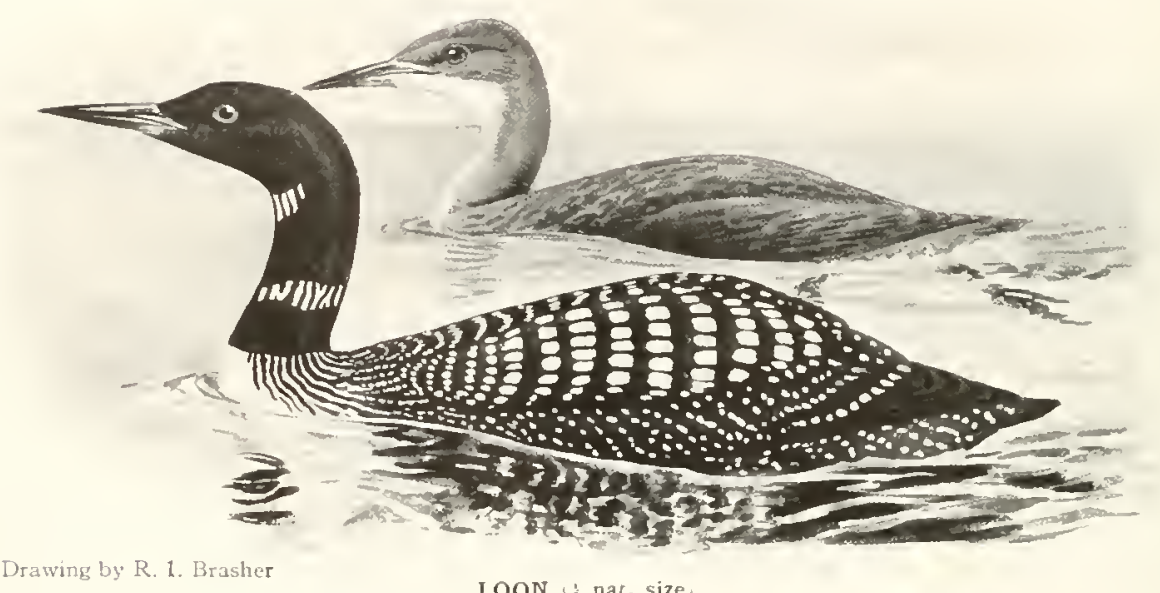

Drawing by R. 1. Brasher

LOON 16 nat. size

A clumsy, awkward traveler upon land, but almost unexcelled as a dive:

Loons take wing with considerable difficulty, but once in the air their flight is swift and usually in a straight line. At all times the sexes present the same general appearance. Their prevailing colors are blackish or grayish above, with the under parts whitish; in summer the darker parts become speckled with white. These markings do not appear in the young nor in the winter plumage of the adults; the very young are covered with a sonty grayish down, changing to white on the lower abdomen. The head is never crested, but both head and neck are velvety. The plumage of the body is hard and compact. The wings are pointed, short, and rather narrom. The eighteen or twenty tail feathers are short and stiff. The hind toe is small and the front toes are fully webbed. The bill is stout, straight, narrow, sharp-pointed, and sharp-edged; it is so constructed that it serves as a spear for catching and holding the slippery fish which are the bird's chief diet.

Though related to the Auks, which show a highly developed gregarious instinct, the Loons are essentially solitary birds, and commonly are found singly or in pairs. The formation of ice in their natural habitats, however, at times forces a considerable number of individuals to occupy the same comparatively small stretches of open water.

The distribution of the Loons is circumpolar, and the single genus includes five species. In the hreeding period they occur generally in the cooler regions of the northern hemisphere, and frequently some distance north of the Arctic Circle; in winter they scatter southward 


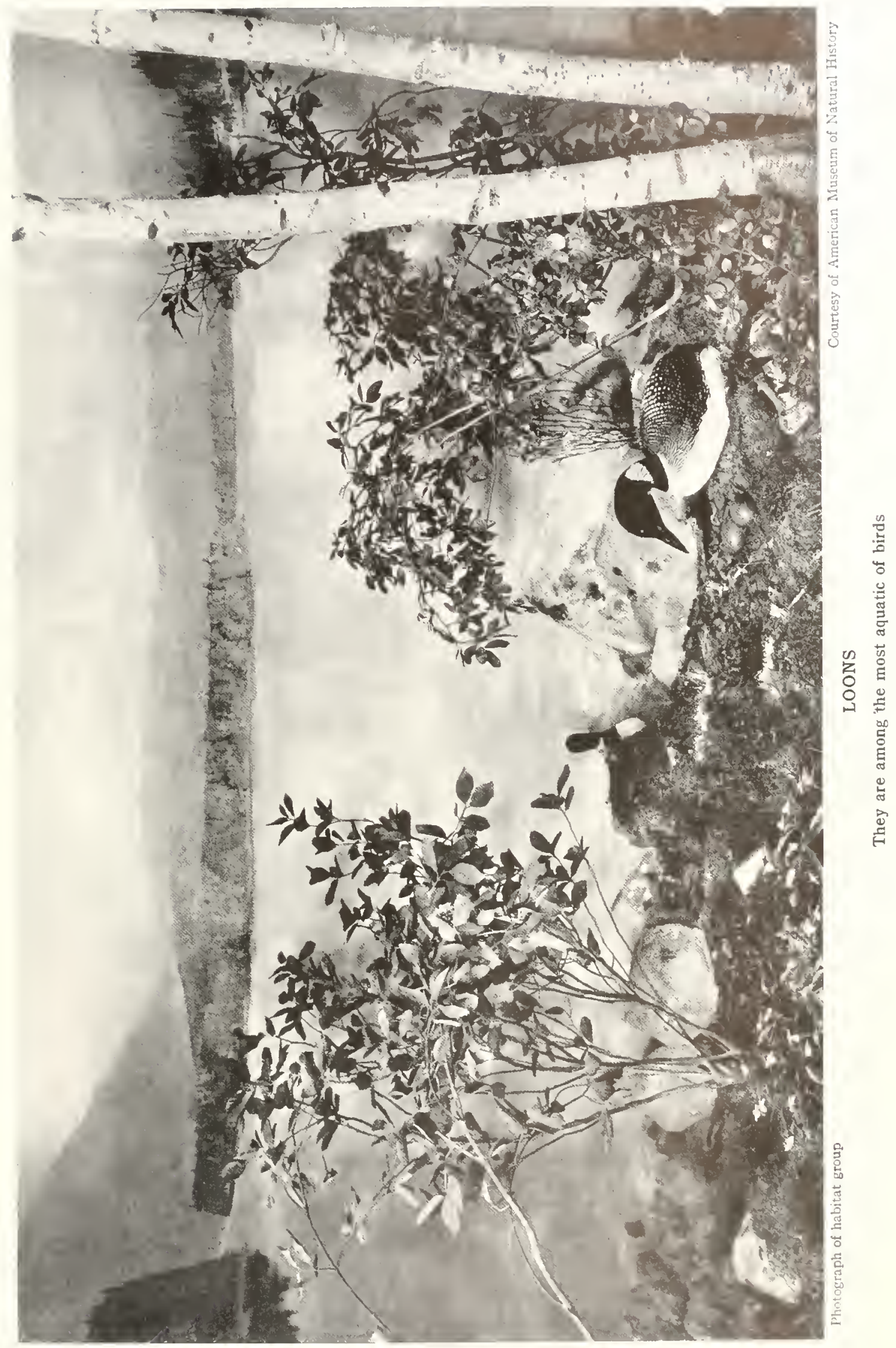


into the temperate regions, especially along the seacoasts. The nests are rude structures, composed of moss and grass sometimes plastered with a little mud, and are built on the ground usually along the shore of a lake and frequently on top of the abandoned lodge of a muskrat. The birds seem to make no attempt to hide their nests, but the two eggs, by reason of their olive or brownish shades, which are broken by blackish or brownish spots, are decidedly inconspicuous.

The ery of the Loon has been variously described as mournful, mirthful, sinister, defiant, uncanny, demoniacal, and so on. At any rate, it is undeniably distinctive and characteristic, and is almost certain to challenge the dullest ear and the most inert imagination, while in those who know instinctively the voices of Nature, especially when she is frankly and unrestrainedly natural, it produces a thrill and elicits a response which only the elect understand.

\section{LOON}

\section{Gavia immer (Briunich)}

A. O. U. Number 7 Sec color l'late.

Other Names.-Common Loon: Pig Loun: Great Northern Diver; Imber Diver: Hell-diver; EmberGoose; NTalloon; Ring-necked Loon ; 13lack-billed Loon: Guinea Duck: Greenhead.

General Description.- Length, 28 to 36 inches. IN SUMMER: Upper parts, glossy black with white spots; minder parts, white. IN VINTER: Upper parts, grayishbrown without spots.

Color.- ADLLTS IN Summer: Head and neck all aronnd, glossy purplish-black with greenish refections; a patch of sharp white streaks on lower throat; another of the same kind on each side of neck, separated in front, but sometimes meeting behind; cutire uppr parts, ainy-corerts, and inner secondaries, glossy black. thickly marked with white spots - those of shoulders. inner" secondaries, and hack, large, square, and regularly arranged traversely, those of other parts oval, smallest on rump and wing-coverts; upper tail-coverts, greenish-black: primaries, dusky: lower parts from neck, ahite: sides of breast, streaked with black; bill and feet, black; iris, red. Anults IN MINTER, ANU
Yotsg: Crown, neck and upper parts, in general, grayish-brown, the feathers of hack with lighter cdges; primaries, lalack: tail, gray-tipped; sides of breast, mottled: chin, throat, and neck in front (narrowly), and under parts, white with some dark feathers on sides and under tail-coverts, thus no black or wlite spots; hill, dusky, bluish-white at base and below: feet, lighter than in summer; iris, brown.

Nest and Eggs.- Nest: Usually a hollow in the sand, without nesting material; in some localities a rough nest is constructed of sticks and reeds; occasionally the top of an old muskrat house is utilized. Eritis: 2, dark olive-gray, stained with brown and spottel with black.

Distribution.- Northern part of northern hemisphere; in North America breeds from Alaska across Arctic North America to Greenland, south to northern California, across the United States at about the parallel $42^{3}$ to Nova Scotia: winters from southern British Columbia, the Great Lakes, and southern New England to Lower Californa, the Gulf coast, and Florida.
Of all the wild ereatures which still persist in the land, despite settlement and civilization, the Loon seems best to typify the untamed savagery of the wilderness. Its wolt-like cry is the wildest sound now heard in Massachusets, where nature has long been subdued by the rifle, ax, and plow. Sometimes at sea, when I have heard the call of the Loon from afar, and seen its white breast flash from the crest of a distant wave. I have inkigined it the signal and call for help of some strong swimmer, battling with the waves.

It is generally believed that in migration at least the Loon passes the night upon the sea or the bosom of some lake or river. The Gulls,
Auks, Puffus, and Cormorants, which live upon the sea, usually alight upon the high shores of some rocky island or on some lonely sand bar at night, lout the Loon is often seen at sea when niglut falls, and its cries are heard by the sailors during the hours of darkness. Notwithstanding the general belief that it normally sleeps on the water, I believe that it prefers to rest on shore at night, when it can safely do so. Audubon satisfied himself that on its breeding grounds it was accustomed to sprend the night on shore. On an island off the coast of British Columbia, where there was no one to trouble the birds, 1 once saw, just at nightfall, a pair of Loons 


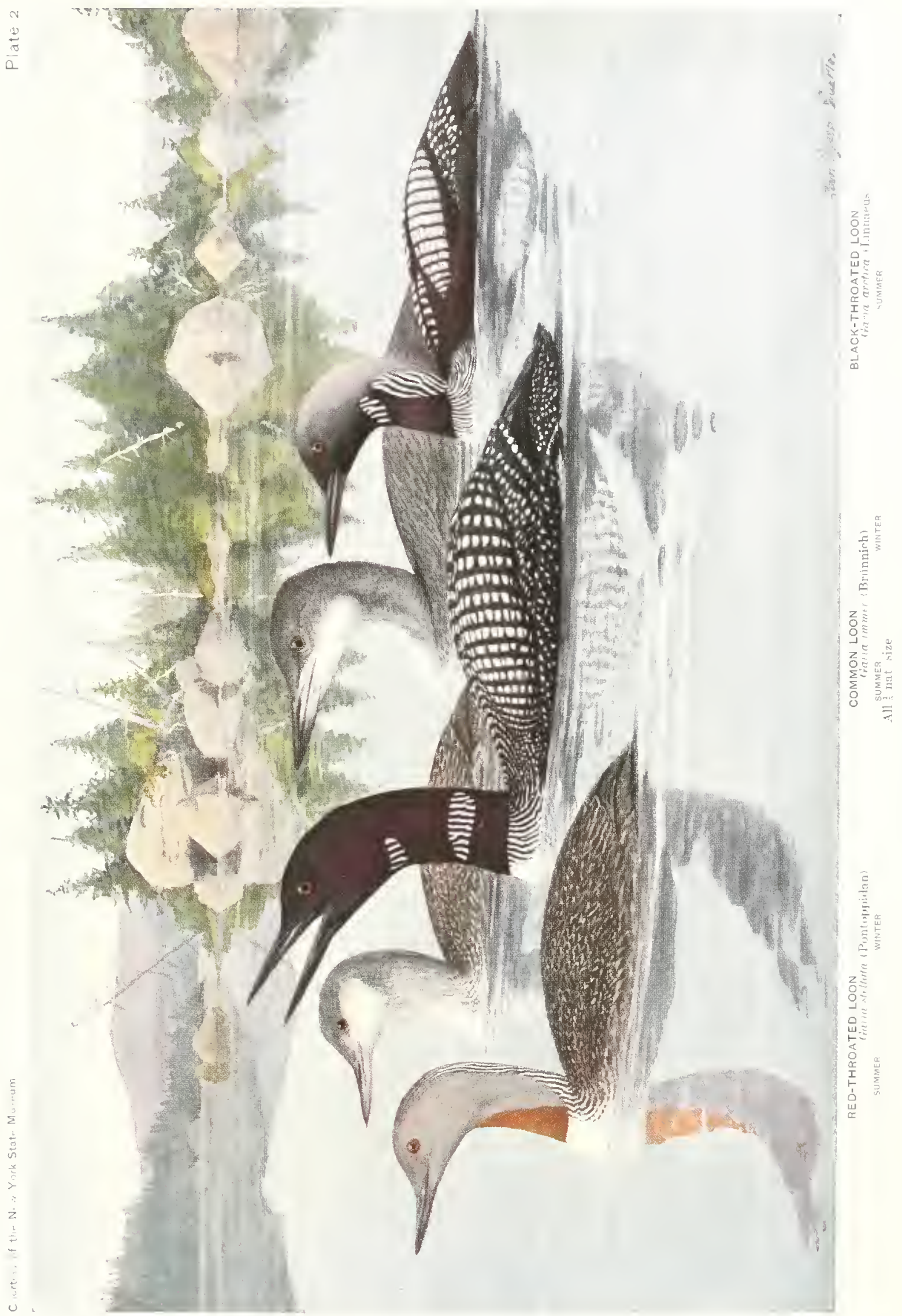



resting flat on their loreasts at the end of a long sandy point. Cripples instinctively seck the shore when sorely wounded, but on inr coast a Loon must keep well off shore to insure ite saffety. and probably few lut cripples (wer land on shores frequenter by man.

The lonn's ne t is usually a metere Inollow in the log or shore near the water's celge on wme island in a lake or pond. Sometimes the nest is lined with grasses and bits of turf: more rarely it is a mere degression on the top of a mushrat's house, and more rarely still it is placed on the shore of the lake or in some delundeling stream Where the birch are not much dinturled, and where food is plentiful, two or thee pairs sometimes nest on the same inland. No doulst there was a the when nearly every northern pond of more than at few acres contained its pair of Loons, in the breeding season, and this in true to-day uf pumb in parts of some Canculian l'royinces. The nest is msually or near the matrin that the bird can spring directly into the water, but sometimes in summer the water receles until the nest is left sume distance inland.

The lown is a clumsy. ankwird traveler upon land, where, when hurried, it flounders forward, using buth wings and feet. Andethon, howeser. says that his sun, J. W. Audubon, winged a Loon which ran about one hundreel yards and reached the water before it was overtaken. Its masul methou of taking to the water from its nest is by plunging forward and sliding on it, hreast. It cannot rise from the land, hence the neeessity of having the nest at the water's erfge.

When the young are hateled the mother carries them about on her hack a few day after which they remain atfoat much of the time until they are fully grown. If food becomes scarce in their native pond they sometimes lave it and travel overiand to another. Dr. James 1'. Flatch of Springtiede, Mas., says that early in the morning the parents and the well-grown young run races on the lake, uning their broad paskles for grojulsion and their half-extenderl wings for plartial support. Starting all together they race fowm the lake, and then, turning, rush biack to their starting print. Such exercises nu doubt strengthen the young birds for the long flights to comes.

The Loon funds some difficulty in rising from the water, and is obligerd to rom along the strrface, Happline its short wings, tuntil it gets inyertus efontigls to rise. It is sairl that it cammot rise at all umlese there is wind to atsist it. Its sureat weight (from eight to nearly twelve pounds) and its shont wings make flight laborious, lut ite rapid wing-beats earry it through the air at great speced. When it alights it often shrots spirally down from a great height, and plunges into the water like an arrow from a bow. It lands with a splash, and houte alome the surface until its impetus is arrested ly the resintance of the water.

The Loon is almost mexeelled as a direr. It is stpposed to be able to lisappear so suddenly at the flash of a ritle as to dodge the bullet. unless the shooter is at print-blank range, hut when two or three crack shots sturumen a small frond in which a Loon is resting it ean usually be secured by sood strategy. 1 mee saw a lenom litled on the water with a shotgun, bett the bird was taken at a disalvantage. It was on the Banana River. Fla., in Jantary, 1000 , and it had followed the fish (which were then very numerous) into the shallow water near the shore. Shoals extended out from the shore fully three hundred yards, so that the hird, in diving and iwimning under wate'. could not use it wings to adrantage. It was much impeded by the shoals and the vegetation on the bottom, and in swimming was so near the surface that its course contd le followed readily by the riplple that it made. Two strong rowers were thus enabled to follow ancl overtake it. It cscaled the first charge of slut, but its fursuers came so chose the second time that the shot went home. In reepr water. where the bird can use its wings and fly under water like a bolt from a crossbuw, it can easily elude a boat. In olil times the gunner used to "toll" the Loon within sunshot by cuncealing himself and waving a brightly colored handierGhet. While imitating the bird's call. But this will rarely swceed to-day in luring one within reach of a slotgram.

Loons are rather solitary in the autumn migration. They leave their nurthern homes and some begin to more southward in septenther, but many remain in the northern lakes until the ice comes. They move sutth along the larger rivers of the interior, but most of those near the Atlantic take the sea ats their highway.

The Loon feeds very largely on fisll. As it rests lightly on the surface it frefuently throts its head into the water and lonks ahout in search

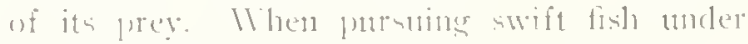
water it often uses it wings, loy means of which it can overtake the swiftest. Whis has been refeatedly observed. It call travel muth faster moler water in this mannet than it ean on the surface by use of the feet alome.

FowARD 1 Jowe Forbust, in Game Birds. llitd-lion'l and Shore birds. 
The Yellow-billed I,oon, (Garia adamsi) White-billed Loon, or Adans's Loon, as it is variously called, is of the same general coloration as the Common Loon. The throat and neck patches, however, are smaller and the bill, which is larger and differently shaped, is pale yellowish white. It is subject to corresponding seasonal changes.

It breeds in northern Siberia, on the islands north of Europe, and in North Anerica from northwestern Alaska, northern Mackensie, and Boothia l'eninsula south to the month of the Jukon and to Great Slave Lake. Its nests and eggs, as far as known, are sinnilar to those of the nore fanilar Loon. In migration the Yellowbilled is found a little south of its breeding range, and specinnens have been reported from Colorado and Grcenland.

\section{BLACK-THROATED LOON}

\section{Gavia arctica (Limnous)}

A. O. L. Number 9 see Color P'late 2

Other Names-Arctic Loon; Arctic Diver: 1;lackthroated Diver.

General Description.- Length. 2- to 30 inches. IN SuMner: Upper parts, glossy greenish-black with white spots: lower parts white. IN WINTER: Upper parts, grayish-brown without spots.

Color.- Ancits in SUMMer: Chin, throat, and front of nock, purplish-black, shading gradually into clian soft arart aray of croan. back of hid, and hindncek, deepest on forehead and face. lightest behind, and separated from black of front of neck by white streaks: a short crescent of white streaks across upper throat; sirles of breast and neck striped with jure white and ylossy black, the black diminishing behind into pure white of under parts: upper parts, glossy greenish black, each feather on shoulders and back with two white square spots near end forming traverse rows: wing-coverts thickly specked with small oval white spote; a narrow dusky band across lower belly; under tail-coverts, with dusky spots; bill, black; ieet, dusky; iris, red. Anums IN Winter, ANu Yolno: Upper parts of head and neck, dark grayish-brown; sides of head, grayish-white finely streaked with brown; uppor parts, brozinish-black, feathers aith broad gray maryins, gizing a scaly appcarance; rump, brownish-gray; primaries and their coverts, brownish-black; secondaries and tail-feathers, dusky margined with gray; forepart of neck, grayish-white faintly dotted with brown, its sides streaked with same: lower parts, pure white: sides of body and lower tail-coverts, dusky edged with bluish-gray; bill, light bluish-gray, dusky on ridge; feet, dusky ; iris, brown.

Nest and Eggs.-Nest: A depression in the tundra or constructed roughly of decayed vegetation. Ecigs: 2. deep amber to pale greenish-gray

Distribution. - Northern part of northern hemisphere; breeds from Kotzebue Sound, Alaska. west along northern coast of Siberia, on islands north of Eturope, and from Cumberland Sound south to Ungava; winters in the southern Canadian provinces; rarely south to Colorado, Nebraska, Iowa, northern Ohio, and long Island, N. I
The general appearance of the Black-throated Laon is like that of its relative, the Common Loon, lut it is somewhat smaller and not nearly so well linown in America since it is seldom seen south of the northern States. There seems to be no reliable record of its appearance south of Long Island. Throughout the interior of Norway and Sweden and far up into lapland, it breeds quite commonly. It is considered to be of rare occurrence in most parts of the Pritish Isles, but on the little islands in the fresh-water lochs from central Scolland northward, and on the Orkney and Shetland islands, may be found its nests.

Its habits alsu are like those of the larger mem- ber of its species. Its progress under water has been estimated at not less than eight miles an hour.

The Pacific L.oon or Pacific Diver (Garia pacifica) is confined to the West. It breeds from Point Parrow, Jianks Land, northern Mackenzic, and Melville l'eninsula, south to the base of the Alaskan Peninsula, Great Slave Lake, and central Keewatin and winters along the Pacific coast from southern British Columbia to Lower Califomia, and Guatalupe Island. In coloration it is similar to the Black-throated Loon, but the gray of the hearl averages lighter and the light spots of the back larger and fewer in number. 


\section{RED-THROATED LOON}

\section{Gavia stellata (Pontoppid(n)}

A. O L Number Ir see color plate:

Other Names,--Sprat Lom, Red-throated Diver; Little Loon: Lape Race: Cape Racer: Scape-grace.

General Description.-Lengtl, 25 inches. Color above, bruwnish-black with white spots; below. white.

Color.-Anelts in Semmer: Crown and broal stripe down back of neck, streaked in about equal amounts with glossy greenish-black and white; throat. sides of head, and sides of mock, ilear a'tum oray with a triangular chestnut patch on lunis throat; upper parts, brownish-black with a green glosi, thickly spotted with dull whitish; primaries, dusky; tail, dusky, narrowly tipped with white; under parts, pure white, shadel along sides and on under tail-cuverts with dusky brown; bill. dusky lead colur; feet, black; iris, hazel. AntLTs I Nixter, AND Fotng: Crown and hindneck, bluishgray; sides of neek, mottled with brownish and white: upper parts, brownish-black, ateryathere thickly marked zuith small oral and linear spots of ahitish; chin, throat, sides of heal, white: no colored throat patch; under parts, as in summer: amount of spottiug variable: in young birds spots usually lengthenel intw olipue lines, preducing a regular diamond-shapeel reticulation.

Nest and Eggs.- NEST: On bank of small ponds; a mere hollow in the ground. Eios: 2, from deep redelish-brown to grayish-green, thinly spotted with brownish-black

Distribution.- Northern part of northern hemisphere: breeds irom Alaska across Arctic America to Greenland, south to Commander lslands, weetern Aleutian Islands, Glacier Bay, across British America to New Brunswick and Newfoundland; winters from southern British Columbia to southern California, and irom the Great Lakes and Maine to Florida; rare in the interior; breeds also in Arctic Europe and Asia. and winters south to the Meditertanean and souhern China.
The Rerl-throated Loon is mainly a salt-water birel while it sojourns in Massachursetts, although occasmonally it is seen on some lake or river. Probably, like many other birds, it was oftener seen on fresh water in early times than now. It is still not uncommon on the Great Lakes, and Davis Bruce of Brockport, N. Y., stated that he had found it on Lake Ontario during every month of the year. In severe weather, when the lakes freeze, this bird, like the Common Loon, is sometimes taken on the ice, from which it is mable to rise, and is ea-ily captured. In autumn it may be seen in small parties or flocks floating and feeding near our coasts. Like Grehes and some wher water-fowl, it uften lies on its side or back while afloat, exposing its white under parts while engaged in dressing or preening the phunage. This species migrates mainly along the cuast in autumn, but as it is not so commonly scen there in spring, some portion of the flight may go north through the interior.

Its habits are similar to those of the Common boon. It is perhaps equally difficult to shoot on the water. When surpriced on land it seeks to escape by a series of hops or leaps, using both wings and fect.

Edwaki, 1 lowe Forbust, in Gome Birds, Il'ild-Fonl and Shorr Birds.

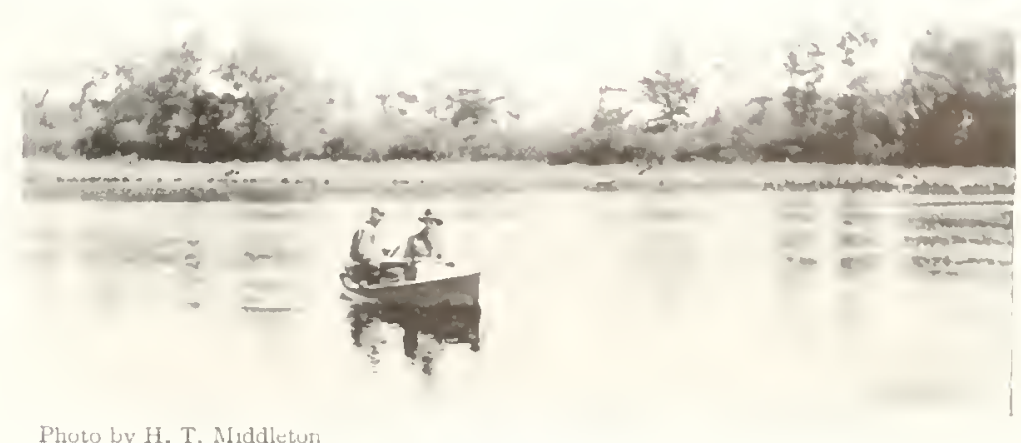

Photo by H. T. Middletun

BIRD-STUDYING 


\section{AUKS, MURRES, AND PUFFINS}

Order Pygopodes; suborder Cepphi; family Alcida

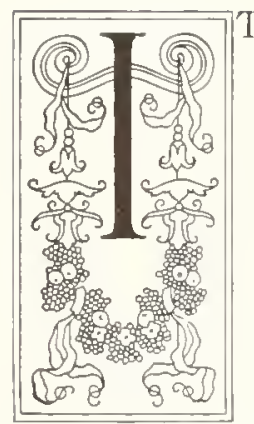

$T$ is a curious and interesting fact that at opposite ends of the earth there should be forms of bird-life which, thongh entirely unrelated and differing from each other even in the signal respect that one is equipped with wings and uses them, while the other is flightless, nevertheless present similar and somewhat grotesque physical peculiarities, and much similarity in their habits. These birds are the Auks of the Arctic and the Penguins of the Antarctic regions, and their external similarity lies in the fact that in both the legs are set so far back on the body that the birds assume a man-like posture, and are clumsy and uncouth in their appearance on shore. In the water both are expert swimmers and divers, though here again they differ in that the Auks use their feet in swimming, whereas the Penguins swim entirely with their wings, and use their feet only in steering their course.

The Auks, Nurres, and Puffins inchude diving Arctic sea-birds grouped under the scientific name Alcida, and embracing about a dozen genera and some thirty species. All members of the family are essentially birds of the Arctic regions, and are especially numerous on the Alaskan and Siberian coasts. Though the Auks resemble the Penguins superficially and in their habits, anatomically their nearest relatives are the Loons and Grebes. From the Loons, however, they differ in lacking a hind toe, and from the Grebes in the possession of a well-developed tail.

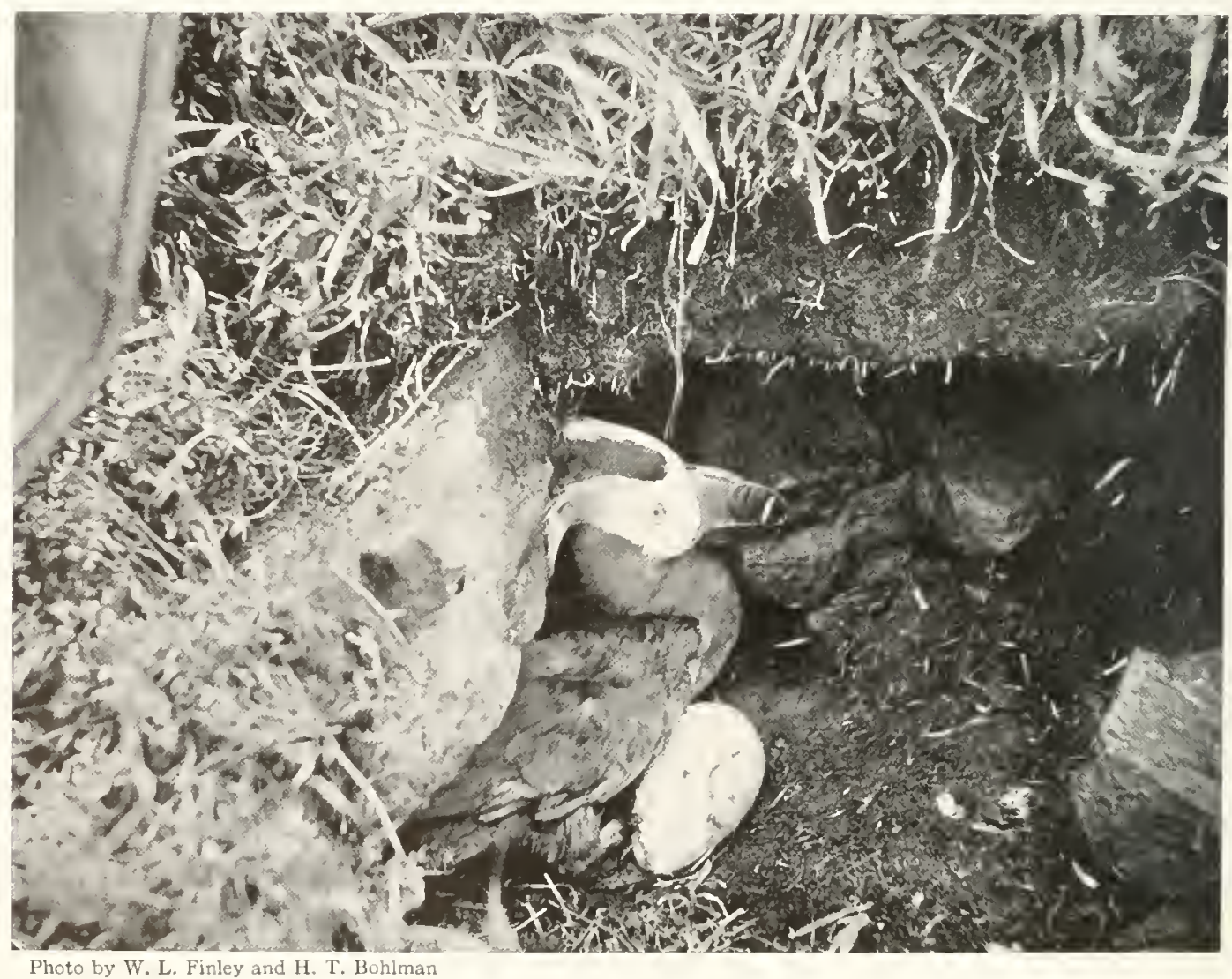

TUFTED PUFFIN ON NEST

Burrow unearthed 
The wings are short, but they are used with great efficiency when the birds swim under water. In their sitting posture on land the birds' fect extend horizontally in front, and they' appear to be resting on their rumps. Un the sea they are in their element, and here they get all of their food, which includes fish, taken chiefly by pursuit under water, and other animal forms. Because of this life their plunage is remarkably thick and dense, and is much used 1 y the Eskimos in making elothing.

In distribution the Auks are very unequally divided between the two northern oceans, the Atlantic having few forms in comparison with the Pacific. 'The largest number of species and the most diversified forms are found on the northern coasts of the Pacific, though the aggregate of individuals of any species found there does not, according to Dr. Coues, exceed that of several Attantic Ocean species. The same authority says that a "more or less complete migration takes place with most speeies, which stray southward, sometimes to a considerable distance, in the autumn and return again to breed in the spring. A few species appear nearly stationary." Many of the migrating Auks pass the winter on the open sea or on drifting ice.

At the approach of spring weather, the birds return to their northern breeding grounds where they gather in immense numbers on rocky cliffs along the coast. No nest is built, but the single egg, which is laid in niches or on ledges, is covered constantly by one or the other of the parents. The color of the egg varies greatly with the different species. The young are helpless when they are hatched, and it is not known with certainty what methods are employed by the parents to get them to the water. It seems not unlikely that the chicks are sometimes carried to the sea by the adults, though doubtless many of them reach the water by scrambling and falling down the cliffs. These Auk colonies are frequently raided by foxes, weasels, and other predacious animals and birds, not to mention the Indians and Eskimos who depend largely upon the birds and their eggs for winter food.

\title{
TUFTED PUFFIN
}

\section{Lunda cirrhata (Pallas)}

\author{
1. () I". Number 1.
}

Other Name.- Sea Parrot.

General Description.- Length, 15 inches. Color above, black; below, brown; bill, himh, much compressed, ridged on sides; a fold of naked skin at corner of mouth.

Description.-ADLlts In Sumer: A tuft of strawyellow feathers on each side of head about 4 inches long, completely surrounding eyes and contintrous with white of face, forehead, and chin (narrowly); crown between the crests and entire upper parps. except a line un wing along fore-arm (which is white), olossy buchlack: entire under parts from chin, including most of sides of liead, sooty-brownish, more grayiah on ablomen; under tail-coverts, wings, and tail, black: bill, fect, and cye-ring, acrmilion; base of bill, pale oily-green ; rosette of mouth, yellow ; iris, white. Antuts IN Winter: No crosts or white on face: bill, mostly dusky with some touches of reddish; feet. pale salmon: iris, pale bluc: otherwise like summer hirds.

Nest and Eggs. - The single egg is laid on the hare ground at the end of a burrow or in natural cavities among rocks, sometimes within sight, sometimes as much as five feet from the entrance; it is dearl-white, showing obscure shell markings of pale lavender or brownish.

Distribution.-Coasts anrl island: of the Arctic Ocean, Bering Sea, and North Pacific, from Cape Lisburne, Alaska, south to Santa Parbara lslands. California, and from Bering Sea to Japan; accidental in Maine and Greenland.
The islands of the north Pacific, scattered along the shores of British Columbia, form, with their surrounding waters and the verdant coast line, a veritable summer wonderland. Here the mirage makes birds sitting upon the water ap- pear like fleets of ships. Sound is magnified until the explosion of a gun and its echoes roar along the shores, a carnival of sound. Swift tides hoil through narrow, rocky passes, while the shimmering heat of summer gives a touch of 
wavering unreality to all the scene. In this enchanted realm thousands of queer birds move to and fro, and none is queerer than the Tufted Pulfin.

Each looks like a masked caricature of a bird as it comes on, pushing its great red beak straight ahead, its red, splay feet spread widely, its long, cream-colored side plumes flying in the wind, and its little wings "working for two." In spring both male and female acquire a white face, which grives them a masked appearance, and the great, gaudily colored beak reminds one of Mr. Inuch and his big red nose. The beak, a remartable appendage, is nuch larger and showier in the breeding season than at any other time. There are eighteen horny plates, ingeniously formed and arranged, sixteen of which fall off after the breeding season, much reducing the dimensions of the basal part. The unclerlying plates are then brown in color. At the same time the white of the face with its plumes disappears, the entire head becomes blackisl, and the bird remains merely a commomplace Puffin until the next breeding season.

On the Farallons, off the California coast, where these l'uffins nest on barren rucks, they deposit their eggs in holes or cavities among the rocks, but on the northern coast, where each rocky islet has a cap of some four feet of eartl, they burrow into this at the top of the precipice overlooking the sea. Some of their tumnels extend but a few inches. These are believed to be made by the young birds. Others delve deeply. and in an old colony a bank will be honercombed in every direction. If one wishes to examine into their housekeeping, under these circumstances he must fasten a rope to rock or tree. rig a "bo'sun's chair," and let himself over the cliff, excavating with his hands like a dog digging out a woodchuck, the stream of dirt passing down the cliff until it reaches the sea far below. Even then he nay not easily succeed in finding the eggs or young in the interminable labyrinth of passages penetrating the earth. Where the tops of islands are hilly, the Puffins dig into the turf, where the land slopes at an angle of about $45^{\circ}$, and often they go in to a depth of three or four feet.

The single egrg. which appears white, is in reality spotted inside the shell structure, as may lee seen by holding it up to a very strong light. The young one is a real Puffin, as it is covered with clown like a powder puff, but as it sits at the mouth of the burrow it looks, at a distance, like a little rat peeping out of its hole.

There has been much speculation regarding the utility of the lill of the I'uffin, and it has been sugrested that it is used to crush mollusks, but this does not seem to be the case, at least during the breeding season, as small fish appear to form its principal food. Apparently it does not use its bill, but rather its feet, in diggring, though this may be an error, and possibly both are used: but certainly the heak is an excellent weapon of defense as all who have attempted to dig out Puffins will testify. Nature has put the most powerful weapon of the mother bird where it will have most effect. Is she sits facing the entrance to her burrow she can deliver the more effective blows in defense of her nest and young because of the great size and crushing strength of her weapon, backed as it is by her hard head and sturdy neck.

Puffins breed on islands occupied also by Gulls, Fuillemots, Murres, Cormorants, and other hirds. Ifter the hreeding season they go to sea where they remain all winter. Their habits and roosting places at this season are practically unknown.

The natives of the coasts and islands of the north Pacific catch Puffins in nets, using their borlies for food and their skins for clothing. The skins are tough and are sewn together with the feathered side in, to make coats or "parkas," as they are called. Thus the Puffins contribute to the comfort and welfare of these simple, primitive people.
Fow ind Howe Fordusir.

\section{PUFFIN}

\section{Fratercula aretica arctica (Limnaus)}

$$
\text { A. O. U. Number I } 3 \text { Siec Color I'late } 3
$$

Other Names.-- Common Puffin : Puffin Auk: Labrador Auk: Sea Parrot: Pope; Bottle-nose; Tammy Norie: Coulterner: Tinker.

General Description.- Length, I3 inches. Color above, black; below, white; bill a'ery decp and ridged.
Description.-Anults in Summer: Crown, grayishhlack, separated by a narrow ashy collar from dark color of upper parts: sides of head with chin and throat, ashy: nearly white between eyes and bill, with a dark dusky patch on side of throat; upper parts, 


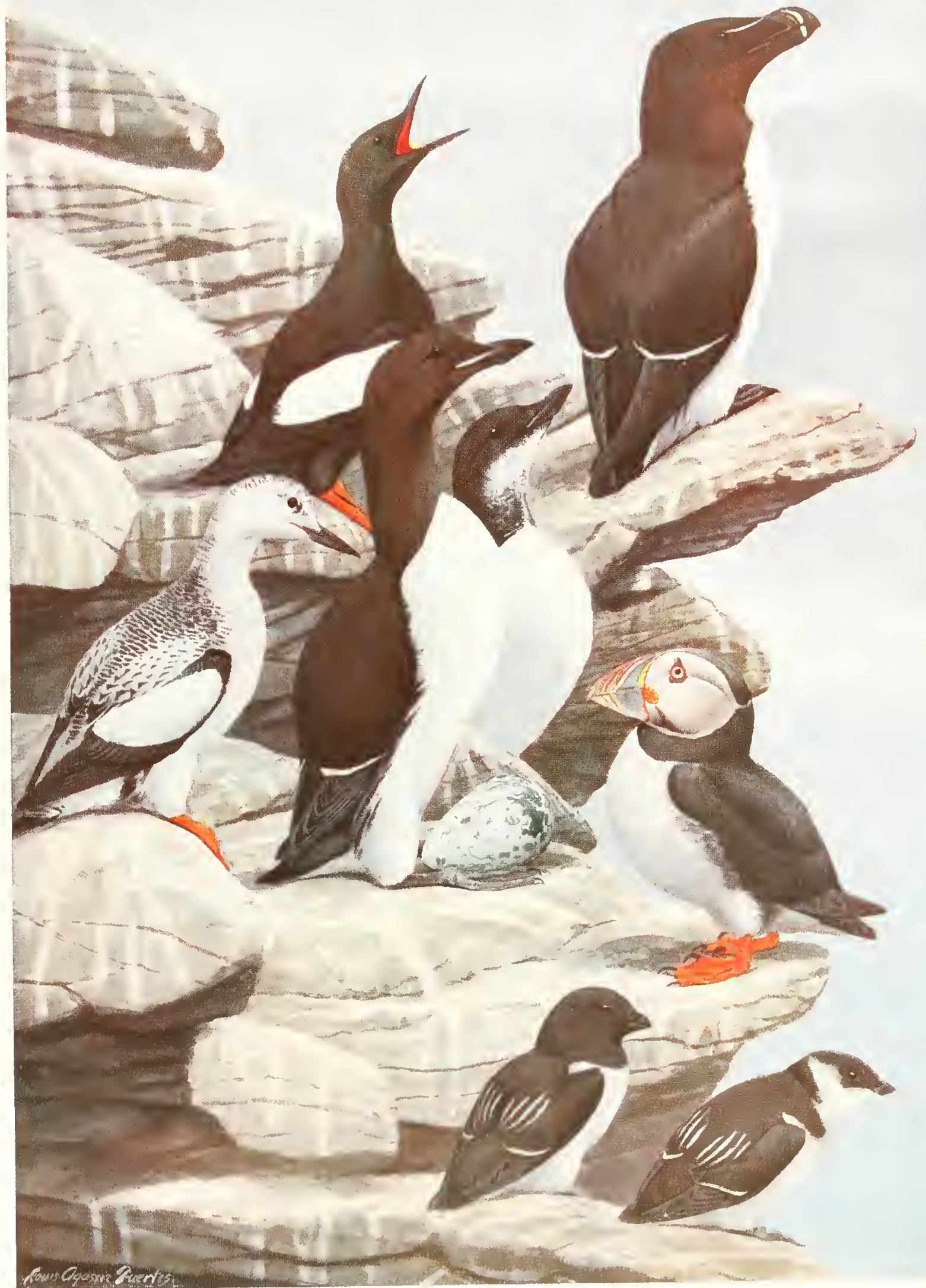



glossy blue-black continuous with a broarl collar around neck in front, not reaching bill: under parts from neck, pure white; sides, dusky; hase uf hill and first

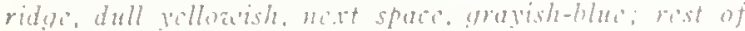
bill, armilion, volloa biloa'; rosette of moull, orange: feet, vermilion; iris, pale bluish-white: conical haperl projections above and behind eve, gratyin-blue: eyelids, vermilion. Anetes in WhTter: Face, durky; no eye-ring or appendages on eyelid; rosette of mouth. shrunken: feet, orange; most of horny appenclages on bill have been sherl, leaving it small and pale.

Nest and Eggs. Nesr: 1 hurrow in the ground I to 4 feet in length. Eus: I, white or bowwishwhite, plain or marked with faint synte, dots, or scratches of lavender: lairl it the end of hurrow on a thin lining of grass.

Distribution.-- Coasts and islands of north Atlantic: breeds in North Anericil from Ungava south to the liay of Fundy and Mane: winters south to Massachusetts: rarely to I, on 1 sland, and l)elaware Bay.

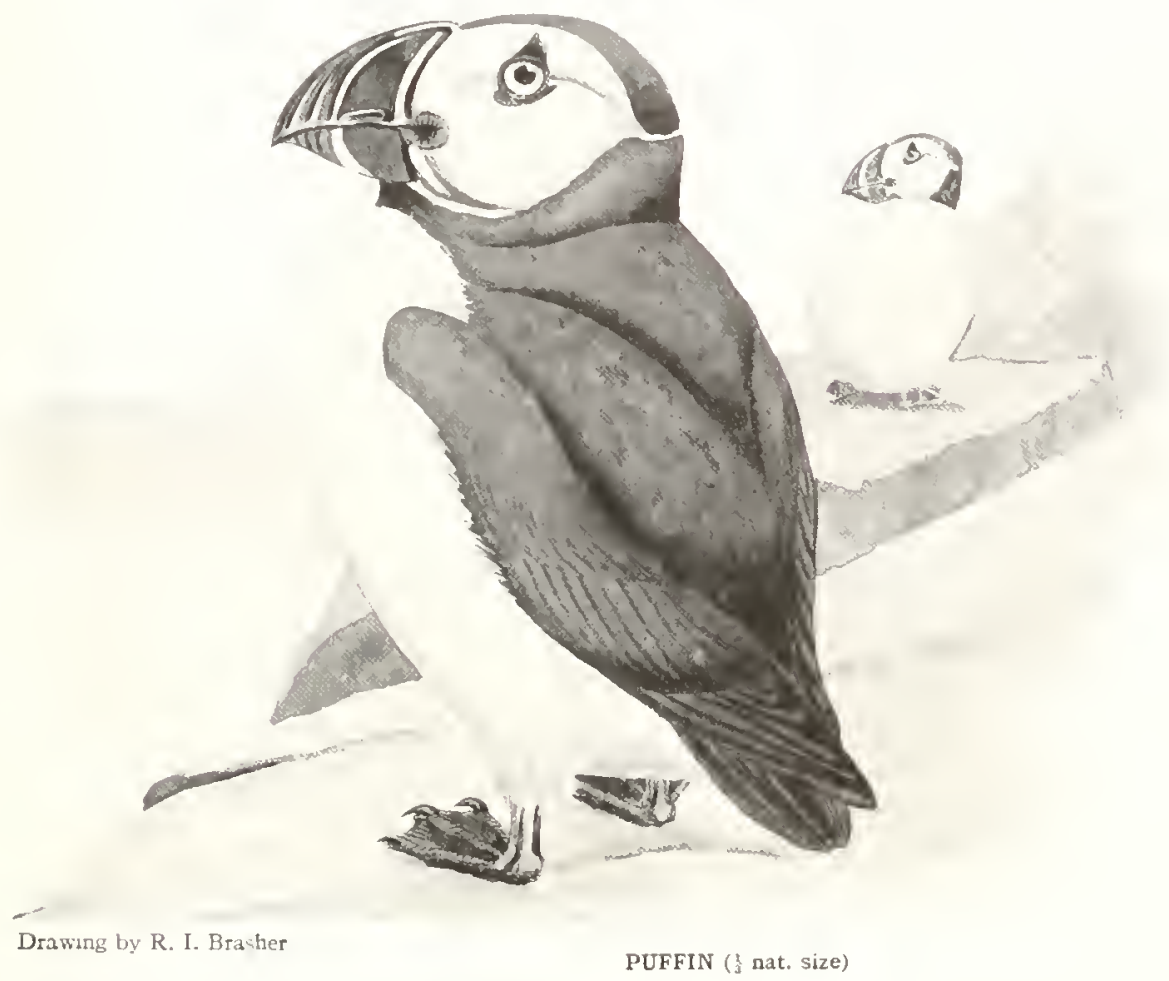

The Sea Parrot of the north Atlantic

" Whether at rest or on the wing, the I'uffin is a curious looking creature," says John Maclair Boraston, the finglish ornithologrist. "It rest they stand rank above rank on the tommost rocky ledges facing the sea, their black backs, collars. and crowns, white faces and underparts, crmhining with their erect attitude and disporition, incline to give them something of military unjformity and regularity. Dut when one noted the great tri-colored beak, the apparently spectacted eyes, and remarked the mild surprine with which the fircls resarded our intrusion, one cumd not resist the idea that there was smmething ludicrously artificial in the make-up of the l'utfin: for surely there never was a bird less bird-like in its appearance than the Puffin at rest. They were tame enough to allow us to approach almost within striking distance, had we heen disposed to strike anything so mild-mannered as a Puffur. When the bird is on the wing, the flight is rapid, hut labored, the wing beatiner violently, and as the bird flies, especially if returning to its burrow with fish, it utters a peculiar sound - a deepthroated, mirthless laughter, as it were, which mity he imitated by litusing in the throat with the lips closed.

"It is a matter of speculation how the Puffin, which catches fish by diving. contrives to retain the first fish in its hill while it captures a second or a third. Possibly the tonorue is used to hold it to the roof of the mouth, while the under mandible is lowered to make the later captures." (Birds hy Land and Sia.)

Much of the grotesplueness of this hiral's appearance is due to its uneouth leak. Which is very large, fattened literally, banderl with red. 
bhe, and yellow, and embossed with horny excrescences. These growths appear only in the mating season, and are sloughed off when that period is at an end, which means, as one observer puts it, that " the Puffin displays his wedding garments on his beak." Puffins are not likely to be seen near land after the breeding season is over. They are skillful swimmers and expert divers: $i n$ their diving they often descend to a great depth, and they are exceedingly quick and sure in their motions under the surface. At their breeding places the birds are likely to appear with remarkable punctuality, and they disappear with their young with corresponding regularity. In fact this departure is methodical to the extent that young birds which have not got the full use of their wings are left behind when the time for migrating arrives. It seens probable that the birds remain mated for life.
On land the bird places the whole length of the foot and heel on the ground and proceeds with a waddling stride. Robbing a Puffin's nest is dangerous business when either of the birds is at home, for they fight desperately and can inflict ugly wounds with their powerful mandibles and sharp inner mails.

The birds show strong affection for one another. If one is shot and falls in the water. others are likely to alight near it, swim around it, push it with their bills, and display in many ways their distress.

From old records we learn that in various parts of the Puffin's European range it was the custom to salt down large quantities of the young birds, to be eaten especially in Lent. To be sure the bird wasn't actually fish, but it tasted enough like fish to satisfy adaptable consciences among the devout.

\title{
CASSIN'S AUKLET
}

\section{Ptychoramphus aleuticus (Pallas)}

\author{
A. O. U. Number 16
}

Other Name.- Sea Quail.

General Description.- Length, $9^{\mathrm{T} / 2}$ inches. Color ahove, blackish; below, whitish; bill, shorter than head, wider than broad at base, its upper outline nearly straight.

Color-- Ipper parts, blackish-plumbeous: head, wings and tail, nearly black; a grayish shade extending around head, neck, fore-hreast, and along sides of body. fading to white on abdomen; bill, black, yellowish at base; feet, bluish in front, blackish behind and on webs: iris, white; a touch of white on lower eyelid.

Nest and Eggs. - The single egg, chalky-white or faintly tinged with green or blue, unmarked, is deposited in a burrow in the ground or in a crevice in rocks on an island or coast adjacent to the sea.

Distribution.- Pacific coast of North America from Aleutian Islands to latitude $27^{\circ}$ in Lower California: breeds locally throughout its range.
While the Cassin Auklet has been found living on some of the rocky islands from the Aleutians to Lower California, yet I have never found one of the birds nesting on the rocks off the Oregon coast.

During the summer of Iijo 3 , Mr. Herman T. Bohlman and I camped for five dlays and nights on Three Arch Rocks which contain the greatest colonies of sea birds off the Oregon coast. Again in 1yI, we lived for four days and nights on these rocks and climbed from top to bottom studying the various birds that live there. We have yet to see our first Auklet about Three Arch Rocks. This has led me to believe that it is rather uncertain as to just where the bird may be found. Mr. L. M. Loomis found the lirds nesting on the Farallons and Mr. Wil- liam L. Dawson found them nesting on some of the rocks off the Washington coast.

Because of its plump shape and size, it has been called a "Sea Quail." In his study of Cassin's Auklet on one of the islands off the Washington coast, Mr. William L. Dawson speaks of spending the night on the slope of the island where the Auklets had their nests. The birds burrow in under the soil, like the Petrels and Puffins, and are largely nocturnal in their nesting habits. The old hirds come in at night to change places in the burrows. The luklet chorus of birds in the burrows, he says, reminds one of a frog pond in full cry. Although the Auklets are quiet in daytime, yet the tumult increases as the night progresses.

Willian I. Finley. 


\title{
CRESTED AUKLET
}

\author{
Athia cristatella (Pallas)
}

1 1). N. Number 18

Other Names.- Suub-unsed Auklet, or Auk; llusky Auklet: Crested Stariki: Sea Ouail; Kanooska.

General Description.- Length, 9 inches. Color ahove, brownish-black: below, brownish-gray. 13ill, shorter than head, with knob at hase: a beautiful crest of from I 2 to 2 t) slender black plumes springing from forehead, recurved gracefully over bill. ahout two inches long: a slender series of white filaments behind each eye, drooping downward and hackward.
Color-Anuls: Brownibh-black ahwe, hrownshgray below; no white anywhere: bill, coral or urange. horn color at tip: feet, bluish-black; iris, white. lor.vi: lacking hill plates, crests, and white filaments on side of hear; a white spot below cye: irin, brown; otherwise as in adults.

Distribution.--Coasts ant islands of Bering Sea and north Pacific, from Bcring Strait sonth to Korliah Island and Japan.
This is essentially a sea-birl of the far North. its normal habitat being the north Pacific (rean ant the islands of Bering Sea. In Tukon Harhor they have been seen in myriads. Their appearance there is thus deseribed by Dr. Charles Townsend in a leaflet prepared for the National Xisociation of Iuduhon Societies:

"The surface of the water was curered with them, and the air was filled with them. Large. compact flocks launched themselves into the air from the lofty cliffs, and careened toward the vessel with great speed and whirring of wings. Twilight did not come until aiter y oclock, and during the long evening the birds were amazingly active. Flocks of them continued to come in rapid succession from the cliffs, many pasing close to the ship at high speed and swinging about the harbor. After the anchor was dromped near the cliffs, a loud blast of the whintle made the Auklets still more abundant.

"These birds appeared to be nesting chiefly in crevices in the eliffs, although they conlid he heard under the boulders near the beaches. To discover the nesting localities is eatsy. () me has lut to walk along the great ridges of rolcanic stones thrown up by the sea. The stone's are roumled and sea-worn like pehbles, hut they are girantic pebbles and cannot readily be noveri. The luklets gn far down among them, perhaps three or four feet, and can be heard chatteribir there during any part of the nesting-seatson. We found that a considerable part of the foot of this and other kinds of Auklets consisted of amphipul crusticeans, or beach-fieas, as they are called, when found under bits of seaweed along the shore. The native lleuts eat luklets, just as they do most other kinds uf rea-birch and capmure them with nets that are like a large dip-net with a long handle.

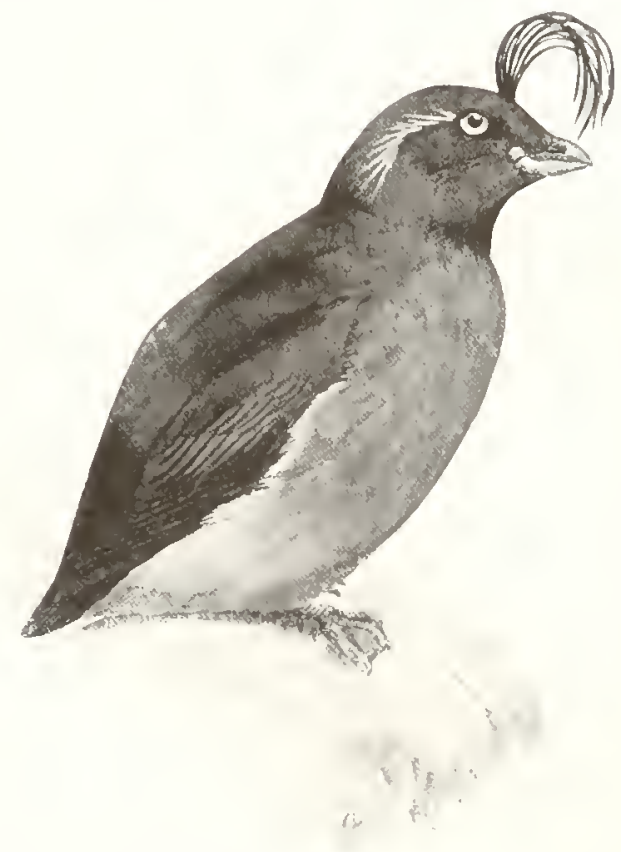

Drawing by R. I. Brasher

CRESTED AUKLET nat, size)

A strangely ornamented bird

"We need not concern ommelves, 1 think, ahout the preservation of the lulilets. They dwell ammong the high cliffs and the bunlder-strewn beaches of a thousand minhallited islands, and limm how to stow awat their egges so silfely that mejther matives nor lilue foxes can get them ('it)ily." 


\section{LEAST AUKLET}

AEthia pusilla (Pallas)

1. O U. Number zo

Other Names.- Minute Auklet: Knob-nosed Auklet; Knob-billed Auklet: Choochkie.

General Description.- Length. 6\%/2 inches. Color above, black; below, white; bill, shorter than head, with knob at base: no crest.

Description.-Adults in SUMmer: Front, top, and sides of head, sprinkled with white delicate feathers: a series of exceedingly fine hair-like feathers from back of eye down back of head and nape; some white on shoulders and on tips of some secondaries: otherwise entire upper parts, glossy-black; throat and under parts, white clouded with dusky, usually more thickly across breast; bill, red. darker above at base; legs, dusky; iris, white. ADults IN Winter: Bristles of head, fewer and less developed; white of under parts, more extensivc, reaching almost around neck; hill, brownish.

Nest and Eggs.- The single egg, chalky-white or faintly tinged with greenish or bluish, ummarked, is deposited in a burrow in the ground or in a crevice among rocks on an island or on a coast adjacent to the sea.

Distribution.-Coast and islands of the nortl Pacific; breeds from Bering Strait south to Aleutian Islands: winters from Alentian and Commander islands soutl to Washington on the American side and to Japan on the Asiatir.
The Least Auklet is one of the commonest of the water fowl in Bering Sea. It congregates in countless thousands on the rocks in Bering Strait. making them look like great beehives. In the spring they are very playful, especially while they are in the water, where they chase each other in great apparent good nature, meanwhile keeping up an incessant but subdued chattering. Like the other Atuklets, they build no nest, but lay a single exg deep in the crevice of a cliff, or among the rocks well below the surface, or in a burrow in the ground.

"A walk over their breeding grounds at this season," wrote Doctor Baird, " is exceedingly interesting and amusing, as the noise of hundreds of these little birds directly under foot gives rise to an endless variation of sound as it comes np from the stony holes and caverns below, while the hirds come and go, in and out, with bewildering rapidity, comically blinking and fluttering. The male linds, and many of the females, regularly leave the breeding grounds in the morning, and go off to sea, where they feed on small water shrimps and sea fleas, returning to their nests and sitting partners in the evening." (North American Birds.)

\section{ANCIENT MURRELET}

\section{Synthliboramphus antiquus (Gmelin)}

A. O. U. Number 21

Other Names.-Gray-lieaded Murrele1; Blackthroated Murrelet: Black-throated Guillemat: Old Man.

General Description.- Length, $10 \mathrm{~T} / 2$ inches. Color above, dark slate; below, white; bill, small and short, with no homy growth at base.

Color.- ADULTS IN SUmmer: Head, black, sooty on chin and throat; a conspicuous white stripe over each eye to nape, spreading on sides and back of neck into a series of sharp white streaks; a trace of white on cach eyelid: upper parts, dark slate, blackening on tail: under parts, white: sides of hody, velvety-black, the black feathers lengthening behind and overlaying the white flanks, extending upward in front of wings, meeting that of nape and there mixing with the white streaks; bill, yellowish-white, black on ridge and base; feet, yellowisl, webs, black: iris, dark brown. Abults
IX WINTER: Upper parts, darker, the slate obscured by dusky, especially on wing, tail-coverts, and runp; forchead, crown, and nape. sooty-black without white streaks; cyelids, sometimes largely white; no black on throat, but dusky mottling at base of bill; white of under parts extending nearly to eyes and far around on sides of nape.

Nest and Eggs.- The single egg, buff with marhings of grayish-lavender and light brown, is deposited in holes or burrows in banks on the coast or on a sea island.

Distribution.-Coasts and islands of the North Pacific: breeds from Aleutian Islands to Near Islands and from Kamcliatka to Commander Islands; winters from llue Aleutians south to San Diego, California, and to Japan: accidental in Wisconsin. 
The Ancient Murrelet is another of the diving birds which fairly swarm on many of iclands along the southert coilet of . Maska. It ranges as far south as California in summer, and then is common on the Commander Islands in the Bering Sea, where the natives call it the "Old Man," because of the curious feather arrangemuent nu the sides and back of the head. These feathers are dropped as winter comes on, so that the ignificance of the populat name may not be apparent when the bird visits its southern feeding vroulucs.

The Ancient Murrelet is an expert diver, and swims very rapilly under water. where it muranes fish with such energy as sometimes actually to drive them to the surface.

\section{BLACK GUILLEMOT}

\section{Cepphus grylle (Linncis $)$}

\section{O [?. Number 27 See color Plate 3}

Other Names.- White-winged Guillemot; Sea Pigeon: Tysty; Geylle; Sprotted Greenland Dove; White Guillemot: Scapular Guillemot.

General Description.- Length, 13 inclses. Prevailing color, in summer, sooty-black: in winter, black and white; bill, slender and straight, with no horny groath at base.

Color.-Sooty-black: wings and tail, pure black; wings with a large white mirne on both surfaces; bill, black; mouth and feet, carmine, vermilion, or coralred; iris, brown. This perfect dress is worn only two months. In Auguet. wings and tail become sray. the white mirror is mixerl with brown, head, neck all around, rump, and under parta, marbled with black and white, the bird looking as if duster over with flour; back, black, the ieathers white-edged; completion of the molt gives the following winter plumage: heail and neck all around, rump, and under parts, pure white: back, hindneck, and head varied with black and white; wings and tail, black, the white mirror perfect.

Nest and Eggs. - Eags: Deposited on the bare surface of the rock, in nooks and crannies of rocky islands on coast: 2 or 3 , white or greenish-white, irresularly spotted and blotched with dusky and laventer sheil markings.

Distribution. - Cuants of eastern North America and northwestern Europe, breeding from southern Greenlasul and Lngava to Maine: winters from Cumberland sund south to Cape Corl; rarely to Long lsland, N. Y., and New Jersey.

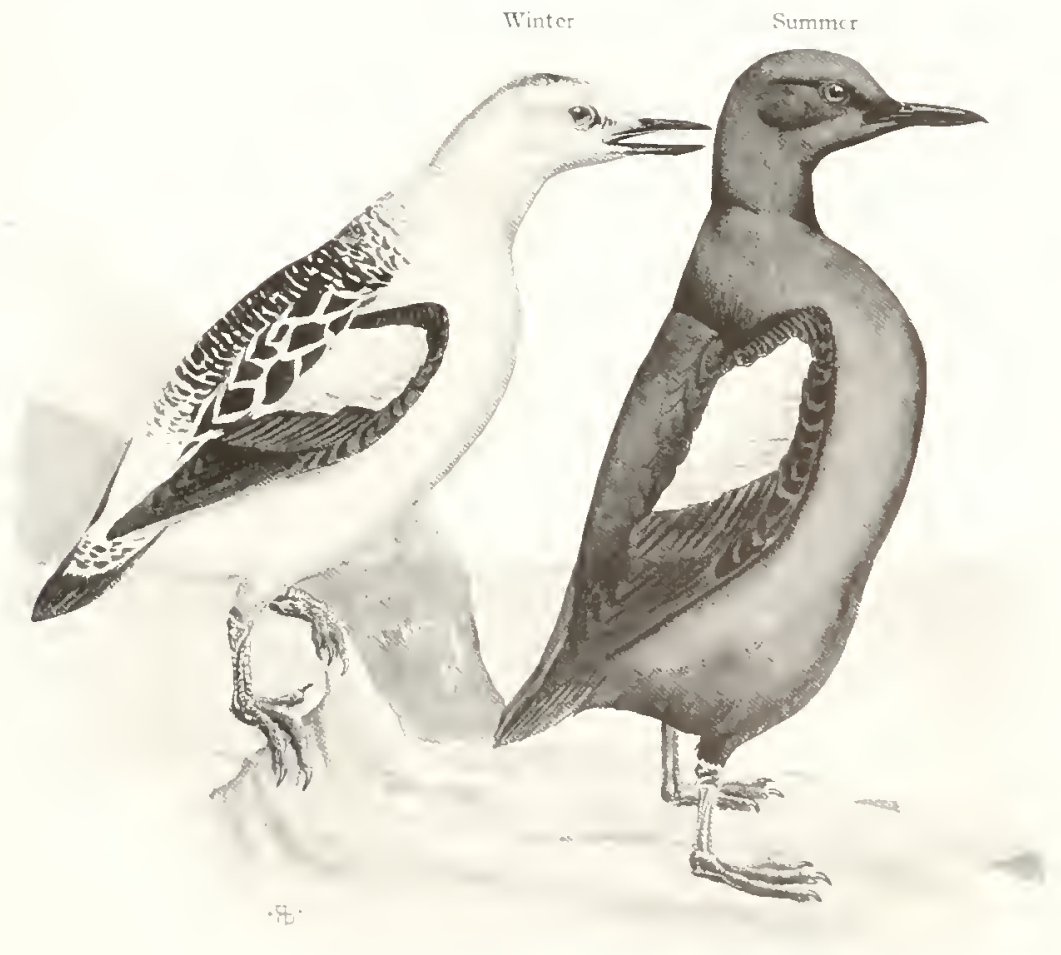

Drawing by R. I. Brasher 
Along the coast of Maine the numerous rocky islands extending in an irregular line out to sea afford farorite nesting places for numerous seafowl, among which the Black Guillemot, or "Sea Pigeon," is by no means rare. Farther north they are more numerous and breed in numbers on Grand Manan Island. New Brunswick, at various places in the Gulf of St. Lawrence, and along the Labrador coast. In approaching their nesting islands one will observe what appear to be short, black Ducks swimming ahead of the hoat, usually several together. One by one they will suddenly disappear, as with surprising swiftness they dive beneath the surface. Under water they are much at home, and by the use of wings. as well as legs, they take their submarine flight to a considerable distance before reappearing. Usually one does not see them again until they rise to the surface well beyond gunshot range. On taking wing they rise reallily from the water. Their progress is swift, strong, and usually directed in a straight line. In flight they rarely rise more than a few feet above the water.

The Black Gutillemot's nest is placed in the cleft of rocks well above the reach of high tides. While clambering over the great jumble of giant howlders, that reach from the water to the higher ground on some of the Maine islands, I have often come upon these birds brooding their eggs or young. The first knowledge of their presence would be when one would spring out from among the bowlders and go dashing away to the sea. Their black bodies and white-lined wings, combined with the red of the dangling, widespraddled legs, made a color scheme well worth seeing. Hidden generally well from view is the nest, and often it would take a steam derrick to reach it, Not the slightest effort at nest building is attempted. The two handsomely spotted eggs are deposited on the bare rocky floor of the little cave. The young are covered with down, literally as black as the "ace of spades." The birds feed on various crustaceans and shell-fish which are secured by diving.

Nany sea-birds of the North journey to southem waters to spend the winter, but the Sea Pigcon ajparently sees no need for exerting itself to such an extent. In fact it can hardly be said to migrate at all, for it is rarely found south of Cape Cod, scarcely two hundred miles beyond its southermmost nesting grounds. At all times they are coast-wise birds, seldom being seen out of sight of land, and never under any circumstances going inland. T. Gilbert Pearson.

\section{PIGEON GUILLEMOT}

\section{Cepphus columba Pallas}

I. O U. Number 29

\section{Other Name.-Sica Pigeon.}

General Description.- Lengtlı, 13 inclies. Prevailing color, in summer, sooty-black; in winter, black and white; bill, slender and straight, with no horny grozeth at base.

Plumage.- White mirror of upper surfuce split by an oblique dark line caused by extension of dark bases of greater coverts increasing from within outward until the outside ones are scarcely tipped with white: nlumage and changes otherwise as in Black Guillemot. Nest and Eggs.- Similar to those of the Black Guillemot.

Distribution.-Coasts and islands of the Arctic Ocean. Fering Sea and Cape Lisburne, and both coasts of the north Pacific from Bering Strait sonth to Santa Catalina 1sland, California, and to northern Japan.
Mr. Dawson says that the Pigeon Guillemot is " unquestionally the most characteristic waterhird of the Puget Sound region," ant explains its sharing the popular nane "Sea Pigeon" with the Bonaparte Gull as follows: "The Gulls are dove-like in posture (at least a-wing), and in their manner of flocling: while the Guillemot owes its name both to its plumpness and to its very unsophisticated, not to saly stupid, appearance." (Birds of IV'ashington.)

E. IV. Nelson found this bird " the most abun- dant of the small Guillemots throughout the North, from Neutian Islands to those of Wrangel and Herald, where we found it breeding abundantly during our visit there on the Corcin." He notes that the hirds are very conspicuous by reason of their white wing patches and bright red leg. When perched on the rocks they squat like Ducks, and when swimming they often paddle along with their heads below the surface.

For brecding operations a few pairs may take 
posiession of a group of small rocks, or a colony of several hundred may share clifis with Cormorants, Tufted Puffins, and Glaucous Crulls. Mr. Finley observes ( $1 \mathrm{~s}$.) that off the Oregon coast these Guillemots nest in isolated places and not in colonics. "They like a crevice or a hole in the face of a cliff for a nest site." On land they have an awkward hambling gait. but in the water they are entirely at ease, and are swift swimmers and expert divers.

\section{MURRE}

\section{Uria troille troille (Limaus)}

\section{A. O. U. Number 30}

Other Names.-Foolish Gullemot: Guillem, or Gwilym; Tinker; Tinkershire; Kiddaw; Skiddaw; Marrock: Willock; Scuttock: Scout; Strany; Lavy; Frowl.

General Description.- Lengtli, 17 inches. Color above, brown: below, white. Bill, narrow and slender.

Color-Anults in Summer: Head and neck all around, rich maroon-brown sharling on upper parts into dark slaty-browa; some feathers of hack and rump with grayish-brown edges: secondaries, narrowly tipped with white; under parts, pure white; sides and flanks with dusky markings: bill, black. feet, dusky: iris. brown. Adults in Minter: White of under parts, reacling bill, on sides of head to level of gape, extending further around on sides of neck, leaving only a narrow line of lark color; the two colors sluading without sharp line of demarcation.

Nest and Eggs.- A single egg. remarkahly variable in coloration, is laid on the rock of cliffs, without any attempt at nest hulding; it varies from white to dark green, spotted. blotched, and scratched with back, brown, and lilac over the entire surface.

Distribution.- Coasts and islands of North Atlantic: breerls in North America from southern Greenland anl southern Ungava south to Newfoundland and Nagrlalen Islands; winters south to Maine.
The common Nurre's natural hahitat is the northern Atlantic Ucean, and various islands therein, but in winter it wanters southward as far an New England, and possilly to New York. though the records of its appearances there seent not to be entirely reliahle. On the water this bird looks much like a Duck, though its neck is shorter and its linl more pointed than is charac-
MURRE (a nat. size)

Drawing by R. I. Brasher

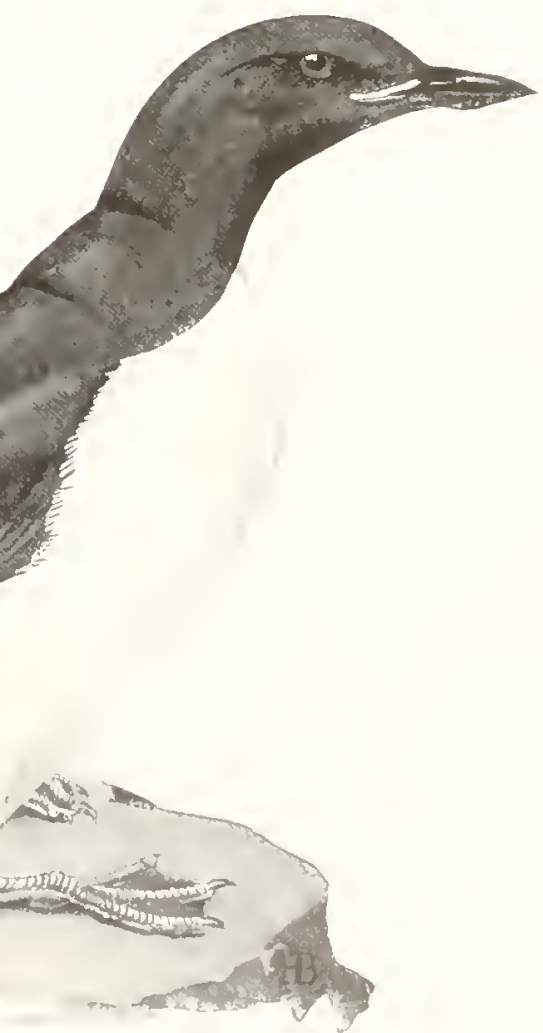


teristic in that family. In their nesting places on ledges of rocky islets they sometimes gather in such numbers as to present a seemingly almost solid mass of birds, while the eggs are found lying so close together that it is actually difficult to walk without treading upon them.

All the Murres are occanic birds, only visiting the rocks during the breeding season, and found inland only when driven there by storms. Their food consists of fish and various crustaceans; this particular species is especially partial to the fry of herrings and pilchards, which are captured at night in the open sea.
Doctor" Chapman remarks that "long-continnerl studies of Nurres on the coast of Yorkshire warrant the belief that, although the eggs of no two Murres (or Cuillemot as it is termed in England) are alike, those of the same individual more or less closely agree, and that the same bird lays year after year on the same ledge. Murres perch on the entire foot or tarsus, and when undisturbed ustally turn their backs to the sea and hold their eggs between their legs with its point outward. When alarmed they face about, bob and bow and utter their low-voiced murre."

\title{
CALIFORNIA MURRE
}

\section{Uria troille californica (II. Bryant)}

\author{
1. 1) 1T. Number zoa
}

Other Names.-California Guillemot; California Egg-bird: Farallon Bird.

General Description.-Similar to the common Murre, but averaging abont an inch longer.

Nest and Eggs. - Like those of common Murre.
Distribution.- Coasts and islands of the north Pacific: breeds from Norton Sonnd and Pribilof Islands south to the Farallons, California; winters from the Aleutian Islands south to Santa Monica. California.
The California Murre is the most abundant sea-bird on the off-shore rocks of the Pacific from Alaska to the Farallons. It is readily

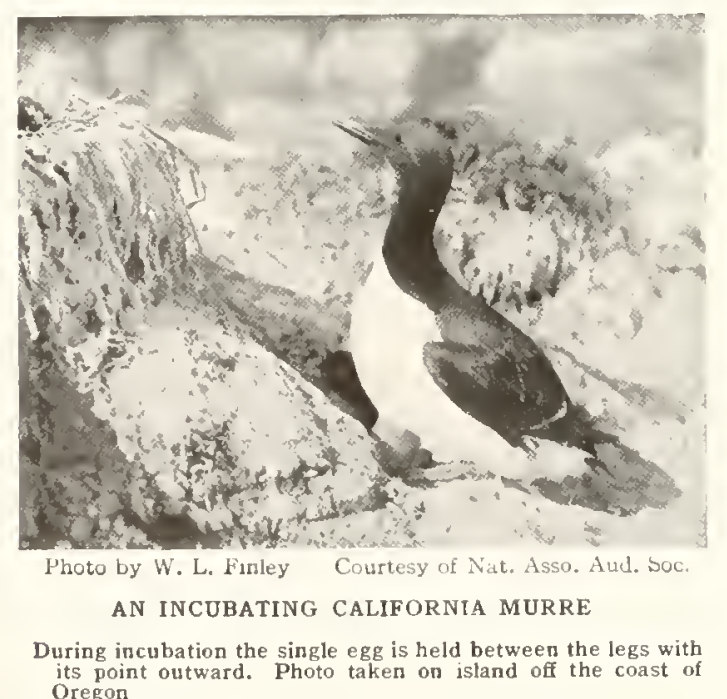

recognized by its snow-white breast and sontybrown back. Its legs are placed clear at the end of its body, so it does a good deal of its sitting standing up. Its attempt to walk is a very awkward performance resembling a boy in a sack race. But in water the bird is very expert. It uses its feet as propellers and its wings as oars. flashing under water with such swiftness that it can overtake and capture a fish.

The Murre is a creature of the crowd. To see this hird in great colonies and to watch its home life, one gets the jolea that a Murre would dic of lonesomeness if isolated. They huddle together in such great numbers on the narrow sea ledges that they occupy every available standing place. There is not the least sign of a nest. The female lays a single egg on the bare rock. One egry is all that can be attended to mnder the circumstances. One might wonder why the birds persist in crowling so close together. Neighbors always seem to be quarreling and sparring with their sharp bills. They rarely hit each other. because they are experts at dodsing. The babble is continuous: everyone talks at the same time.

The peculiar top-shape of the Murre's egg mevents it from rolling. The practical value of this may be seen every day on the sloping ledges. We tried several experiments and the eggs were of such taper that not one rolled over the edge. IThen an egg starts down srade, it does not roll straight, but swings around like a top and comes to a standstill. The shells are also very tough and not casily broken.

One day we lay stretched out on a ledge just 
above a hig colony where we could watch the ordinary run of life and not disturl the hirds in any way. When a Murre arrived from the fishing grounds, he alighted on the outer edge of the shelf. Then. like a man in a Fourth of July crowd, he looked for an opening in the dense front ranks. Seeing none, he boldly squeezed in, pushing and shoving to right and left. The neighbors resented stuch behavior and squawked and recked at the new arrival. But he pressed on amid much opposition and com- plaint until he reached his mate. They changed places and he tonk uip his vigil on the egg. The mate, upon learing the colnny, inctead of taking flight from where she stuod, went through the former proceeding, often knocking over several neighbors who protested virorously, jahbing at the parting sister. Arriving at the edge of the ledge, she dropped off into space. The continuous going and coming macke an interesting performance for the onlooker.

Willian I. Finlev.

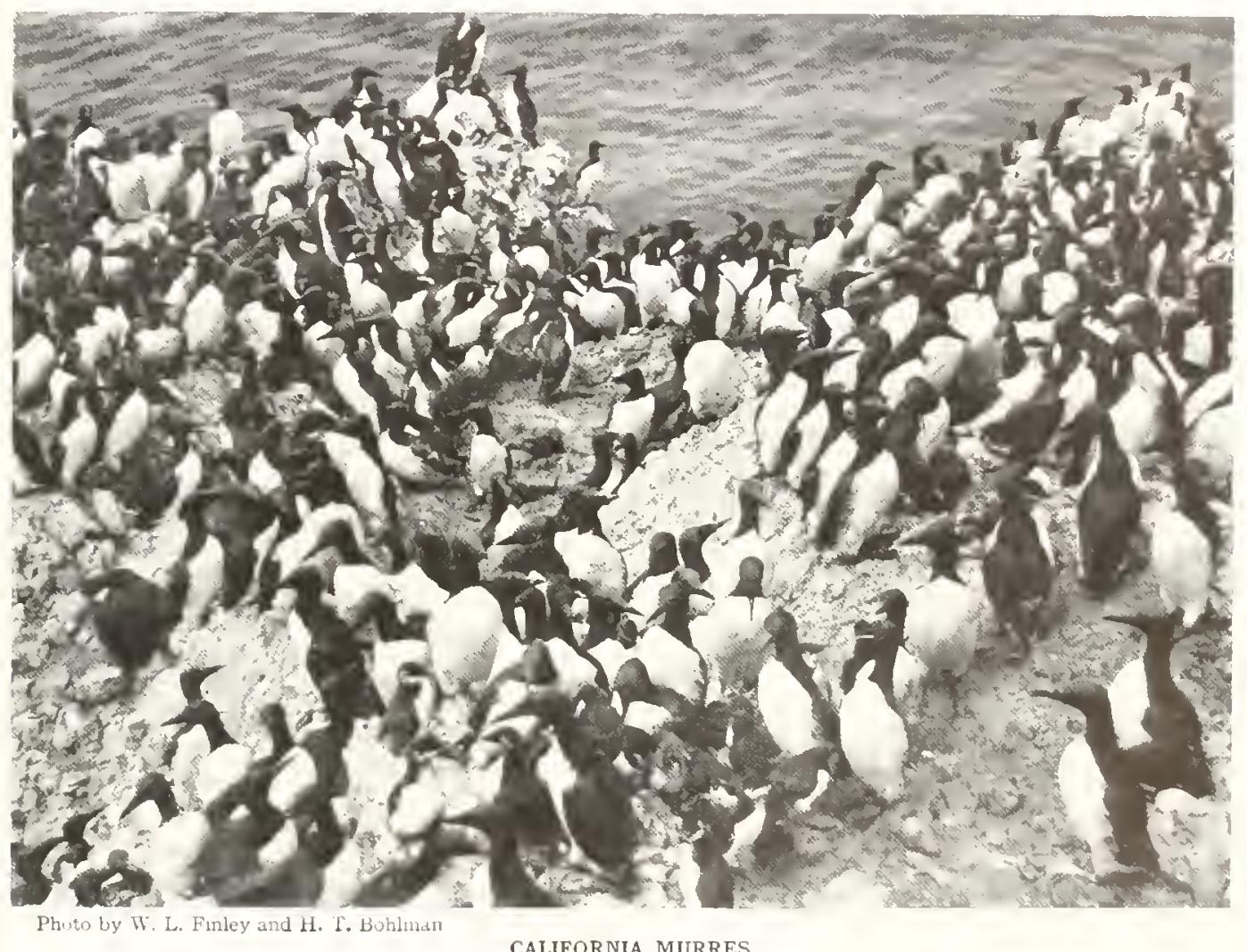

Off Oregon coast on Three Arch Rocks Reservation

\section{BRÜNNICH'S MURRE}

Uria lomvia lomvia (Limatus)

A. O. U. Number 31 see color Plate 3

Other Names.-Franks' Guillemot: Thich-billed Guillemot: Thick-billed Murre; Brunnich's Guillemot; Pular Guillemot; Egg-bird.

General Description.- Length, 19 inches. Similar to common Murre in plumage and changes, but crown darker in contrast with throat and irles of neck: bill. shorter and stouter with cutting edge of upper jaw Alesh-culored.
Nest and Eggs. - Indlistinguishable from those of the Murre.

Distribution.- Coasts ancl filands of north Atlantic: breeds from southern Ellesmere Land. and northern Greenland to Hudson Lay and Gulf of St. Lawrence: revident in Greenland and 1 huthon Bay; south rarely in winter from Maine to South Carolina, and in interior to northern Ohio, central Indiana and central lowa. 
Brunnich's Murre comes as near being like the Antarctic Penguins as any other North American species. It is built primarily for swimming and diving, and is a poor walker, waddling awkwardly in an upright position.

Except as it may climb out of the cold water on a cake of ice, its only chance to exercise these poor gifts is during the short summer in the Far North on its brceding grounds. There the Aurres, mingled with the other species, resort

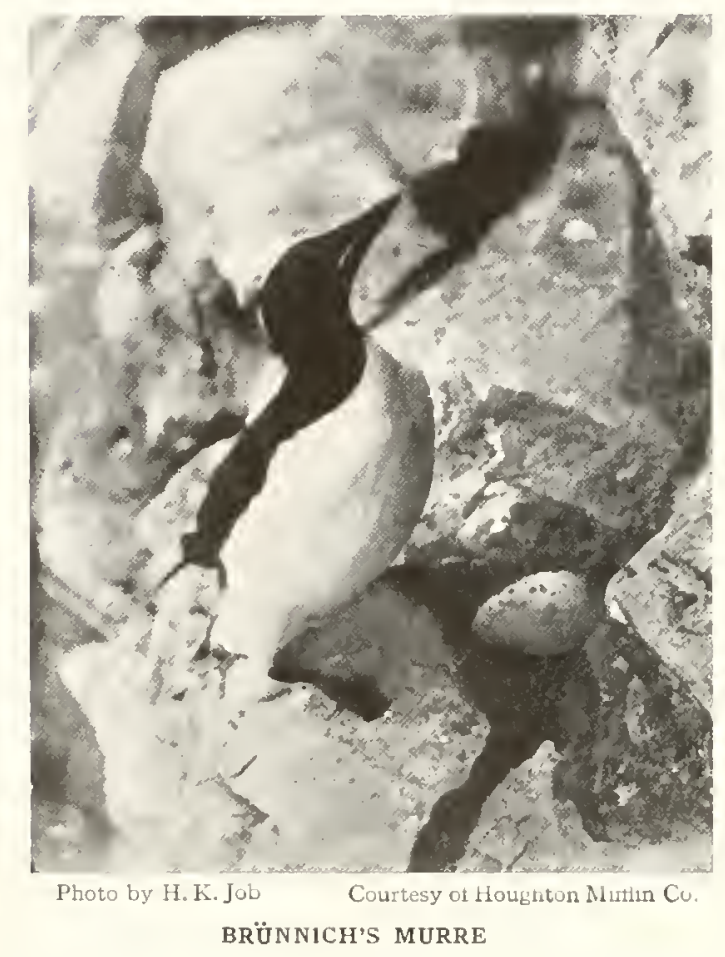

Presently it will lift its egg onto its teet and hold it there for incubation

to precipitous shores or rocky islands, from the Gulf of St. Lawrence away up to northern Greenland. I have visited the colony on Great Bird Rock, Magdalen Islands. Ifere, in June, I found them standing in rows on the narrow ledges of the cliff, usually with back to the sea, each bird holding between its legs one large pearshaped egg. These eggs have very hard shells, and are so shaped that they roll in a circle, which helps to prevent their falling off the cliff. They are colored a great variety of tints of green, blue, buff, whitish, and are so variously marked that it is impossible to find any two alike. Usually the Nurres crowd upon these ledges as thickly as they can find room to stand or squat.

From these ledges they throw themselves with confident abandon, and, with exceedingly rapid wing beats, circle out over the sea and back again to the rock. Otherwise they alight on the water with rather a heavy splash, and are apt to dive forthwith. They can be seen here and there swimming about, distinguishable from Ducks by the fact that their posterior part floats rather high - rominding one of the ancient ships as described by Vergil, with "lofty sterns."

Their hoarse haritone voice is almost human, and they are supposed to say murre. When I first heard them on the rocky ledges close at hand, I was involuntarily startled, so much did it sound to me like someone calling my boyhood nickname, "Herb, Herb!"

Unless one can visit a breeding colony, about the only way to cultivate their acquaintance is to get offshore in winter, on the bleak, wind-swept ocean, not much further south than Nantucket shoals, or, better, the coast of Maine. Miles off Cape $\operatorname{Cod}$ in mid-winter, from fishing vessels I have seen them by hundreds. Flocks of them dotted the ocean in all directions, or moved in lines swiftly through the air, to plunge into the water and disappear like stoncs, presently to bob up many rods further off. Occasionally at the entrance of harbors, in bitter cold weather, I have seen them perched on some slanting pole or heacon, from which they would plunge directly into the water.

Though oceanic in habit, this particular species seems to have a peculiar faculty, as has the Dovekie, for getting into trouble by wandering from its real element. After winter storms they are liable to be found far inland, sometimes stranded in a snow bank nut in some field, or on the ice of a pond or strcam, vainly sccking to fincl water. In such cases they are enaciated and must perish, as they are mahle to rise on wing from any surface except water. When word comes of a queer unknown bird which stands upright on the ice or in the snow, it is a likely guess to call it a Brünnich's Murre.

Herbert K. Jor. 


\section{RAZOR-BILLED AUK}

\section{Alca torda Linncets}

1. O L. Number 32 see Color I'late 3

Other Names.- Razor-bill; Tinker.

General Description.-Length, 18 inches. Color above, black; below, white. Bill, flatly compressed; tail. pointed.

Color.-ADLits in StMmer: Head and neck all around, and upper parts, black, more brownish on former, a slight greenish-glons on latter; tips of secondaries and entire under parts from neck, white; a sunken line of white from eye alongside of foreheal to bill: bill, black, erossed by a white line; feet, dusky; iris, brown. ADLLTS IN Wlater: White extending to bill. invading sides of head to level of eyes and neck; no white line from bill to aye. color uf upper part-, ituller

Nest and Eggs. - Usnally one egg, sometimes two. is laid on the bare rock of clifis or inlands along the coast, very variable in shape and size of markings: white or bluish, spotted and bhotched with sepia on black, these spots sometimes wreather in a circle around the large end: in others diffused over entire surface.

Distribution. - Coasts and islands of the north Atlantic: breeds on American side from southern Greenland to Newfoundland and New Brmnswick; winters from New Brunswick and Ontario to Long lsland and rarely to North Carolina.
The Razor-billed Auk presents a striking and interesting aprearance in the water, which it rides as buorantly as a cork. Like all of its lind. it is exceedingly quick and clever at diving, a method of escape which it always adopts in preference to flight, when it can. It slips under the surface with hardly any perceptible or audible splash, and it is quite impossilile to tell where it will reaplear. When fairly suhmerged the hird swims - using both winss and feet - with astonishing speed and often descends to a considerable depth. It feeds bargely mon firh and varions small marine creatures, and takes virtrally all of its food from the sea. When it chooses to take to its wings, it ean Hy with nuch rapility. In summer it is decidedly sregarion and the flocks often are seen far trom land. If then overtaken by heavy gales, large numbers of the birds are drowned.

As the breeding season approaches, the birds abandon temporarily their nomad sea life ant gather in large flocks at established breeding places, preferably on cliff overluoking the ocean, and containing an abundance of nichen and recesses, where the single egg is laid, no nest heing made. The incubating bird is very loath to leave the egg, anrl often when so engaged may be taken in the hand. There are many evidences that the birds mate for life.

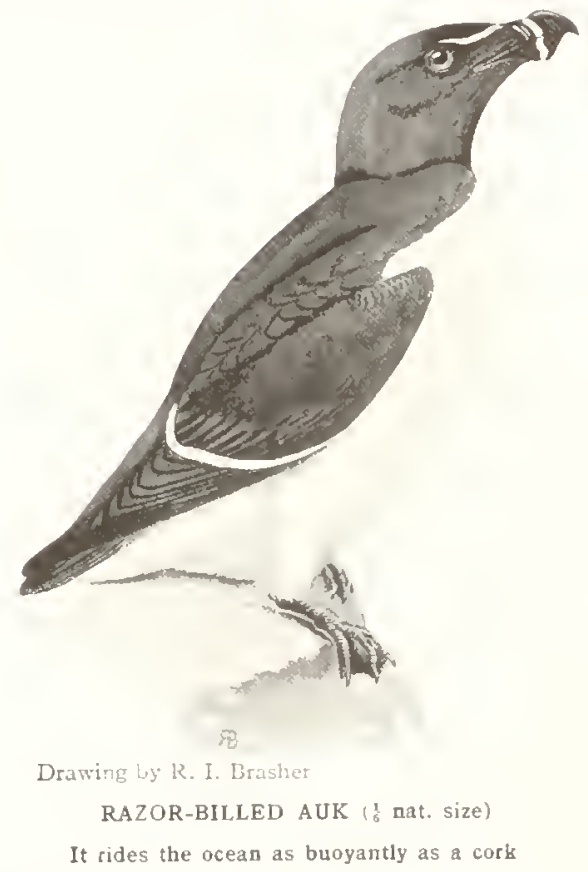

GREAT AUK

Plautus impennis (Linnous)

Other Names_-Garefow: Penquin: Wobble.

General Description.- Length, 30 inches. Color above. black: below, white.

Color--Adelts: Hood and entire upper parts including wings, bjack; ends of secondaries, white forming a traverse band: under parts, white extending to a point on throat: a white oval spot between bill and eve; lill, black with lighter grooves; feet, black; iris, brown.
Nest and Eggs.- NEST: Site wrobably similat to that of the Razor-billert Auk. Ecor: 1. white or bluishwhite. spotted and blotcherl with sluates of nmberbrown and sepia.

Distribution. - Formerly inlnabited coasts and inlands of the north. Atlantic irom near the Artic Circle south to Massachusetts and lreland, and probibly south casually to South Carolina and Florita and the Bay of Biscay: now extinct. 
The Great Auk was the most powerful and swiftest diving and swimming bird in North Anerica. It had to be, as it could not fly. In order to survive it must be fast enough not only. to pursue and overtake the swift-swimming fish in their native element, but also active enough to escape sharks and other predatory fish that otherwise might have exterminated it. Also it was obliged to follow the smaller migratory fish southward in winter and northward in spring.

It lias been pictured often among the icebergs, but it was not a bird of the Arctic regions and was not found within the Arctic Circle. It is believed to have inhabited southern Greenland, but that was centuries ago when the climate of Greenland probably was warmer than it is now. In primitive times, when man was a savage, the Auk was safe upon its island home in the raging sea, which men in their frail canoes visited rarely and in small numbers; but civilized man, coming in large companies in ships that sailed the seven seas, armed with firearms, brought extermination to all flightless birds which came under his notice, and so the Great lak was one of the first of the North American birds to become extinct in the nineteenth century, the century that will always be noted for its great destruction of birds and mammals at the hand of man.

The Great Iuk had been linown in Europe for centuries when it was first discovered in North America. This was in 1497 or 1498 , when adrenturous. French fishermen began fishing on the banks of Newfoundland. The birds were taken there in such enormous numbers that it was unnecessary to provision the vessels, as the fleet conld secure all the fresh meat and eggs needed by visiting the bird islands. Jacques Cartier, on his first voyage to Newfoundland in I 334, visited an "Island of Birds" which, from the course and distance sailed from Btena Vista, must have been what is now known as Funk Island, the last breeding place of the Great Auk in America, where the crews filled two boats with the birds in "less than half an hour" "and every ship salted down five or six barrelfuls. He also found the Great Iuk on the Mlagialen Islands in the Gulf of St. Lawrence. The hird became known among the French fishermen as the Pingouin (Penguin). There were at least three Penguin islands about Newfoundland and another near the tip of the peninsula of Nova Scotia, while numerous birds apparently sum- mered at the head of Buzzards Bay and about Cape Cod.

The Auk migrated from Labrador to Florida. It was common at Nahant, Mlass., and about the islands in Massachusetts Bay in the early years of the nineteenth century and was taken now and then near Plymouth, but had disappeared at that time from the upper end of Buzzards Bay. When Audubon visited I abrador in I832, he was told that fishermen still took great numbers from an island off the coast of $\mathrm{New}^{\mathrm{T}} \mathrm{-}$ foundland, but, from all accounts, it seems probable that the bird was extirpated on the coasts of North America before IS 40 . Apparently the Great Auk was destroyed in America before it was extirpated in Europe, where the last recorded specimen was taken, off Iceland, in I 844 .

Its destruction was accomplished first by the demand for the eggs and flesh for victualing fishermen and settlers, next by the demand for the feathers, and last by unrestricted shooting. When the supply of eider-down and feathers for feather beds and coverlets gave out, about i, 60 , because of the destruction of the breeding fowl along the coast of I abrador, some of the feather hunters turned to the Penguin islands off the coast of Newfoundland. Cartwright said ( 1775 ) that several crews of men lived all summer on Funk Island, killing the birds for their feathers; that the destruction was incredible; and that this was the only island that was left for them to breel upon. Nerertheless the species continued more or less numerous about the shores of Newforndland until about 1823 and then gradually disappeared before continuous persecution. Dr. F. A. Jucas, who visited Funk Island in I8-8, found such enormous numbers of the bones of this species that he concluded that "millions" must have died there. Today there are about eighty mounted specimens in existence and not many over jo eggs preserved in museums and collections.

This Auk was readily alarmed by a noise, as its hearing was very keen, but it was not wary if approached silently. When on land it stood upright or rested on its lreast, and its locomotion was slow and difficult, so that it might be easily overtaken ancl killed with a club. In the water. however, it was so swift that a boat propelled by six oars could not overtake one. It is believed to have fed mainly upon fish, but its habits never were studied and described, and, therefore, they are unknown. EDWARD Howe Forbush. 


\title{
DOVEKIE
}

\section{Alle alle (Linnous)}

\author{
1. O L. Yumber is cere colom Plate 3
}

Other Names-Little Auk: Sea Dove: Alle; Rotcli: Ice-lind.

General Description.- Length si, inchen. Colur above, back: helow, white: hearl and bill, formed loke those of a Quail.

Color- Anths in Sim Mer: Head, neck all around, and upper parts. glossy blue-black: sides of head. neck, and throat. shaded with sooty-hrown: three or four white streaks on shoulders; secondarich, tipped with white: under parts, mre white; hill, hlack: feet. flesh-color in front, black behind and on webs: iris.

The little Dovelies ut "Sea lowes" breet along the coasts of Greenland and other rea islands of the Atlantic, north of latiturle (x)? and in winter come down the coast where les ice abounds and where. consermently, fond is more easily secured. New Jersey is about the usual limit of this species southern jurney. They stay in small flocls in the open wat and feed ly diving. Ipparently at this season they come on land but rarely.

Cape Hatteras, ornithologically, is a very interesting place. Here the warm waters of the fulf stream meet and neutralize the last remaining vestige of the cold bearing currents from the north. Is the distribution of animal life is largely deternined by climatic conditions. the North Carolina coast affected bx these currents becomes the meeting place of many northward moving species that naturally inhahit wamer regions, and southward moving species from the cold countries to the notth. The extrene southern migration of the Jovekie illustrates this interesting fact. I few miles nosth of Cape Hatteras I found, one December some years ago, one of these little wanderers. It was sitting on the beach in a tired-out condition and made but feeble attempts to encape when I took it in my hands. Then I liscovered the canse of its enaciated condition : one foot was missing. 1)oubtless it had been bitten off by some ficl. With its power of rliving in the ocean thus reduced at least one-half, its chances for securing a livelihood were all but gone, and in the end the tide harl cast it upon the shore. Within a few hours it died, despite the most energetic efforts to induce it to eat such food as was availatsle.

The Eskimos kill many Sea Doves and use their feathered skins for making the fird-skin shirts with which they help warl off the biting fros of their country. The birlis are taken in

$$
\text { Vol. } 1-4
$$

brown. ADCLTS in WINTER White of under parts extending to hill. invading siden wi hearl and neck and nearly meeting on nape; otherwhe as in summer.

Nest and Eggs. - I single greenish-blue egrg laicl in crevices of rocky cliffs on islanch or crasth near the sea.

Distribution.- Coasts and islands of north Atlantic: hreeds from liane liasin and Baffin Eay east to Franz Josef land; winters from southern Greenland south (1) Lung lsland (X. Y.), and rarely to Delaware bay ind Surth Carolina: accidental near Melville Ialand. ancl in Misconsin. Michigan. Ontario. and Bermuda.

nets which the natives wield over the face of the cliff where the birl crowd together to breed.

"I have ulten thought," wrote Audubon, "how easy it wonlil he to catch these tiny wanderer

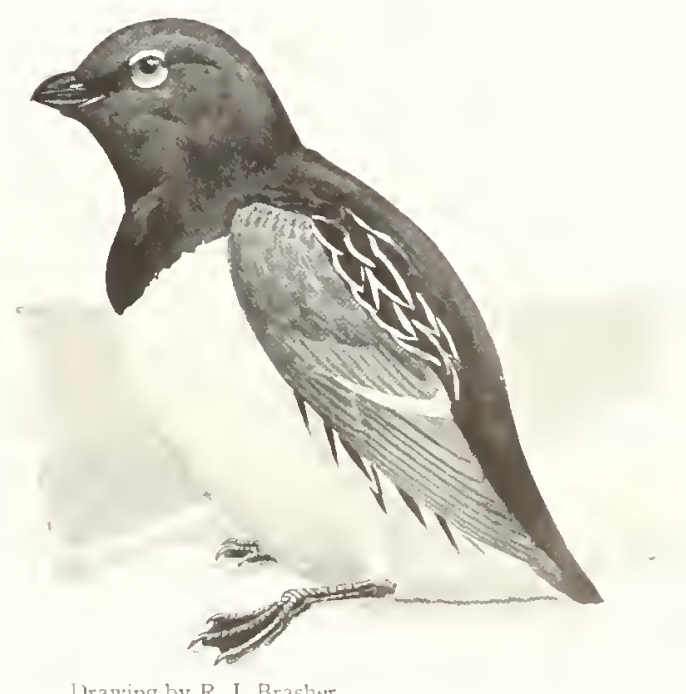

Drawing by R. I Brasher

DOVEKIE $\left(\frac{1}{2}\right.$ nat. size

These small Sea Doves manifest very little apprehension of danger from the proximity of man

of the ocean with nets thrown experty from the buw of a boat. for thes manifest very litule anprehension of danger from the proximity of one. in nomuch that I have seen several hilled with the oars. Thune which were caught alive and placed on the deck, would at first rest a few minutes with their borlies flat, then rise upright and run about lriskly. or attempt to fly off, which ther sometimes accomplisherl. When they happened to $g_{0}$ in a straierht course the whole lenerth of the -hip, as a (o rise eavily over the lublwarks. (1) effecting their escale they would aliglt on the water and immediately disappear."

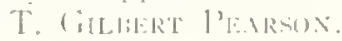




\title{
ORDER OF LONG-W INGED SWIMMERS
}

\author{
Order Longipennes
}

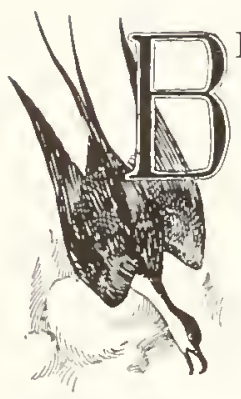

IRDS of the order of Long-winged Swimmers are cosmopolitan in distribution and are generally seen on the wing over or near water. In the order are three families: Skuas and Jaegers, Gulls and Terns, and Skimmers. They resenble most nearly the Tube-nosed Swimmers of all the water birds, but the character of the nostrils plainly distinguishes them without reference to internal anatomy. These birds have the nostrils lateral and open. The wings are long and pointed. Usually the tail is long. The legs are comparatively free and project from near the center of the body; the thighs are bare for a short distance; the tarsi are covered with horny shields of varying sizes. The toes are four in number, but the hind one, which is elevated, is very small (sometimes rudimentary); the front toes are webbed. Their bills are strong and thick; the Skuas, Jaegers, and Gulls have hooked, hawklike bills; the Terns have sharply pointed ones; and those of the Skimmers are bladelike.

Although there is no sexual variation in coloration in the species included in this order, there are seasonal and age differences. Their voices are shrill or harsh. Fish is the main item of their diet.

The eggs are few, usually numbering but three. The young are covered with down when hatched, but are helpless and the parents care for them in and out of the nest for some time.

\section{SKUAS AND JAEGERS}

\section{Order Longiponnes; family Stercorarïda}

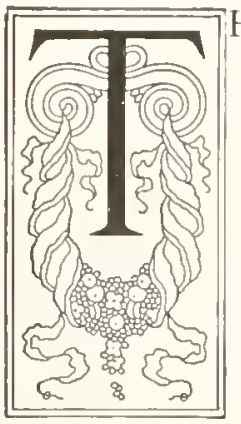

HE Skuas and Jaegers are closely related to the Gulls and Terns; in fact they are Gulls with habits and structure modified sufficiently to justify their inclusion in a distinct family, the Stercorariida, while still remaining in the same order, the Long-winged Swimmers. Not the least striking of these modifications is a well-developed thieving propensity, with the result that they are often and variously called "Robber Gulls," "Sea Hawks," "Teasers," and "Boatswains." Generally they are aggressive and daring birds, graceful, skillful and powerful in flight, by reason of which they are able to overtake their weaker and more timid relatives and force them to disgorge their food, which the pursuer catches in its fall. Because of these practices they are often spoken of as parasites, but the practice itself is essentially predatory rather than parasitic.

'The birds' bad habits are not confined to this aerial robbery, however, for certain species are known actually to eat young birds and eggs, and even small mammals.

The Sliuas and Jaegers have wings of only moderate length for this group, the primaries are unusually wide and are rounded at the ends. The tail is relatively very short, but is broad and nearly even, the middle pair of feathers being larger than the others in adults. The body is stocky and heavy and powerfully muscled. The claws are strong, sharp, and ctrved.

There is general tendency toward a sooty blackish coloration of the upper parts in the older birds with a gilding of the head and hindneck and a whitening of the shafts of the white feathers toward their bases. The young are smaller than the adults and are: profusely streaked with rufous; several years are required to reach the color and dimensions of the adults. 


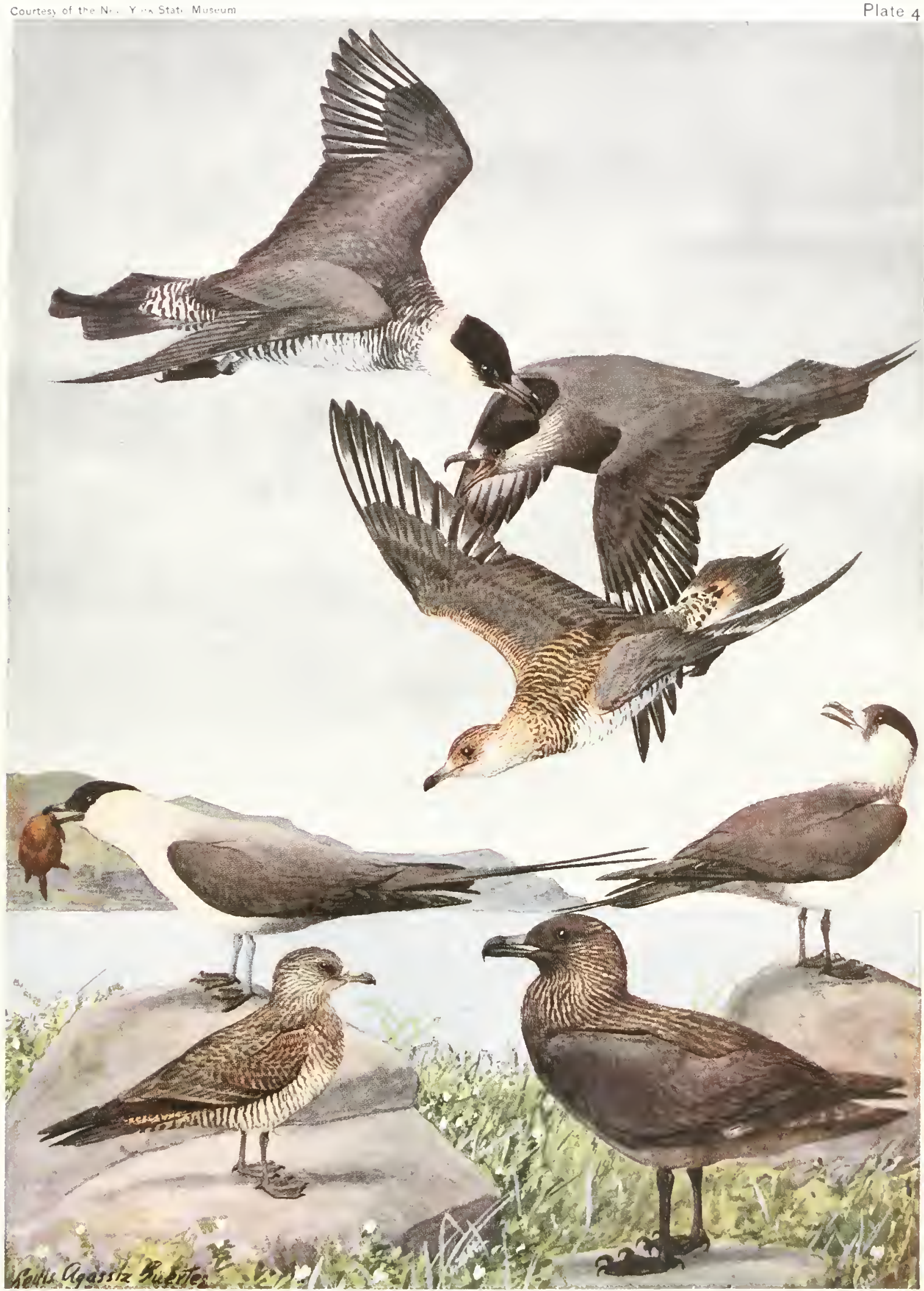

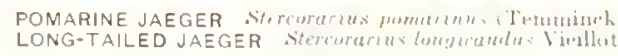

PARASITIC JAEGER 



\section{SKUA}

\section{Megalestris skua (brumnich)}

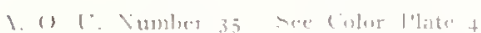

Givll.

Other Names...-Sea Hawk; Sea Jlon: linuxie: Skua

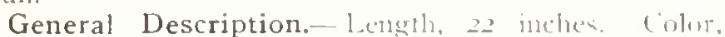
hlackinh-brown.

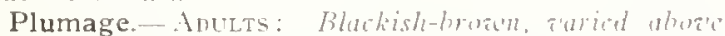
with chestunt and whitish (cach feather dark-colored with a spot of chestmut toward end, wharling into whitish along shate): on nape and acrus thruat, reddish-yellow with narrow white streak wn each featler; crown and sides of head, with little whitish: wings and tail. dusky, white fur some distance from lave - inncealed on tail by long coverts, but showing on primaries as a conspicuous spet; bill, black with gray cere; feet, hlack:

The Skua is one of the laresest and stronerent members of its rapacious erents, and is much given to robling the smaller sea birds, in the mammer of its relatives. It eccalsionally strays along the North American coatsts as far sonth as the northern boundary of the United States. There are records of its having been taken at least three times off the const of $\mathrm{M}$ ilssachusetts. A single melividual was shot on the Niagara

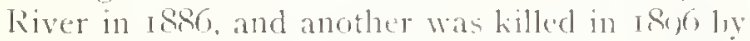
colliding with the lighthouse at Montatuk Puint. Long Island, N. I. ma, bown. Ansther plumage, not knewn to be clarac

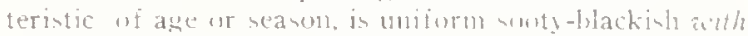

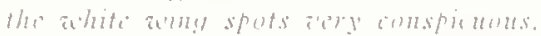

Nest and Eggs. - Nest: A deprention in the wrans; lined with grass and moss. Erits: 2 or 3. olute or drab. irregularly marked and hothed will elark olive-brown atuel sepia.

Distribution.- Cinast and islandes of the Nurth Atlantic; brecels on Lady firanklin lsland (Hudion Strait). in lceland, and on the farese and shetland islands: wonters on fishing lanks off Newfoundland and Nowa Seotia: rarely south to Long Island, X. I.; in Europe wuth to Gibraltar.

Little seems to have been set down concerning the hathits of the hird, which, howerer, probalsly 1o not differ exentially from those of the Jaeners. It does not assemlile in flucks. Seldom are eventwo prats seen losether. It is famed for it courage and latring in attacking and teasing Gulls and forcing them to give up the fish they have catught. Ineleed, its seientific name is an apt charaterization mequlestris is from two Greek words which, translated, are "larere pirate craft." In flight it hals a striking aluearance.

\section{POMARINE JAEGER}

\section{Stercorarius pomarinus (Timmmik)}

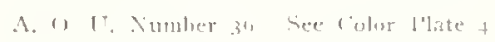

Other Names.-Full llunter; Sea kinbler; liull Chaser; Jaeger Gull.

General Description.- Lelgth, 24 inches. Color above, brownish-blick: lrelow, white.

Description.-Ablits in Parendis Plimage: Crown brownish-black extending helow eyes and on sides of lower bill: back, wings, tail, upuer and under tailcmerts, deep brownish-black: under parts from chin and neck all around, pure white - the sharp feathers of back and neck, light yellow; bill, horn color wharling to black; feet, black; iris, hrown. Neski.y Andet: A row of brewn spots across hreast: sides harrel with

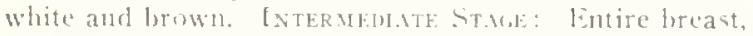
lorown mottled with white; upper tail-coverts and some wing-coverts, batred with white: ieet, Blotched with chrome yellow. In breeding and nearly arlult plumage the ta'd antral tail-feathers propet about four inches and are facted at risht anchles to the shajts: in the intermediate plumage the rentral talil-feathers project only one inch and irte not twisted: thene rentral feathers are rounded at the tip. Yoxne or Tuf. Sink: Whole forly traversely hared with dull rufous; wl head, neck. and under parts this color prevails. the lands very numerous, almut same wirlth as the lark color: on Hanks and usler tallewelts the hars are wider, palel and almost white; on balck and wimf-coverts, brownjshblack, mearly unifurm, prechmmates; primaries and tril-feathers, dusty, disker at tips: hearl and neck. montly pale rufous with a durky yout in iront of eyes: fest, bright yellow. These plumages are evidently progressive with age and are indepenalent of sex and sentsul, and different fromb the followiug: D) IRK PIIASE: 
Plumage, blackish-brown all over, shading into black on crown, lightening on abdomen: primaries, whitish at hase; feet, blotched with yellow and dusky: middle tail-ieathers projecting but half an inch.

Nest and Eggs. - NEST: On the ground in northern marshes, of grass and moss. Egrs: 2 or 3, olive, pale greenish, or brownish, spotted with dark brown.

Distribution. - Northern part of northern hemi- siphere: breeds from Melville Island and central Greenland south to northern Alaska, northern Mackenzie, and Baffin Lancl, and also on Arctic islands of eastern hemisphere; winters off Atlantic coast south to New Jersey; in fall migration common along the California coast: winters south to the Galapagos, Peru, Africa, and Australia; accidental in Nebraska; occurs irregularly on the Great Lakes.
My first experience with that bold maritime rolber, the Pomarine Jaeger, was on a day late in Angust, many years ago, when I crossed some Cape Cod sand-dumes and came in sight of the sea. Flocks of Terns and small Gulls were hovering over the water in all directions. Over then were big dark-colored birals with long tails
On the fisling-banks out at sea, wherever the Shearwaters and l'etrels gather. from August on through the autumn, I have usually found this Jaeser in attendance. With them are apt to be about as many Parasitic Jaegers and an occasional one of the Long-tailed species. The Jaegers are seen flying about, not close to the water like

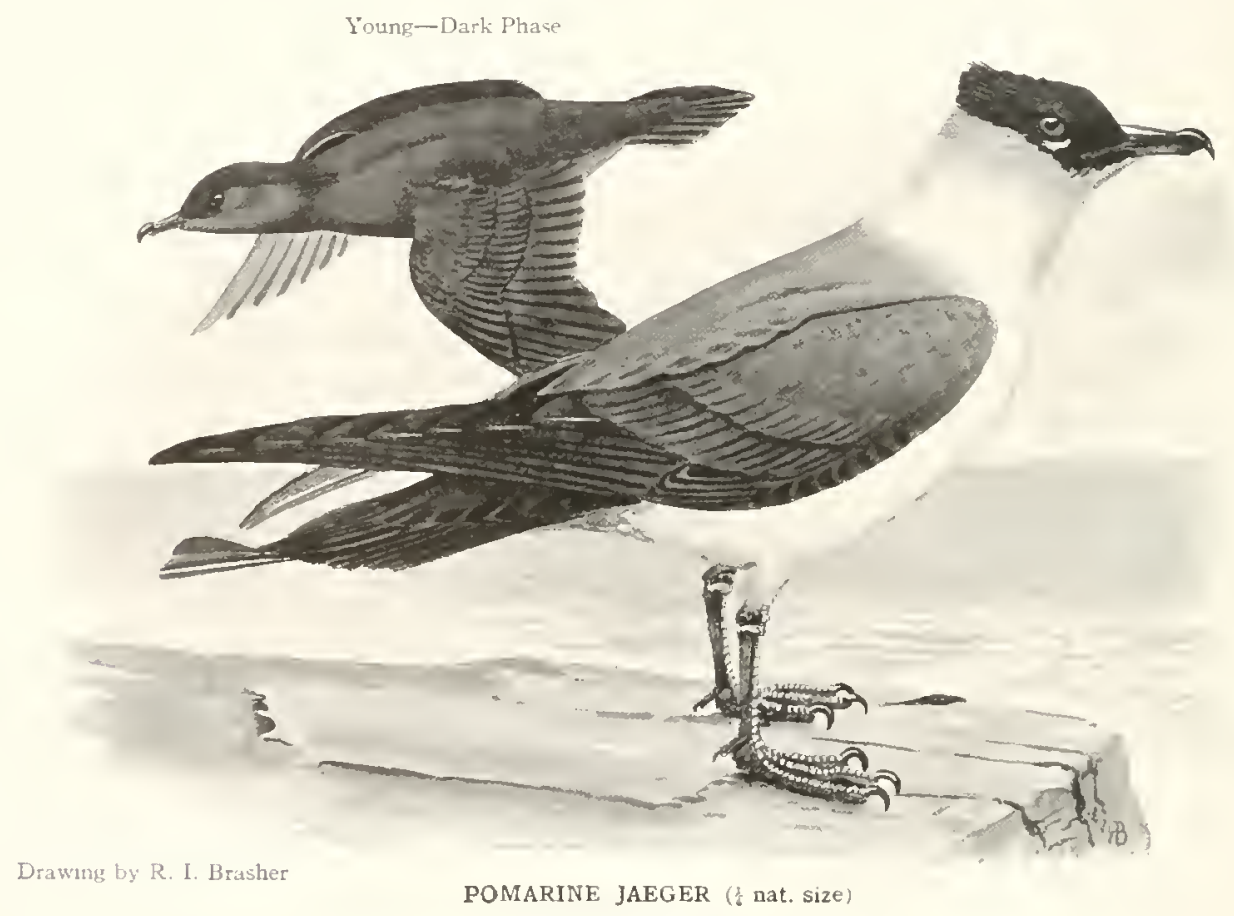

A bold maritime robber

coursing about with strong, swift flight. Now and then one of these would select for its victim a Tern which had just caught a fish, and give chase. No matter how the unfortmuate one might dart and dodge, the Jaeger followed every move. and by savage attacks finally compelled it to drop the fish. Then by a spectacular swoop the robber would seize the booty in mid-air. When no rictims are awalable for a hold-up, the Jaeger turns scavenger and picks up read marine life like a true Gull, but its meference is for depredation. the others, but higher up. say fifty to seventyfive feet, as though to get a better view, to detect any weaker bird which makes a lucky strike. Though sonewhat shyer than the rest, they are bold enough upon occasion, especially when eatables are being passed around. Sonetimes I have brought them nu quite close by making believe to throw something overboard. I have bated up numbers of them hy throwing out fish livers, and marle the most of the opportunity in securing photograples. At close range it was fascinating to study the different individuals as 
they appeared. owing to their great variations in plumage, all the way from the snoty phase to that of the adult with white under parts.

Jaegers are Aretic-breeding birds, not nesting in colonies. like the fulls and Terns, lut in scattered patiss. Sinch deatructive burls would hatdly make mod colonizers. They are atid to be great nest-roblets. and woe to the hivd which leaves egese of youms exposect wh these savages. JikH:k K. Jus.

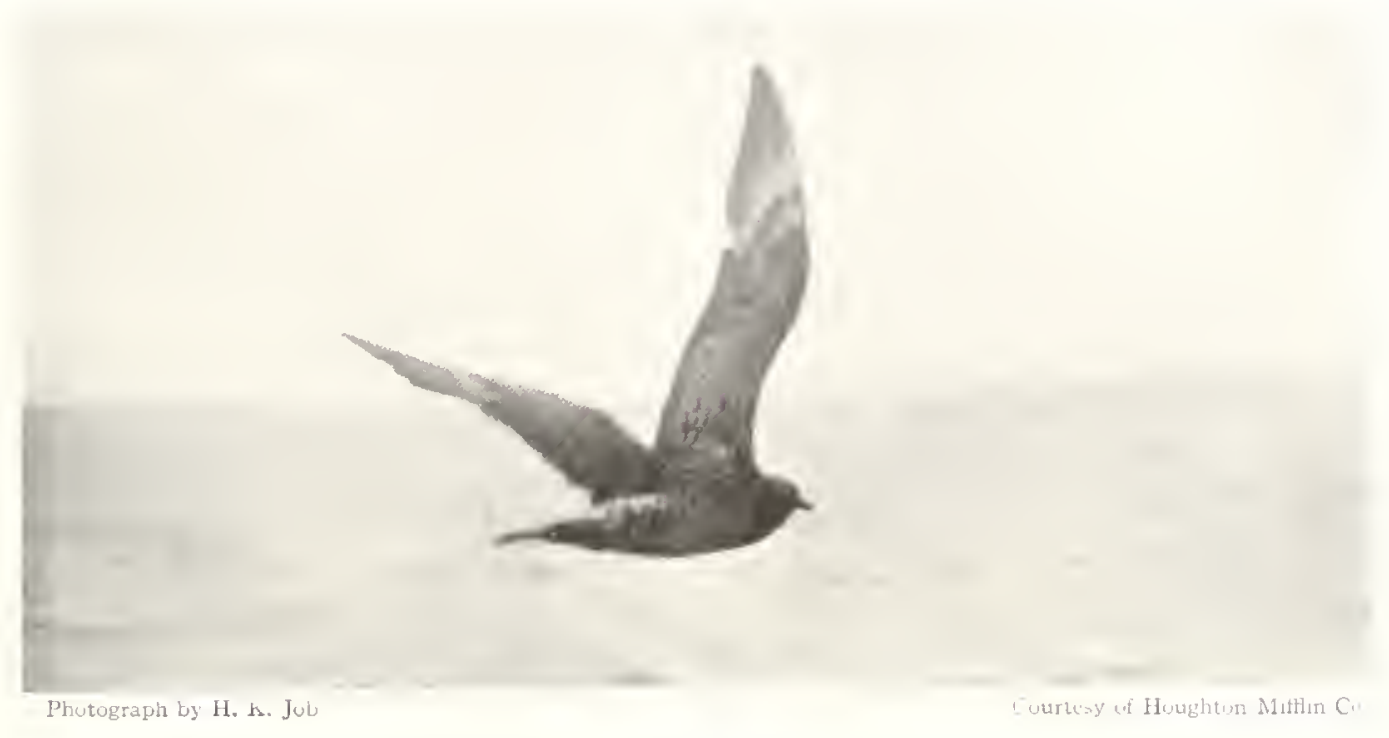

POMARINE JAEGER

In quest of a victim

\section{PARASITIC JAEGER}

\section{Stercorarius parasiticus (Limnams)}

1. (1) [". Sumber 37 see Lohor l"late 4

Other Names.-Skait-bird: linatswain: Marlinespike: Teaver: Dung Flunter: Nan-w"war: Richarelson', Jaeger: Black-toert Gull: Aretic Hawk Gull.

General Description.- Jemgth, 20 mehes. Cohor abuse, brownish-black: helow, white. Ta' midile bil-

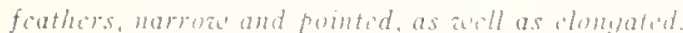

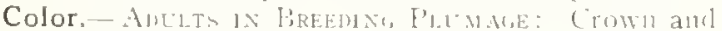
back of head, crested. the teathers sharp and stiff; crenth and whole uperer parts, slaty brownish-black, shading into black on wines and tail; chin, throut, sides of head, neck all around, and under parts, pure white, the harp feathers on lack of neek, light yellow; muler tail-eoverts, dusky: bill, lonrn colur, rlarker at end; feet.

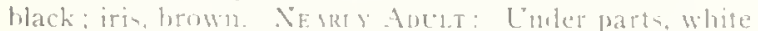
but mottled everywhere with dusy patches, heaviest acrose breast, on sides, and moder tail-coverts; center line of throat and alsomen, nearly pure white; iew. with small yellow blotches or not: otherwise as in breerling plumage. J) IRK P'HAse: lintire plumber. dusky, darker and more slate-colsored itsure. lishter and

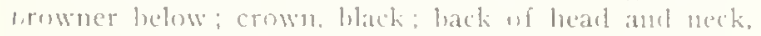

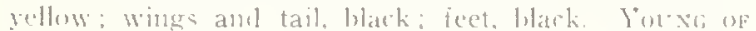
rule Year: Entire plumage, hared with rufons and
Irownish-black: sellowish-rufons prevails on hear and neck with dark shaft line on each feather; there shait lines enlarese until between thonleres they secupy the whole of each feather exrept a narrow rufous border: o, breast rufous becomen almunt white. with traverse hats of bruwn, this palturn cultinumer wer the entire muler parts; primaraes, dusky, narowly tiped with rufous

Nest and Eggs. NEST: A clepression in the gromud near water, spardy lined with gram and lead heaves. lins: 2 or 3, nlive, greenish, gray, or brown, narked and blotcherl with shales of hrown and pale lavenuler over entire surbice.

Distribution.- Xurhorn gat wi nurthern hemi-

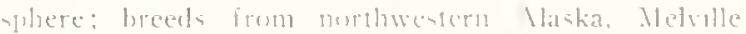

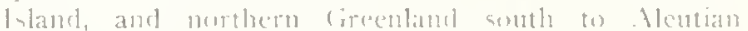

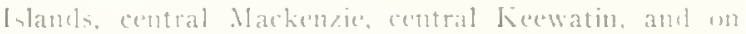

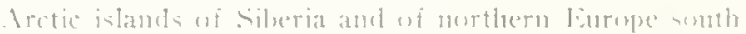

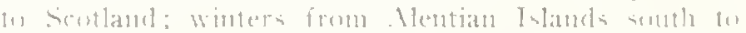

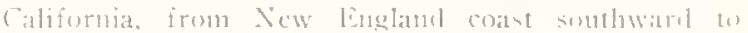
Frazil, in Inutralia, atul from the costet of Furne

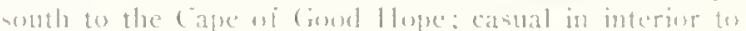

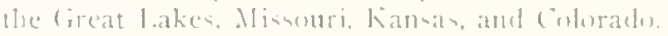


As its name implies, the Parasitic Jaeger is a robber and lives largely on what it can take by force from its smaller brethen. It is large. and very strong and swift in flight, and the Eskimos call it "the cannihal" because, they say, once upon a time it killed and devoured men. Ii is much swifter and quicker than the Pomarine species, which it attacks and drives away, but it is less graceful on the wing. Accorling to Edward II. Nelson, these birds bully and rob the Gulls and Terns, forcing them to disgorge fisls which they have caught, and swonping below them snatcly the fond as it falls, very much in the manner of the Bald Eagle robbing the Fish Hawk.

These Jaegers often lunt in pairs and will then attack and rob even the Glaucous-winged Gull, which could make short work of its tormentors if it could only get at them. "liut the parasites are ton adroit, too elusive, and too desperately persistent." says Mr. Dawson. "The Gull hates to do it, but also he hates to be buffeted and hustled away from the fishing-grounds. Here, take it, you scum, and be off with you!',

\section{LONG-TAILED JAEGER}

\section{Stercorarius longicaudus Vieillot}

A. O U. Number 38 tiee (olor Plate 4

Other Names.- Arctic Jaeger: Gull-teaser.

General Description.- Length, 23 inches, Color above, deep purplish-slate; helow, white deepening into slate. During breeding season, crowns have slight crests. This is a smaller bird than the Parasitic Jaeger. the greater length being due to the cotrcucly long tailfeathers.

Color- Adults in Breeving Plomare: Lores and side of hearl above eye to nape, brownish-black; neck all around light straw-yellow: above with wing and tailcoverts, deep purplish-sfate, deepening on primaries, secondaries, ontside tail-feathers, and ends of central pair into lustrous broanish-black: chis, throat, and ujper breast, white gradually shading into the dark slate of abdomen and nnder tail-coverts; bill, dusky with black tip; feet, grayish-bhe; toes, wehs, and claws, black; iris, brown. IMMATLRE: Changes of plumage identical with those of previous species. DARK PHASE: Very rare.

Nest and Eggs.- NEST: Depression in the ground. scantily linerl with dry grass and leaves. EGGs: 2 or 3. dark greenish, thickly spotted and blotched with brown.

Distribution, - Northern part of northern hemisphere; breeds on Arctic islands of Europe and Asia, and coasts of Kotzebue and Norton sounds, northern Mackenzie and northern Hudson Bay to northern Greenland; winters south to Gibraltar and Japan; in migration not rare off New England coast; casual on the Pacific coast south to California: accidental in Manituba, Iowa, Illinois, and Florida.
Nelson describes the long-tailed Jaeger as "the most elegant of the Jaesers in its greneral make-np, and especially when on the wing. At this time, the bird shows all the srace and ease of movement which characterize such birds as the Swallow-tailed Kite, and other species with very long wings and slender bodies. It appears to delight in exlubiting its agrility, and 1 wo or more frepuently perform strange gyrations and evolutions during their flight as they pass back and forth over the low, flat country which they frequent. It is, like the T'arasitic Jaeger, found more plentifully along the low portions of the coast than at sea, and is very numerous along the coast of Norton Sound."

Like the other members of the genus. this Jaeger is a persistent and merciless robber of the smaller Culls, swooping down on them and forcing them to disgorge fish or mollusks they have taken, and capturing the food as it falls. Flocks of Kittiwakes are likely to be accompanied $b y$ one or more of these Jaegers industriously ensaged in this brigandism.

The species may be readily identified by the marked elongation of the central tail-feathers. Georie Gladden. 


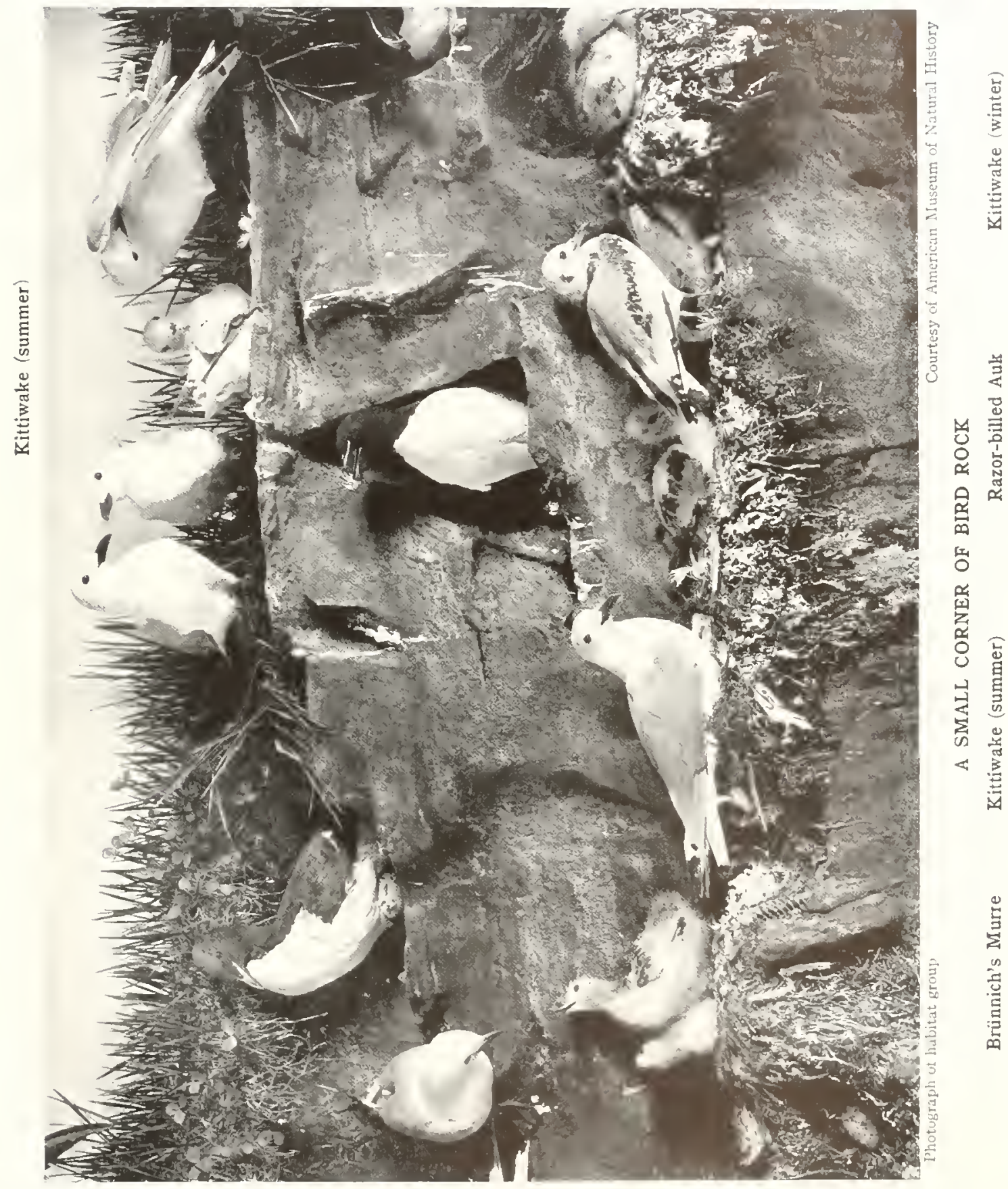




\section{GULLS}

Order Longipennes; family Larida; subfamily Larina

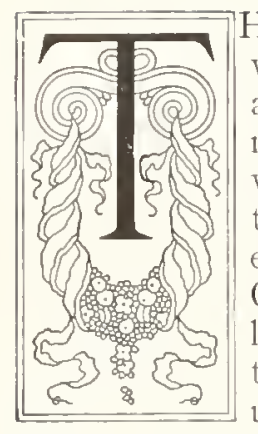

HE Gulls comprise the subfamily Larinc of the Gull and Tern family (Larida) which is part of the order of long-winged swimmers (Longipenues). There are about fifty species of Gulls, some of which are often found far inland, but most of which show an especial fondness for the seacoasts and their immediate vicinity. As a rule they are larger than their allies, the Terns, from whom they differ also in generally having almost square tails, though there are exceptions to this rule in the form of Terns with nearly square tails and of Gulls with tails which are more or less forked. An invariable difference, however, is in the structure of the upper bill, which is ridged and hooked at the end in Gulls and virtually straight in Terns. When hunting food, Gulls usually fly with their bill nearly on a line with the body, while Terns earry theirs pointed downward. Again, the Gulls alight freely on the water to feed, whereas the Terns hover and plunge for their food.

The Gulls show considerable variation in color, and some seasonal changes in plumage which have eaused confusion in identifying species. "The predominating color of the adult birds," says Stejneger, "is white with a gray mantle, varying in shade from the most delicate pearl-gray to dark blackish-slate or nearly black, and the head is often more or less marked with black in summer. The seasonal change is not great, and affects chiefly the color of the head, which, in species with black heads, turns white in winter, while the White-headed Gulls usually get that part streaked with dark during the same season."

All of the species are web-footed and swin readily; they show little skill in diving, however, and the living fish they prey upon are chiefly the hind which come near the surface of the water, like the herring. On the wing they show perfeet ease, and remarkable quickness and eleverness in their maneuvering, especially in the wind. It is certain, too, that they are capable of very long flights.

Gulls are markedly gregarious, and this instinet is especially in evidence during the breeding season, when several species may congregate on favorite nesting ledges to the number of thousands, if not millions. Their nests are composed usually of seaweeds and moss, and the eggs, usially no more than two or three, range in color from bluish-white to brownish, with blotches and spots of black, brown, or purplish.

Flocks of Gulls resting lightly on the waters of our harbors or following the wake of water craft are a familiar sight, but not every observer of the graceful motions of the birds is aware of the fact that Gulls are the original "white-wings." As sea scavengers they welcome as food dead fish, garhage, and offal of various sorts, and their services in cleaning up such material are not to be regarded lightly. It will surprise many to learn that certain Gulls render important inland service, especially to agriculture. At least one species, the California Gull, is extremely fond of field mice, and during an outbreak of that pest in Nevada in $1007^{-8}$ hundreds of Gulls assembled in and near the devastated alfalfa fields and fed entirely on mice, thus lending the farmers material aid in their warfare against the pestiferous little rodents. Several speeies of Gulls render valuable service to agriculture by destroying insects also, and in spring hundreds of Franklin's Gulls in Wisconsin and the Dakotas follow the plowman to pick up the insect larva uncovered by the share.

That at least one community has not been unmindful of the substantial debt it owes the Gull is attested in Salt Lake City, where stands a monument surmounted by bronze figures of two Gulls, erected by the people of that city "in grateful remembrance" of the signal service rendered by these birds at a critical time in the history of the community. For three consectitive years - I 848 to I 850 - black crickets by millions threatened to ruin the crops upon which depended the very lives of the settlers. Large flocks of California Gulls came to the rescue and devoured vast numbers of the destructive insects, until the fields were entirely freed from them. It is no wonder that the sentiment of the people of Ltah, as reflected through their laws, affords Gulls the fullest protection. It would be well 


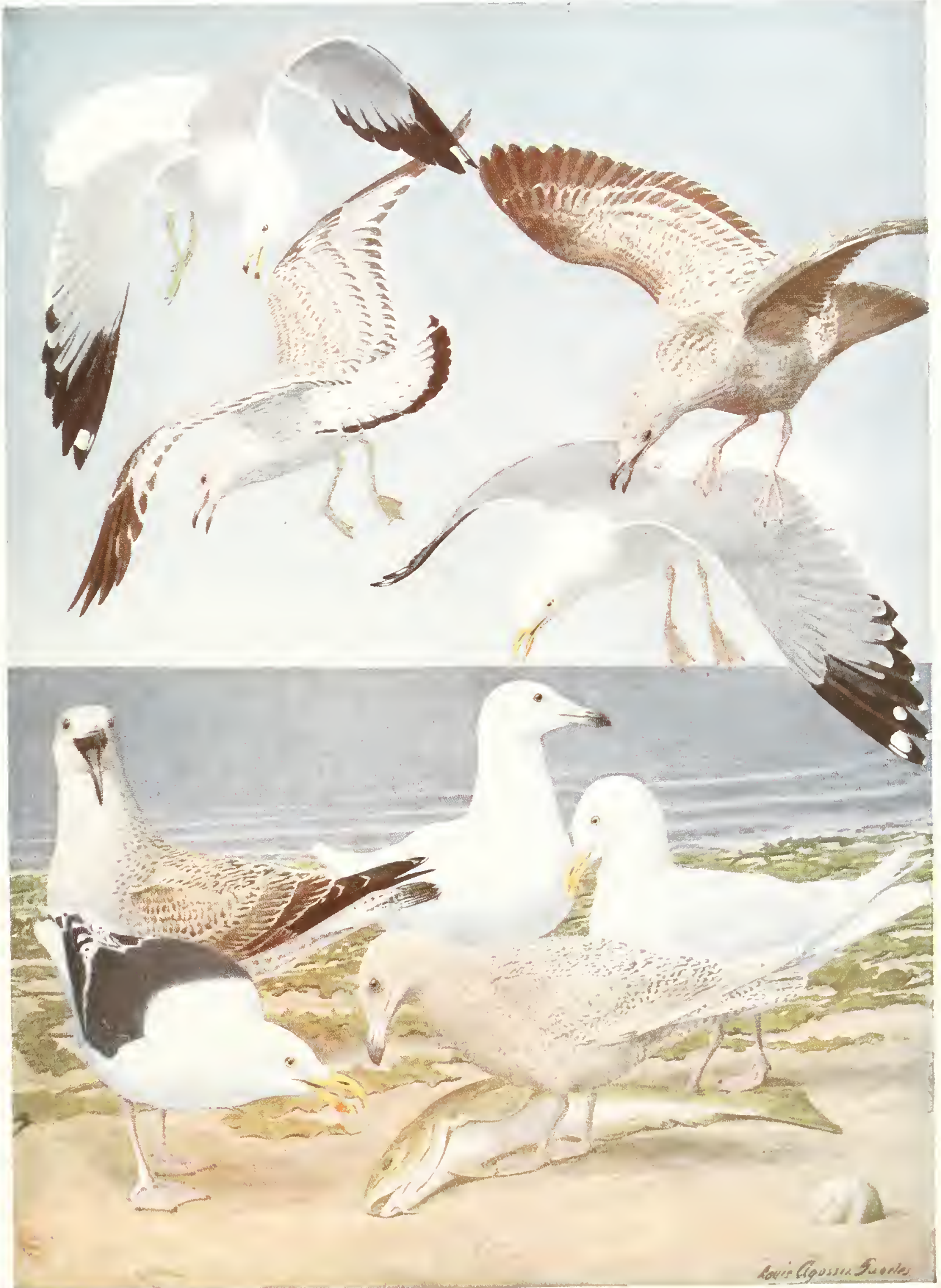



if such sentiment prevailed clsewhere throughout the United States. However, within the last few vears much progress has been made in protecting these most beautiful dwellers of coasts and marshes.

\title{
IVORY GULL
}

\section{Pagophila alba (Gimmervis)}

1. (). I' Sumber 39 see (ulor I'late 6

Other Name-Snow-white Gull

General Description. - Length, 18 inches. White.

Color.- Intets: Enture plomage, fure white; shaft of primarses straw yellow : bill, dull grecnish, yellow at tip and along cutting edges; fect, black; irts, brown ; eyclids, reel. Focxi: firont and sickes of head, duckygray : neck all around with irregular spotting of brownisli-gray; shoulders and wing-coverts with brownishblack spots, thicker on lesser coverts: tips of primartes and tail-feathers with dusky spots.
Nest and Eggs.- NEST: In niches of diffs; cunstructed of grass and redweed, and lined with moss and a few ieathers. Eass: 2 to t, olve-buff, spotted with different sharles of brown and gray.

Distribution. - Aretic seas; breeds from Melville l-land and northern liatfin land to northern Greenlanil and Arctic islands of eastern hemisphere; winters in the extreme north, rarely south to British Columbı. Lake Untario, and Long Juland. N. Y, ; in Europe soutls to france.
The first word of the reientific name of the Trory Gull expresses its chief characteristic. just as the secunt word-alba, the Latin for "white" - is descriptive of its plumage. Payophila is from two lireek words meaning "ice" and "lovingr." Hence this beautiful snow-white Gull is a rate visitant to the temuerate zone of this continent from its home in the Aretic seas. The only verified record of the alppearance of the bird in New York seems to be that furnished by Willian 1)utcher of one shot in Great South Bay. L. 1., near Sayville, in January, 1893. Another observer reports having seen a single nember of the slecies near Mt. Simai l Iarbor, in Suffolh County, $X, Y$. ln smomer it recurs frepuently on the Arotic island of the castern hemisplere. and in winter it ranges southward to France. The greenish-yellow beak and the black legs are in striking comtrant to its heatiful snow-white plumase. It differs [rom otines (iulls in the comparative shortness of its beak, and slightly taperinger tail.

The lvory Gull is a glutton whenever it can (1)tain the flesh of seals or the hlubber of whalen. It will watch a seal-hole in the ice, waiting for the seal, whose excrement it devours.

\section{KITTIWAKE}

\section{Rissa tridactyla tridactyla (Linnous)}

\author{
1111 . Number to see culor liate o
}

Other Names. - Common Kittiwake; Kittiwake Cunl : P'ick-me-up: Coddy-Atoddy': Tarrock.

General Description.-Length, 18 inches. Color. white witl pale graysla-blue mantle. Hind top, absont or rudimintury; tail, shightly notched.

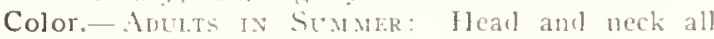
arounel, umeler parts, and tail, pure white: mantle. pale graysh-blue: wing-coverts and secondaries similar,

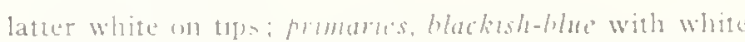
ublong spaces on inner webs, the second, third and fourth with white tign: fort, hlackish: bill, light yollew tingerl with olve: iris, brown: eyclids, red. ADtots is IVINTer: liack of heart, nilpe, and hicles of breast, shated with color wf back: a lusky patch behind use and a small black creacent in front of eve; bill, dnsky-olive otherwise as in smmmer. Foress: Eyecresent and spot 
behind eye as 11 winter adult plumage; a broarl bar across back of neck, lesser and middle wing-coverts. inner secondaries, and a terminal bar on tail, hlack; tirst four primaries with outer webs, uter half of inner webs and ends for some distance, black; the rest, pearly-white.

Nest and Eggs.-Nest: On rocky ledges overlooking the water; made of grass and seaweed. EGos: 2 or 3. sometimes 5, buff, brownish-gray, or greenish- gray, irregularly spotted with sharles of brown and lavender.

Distribution.-Arctic regions; breeds from Wellington Channel and northern Greenland south to Gulf of St. Lawrence, and from Arctic islands of Europe and western Siberia to southern lirance: winters from Gulf of St. Lawrence south to New Jersey, and casually to Virginia, Bermuda, and the Great Lakes; accidental in Missouri, Colorado, and Wyoming.
The graceful and industrious little Kittiwake has several interesting and characteristic traits. It pursues its prey after the manner of the Terns. hovering over the water and plunging head foremost into the sea, with all of the dash and vigror of a Kingfisher. These Gulls are often seen following right whales apparently to get the fragments of tish rejected or dropped by those monsters. Observers who have watched the birds doing this say that they act as if they knew when the whales must rise to breathe.

The Kittiwake feeds mainly on fisln, but will take almost any animal or vegutable refuse it can find. For drinking it prefers salt water to fresh, and it is often seen sleeping peacefully, floating on the great rollers, with its head tuckerl under its wing - literally "rocked in the cradle of the deep." It is a great wanderer, and de- cidedly democratic in its disposition, for it is often found in the company of other Gulls, Terns, and varions other sea-birds.

It takes its vernacular name from a fancied resemblance between its cry and the syllables "kit-ti-wake." In its scientific name, Rissa is its lcelandic name, and tridactula is from the Cireek, meaning "three-toed," and refers to an anatomical peculiarity of the species.

The Pacific Kittiwake (Rissa tridactyla pollicaris) is a geographical variation of the Common Kittiwake. The two differ but very little. The former occurs off the coasts of the north Pacific, Pering Sea, and the adjacent Arctic Ocean, breeding from Cape Lisburne and Herald 1sland south to the Alentian and Commander Islands, and wintering from the Aleutian Islands south to northern Lower California.

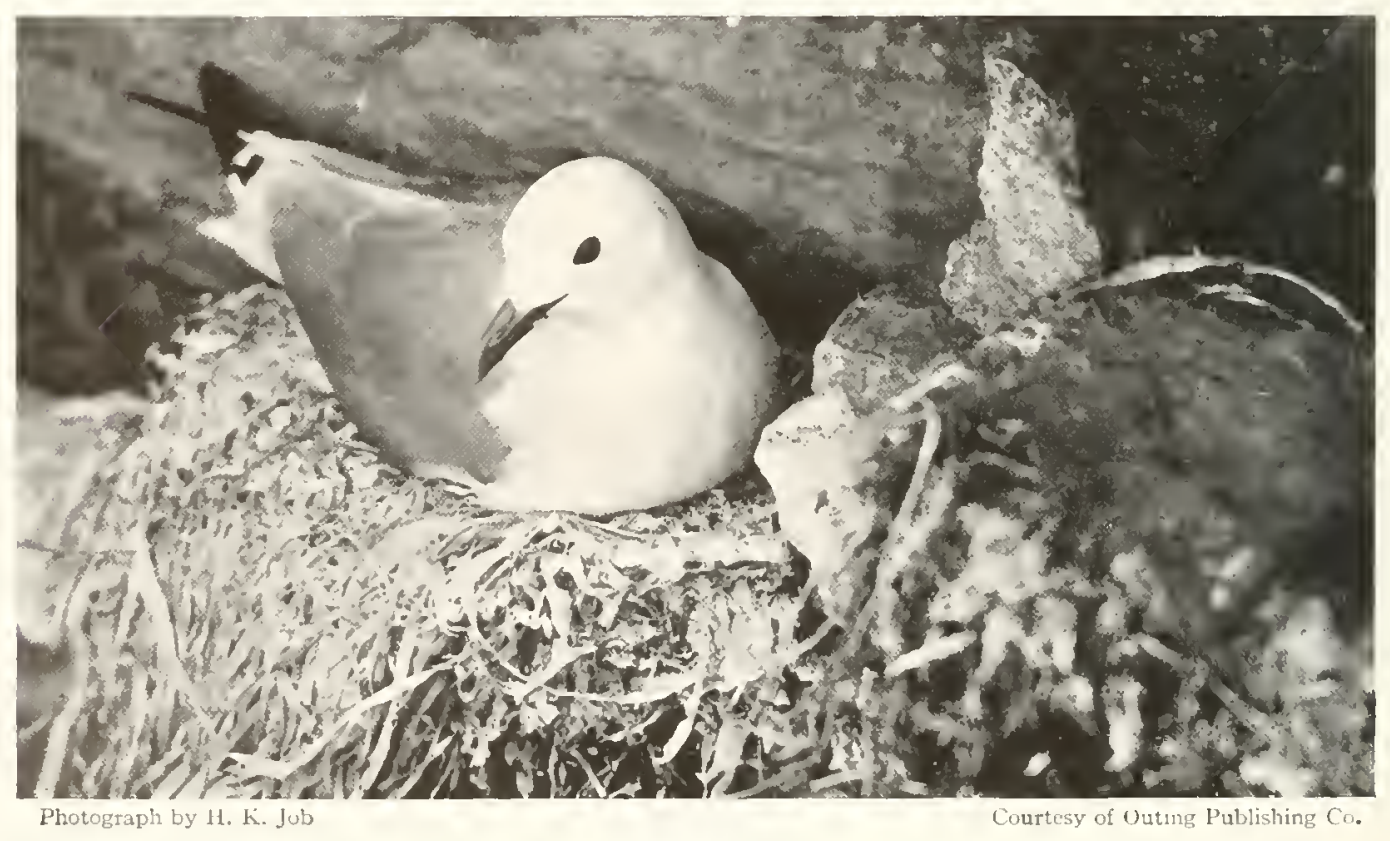

KITTIWAKE

1n its nest on a cliff 


\section{GLAUCOUS GULL}

\section{Larus hyperboreus Gunnerus}

1. A $\mathrm{I}^{\mathrm{r}}$. Number 42 see Color Plate 5

Other Names,-Burgomaster: Burgomaster Gull: Ice Gull; Harbor Gull; Blue Gull.

Length. - 30 inches.

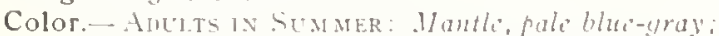

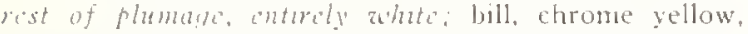
more waxy on end with a bright vermilion spot at augle: lexs, pale fleth color; iris, light yellow. Aduts 1N WINER: Simmlar to summer plumage, but head and hindneck tinged with rale brownish-gray. Yor"vo: Lpper parts, whitish nottled with raw umber, fale reddish-hrown. and dusky, this coloration heavest on back; nnder parta, nearly uniform pale brown; wings and tail, barred with same; lill and legs, pale flesh color, the former black-tipped; iris, brown.

Lncler one of its popular names, the "Burgomaster Gull," the Glaucous Gull was made famouts, or rather infancus, by Celia Thaxter's poem. which described its rapacious habits. This poem found its way into many school reading books of a generation ago. It gives a rivid and stabstantially accurate picture of the appearance and activities of a group of sea birds, and portrays one of the characteristics of the Burgomaster. Indeed, according to other observers, the bird not only robs smaller fiulls and other sea birds of the fish they catch, but eats their eggs and young and sometimes the adult birds themselves. It is recorled that a member of Koss"s expedition to the Irctic regions shot one of these Gulls which, umon being struck, dicgorged a I.ittle Ank it had just levoured, and when dissected was found to have another member of the same species in its stomach
Nest and Eggs.- NEST ln tussocks of grass, constructed of seaweed and dry grass. Eustis: 2 (1) 3. White to dark grayish-brown, blotched with brown and hrowuisla-black.

Distribution.-Arctic regions; breeds from northwestern Alaska, Melville Island, and northern Greenland, south to Aleutian lilands, northern Mackenzie. and central Ungava, and on Arctic islands of eastern homisphere; winters from the Aleutians and Greenland south to Monterey, Califorma, the Great Lakes, and Long Island. N. Y.. and casually to Bermuda, Corth Carolina, and Texas; 11 Eurone and Asia south to the Mediterranean, Black, and Caspian seas, and Japan.

Fishing fleets are likely to have the company of one or more of these Gintls, on the watch for any oflat that may he thrown overboard. Under such conditions it has often been caught with a hook and line with a fish as bait. Though naturally timid and suspicious, its fondness for offal is likely to overcome its caution, and cause it to enter bays and even inland waters. Several specimens have heen taken in the lower Hudson River and in New York Bay, ani individuals have been seen in the Great Lakes.

A curious trait of this Gull is its apparent disinclination to alight in the water. In its natural habitat it alights generally on the lighest point of an ice hummock. It displays none of the affection for its kindred which is characteristic of most of the Terns and Gulls, and will promptly desert either young or mate when they are in danger

\section{GREAT BLACK-BACKED GULL}

\section{Larus matinus Limnous}

1. 1) It Number 47 see Color Plate 5

Other Names. - lilack-backed Gull: Saddleback; Coffin-carrier: Cobb: Wagell.

Genera! Description.- Length, 30 inches. Color. white with a leep slate mantle.

Color.-Anuts in Sum MeR: Hantle, derp dark slate aith a purplish timur secnndaries, broadly tipped with white: primaries, hack. white-tipped: rest of plumage. pure white: bill, chrome yellow, tip wax yellow with a large apot of bright vermilion on angle; legs, pale flesh color: iria, lemon-yellow: evelids, vermilion. Ancits in Mixtek: Similar to summer folumage. lut liead and neck streaked with dusky. Souvo: Aluve, dull whitish. mottled with brown and pale chentunt: wing-coverts and secondaries. dull brown with light edges; primaries, plain dusky, tipped with white; tail, brownish-black, farling to white at base, imperfectly harred with brown: forehead. crown, and under plarts in general, dull whitish, mottled on abdomen with brown and dusky; throat, usually inmaculate but sometimes like breast with faint brownish streaks.

Nest and Eggs. - Nest: Ustally on small island: large and bulky; constructed of iry grasses aud wellcupped. Esis: 2 or 3. pale olive-gray, hlotched with dark brown and black, with ame purplish spots.

Distribution.- Coants of Norlh Allantic: breeds from North l)evols J sland and central Greenland south to Nosa Sontia, and to latitude $50^{\circ}$ on Furopean coasts: winter from southern Greenland south in the Great lakes and Delaware Bay (casmally to lilorida), and the Canaries: accidental in Bermuda 
John Maclair Linraston, an English ornithologist, included the following characterization of the Great Black-backed Gull in his book Birds by Land and Sea:

"A staider and more deliberate flight marks the movements of the Great Plack-backed and as he passes slowly before you, his eye on a level with your own, the brow seems to beetle in a set frown, and the glass catches the expression of the deeply set eye. It seems an old eye, wise, anthoritative. And, in fact, the birl may have been old when you were a child, for it requires four years for a Great Plack-back to acquire all the marlis of maturity, and its lifetime may well
1) leasure is aroused, he will return again and again to swoop at you with menacing cry. "The sea is mine,' he seems to say; ' and the smitten rocks. Get back to your brick-and-mortar cages with their glass peep-holes.' A century of the sea may well give a sense of prescriptive right."

This beautiful and dignified bird is frequently seen as a winter visitant off the shores of Long Island (between Septenuber and March) and on the Great I akes. Its breeding places are confined to the Atlantic coast. It is very shy but exceedingly noisy. William Brewster says that he identifiert four distinct cries: "a braying ha-

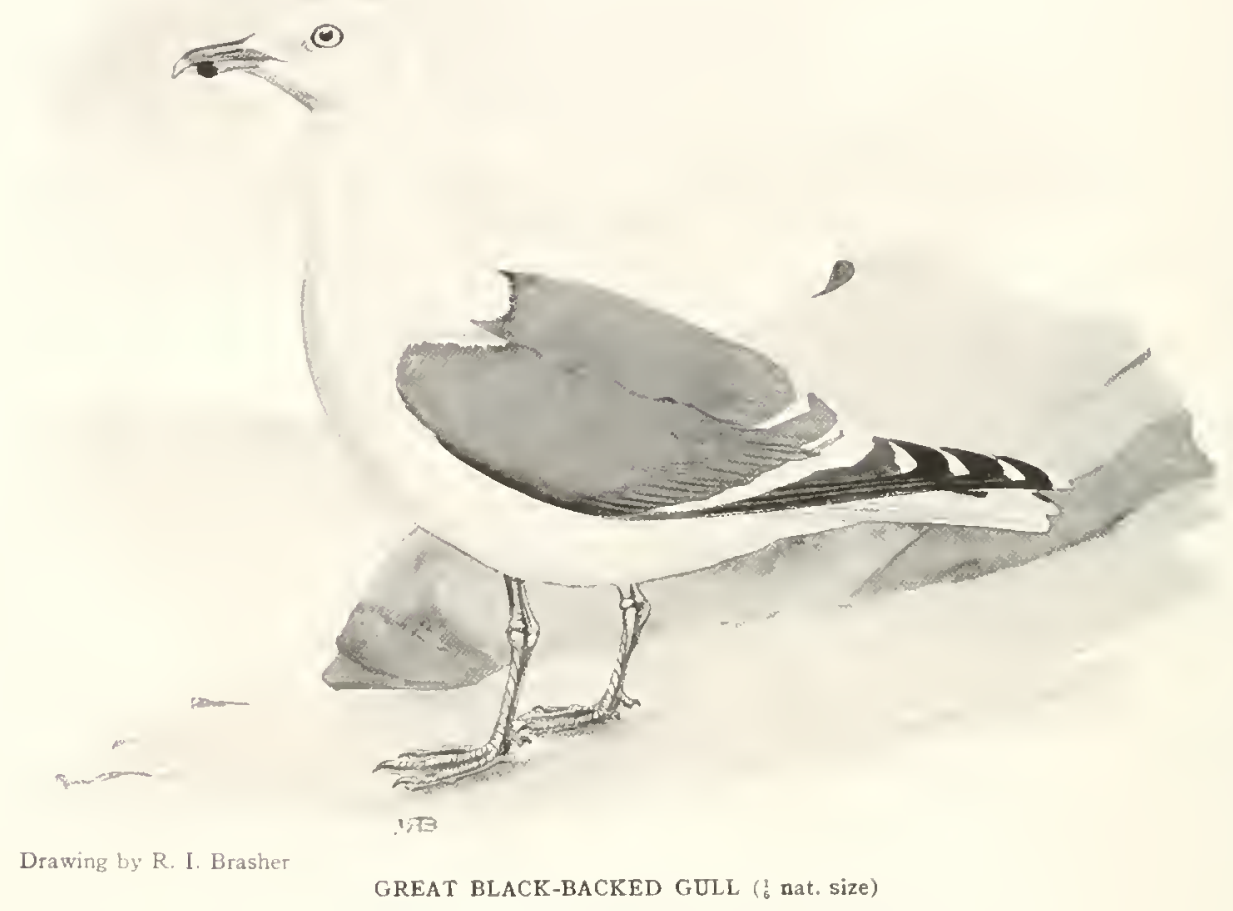

Four years are required for this Gull to attain maturity

be a century. It will take offence at your presence more readily than the other fulls, and as it passes, utters a low Ha-ha-ha-ha! and sails on solemnly leaving you admonished. If his dis- ha-ha, a deep kcoa', kfow', a short barking note and a long drawn groan, very loud and decidedly iniuressive." The koou cry suggests the note of the Green Heron.

\section{HERRING GULL}

\section{Larus argentatus Pontopfidan}

\section{A. O. U. Number $5 \mathrm{t}$ See Color Plate 5}

Other Names.-Common Gull: Harbor Gull; Sea Gull; Lake Gull; Winter Gull.

General Description.- Length. 24 inches. Color, pure white with grayish-blue mantle.

Color.-AuUrts in SuMMER: Head, neck, tail, and under parts, pure white; mantli, arayish-bluc; outer primaries, dusky with white spots and tips; center ones, color of mantle with black subterminal bar and 
numer ahti tips: rest of primarles and secondaries, with white tipu: bill, chrome yellow with red spot at

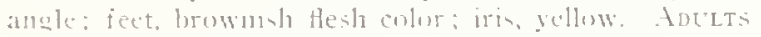
1Y IVTER: Similar to -ummer plumage. hut head and neck streaked with durky and yellow of bill duller. Fotso: Dull whilinh, varied everywhere with shades wi brown and dusk: tail, plain brown: primaries anul secondaries, hrown with white tips; bill, pale flesh colur, lunky at end: lege, nesh color; iris, loruwn. There is much variation in the amount of dusky color in individuals: young wi lhe year are somemes almost entirely sooty-brown: this changes with the gratual acyusition of lighter tipn and erlges of the feathers. hinally reaching the nerfect adult plumage in three year.

Nest and Eggs.- NEST: Somelimes on the ground. wcasionally in trees: gromud nent wevally mere depres- sions with scant nesting material; tree nents bulky and well constructed of strungly interwoven grasis and moss. Eikis: 3. light bluinh or greeninh-white to dark wiveliruwn, irregularly lolotched, spotted, and scrawled with lark brown and black

Distribution,- Northern hembithere; in America breeds from south-central Alaskit acrom British Imerica to Cumberland Sound, south to liritish Columliar, across the Uniterl Slates on about the pratlel 43 to. Naine, and in liurope south to morthern france and ean 10 Whice sea: winters from nurthern borler of Lnited States southward to Lower California and western Mexico, and from Gulf of St. Lawrence and the Cireat lakes south to the liahamas, Cuba, lucatan, and coast of Texas, and in lurope to Mediterranean and Lispian seas
The most abundant Gull along the Atlantic wast of the Lnited states is the faniliar Herring Gull. It is the -pecies we find following the coast-wise shiph towking eagerly for any scraps of fond that are thrown overboard from the conk's galley. It how ticke we may find them. of ten by humelects. standing on the exposed bars and mud flats. They come into the harloors and fly about the pier. They wanler far tup the rivere and are contintally met with even on the smaller lakes of the interiur Their food consists largely of finll, and the fact that some denizen of the dees ma have been dearl many days before the waves cast it mon the beach makes no slifference with them. They are as fond of carrion as in a Vulture. One peculiar habit they harr is the breaking of cham shells in a most unumal manner. When the water is fow they sait neer the mucl flat motil a clan is discovered. 1)ropping down they grasp it in their feet and Hy away to a portion of the leach where the sand is pracked hard and here from a height of forty (Ir fifty feet they let it fall. I have seen one repeat this performance fourteen times before the shell broke and allowed it to enjoy the feast it so much craverl.

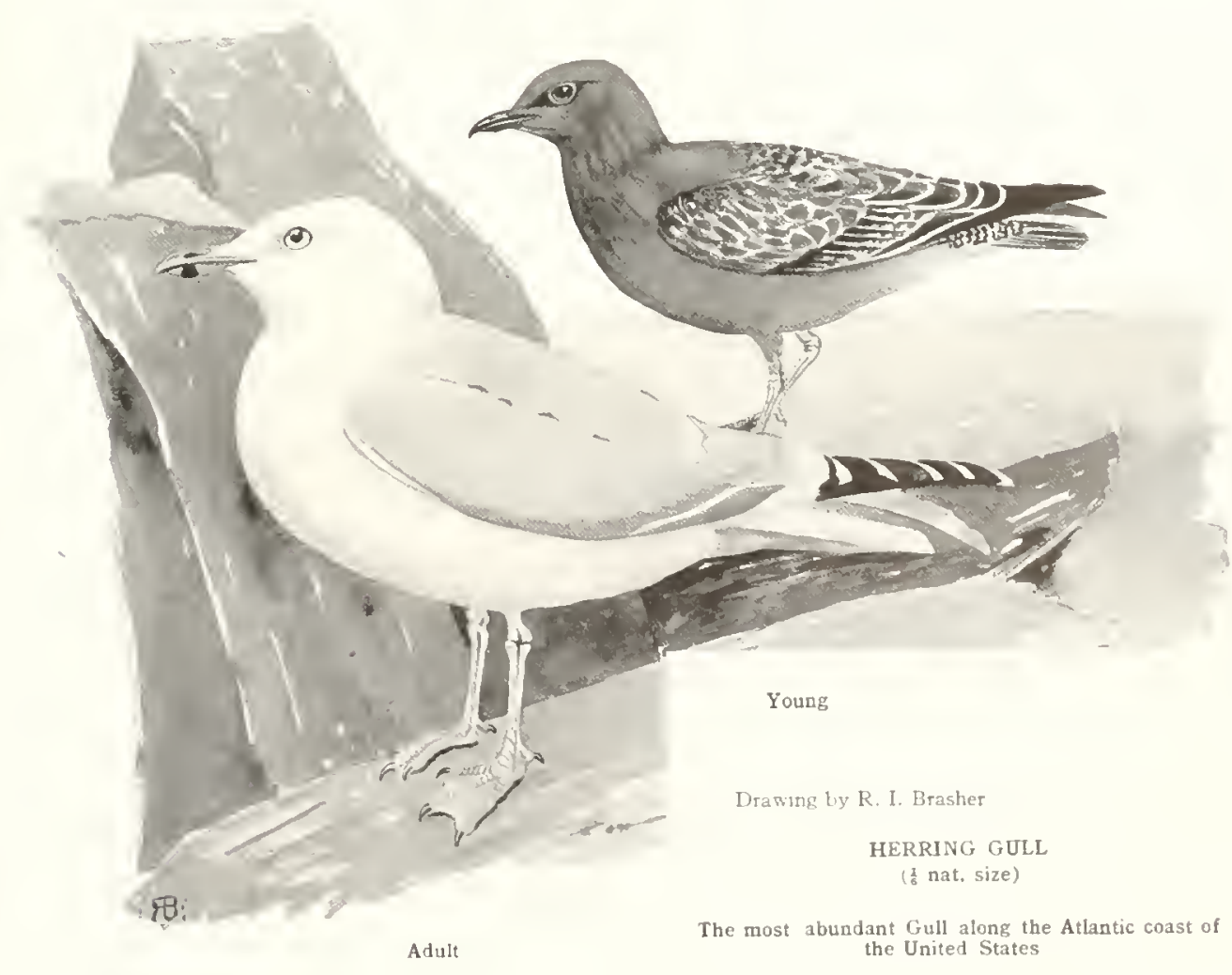



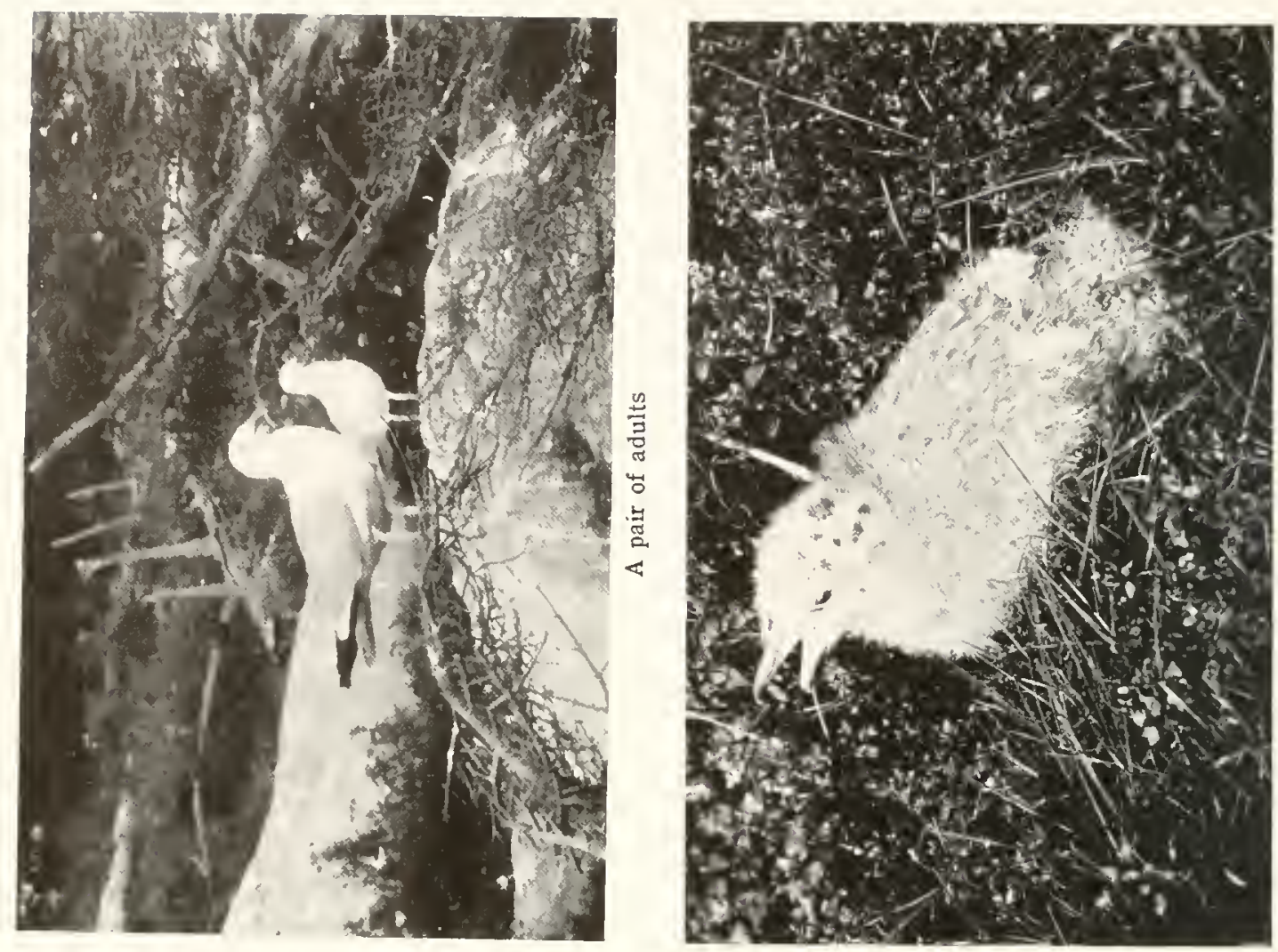

$\bar{\Xi}$
.
00
0
$\bar{\partial}$
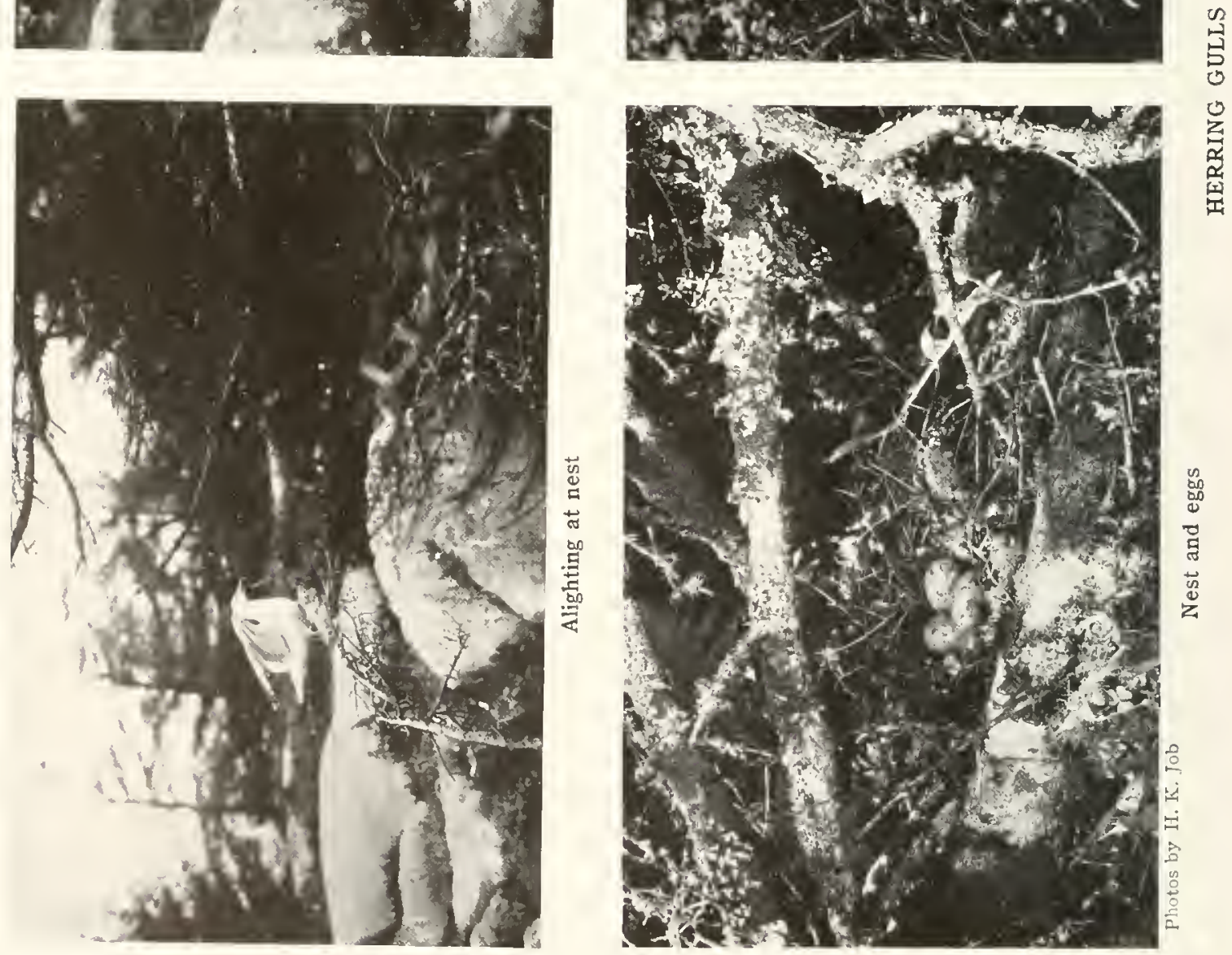

莕 
Herring (iulle breed on the rocky islands off the coast of Maine and thence northwart. Frequently they assemble in very large numbers at this season. I'robal,ly 10,000 nest annually on Great Duck Jsland and the colony on the island of No-Man's-1and, Maine, has of recent years been even larger. The nests are marle of grats and are often hidden in elumps of grass, by the side of logs or anong piles of bowlders. Within a few days after hatching the youner are able to run about and when a visitor walles through a breeling colony at this time the young birds go scuttling away in erery direction like so many dirty little sheeg. Although hard to catch they at once become docile when picked up. I have sometimes amused myself by laying them on their backs where they will often remain perfectly still until a row of half a dozen have thus been assembled.

Apparently these Gulls are their own worst enemies, as hundreds of young are ammuatly litled by the old birds, who peck them on the head. Infortumately the youns alpear to he unable to distinguish between parent and neighlurs, and when an old one alights nearby they come up trustingly in quest of food: frequently swift death is their reward.

Formerly hundreds of thousands of this species were killed in summer for the millinery trade; but the Audubon Law now makes this a misclemeanor in every State where they are found, and wardens employed by the National Association of Audubon Sixcieties to-day graard all the important breeding colonies in the United States.

There are nesting communities of them at various places in the interior as, for example, lake Champlain, Mlonsehearl Lake, and the Creat Lakes. A very similar subspecies known as the Western Gull (Larus occidentalis) inluabits the Pacifie coast of Nortl America.

T. (IILARET l'EARSON.

\section{CALIFORNIA GULL}

\section{Larus californicus Lurirence}

\section{O. [T. Number 53}

General Description.-Length, 23 inches. Cilor, pure white with pearly-hlue mantle.

Color.-ADtuts in Summer: Mantle, pearly-blue; outer primaries, hlack with white spots and tips, the

black grading to a narrow bar on sixth primary; secundaries, white-tipped; rest of plumage, pure white: bill, chrome yellow, a vermilion spot at angle below with a small hlack spot above: feet, ducky hish-gren:

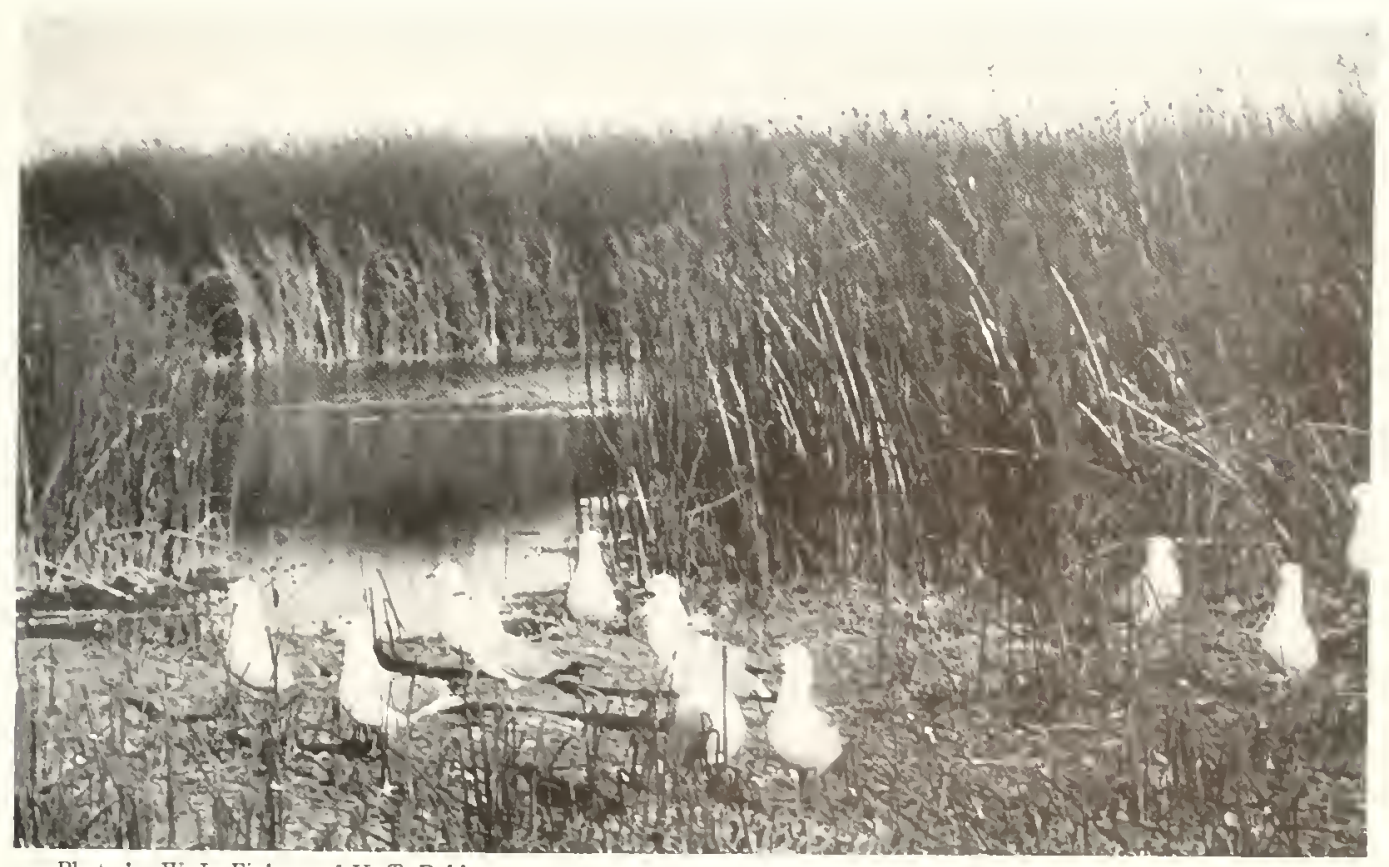

Photo by W. L. Finley and H. T. Bohlman

They generally nest in colonies on the inland lakes of western United States 
Webs, Wloa'; iris, brown; eyelids, red. ADUuts IN IINTER: Similar to summer plumage, hut head and neck streaked with dusky and bill much duller. Young: Jull whitish, mottled with dusky on head, neck, rump, wing-coverts, and secondaries; back, grayish-blue. feathers with lighter edges: bill, dull thesh color: terminal half, dusky.

Nest and Eggs.- NEsT: On the ground; constructed of small sticks and grass. Ecos: Usually 3 or 4 , some- times 5, pale bluish-white to brownish-clay color, blotched with dark brown and black zigzag markings.

Distribution.- Western North America; breeds from east-central British Columbia and Great Slave Lake south to northeastern California, northern Utah, and northern North Dakota; winters from its breeding range southward to Lower California and western Mexico; accidental in Kansas, Texas, Colorado, Alberta, and Hawaii.

\section{RING-BILLED GULL}

\section{Larus delawarensis ()rd}

\section{1. (). U. Number 54 See Color l'late 5}

Other Names.-Common Gull: Lake Gull.

General Description.- Length. 20 inches. Color, pure white with pale bluish-gray mantle. Easily coniused with the Herring Gull.

Color.-Adelts IN Summer: Mantle, pale bluishgray; first primary, black, white spot near end; cecond. plain black; third, black with gray space on inner web: next three, black-tipped; rest of primaries and secondaries, color of mantle; rest of plumage, pure white: bill, greenish-yellow with a broad land of black ancircling it at anmle; teet, greenish-yellow; iris, pale yellow; eyelids, red. Anvits ix WINTER: Similar to simmer pitumage, but hearl and neck behind spotted with dusky. Focna: Above, mottled with brown and grayish-blue; wing-coverts, mostly dusky margined with lighter: secundalies and prinaries, with a sulternninal brownish area shading forward into gray; tail, with a broad subterminal band of dusky and indistinctly barred with brown; below, faintly mottled with brownish; bill, flesh color, dusky on terminal half; legs, dull greenishyellow: iris, brown.

Nest and Eggs.-NEST: In the grass in marshes; built of dead reeds. EGGS: 2 to 3, bluish-white to dark lirown, spotted and blotched with different shades of brown and lavender.

Distribution.- North America at large: breeds from southern British Columbia across British America to southerı Ungava, south to Oregon, Colorado, North Dakota, central Wisconsin, central Ontario, northern New York (casually), and northern Quebec; winters from northern United States southward to Bermuda, the Gulf coast, Cuba, and southern Mexico.

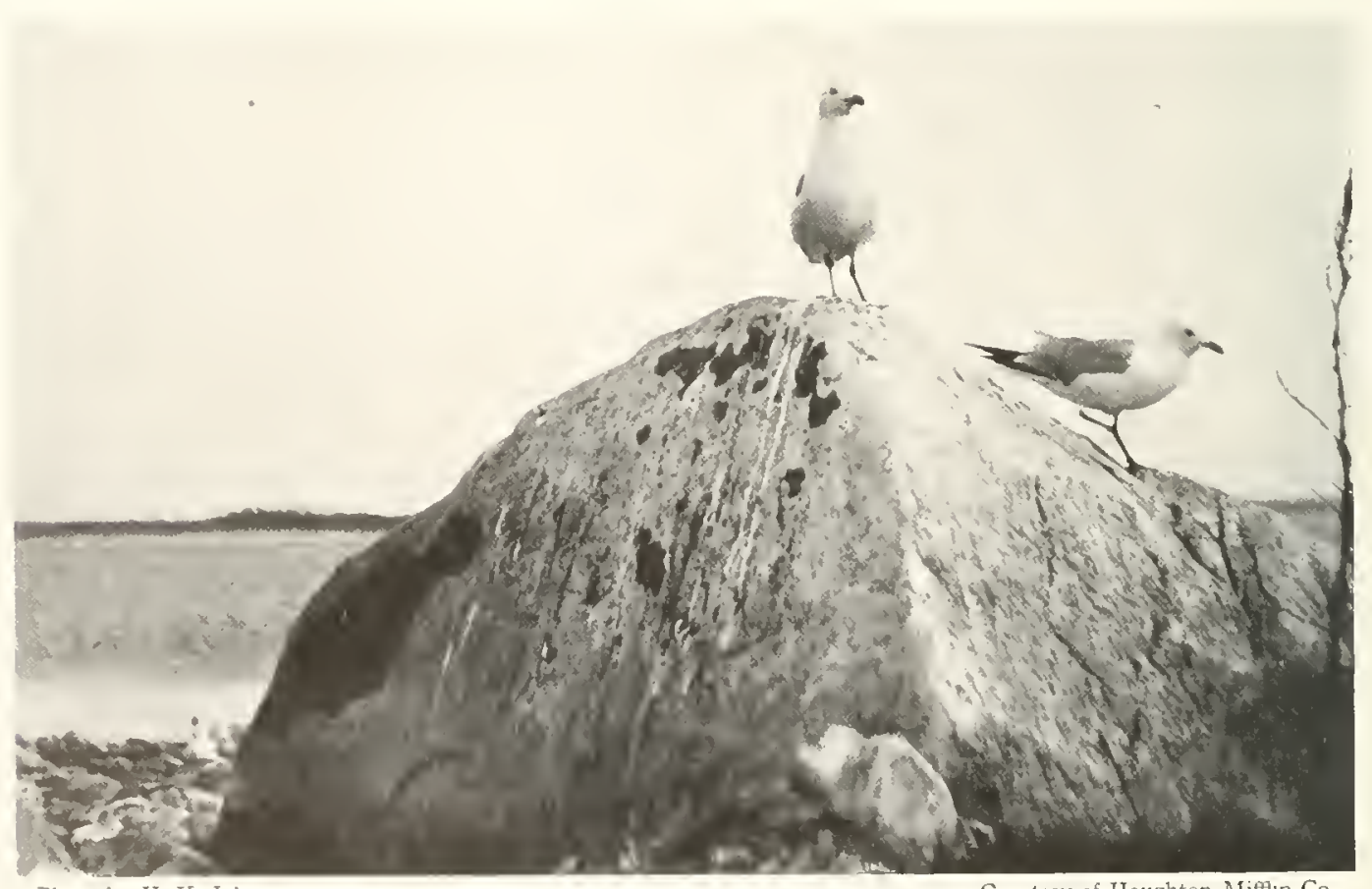

Photo by H. K. Job 
The versatility of the Gull shows his degree of intelligence. He is equipperl for life on the water. His webbed feet are for swimming. but he doesn't seem to care whether nature equips him for the sea or not. His taste often runs to angle-worms instead of sardines. As the notion takes him, he will take up quarters about a pig-pen or a garbage pile, follow the plow as a Blacklbircl toes, picking up angle-worms, or he will sail along in the wake of a vensel for days at a time to satisfy his taste for scraps.

The California and King-billed (inlls generally nest together in big colonies on the inland lakes through the western fart of the United States. In many places, these birds are of great cononic importance. I have seen them spread ont over the fields and through the sagebrush and get their living by catching grasshonpers. In Ltah, the Gull lives about the beet lields and alfalia lands and follows the irrigating ditches. When the fields are irrigated and the water rushes along, seeping into boles and driving mice from their burrows, the Gulls flock about and gorge thenselves on these rodents.

After the nesting season, large floclis of California and King-billed Gulls of ten collect along the southern coasts to spend the winter. While at Santa Monica, California, during the winter of Igos and roo6, I often watched the flocks of Gulls returning every evening from far inland where they had been skirmishing during the chy. I often saw them about the gardens and in the fields. I lew miles from the acean is the Soldiers" Home at sawtelle. The sarbage is hanled two or three times a day over to the pigpens. When the dump wagnn reaches the pers. the driver not only always linds himself besieged by a lot of hungry porkers, but a flock of Grills

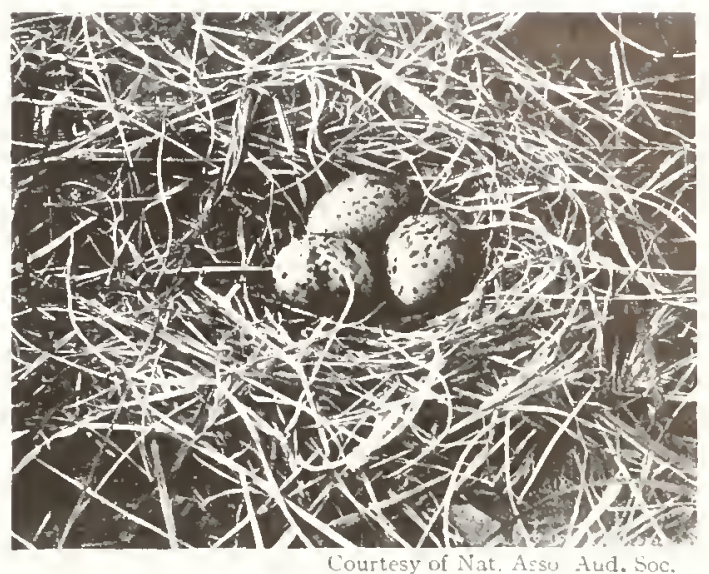

NEST AND EGGS OF CALIFORNIA GULL

is always at hand to welcome his arrival. They sit around on the sround or fences waiting patiently. The Gulls and pigs eat together. The Gull doesn't care if his coat gets soiled, for he returns to the shore each evening and takes a good bath before bedtime.

William L. Finley.

\section{HEERMANN'S GULL}

Larus heermanni Cassin

Other Name.-White-headed Gull.

General Description.- Length, 20 inches. Head, white: body. bluish-gray.

Color.-ADults: Head all around, pure white, shading on neck into bluish-ash of under parts and into the dark blush-slate of upper parts: rump and upper tailcoverts, clear ash; primaries, black with narrow white tips: tail, black narrowly tipped with white; bill, brimht red, hack on terminal third; feet, dusky-red: iris, hrown: eyelids, red. Young: Head and throat, mot- thed with dusky and dull white: upper tail-coverts, gray; tail, broadly white-tipred; otherwise similar to adult plumage.

Nest and Eggs.- Nest: Probably similar to others of the genus, Eics: Dull yellowish-drab, scatteringly marked with spots of brown and lilac.

Distribution.--Pacific chast of North America; breeds in Lower California and western Mexico: misrates north to southern British Columbia: winters irom morthern California southward to Guatemala.
As Mr. Dawson say's, "Heermann's Gull is an inveterate loafer and sycophant. Of southern blood (we have just learned that he is bred on the islands off the coast of Mexion) he comes north in June only to float and loaf and dream throughout the remainder of the season. Visit the 'Pird Rocks' of Rosario Straits early in July and you will find a colony of Glaucouswings distraught with family cares and wheeling to and fro in wild concern at your presence, while upon a rocky knob at one side, a whitewashed club room, sit half a thousand Heer-

$$
\text { V)L. I - 5 }
$$


manns, impassive, haughty, silent. If you press inquiry they suddenly take to wing and fill the air with low-pitched mellow cries of strange quality and sweetness. And go where you will at that season, the Heermann's Gull is guiltless of local attachments - in the North." (Birds of Irashington.)

Another observer notes that these Gulls display considerable intelligence in their pursuit of herring, when the fish are traveling in schools. The birds approach these schools from the rear along in the direction the lerring are swimming until the fisl come to the surface, when the birds renew their diving captures.

The systentatic robbery of the Pelicans, an amusingly impudent performance, is also described by Mr. Dawson. "Often a long train of Pelicans is seen, as the tide is rising, slowly wandering around the bay, each one attended by one or more of these Gulls which are usually some distance hehind. Whenever a Pelican awkwardly plunges into the water and emerges with

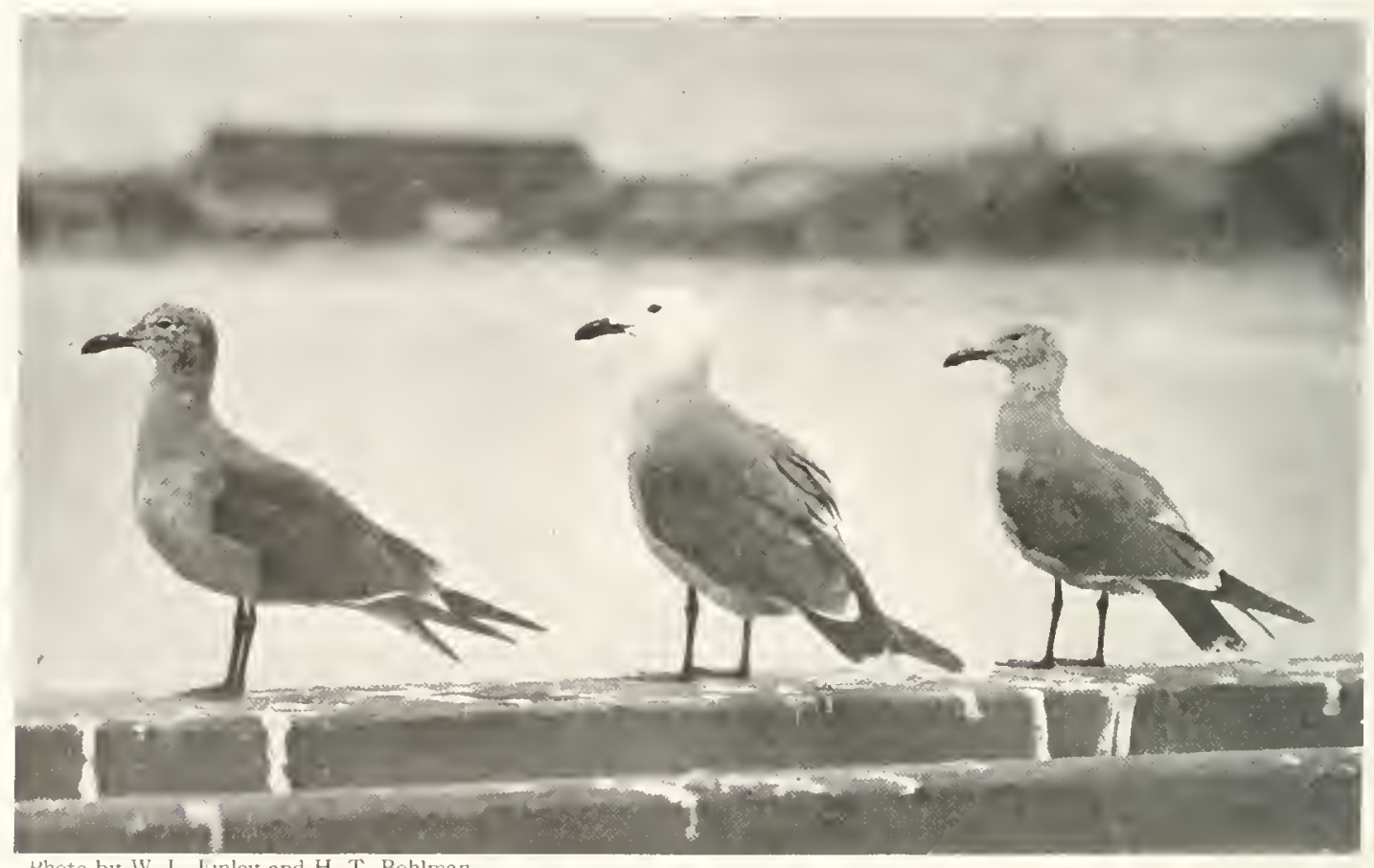

thoto by W. L. I mley and H. I. Bohlman

HEERMANN'S GULLS

They are inveterate loafers, and, while other Gulls are engaged with family cares, they stand on one side, impassive, haughty, silent

and talie the fis near the surface by diving for them. As the herring discover their pursuers they sink some distance, but the school continues to travel in the same direction. The Gulls seem to know this, for after having reached the head of the school, they circle to the rear. and follow its enormous scoop net full of fish, its parasites are sure to be ready and fearlessly seize the fish from its very jaws, the stujid bird never resenting the insult, or appearing to take the least notice of the little pilferers which it conld easily rid itself of hy one blow, or even swallow alive."

\section{LAUGHING GULL}

\section{Larus atricilla Linnous}

\section{1) (1) Jumber 5 S Sce culor l'late}

Other Name.-Elack-lieaded Gull.

General Description.- Length, 16 inches. Color, white with dark slate-gray mantle and almost black hood.
Color.-Adults in Summer: Hood, dark slaty-black extending further on throat than on back of head; a white spot above and below eye; neck all around. rump, tail, tips of secondaries and primaries, and entire under 


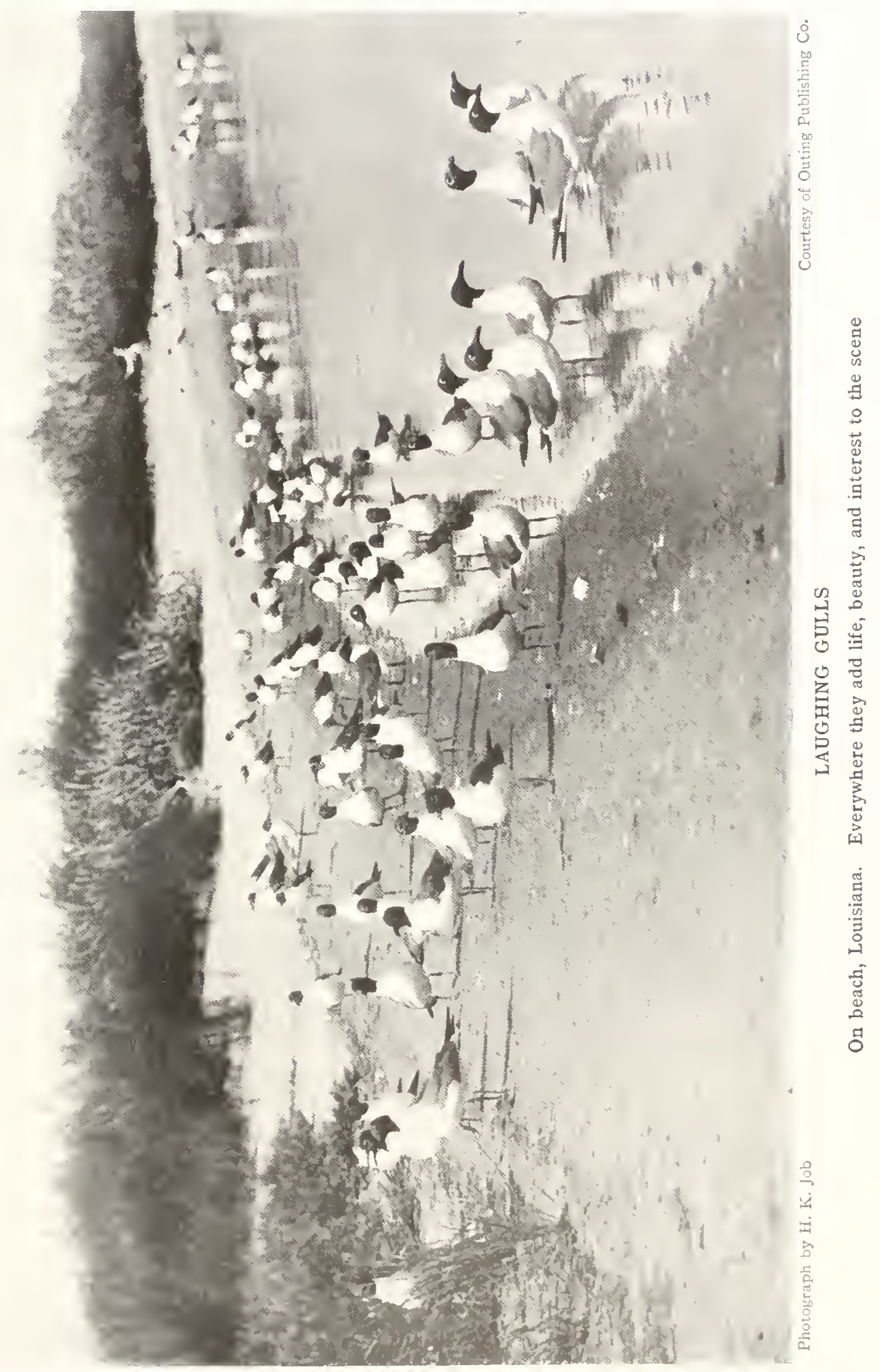


parts, white, the latter with a rosy tinge: mantlc, dark slate-gray; outer six primaries, black; bill, deep carmine; feet, hlack; iris and edge of eyelids, carmine. AncLts 1N Winter: Under parts, without rosy tint: head, white, mottled with dusky; bill and feet, dull. Young: Nantle, variegated with light grayish-brown; primaries, brownish-black, lighter on tips; secondaries, dusky on outer webs; tail, with a broad terminal band of dusky with narrow white tips: upper tail-coverts, white; bill and feet, brownish-black tinged with red.

Nest and Eggs.- Nest: On the ground in marshes; constructed of seaweel, sedges, and eelyrass, Ecos: 2 to 5 , from dull grayisls to dark olive, heavily marked with spots and splashes of brown, black, chestnut, and lav'ender.

Distribution.- Tropical and temperate coasts of North America; breeds from Maine (rarely) and Massachusetts (abundantly but local) south on the Atlantic and Gulf coasts to Texas, the Lesser Antilles, and Venezuela; winters from Georgia and Gulf coast south to western Mexico, Chile, and Brazil; casual in Colorado, Nebraska. Wisconsin, Ontario, and lowa.

The Laughing Gull is well naned, for seemingly it laughs. No great stretch of the imagination is required to assume that its loud cries are those of real mirth. It is a handsome creature in the breeding season, with its dark mantle. black head, and white breast faintly tinged with the color of the rose.

It breeds normally along most of the Atlantic coast of the United States. Until recent years it has been almost extirpated by constant persecution on the New England coast but now, under protection, its numbers are increasing. It nests on sandy islands, usually in tall thick grasses or shrubbery: in the north it builds a sulsstantial warm nest of grasses and weeds, but in the south a mere hollow in the sand often suffices. In pleasant warm weather the birds are seen to leave their nests, trusting apparently to the heat of the sun. but in cool or stormy weather the female incubates closely. The young leave the nest soon after they are hatched and run about on the sandy soil, squatting and hiding in the thickest cover at the first alarm. Meanwhile the farents wheel high overhead, uttering their notes of apprehension. These hirds are very gregarious and lireed, as well as feed, in flocks.

Their food is largely composed of marine objects picked up on bars, beaches, flats, in the beds of estuaries and even at times in the salt marshes lut ever near the sea Audubon tells how the Laughing Gull robs the Rrown Pelican

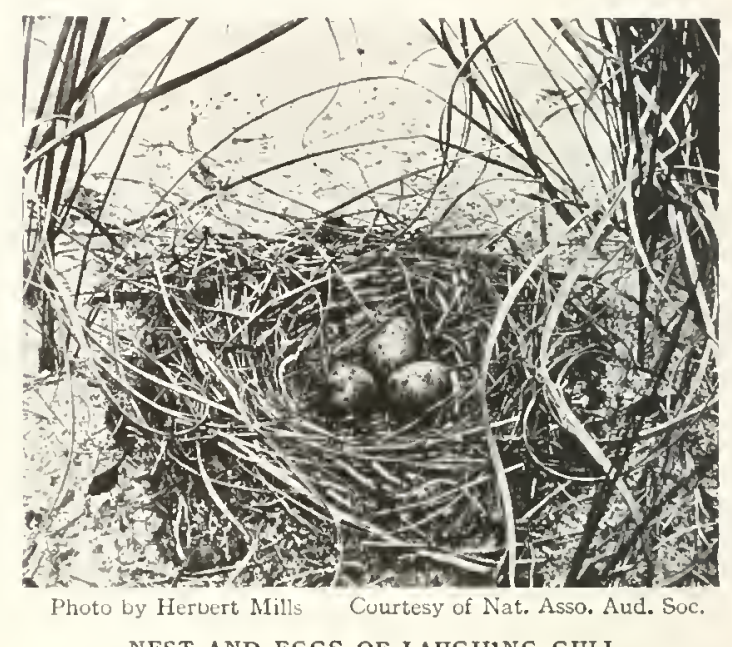

NEST AND EGGS OF LAUGHING GULL

Passage Key, Florida

in Florida. Waiting until the Pelican dives and comes to the surface the Gull alights upon its head and snatches the small fish from its enormous bill. Sometimes this Cull follows schools of porpoises for the small fish that they drive to the surface. Everywhere it adds life, beauty, and interest to the scene.

Edward Howe Forbush.

\section{FRANKLIN'S GULL}

\section{Larus franklini Richardson}

$$
\text { A. O. U. Number } 59
$$

Other Names.-Prairie Pigeon; Franklin's Rosy Gull.

General Description.- Length, 14 inches. Color, white with dark bluish-slate mantle and dark slate hood.

Color.-Adults in Summer: Hood, dark slate extending around upper part of neck as well as on head; evilids, whits; mantle, dark bluish-slate; outer primaries, with dusky hars near tip, this color graduating from about 2 inches in width on first to a small bar on sixth; primaries and secondaries, white-tipped; tail, pale grayish-blue, the three ontside pairs of feathers, white; neck all around, rump, and whole under parts, 
white, the latter with rosy tint; bill, carmme crossid with black near ind; legs, lusky-red. ADULTS IN MINTER: Similar to summer flumage, luat without hood; a tew slaty featlers aroumd eyes and on sides of head; no rosy tint below: bill and feet, dull. locsi: Traces of hood; outer 5 or 0 primaries, wholly black; mantle, bray or bruwn, varicel with hluinh-gray, according to age: tail, antry-whice with a broad black subterminal bar; mater parts, white; bill. dusky, raler at base below; feet, Hesh culur: iris, dark bruwu.

Nest and Eggs.- Nest: On the ground among

A typical scene of the interior prairie region. say in the Dakotas or Manitoba, is the farmer 1)lowing up the rich black soil, on a cold windy day in early spring, followed alnost at his heels by a troup of dainty white lirds which are picking up the worms and grubs exposed to view. standing rushes and grass of marshes borderng lakes ur rivers; constructed of dead rushes, brits: 3 , varying from dull white to olve-drab, matked with bold blotches and ziszag lines of umber-brown anul serph.

Distribution.- Nerth and Sulth Ancrica: heeth from sonthwestern Saskatchewall and southwestern keewatin to Suntly l)akuta, lowa, and southern Minuesota: winters from the Gulf coant of Louisiana anil Texas southward to beru and Chile: very rare on the Atlantic coant: accidental in (Ttah. Ontario, Uhio, Iirginia, and the Lesser Antilles.

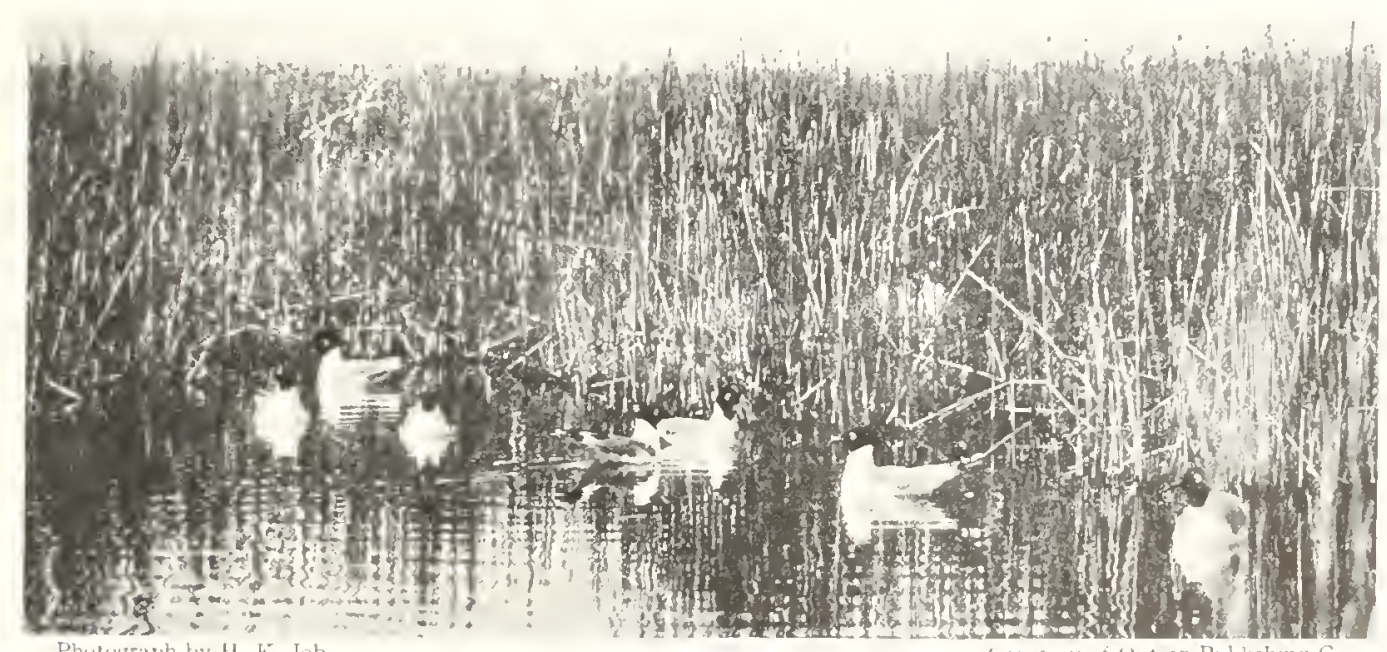

Phulugraph by 1 . I. K. Job

FRANKLIN'S GULLS

On nesting ground

He calls them "I'rairie l'igeons," a pretty and appropriate title, though in reality they are Franklin's Gitlls. Sometimes they have been called the Rosy Gull, becanse when the feather: of the unrler jarts are opened w1 there is scen to be a faint rosy fush, as clelicate as that of the tea-rose.

This full is as typical of the pratric as is the Western Meadowlark or the Prairic Horned Lark, though in a different way. I hould characterize it as the "courser" of the prairies. Bands of them are uswally seen flying stearlily along in a line or some regular formation, uttering flute-like cries, perpetually on the move. To a degree they strike one as birds of mystery, especially if one be curious to know whither they are roaning. ( briously, however, they are flying either to or from their nesting-ground.

In their hreeding habits they are about as distinct and spectacular as any other North American species. Selecting some marshy lake, where reeds or rushes srow from water, thousands of them will come together and lonild somi-floating nests of dearl stems, fartly huoyed by the vegetation and filled in from the bottom. If a person wade or must a boat to the edee of the colnny, the air is full of indignant and screaning birrs, alwaye grateful and heautiful, no matter how exciterl they become. The nests are snly a few fect apart, each containing two or three trpical grull-like egers by the hast weok of Mlay. If the intructer lecepse iquite still, one or both of the owners may finally alight and stand on the nest. but neither will inculbate as long as anvone is in sight. The downy young swim from the nests soon after they are hatched, and in a colony in 


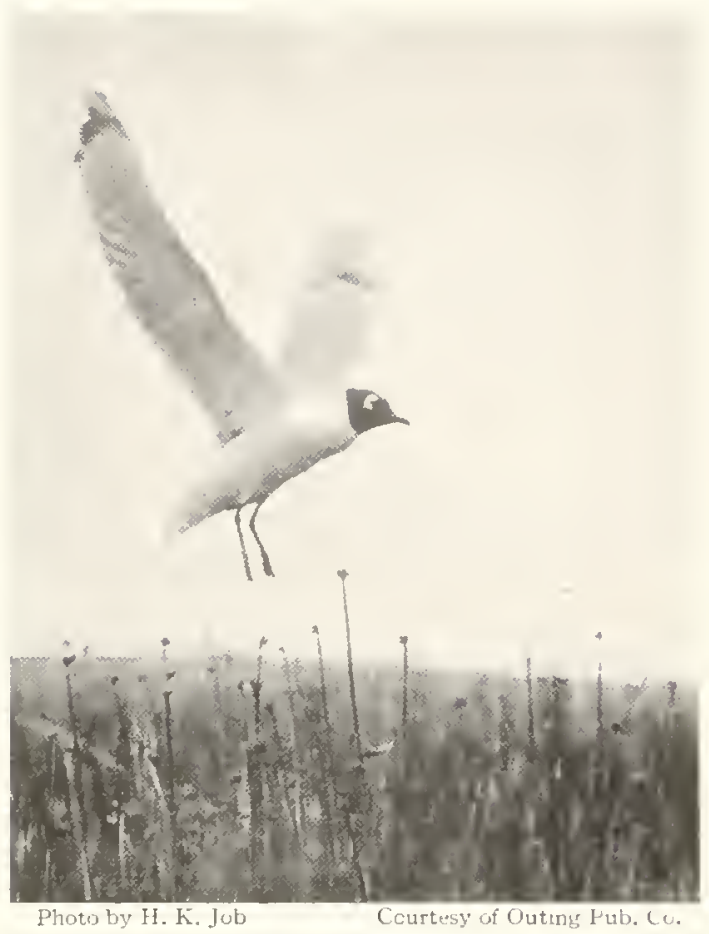

FRANKLIN'S GULL

Dropping down among the reeds to its nest late June and July the equatic vegetation seems alive with paddling pulf-balls.

In their feeding habits during the warmer part of the year they are largely insectivorous. () ut in the narshy lakes they feed a great deal upon nymplis of the dragon-fly, and on any insects or larve locally available. On the plowed fields they find many injurious grubs and cutworms. Later they are active in pursuit of grasshoppers.

Their flocking is very spectacular, both when they are preparing to leave in the fall, and when they arrive in spring. In selected places, especially near the nesting-grounds, the prairie is sometimes fairly white with them.

Gutls are supposed to be chiefly maritime birds, but this species is a seeming exception. In fact the Rosy Gulls are rarely seen either on the Atlantic or the Jacific coast of the United States, though in winter some of them at least come out along the Gulf coast, and follow it down into South America. But it would seem hard to one who has known it in the sloughs and on the j)rairies to picture it flying over the ocean, where it could casily be mistaken for the Laughing Gull.
Herbert K. Job.

\section{BONAPARTE'S GULL}

\section{Larus philadelphia $(\mathrm{Ord})$}

\section{O U. Number to Siee Color Plate 6}

Other Names.- Bonaparte's Rosy Gull; Blackheaded Gull; Sea Pigenn.

General Description.- Length, 14 inches. Color, white with pale bluish-gray mantle and dark slate colored head.

Color.-Adults in Summer: llead, dark slate reaching further in front than behind; a zihite fatch abowe and another boloae cye; mantle, pale grayish-blue; most of primaries asith black tips; neck all around, tail, and under parts, pure white, latter rose-tinted; bill, black; gape and eyelids carmine; feet, coral-red; webs, vermilion. Adults $1 \mathrm{~N}$ Winter: No hood; crown and back of head, mottled with dusky; back of neck with tint of color of mantle; a crescont before cye and patch on side of head. deef slate; bill, light-colored at base below; feet, flesh color. Youxg: No mottling on crown ; a patch of dusky on side of head; wing-coverts and shoulders, dusky-brown with lighter edges; pri-

Bonaparte's Gull is one of the smaller American Gulls, and unlike most of that fanily is sometimes found in flocks which often resort to plowed fields and swamps where the birds feed on insects and earth-worms. Its favorite haunts, however, are coasts, rivers, and lakes, where it feeds much after the manner of the Herring Gull. maries and secondaries, dusky tipped; tail white with a subterminal dusky bar; bill, dull flesh color; feet, light flesh color: iris, brown.

Nest and Eggs.- Nest: On the ground in marshes, usually on elcvated hummocks: constructed of small sticks and dead grasses. Egrs: 3, olive-gray with a wreath of dark and light brown spots around large end and some scattered markings of the same color over whole surface.

Distribution.- North America in general; breeds from northwestern Alaska and northern Mackenzie south to British Columbia and Keewatin; winters from Maine to Florida: on the Pacific coast from southern Pritish Columbia to Lower California anrl western Mexico, and on the Gulf coast to Texas and Yucatan: in migration west to Kotzebue Sound and east to Ungava; casual in the liahamas and Bermuda; accidental in Europe.

Along the seacoast the Bonapartes are decidedly gregarions and often associate with Terns and other Gulls. Unlike their relatives, however, they are not given to following ferryboats and other craft from which offal and garbage are thrown overboard. In these surroundings their diet is chiefly marine worms and crustaceans 


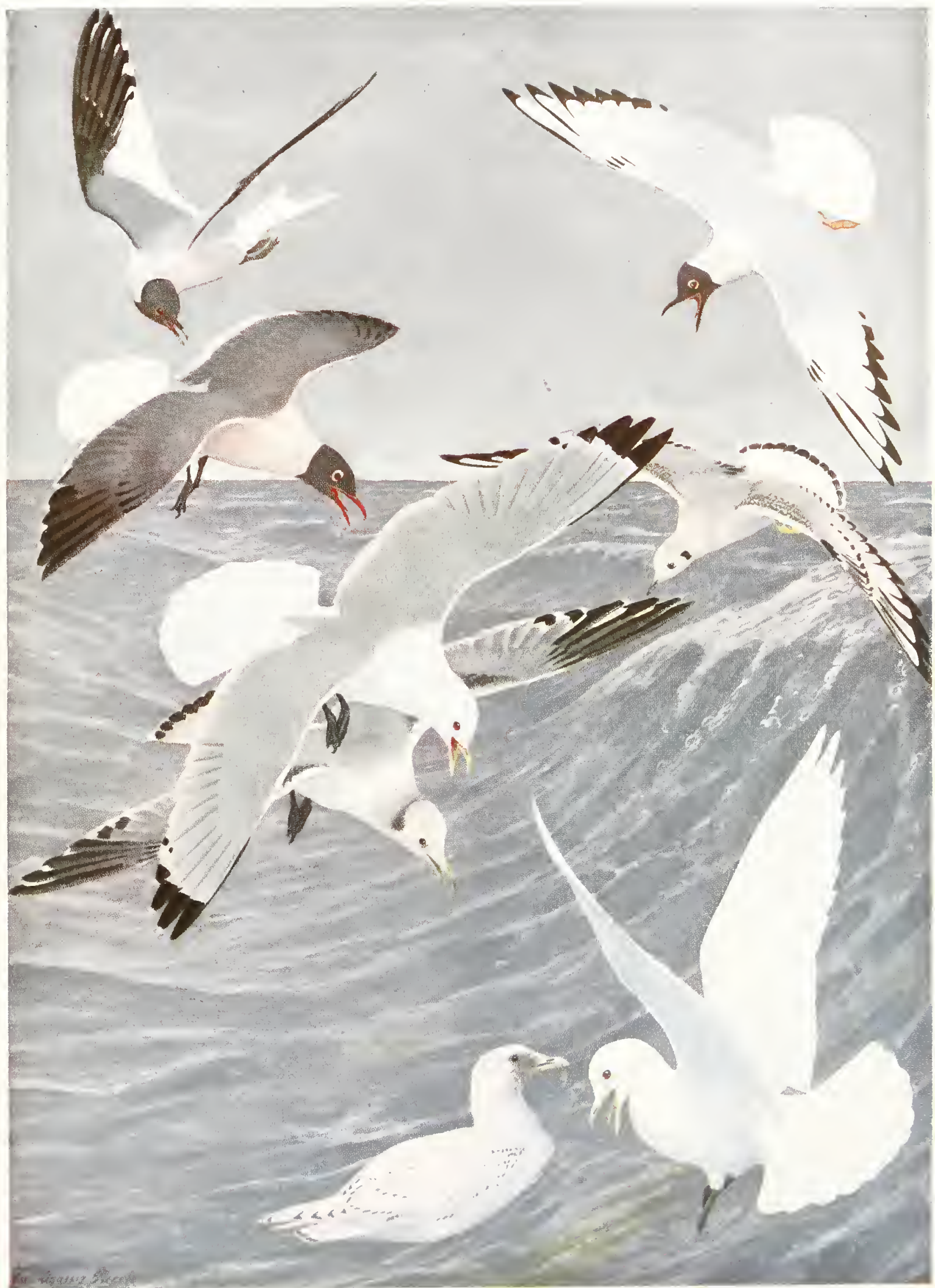

SABINE'S GULL ANULT N SUMMER

LAUGHING GULL ADULT SN SUMMEH 
which they lind on tide flats, in channels, and on livelp-lueds.

1 peculiarity of this bird's flight, which is sraceful and fairly swift, is dhat calch stroke of

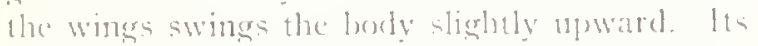
manculers on the wing are often very shillful. especially at trick it has of smoldenly stopuping its progress and sweepring hackward amel downward to insperet an shject seren on the surfate of the water. In general it thingle is more like that wf the Terus than the omlla.

BONAPARTE'S GULL (! rat. size)

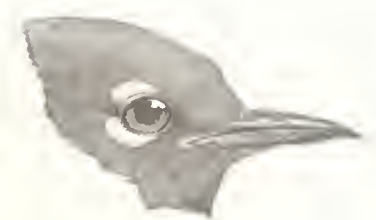

Although a shore bird, it is often found in plowel

fields feeding on earthworms

Drawng by R. I. Bristu ?

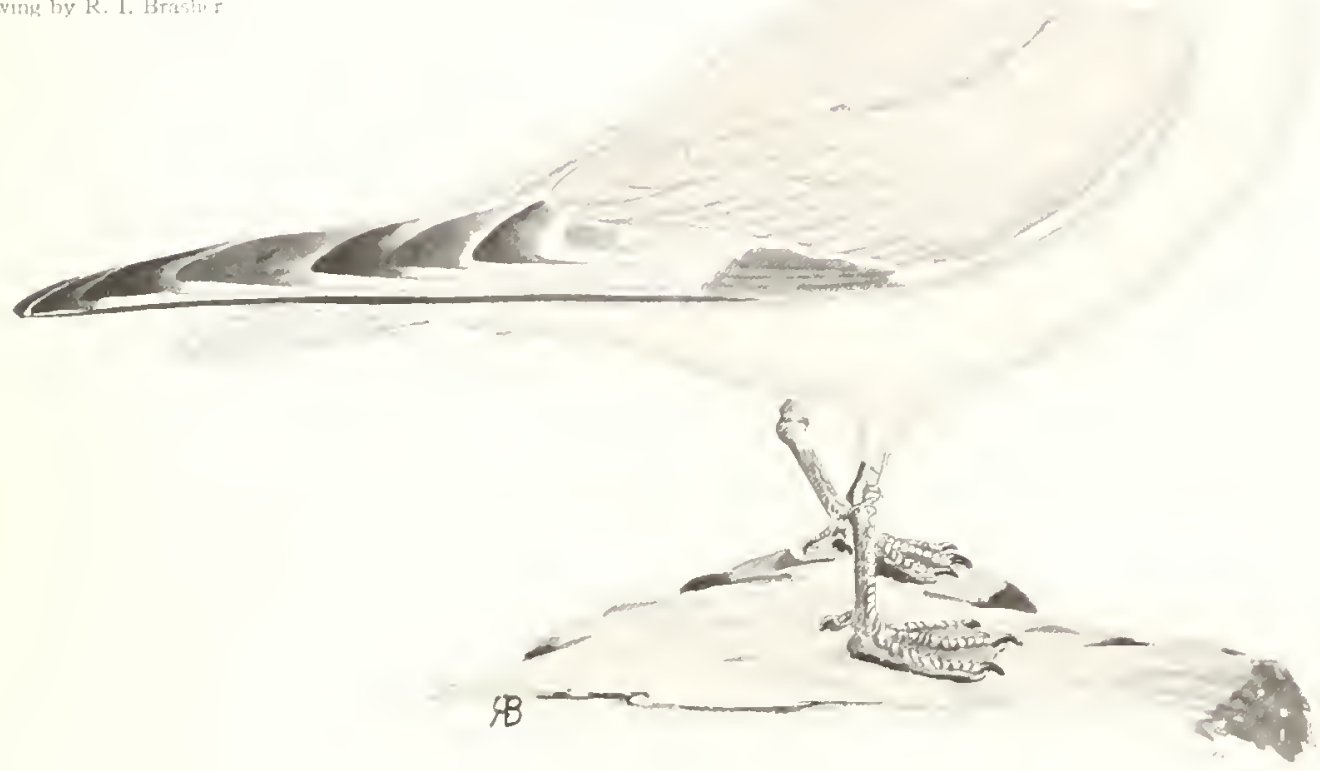

\section{SABINE'S GULL}

\section{Xema sabini (1. Subino)}

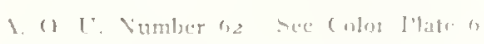

Other Names.- Hawk-tailed Gull; Fork-tailed Cull.

General Description.- Length, 14 inches. Color, white with blush-gray mantle and rlark slate hood. lail, forked with the fouthers rounded, not pointed, at the ernals.

Color,-AItLTS IN StMMER: Jleads with home oi lark slate bounded behind by a nurroan border of black mantle. bluish-gray; edge of wing, blark; fore outer primaries and that conerts, black with small white tips: rest of primaries, ahitr: onter secomblaries, white: the gray of mantle extending diagonally across (1) end] of muer secondaries: neck, taid, and entire moler parth, white, the last with rosy hue: bili, black to angle. yellusw, cluonc, or orange from angle to tip: gape, vermilion: fecl. black; iris, reddish; edges of eyclids, orange. Ancl.T IN WINTre: Entire head. white with some dark ieathers on crown and sides; bill, duller; no rosy liue; wherwise as in summer plumage. Youno. Head, back oi neck, and upper parts in general, transversely barred! with slate-gray and dull whitish; under parts, white: tail, white witl a har of black one inch wisle on midelle feathers, this colne narrowing onuward; bill, dusky flente color: legge, flesh color.

Nest and Eggs.- NFGT: A Aejuression in moss or and, lined with fine dry grans. Elocs: 2 or 3. decp alive-brown ohecurely spotterl and blutedeed with darker viales of the same.

Distribution. Arctic regrons to Sonth America: breesls on the coast of Alaskia from Kuskokwim River to Nurton Sound, and in furthern Mackenzie, morthern kewatin, and northern Greenland, and on Tamyr Peninsta in norlbwestern siberia; in migration on botl coasts of United Siates and casual in interior: winters along the coant of Peru. 
Sabine's Gull is essentially an Arctic species, though it occasionally wanders as far south as the North Atlantic States and has been taken as a straggler on Long Island, on the Great Lakes. and on Great Salt Lake, Utah. In any of its plumages it may readily be recognized by its forked tail-whence one of its names. The normal diet of this Gull appears to be composed partly of marine insects, most of which probably are obtained on beaches where they are left by receding waves. The species seens first to have been described by Sabine, from specimens taken by his hrother, a member of the Northwest Expedition of 1818 , on one of a group of rocky islands off the coast of Greenland.

Georrie Gidaden.

\section{TER N S}

\section{Order Longipennes; family Larida; subfanily Stemina}

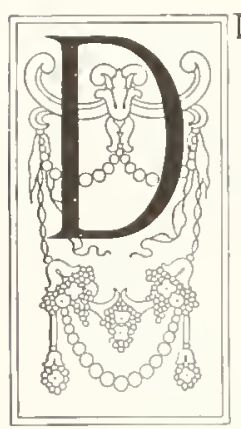

ISTRIBUTED throughout the world are over fifty species of Terns, ten occurring regularly in North America. These birds belong to the family Larida which includes the Gulls, and is part of the order of Long-winged Swimmers. All of the species are exceedingly graceful and expert on the wing, and some show extraordinary endurance in flight. This is true especially of the Arctic Tern, whose journey from the Arctic to the Antarctic and back each year, is one of the most astonishing known feats in the bird world.

The Terns are often called "Sea Swallows," and for obvious reasons, as several of the species are not unlike large Swallows both in appearance and in flight. They are generally smaller than the Gulls, and their bodies are more elongated, but in coloration they more or less resemble their larger relatives, whom they also resemble in their food and feeding habits, with the exception of their diving practices. The Terns hover and plunge for their food, while the Gulls alight on the water to feed. Because of this characteristic, Terns have often becn called "Strikers."

Again like the Gulls, the Terns are decidedly gregarious and often breed in colonies of thousands on ledges; some of the species occasionally place their nests on the limbs of large forest trees. Generally the nests on the grounds are little more than mere depressions, and often they are placed so close together that in walking through a nesting place, it is difficult to avoid treading upon either the eggs or the young. When hatched, the young are covered with down of a mottled pattern, and, although sometimes they will enter the water of their own accord and swim about, they are dependent upon their parents until they acquire the power of flight.

\section{GULL-BILLED TERN \\ Gelochelidon nilotica (Limmans)}

1. U. U. Number 63 Siee Color I'late 7

Other Names.-Marsh Tern; Egyptian Tern; Nuttall's Tern: Anglican Tern: Nile Tern.

General Description.- Length, 13 to 15 inches. Color, white with light bluish-gray mantle. Bill, stout and short, and cured ozer at tip.

Color.-Adults in Sumaer: Croz'n and crest, glissy gre'nish-black, extending to level of eyes, leaving only a narrow white line on upper side of bill; mantle, light grayish-blue: primaries, grayish-black but heavily silvered, appearing much lighter; tail, color of mantle fading to pure white at base; chin, throat, neck all around, and under parts, pure white; bill, black, usually with narrow yellow tip: legs, greenish-black; iris, brown. ADUIS $\mathbb{I N}$ Winter: The forehead and fore- part of crown, white; black restricted to hind head and nape; side of head and a spot in front of eye, gray; otherwise similar to summer plumage.

Nest and Eggs.-NEST: A mere depression among the reeds of marshes: sometimes on sandy shores. Ecos: 3, olive-buff irregularly marked with umberbrown, blackish, and lavender.

Distribution.- Nearly cosmopolitan; breeds in North America, on coasts of Texas, Louisiana, North Carolina. Virginia (formerly to New Jersey), and in the Bahamas; wanders castually to Maine and Ohio; winters in southern Mexico, Central America, and all of South America: breeds also in Europe, Asia, and Australia, wintering to northern Africa. 
It seems clear that the Gull-hilled Tern is decreasines rapiclly in numbers. Gnee cummonor at leasi not actually rare - along the Atantic coast, it now, accordingr to D)r. (liapmun, seldom. ii ever. lreeds notth of Collis Island. Ia., where it was found nesting in great number. ly l)r. Riclgway and 1)r. llenshaw in 18-9. Here Dr. Ridmway noted ospecially its cry, which he described as a chattering laugli, wherefore he thought it might well be named the Laurring Tern - its scientific nme literally means "laughing swallow of the Nile." The same observer noted that the bird showed muth more conrage in defending its neat than do sther Terns; it swonperl clownward and straight at the intrufler, often nearly striking him witls its bill, and in its attompt to change its course the rush of the air through its winge matle a booming ound not unlike that promiced ly the Nighthawk when it checks its downward plunge.

This hird differs superficially from its kind in having a shotter and comparatively heavy bill, and a shorter and less distinctly forked tail. It is also less excitable than the Common Tern.

\title{
CASPIAN TERN
}

\author{
Sterna caspia Pallas \\ A. O U. Vumber us see Color Plate 8
}

Other Names. I mperial Tern: Casnian Sea Tern.

General Description.- Length, 20 to 23 inches. Cnlor, white with grayish-blue mantle. Tail, slinhtly forked with outer feathers rointed: wings. long and slender.

Color-Antits ix sumur: Crown, glousy greenish-black; a white spont on lower eyelid; mantle, grayishblue, but so heavily ilvered when new as to appear light gray : rest of joltumige. pure white; hill, bribht a'dmilim, feet, back; iris, hrown. ADCrts In Winter: The crown is broken by white and some dusky feathers show on wing-enverts.
Nest and Eggs.-NEsT: A mere hollow scomper in dry sand. Eirs: 2 or 3, pale nlive-huff, rather evenly markerl with spots of dark brown anrl laventer.

Distribution. - Nearly cosmopnlitan; breeds in North America at Great Slave Lake. Klamath Lake. Oregon. on islands of northern Lake Michigan, on cont of couthern Lahrador, and on cnast af Texas. Louisiana. Mississippi, South Carolina and (formerly) Virginia: winters from const of central California to Lower California and western Mexico, and on the Sonth Atlantic and Gulf coasts: casual in mieration north to Alaska. James Ray, and Newfoundland?

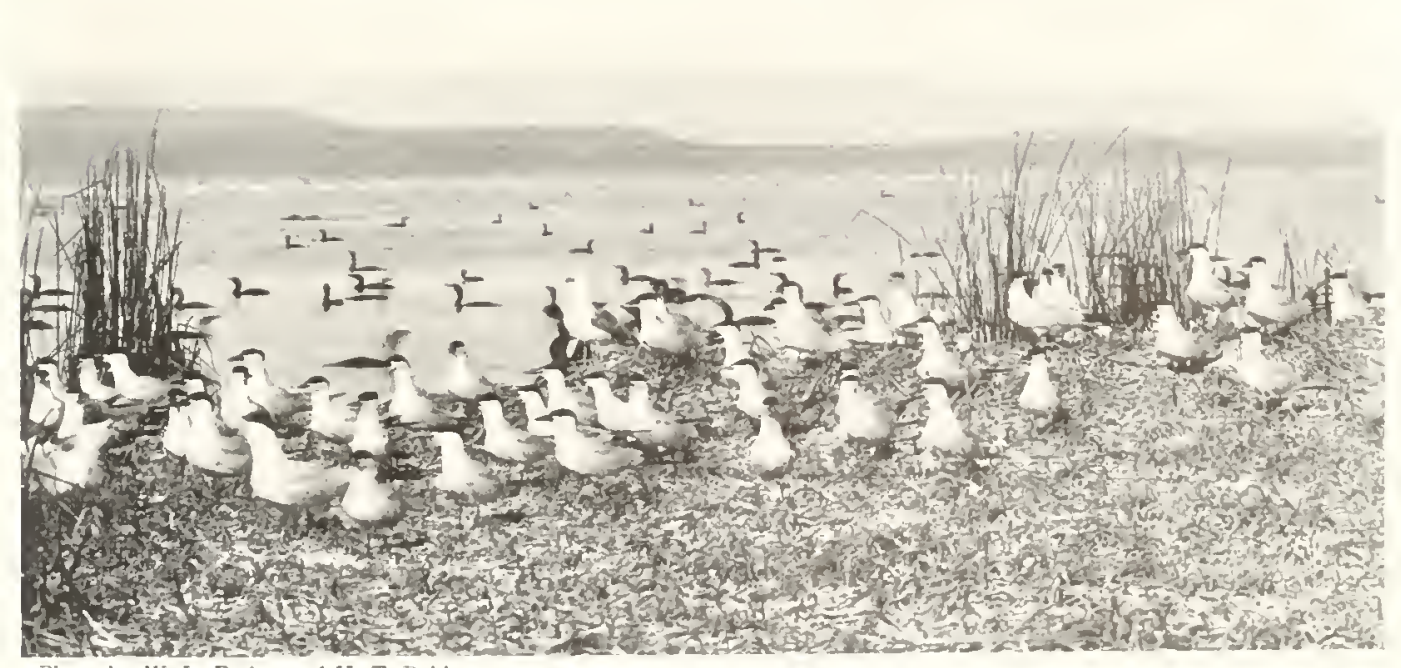

Photo by W. L. Finley and II. T. Bohlman 


\section{FORSTER'S TERN}

Sterna forsteri Nuttall

A. O. U. Number on see Color I'late?

Other Names.-Haveli's Tern (immature): Sea Swallow.

General Description,-Length. I5 inches. Color. white with pale grayish-blue mantle. Tail, forlied for balf its linyth. Not distinguishable from either the Common Tern or the Arctic Tern excent with specimens in hand.

Color.- Adults in Summer: Crown, glossy black not extending below eye; mantle, pale grayish-blue: primaries strongly silvered; entire under parts and rump, white; the tron lony outside tail-feathers, ahite on outer acb, dusliy aray on inner; bill, oranac-yellow', terminal half, black with the extreme tiv vellow; feet, bright orange: iris, brown. AntLTS IN WINTER: Crown variegated with white; nape, dusky; a distinct black bar on sides of head embracing eyes; outside tail-feathers, shorter than in summer; bill, dusky except at base below: feet, dusky yellowish.

Nest and Eggs. - NEST: In marshes; constructed of dead reeds and stems of water plants and lined with finer reeds. EGgs: 2 or 3, varying from pure white or pale green to warm brownish-drab irregularly spotted with brown, umber, and lilac.

Distribution.- North America at large; breeds in California, Oregon, Nevada, southwestern Saskatchewan, and Manitoba sonth to northern Colorado, northern Nebraska, northeastern Illinois and southern Ontario. and on the cuasts of Texas. Louisiana, and lirginia; winters from southern California, Gulf of Mexico, and South Carolina suuthward to Guatemala; rare as far north as Massachusetts; casual in lirazil.
The Caspian Terns nest in colonies through the lake region of southern Oregon. They gather on one of the tule islands. W'e found two of the largest colonies on Lower Klamath and Malhenr lakes, where these birds were living near a colony of California and Ring-billed frulls. When we first risited lower Klamath Lake, in 1905. we found these Gulls and Terns together with White Pelicans, Farallon Cormorants. Western Grebes, and Great Blue Herons, gathered in what might have been called one immense colony in the tules on the northwest side of the lake. Since that time, lowever, owing to disturbance, the birds have scattered: the Gulls, Terns, and Grebes have moved their colonies to other parts of the lake.

As one cruises abont these lakes, he sees the graceful little Black and Forster's Terns flitting along over the surface, dropping here and there to pick up a bit to eat. The Caspian Tern is much larger than these two and is sometimes mistaken for a Gull. However, the exceedingly long wings, jet-black cap, and deep-red beak are

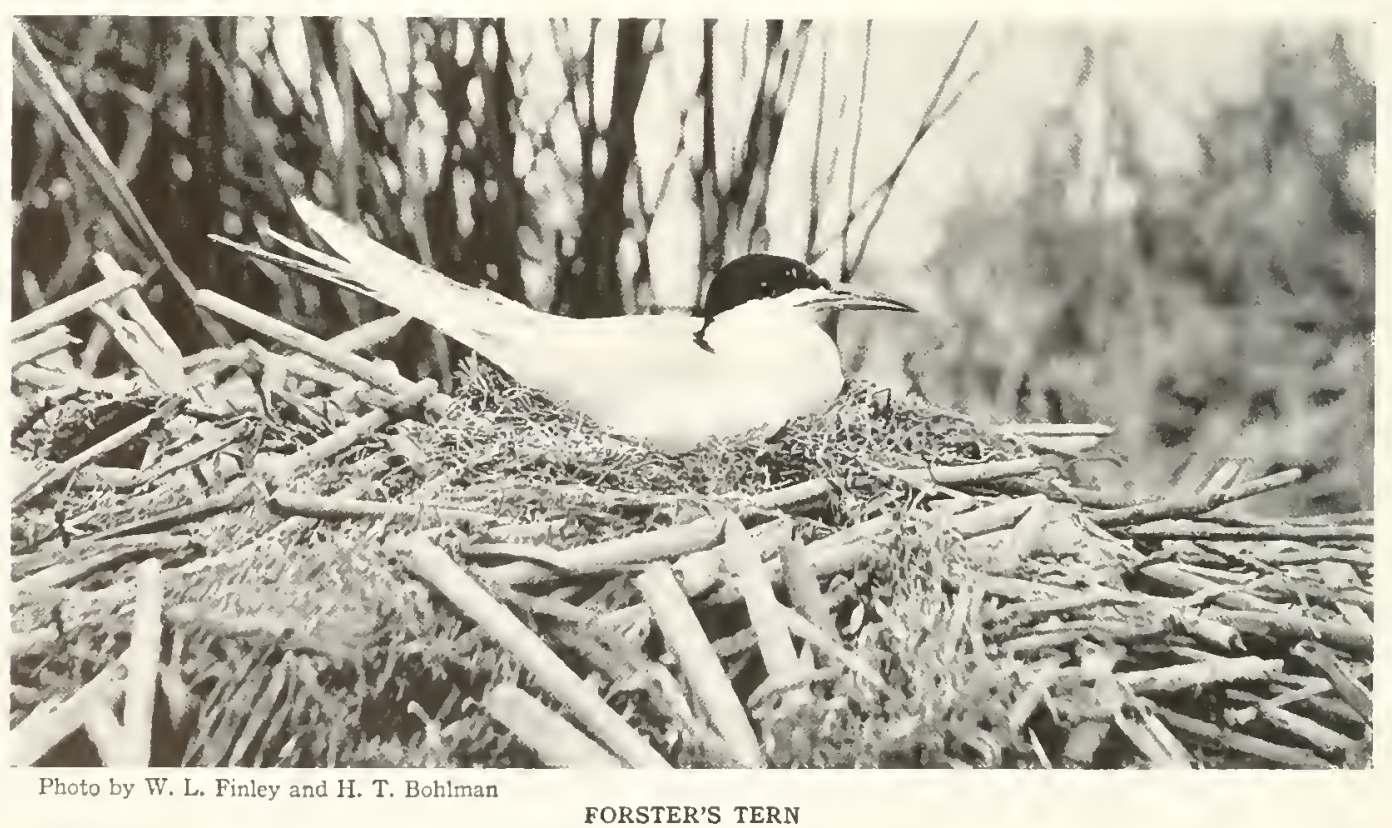

On nest built on a muskrat house 
the distingmohing features of this hird. $\mathrm{W} \mathrm{e}^{2}$ som learned to reeognize their larsh call note, for each morning they came Hying over the camp. cruing Crack-a-day-o! Crack-a-day-o!

Forster's Tern is readify reconnized by its deeply furlied tail: the outer leathers are very long and narrow. Ls it tlits aleng orer the watter. its sharp bill is ever pointing downward and its eyes are watehing the surface of the watcr. Jiecatuse of its lreautifu! velvety plumage. the long pointerl tail- and wing-ieathers of this bird were formerly a much-sought adomment for wonen's hats.

While the lilack Tern resembles Furster's Tern somewhat in size, yet Nature has made a striking difference in its drese. It can never be mistaken when once seen, for its fore parts are pure black and the wings and tail slaty-graly. This bird and the Forster Tern differ in their nesting habits from the Caspian, hecalle they to not crowl together in a colony. They are socialile, however, and like company. The nests of both these lirds are often a little floating mass of regetation on the surface of the water, or oftentimes the nest is placer on a muskrat house. Where one nest is found, a few others are likely to be somewhere around in the same locality. I have at times found nests that contained eges of both Forster's and Caspian Terns.
1 peculiar habit of these swallow-like hirds tender greatly toward their destruction at the hands of frlume hunters. When a hunter shot one of them and it fell womeled to the surface. all the other Turns nearlw wonld be attracter] to the bircl on the watter and ther hovered about and served as casy mirk for the jumer.

Ey buthling a blind in which to hide nearly a colony of Caypian Terns w Mallew Lake, we had a splendid chance 4 sturly the home life of these birls. There ware several humbled nesting close together, we hususekeeping was in no sense a communal matter. Fatel bird had its own particular nest spot and the invasion of that place by any other Term meant a challenge for fight. When the Terns harl young. their sreatest anxiety seemed to be to keep them crouching low in the nest. so that they would not rum away and get lont in the erowrl. If a young bird did start to rum out of the nest, he was immediately pouncerl unom by his own parents and pecker and beaten until he dropped flat to the ground or hist in the leaves. If a young bird ran to a neighboring nest or old hird for protection, he receiverl a fusillate of blows that knocked hin over. A voung lird, therefore. that wandered from his own nest spot was likely to be pecked and beaten to death.

Willan L. Finley.

\section{ROYAL TERN}

\section{Sterna maxima Boddacrt}

Other Name. - Cayenne Tern.

General Description.-Length, 20 inches, Color, white with very pale bluish-gray mantle. A prominent glossy greenish-black crest on liack of heard.

Description.-Adults in Summer: Crown, glossy greenish-hlack not crtending bolore tyes: mantle, very pale bluish-gray, shading to white on rump and ends of inner secondaries: first five primaries with grayishhlack spaces toward tips: rest of primaries and most of secondaries, pale pearl-blue: sides of hearl, chin. throat, rump, tail, and under parts, white: tail, forked for half its length: bill, orange-red; feet, hlackish : iris, hrown. AntITS IN WINTER: Forchearl, white: most of crown, varicgated with hlack and white, the black ex- see Color Plate 8

tending forward on sidc of head as far as eve: tail. tinged with color of mantle and rlarkening toward tip into a deeper gray; less forked than in summer.

Nest and Eggs.- NEST: A bollow in the sand. Egrs: 2 or 3, whitish to yellowish-ilrab, blotched with dark umber, sepia, and lavender.

Distribution.- Tropical coasts north to United States: breeds in West Indies and on south Atlantic and Gulf coasts from Virginia to Texas; wanders casually to Hassachusetts: not rare in stmmer from san Francisco Pay southward to western Mexico; winters from southern California and Gulf of Mexico south to Pern and Prazil, and on west coast of Africa from Cibraltar to Angola.

the smaller Gults by the manner in which thes hold their heads while in tlight. I cinll's bill points forward on a plane with its body, while a Tern carries its bill pointed directly downward becalse of its arde size and conspicuots striking birds to be seen along onr southern coast. They may easily be distinguished from

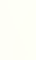




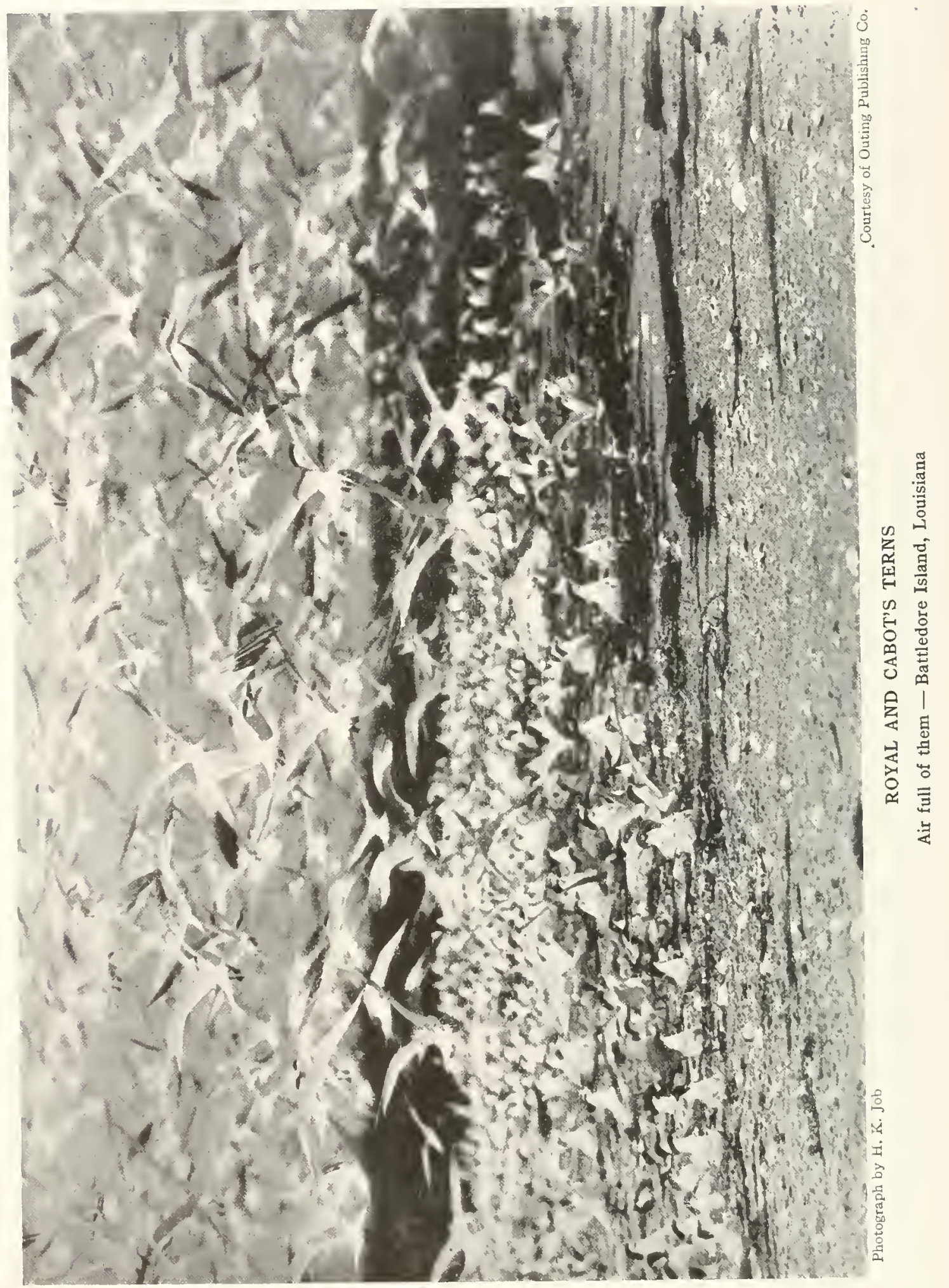


like a mosquito. Their food consists chiefly of small fish which they gather by plunging directly into the water, nstally from a height of several yards. So much force is put into the blow that the bird often disappears beneath the surface. In Florida these Terns often rob the slow-moving Brown Pelican of his hard-earned prey. They are distinctively birds of the sa!t water and rarely come inland. They seldom appear in small harbors, and we never find them flying about wharves and fish factories as we to the Citlls.

Like most sea-birds the koyal Terns assemble in colonies to rear their young. Their eggs are laid on the bare sandy islands with no attempt at concealment. No other birds in North America make their nests so near together; in fact, when they are incubating it is often difficult, at a little distance. to see the ground between them, so closely do they sit.

A few years ago I visited a colony nesting on Royal Shoal Jsland in l'amlico Sonnd. North Carolina, where probably there were some four thousand eggs scattered alout on the sand among the shells. A high tide sometime before had washed at least a thonsand of these from their resting places and left them in a great windrow along the beach. The bereaved birds had then moved over to higher ground on the other side of the egg area and scratched ont new nesting places. In toing this they look possession of a plot of ground already occupied by a colony of Black Skimmers. They simply kicked the Skimmer's egas away or covered them with sand and at once trok np the dnties of inculation serenely indifferent to the mild yrotestations of the discomfited Skimmers. Ustally other species of "Terns, and frequently" Skimmers and Oyster-catchers, breed on the islands occupied by the koyal Terns lut never, so far as I have observed, within the actual botndaries of their colony. The one exception to this is the rare Cabot's Tern which their bis neighbors seem to have taken monder their special protection. The I wo species fly together, feed together, nest together, and - perhaps - die together.

The Royal Terns were largely exterminated in many sections of their range by the gumers of the millinery trade some years ago, but under the protection of the wardens of the Audubon Societr they are again increasing in numbers. Their chief breeding places today are on the islands off the coast of Virginia, North Carolina, sonth Carolina, and Louisiana.

T. Gilbert Pearson.

\title{
CABOT'S TERN
}

\section{Sterna sandvicensis acuflavida Cabot}

\author{
A. 0. I. Number 67
}

Other Names.- Sandwich Tern; Kentish Tern: Boys' Tern; Ducal Tern.

General Description.- Length, If inches. Color, white with light bluish-gray mantle and tail.

Color.-Adults in Summer: Crown and crest, glossy greenish-black extending below eyes but leaving a space alongside of bill white to the end of the feathers; mantle. light bluish-gray shading on rump and upper tail-coverts into pure white: first four outer primaries witl black space near ends; tail, color of mantle: bill, black, the tip for about one-half inch bright yelloa'; feet, blackish; iris, brown. AuULts iN Winter: Crown, white varied with black shaft lines; crest, brownish-black: outside tail-feathers, shorter than in summer; yellow tip of bill less in extent and duller: otherwise as in summer. Young: Forehead, crown, and nape, brownish-black variegated with white, upper parts, marked everywhere with irregular spots and transverse bars of dusky: primaries, as in adult; tailfeathers, tipped with dusky; bill, smaller and weaker, brownish-black, the extreme point only, and sometimes not that much, yellow.

Nest and Eggs.- Nest: On sandy shores, in colonies. EgGs: 2 or 3, creamy or buffy, irregularly spotted and scrawled with dark brown, chestnut, black, and lavender.

Distribution. - North and Sunth Anerica: breeds from North Carolina to Florida and Texas; winters from the liahamas. Florida, and Louisiana south to Central Anerica, Greater Antilles, Colombia, and 1'razil; acciclental in Ontario, Massachusetts, New Jursey and Lesser Antilles.
The Cabot's Tern in flight at a distance resembles its more famous relative the Arctic: however, it is a more stontly built bird: also its tail is relatively shorter, while its head-feathers form a crest, which the bird can make quite conspicuous when it is angry or exciterl. In diving for its prey it often disappears entirely beneath the surface, and apparently descends to a much 
sreater depth than do other Terns. When breeding in colonies, the Cabot's Terns often place their nests so close together that it is difficult to avoid stepping on them while one is exploring the prenises.

Some ornithologists attribute the remarkable variation in the coloration of this Tern's eggs to the fact that they are incubated alternately by the male and the female, one bird being ready to cover the eggs the instant the other leaves them. Under these conditions the law of natural selec- tion cannot operate in such a way as to elininate an egg of conspicuons coloration, which is true of many Terns' eggr:

There is apparently reliable evidence that these Terns mate for life, and return year after year to the sinne nesting region, though not necessarily always to the same spot. English observers have noted that the birds change their actual breeding ground from tinne to time, though apparently the same general colony is dikely to return to the sane island.

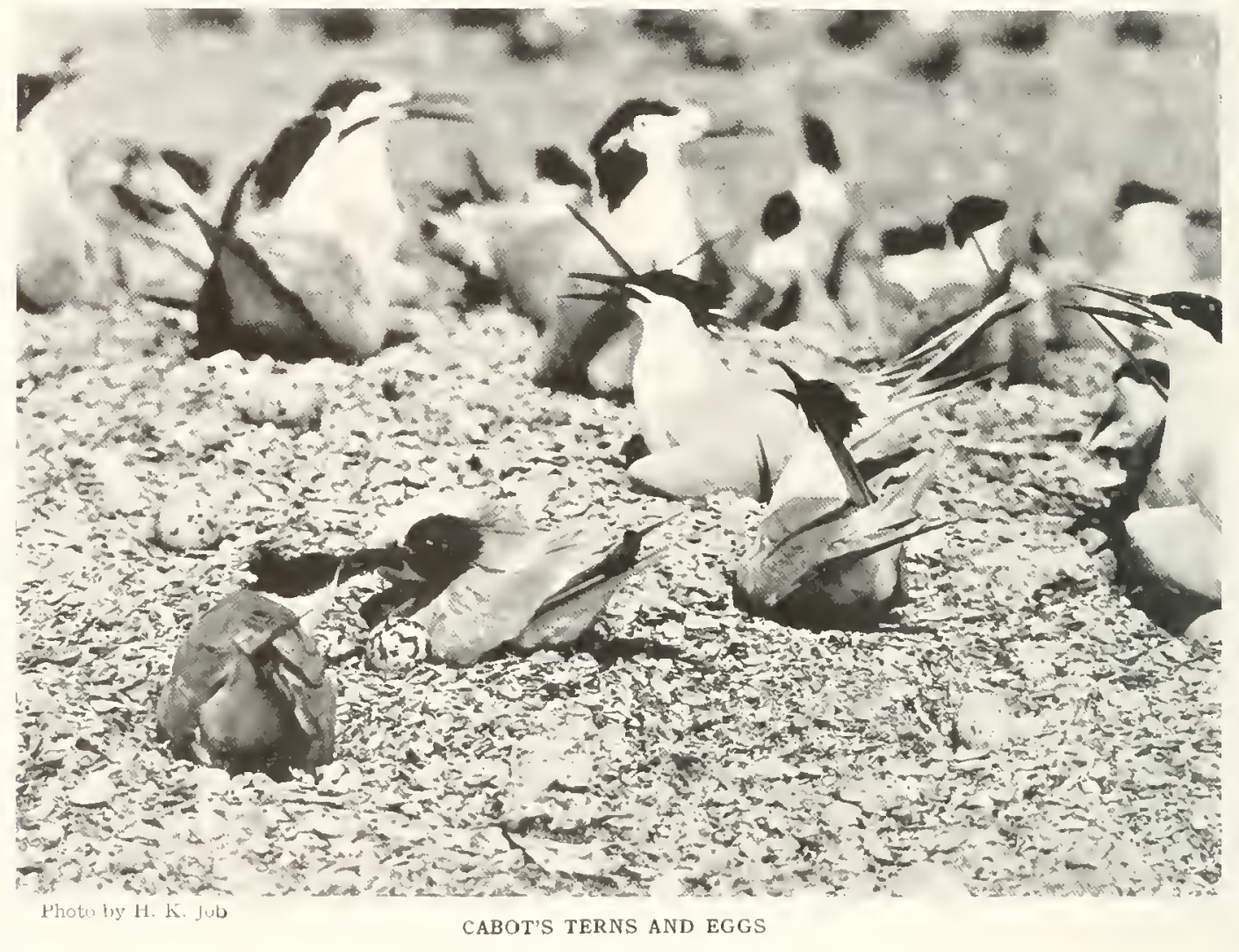

Ereton Island Reservation

\section{COMMON TERN}

Sterna hirundo Limnons

Other Names.-Sea Sivallow; Wilhom"s Tern;
Summer Gull: Mackerel Gull: Lake Erie Ginll; Bassgull : Red-shank:

General Description.--Length, 15 inches. Color, white with mantle of pale pearl-blue.

Color.- Aduls in Summer: Crown, lustrous greenish-black extending to lower level of eyes: mantle, pale pearl-blue deepening on hack, ending abruptly on rump which, together with upper tail-coverts, is pure white; throat, chin, and sides of head, pure white shading insensibly to a much paler tone of color of mantle on entire under parts; onter primaries, grayish-black strongly silvered: secondaries, pure white shading to grayish-blue on end outer pair of tail-feathors. arayish- 


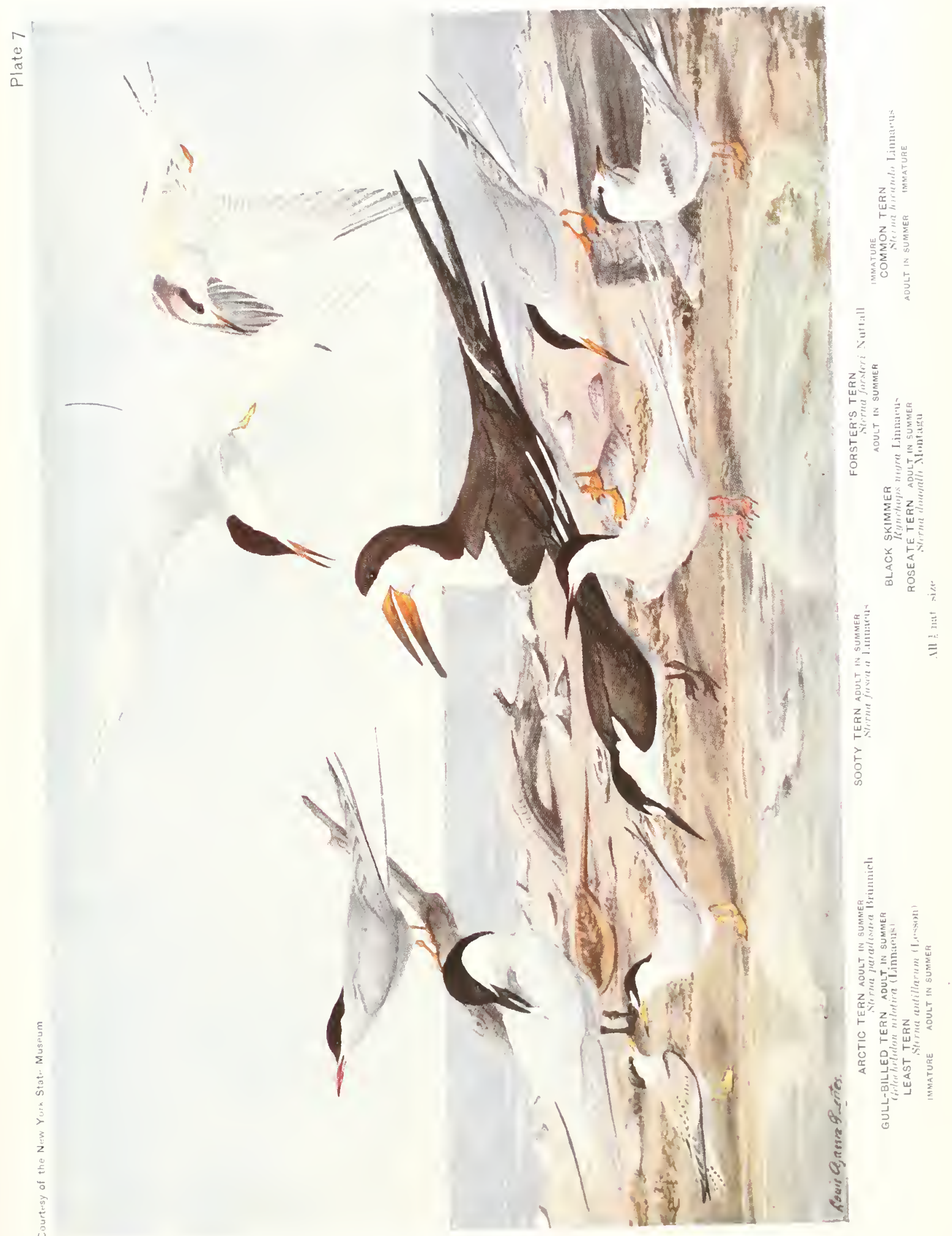





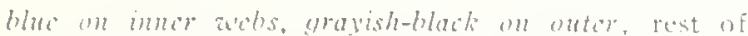
tail-feather, whth inner wels. pure white, onter wehs,

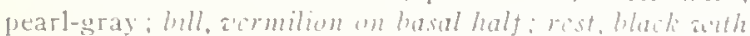
vellow on coltrme tip: feet, cural-red: iris, decp brown. Aollts in Wintek: Forehead and most of crown. white; under parts, nearly pure white; bill and leet, duller; otherwise as in summer. IMMATLRE: Similar to winter adults, but back mottled or washed with light brownish and bill brownish.

Nest and Eggs. - Niss: Sometimes nonte. lout generally a hollow in the sanel lined with grass anel dry

The level rays of the rising sun, coming up from the other side of the world, stream over the heaving sea. lighting up an islet where the surf beats unceasinerly umun shifting sands. Thi islet of recunt wrigin has rinen from the sua, thrown up hy the surging tempestuous waters of the Atlantic and is destitute of all vegetalote life. As our boat lands through the plunging surf a cloud of white birds rises and storms about us with harsh resounding cries. Ter-arr, terererr they call with many variant sound until all hlend in one great monotone of angry entreaty. As we leave the beach at troop of lowny young riats and noves toward the farther shore, ansmented as it goes by others lying hidden behind every

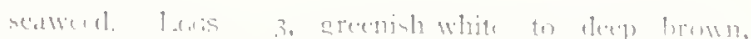

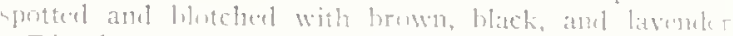

Distribution.- Northern heminhere, morthern South Imerica and Africa; luedels from lireat Slave Lake. central Kewwatin, and southern ('ngava south to southwestern Sashatchewan, northern North Dakota, south"ru Wisconsm, northern Ohio and North Carohna: winter from Florida sunthward to Brazil; casual in migration on Pacific coast from British Culumbia to lower California. In eastern hemisphere, breeds in Linrope and Asta and wonters in lndia and Airua.

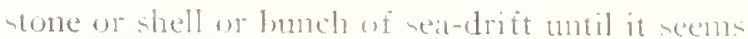
like a feathered army marching in one continuous front across the iste. As they reach the farther shore they to not hesitate, hit throw themselves inter the surf, mily (1) be tossed back again drenched and sorery upon the streaming sincls Stand back now, lice quietly down, and wateh them swimmines, tumblins in the surf, returning to the island, solicitom wy suarded he their wateh[ul parents. We have fonmd a colony of (ummon Terna! Nom we see that there are many ears laid on the hare sand or in slight hollows where a fow stomes or bits of seaweed haw heen collected hy the parent birds.

Where nesting material is plentiful this Tern

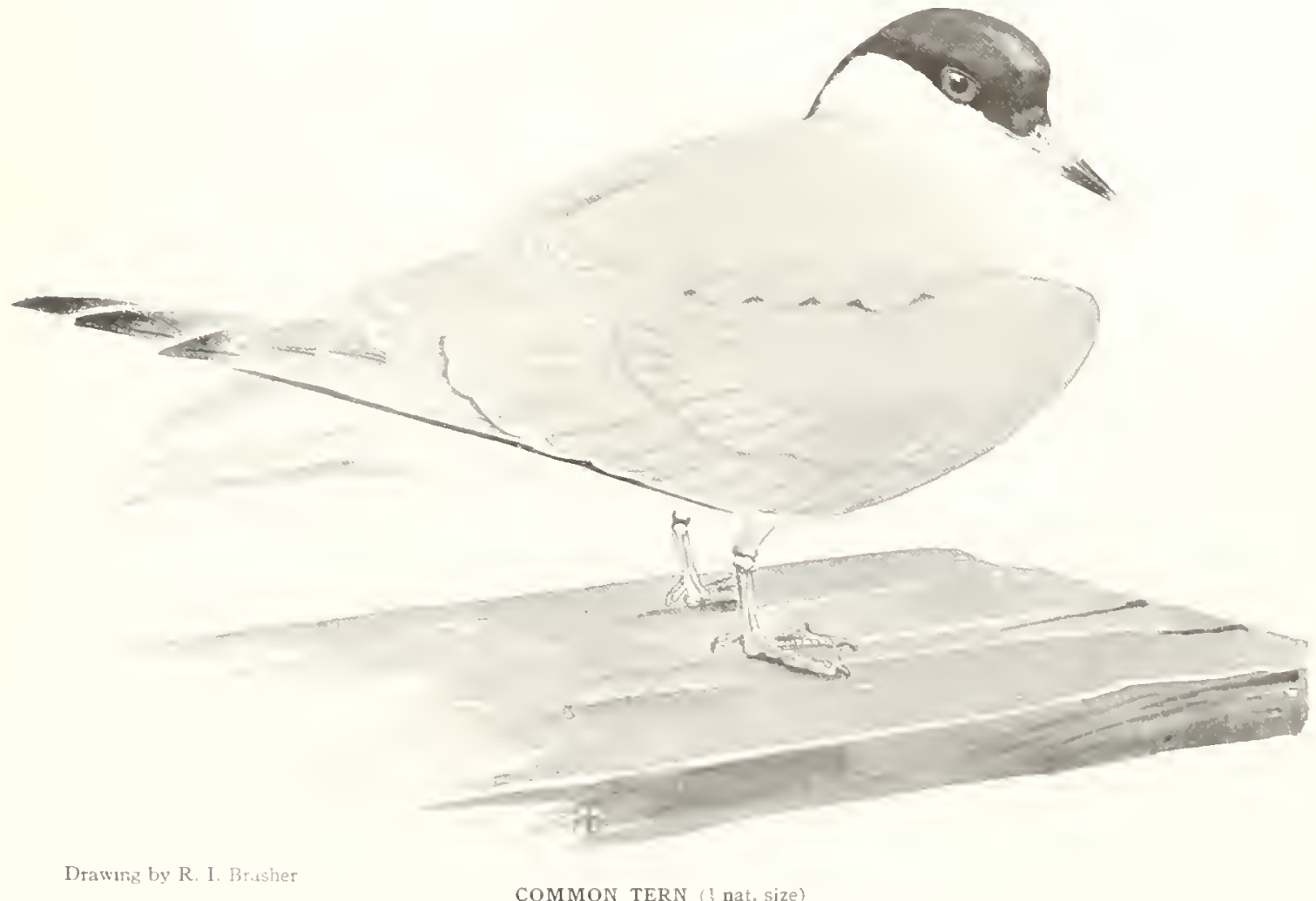

Drawing by R. I. Brisher

COMMON TERN (1 nat. size)

It is useful to the fisherman, guiding him to schools of edible fish 
sometimes builds a substantial nest of sticks, seaweed, and grasses, placing it just above highwater mark along the leach. At times it nests in thick grass on high islands, and on the Magdalen Islands Maynard found it breeding on the tops of grass-topped rocks 200 feet above the sea. The eggs are commonly laid in May or June but many are deposited as late as July. In New England. however. most of the young are able to fly early in August: and then the families join in flocks, leave their breeding places and forage over the country. At this season and in September some of them frequently go up the rivers and sometimes to inland ponds, where they probahly find small fry in the warm waters.

In fishing they usually fly with the bill pointing downward, and, when they observe their prey. dive like a flash to the surface, often immersing the head but seldom going entirely under water. Several naturalists have followed the lead of Giraud in asserting that this birl, though webfooted, never dives and rarely swims, appearing to avoid the water. except as it is obliger] to descend to the surface to procure food. It is true that it does not, like rulls, rest often on the surface but in hot weather near its breeding gromuds small parties may lee seen floating on the waves bathing and throwing the spray alout with the abandon and enjoyment of the true waterfow - and they swim exceedingly well.

These birds are useful to the fishermen as they serve to mark the presence of schools of edible fish. These fish drive the small fry to the surface, the telescopic eyes of the Terns mark the disturbance from afar and when the fishermen see the gathering. plunging flocks they put off

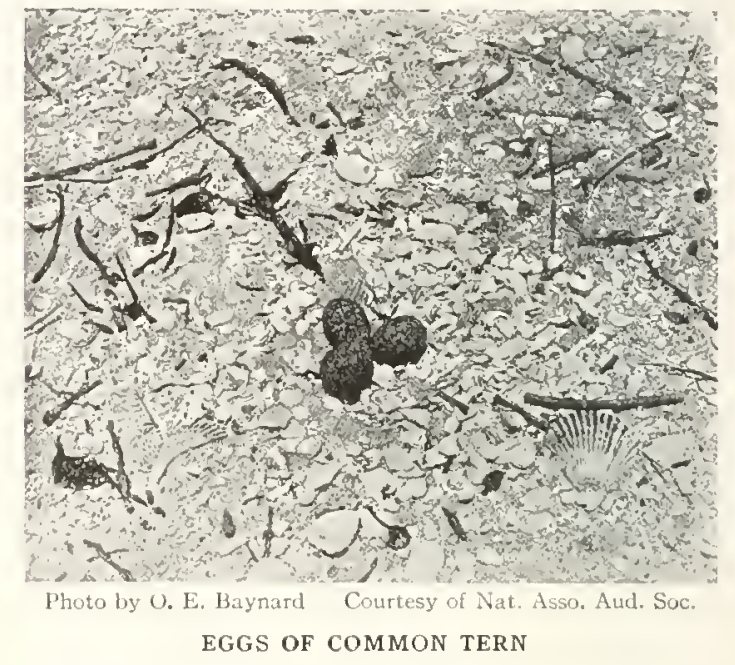

A hollow in the sand, a few bits of grass and dry seaweed, and the nest is ready for the three eggs

in their boats. well knowing that their work lies there.

This Tern feeds largely on small fry, shrimps and other small crusticea but also at times on grasshoppers and many flying insects.

EDWARD Howe Forbusu.

\title{
ARCTIC TERN
}

\section{Sterna paradisæa Brïnnich}

\author{
A. O. U. Number $7 \mathrm{I}$ See Lolor Plate?
}

Other Names.-Common Tern: Sea Swallow; Paradise Tern; Crimson-hillerl 'Tern: Long-tailed Tern: Short-footed Tern: Portland Tern; Pike's Tern.

General Description.- leength, if to I7 inches. Color, pale bluish-gray, lighter below.

Color.- Anults in Suman: Crown, lustrous greenish-black encroaching on lores so as to leave only a slender white line of feathers on upper side of bill: mantle, pale bluish-gray: moler parts, a little lighter shade of color of hack, facling into white on chin, throat, and edges of black cap, ending abruptly at under tail-cozerts which are pure white: outer primaries, silvery-gray; inner webs, mostly white: inner primaries. color of back, broadly tipped with white: tail, very long, pure white, with outer web of outside feather grayish- black: bill, carmine; feet, coral-red : iris, brown. Anuts IN Minter: Forehead, white; crown, white with nar row black shaft lines, widening behind and merging into solid black on nape: a dark stripe on side of head: under parts, nearly white: otherwise as in summer. I MATLRE: Like winter adult, but tip of bill black.

Nest and Eggs.- Not distinguishable from those of the Common Tern.

Distribution.- Nearly cosmopolitan; breeds from Massachusetts north to northern Greenland, across Arctic regions to northern Alaska, and in entire Arctic regions of Europe and Asia: winters in Antarctic Ocean, south to latitude $74^{\circ}$ : in migration, Pacific coast south to southern California, and Atlantic coast south to Long 1sland; accidental in Colorado. 


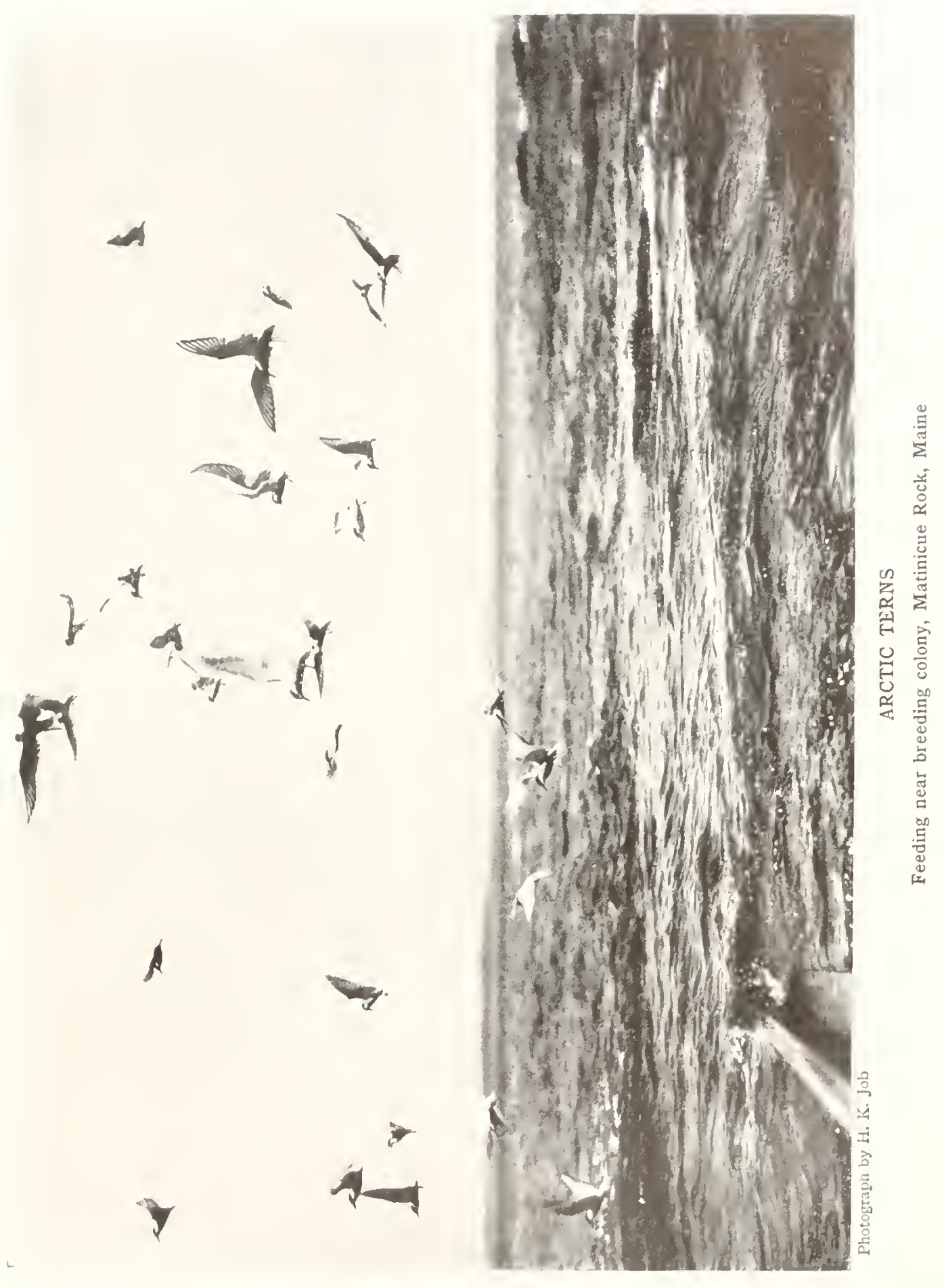


The world's migration champion is the Arctic Tern. It deserres its title of "Arctic," for it nests as far north as land has been discovered; that is, as far north as the bird can find anything stable on which to construct its nest. Indeed, so arctic are the conditions under which it breeds that the first nest found by man in this region, only $7^{\mathrm{T}} \mathrm{2}^{\circ}$ from the pole, contained a downy chich surrounded by a wall of newly fallen snow that had to be scooped out of the nest by the parent. When the young are full-grown the entire fanily leaves the Arctic and several months later they are found skirting the edge of the Antarctic continent.

What their track is over that I I,OOo miles of intervening space no one knows. A few scattered individuals have bcen noted along the United States coast south to Long Island, but the great flocks of thousands and thousands of these Terns which range from pole to pole have never been noted by an ornithologist competent to indicate their preferred route and their time schedule. The Arctic Terns arrive in the Far North about June 15, and !eave alout August 25. thus stay- ing fourteen weeks at the nesting site. They probably spend a few weeks longer in the winter than in the summer home, and this would leave them scarcely twenty weeks for the round trip of 22,000 niles. Not less than 550 miles in a straight line must be their daily task, and this is undoubtedly multiplied several times by their zigzag twistings and turnings in pursuit of food.

The Arctic Tern has more hours of daylight and sunshine than any other animal on the globe. It the most northern nesting site the midnight sun has already appeared before the birds' arrival, and it never sets during their entire stay at the breeding grounds. During two months of their sojourn in the Antarctic the birds do not see a sumset, and for the rest of the time the sun dips only a little way below the horizon and hroad daylight is continuous. The birds therefore have twenty-four hours of daylight for at least eight months in the year, and during the other four months have considerably more daylight than darkness.

Wells W. Cooke, in Bird Migration.

\title{
ROSEATE TERN
}

\section{Sterna dougalli Monta!nt}

\author{
A. I N Number 72 See Color llate
}

Other Names.-Graceful Tern; McDougall's Tern. General Description.- Length, 15 inches. Color above, rearly-gray; below, delicate rose-pink.

Color-Anthts in Summer: Crown, glossy black reaching to lower border of eyes: mantle, delicate pale pearly-gray; neck all around and cutire undw parts, $a$ delicate rose pink; primaries, grayish-black strongly silvered; long tail-fiathers, whitc on both wets; bill. black, extreme tin, yellow, reddish at base; feet, vermilion; iris, brown. ADULTS IN W1NTER: Forehead and cheeks, white; crown, hind head, nape, and sides of head, dusky mottled with white above; below, pure white without rosy tinge; lesser wing-coverts, brown-

The Roseate Tern is the embodiment of symmetry and grace - its flight the poetry of motion. Its elegant form tapers and swells in lines of beauty. Its lustrous plumage reflects the yellow rays of the sum and the pale refracted light of sea and sands in evanescent pink and rosy tints. These are seen in perfection only in the living bird and fade when the light of life fades from its eyes. The stuffed and distorted specimen on ish; tail, less forked, pearly-gray like back; bill, dull black with yellow tip and brown base. IMMATURE: Similar to winter adult.

Nest and Eggs. - Nesting similar and eggs inclistinguishable from those of the Common Tern excent by comparison.

Distribution.- Temperate and cropical regions; breeds locally from Sable Island to Long lsland, N. Y., and from the Bahamas to the Lesser Antilles and Venezuela; formerly from Maine to Florida; rare migrant in Central America; winters from the Bahamas to Brazil : accidental in Ohio: occurs on the coasts of a large part of the eastern hemisphere.

the mutseum shelf has lost the grace, beauty, and color of the living thing and remains but a sorry travesty of the life that is gone. It seems a bird of ethereal origin, fitted only for the balmy airs of tropic isles but it follows north the coast of both hemispheres and is found in Maine on one side of the Atlantic and in Scotland on the other.

lears ago, when fashion called for its plumage and there was none to save, this bird was almost 
exterminated on the Atlantic coast. The adults were hut on their breating grounds and the young left to starre in the nests, but now. muler protection, they are berinning to increase and may he found breeding with the Common Terns on isolated islands off the New England cuasts. This Tern keeps mostly to the sea and its hays, sounds, and estuaries. Its nest is built ofturi among low vegetation and the young can latrolly be distinguished from the downy chicks of the Common Tern. The adult hirds, however, are quite different from that species, a little slumer and more gracetul in tlight. They maty los readily identified by the black hill, the longer errace iul white tail, the rosy anparance of the breats and other ander pants, and their incisive nutes. When excited, they call hevit, hovit, ending with a prolonged ery, hut the alam note commonly heard is cac, cac. In the latitule of New England, about the first of August, the young are well able to $\mathrm{fly}$, and they join the wandering flocks which visit the shores, far and near, before the sonthern migration hegins.

linward Hume Fordusi.

\section{LEAST TERN}

\section{Sterna antillarum (Losson)}

1. (1) [. Ximber 7 ace color l'bate 7

Other Names.- Silver Ternlet: Sea Swallow: Little Strikir; Little Tern; Minnte Tern.

General Description.-Length, ") inches. Color ahowe, pale grayish-blue; below, satiny-white.

Color.-Adelts in Sumarer: Crown, glossy greenishblack with a narow white crescent ath horns reding aho's eyes and atending to bill, but separated from white of cheeks by a dusky line through eye to bill; cntire upper parts, including tait, pale trayish-blue roching to the black cap and fading on sides of liead and neck into satiny-white of all under parts; two onter primaries, black with white space un inner webs; rest of primaries, a darker shade of colur of hack; bill, willow tipped with black: fict, opung villoas: iris, brown. Ancles is MiNTER: Forthead. lures, and crown, white, the latter with black shaft lines; back of head and nape, dusky, connecting with a narrow streak through eve: hindneck, white; mantle, darker than in

Unquestionilyly the most dainty of all the Ancrican sea-birds is the Least Tern. This petite little creature is adorned with a pair of silvery-gray wings that cary it on long voysus up and fown the coast. From its winter home in the tropics it comes north in spring to Califormia and $M$ assachusetts and in buth States it finds : summer home. A few pass up the Mlissis-ipli valley and it has been recorded as far north as Soutli Makota. Thirty years ago they swarmed literally by thousands in our Atlantic waters near the shore-line but the feather-hunters matce sall work of them. There is a record of ten thousand having been shot for their feathers on colb Island, Virginia, in a single season. This was of course done in the summer and the orplatned young were left to perish on the beache: summer; edge of wing and a band along forearm, grayish-black; most of primaries, plain dusky.

Nest and Eggs.- Nest: In pebbly depression or on the dry sand of beaches. tugs: I to 4, from valu grtenish to dull drab, spotted over entire surface with splashes and dots of different shades of clear brown and some lavender.

Distribution.--Tropical and temperate America; lireeds on coast of southern California and on Gulf coast from Texas eastward; also northward to Missuri (formerly Iowa) and northwestern Nebraska: has vccurred in Misconsin and South Dakota: breeds also from the coasts of Massachusetts, Virginia, North Carolina, and Florida south to the Bahamas. Niest Indies, Britist Honduras, and Venezuela: $110 \mathrm{w}$ rare everywhere; in migration occurs on the coasts of Lower California and western Mexico; winters from Gult coast to Venezuela and Peru.

At one time larere colonies axinted in the someds of North Carulina: but their numbers becanc so reducerl that when the \aduben Socicty wardens were first established in that territory, in the spring of ro 3 . only sixten exps were laid in the birel colonies that year. They have responded splenelidly to protection and although many years must clapse hefore wa can hope to have them as abundant as former!y they are nevertheless increasing in a most encouriging way.

dike the other members of this family they prey mainly upon small fish which they calpture by at wift plunge from the air. They do not confine themselves entirely to this rliet, however. and often catch such insects as are found hring over the marshas.

lexat Terns are wsually sech in small scattered 
flocks. They are very sympathetic and solicitous about the welfare of their fellows that chance to get into troulle. Any old Tern hunter will tell you that, if one be shot down, its friends will at once come and fly anxionsly about emitting their little squeaky cries of anxiety. It was thus often possille to bag almost the entire company. When a flock was seen and the gumners found difficulty in oltaining the first bird to serve as a lecoy, they were induced often to approach the boat by the simple experlient of tying a handkerchief to a stick and throwing it into the air. The sight of this object, which at a distance

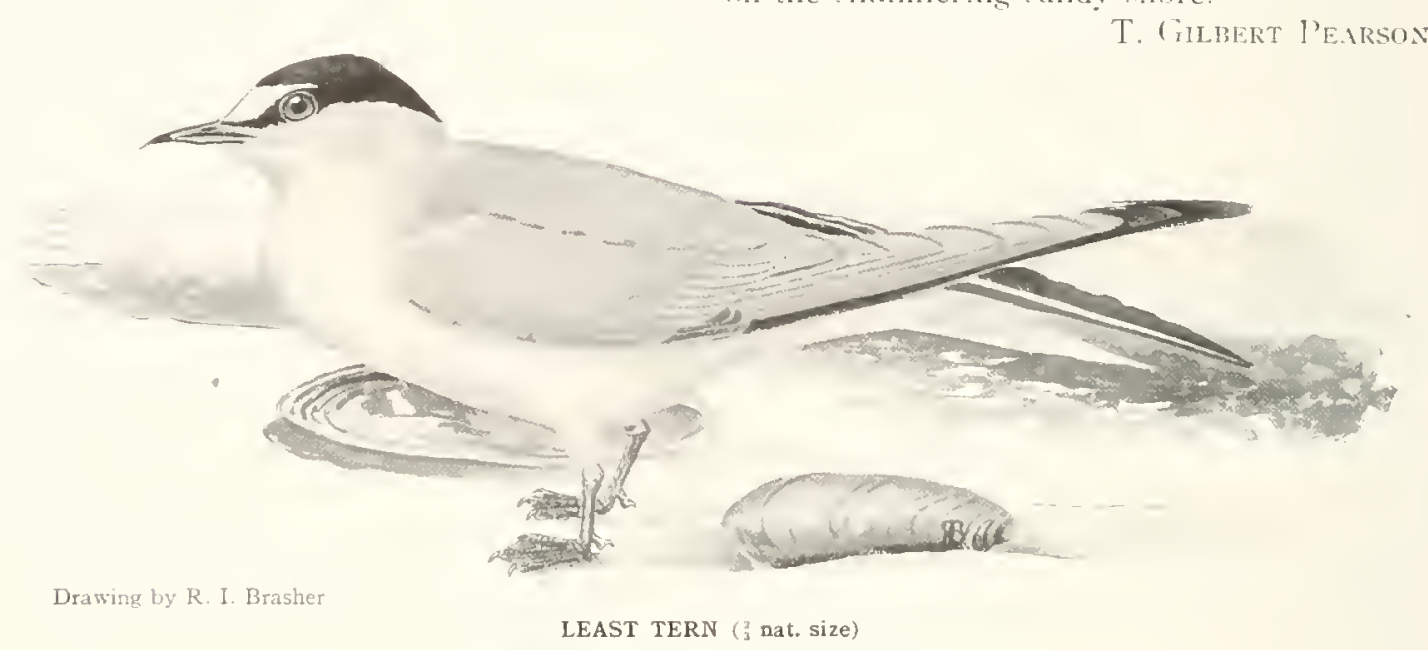

The most dainty of all the American sea-birds

\section{BLACK TERN}

\section{Hydrochelidon nigra surinamensis (Gmelin)}

\section{A. O. U. Number 77 See Color I'late 8}

Other Names.-American Black Tern; Short-tailed Tern; Semipalnated Tern: Surinam Tern.

General Description.- Length, 9 inches. Upper parts, leaden-gray; head and under parts, black. Bill. very sharp and slender, shorter than head; wings. long and pointed with no distinct markings; tail, short and but slightly forked: feet, webbed only to midclle of toes.

Color.-ADelts iN SUmmer: IIcad and neck and entire under parts as far as the tail-coacrts, jot black: under tail-coverts, pure white: on back of neck and between shonlders the black shades into leaden-gray, which color extends over entire upper parts to the ends of tail-feathers; primaries, grayish-black; outer secondaries similar, inner secondaries like back; shoulder of wing, narrowly white-bordered: bill, black; gape, carmine; feet, dark red-brown; iris, brown. ADutrs in Winter: Forelread, sides of head, neck all around and somewhat resembles a falling Tern, nsually brought the birds on the run.

me many other Terns the nest of this species The eggs are nsually two in number, al If aresting before it took flight. Nated lirds in tomg sights of a visit to a Least Tern colony is to see one of these little, gentle creatures feed his mate as she sits lurooding her eggs shore.

\section{T. (illbert J'EARSON.}




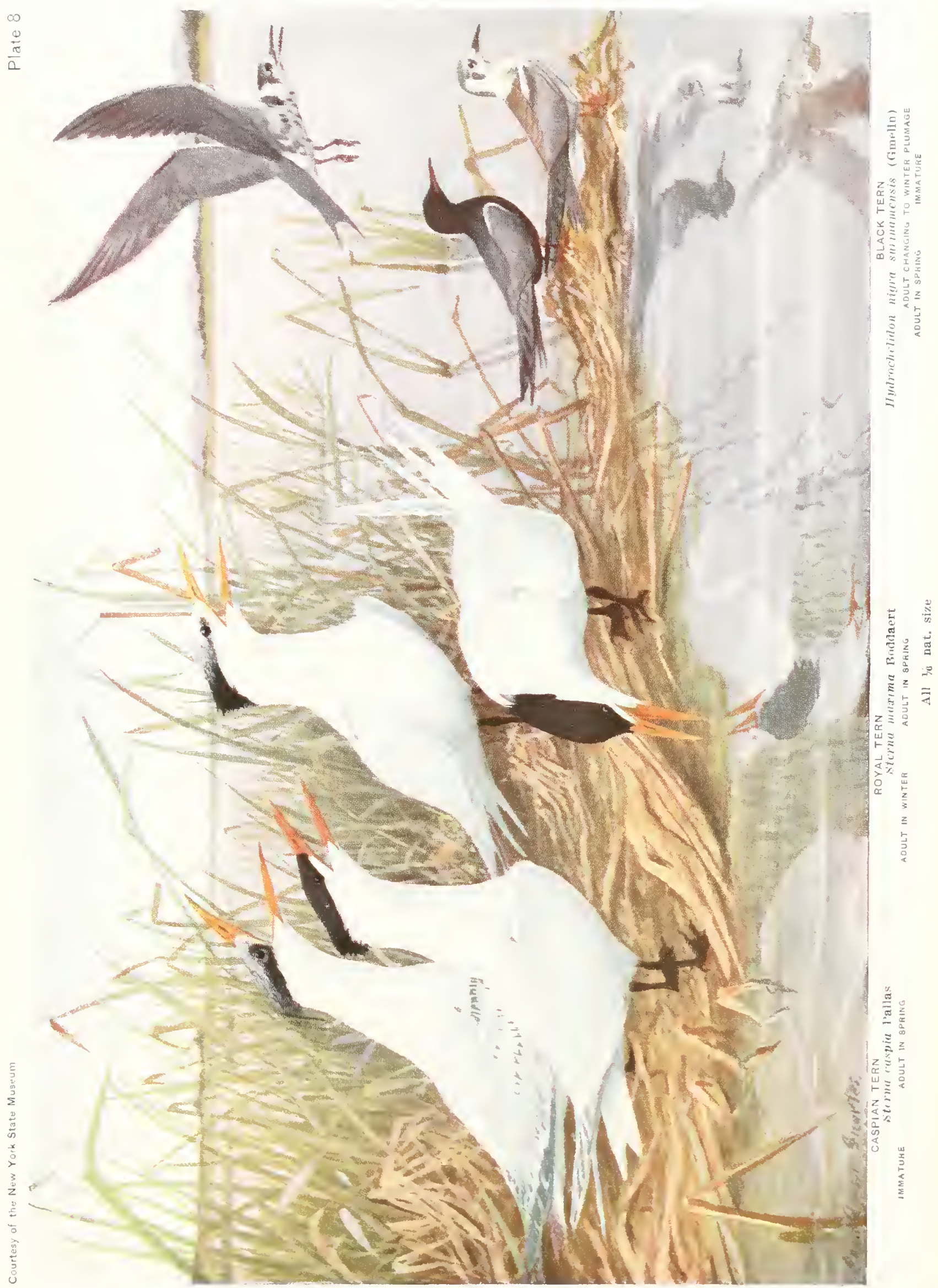



The lilack Tern is a species of really unique personality, and might be characterized as the "aquatic swallow" of the slomghs of the northwest. It may be recognized as the dark gray bird with black under parts, in general form and motions not unlike a l'urple Nartin. which may be seen flitting about over the prairies, especially in the vicinity of wet grounds or slonghs, pursuing insects like any Swallow. In late summer and early autumn these birds gather into large loose flocks, and are very much in evidence. Where the Franklin's Gull is found, the Black Tern hardly can fail to be present, thomgh, as the Tern is much more widely distributed, the converse is not true. persistent attacks. (On one occasion they hit me so hard on the top of the head that, even though I wore a cloth cap, their blows gave me a severe headache. Ifter hatching. the young do not remain long in the frail nests, but quickly take to the water, and swim about through the aquatic vegetation, watched over by their parents, and brooded from time to time wherever they may crawl out upon any convenient spot.

As far as is definitely known, these Terns breed only in the western interior of the United States and Camada. (In one occasion, however, when I landed on a low sandy sland on the Atlantic coast, near Cape Charles, Virginia, I was surprised to find a considerable number of them,

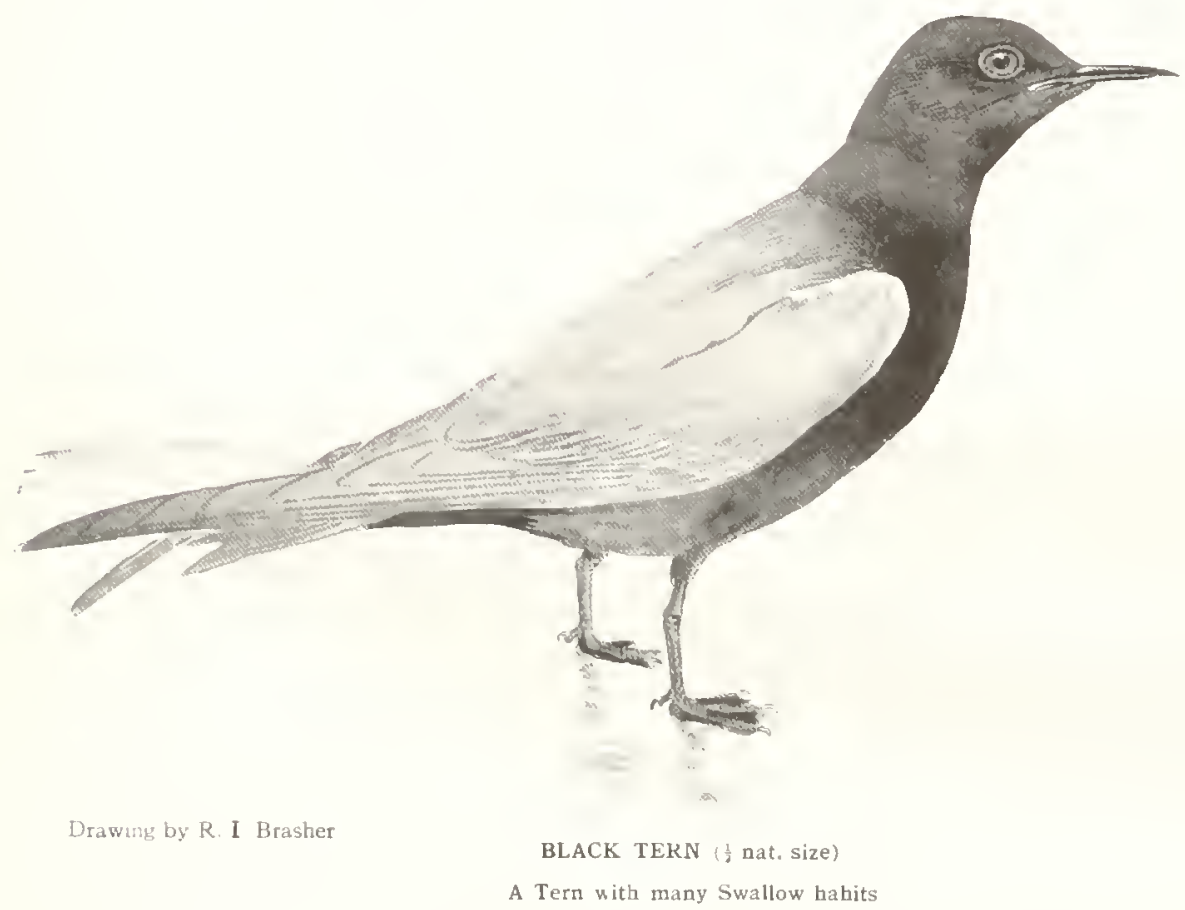

llere, in these sloughs and marshes, it lreerls in abundance, and is one of the last of all to deposit its eggs - about the middle of June. The nest is the merest apology for such, being a slicht depression, lined with a few wet stems, on some little hummock of mud or débris which may happen to project from the water. Sometines the nests are partly floating, but heavy rains must work havoe with them. Two or three eges are laid.

The parents are verv solicitous when their home is approached. They dart about screaming and make angry swoops at the hearl of the intruder, in fact often striking hard with their bills. Nore than once 1 have suffered from their all in full arlult plumage, with black breasts. They were with other species of Terns, and acted exactly as on their western breeding-groumds. hovering over me screaming, and dashing furiously at my head. Unfortunately there had been a high storm tide, which had destroved every nest on this barren sand har, including those of Forster's Terns and those of Black Skimmers. Both of these latter had constructed new nests and were resentful of intrusion. Where the Flack Terns hovered there were little hollows in the sand, lined with grass, smaller than those of the other Terns, just the size that the species constructs in the West. It was unfortunate that 1 could not return to the island later. 
as I am positive they must lave been breeding there, and this is the only case thus far known

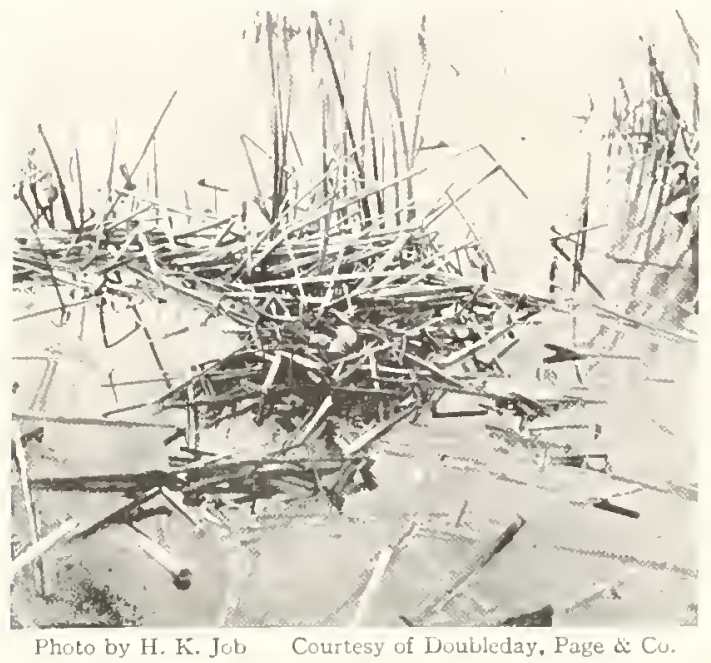

NEST OF BLACK TERN

The merest apology for a nest, being a slight depression, lined with a few wet stems, on some little hummock which may happen to project from the water

of any evidence of their breeding on the Atlantic coast.
On another occasion also I witnessed a peculiar happening with the species. It is well known that they do not breed until two years old and in full plumage. In their second summer they are in an immature, white-breasted phase. In winter all migrate down into Central and South America, and only a comparative few of the immature plumaged lirds of a year old are observed in our borders. In June, 1915, while cruising along the western coast of Louisiana, I saw great clouds of rather small birds, resembling in the distance fliglits of Golden Plovers such as 1 had seen many years ago, performing crolutions high in the air, and then settling down on the shores of a sandy inlet back of the outer beach. We managerl to land and cross to it, and were amazed to find there swarms of Black Terns, nearly all in the one-year-old plumage, with a very few adults intermingled, fairly covering the flats for probably a comple of miles. There must have been tens of thousands of them, and their identity was proved by collecting a few. This would indicate that the young remain well to the south, not migrating north to any considerable extent until fully mature.

Herbert K. Job.

\section{NODDY}

Anoüs stolidus (Limorus)

$$
\text { A. O IT. Number to }
$$

General Description,- Length, 16 inches. Color of head and neck. gray : of boly, hrown. Tail, rounded, the central feathers longest.

Color.-Forehead, white: crown, leaden-gray: sides of head and neck all around, bluish-slate with a dark spot in front of eye; rest of plumage, deep brown blackening on wings and tail; bill, black: feet, dark reddish-brown; iris, brown.
Nest and Eggs.- NEST: In low bushes; constructed of sticks, leaves, and grass. Ergs: 1, warm buff, spotted and blotched with reddish-brown and lavender, chiefly around large end.

Distribution.- Tropical coasts. Freeds on Florida Keys, the coast of Louisiana, and in the Pahamas and Vest 1ndies; winters south to Brazil and Tristan da Cunha Island.

\section{SOOTY TERN}

\section{Sterna fuscata Linnous}

1. O U. Number is Siee Color Plate 7

Other Names.- Egg Bird: Wide-awake.

General Description.- Length, I5 to 17 inches. Color above, black; below, white.

Color.-Adults: Entire upper parts, black with a slight greenish-gloss; a white crescent on forehead extending above eyes, separated from white cheeks by a black hand from eye obliquely downward and forward to bill: sides of bead to eyes, half way around neck, and entire under parts, white; primarics and secondaries, black, lighter on inner webs of former, white on inner webs of latter; long outside tail-feathers, white: bill and feet, black; iris, red. Young: Entire plunage, 
snuky-brown, graysh on abdomen; upper wing-coverts and shoulders, tipped with white griving a spotty appearance; feathers of back. rump. and upper tailcoverts, margined with dull rufous: primarjes and tail, black, the latter lut little forked: bill. black above, dull redelish below: eyes and feet, dusky-reil.

Nest and Eggs.-On sandy beaches I to 3 egrs are dropped with slight attempt at a nest; the egers are creamy ur buff, sparsely sputted and splashed with light hrown, landyke brown, and lavender.

Distribution.- Tropical and suhtropical coasts, excent Pacific coast of bouth America: breeds from Florida. Louisiana, and Texas throushout the Bahamas, llest Indies, and tropical islands of the Atlantic : rarely north to Maine: winters from the Gult coast to Lirazil and the Falkland Islands.
As there is more or less similarity in the appearance. habits, and liabitat of the Solkly and Sonty Terns it becomes proper as well as convenient to treat the two species tugether. For most of the following facts, we are induhterl to Iolun B. Matson's carefully preparel nonograph. "The Behavior of Noldy and Sonty Turns." this being one of the Papers from the Torturgas Laboratory of the Cameyic Institution of $\mathrm{H}$ wsh- fool, and that it is applied to the Tern in question hecause of the bird's tameness or stupidity. especially when on the nest. Ilow much justification there is for this explanation will alpcar from Mr. Matson's deseription of the Nodrly's concluct rluring the nidification perind. Is he shows, the name undoubtedly has reference to the bird's curious norlding halit, of which he gives the following description :

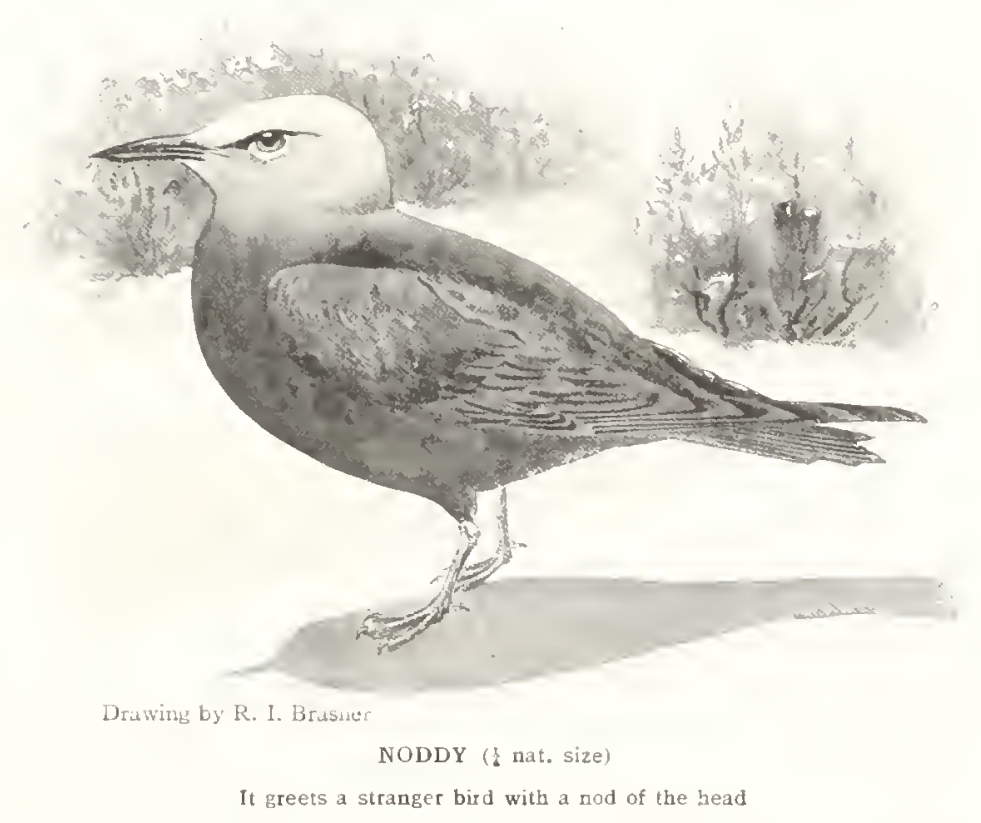

ington. Mr. Matmon remarks that "extencled statements of the instincts and habits of these birds are not extant." The habit of the hirds of assombling on islands has been noted hy rarious naturalists and travelers, hut nearly all information eoncerning them has to do with their traite during the nesting season, and little is buown of the remainder of their lives. What Mr. Matson records eroncerning their tomestic conduct should, however, receive the careful attention of all who are interested in these comparatively litte known hirds.

Certain of the dictionaries inform the rearlers that the word "Noddy" means simpleton or
"This noulding reaction is onc of the most interesting and ludicrous acts of the Nodely Tern. $t$ is quite clahorate. Two birds will face each other, one will then bow the head almost to the ground, raise it quickly almost to a vertical position, and then quickly lomer it. He will repeat this over and over astin with great rapidity. The other hird gotes therugle a similar pantomime. It a stranger hird alights near a grompl. he salutes those nearest, and is in turn silluter hy them. During the pantomime a somol is rarcly heard."

Mr. Nitson observed these singular bircls on Pird Key, a very small coral islanel alont sixty- 
five miles west of Key IIest. The Terns arrived for the nesting season during the list week of April. It was observed that their food consisted of small fish of various kinds; that they never swam or dived, and that they never touched the water except when drinking, bathing, or fishing. They drank sea water, which they took on the wing by dipping the opened beak into the sea. They bathed by dipping the breast and head, and did not immerse the whole body. Frequently they followed schools of minnows which were driven to the surface by larger fish, and which they canght with their bills. This fishing was done by groups of Noddies and Sooties to the number of from fifty to one hundred formance. It is begum by the male, who nods vigorously to the female. She responds by thrusting her bill down his throat while he regurgitates the fish he has caught. Then the male flies away to return presently with a stick, and the nest-building operation is begum without further ceremony. The nest is made of dead branches, or seaweed, or a combination of both, and it may be lined with shells, upon which the eggs are laid. The building nuay be done jointly by both sexes or, apparently, by either working chiefly unassisted. It is far from true that the brooding bird displays indifference when an intruder approaches, says Mr. Matson. On the contrary,

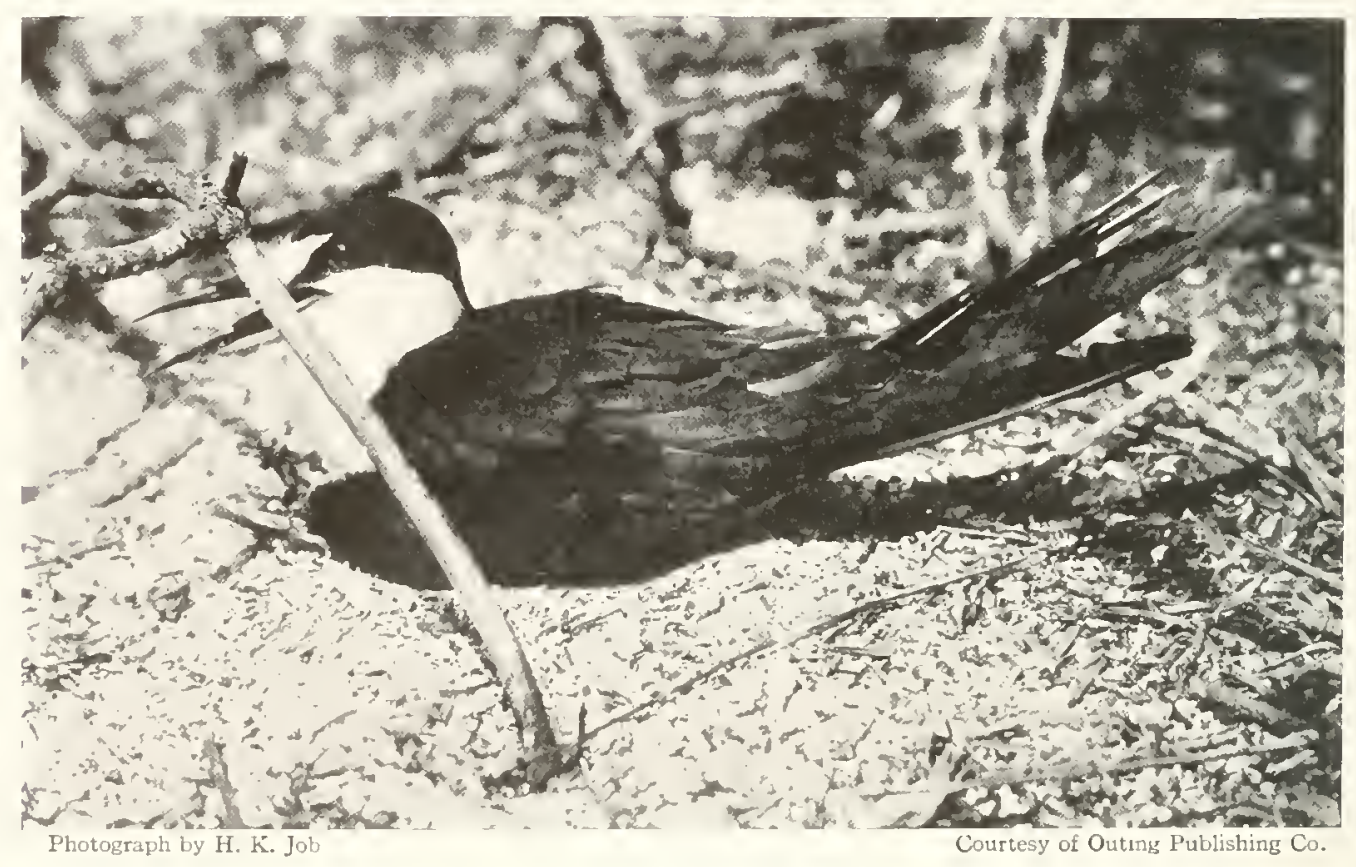

SOOTY TERN ON NEST

Mr. Matson noted that the Noddies left the island at about daybreak, fished for about two hours, and then returned to relieve their mates, who therempon flew out to sea for their turn at fishing. Refore the single egr is laid the male Noddy does all of the fishing and feeds the female. After the egr is laid the birds relieve each other at interval of about two hours. During the laying and brooding season the male Sooty probab!y stays out over the water all day. but during the laying season he returns at night to feed the female, while in the brooding season he relieves the female. It seems probable that the birds feed within fifteen knots of the shore.

The courtship of the Noddy is a curious per- though they may permit a very close approach. even to within handling distance, they strike savagely with their sharp heaks, and Mr. Watson says he has been attacked by the flying birds with sirch spirit that his hat was knocked off and his scalp cut by their bills. Incubation requires from thirty-two to thirty-five days, and the parents share the labor of feerling the young. The Nodlies made use of nests of the previous season. lo adding new material: and that this operation, apparently, was repeated several times seemed probable to Mr. Watson, as some of the nests were very large and bully. But he found no proof that the same pair actually returned to the same nest. Often the birds built in low bushes, 
but in no mstince was the nest placed directly on the ground, for it was nuticed that wen nests which seened to be so placed were in reality resting on a worn-dinu turf of crass.

The ne.t of the Sonty Torn, on the other hand, was at the nost no inore than a shallow oral lepression, hollowed out of the sand by the bird's claws. Sonnetimes this nest was fashinneri under baybery bushes, and occasionally it rim t) feares was gathered about the edge, hut these leaves were only sucl as the bird conld reach while she was covering the egos. These hirds have very definite illas alout their property riglts, according to Mr. Mat on. That is, they evidently consider a plot of cround from fourteen inches to two feot stuare within which their nest is placed as their private premises, and they will leave their euss or even their young to drive away any other bircl that comes within their domains. This jealousy cultse: almont combtant commotion and uproar in the colony; for, if a bird upon returning to its mate dnes not alight literally within its own vard, and attenuts to Walk to its own nest, it will be set tpon by every other birl throtigh whose premises it passes. Against human intrulers, however, it defends its hone somewhat less vigorotisly than does the Nodily. The birls share inculation, and sometimes one will brood the eges for two days in sticcession hefore being relieved. They never

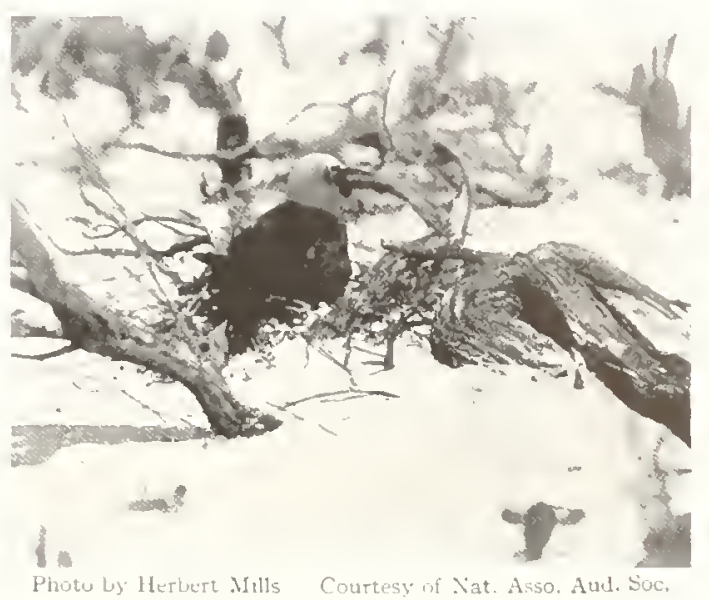

A NODDY NESTING UPON THE BARE GROUND

Only a few sticks have been gathered around the rim of the nest

rest or swim on the water and. apparently, gret so little sleep that they are called the "Wideawalie Tertss."

\section{SKIM M ERS}

\section{Order Longipennes: family Runchopide}

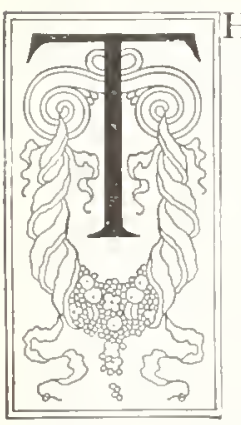

HE Skimmers eonstitute a single family, Runchopida, which includes five species. Like the Loons and Grebes, they evidently are very old forms, as their fossil remains have been found in Patagonia in the strata of the Tertiary Period. In several respects they strongly resemble the Terns, but they differ from them and from all other lirds in the curious structure of the bill, which is long, and much compressed laterally, the lower mandille, which is mtuch longer than the unver, being as thin as it knife-blade. The upyer mandible is peculiar in that it is movable. These differences are plainly modifications which fit the bird for its method of eapturing its foud (shrimps, small fish. and other animal forms) by skimming the surface of the water with the lower mandible, the upper being kept slightly raised meanwhile. This manner of feeding is suggestive of that of the whales. They hunt their food in companies and are partially noeturnal in their habits.

The birds generally are pure white below, and black, with sone white tipuing of the feathers on the upyer parts. Their hodies are from sixteen to about twenty inches long, their wings slender and long, the tail short and slightly forked; the feet are small with the webs between the middle and the inner toes decply notehed.

Skimmers build no nest, lut lay three or four eggs in a slight hollow in the sand. "The Black Slimmer is the only member of the family which oceurs in Anerica. 


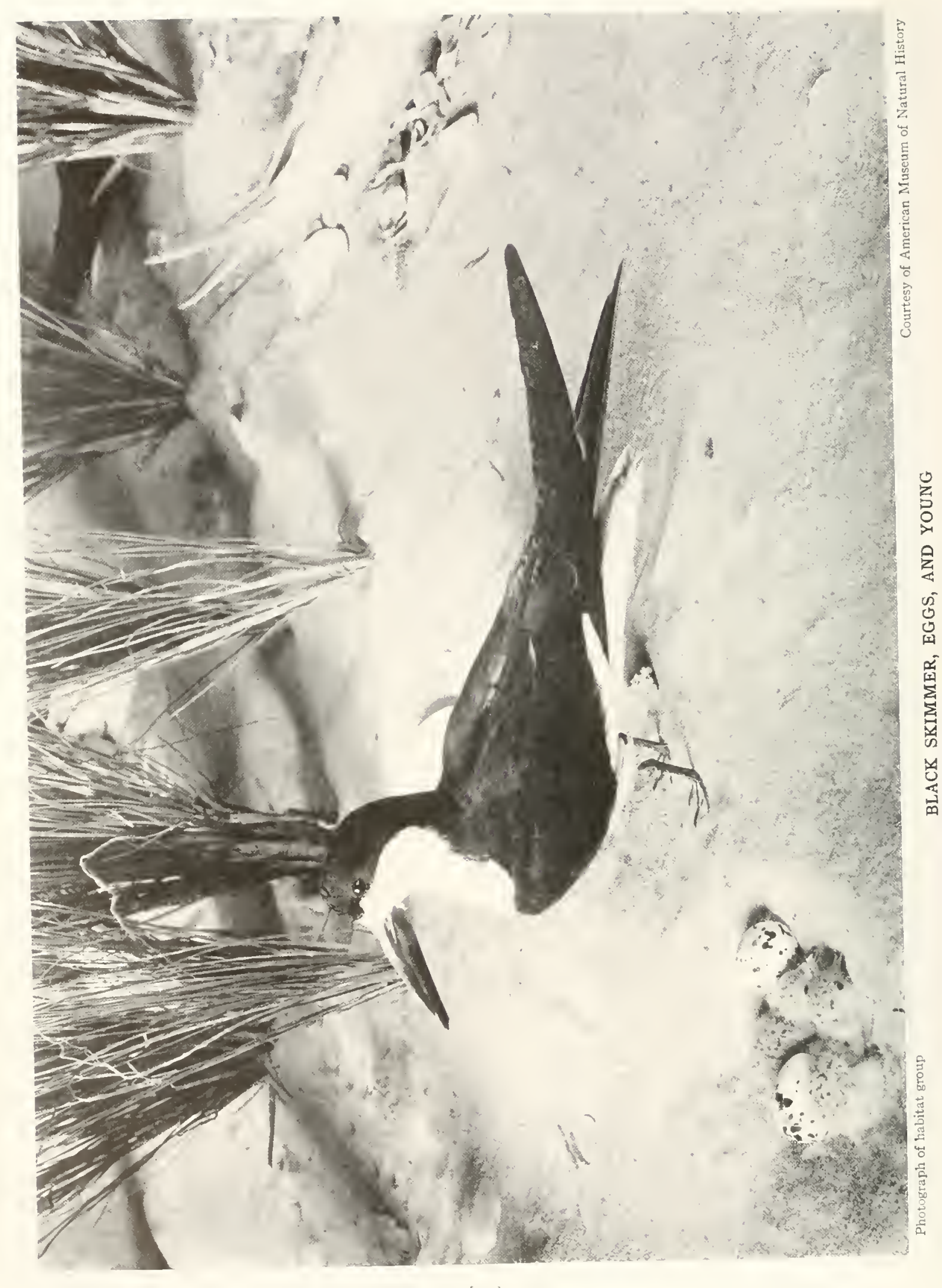




\title{
BLACK SKIMMER
}

\author{
Rynchops nigra Limncess
}

A. O. U. Number so tee f whr l'late 7

Other Names.-Cutwater; Scisurbill: Shearwater; Storm Gull.

General Description.- Length, io (1) 20 inches. Colur aluse, black; below, white.

Color.- Crown, sides of heal to below eyes, back of neck, and entire upter purts, glossy hlack; forchead, irles of head below eycs. sicles of neck, and whole under parts, pure white with a rosy tint in spring ; tips of inner four primaries and secondaries, white; tail, white, the central teatheri black; basal half of bill, carmine, rest black; leet, carmme- irs, lrown. l) $0 W \mathrm{NI}^{-}$Loung: Sancl-colored.

Nest and Eggs.- EGig: Dejositerl on the hare rand; 4. White to pale buff, spotted and blotched with dark browns and black and some lavender.

Distribution.- Tropical and temperate America: strictly martme; breels from lirginia formerly New Jersey) to the Gutf coast and Texas; rarely north tw the bay of Fundy; winters from the Gulf coast to Colima, Mexico, anu Costa lica; casual in West Indies.
Five species of the Skimmer family inhabit the warmer portions of the earth. (1ne of these. the Black Skimmer, reaches the shores of the Lnited States and is distributed along the Gulf of Mexico from Texas to hey Heat, and northward alome the Atlantic coast to Virginia. It is a larse, lonerwinged bird, black above and white lreneath. The bill of this birl is most mique, boll mandibles being thin and flat like a knife-blade, and come logether edgewise, and not like a duck's bill. The under one is an inch or more longer than the upper, and this is fushed forward under the surface of the water as the Skimmer with open mouth flies along the sea lonking for the small marine animal-life upon which it feeds. In search of foud they often follow along the narrow crecks throust the marshes and at tines (nter the onter bays and river-mututle. Ther never go inland, nor do they travel very far tis sea. When Skimmers first appear in sprine along onr southern beaches they come in flucks of hundreds or eren thousands. At this season they are very restless and the llocks are continually taking flight from one heach or bar to another, and their shouts fairly drown the roar of the surf.

They are nore or less gregarions throughout the summer, and assemble in colonies to rear their

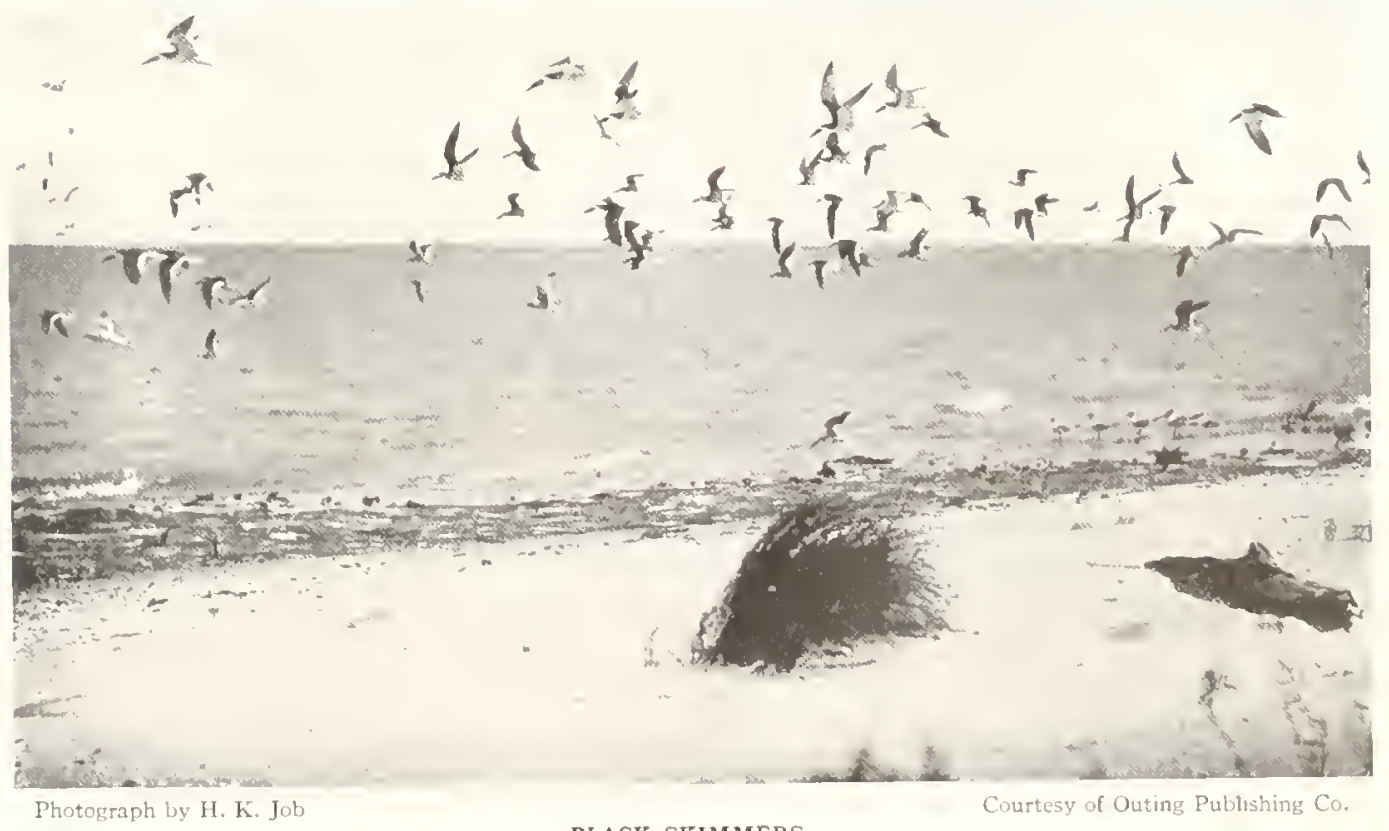

BLACK SKIMMERS

On Battiedore Island, Louisiana 
young. Their nesting places are situated on sand spits running out from shore or on small isolated islands of sand and sea-shells. The nest is a simple, unlined hollow in the sand which the bird makes by tuming its body around nuany times. The eggs vary from three to five in number and are variously spotted and blotched. no two being exactly alike. If the nests are robbed, a second nest is soon made and another clutch of eggs is laid. Very often groups of breeding Skimmers assemble on the same sandy shore where Terns are nesting. but use a territory more or less separated from that occupied by the Terns. They are poor fighters and are little disposed to defend agsressively their rights.
For this reason, and also because they begin to lay well after their neighbors have taken up their household duties, they are forced to take such accommodations as the "Terns may deign to leave them. If you approach one of their nesting places the Skimmers will leap into the air and bear down upon you with hoarse cries, but I have never had one come near enough actually to strilie me.

One of the local names for these birds is "Shearwaters." Along the Virginia coast they are known as "Storm Crulls." They are never shot for food, but their eggs are regularly taken by fishermen unless the colonies are carefully siarded.
T. Gilbert Pearson.

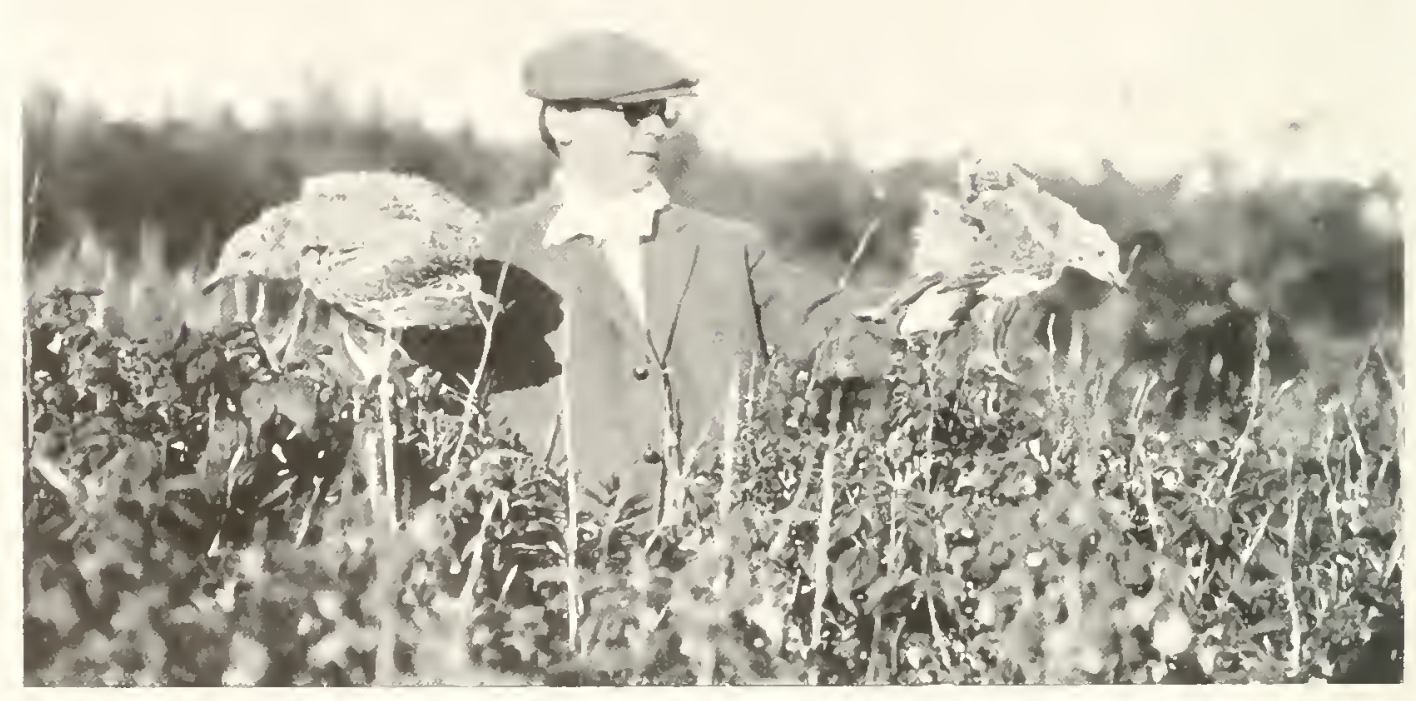

T. GILBERT PEARSON HUNTING YOUNG HERRING GULLS HIDING IN THE WEEDS 


\title{
ORDER OF TUBE-NOSED SWIMMERS
}

\author{
Order Tubinutes
}

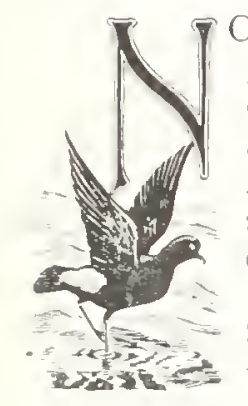

OSTRILS opening through tubes are the distinguishing characteristic of this group of birds. Not only is the order cosmopolitan in distribution, but many of the species are found throughout the world. Two families - the Albatrosses and the Fulmars, Shearwaters, and Petrels - represent the order in North America. In the first of these families the tubes enclosing the nostrils are separated and placed one on either sicke of the bill; in the other the tubes are connected and are on top of the liill.

An unusual range in size is exhibited by the Tube-nosed Swimmers: the Storm Petrel is the smallest of the natatorial birds, while the Giant Albatross is unsurpassed in wing cxpanse in the entire bird kingdon. They are unequaled in the power of flight. As a rule they keep far off shore, only visiting land for the purpose of reproduction. They live practically in the air, flying low over the water and snatching their fond of marine life and oil matter from the surface of the sea. So far as is linown, but one egy is laid each ceason: some species nest in a burrow, but others lay the egg on the ground. The roung are covered with down when hatched, generally of a sooty or gray color, but are helpless and in need of the parents' care for some time.

Birds of this order have no bright marhings in their plumage and are usually gray, or black, and white. There are no sexual variations in coloration and the seasonal differences. if any, are undetermined. The plumage is very compact and oify. The wings are long, narrow, and pointed, and the tail rather short. The bill is hooked and enlarged at the tip, the upper mandible being longer than the lower and curved downward. The covering of the bill is in several horny plates, showing seams between. The three front toes are webbed and the hind toe. when present, is small and elevated.

\section{ALBATROSSES}

\section{Order Tubinares; family Diomedeida}

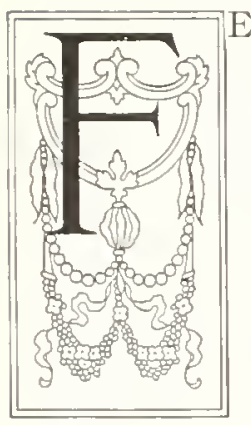

EV birds make a stronger appeal to the imagination than do the Albatrosses, with their complete mastery of an art which has been a profound mystery to man until very recent years, and in which he can never hope to be more than a clumsy tyro in comparison with these great conquerors of the air. Much mystery has been made of the evident ease mith which these great birds follow a rapidy moving ship for hours or even days at a time, with seldom or never an apparent movement of their wings. But an Albatross is not a supernatural creature and therefore cannot defy the lams of physics. Hence it is obvious that the hird nutst move as the result of the action of some motive forceeither the pressure of the wind on its wings or the movement of the wings themselves. On this interesting subject we have a pretty definitely expressed opinion from a trained naturalist, the late Ilenry N. Moseley, one of the party of scientists who circumnarigated the globe in the (hallonger expedition of IS;2-IS;0.

"I believe," wrote Mloseley, " that Alhatrosses move their wings much oftener than is suspected. They often have the appearance of soaring for long periods after a ship without flapping their wings at all, but if they be very closely watched, very short but extremely 


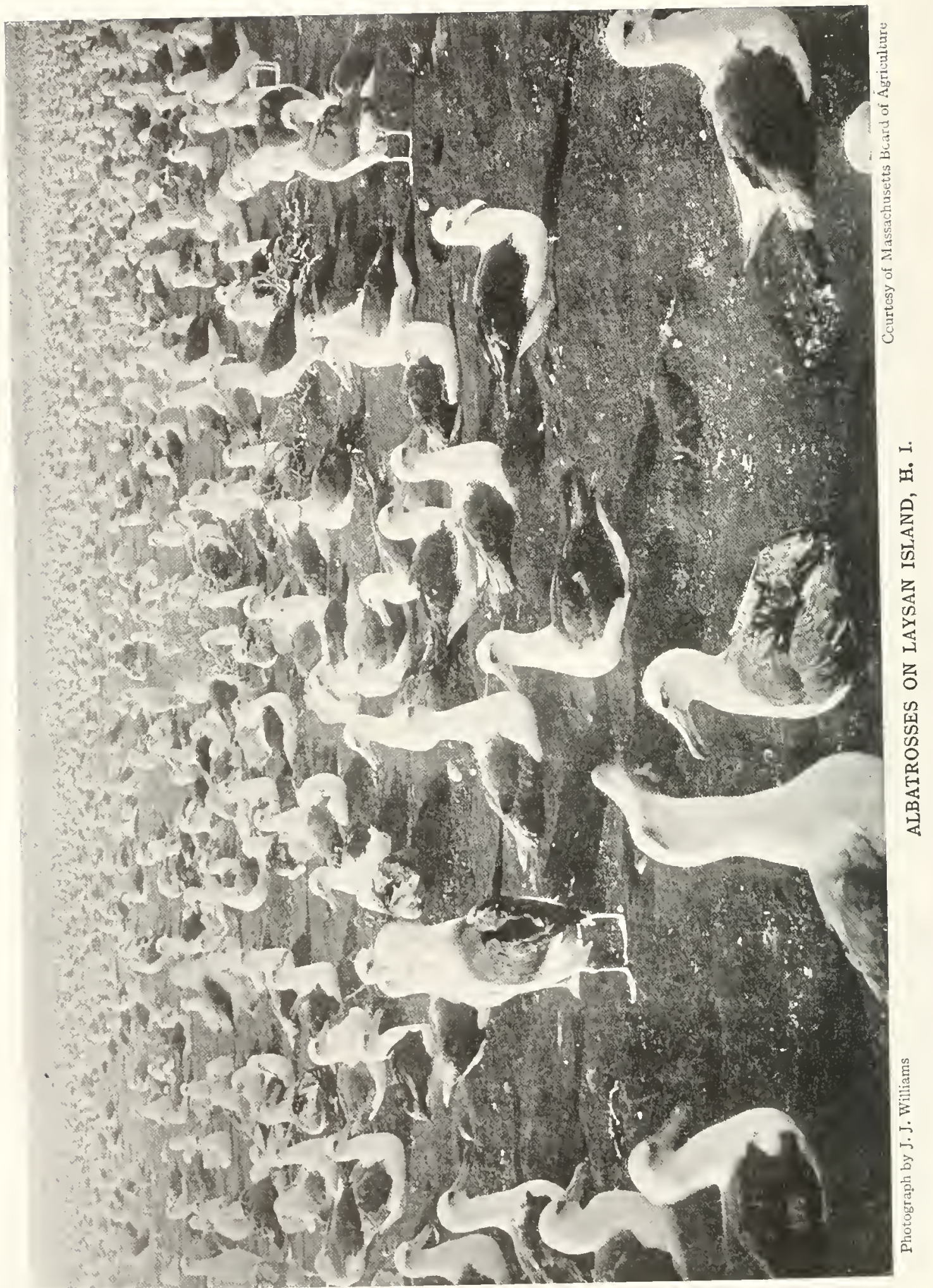


quick motions of the wings may be detected. The appearance is rather as if the body of the bird dropped a very short distance and rose again. The movements cannot be seen at all unless the bird is exactly on a level with the eye. A very quick stroke, carried cien through a very short are can, of course. supply a large store of fresh momentum. In perfectly calm weather, Albatrosses flap heavily." (Notes by a Naturalist.)

Professor Hutton's description (in the Ibis) of the flight of the Mlbatross is probably as accurate as any:- " With outstretched, motionless wings he sails over the surface of the sca, now rising high in air, now with a bold sweep, and wings inclined at an angle with the horizon, descending until the tip of the lower one all but touches the crests of the waves as he skims over them. Suddenly he sees something floating on the water and prepares to alight; but how changed he now is from the noble bird, but a monnent before all grace and symmetry. He raises his wings, his head goes back and his back goes in; down drop two cnormous webbed feet straddled out to their full extent, and with a hoarse croak, between the cry of a Raven and that of a sheep, he falls 'souse' into the water. Here he is at home again, breasting the waves like a cork. Presently he stretches out his neck, and with a great exertion of his wings runs along the top of the water for seventy or eighty yards, until, at last, having got sufficient impetus, he tucks up his legs, and is once more fairly launched in the air."

Moseley's statement that Albatrosses flap heavily in calm weather should set at rest the oft-reported assertion that they never move their wings in flight, while the observation that there is actually some occasional movement even when the wings seem to be motionless must, of course, be accepted as entirely accurate, even though that acceptance necessarily destroys the cherished notion that the bird has and exercises supernatural powers. But even after it has been explained in perfectly cold-blooded scientific language, there should be enough of the truly remarkable left in the flight of the Albatross to create a profound impression upon any mind which does not insist upon seeing the supernatural where it does not exist. These notions of the supernatural are, of course, especially prevalent among sailors, who are famous for the variety and picturesqueness of their superstitions. And we are indebted to their Albatross superstition for having inspired Samucl Tavlor Coleridge to write "The Rime of the Ancient Mariner," which, so Swinburne says, "for melody and splendor it were hardly rash to call the first poem in the language."

About sixteen species of the Allatross are known, and all are essentially birds of the subtropical or southern tropical seas, although the Black-footed and Laysan speeies sometimes wancler as far north as Alaska, and either is occasionally seen off the Pacific coast of the United States. Though their wings when extended may measure twelve feet, or even more, their bodies rarely weigh more than eighteen pounds. The food of these great hirds consists of fish, cuttlefish, jellyfish, offal, and refuse thrown overboard from the ships they follow. Such matter they seize eagerly, a habit which is taken adrantage of by brutal or thoughtless persons who eatch the bird by trolling with a long line and a hook baited with meat or fish.

\section{BLACK-FOOTED ALBATROSS}

\section{Diomedea nigripes Auduhon}

1. O I. Number $8 \mathrm{I}$

Other Name.- Goony.

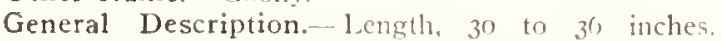
Color above, dark chocolate-brown: helow, gray. Tail, short; wings, very fong and when folded reaching to or heyond tip of tail.

Color.-Anults: Top of head and upper parts, dlark chocolate-brown; leaden-gray below whitening on front of head and at base of tail; a spot in front of eve and streak above it, hlack: feathers of upper parta with paler erlges; bill, dusky; fect, black. Young: Similar to adult, but less white on face, and upper tail-coverts dusky. 
Nest and Eggs.- NEST: On the gronnd, usnally on isolated islands of the ocean; there is little attempt at nest building, the single egg being surrounded merely by seaweed.
Distribution.- North Pacific; breeds on islands northwest of Hawaii and on Marshall Islands: occurs off the coast from southern Alaska to California and western Mexico, and off coasts of China and Japan.
I have a distinct picture in mind, when out on the Pacific, of a big dark long-winged bird coasting down the troughs of the waves and aëroplaning over the mountainous crests. I scarcely ever saw the bird liglit and feed on the water. yet of course, it follows the ship, for scraps. The bird is more a part of the sea than the Crull. It curves in great circles over the maddened sea purely for the love of flying. I asked its name of one of the sailors and he called it a "Goony." I told him it was a Black-footed Albatross.

The Albatross will always be known in English literature through Coleridge's poem, "The Ancient Mariner." What a lesson against the wanton killing of a friendly bird!

WILLIAM L. Finley.

\title{
LAYSAN ALBATROSS
}

\section{Diomedea immutabilis Rothschild}

\author{
A. O. $[$. Number 82 I
}

General Description. - Length, 3 feet. Color ahove, smoky-brown; color below, white. Tail, short; wings, very long and when folded reaching to or heyond tip of tail.

Color.- Head, neck. lower rump, and under parts, white; back and shoulders, smoky-brown; wings and their coverts, blackish-brown; tail, hlack shading to white at base: bill, gray, blackish at tip, yellow at base below; feet, fleshy-pink; iris, brown.

Nest and Eggs. - The single egg is deposited on the ground on Laysan and adjacent islands of the North Pacific.

Distribution.-- Laysan and Nidway islands to San Geronimo and Guadalupe islands, Lower California.
The Laysan is the Albatross whose ruthless slaughter and narrow escape from complcte extinction constitute an episode revealing the most heartless and hideous brtutality ever perpetrated by man upon the lird-world, which is saying much. The island of Laysan, which gives its name to this beautiful and interesting species of one of the most wonderful of all the birds, lies in the Pacific Ocean about 700 miles west by north of Ilonolulu. It is barren, except for a scanty growth of shrubs, and therefore has never been inhabited by man, but for a great many years had heen the home and lireeding place of the Laysan Albatross, the Black-footed Albatross, the Sooty. White. Noddy, and Hawaiian Terns, the Bonin Petrel, two species of Shearwater, the Red-tailed Tropic-bird, two species of Booby, and the Man-o'-war-bird. A photograph of the island, taken in I gog, shows a great plain, about a mile in area, not only covered, but actually crowded, chiefly with Laysan Albatrosses.
For several years guano had been shipped from this island, and the Albatrosses were robbed more or less persistently of thcir eggs, but were not otherwise seriously molested. Then came the episode referred to ahove, which is described by Di. Vrilliam T. Hornaday in his book Our Tanishing W'ild Life:

"At last, however, a tentacle of the feather trade octopus reached out to lialysan. In an evil monent in the spring of 1909 , a predatory individual of Honolulu and clsewhere, named Max Schlemmer, decirled that the wings of those Albatrosses, fiulls, and Terns should be torn of and sent to Japan, whence they would undoubtedly be shipped to Paris, the special market for the wings of sea-birds slaughtered in the Pacific. Schlenmer the Slaughterer bought a cheap vessel, hired twenty-three phlegmatic and coldblooded Japancse laborers, and organized a raicl on Laysan. With the utnost secreey he sailed from Honolulu, landed his bird-killers upon the sea-bird wonderland, and turned them loose upon 
the birds. For several months they slauglitered diligently and without merey. Iplarently it was the ambition of sichlemmer to kill every bird on the island.

"By the time the lird butchers lad accumulated between three and four carloads of wings, and the carnage was half finicherl. Willan $A$. Bryan, professor of zorilogr in the Collese of Honolulu, heard of it and prompity wired the United States Govermment. Without the loss of a moment the Secretary of the Nary dispatchel the revenue cutter Thetis to the shambles of I aysan. When Captain Jacols arrived le found that in round numbers about three hundred thousand birds had been destroyed, and all that remainerl of them were several acres of bones and dead horlies. and about three carloats of wings, fuathers and skins. The twenty-three Japanese poachers were arrested and taken to Homolulu for trial, and the Thetis also brought away all of the stolen wings and plumase, with the exception of a shedful of wings that had to be left behind on accomnt of lack of carrying space."

In IoI , the lowa State University sent to I.assan a scientific expedition under charge of Professor Homer R. Dill. His report on the conditions he found is a terrible indictment, from which the following may be quoted: "An old cistern back of one of the buildings tells a story of cruelty that surpasses anything else done by these heartless, sanguinary pirates, not excepting the practice of cutting wings from living birds and leaving them to die of hemorrhage. In this dry cistern the living birds were kept by hundreds to slowly starve to death. In this way the fatty tissue lying next to the skin was used $u p$, and the skin was left quite free from grease so that it required little or no cleaning during preparation. Many nther revolting sights, such as the remains of young birds that had been left to starve, and lirds with broken wings and deformed beaks were to be seen. Killing clubs. nets, and other implements used by these nurauders were lying all ahout.

"This wholesale killing has had an appalling effect moon the colony. It is conservative to say that fully one-half the number of birls of both species of Albatruss that were so abundant in ioo3 have been killed. The colonies that remain are in a sadly decinated condition."

The lromist and effective interference of the Government was dne to the fact that in Feloruary, roon. I'rosirlent Koosevelt jssued an executive order creating the Hawaibu lsland Reaervation for birds, which includes litysan Island and Vis. I -7 several other islands and reefs. But for that interference, the laysan Albatross might have been reducel to is posint which would have seriously threatened it with extermination.

Scientifically the Albatross is best known through Mr. Walter K. Fisher's photographs and descriptions. In MIay. woz, he visited the Island of laysan. where he found the Flack-fonted and Laysan Albatronses brealing in great numbers. His account of their nesting habits, courting antics, and peculiar dances is well worth reading.

In the luk for January. Iyot, he writes: "The Alhatross lays one egg on the ground, usually in a slishtly raised nomml with a shallow basin in the top. . . . The exre is laid alonut the middle of November. . . The young are not hatched until Fehruary, and then begin the six months of hard work to feed the hungry babies. Thef grow slowly, for hirds, and it is not till the last of July that the most venturesome follow their parents on short Hights to the sea. A few weeks later all are on the wing, and with the old birds they scatter far and wide over the Pacific."

Speaking of the peculiar dance of the Alhatrosses, Mr. Fisher says, " The old birds have an innate objection to idleness, and so for their diversion they spend much time in a curious dance, or perhaps more appropriately a cakewalk.'. At first two birds approach one another, bowing profoundly and stepping heavily. They swasger about each other, conrtesying solemnly, then surldenly begin to fence a little. crossing bills and whetting them together. sonetimes with a whistling sound, meanwhile pecking and droppling stiff little bows. All at once one lifts its closed wing and nibbles at the feathers bencath, or rarely, if in a hurry, quickly turns its head. The partner during this short performance assumes a statuesque pose, and either looks mechanically from side to side, or snaps its bill loudly a few times. Then, the first bird bows once, and pointing its head and beak straight upward, rises on its toes, puffs out its breast. and utters a prolonged nasal Ah-h-h-h, with a rapidly rising inflection and bovine quality.

Often both birds raise their lieads in air and favor the appreciative audience with that ridiculous and indescribable bovine groan. . . . Oceasionally while 'cake-walking' one will lightly. pick up a straw or twis. and present it to the other, who does not aceept the gift. lowever. but thereupon returns the compliment. When straws ane promptly dropped, and all hands besin bowing and walking about as if their very lives depended upon it." Grorom GLandex. 


\title{
FULMARS, SHEARWATERS, AND PETRELS
}

\author{
Order Tubinares; family Procellariida
}

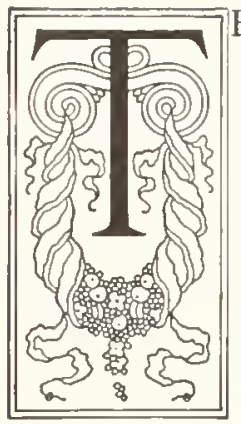

HE Fulmars, Shearwaters, and Petrels are the family Procellariida and with the Albatrosses form the order of Tube-nosed Swimmers. As the name of the order indicates, its chief point of difference from all other orders is the tubular form of the nostrils. Other characteristics are: the bill, hooked and enlarged at the tip and with the upper section longer than the lower and with the covering in several horny sections; the tail, rather short with twelve or fourteen feathers; the wings, usually long and pointed; and the hind toe, either small or lacking, and, if present, elevated. The plumage is compact and oily and shows a tendency toward uniformity in coloration. Often the bodies of the birds in this family are so fat that they can be used for illumination.

Over the oceans of the world are distributed nearly one hundred members of this family. About thirty-five are of regular or accidental occurrence in North America. Not a member is ever found inland unless driven there by a storm. Neither do any of them frequent the shores except for the purpose of reproduction. They spend practically all their time on the wing, and gather their food of marine animals and oily matter from the surface of the water.

So far as is known, the members of this group lay only a single egg. The Fulmars nest in colonies, like the Gulls, on the small islands near the shores of the North Pacific and North Atlantic. Of the nesting habits of the Shearwaters, very little is known; some breed on the islands of the North Atlantic, and it is probable that others breed on the islands of the southern hemisphere, coming north as the southern winter sets in. Some of the Petrels breed in the northern hemisphere and others in the southern. The species in this group concerning whose nesting habits we do know something usually deposit the lone egg in a burrow or a cavity. The young when hatched are covered with down, usually of a grayish color, and are cared for in the nest. At first they are fed by regurgitation on an oily fluid.

\section{FULMAR \\ Fulmarus glacialis glacialis (Linncus) \\ 1. $)$ U. Number 86}

Other Names.- Fulmar Petrel: Molly Hawk; John Down; Sea Horse; Mollinoke: Mallemuck; Noddy.

Length. - 18 tr 20 inches.

Color.- Licht Phase: Mantle. pale bluish-gray restricted to back and wings or extending also on head and tail; primaries and secundaries, dark ashy-brown: a dark spot in front of eye; rest of plumage, pure white; bill, yellow, tinged with green above and below; feet, pale gray: iris. brown. DARK PHASE: Entire plumage, smoky-gray, paler below; feathers of upper parts, with darker margins; primaries, ashy-brown; bill, dull yellow; feet, dusky-gray; iris, brown.

Nest and Eggs.- The single white egg is deposited in a crevice of the rock.

Distribution.- North Atlantic; breeds from northern Greenland to Cumberland Sound, and east at least to Franz Josef Land; ranges north to latitude $85^{\circ}$ and west to Nelville Island; winters south to fishing banks off Newfoundland and to Georges Bank off Massachusetts, rarely to New Jersey.
The Fulmar is a circumpolar lird of the northern hemisphere. It breeds in countless numbers in Greenland, Franz Josef Land, Baffin Bay, lceland, Spitzbergen, St. Kilda, and other regions throughout the northland. It is one of the largest of its family in the northern hemisphere, and an untrained or careless observer might mislake it for a Full, but its peculiarly constructed bill separates it distinctly from that family, and puts it among the so-called "Tube-nosed Swimmers." Moreover, its fliglit is much more like that of the Albatross and differs sharply from that of the Shearwaters and Petrels. As Percy R. Lowe says (in Our Common Sea-birds): "With out- 
spread wings, stretched stiff as a board, it will remain poised and batanced against a strong half-gale, ur glide through the air with wotderful srace by the minutes together, now skimming over the crests of the waves or following down into their deep troughs. now stopping to aliwht. feet first, on the surface, in orrles to pick up some scray fool or some mollusk which it has espied. In coloration, too, the Fulmar approaches more nearly to the. Alyatross than to the rest of its family," while in nesting hahits it "seems intermediate between the Albatross. which nests on the flat oceanic islands in the open, and the true Petrels, which nest in holes or burrows in the ground or loose racks."
Inother peculiarity of this bort is that it is almost voiceless. Even when its nosting places are invaded and hundrecls or even thousands of the fulmars take to their wings, they satil about in utter silence, like so many ghosts of birds. They are strictly pelagic in their habits except during the breeding season. (Ju the ocean they are nuch given to following whaling ships for the blubber and oily scraps thrown overboard. This fond they seem never to eat while on the wing, but inviriably to devour it while floating on the surface of the water, after the practice of the Alhatross. To the crews of the whalers and seaters the bird is well kinown, and to them it swes the names of "Mollimole" and " Noddy."

\section{GREATER SHEARWATER}

\section{Puffinus gravis ( O'Reill $Y^{\prime}$ )}

\section{. O. [T. Number $8_{0}$}

Other Names.-Hagdon; Hag; Haglet: Wandering Shearwater; Common Atlantic Shearwater; Cinereous Puffin.

General Description.- Length, is to $2 n$ inches; spreat of wings. $3^{6}$ to 45 inches. Color ahove, dark brow: below, white
Color.- Lpper frarts, dark hrown, charling on head to grayish-brown: usually lighter nn hindneck, darkest on imer secondaries and rump. the feathers of back, rump, and wing-coverts edged with pale brownishash; crown, minorm brown extending on sides of head to level of gape, with line of demarcation from white

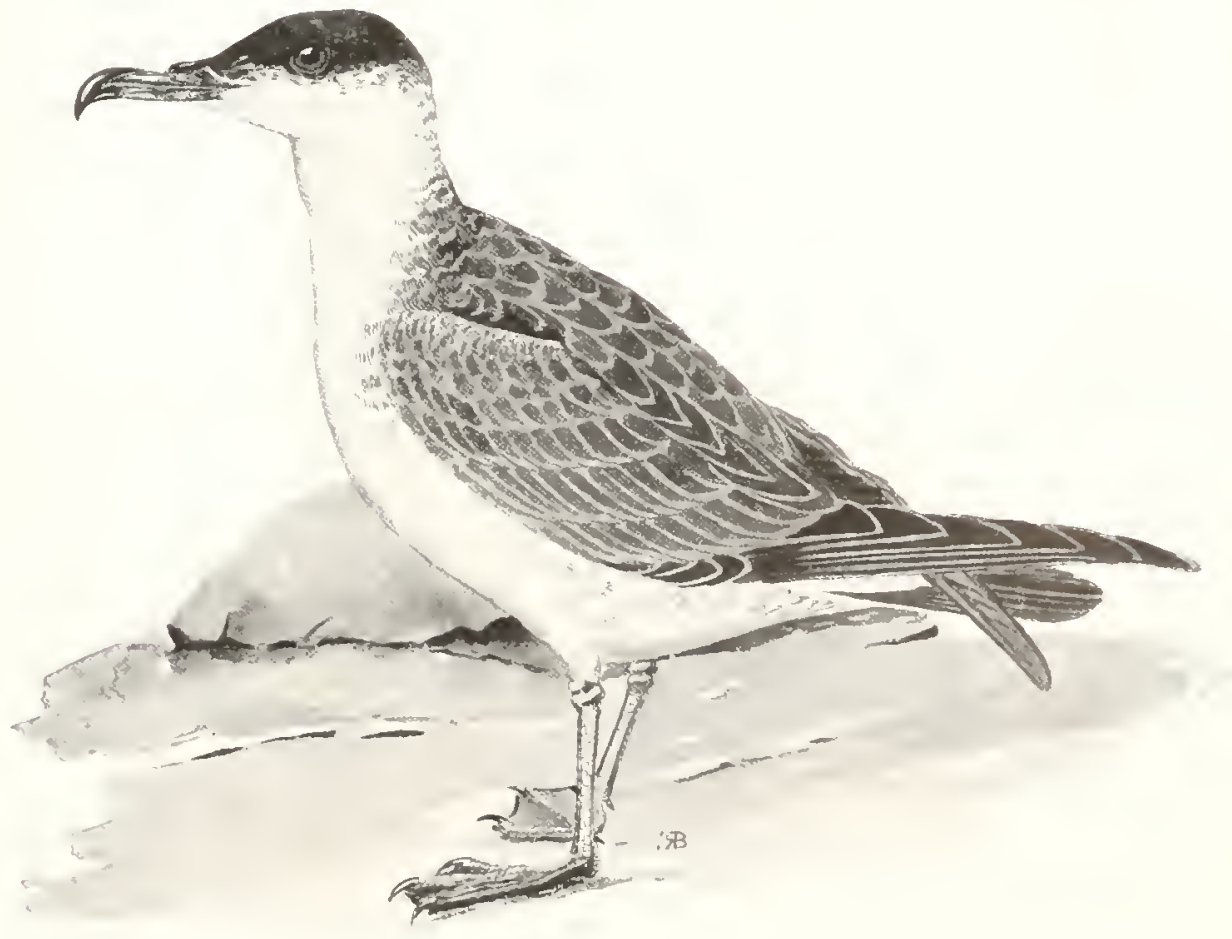

Drawing by R. I. Brasher 
of throat distinct; upper tail-coverts, white with dusky bars or centers: primaries, brownish-black, lightening toward base; entire mnder parts, white with large dark brown patches on sides and flanks; under tail-cozerts. dark grayish-broa'n with white tips; tail, brownishblack; bill, rusky horn color: feet, yellowish flesh color: iris, brown.

Nest and Eggs.- Little is known concerning its nesting; it is supposed to breed in a burrow on islands of the north Atlantic, laying a single white or yellowish-white egg.

Distribution.--Atlantic Ocean, from Arctic circle south to Cape Horn and Cape of Good Hope: occurs off the eastern coast of North America from June to November; occasionally visits the British Isles during the autumin months.
From the firm deck of a great ship out under the vast circle of the sky, surrominded by the hearing, racing ocean swells, the heart sickens at the thought of being left there alone. But to the Shearwater this is home. It needs no companionship and sceks none. On long slender wings, extending some three feet, it goes on, almost ever on, upon its lonely course. A series of rapid beats give it momentum for a prolonger

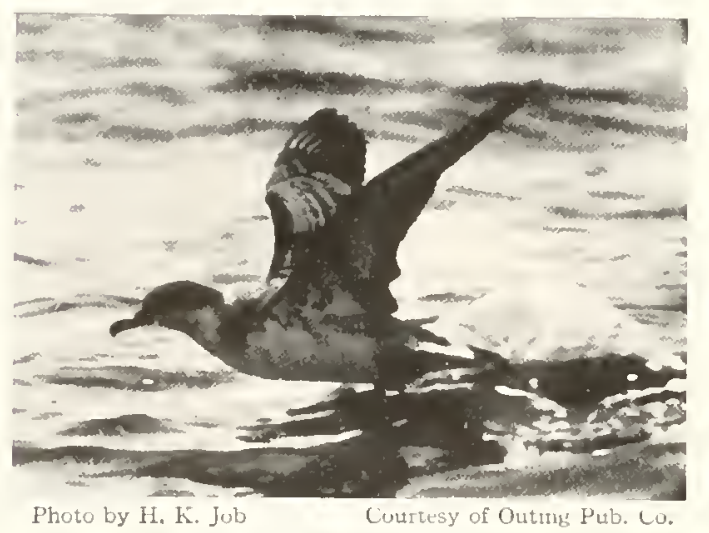

GREATER SHEARWATER

Off the coast of Massachusetts

glide upon stiffly extended pinions, even into the very teeth of the gale. Tipping to one side, the better to trim sail, it skims along never to reach a destination, for it seems ahways going, never arriving.

Such is the rather large gray sea-hird with white breast which we may meet from late spring to advanced autumn well off our Atlantic shores, hardly nearer than where land appears only as a distant haze. Though this is the most common of our Shearwaters, few of our human kind are privileged to enter its select social circle. Deep-water fishermen know the birds well, calling them "Hags" or "Haglets," Floating uffal or grease thrown from the vessel, especially when anchored on the fishing-grounds, sometimes draws quite a concourse. At such times they can be cnticed very close, and can even be caught with hook and line and be drawn squealing and fighting upon deck, from the hard surface of which they are mable to take wing.

In caln weather they caln be seen resting on the water, and it is one of the few occasions when they seen really social, sitting around and chattering to one another. At such times they take to wing with some difficulty, for want of wind, and I have almost run them down by steering straight for them.

Their food, besides floating animal or vegetable matter, consists of varions marine organisms, particularly small fish. The appearance of a school of the latter will quickly, as though by magic, draw a crowd, even though few or none may have been previously noticed. They plunge headlong into the water and flap about as though mad, or else renain on wing and patter with their feet over the surface. The frightened fish submerge, and immediately each bird is off on its !onely wanderings.

No one has yet discovered the breeding haunts of this singular creature, but they are undoubtedly on some desolate Antarctic island where, in a burrow or a hole in the rocks, the female deposits one large white egg, after the usual Shearwater manner. The southern summer, when they nest, is our northern winter. When nesting time is over, and the only bond hut death strong enough to keep them ruiet is relaxed, they renew their roanning. Oceans are hardly wide enough to circumscribe their enersy, and thus, driven by the returning wanderlust, they visit us during our warmer months.

The lest places to find Shearwaters, as well as the other "ocean wanderers," apparently are the fishing "hanks." where fishing vessels congregate. I have found them in considerable numbers five to ten miles or more southeastward off Chatham, Mlass., and off Cape Sable, Nova Scotia. Fishermen report them ahundant on Georges, Grand, and other banks. Though seen from May or June to November, the period of July to September seems to represent the height of their season with us. HERmert K. Job. 


\title{
SOOTY SHEARWATER
}

Puffinus griseus (imelin)

1. 1) I'. Vimber 95

Other Names. Black Hag; Plack llagdm; Darkbodied Shearwater.

General Description.- Length. io to 18 inches: spread of wings, fo inches. Plumage, dark sooty-brown above and below.

Color-C Inifurm dark sooty-bron'th. blackening on ainus and tuil: more souty-gray below with paler throat: bill, elusky-bluish horn, the tube, ridge, and bull blackish; incide of leg and upper side of feet. flesh crilur: outside of outer toe and under side of teet, Watkish.

Nest and Eggs. - Nest: Probably a burrow in the slound on sea jsland of the Soutl Atlantic, a single white egg being deposited at the enrl of the hurrow.

Distribution.-Oceans of southern hemisphere: wecurs in summer on the Pacific cont irom southern Alaska to Lower California, and on the Atlantic coast from Guli uf St. Lawrence tu Sisuth Carolina.

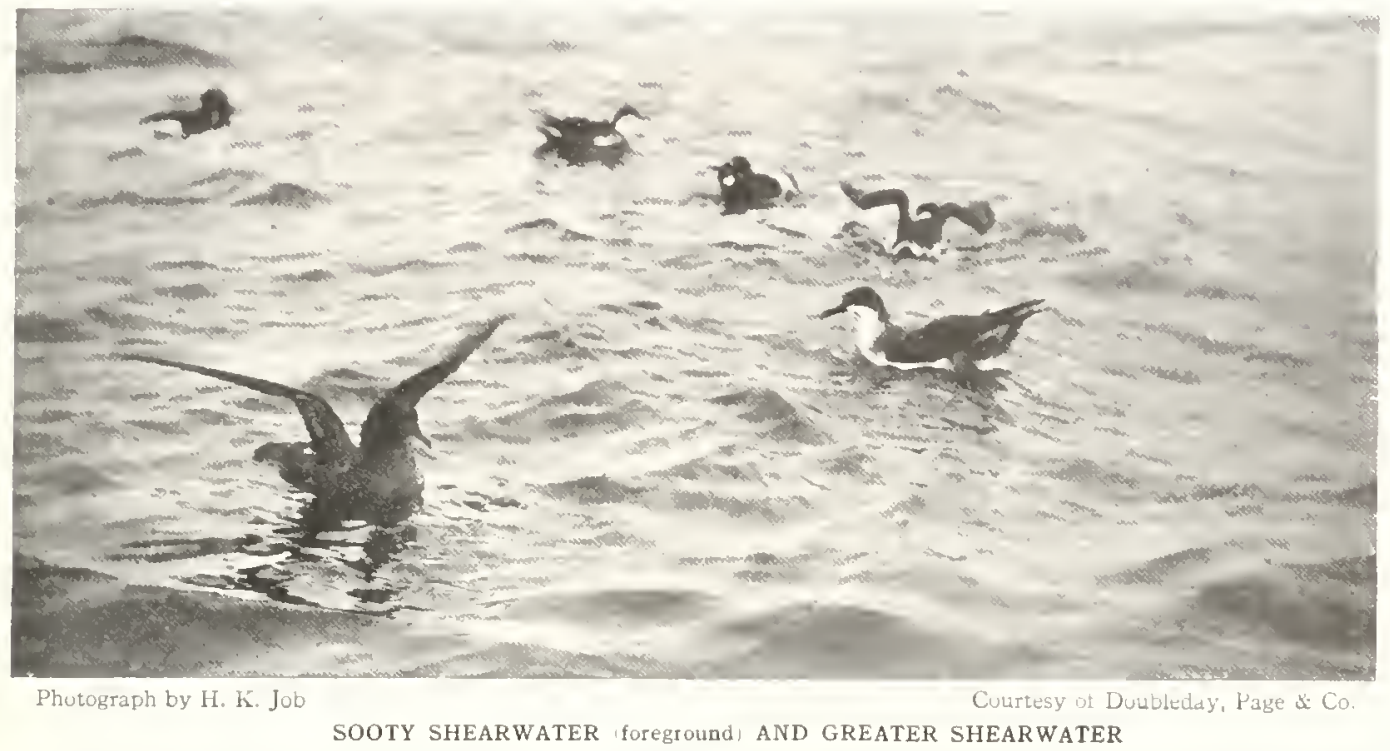

\section{CORY'S SHEARWATER}

\section{Puffinus borealis Cory}

\author{
1. 1) I Vumler $\& S$
}

General Description.- Length, 20 inches; sprearl of wings, to to 45 inches. Color above, brownish-ash; below, white.

Color-- Lpper parts, brownish-ash ; feathers of back. with pale tips: those on nape and sirles of neck narrowly tipped with white: the ash on sides of hearl and neck and white of nnder parts gradually mingle; tips of upper tail-coests. white: monder eyelid. white in contrast with ashy-gray of head; wings and tail, brown-

Somewhat smaller than the Greater Shearwater. the Sooty Shearwater very closely resembles it in habits and flicht, but difers from it markedly in phunage, which at a distance looks as black as that of a Crow. It would seem decidedly strange that this hird escaped entirely the notice of IVilson, Nuttall, and Audubon, but ish-gray: sides and flanks, tinged with ash: under tailcoverts, white, the longest tinged near enrls with ash which extendinearly to tips of the longent tail-feathers; hill, greenish-black, yellow at base and on tip; ieet, greenish-black; iris, brom.

Nest and Eggs.- Unknown but probab]y similar to others of the genus.

Distribution.- Coasts of Mascachusetts, Rhole lsland, and Long luand (August to November)

for the fact that even now its nesting labits are unknown, not have its nest and exes heen discorered.

Cory's Sluearwater is ever more a stranger: it has been sexth only off the Atlantic const between Massachusetts and Long Island. from Angust to November. 


\section{WILSON'S PETREL}

Oceanites oceanicus $(K u h l)$

1. () C. Number 109

Other Names.-Common Stormy Petrel; Mather Carey's Chicken; Long-legged Storm Petrel,

General Description.- Length, 7 inches. Color, dark suoty-brown. Ligs, lony and stilt-like; tail, squarc.

Color-Body, dark sooty-brown; wings and tail, black; wing-coverts, pale gray; upper and under tailcoverts, sides of rump, and base of tail, white; bill and fee, black, latter with a large ycllow spot on aichs: iris, brown.

Nest and Eggs.-Nest: In burrows or in crevices on Antarctic islands in February. EGGs: 1, white.

Distribution. - South polar regions north to Labrador and British Isles; common off the north Atlantic coast of America from May to September: accidental in Ontario.
Nearly everyone who crosses the Atlantic or makes a coasting voyage must have noticed those tiny dark-colored birds about the size of Swallows. with a conspicuous rateh of white on the rump. On rapidly fluttering wing they circle about the vessel, or wander irregularly orer the waves. At times they hover at some particular spot, pattering their feet in the unstable element while a-wing. These are Petrels, often called "Mother Carey's Chickens." They are so distinct from all other birss that no one who gets a fair look could possibly mistake them. The first ones are sighted several miles off shore, and they are quite inclined to follow ressels far out on the open ocean. They are hirds whose home is on the ocean waves. Some of their scientific Latin names appropriately describe them as "runners on the sea."

Two species represent their kind on our Atlantic coast. One is slightly the larger with a forked tail, and is known as Leach's Petrel. The other, which has the tail square or slightly rounded at the end, is Wilson's Petrel. It is the species mostly seen off shore during our summer season. Like their relatives the Shearwaters, they breed on the far southern islands of the

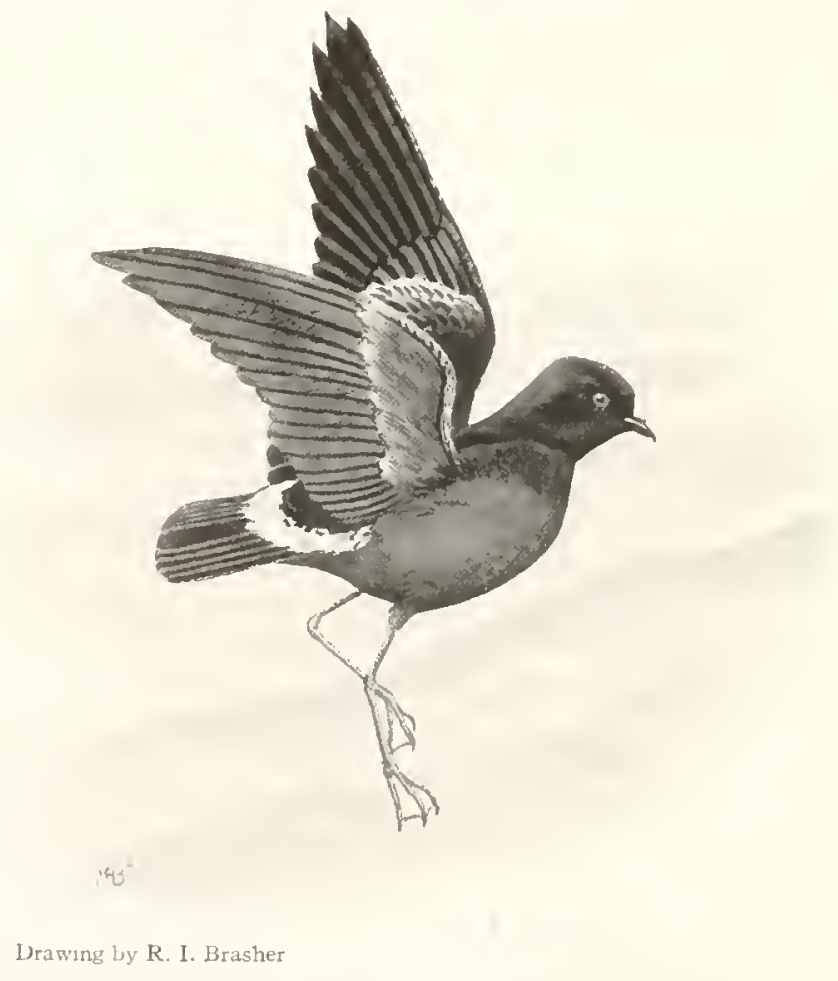

WILSON'S PETREL, (\% nat. size)

Its home is on the ocean's waves 
Antarctic, mesting in February and laying a single white egg in a burrow. For a winter tour they wander thousands of miles and enjoy our northern summer, from about June to Getoluer.

Being summer tourists with us, they are lextter known than though they came with Boreat, and for the same reason it is this species which is generally observed in summer south of the latitude of Maine, ats the other species is a northern breeder. Excursionists from New Jork City to the lower bay often see these birds in considerable numbers. (N) year, on July 13 , a roasting lot day ashore, I was refreslued and lelighted with the constant sight of these Petrels from the steamer flying between the heated widerness of briclis and the New Jersey shore resorts. Som times I have almost liver with them while fishmgr offishore from Chatham. Mass. It was more fun than fishing to throw out fish liver. which floats, and draw the Petrels by scores around the stern. Especially on calm days they would come up so close that I have seen them caught by hand. It afforded splendirl opportunity to watch them at close range as they emulated the tpostle l'eter, from whom they are named because of their curious propensity to "walk" on the water. When canght they proved very unapostolic, and vonnited up) liver or ejected thus or from their nostrils some dark yellow, strongly scented oil. As they flew and fed so close at hand, their pretty little twittering was very noticeable.
The marvel of these birds is their well-nigh ceaseless activity. On a very few occasions, when the weather was alm and lowery, especially before stom, I have seen flocks of them huldled together mpon the ocean "flowr." At wher times, one sees unly that eternally restless

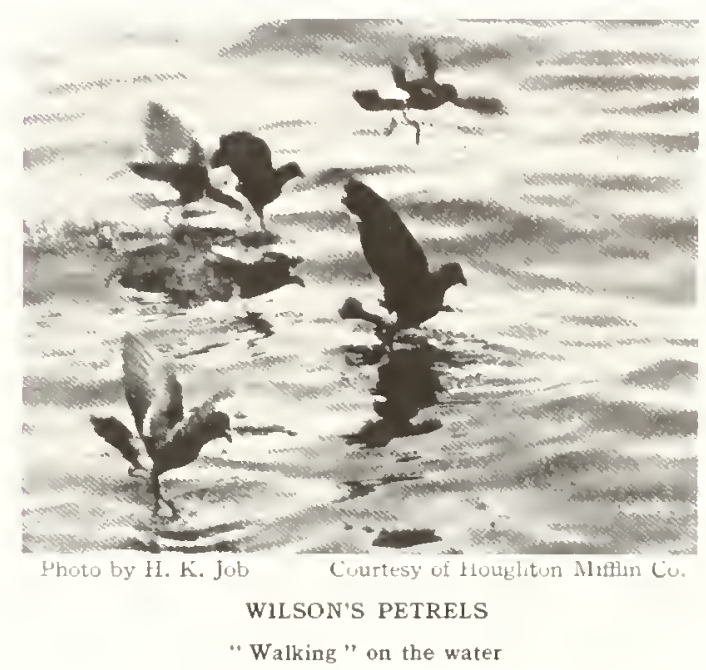

wandering, quartering over the ocean to pick up oily refuse or small marine life. When waves rage and break, they evirlently must remain on the wing day and night. This is a life only for those to whom weariness is foreign.

Helibert K. Jur.

\section{LEACH'S PETREL}

\section{Oceanodroma leucorhoa (T'icillot)}

A. O. U. Number 100

Other Names.-Common Fork-tailed Petrel; Leach's Fork-tailed Petrel: White-rumped Petrel.

General Description.- Length, \& inches. Color, browninh-black. Liys, short: tail, forked, outer feathers more than $I_{2}$ inch longer than middle pair.

Color.- Brownish-black, grayer on wing-coserts and below: primaries. black: upper tail-coverts, pure white; bill and feet, black; iris, brown.

Leacli's Petrel and Wilson's l'etrel are supplementary each of the other. The former breeds north, the other south, lut the latter meets its relative in the summer near its breeding grounds. The fact that 1 have never becn able - perhaps partly from lack of abundance of opportmity to meet any l'etrels off our Atlantic coast in winter makes me wonder whether some day Leach's may not be found to return the compli-
Nest and Eggs.- Nest: In burrows on the ground. EGGs: Single, whitc, mmarked, or wrealhed with fine light red spots around the larger end.

Distribution.- lioth cuasts of North Anerica. breeds from the Aleutian and Copper islands, Bering Sea, south to Sitka, and from southern Greenland sunth t) Maine and the Hebricles; casual in migration south to Tirginia.

ment and risit its relative in its remote sonthern home.

All the Petrels I have identified off southern New England shores in smmmer have heen IIi!son's, which is natural enough, since leach's is 1 ol known to breed south of 11 aine. There and northward 1 have found it nesting. 1 lundreds of them resort to the same barren islands. In the turf each pair digs a little burrow the size of a 
rat-hole, and about the middle of Jime each hole contains a single fragile white egg. As we land there is not a sign of a bird. Put sometimes we can smell the peculiar odor like that of the oil they eject, characteristic and persistent and which lasts in mounted specimens for years.

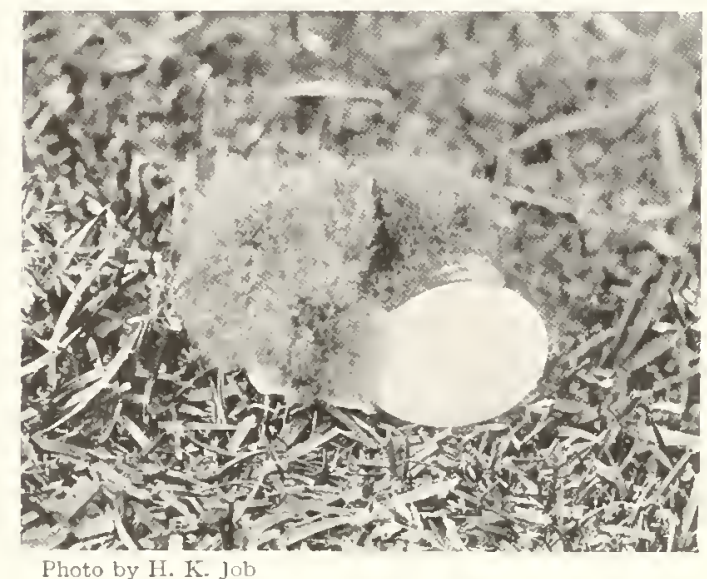

LEACH'S PETREL

Young and egg removed from burrow

Presently we notice the little holes, which run almost horizontally, just below the roots of the gyass. A hand inserted tu, to the elbow lands in a little chamber where the brooding bird is now imprisoned. At the beginning of the breeding season I have found both male and female in the burrow: later, only one, which may be of either sex, as both sexes incubate. The other partner is supposed to be out at sea, but it is a curious fact that in daytime no Petrels are seen in the vicinity of the islands where they breed. Nor have they been proved to remain in other burrows or hide in holes of the rocks. After dusk the Petrels emerge from their burrows. and there are lively times. Dark forms dart around like bats, twittering, and also uttering a singular little plaintive " song," as it may well be called.

Where animals, such as dogs or cats, are kept by fishermen or lighthouse leepers on islands. I have found that they make a regular practice of digging ont and eating Petrels, nntil the colonies are depleted or exterminated. Such practices should be prevented.

Iater in the summer, investigation of the holes reveals the presence of soft. fuzzy young. covered with thick coats of gray down. lighter in color than the parents. I have found them as late as September without a single feather - perhaps the result of robbery of the nests. Such occurrences might have given rise to an old superstition that Petrels hibernate. Winter apparently drives them at least further south than our bleak north Atlantic coast.

Once 1 tried to make a captured Petrel of this species sit for its pricture. Its ceaseless actirity. was something astonishing. No wonder it can outlast gales and billows in many a test of endirance.

\section{FORKED-TAILED PETREL Oceanodroma furcata (Gmelin)

$$
\text { A. 1). U. Number } 105
$$

Description.- Length, 9 inches. General color, light bluish-yray, fading to white on chin, throat, and under tail-coverts; bend of wing and space around eye, dusky ; bill and feet, black. Tail, slightly forked; bill, small and weak.

Nest and Eggs.- NEST: A hole in a bank; thinly lined with dry grass and fine roots. Ergs: Single, dull white with minute dark specks evenly dusted over the large end.

Distribution.- North Pacific and adjacent Arctic Ocean; breeds from Commander and Aleutian islands south to islands off Oregon: in migration occurs on both shores of Bering Sea north to Kotzebue Sound; wanders south to San Pedro, California.

\section{KAEDING'S PETREL \\ Oceanodroma kaedingi Anthony}

A. O. U. Number 105.2

Description.-Length, 8 inches. General color, sootyblack; upper tail-coverts and side of under coverts, white: wing-coverts, brownish; bill and feet, black, Tail, slightly forked; bill, small and weak. Similar to the Forked-tailed Petrel, but smaller in size and darker in color.

Nest and Eggs.-Nest: A burrow in a bank or under a pile of stones; lined with grass, pieces of bark, or chips of wood. EGGs: Single, white.

Distribution.-Pacific coast of North America; breeds on islands off Washington. Oregon, and California from Cape Flattery south to the Farallons: in migration south to Guadalope. Socorro, and Clarion islands. 
On Three Arch Kocks off the Oregon coast, we found hoth the Forked-tailed and the Kaeding Petrels nesting. The latter birds, however, were far more abundant than the former. One might renain about these rocks for a month, climbing over them every day. and not lnow that a l'etrel is there, for they are never seen flying about the rocks in davtine.

Ve climbed to the grassy slope on the north side of the outer rock. My first acquaintance with these two birds was when I dropped on my knees and dug out a single white egs. Then, as I dug a little farther, I saw a Kaeding's Petrel that had crawled back in the extreme corner to hide.

The Petrel nestling is a fluffy ball of down. One parent stays in the burrow with the nestling during the lay, while the other is far ont on the ocean. The parent feeds the youmg by thrusting the leak down his mouth and injecting into it a yellowish Huid. Both old hirds are experts at this. If you take one out of the burrow, he will immediately "play Jonal " in your direction with surprising power of projection. A dose of rancid fish oil shot up your sleeve is not pleasing to your nerves or your nostrils.

I shall never forget the evening we made a langerous trip to the top of the rock and hirl on the north slope. As it grew chark, the Fetrels began coming in to the island like a swarm of bats. Those in the burrows came chittering out to meet them. The ground beneatl semed full of squeakings and the air full of soft twittering and whistlings until it felt uncanny. We frequently felt the breath of swift wings, but it was like a fantasy, for not a bird could be seen, nor cren a shadow. I Iow one of these Fetrels could lind his own home and his mate in an acre of nesting holes hidden all about in the crass and in the darkness of night is one of those mysterious things that we camot solve.

WILLAM L. FINLEY.

\section{STORM PETREL}

Thalassidroma pelagica (Limncus)

A. (). IT. Number 104

Other Name.- Mother Carey's Chicken.

General Description.-- Length, $5^{1}{ }_{2}$ inches. Color, brownish-black. Leys, short: tail, square.

Color.-Glossy brownish-black, browner betow; uper tail-coacrts, white ailh hlack lips; under tailcoverts, streaked with white; bill and teet, black; iris. brown.
Nest and Eggs.-Nest: Holes excavated by the bird under rocks. Eugs: One, white.

Distribution.-Easterly parts of the Atlantic Ocean south to the Mediterranean and west coant of Africa: occasionally found on the Newfoundtand Banks and off the coast of Nova Scotia; breeds on islands off ireat tiritain.

\section{LEAST PETREL}

\section{Halocyptena microsoma (olles}

1. O. L. Number 103

Other Name.-Wedged-tailed Petrel.

General Description.- Length, 6 inches. Color. brownish-btack. Tail, rounded.

Color.- 1,untrons brownish-black, whthut any white, darker on upper parts, blackening on wings and tail, slightly grayer un greater wing-coverts; bill and feet, black; iris, brown.
Nest and Eggs.- The single egg, white with a ring of black specks at cud, is laid in a crevice of rocks. not in a burrow.

Distribution.- Eastern Pacific Oetan; breeds on islands off Lower California; south in migration to western Mexico. I'anama. and Ecuador: vecasionally fumbl north of breeding range.
What the Wilson's and Leacl's l'etrels are to the western waters of the Atlantic, the Storm l'etrel is to the eastern, and there is strong resemblance lectwen the aplearance and habits of the three birds. The Storn ['etre] appears only occasionally off or near the American coast, and then doubtless in most cases accidentally.
Similar in its relation to the western coast is the Least I'etrel, a Pacific Ocean form, seen occasionally off the coast of California, but essentially a bird of the islands far from either shore of that vast sea. This hird's halits are also distinctly Petrel-like and need no separate description. 


\title{
ORDER OF TOTIPALMATE SWIMMERS
}

\author{
Order Steganopodes
}

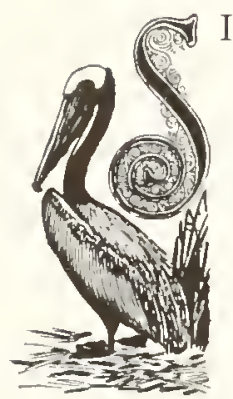

IX families are gathered in this order. All the members are large birds, two feet or more in length, but they differ greatly in appearance and habits. However, they agree in having all four toes joined with webs - hence the name "Totipalmate" has been applied to this group. Their bills are horny and are usually hooked and hard at the tip. Their mouths can be opened very wide; their tongues are small and knoblike. Each bird is equipped with a gular or throat pouch. The nostrils are very small or rudimentary.

Nests are built on the ground, on rocky ledges, or in brushy trees near the water. The eggs are single or few, usually plain-colored, but covered with a chalky incrustation. The young are hatched helpless and naked, but are soon covered with down. All of the Totipalmate Swimmers are carnivorous in diet, their food consisting almost entirely of fish.

\section{T R O PIC-BIRD S}

\section{Order Steganopodes; family Phaëthontida}

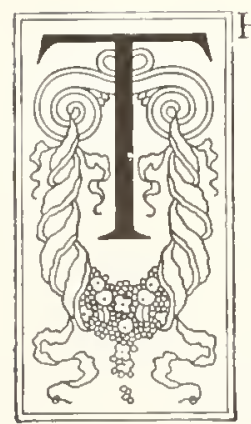

HE Tropic-bird's habit of prolonged soaring, often at a great height, and, as it were, in the very path of the sun, suggested to Linnæus its family name Phaëthontida, which is in reference to the Greek mythological tale of Phaëton, the son of Helios, the sun god, who induced his father to let him attempt to drive the chariot of the sun across the skies, but lost control of the horses and scorched the earth by driving too near it, wherefore he was killed by a thunderbolt of Zeus.

The Tropic-bird family includes six species, two of which breed as far north as the tropic of Cancer, and are often found about the West Indies, while individuals occasionally wander along the eastern coast of North America even as far north as Newfomndland. All have white plumage of satiny appearance, often with a pinkish tinge, and a black patch or bar in the eye region. The bill may be red, yellow, or orange in color, is pointed and somewhat curved, and the edges are toothed. The wings are long and rather slim; the tail is composed of from twelve to sixteen feathers, of which the central pair are much elongated and are slenderer than the others. Excepting the last-named peculiarity, the Tropic-birds resemble in their contour large Terns. They differ from the Man-o'-war-birds in general color, and in the shape of the bill, as well as in the absence of the throat sac, and the naked arca about the eyes, and by the long central tail-feathers. The plumage of the sexes in the adults is alike, but the immature birds lack the long tail-feathers and show more irregularity in their marking.

The flight of the Tropic-bird differs from that of the Albatross in that it is accomplished by uniform, rather rapid, and entirely apparent wing-strokes, whereas the movement of the Albatross's wings usually is so slight as to be almost imperceptible. Nevertheless the Tropic-bird's flight performances are often very spectacular, and include frequent and thrilling dives from great heights into the ocean. Moreover, its power of sustained flight for enormous distances is fully established, though it frequently shows signs of exhaustion by dropping into the rigging of a ship in mid-ocean, an evidence of weariness which is seldom, if [88] 
ever displayed by the great bird of the Ancient Mariner. It often follows ships for long distances, and is called by seamen the "Boatswain" or "Boatswain-bird," terms which sailors apply also to the Jaegrers. Like many birds of great flight power, the Tropic-bird has a clumsy, shuffling gait on shore.

The food of the Tropic-bird consists chiefly of fish, squids, and the like, which are taken by diving from the wing. Its only note is a harsh eroak or chatter. It breeds in colonies, and no nest is built. The single reddish-brown or buffy egg, more or less siveckled with brown, purple, or gray, is laid in a hole or a erevice, or sometimes in a tree cavity, and incubation is shared by the pair. The bird engaged in this operation is not easily dislodged, but resists the intruder by pecking, snapping, and screaming. This spirit is taken advantage of by plumage collectors, who seize the sitting bird and pull out its tail-feathers to be used in "decorating" women's hats.

\section{YELLOW-BILLED TROPIC-BIRD}

\section{Phaëthon americanus Grant}

1. O. U. Number 112

Other Names.- Boatswain; Boatswain-bird: Bosenbird; Longtail.

General Description.-Length, 32 inches. Prevailing color, white.

Color.-Adult: General plumage, pure rihiti'; in breeding season tinged with rosy on under parts and long tail-feathers: lores. a stripe over and behind eye, and on side of head, black; a band on wing from inner coverts to inner secondaries, outer primaries, and shafts of tail-feathers, black; bill and jeet, yellow; toes, black;

Imagine to yourself a beautiful Dove with two central tail-feathers sweeping out hehind to a distance of a foot and a half, and you will have a fairly correct mental picture of the Tropicbird. As I have watched this creature from the deck of a steamer in the Caribbean Sea, or in the lacific Ocean, and observed its exquisite form and grace, I have more than once vowed to myself that here indeed is the most appealing, if not the most graceful, of all birds on the sea. The plumage is silky white, with just enough black on the wings and head to emphasize the dazzling glory of the whole effect. They fly rapilly, and while feeding wing their way along over the water at an altitude of forty or fifty feet. " Longtails" is one of the names by which sailors know them.

The Yellow-hilled Tropic-bird is an inluabitant of the coasts of tropical America and the nearby islands. The northernmost breeding grounds appear to be the rocky cliffs of the Bermuta lslands. Here un to a few vears ago they came in spring by thousand to rear their young and would remain in the neighboring waters until the iris, dark hrown. Young: Plumage, similar, but extensively marked with black bars or crescents on nost of upper parts and with spots on tail.

Nest and Eggs. - The single egg, chalky-white heavily spotted with brown, is laid in crevices or crannies of rocks on isolated sea islands.

Distribution. - Florida and Bermuda south to the West Indies and the Atlantic coast of Central America: accidental in western New York, Nova Scotia, and Arizona.

approach of cold weather would drive them again to the southward. They are not particularly popular with fishermen here, who complain that they eat many squids which should be left for men who want to use such bait when they desire to go angling. The nest is placed in holes and cracks of the rocky faces of the islands and sometimes among the low scrubby trees and bushes higher on shore.

As only a single egg appears to be laid in a season it will easily be seen that no great amount of persistent killing of the birds is necessary to reduce their numbers. L'nless a sentiment is rapidly developed for their protection on these islands, the "Bosen-birds," as they are often called, will probably cease to grace these waters and one of the islands' natural beaties will be gone forever.

Writing in Birl-Lore in 1013, Karl Plath tells of the movements of the Tropic-birds on hand as he watched them in the Bermuda Islands:

"One of the noticeable features of the Tropichird is its inability to walk upright or to stand on it a leges a fact which is not generally understood 
by taxidermists, who usually mount the bird standing on its feet like a Gull. The usual gait is an awkward waddle, or it proceeds in a series of hops. I have also seen them jush themselves along by means of their feet. Before launching in the air, they creep awkwardly, with much flapping of wings, to a suitable height, and then drop, sometimes in the water before regaining their equilibrium, when they are among the most graceful of sea-birds." T. Gildert Pearson.

\section{GA N NETS}

\section{Order Steganopodes; family Sulide}

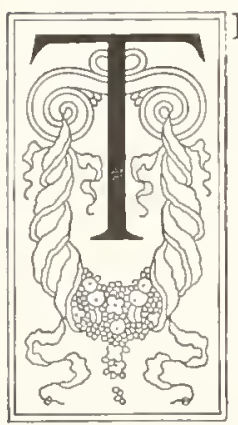

HE Gannets constitute the family Sulida, and comprise the birds of that name (also called "Solan" Geese, "solan" being apparently from a Scandinavian term meaning "sea") and the Boobies. "Gannet" is thought to be derived from the Old English gan, meaning "gander" or "goose-like." There are eleven species in the family, and of these one is essentially a northern bird and migratory, while the others range along the tropical and subtropical coasts of the world. All are strictly sea birds, but they prefer the coastal waters and are not found at any considerable distance from land except when they are migrating. On the wing they move rapidly, alternating vigorous wing work with periods of sailing. They feed almost exclusively on fish, which they capture by diving from the wing, often from a height of forty feet or more, and with such force that they disappear entirely beneath the surface, their impact being sufficient sometimes to send the spray ten feet into the air. This constitutes one of the most picturesque and vigorous feats performed by any sea bird. Fish of considerable size are swallowed practically whole (which is made possible by a throat which can be greatly distended), and are disgorged for the young. All members of the family are highly gregarious, and nest in large colonies on uninlabited coasts or isolated islands. The bird builds a rude nest composed of seaweeds and grass and lays one or two eggs, chalky-white or dull white in hue.

The Gannets are comparatively large birds, their length being from about two to three feet. Their wings are relatively long, and acutely pointed, while the tail is wedge-shaped and consists of from twelve to eighteen feathers. Their legs are short and stout and placed nearly at the center of the body. The feet are completely webbed. The neck is rather long, and the head large. The bill is strong, cylindrical, and tapers to a point where it is slightly curved, though never actually bent into hook form. The plumage is compact and its characteristic coloration is white on the body with black or dusky wings and tail, though some species are sooty-brown or dusky.

\section{BOOBY}

Sula leucogastra (Boddacrt)

A. O. U. Number 115

Other Names.- Brown Booby; Y Yllow-footed Booby ; Catesby's Booby; Booby Gannet.

General Description.- Length, 30 inches. Color above, dark brown; below, white.

Color.- Adults: Plumage, dark brown, abruplly white from neck on under parts; bill and bare parts of head, variably colored, mostly dull greenish or yellowish: feet, similar; iris, white. Yousc: Plumage, grayish-brown, paler below variegated with white on under parts from neck; bill and feet, obscured.
Nest and Eggs.-NEST: On low bushes of tropical keys: constructed of sticks and weeds; in some localities eggs deposited on bare sand or rocks, without any attempt at nest building. EGos: 1 or 2, dull chalky white.

Distribution.- Atlantic coasts of tropical America and Pacific and Indian oceans: rare on south Atlantic and Gulf coasts of the United States from South Carolina to Louisiana: accidental on Long Island, N. Y., and in Massachusetts. 


The booly is a common bird in the Mest Indies and on the coasts of tropical lands to the south. While on ship-board in the l'acific ()cean off the coast of Panama and Nicaragua I observed these birds in sight at all hour of the day. Their flight is strong and easy, ant the flapung is alternated with lrief intervals of sailing. It times they would wheel on set wings and plunge headlong into the sear. Their food consists of marine animal life, fi-h crivlently constituting the bulk of their menu, as the frirds were usually more numerous in the neivhborhood of schools of porpuises. (1) theter occistions I saw boobies standing on the lacks of latking sea-turtles, one of which secmerl not at all disturbed by the weight of two birds that were taking a rest on his broad caraprace.

Proolies collect in numbers to nest on lonely isles. In Camps and Cruises of an () rmitholonist. Doctor Chapman has written of the habits of a colony of fifteen hundred pair of lionhies which he visited and stullied in the spring of 100 - The place was a small islancl linown as Cay Verde, lying wn the outer fringe of the IBahama Islands. The nests were simple affairs placed on the ground. Two eggs are laid abrut it week alpart. but for some reason rarely more than one youns bird is reared. Of their domestic habits he writes:

"In spite of the apparent sociability expressed by their comnumal habits, the Borbies immedi- ately resented the trespass on their home ite by one of their own kind. Where the nature of the sround permited, their nests were placed with mure or less regularity six or eight feet from one another. Is long as a linel remained within its own clomain haviner a cliameter of approximately six or eight feet, it was not molesterl, but let it or its young adrance loyond these limits and they were jomptly attaclied.

"So closely, however, are the birds confined to their own little areas that difficulties of this kind ate rare and under normal conditions peace reigni in the rookery. lint when we walked through the rookery, the birds in escaping from the larger evil forgot the lesser one and inalvertently backed on to a neightior's territory, the unumal cause of the trecjass was not accepted as an excuse and they frund the "frying pan' was worse than the "fire, as the enraged owner. with bustling feathers, furiously assailed them with open bill, smmetimes taking hold. At these times, and whenever the hirds were alarmed. they gave utterance to hoarse, rancorous screams or screeches, though, as a rule, they were comparatively silent."

In summer Poobies occasionally range up the Itlantic coast as far as reorgia, but such vicits are rare, for they are distinctly birds of tropsical and subtropical seas. I nlike the Albatross and l'etrel, they are seldom seen far from land.

\section{T. Gilbert PE.ARSON.}

\section{GANNET}

\section{Sula bassana (Limans) \\ 1. 1) [7. Number It7 sice color I'late 9}

Other Names.-Common Gamet; White (iannet: Solanrl Gonse; Solan Goove: Sulm Gonse; Jan van Gent: Grand Fou.

General Description.-Length, 3 feet. Prevailing color, white. Gousi-shaped.

Color.-ADuts: Plumage, white: primaries and their coverts, black: head with a plale wanh oi amberyellow; bill, grayish tinged with greeninh or blukb: Iores and thruat sac, black: feet, black with greenish or bluish scales; iris, white or pale yellow. Focno: Flumage, dark brown with a tinge of olive, unotted or streakel everywhere with white: an heal and neck the spots tending to form sireaks, on back and wing-coverts. triangular, usually one on end of each ieather: primaries

The Gannet is the largest bird of our north Itlantic coast. It is about three feet from tip of bill to end of tail. It is four feet and more between the tips of its outstretched wings, and and tail, dusky. Intermediates between these two plumages are common, as it requires three years to reach periect plumage.

Nest and Eggs. - NEST: On precipitous cliffa overlnoking the sea: constructed principally of seaweed. Eogs: Single, pale greenish-blue, flaked with chalkywhite.

Distribution.-- Coasts of North Atlantic: breeds on [irivl Rock and Punasenture Island in the Gulf of St. Lawrence and on islands off liritish lsles: winters from North Carolina coant ruth to Gulf of Mexico, and on roast; wi morth Airica, Madeira, and the Canaries; wcurs off eatern United States in migration: castual nurth to Greenland; accilental in Indiana and Ontario.

its heary fouly and muscular neck womld make it a formiclale antagonist, if it were muilistic in its disposition. It is a white hird with black-tipped wings and its color renders it a conspicuous 
object as it flies about over the dark waters of the winter sea. The Gannet likes the association of others of its kind, hence if you find one you are pretty sure to see others in the immediate neighborlood. They range all down the Atlantic coast to Florida, and it is not an unconmmon sight to see small flocks almost anywhere off the shores of the eastern United States, disporting themselves in the water just outside the breakers, or whe eling about in quest of fish.

They fly usually at a height of from sixty to a hundred feet above the water. Dr. F. A. Lucas says: "The height at which the Gannet flies catch, and then rises in pursuit of other game." Crannets breed north of the United States. Bird Rock in the Ciulf of St. Lawrence and Bass Rock at the Firth of Forth contain wellknown breeding colonies of enormous numbers. The nests are usually built on ledges overlooking the sea. Where these are broad, the entire area is covered with nests, just enough space being left between them for the birds to come and go with comfort. Where the ledges are narrow and there is room only for a single row of nests. one will find nearly every brooding bird sitting with its tail pointed outward and its head in close

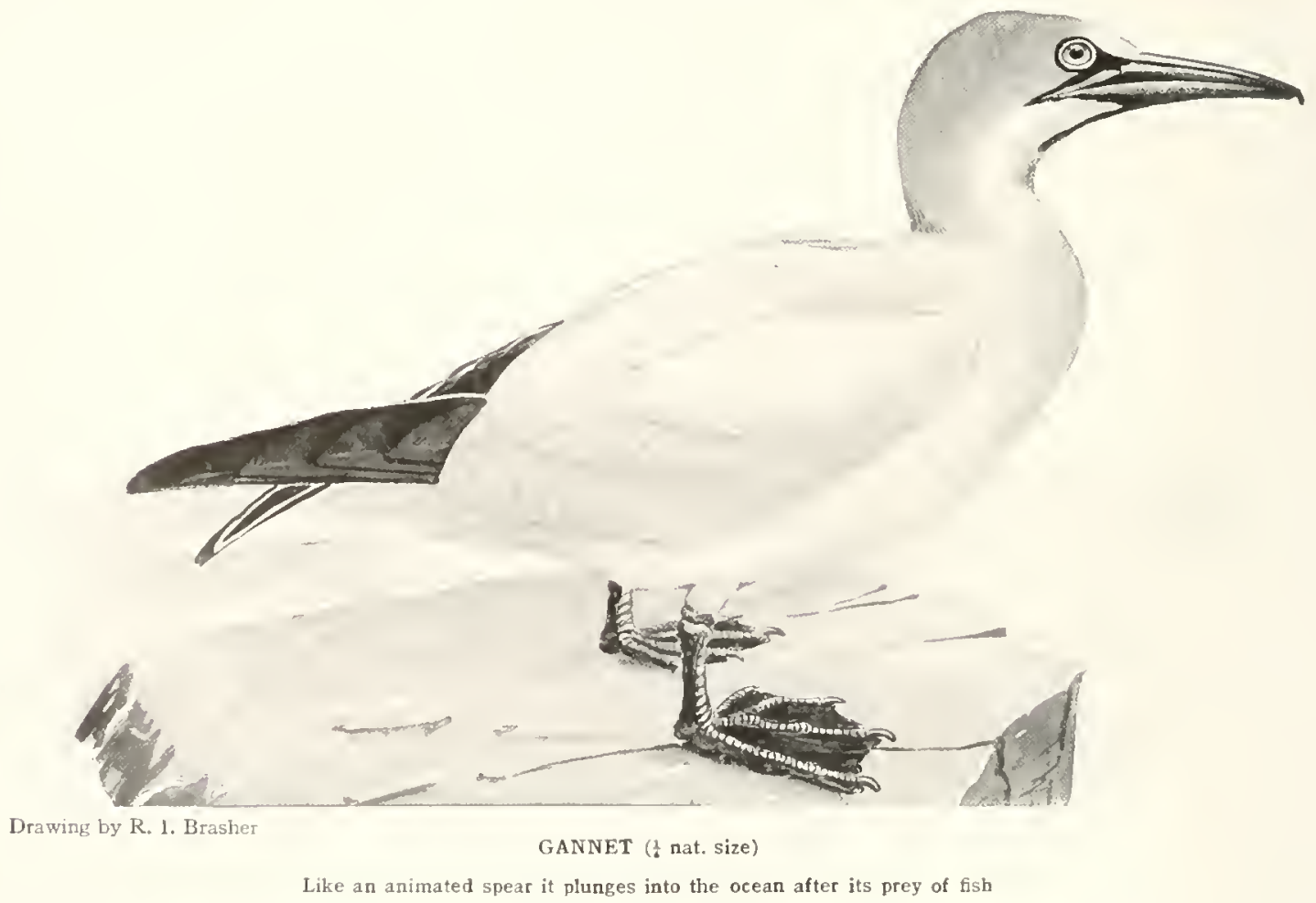

above the water is proportionate to the lepth at which the fish are swimning beneath, and Captain Collins tells me that when fish are swimning near the surface the Gannet flies very low and darts obliquely instearl of vertically upon its prey. Slould any finny game he seen within range, down goes the frannet headlong, the nearly closed wings being used to guide the living arrow in its downward flight. Iust above the surface the wings are fimly closed, and a small splash or spray shows where the wingerl fisher cleaves the water to transfix its prey. Disappearing for a few seconds, the bird reappears, rests for a moment on the water, long enough to swallow his proximity to the rocks. One egg is laid. It is covered with a calcareous deposit that can readily be seratched off. The young are latched naked. The down, which alpears in a few days, is of a yellowish hue. Inmature birds have a peculiarly spotted appearance, as the brown feathers with which they are covered are each centered with a wedge-shaped dot of white.

It is extremely rare that the Gannet is found inland, the ones which have heen occasionally reported doubtless being individuals that had lost their way, or had been driven by storns from the ocean, on whose bosom they are so much at home.
T. Gilbert Pearson. 
DARTERS

\author{
Order Stegunopodes; family luhingide
}

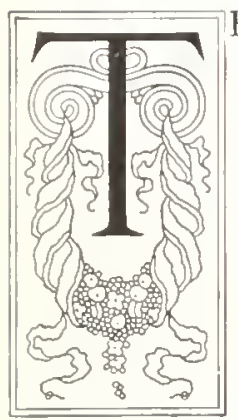

HE Darters (also called Anhingas and Snake-birds) comprise the family Anhingi$d a$, inchude four species, and are generally distributed throughout the tropic and semi-tropic regions of both hemispheres. They have an elongated body. covered with small feathers and soft down; a very long, slender, and snakelike neck; sniall, compressed head; and a slender, nearly straight, and very acutely pointed bill, nearly twice as long as the head, and like that of the Herons. In these respects (excepting the greater length and sinuosity of the neck, and the fact that the bill is not hooked, though it is somewhat serrated) they bear a general external resemblance to their nearest relatives, the Cormorants. The structure of the neck, however, is peculiar in that it is bent at the eighth or ninth vertebra, and is equipped with a singular muscular mechanism by means of which the bird may throw its bill forward with a rapier-like thrust, and impale its prey.

Darters' wings are long and pointed, while the tail is somewhat long, and is rigid, broad and fan-shaped; it is composed of twelve feathers which widen toward the ends; the outer pair are ribbed in a singular manner. The feet are short, and the legs are placed rather far back on the bodies, but the birds perch readily and with apparent ease. They are not marine in their habits, and are not likely to be found near the seacoasts, their favorite habitats being dense swamps. Their flight is swift, and they dive with astonishing ease and quickness. By nature they are timid and watchful; when frightened they drop from their perch into the water, and vanish not only noiselessly, but without causing more than very slight ripples. Once under water they swim very swifty. When they are alarmed while swimming on the surface, they disappear by sinking gently backward, atter the manner of the Grebes. Frequently they swin with the body submerged but with the head and neck protruding in a manner which strongly suggests a water snake.

These singular birds feed chiefly on fish, which they capture, not by diving, but mainly by a pursuit which is like that of the Loons and Grebes. They are gregarious and build, in hrush near the water, rough nests in which they lay usually three or four eggs, of a pale bluish color and having a white chalk-like incrustation.

\title{
WATER-TURKEY
}

Anhinga anhinga (Limaus)

1. (1) [7. Sumber 118

Other Names.-Anhinga: Darter; American Darter: Black 1)arter: Liack-bellied Darter; White-bellied Darter (young): Snake-hirrl.

General Description,-1,ength, 3 fect. Culor, black.

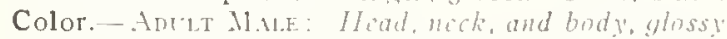
grenish-black: wings and tail, nlain black, latter tipped with white; wings with a broad silvery sray band formed ly greater and middle coverts: levier wing-coverts, spotted, and shoulders, striped with silvery-gray; in breeding plumage, back of neck with a mane of long black feathers and a lateral series of hair-like brownish-white plumes: biil, yellow, dnskygreen on ridge and tip; hare space around eye, lividgreen; sac, orange; feet, dusky-olive and yellow; webs, yellow; iris, from carmine to pink. Anela findale Throat and breant, light brown hordered behind with rich chestnut; feathers wi back with brown edges and white centers; head and neck, ylazed brow'n saried with ruious, buff, and whitish.

Nest and Eggs.- Nest: In swamps or hayous, on mall trces or lumbes over water: constructel of sticks. leaves, dry grass, roots, aurl moss. Eritjs: 2 to 5 . bluich or lark greenish-white overlaid with white chalky incrustation.

Distribution.- Tropical America north to western Mexico, Texas, Florida, southern lllinois and North Carolina: casual in Kansas; accidental in New Mexico ant Arizona 
The Water-Turkey is no more a "Turkey" than the Nighthawk is a "IIawk." yet this is the name by which the American Darter is almost universally known to the people of the sonthern States where it is found. Of late years ornithologists have adopted the name, dropping the worl "Anhinga," which was formerly userl. This species haunts the shores of tree-fringed lakes and rivers, as well as the wider stretches of lakes and sloughs, if bushes or trees are here convenient upon which it can perch. It is a longnecked, long-tailed, and short-legged bird about three feet in length. The general color of the male is a glossy black. The female has the entire head, neck, and breast grayish-brown. They are silent hirds and live manly in the

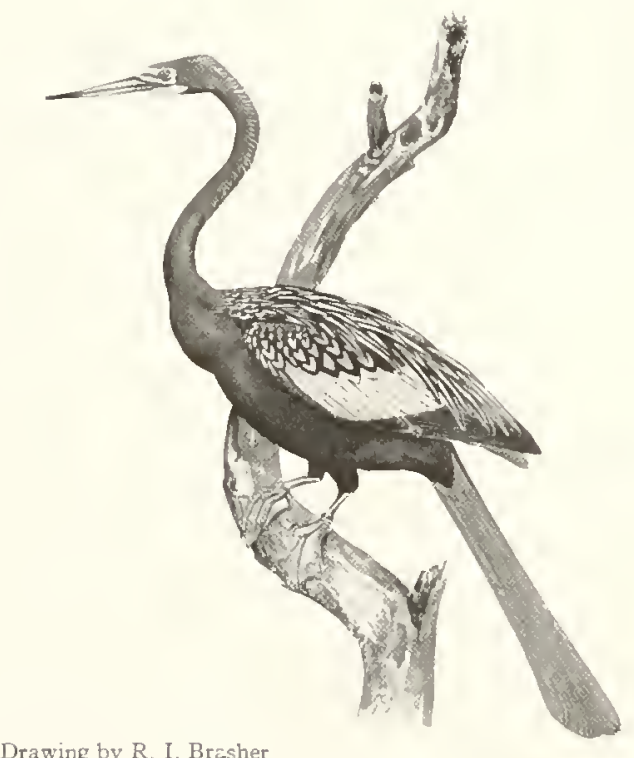

Drawing by $R$. I. Brasher

WATER-TURKEY ( $\frac{1}{8}$ nat. size)

A bird of haunting mystery

silent places of the wilderness. Their whole life seems to be pervaded with a haunting mystery. It is undoubtedly the bird to which the rural preacher referred when he said, "Where the Whangdoodle mourneth for its first-born."

When you come upon one sitting on some limb deep in the swamp it will at times fly swiftly out of sight, only to return again and again, each time higher in the air until, having attained an altitude of several hundred feet, it will circle about apparently on motionless wings like a Hawk. Again, and especially if it does not suspect itself seen, it will drop from the perch into the water beneath with only the faintest splash, and after swimming to a safe distance will cautiously peer out with only its slender head and beak exposed. Often it swims with body out of sight and with its long neck protruding in a most eerie and snake-like fashion.

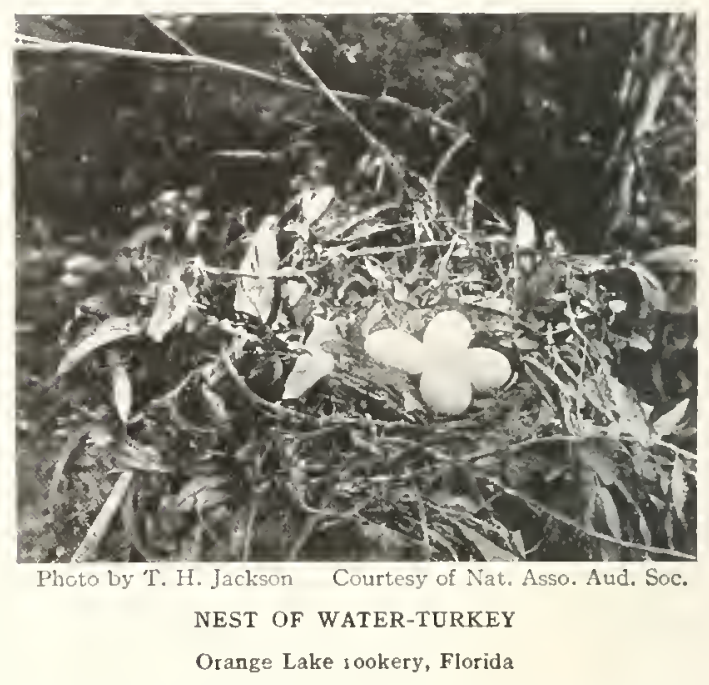

The Wrater-Turkey's food consists mainly of fish which it eaptures as it swims beneath the surface. When emerging from the water it often ascends some sloping log or bush with low

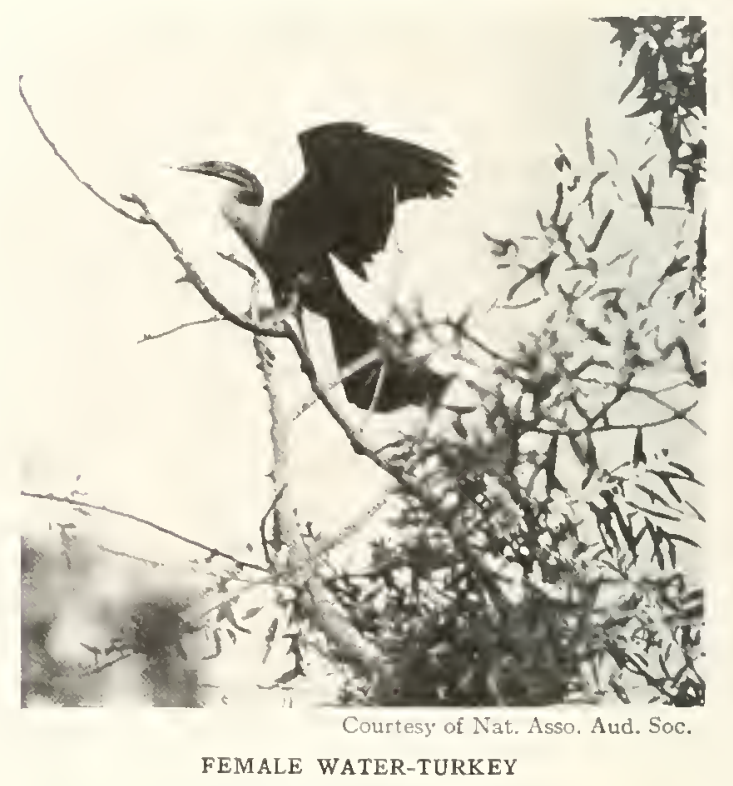

At Orange Lake rookery, Florida

hanging limbs. The toes of its stout webbed feet terminate in sharp claws which enable it to clinb with ease. Here, with wings spread, it will remain for a time drying its feathers in the sunshine. 
They assemble in numbers, sometines several dozen pairs together. for the business of nest building. Often they breed in colonies with Herons and Ibises, but not always: for I have found as many as twenty-five nests at a time, all clustered about in a dozen trees, and no other water birds near. The nest is a bulky affair of sticks and often some of the long gray Spanish moss is used. All the nests I have ever examined also contained freshly plucked leaves, which appeared to have been placed as a finishing touch just before the eggs were laid.

They inhabit the low countries, breeding in the coastal regions as far north as Nortl Carnlina and up the Mississippi valley to southeru Illinois. They are fresh-water hirds and rarcly appear where the sea-water runs.

T. Gilbert Pearson.

\section{CORMORANTS}

\section{Order Steganopodes; family Phalacrocoracida}

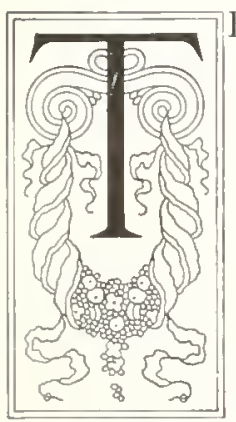

HE Cormorants comprise two genera, the Phalacrocorax, embracing the true Cormorants, or "Shags" as they are frequently called, and including about thirty species, and the monotypic Nannoptermm, with Harris's Cormorant, the flightless and rare bird of the Galapagos Islands, as its single representative. This bird is very large and uses its wings only as fins in swimming.

Of the true Cormorants, about ten species occur in North America. They are chiefly maritime in their habitats, though some species are often found in fresh water far inland. They are disposed to be decidedly gregarious at all seasons, and during the breeding period they assemble in large colonies on ledges or rocky islands along the seacoast. IThen migrating they fly at a considerable altitude, but ordinarily they do not rise far above the water. They dive readily in pursuit of fish, but always from the surface or a low perch, and not from the air.

The superficial physical peculiarities of the Cormorants include a bare, expansible membrane under the lower mandible; a compressed bill of which the upper half is strongly hooked; nostrils which apparently in the adult do not admit air, the birds breathing through the mouth; and the claw of the middle toe armed with a comb-like process used in prcening the plumage. The stiff and rounded tail of twelve to fourteen feathers is employed to assist the bird in walking and climbing. The birds are usually from two to three feet long, and the body is elongated and powerfully muscled. The neck is rather long and the legs are short and stout, and set far back. The wings are comparatively short, extending but slightly beyond the base of the tail. The plumage is very dense, and is generally dark in color, with greenish and bluish shcens. Frequently the head is crested, and during the breeding season may be further ornamented by plumes of slight feathers of hair-like structure.

That Cormorants can dive to a great depth is indicated by the record of one caught off the coast of England in a crab-pot i 20 feet below the surface. They feed entirely on fishes, which they pursue and capture under water where they use both their feet and wings in swimming. If the fish captured has been seized in a position which makes swallowing it inconvenient, it is tossed into the air and caught again in a way which simplifies the swallowing operation. 'This diet gives the Cormorants' flesh a strongly fishy flavor, though this is less pronounced in the young birds and these are sometimes eaten.

Cormorants build rough nests, composed mostly of seaweeds, and placed usually on the ground, though sometimes in low bushes. The eggs are from three to five, of a greenish blue tinge, and covered with a crust of lime-like matter. The young are hatched naked but are soon covered with a black down. They feed by thrusting their heads down the throats of the parents and extracting the partly digested fish therefrom.

$$
\text { Vol. } \mathrm{t}-8
$$




\section{CORMORANT}

\section{Phalacrocorax carbo (Linnaus)}

A. O. U. Number íg See Color Plate 9

Other Names.-Common Cormorant; Shag.

General Description.- Length, 3 feet. Prevailing color, black. Throat sac, heart-shaped hehind.

Color-Adults in Breening Plumalie: General color, glossy olize-black; feathers of back and wingcoverts, bronze-gray, sharply edged with black; primaries, secondaries, and tail, more grayish-black; a conspicuous white patch on flank: numerous long white plumes on head and neck; a black crown crest about I inch long; bill, dusky; bare skin around eyes, livid greenish; throat sac, yellow, bordered hehind by a band of white feathers; feet, black; iris, green. ADULTS IN WINTER: Nocrest or white feathers on head and rump. Young: Top of head and hindneck, brownish-black: back and wing-coverts, grayish-brown, the feathers with dark margins, some edged with white; throat, brownish-white; mdw parts, whitish, dusky on sides and across lower abdomen; bill, grayish-brown, black on ridge and tip; bare skin of face and sac, yellow.

Nest and Eggs.- Nest: On the ground, among rocks; constructed of sticks, moss, seaweed, and kelp. Equs: 3 to 4 , bluish-green coated with a white chalky substance.

Distribution.- Northern hemisphere: breeds from central Greenland south to Nova Scotia, and east through Europe and Asia to Kamchatka; winters from

The Cormorant is found generally throughout almost all of the northern hemisphere. From its breeding grounds in labrador and

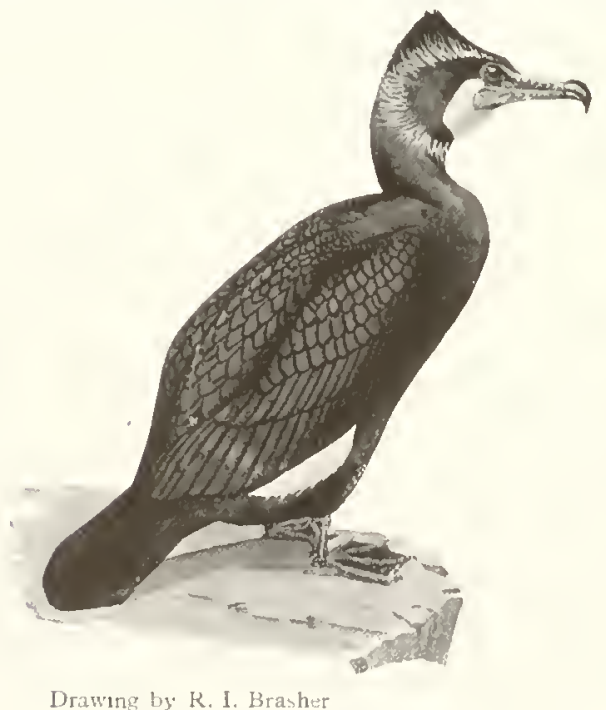

CORMORANT ( $1^{\frac{1}{2}}$ nat. size)

A hird of strange appearance and interesting habits

Greenland it strays southward in summer, and occurs on the Atlantic coast in winter. It is seen occasionally on inland waters, but such visits probably are purely accidental, as its southern Greenland to Long Island, N. Y., rarely to Lake Ontario and Snuth Carolina, and from the Mediterranean south to southern Africa. Australia, and Malay Peninsula.

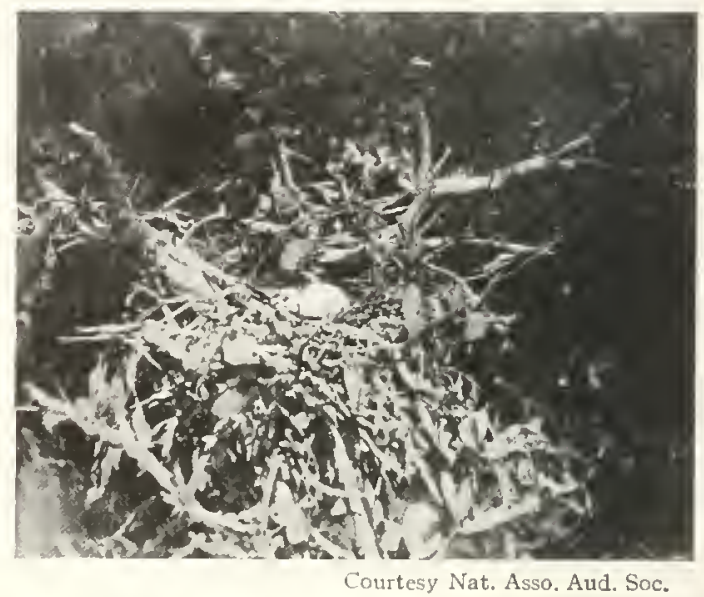

NEST AND EGGS OF CORMORANT

nomal habitats are the scacoast and the mouths of large rivers.

It lives almost entirely upon fish, which it captures under water by swimming with both wings and feet, sometimes at a considerable depth. In these operations it is very skillful and swift, while its powerful hooked bill forms an effective weapon for seizing and devouring its prey. The young are fed by regurgitation, during which the infant thrusts its hill far down the throat of the parent.

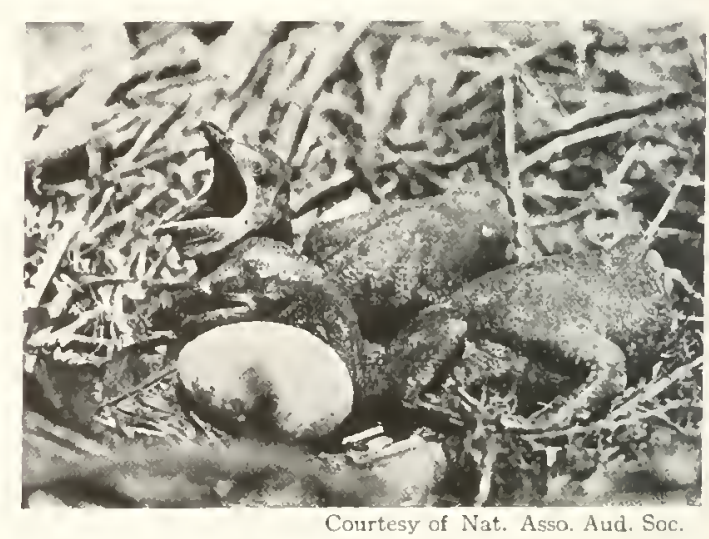

YOUNG CORMORANTS

They are naked when hatched, and do not leave the nest for ahout a month 


\title{
DOUBLE-CRESTED CORMORANT
}

\author{
Plualacrocorax aurjus auritus ( L, $550 \mathrm{n})$
}

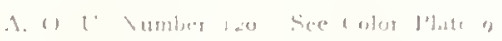

Other Names.- Crow l)urk; Shaser Minter-"lurkey; Lawber; Nigger fouse.

General Description.- I.ength, 3.3 molhes. I'rcevall

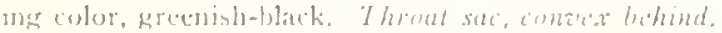

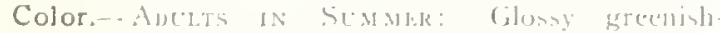
black; fcathers of batk and wougs, coppery-gray with narrow distmet black edges and black-shafted; two curly black erents on heat; no white flank patehes or

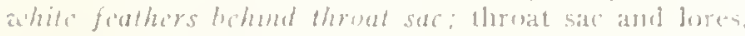
orange : bill, dusky ; fect, black: iris, green; evelisl, l, lace

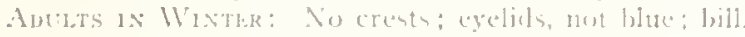
yellow, duaky on rirlge"; gular sac, red in front, yellow wher behind. Youna. J'lam lark brown, graysh or whitish below.

Nest and Eggs.- Nest: (Juthe grounde) constructed

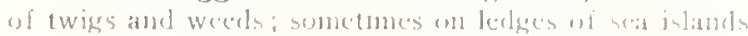

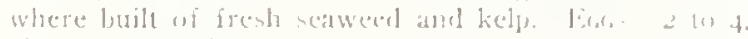
Hush-green with whute dalaby inerustation.

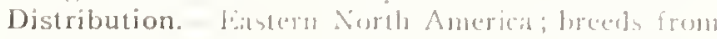

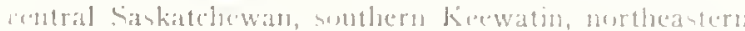
Cucher and Newfombland soutle to morthers Utah.

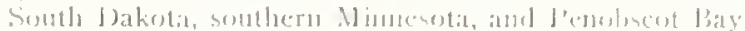

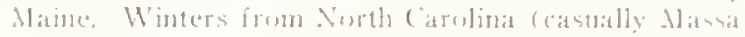
(duncets) south to the Gulf coast; caunal in bermulda
Cormorants are found in suitable plates all over North Inerica. They are wonderiul divers and secure their prey while on their ulumarine excusoms. They ale very common on the corast and maly easily be seen at many places, as, for

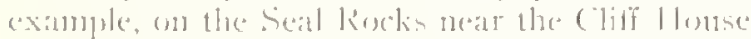
at Sin lifancisco, on PBlack llorse lstand off the coist of bande, and on almost coery luay and

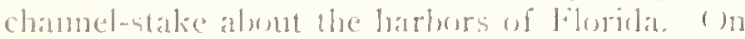
rocky coants their nests are buik on clibs overlooking the sea, ats on the larallon lstands, (alifromia, and the Three Arch kirecte lelanels of ()regon. In the inteptur the nests are often luilt on the ground of on the rubles in the islands of

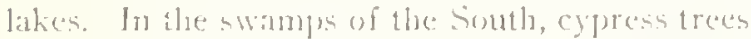
are userl, and along the (julf coast of librirlat larese numbers loreed on lle low mangrove trees dhat coner the keys.

Sume yeats ater l visterl a typical colomy of thesce birds in lige lake, in castern North Carolina. 1.ow-spreading cypress trees, theor topes renclings, as a rule, not more thath fifteren feet aluse the water, were the siten chescen for the nests. lighteen treen scatlered alomer the swantey shrore for a mile and a half were thus ocenpined. Ifow tress contained but a single nest. Some were occupicel dy two, while in ohlues six, eight, ten, and eventwelve nests were noted. (me tree ermatinerl thirty-eight, all of which contained either egges or young. The number of accupante of a nest was in all cases collere two or three. (juce humelred and fifty indabsited nesti were erumted in the communtity.

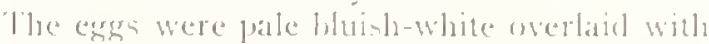
it clablky coating and were alunt two and onelaili inches fouge. Mhen first hatched the young are nakerl and look like little, amimaterl, groway

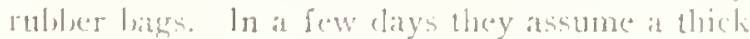
growth of black down.

"lhe ford of these birds must have comnined latrgely of ecels, for in nearly "reery neet signs of

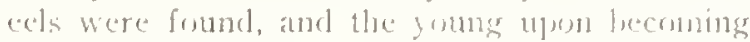
acited disgurged fromencent- af ace which showerefl down upen us as we attemperl to climb the trees.

The Cormorants hate many local mandes, such

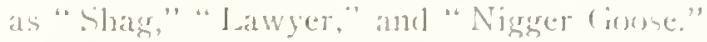

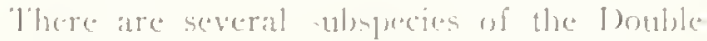

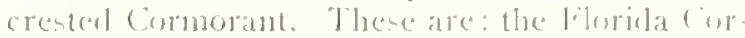
morant (Phalacrocorax anritus lloridanus) wf Sorth Camolina, librida, and the liuli coatt; the White-erested Commorant / halusrocorax auritus incinatus, uf Alatiat and the listallon (intmotant (Phulacrocorax anrilus albociliatus) uf

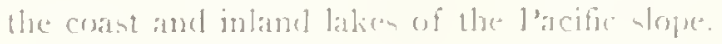

Market fishermen ererywhere complain of the inroals these lifels make on the froml lishes of the sat, but a recent inde-ligation carricel out in

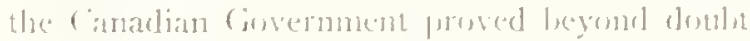
that the destruction wrought ly commonat in the Gulf of st. Leawrene has leen evertaterl

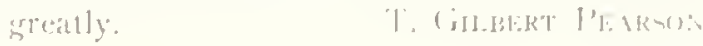




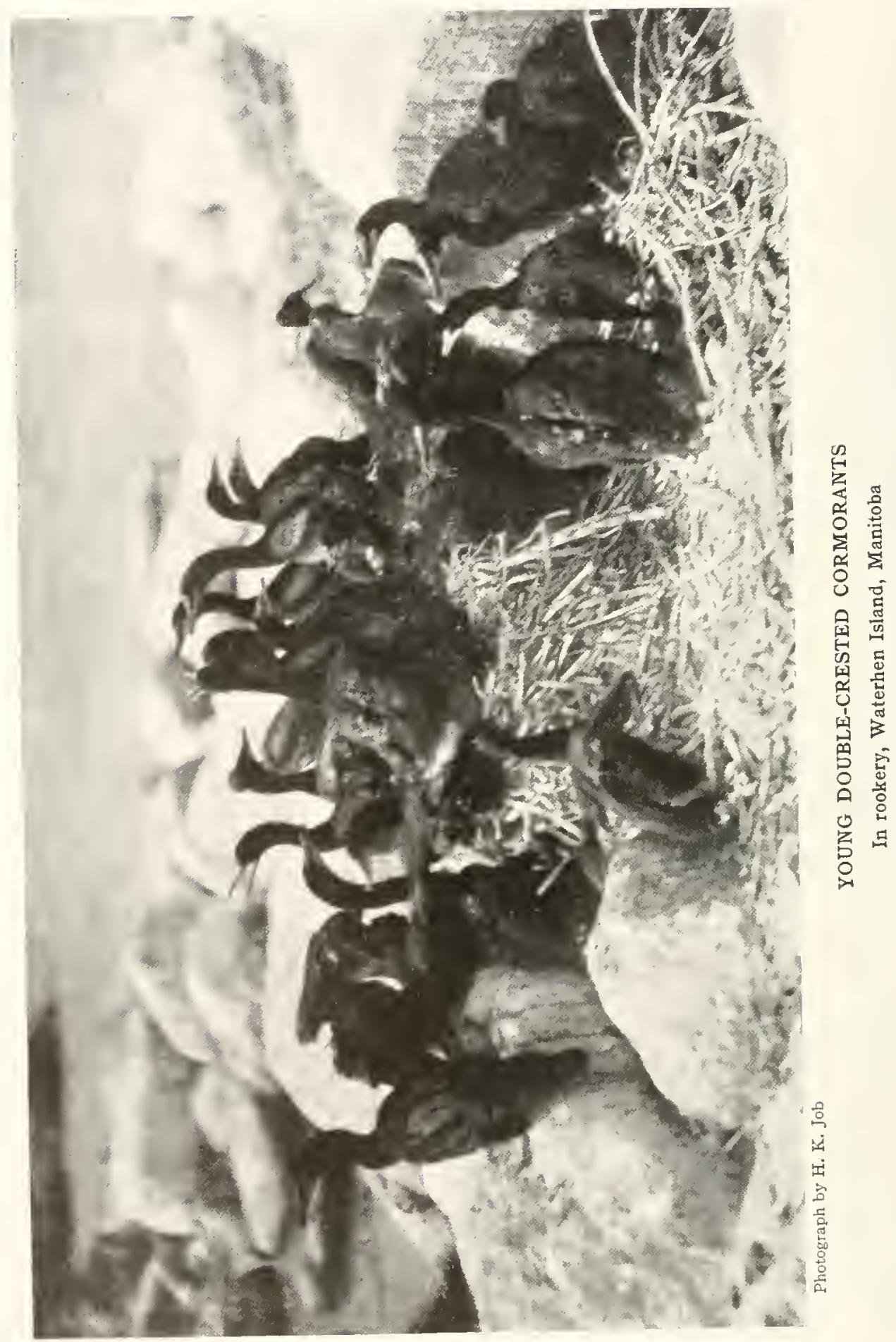




\section{BRANDT'S CORMORANT}

Phalacrocorax penicillatus ( $B$ rundt)

Other Names.- Penciled Cormorant: Tuited Cormorant: Townsend's Cormorant: Shag: Brown Cormorant.

General Description.- Length, 33 inches. Irevailing color, blackish. Throut sal, heart-shaped hohind: head, not cristed: bill, slender and nearly straight; tail, short.

Color-Adelts in Brenung Plemane: General color, deep glossy greenish-black with viulet or steelblue reflections on neck and head: feathers of middle of back, plain, thowe of shoulders and wing-coverts with narrow black edgings; a series of yellow straight filamentous plumes two inches or more in length along each sile of neck; many others longer and somewhat wetbed on shoulders: throat sac dark bluc: a border of mouse-brown feathers behind gular sac; bill, rlusky; feet, black: iris, green. Anclts IN WINTER: Plumes, absent. Young: Plain blackish-brown, more ruaty below; abdomen grayish; shoulders and wing-coverta, paler-edged.

Nest and Eggs.- Nest: On ledges of rock islands: a compact structure of eel grass or seaweed, cemented with guano. Eus: 3 to 5, light greenish-blue, with the usual chalky deposit.

Distribution.- Pacific coast, from V'ancouver lsland to Cape San Lucas.
Brandt's Cormorant is abundant on the l'acific coast. Its general demeanor, as it perches on rocks or snags, suggesests that it is a rather dull and sluggish bird, lut in reality it is very suspicious and wary, and this state of mind is shown flainly by its manner when it is in the water. Then its long neck is stretched to its fullest length, and its head is constantly turning from side to side, as if it feared the approach of an enemy from any direction.

The Cormorant dives readily and skillfully, and uses both its winge and its feet in making headway under water. In fact it seems quite as much at lrome in the water as a Duck, and yet, for some altogether mysterious reason, it has the very unducklike habit of perching in the sunshine, with wings spread, and evidently waiting for its plumage to dry. The Northern Raven and the Western Crull seem to have a special weakness for the eggs of the Cormorant, of which fact aprarently it is very well aware: for, when the Ravens or Culls are about, the Cormorant that is inculatins will not leave the eggs until its mate is at hand to take its place immediately.

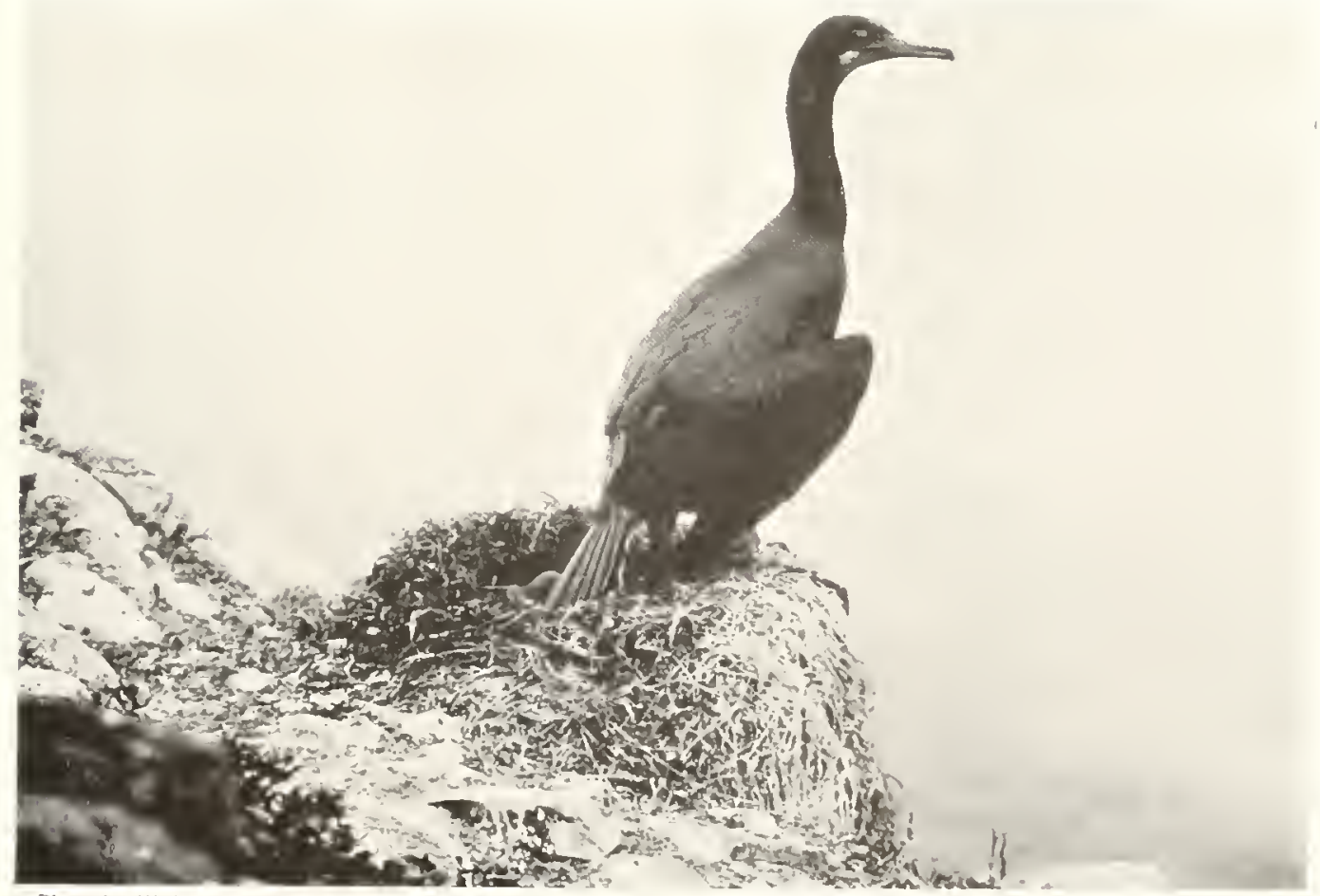

Photo by W. L. Finley and H. T. Bohlman 


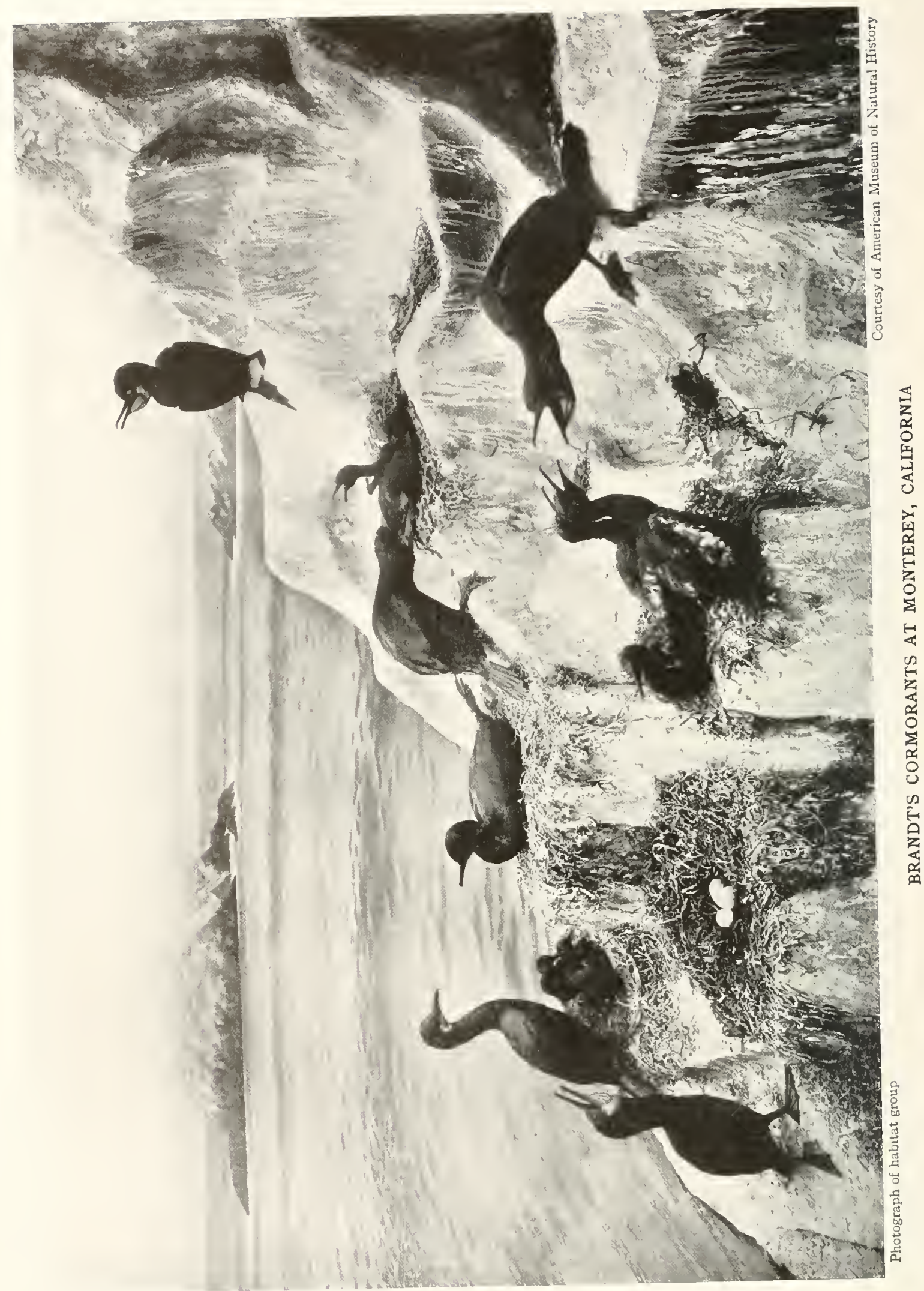




\title{
PELICA N S
}

\section{Order Steganopodes; family Pelecanida}

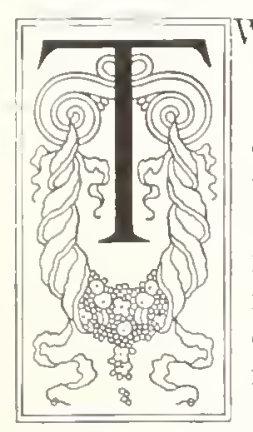

WELVE species of these singularly grotesque but interesting birds are recognized, and they oceur generally throughout the temperate and tropical regions of both hemispheres, three of them being North American. They are birds of considerable size, their hodies varying in length from fifty to seventy inches, while some have a wing expanse of nearly ten feet.

The distinctive feature of the Pelican is the great pouch which depends from its lower bill. As the bird's bill may be eighteen inches long, it will be realized that the capacity of this ponch, six inches or more in depth, is very considerable. Some of the species use this pouch very much as a scoop net is employed, and all of them store in it fish which they take to their young. Most of the bird's prey is captured in this manner, though some is taken by diving. Another physical peculiarity is the excrescence which develops at about the middle of the upper mandible during the breeding stason. What, if any, purpose it serves is not known. It is shed coincidently with the fall molt.

The Pelican on land is very ungainly, its uneouth appearance being due in part to the awkward kink in its neek, which produces the inmpression of great discomfort. In point of fact, however, this position is due to the singular articulation of the eighth or ninth vertebra with the one on either side, so that it is really impossible for the bird to straighten its neck. The Pelican's flight is a combination of flapping and sailing, and though not rapid is steady and confident. A long line of these birds, flapping and sailing alternately, and often in nearly perfect unison, is an interesting spectacle.

These birds are decidedly gregarious and often breed in very large colonies. They build on the ground large nests composed of sticks. The eggs are from two to five in number and are bluish-white in color.

\section{WHITE PELICAN}

\section{Pelecanus erythrorhynchos Ginclin}

\author{
A. O $L^{T}$. Number 125
}

Other Names.-American White Pelicall; Common Pelican (of the North).

General Description.- Length, 5 feet; spread of wings. 9 feet. General color, white. Bill with pouch hanging from under side.

Color.-Adults: Plumays, white arith black frimarics: lengthened feathers of back of head, breast, and some of the lesser wing-coverts, pale straw-yellow bill and feet, yellow tinged with reddish; lower part of hill, brighter than upper, which has the ridge whitish pouch shading from whitish in front through yellow and orange to red at bave; bare skin around eye. orange; eyelids, red; iris, pearly-white. Iotno: Lesser wirg-coverts and some feathers on head, grayish: bill and feet. dull vellowiah otherwise an in arlults. Nest and Eggs.- Nest: On the ground; constructed by the bird scraping the sandy soil into a heap about half a foot high and erecting a shallow platiorm of sticks and weerls on this hase. EGos: 2, dull chalkywhite with a chalky incrustation.

Distribution.- Temperate North America; breeds from southern Pritish Colmmbia, Great Slave Lakc, and southwestern Keewatin to Manitoba, North Dakota (formerly southem Minnesuta and South Dakota). Utah. and southern California: winters from southern California to Gulf Staten, Flurida, and Cuha sonth to western Mexico and Costat Rica; casual in migration eavt to Atlantic coast. north to New Brmawick.
The Anerican White lelican was formerly found in the Fast as well as in the West, hut the range of the bird has contracted until it is rarely seen on the Atlantic coast. The hird formerly nested in Minnesota, but the most eastern nesting sile to-day within the United Sitites is in North Dakota. I hird so conspicuous in size and color, and one that nests on the ground, can 
never rear its young free from the disturbances of predacious animals and man unless it can find a remote island upon which to breed. The natural home of the bird is on some sandy or tule island. where a large number of them nest together. This showy bird would soon have been extinct had it not been for the cfforts of the National Association of Audulon Societies in seeking out the ancestral hreeding places and having them set aside as Federal wild-bird reservations. The largest colonies of White I'elicans in the United States are fornd on Malhenr Lalie, Klanath Lake, and Clear Lake reservations in southern Oregon and northern California.

Throngh the western part of the United States, the Pelican season begins in April after the snow and ice have melted and lasts till August or September, when the young are able to care for themselves. Sometimes one will find eggs just hatching from Nay up to July. The Pelican generally lays two or three eggs and incubates about four weeks before they hatch.

The Pelican has a large skinny lag that hangs from the lower jart of his lill. This, when distenderl, holds several quarts of water. When not in use, this sack is contracted so it occupies very little space. The White Pelican uses this as a dip-net by swimming atong and scooping up the young fry. It was formerly thonght that this pouch served to convey live fish swimming in water to the little Pelicans at home, but, as Aulubon remarked long ago, it is doulteful whether a l'elican could fly at all with his burden so out of trim.

The first time I ever saw a motley crowd of half-grows l'elicans, I thought Nature had surely done her best to make something ngly and ridicnlous. It was a warm day and the birds stood around with their mouths open, panting like a lot of dogs after a chase, their pouches shaking at every breath. When l went near, the youngsters went tottering off on their big webhed feet with wings dragging on this side and that, like poorly handled crutches. The youngsters huddled together by hundreds in a smail place. Those on the outside pushed and climbed to get near the center, till it looked worse than any football scrimmage I ever saw.

One might wonder how such a huge-billed bird as a Ielican could feed helpless chicks just ont of the egg. It was done with apparent ease. The old bird regurgitated a fishy soup into the front end of his pouch and the baby Pelican pitched right in and helped hinnself out of this family dish.

As the young bird grew older and larger, at each meal he kept reaching farther into the big pouch of his parent until finally, when he was half-grown, it was a most remarkable sight. The mother opened her mouth and the whole head and neck of her nestling disappeared down the capacious maw, while he hunted for his dinner in the internal regions.

WiLLiAM L. FinLEY.

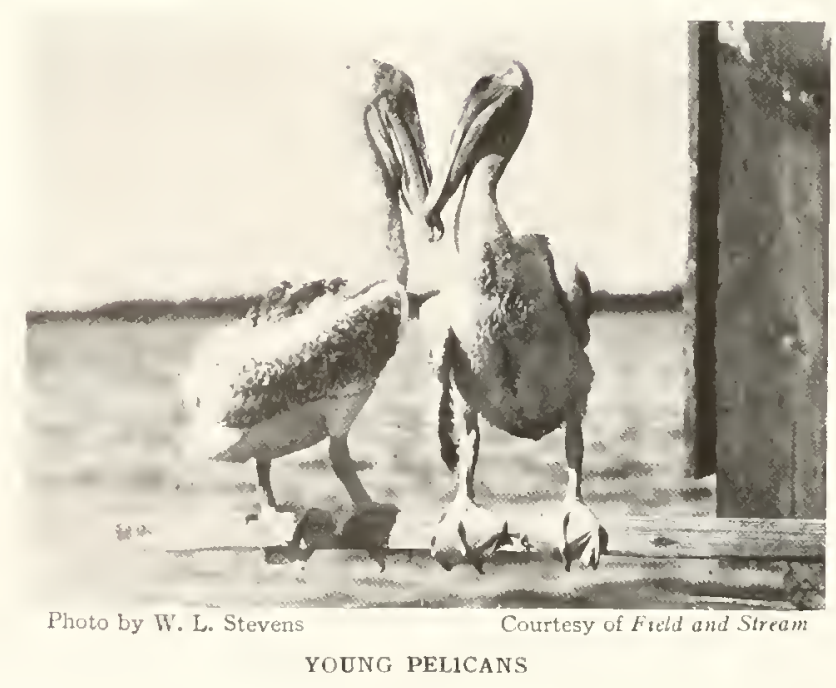




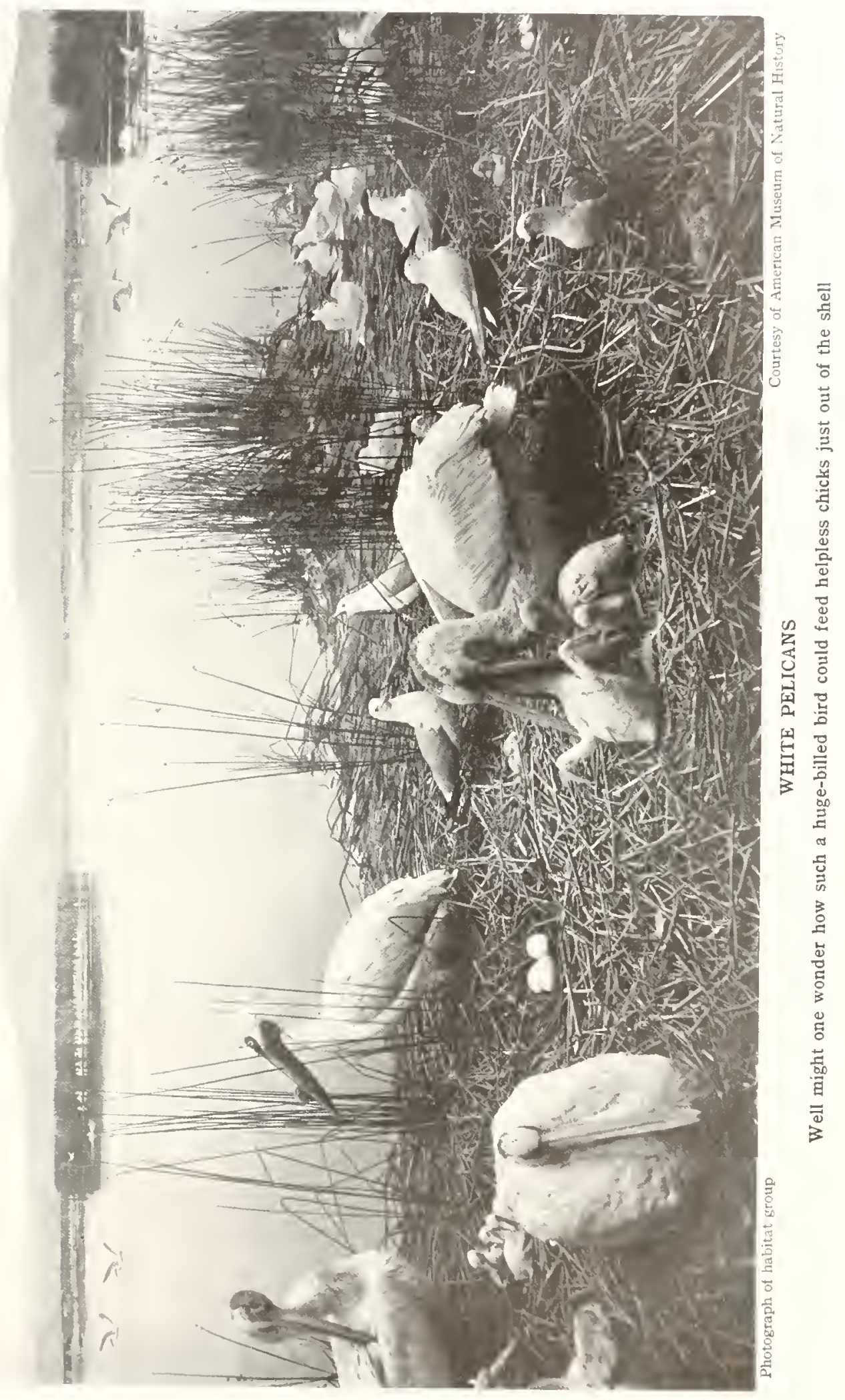




\title{
BROWN PELICAN
}

\section{Pelecanus occidentalis Linncus}

\author{
A. O. U. Number $t 26$
}

Other Name.- Common Pelican (of Florida).

General Description.- Length, 4t/2 leet; spread of wings. $6 \frac{1}{2}$ feet. General color, brown, darker above. Bill with pouch hanging from under side.

Color.-Adults: Head, white tinged with yellow on crown, the white cxtending down neck in a narrow border on side of pouch; rest of neck, dark chestnut; upper parts, dusky brocm, each feather whitish-centered; wing-coverts, pale gray with white streaks; primaries, black; secondaries, dark brown with pale edges: tail-feathers, gray; under parts, grayish-brown striped with white on sides and flanks; lower foreneck, variegated with ocher, chestnut, and black; bill, mottled with light gray and dusky, tinged in spots with carmine; bare space around eyes, blue; iris, white; eyelids, red; pouch, blackish: feet, black. In winter most of the neck is white. Young: Neck, plain brownish; other plumage similar but less intense than in adults.

Nest and Eggs.- NEST: In rookeries, on shores or marshy islands, usually on the ground or sometimes in low mangrove bushes; constructed of sticks, coarse grass, and weed stalks and lined with finer grasses. EGGS: 2 or 3, chalky-white.

Distribution.-Gulf coast of United States and Atlantic coast of Central and South America; breeds from Florida and Louisiana south to Brazil; rare in North Carolina; accidental in Wyoming. Nebraska. Iowa, Illinois, Indiana, Massaclusetts, and Nova Scotia.
The Brown Pelican is an interesting southern and tropical bird, great of bulk, powerful in flight, and withal a mightly fisher. It is numerous on our Atlantic coast from South Carolina to Texas, where it breeds on various isolated islands. Fishermen dislike it because the pouchnet which it carries under its great beak is large, and its appetite for fish in proportion. But, considering that man's nets are so much vaster, and that two or three men kill more fish in one day than can thousands of Pelicans, surely there are fish enough in the ocean that we should not begrudge the lives of these interesting and spectacular birds. It is not Pelicans that will ever exterminate any species of fish, but only avaricious man, who all too often petrifies his soul and artistic sense through inordinate greed of hoarding. The poor Pelican never hoards, but only satisfies the stern behest of lunger.

The sight of the advancing wedge or line of

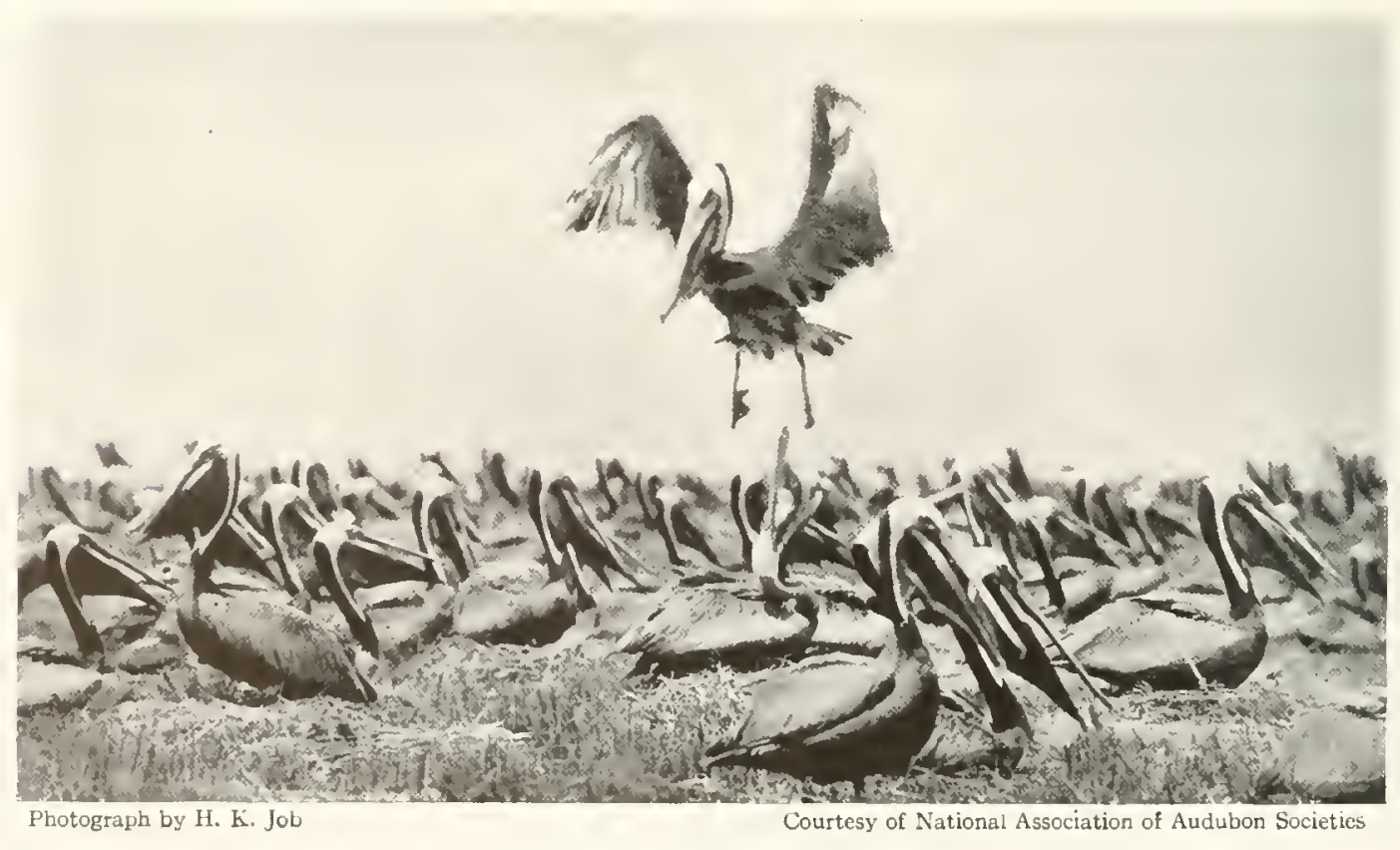

BROWN PELICANS

On East Timbalier Reservation, Louisiana 


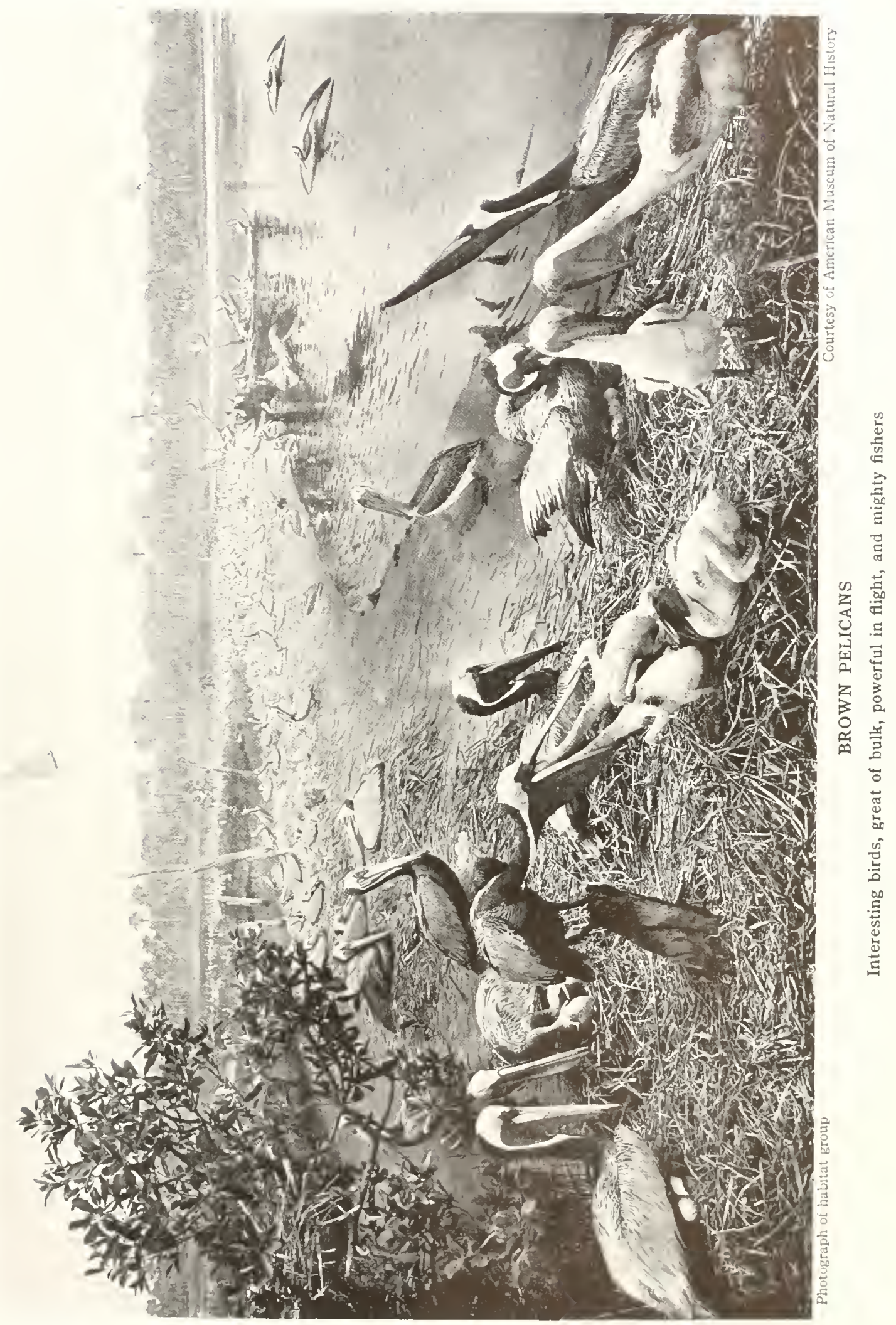


great Pelicans, with their heavy flappings and intervals of soaring, is impressive, as is the amazing headlong plunge into the sea after fish. Nirthprovoking is the sequel sometimes witnessed. The smaller Laughing Gull follows the great Pelican and hovers above the spot where it phunges. The Pelican soon emerges, holding the fish, which it has seized, in its bill. The fish, perchance, must be turned, and the mouth ftl of sea-water ejected. While the Pelican is arranging matters, the Cull alights on the great beak, leaning over to watch. No sooner is the bill opened than the sly Gull reaches in, seizes the fish, and flies away, we may well imagine laughing. The solemn old Pelican sits there blinking. too much astonished at first to move. Finally the dread truth seems to dawn on the dull mind. With a few disgtusted flaps, away it goes in pursuit of another fish.

On some islands the Brown Pelican breeds on the mangrove trees, constructing quite a bulky nest of sticks. On others, which often are mere low sand-bars, the nest is a mere hollow in the sand, only slightly lined. Two or three large coarse-shelled white eggs are laid. On the trees they are comparatively safe. but on the grotnd storms and floods often wash them away and break up the nesting. The birds rlo not attempt to rescue eggs, when these are drifted together in windrows at high-water marks, but sit off on the water and solemnly ponder. Ustally, in time, they will lay again.

Pelican Island, in Indian River, Fla., is the best-known breeding colony, the first such to be made a government reservation. Formerly there were mangrove trees, but these have died off, and the thotnsands of Pelicans nest on the ground. Now and then a storm floods the island and destroys all eggs and young. It is remarkable that in this protected colony the birds each year have nested earlier and earlier, until now laying is begun in November, though on the west coast of Florida the eggs are not laid until April and May.

On June 21, 1915, I visited a great colony of ten or twelve thousand breeding on East Timbalier Island, on the west coast of Lotisiana, this also being a government reservation. Though it was so late in the season, the Pelicans had just laid their eggs; not one had yet hatched. The nests were all on the sand of the low island. Their lateness may have been die to robbery or disaster elsewhere earlier in the season. At any rate, it made them too late to mature the young before a terrible tropical hurricane visited the coast in August, and every one of the thotisands of young birds on the islands perished.

Surely the birds have enough to contensl with without having man as an enemy!

HERBEKT K. JOB.

\section{MAN-O'-WAR-BIRDS}

\section{Order Steganopodes; family Fregatida}

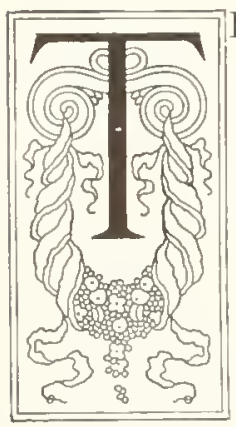

HE Man-o'-war-birds, or Frigate Birds, as they are often called, include two species constituting the family Fregatida. The larger (Fregata aquila) occurs in subtropical and tropical seas of both hemispheres, mainly north of the equator, and risits more or less regularly the coasts of California, Texas, and Florida, wandering northward occasionally as far as Nova Scotia. The other forms appear in the central Pacific and Indian oceans, and further south.

In general the Man-o'-war-birds' plumage is uniformly blackish in the adult males, while the females have the upper parts blackish and the sides and lower parts white. Other characteristic physical peculiarities are the unusually long and stoutly hooked bill, the very short shank, the serrated claw of the middle toe, the narrow web between the toes, and the pneumatic structure of the bones of the skeleton, which makes the body lighter than that of any other bird in proportion to the length of the wings, which are greatly elongated. The tail also is long and deeply forked like that of the Barn Swallow.

Their most curious physical feature, however, is the pouch or air sac of the male, which lies along the throat and, when fully distended, extends forward as far as the end of the bill, and downward so as to obscure the breast. When completely inflated (which is accomplished by means of tubes connected with the bronchi) it presents the appearance of a large, scarlet balloon. Doubtless this is a sexual manifestation, and plays a part in the courtship 
demonstration analogous to the Peacock's display of his upper tail-coverts, the strutting of the Grouse, and so on. When the pouch is deflated it is invisible bencath the plumage of the neek.

Like the Sliuas and Jaegers, the Man-o'-war-birds are predatory in their habits, and get a large part of their food by robbing the Gulls and Terns, pursuing them and foreing them to drop or disgorge their food, which the pursuer eatches as it falls. In their flight they are probalily the most graceful and dashing of all birds. They soar for hours at a time with no apparent effort, and frequently make astonishing aërial dives from very great heights. They build their nests, sometimes on the ground and sometimes in stunted bushes, of small, dead twigs, and lay usually one, sometimes two, white eggs about the size of those of a domestie hen. In their breeding habits they are decidedly gregarious, and grouls of nests are of ten placed very close to one another, even when there is no necessity for such proximity.

\section{MAN-O'-WAR-BIRD}

\section{Fregata aquila (Limnous)}

1. $0 \mathrm{~L}$. Number $1 \geq 8$

Other Names.-Hurricane Bird; Frigate Hird: Rabihorcado.

General Description.- Length, ahout to inches. Plumage, brownish-black.

Color-Anut Mile: Phumayc, brownish-black with green or purplish reflections on head and shoulders, where the feathers are long and lance-shaped: below. plain : bill, varinus sharles of whitish, flesh color, bluish. or blackish; bare space around eye, livid; sac, carmine to orange; iris, brown; feet, dusky. Adult liemale: Less iridescent than mile: feathers of back, less elon- gated; back of neck, hrown; wing-coverts, mostly hrown with darker centers anl paler edges; formech. breast. and side's, pure white.

Nest and Eggs._- XEst: Usually on low trees or bushes, sometimes on rocks; extraordinarily small for the size of the bird, and flimsily constructed of a few Iry twigs. EGGs: I to 3. plain white.

Distribution.- Tropical and subtropical coasts; in America north to southern California, Texas, Louisiana, and Florida; accidental in Kansas. Wisconsin, Iowa, Ohio, and Nova Scotia.
The Man-o'-war-bird is a genuine feathered aëroplane, if any hird is deserving of that distinction. Without moving its wings, seemingly for hours at a time, it calmly floats high in air. ascending in spirals, or drifting lazily along. directing its easy flight by changes of the angle of its "planes" so slight that any such effort is not apparent. In this respect, and perhaps in certain others, there is a resemblance to the Fuzzards, which, in flight and lack of industry, manifest the soporific influences of the tropics. It is distinctly a tropical bird, sełdom being seen further north than along the coasts of Florida. the (iulf States, and southern California.

Breeding is conducted mostly on tropical or subtropical islands, where crude nests of sticks are built on mangroves or low trees or bushes. in each of which one plain-white egrg is laid. In the Bahamas large colonies of the birds nest, and eggs are usually seen in February. By late spring the period of nesting is over, and they forthwith appear in large numbers on our Flor- ida and Gulf coasts. They are not definitely known to breed in the United States, thongh 1 think it probable that they do so occasionally, as there are reports of this on islands off the coast of Louisiana, and on an island near this group in June a member of our party picked up an egg, dropped on the sand, which clearly belonged to this species.

This bird is very impressive by reason of its size and the enormous stretch of its long, narrow wings, meatsuring some seven and one-half feet across. When a great flock of thousands soar on motionless pinions, they appear like an aërial army of invasion. Tet after all they are sluggish, lazy creatures. 1 have watched them go to roost at sundlown in bushes or mangrove trees by the shore, and seen them sleeping, with head under wings, when the sun was some hours aclinb. Of course, they eat, but somehow I have seldon seen then actually securing food. Occasionally I have watclied one snatch a fish or other marine creature from the surface of the 
ocean, but usually they are seen lazily floating in space, or else on their roosts or flocking on the beach.

On Bird Key, Dry Tortugas, off Florida, some hundreds of them stay in the Tern colony during the nesting season. While I was there they committed no depredations, but the warden says they attack the Terns as these are bringing fish for their young, compel them, through vicious swoops, to disgorge, and deftly catch the delicacy, usually before it reaches the water. Thousands of them, likewise, stay on Indian Key Reservation, Fla., near St. Petersburg, and wonderful soaring flights may be seen poised over the island. At close range their great hooked bills give them a rather fierce appearance, though of talons they have little to boast, their feet being weak and clumsy, fit only for perching. But their wings might well be the envy and despair of many another bird. Herbert K. JoB.

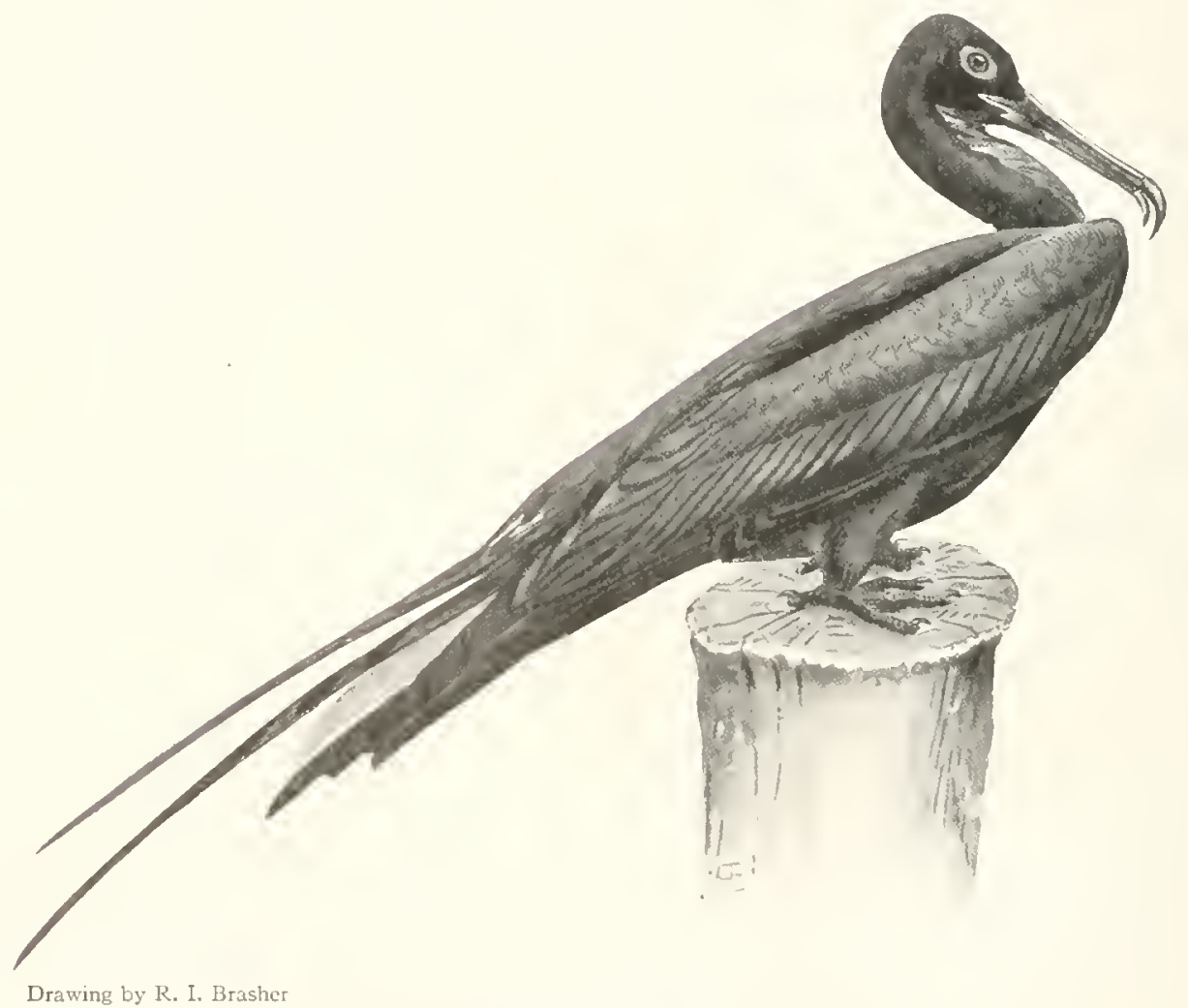

MAN-O'-WAR-BIRD ('s nat. size)

A genuine feathered aëroplane 


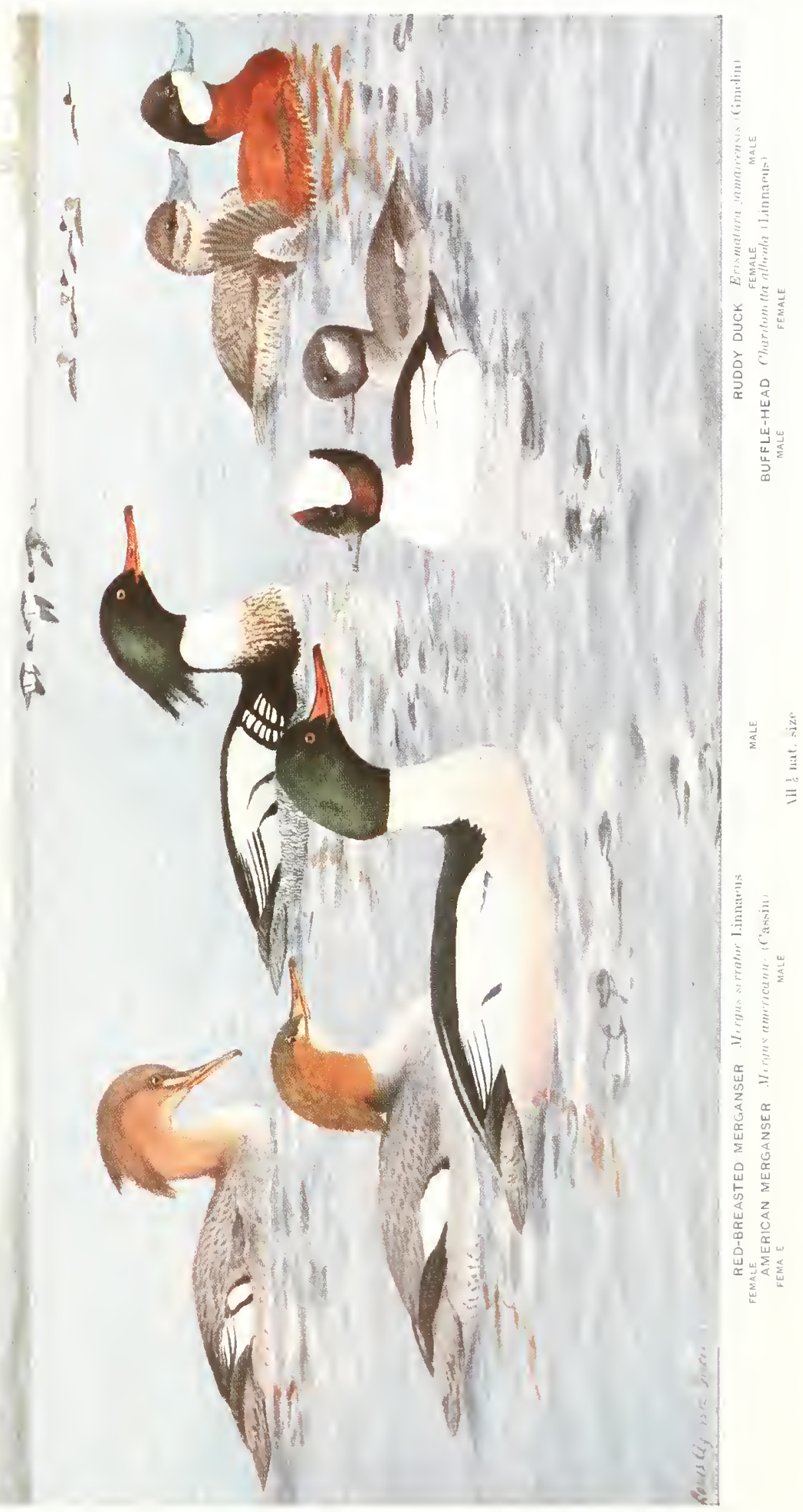





\title{
ORDER OF LAMELLIROSTRAL SWIMMERS
}

\author{
order. inseres
}

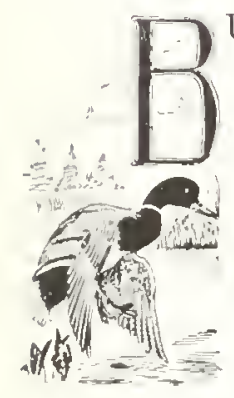

UT one family is included in this order; this, however, is divided into five subfamilies: Nergansers, River Ducks, Sea Ducks, Geese, and Swans. The general appearance and habits of this gronp are well known through their familiar representatives in barnyards and parks. There are about two hundred species scattered throughout all parts of the world; alout fifty occur in North Imerica. Economically they are among the most important of all birds.

The name given to the order is descriptive of the bill which is charaeteristic of all the members of the order except the Meryansers. This subfanily have round bills with saw-tonthed edges, but the Ducks, Geese, and Swans have the lill flat and lamellate, or fitted along the edges with a series of flutings, with a membranous covering, and with a nail, or hard spot at the tip. Other characteristics of the Lamellirostral Swimmers are: tail generally short; wings moderately: long; legs short and placed far apart, not so near the center of the body as in the Gulls and not so far back as in the Grehes; the linee joint buried in the general body covering and the thighs feathered nearly to the heel joint; toes four in number, hind toe free and elevated, front toes webbed; a peculiar waddling gait; neck usually long; plumage soft and dense, especially on the lreast, with a copious covering of down.

The nest is placed on the ground, or among rocks, or in the hollow of a tree or stump. The eggs are usually numerous, of an oval shape, and plain in color. The young are covered with down when hatched, and as soon as this natal down is dry they are able to leave the nest and follow the mother.

There is a great variety of coloration among the birds of this order. With some species the female is the brighter, in others her dress is as plain as that of any Sparrow while the male is gandily clad, and in other species there is no difference in coloration between the sexes. In sone species the postnuptial molt of the male is not complete - an unusual proceeding in the lird world. This incomplete change is called the "eclipse plumage "; at this period these birds also lose their power of flight, because all the flight-feathers are shed at one and the same tine. The eclipse plumage is worn only until the wing-feathers are regained, when it is shed and the distinctive male plumage again acquired.

\section{MERGANSERS}

Order Anseres; family Anatida: subfamily Mergina

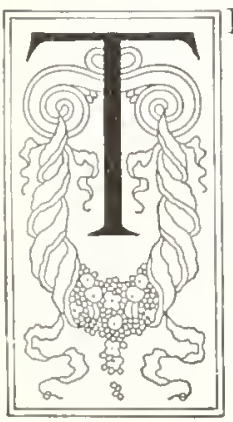

HE Mergansers constitute a small group (Mergina) of fish-eating Ducks often called Fishing Ducks, Sheldrakes, or Sawhills. They are characterized hy comparatively long, narrow, cylindrical bills, whose saw-toothed edges enable the birds to seize and levour fish of considerable size. This diet imparts a rank favor to the flesh of the various species, except that of the Hooded Merganser which evidently takes fond enough of other kinds to counteract the effect of the fish eaten. This species and the common Merganser are also peculiar in that they nest in hollow trees or on a ledge of a cliff. All of the species have more or less striking and beautiful plumage and both sexes are usually crested. There are nine recognized species of Mergansers, three of which range throughout North America and as far south as Cuba. 


\title{
MERGANSER
}

\section{Mergus americanus Cassin}

\author{
1. O. T. Xumber I 29 Sce color Plate to
}

Other Names.-American Goosander: American Sheldrake; American Merganser; Greater Merganser; Pond Sheldrake; Big Sheldrake: Fresh-water Sheldrake; Winter Sheldrake; Buff-breasted Sheldrake; Buff-breasted Merganser: Fishing Duck; Fish Duck; Saw-bill; Big Saw-bill; Break Horn; Dun Diver (female); Morocco-head (female).

General Description.- Length, 25 inches. Adult males have the head and upper parts greenish-black, while the females and immature have the head red and the upper parts gray; all have the under parts white. Bill, cylindrical.

Color.-Adult Male: Head and upper part of neck, dark lustrous green; upper parts, giossy black shading to ashy-gray on rump and tail, this color running up back of neck acutely but not reaching the green of hicad; outer edge of shoulder and most of wing. pure white, crossed by one black bar formed by bases of greater coverts; primaries and outer secondaries. black, the latter shading to white and black inwardly; under parts, pure white, shaded along sides with pale pinkish where marbled with dusky; bill and feet, vermilion; hook of bill, black with some of the same color on ridge; iris, red. Anult Female: Head and neck, reddish-brown; the slight crest more brownish; chin, throat, and under parts, white: upper parts, ashy-gray, the feathers slightly darker centrally; white of wing restricted to a patch formed by secondaries and greater coverts; primaries, dusky; bill, reddish, paler at base with dusky ridge: feet, orange with dusky webs; iris, yellowish-red. IMMATURE: Similar to adult iemale.

Nest and Eggs.- Nest: In hollow tree, on ground, or in crevices of rocks; constructed of moss, leaves, and grass. and warmly lined with down. EGGs: 6 to 10, pale buffy.

Distribution.- North America; breeds from southern Alaska across British America to southern Ungava and Newloundland, south to Oregon, South Dakota, $M$ innesota, Michigan, Vermont, New Hampshire, Maine, and northern New York, and in mountains south to northern California, central Arizona, northern New Mexico, and Pennsylvania (formerly): winters throughout the greater part of its range south to northern Lower California, northern Mexico, Texas, Louisiana, Florida, and Bermuda.
In the dead of winter when the "white death" covers the land and even the ice-bound waters, we may find here and there in the courses of the larger New England rivers an open stretch where the floods foam over the rocks of a broken rapid. Here we may see a pair of large wild Ducks breasting the torrent, swimming and diving as composedly in the turmoil of waters as if they

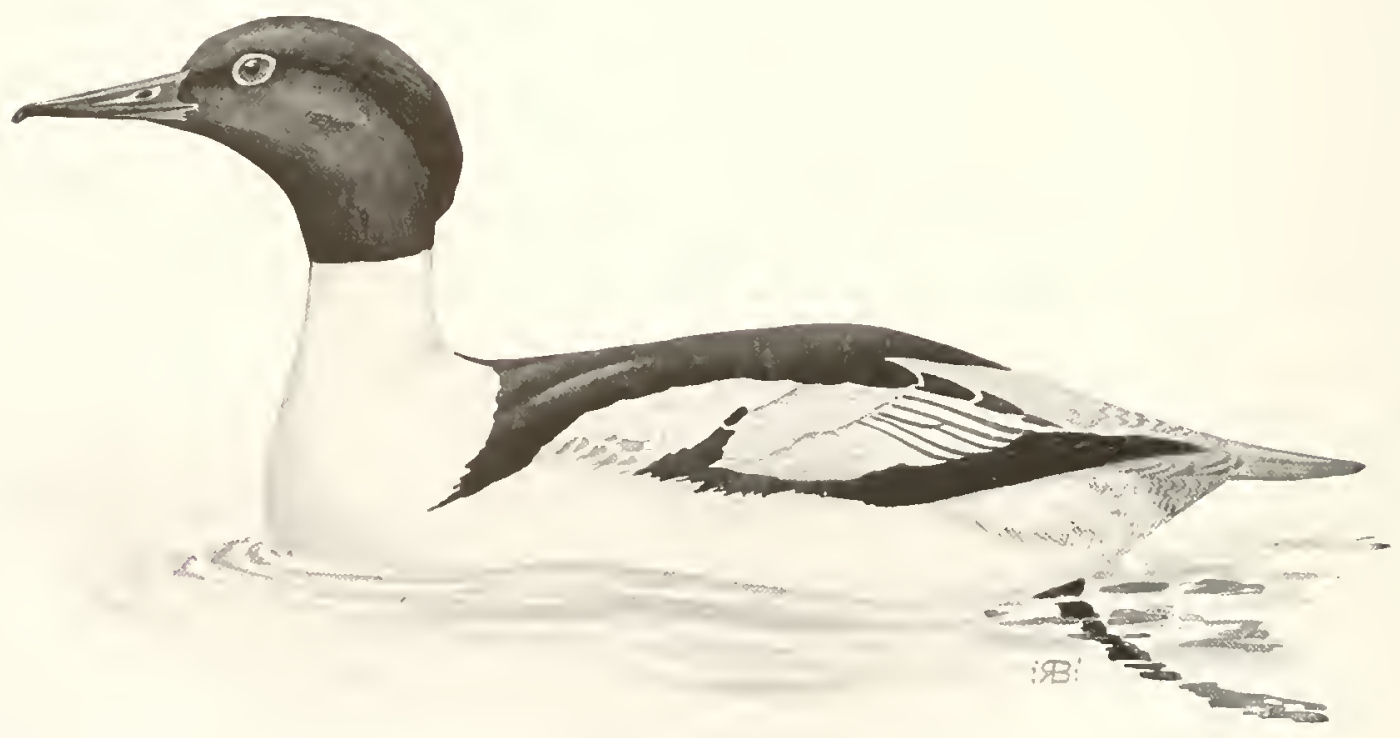

Drawing by R. I. Brasher

MERGANSER (', nat. size)

A fresh-water bird, rarely seen on salt water. 
were taking their exercise in a placid lake. "Their marking, the dark green slossy head of the male, its crlistening light under parts, and the crested head of the fenale at once identify tinem as Mergansers, for this is the only American Duck the female of which is crested while the adult male is not. The feathers on the head of the male are elongated somewhat hut he has no such crest as that of the female. The young of both sexes are more or less crested.

The birds are silent and if undisturber they diligently dive and chase their tinny prey beneath the surface. If disturbed they rise and $\mathrm{fly}$ to some other rapid, for only in such places can they find food in winter. Sometimes when suddenly alarmed they croak solemmly but this is rare. Ordinarily they fly at a speed of perhaps forty miles an lour but if startled they can distance a railroad train going at that speed.
This is a fresl-water hird, rarely seen on salt water except when driven there by very severe freezing weather. As soon as the ice breaks up in spring numbers of these slueldrakes may be seen in the ponds and rivers of the North following retreating winter to his lair

The Mermanser nests normally in hollow trees and is said to carry the roung to the water in its bill. It feeds mainly on fish that are not much valued by man, such as minnows, chubs, and suckers, and in the salt water it devours also crustaceans and mollusks.

Its flesl as ordinarily cooked is so rank and strong that its Haver is not numch superior to that of an old herosene lamp-wick but sone of the hardy gumners of the Atlantic coast hnow how to prepare it for the table in a way to make it quite palatable.

EDWAKD HOWE FORBUSH.

\section{RED-BREASTED MERGANSER}

\section{Mergus serrator Linnaus}

\author{
A. () I'. Number 130 See Color Ellate 10
}

Other Names.-Shelduck; Shell-bird; Long I cland Sheldrake: Spring Sheldrake: Salt-water Sheldrake; Saw-bill; Common Saw-bill; Fishing Duck: Fish Duck; Red-breasted Sheldrake: Red-breasted Groosander; Sea Robin.

General Description.-Length, 24 inches. Adult males have the head and upper parts greenish-black while the females and immature have the hearl red and the upper rarts ashy-gray; all have the under parts white, but the males have a band of brownish-red on the hreast. Both sexes have a long crest of thin pointed feathors.

Color- - Ault MALE: Head and upper neck all around, dark mallard green: under parts, white, usually with pale pinkish shading; fore-hreast. brozanish-red stroked with dusky: sides, fincly a'ated with the sume color: fore-hack, shoulders, and long inner secondaries, black; middle and lower back, gray waved with whitish and dusky : rump and tail, grayish ; a narrowe black line extendine up back of nock, reachine color of had: wings, mostly white; inner secondaries, edger on outer web with hlack: lesser coverts, encircled hy black; two black hars acrois wing behind greater coverts; pri-

maries, dusky; bill, carmine, dusky on top and tip; feet, bright red; eyes, carmine. ADUn Female: Crest, double; head, chestnut, more brown on crown and crest; throat, paler but not white; beneath, white, shaded on sides with ashy-gray; above, plain ashy-gray, the feathers dark centrally; white of wing restricted to a patch formed by ends of greater coverts and outer secondaries: the base and ends of greater coverts dusky : primaries, plain dusky: bill, red, paler at base, with dusky ridge and tip; feet, dull reddish, webs darker: iris, red.

Nest and Eggs. - NEsT: On the ground, in brush or crevices of rocks, near water; made of leaves, wrass. and mosses, and limed with feathers and down from the parents. EgGs: 6 to 12 , usually 9 or 10 olive buff.

Distribution.- Northern part of northern hemisphere: breeds in North America from Alaska along Arctic coast to Greenland (latitude $73^{\circ}$ ) south to British Colunbia, Alberta, Minnesota, Wisconsin, northern New York, Maine, and Sable Island: winters throughout most of its range south to Luwer California. Louisiana, and Florida; oceurs casually in the Bermudas, Cuba, and Hawaii.
The Red-breasted Nerganser is a swift and rather silent flyer, and an exceedingly expert diver. While swimming on the surface it sometimes raises and lowers its crest. This is more

$$
\text { IกL. } 1-9
$$

of a marine species than the American Merganser, but is nevertheless not uncommon in the interior of the country, particularly in the lake regions, during migration. 
In the winter, most of the birds of this species which are seen in Massachusetts appear to be full-plunaged males, while in summer the few which remain witl us appear to be females. Some of them, however, may be males in the "eclipse" plumage. I have noticed that practically all the birds seen in winter in Florida are females or young. This, together with the fact that most of those seen in Massacliusetts in winter are males, seems to indicate that the hardy males do not go so far south in winter as do the females and young.

The Red-breasted Mergansers feed largely on fish, diving and charging through the schools of small fish, which they seize and hold fast with their saw-toothed bills. Thoreau notes that he saw Sheldrakes (presumably of this species) chasing fish by both swimning and flying along the surface. A few shell-fisin are eaten at times. Edward Howe Forrusi, in Game Birds, Irild-Foal and Shore Birds.

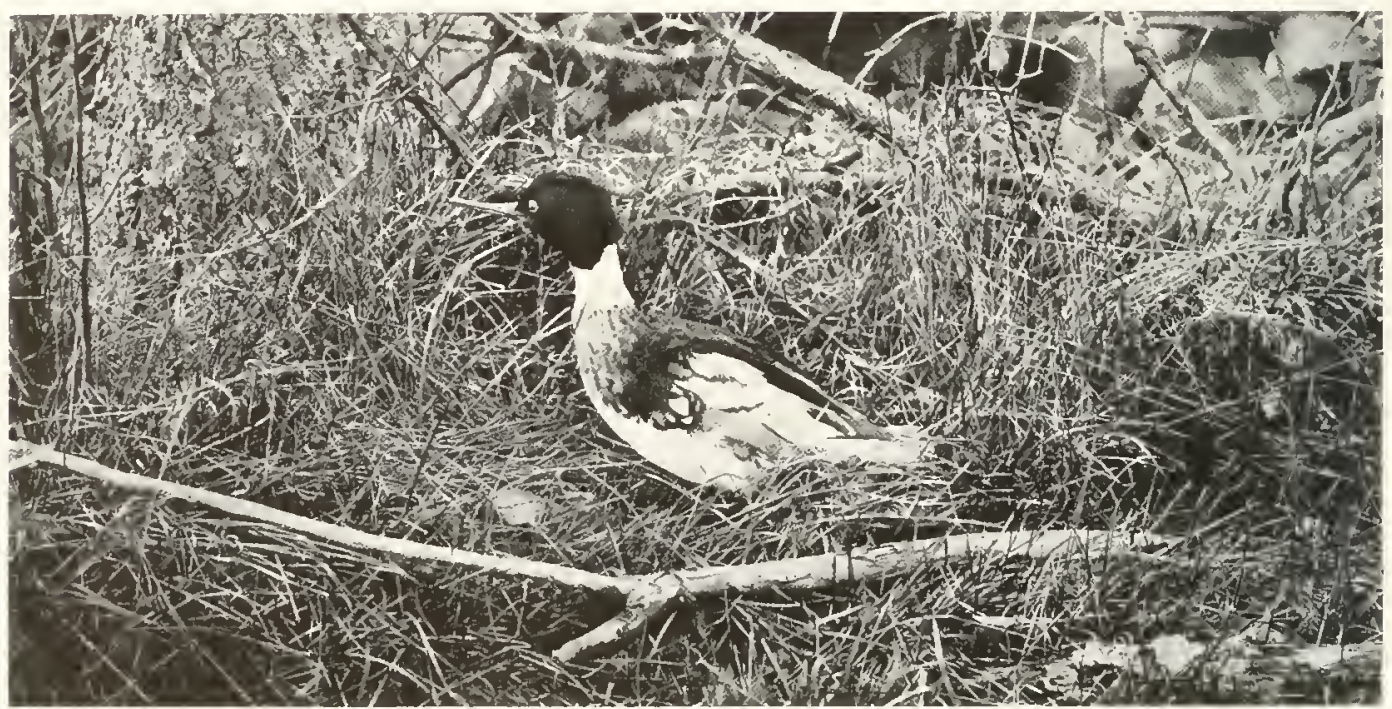

RED-BREASTED MERGANSER

Courtesy of \$. A. Lottridge

A swift and rather sileat flyer, and an exceedingly expert diver

\title{
HOODED MERGANSER
}

\author{
Lophodytes cucullatus (Linnous)
}

$$
\text { A. O. [T. Number r } 3 \text { I see Color plate is }
$$

Other Names.-Hooded Sheldrake: I.ittle. Wood, Swamp. Fond, Mud. Pickax, or Summer, Sheldrake: Little Fishing, or Fish, Iuck; Little Saw-bill Duck: Saw-bill Diver; Round-crested 1)uck: Fan-crested Duck; Tree Duck; IVood Duck; Spike-bill; Hairycrown; Hairy-head; Moss-head; Tow-head; Tadpole: Water Pheasant.

General Description.- Length, 1-1/3 inches. Males are black above and white helow: females are grayishbrown above and whitish below. Bill, narrow and thin. The adult male has a thin semi-circular crest capable of being opened or shut like a fan

Color.- Adult MALE: Head, neck, and upper parts, hlack shading to brown on lower back; crest. mostly white with narroz black border bchind and wider black space in front: the white extending a little below level of eyes; breast and under parts, white, invading the black area just in front of wings by two broad streaks; a white speculum with two black bars formed by the onter webs of secondaries and yreater coverts; inner secondaries, black with white center stripes; sides below, regularly and finely waved witl rufous and black; under tail-coverts, waved with dusky; bill, black: feet, yellowich: iris, yellow. Adult Female: Crest bushy; head and neck, grayish-chestnut, browner on crown; back and sides, dusky-brown, the feathers with paler edges not waved; speculum of wing, smaller and crossed by only one dark bar: throat and under parts in general, whitish; bill, dusky, orange at base below; feet, brownish 


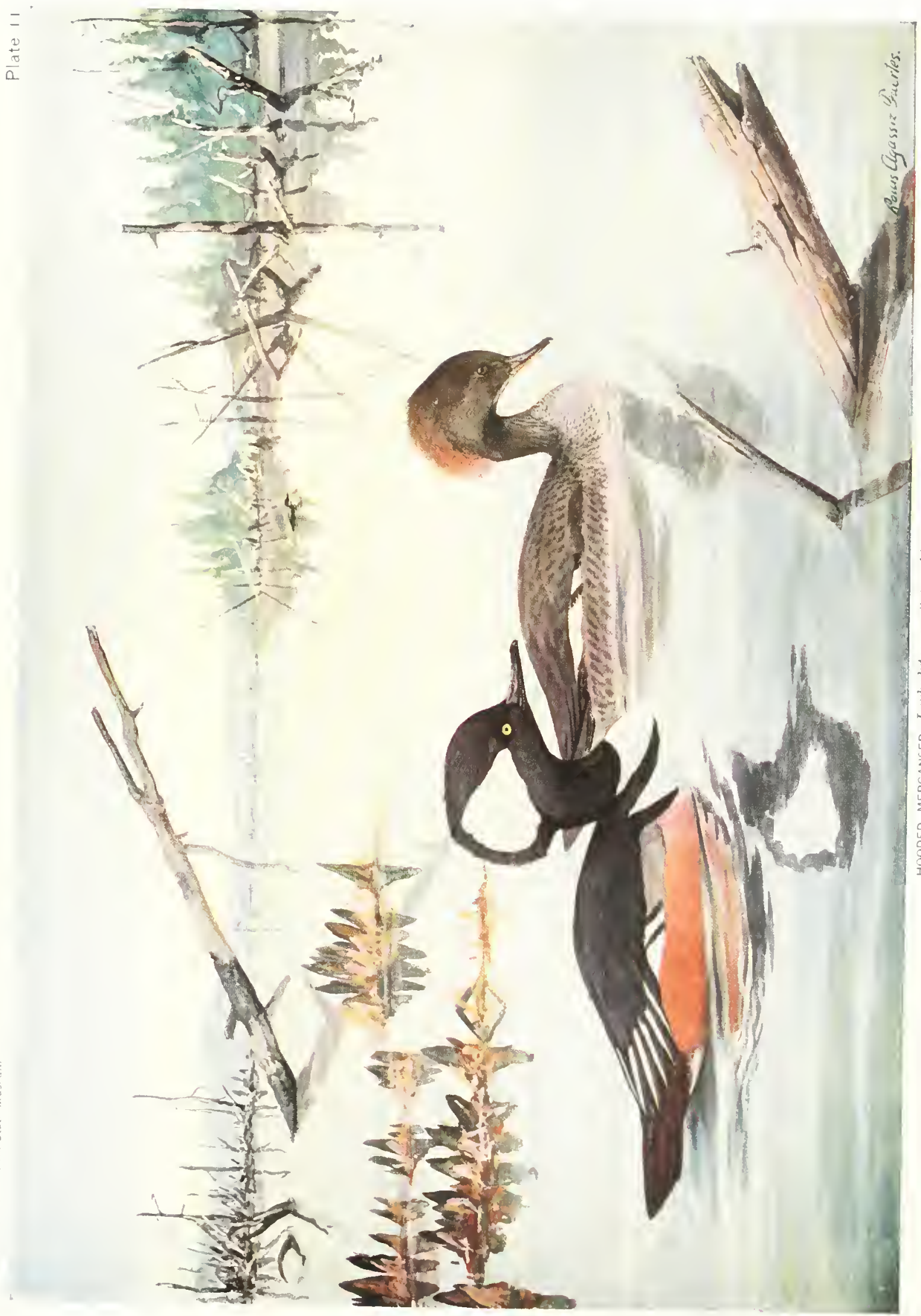



Nest and Eggs. - Nest: In hollow trees, lined with grass, leaves, feathers, and down. Eicis: 0 to 10 , ivory white.

Distribution. - North America at large: breeds from central British Columbia, Great Slave Lake, across British America to Newfoundland south to southern
Oregon, northern New Mtexico, southern Lousrana, and central Forida: winters in southern liritish Columbia, across the United States on about latitude 4 I south to Lower California, Mexico, the Gulf States, and Cuba: rare in northeatern part of range: recorded from Alaska, and from Europe and Bermuda.
The Hooded Nerganser is a distinctively Amorican bird and is the most beantiful of its fantily. Vivacious, active, elegant in forms, grace$\mathrm{f}_{\mathrm{t} l}$ in carriage, its presence adds a peculiar charm to the little ponds and streams on which it delights to disjort. It frequents clear streans and muddy pools alike, and its white and black plumage strongly contrasted against the slining water and the surrounding foliage makes a picture not soon forgotten. One who has seen a small flock of this species playing on the dark waters of a tiny shaded jool with two or three beantiful males darting about among the others. opening and closing their fan-like crests and throwing the sparkling drops in showers over their glistening plumage, will rarely finel anywhere a finer and more animated picture of bird life.

It is well known that this bird nests in hollow trees and that the young are either carried to the water by the mother soon after they are hatehed, or are jushed ont of the nest and, falling unhurt to the gromed, are led to the water by the parent. She seems to be rather a silent bird, but has a hoarse croak at times and probably has vocal means of communication with her little ones. This Duck is exceedingly swift on the wing, a proficient diver, and a fast swimmer both on and under the surface. Its tootherl hill places it with the fish-eating Ducks, but it feeds on vegetable matter also. and Col. John E. Thaver says that " it readily eats corn." No donbt it could be donesticated, and if so it would make a yreat addition to the ornanental waterfowl on parks and large estates. Notwithstanding its umpalatable fishy flavor it is shot by gumners at every opportunity and has decreased greatly in numhers where formerly it was common.

Euward llowe Forbush

\section{DUCKS}

Order Anscres; family Anatida; subfamilies Anatine and Fuliguline

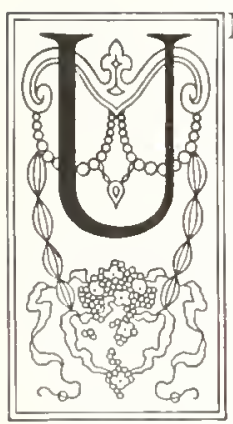

NDER the general term "Duck" are included a very large variety of forms, some of which do not measure up to the popular notion of what a real Duck is. From the scientific point of view, the Ducks include a large group of birds constituting the subfamilies River Ducks and Sea Ducks of the order Anseres or Waterfowl. Most of them have the body longer than the neck, and a broad, flattened bill, while the front of the tarsus is fitted with overlapping scales. The sexes are unlike in color. The characteristic "waddle" of the Duck on land is due to the fact that its legs are placed far back on its body, an arrangement which, however, increases its skill in swimming and diving. The wings are rigid, strong, and usually pointed, and capable of driving the bird's body at great speed; the plumage is exceptionally dense and soft.

Wild Ducks fall naturally into the two groups known as River or Pond Dueks and Sea or Bay or Diving Ducks. The sea Ducks (which are found virtually all over the workd) differ from the River Ducks in having the hind toe broadly lohed or webbed, and include species mainly of large size. The terms "Sea" and "River" should not be taken too literally, for certain species of each group may be found on the ocean, on rivers, or on bodies of fresh water well inland. The Sea Ducks, of which about seventy species are recognized, feed mainly on mollusks, shellfish, and the roots and seeds of aquatic plants, which they get by diving, often to a considerable depth, as is proved by the fact that in lake Erie Old-squaw Ducks have been caught in fishermen's nets at depths of from eighty to one hundred feet 
Most of their feeding is done in daytime, and at evening they go out to sea where they pass the night often several miles from shore.

The River Ducks, of which there are about seventy species, get most of their food by searching the bottom in water so shallow that diving is not necessary. With a few exceptions - notably the Canvas-back - their flesh is more palatable than is that of the Sea Ducks. Again, the Sea Ducks often go in enormous flocks, while the River Duck flocks are comparatively small, rarely exceeding forty or fifty individuals. The range of the River Ducks, like that of the Sea Ducks, is very wide, representatives of the group occurring in both hemispheres. The plumage of both groups displays a very great variety of colors, from the plain hues of the Black Duck to the remarkably gaudy and variegated Wood Duck. Usually the secondary quills of the wings show patches of varied or iridescent color and this patch is called the speculum.

Excepting the Wood Duck, all of the American River Ducks build their nests, which are composed of grasses, leaves, moss, and the like, on the ground, sometimes on dry land at a distance from water, but more frequently in swampy land, where the grass is high enough for concealment. Their eggs usually show shades of green, buff, or crean colors. The Sea Ducks also build ground nests of leaves, grasses, twigs, seaweed, and the like, which are lined with down from the breast of the sitting bird. The eggs number from four or five to a dozen or more, and are buffy, greenish, bluish, or cream in color.

\title{
MALLARD
}

\section{Anas platyrhynchos Linnars}

\author{
A. O. U. Number 132 see Color l'late 12
}

Other Names.-Common Wild Duck; Stock Duck; English Duck: French Duck; Green-head (male); Gray Duck (female); Gray Mallard (female).

GeneraI Description.- Length, 22 to, 24 inches. Color of male: head, green; back, grayish-brown; under parts, gray with purplish-chestnut breast. Color of female: dusky-brown and tawny, variegated and lighter below than above.

Description.- Adult Male in Winter and Breeding Plumare: Frequently several of the upper tailcoverts curl upward. Head and upper neck, glossy green. with shadings of purple and deep Prussian blue; around neck, a white ring; back, grayish-brown, more brown in center and on shoulders; lower back, rump. and tail-coverts, glossy black; tail, mostly whitish with center feathers long and recurved: speculum. violet. furplish. and grecnish, framed in black and white tips of groater coaterts and secondarics, forming alt together two black and two white bars; lesser wing coverts, plain grayish; breast, rich purplish-chestnut; rest of under parts, silvery-gray fuely zigzagged with dusky; bill. olive; feet, orange-red; iris, brown. ADULt MALE IN Summer: Similar to female. Adult Female: Entire body, variegated witl dusky-brown and tawny, with yellowish-brown edges to most of feathers, lighter in color below than on back; head and neck, quite buffy with streaks of brownish; wing as in malc: feet, dull yellow: bill, dusky spotted with orange; iris, brown. 1 mature: Similar to adult female.

Nest and Eggs.- NEST: On the ground in a tussock of grass or weeds; built of fine reeds, grass, or leaves; well lined with down. Ecos: 6 to Io, pale olive or buffy-green.

Distribution.- Northern hemisphere; in North America breeds from Pribilof Islands and northwestern Alaska across British America to Greenland, south to Lower California and across the United States on about the parallel of $37^{\circ}$; winters from Aleutian Islands, Montana, Wyoming, Nebraska, southern Wisconsin. Ohio, Maryland, and Nova Scotia (rarely) south to Mexico, the Lesser Antilles, and Panama; casual in Permurla and Hawaii.
Asked to name the one duck most important to the human race, the economist would reply at once - "The Mallard." Other ducks are numerous in certain lands but the Mallard occupies mosi of the northern hemisphere and is abundant wherever it has not been destroyed or reduced in numbers by man. Wild Mallards have furnished mankind wilh countless tons of food from time immemorial and domesticated Mallards have provided our race with vast 
quantities of eggs, flesh, and feathers for thousands of vears. The Mallard, bred while in domestication, forms an important part of the food supply of China, the most populous country on the globe, and now the Petin Duck is the staple stock of many a hucse poultry plant in America. The Mallard is the chicf waterfow? of most game prenerves, on some of which 10,000 birds are reared annually. It has gained its ascendancy anong the waterfowl of the world by taking advantage of every opportunity to increase and multijly. It never overlooks a chance. One spring day Dr. William T. Hornaday, director of the New lork Zoological l'ark. found in Montana a little water hole hardly ten feet across; all alout in every direction for miles and miles stretched a renert of sage-brush shim- young are hatched. Then she leads them to water. watches over them, driving away their weaker enenties and decoying away the stronger, while the little ones stulk, dive, or hide among the water plants. Inherited experience has taught them the way of life; lut many are seized by great fish, frogs and turtles, and no doubt the Hawks capture sone. The loruel is lage, however, and the survivors are many

When advancing winter seals the waters of their northern home and warns them to be gone, then there is a great figrit from northwent to southeast, for few Mallards breed in the East, but many winter there. They reach the Atlantic from Maine to the Carolinas and, moving south. spend the winter largely in the southern States. EnW lRD Howe Fokbusu.

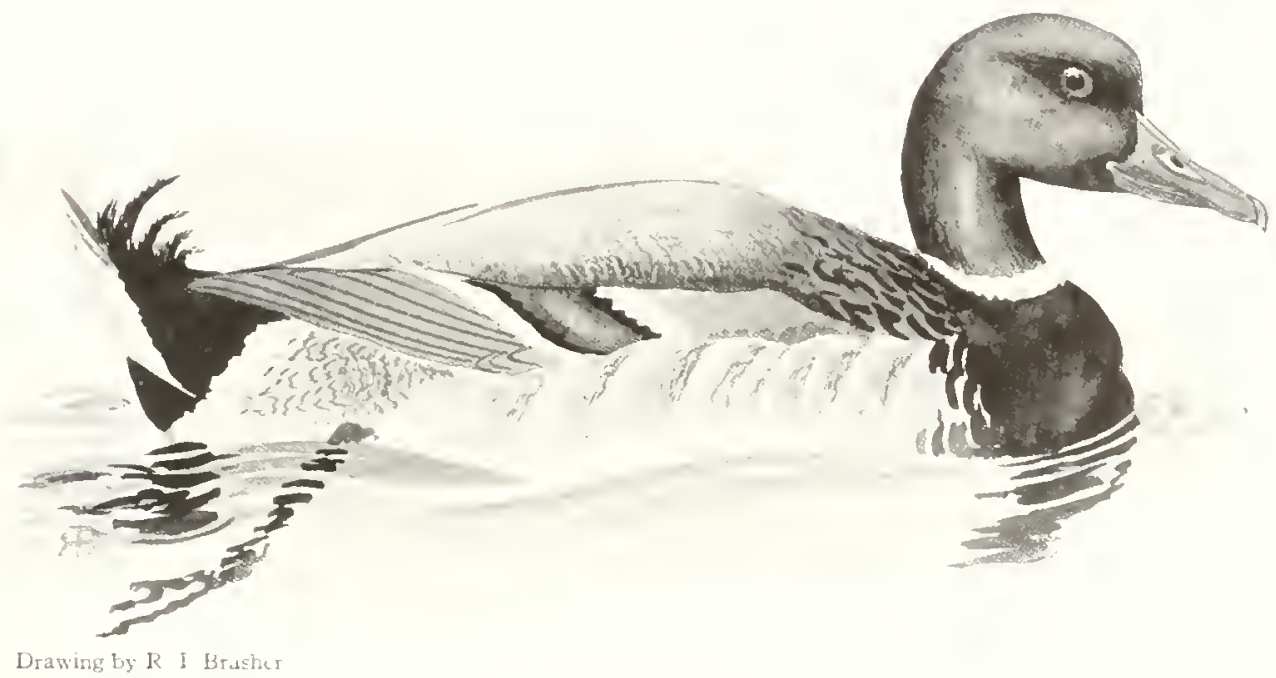

MALLARD (a nat. size)

The chief waterfowl of most game preserves

mering in the sun. As he dismounted to drink, a female Mallard sprang from her nest in the sage-brush by the side of the little jool. One can understand from this episode how the Mallard has been able to spread over the northern hemisphere.

The Mallard is wary, wise, handsone, and strong. When in security it is one of the moisiest of all Ducks and its lourl guack has become typical of the Duck the world around, but when in ranger it can steal away as silently as the shades of night. It is a hardy bird, remaining in the North even in winter wherever open fresh water and food may be found. The female nests very early in the season. lines the nest and covers the eggs with down, and rarely leaves them until the
"The Mallard is quite omnivorous in regard to its food. The inmal fool consists of small fross, tadpoles, trads, lizards, newts, small fish, fish fry, snails, musiels, leeches, earthworms. mice, and similar small game that it finds about the pond and in the edges of the woods. Its regetable food includes grass, many species of seeds and aquatic plants, grain, muts, acorns, fruits. etc. It is particularly fond of wild rice. In the Sonth the Mallard is one of the friends of the rice farmer, as it destroys the scattered rice or volunteer rice of the field. which, if left to grow, would sreatly resluce the value of the crop. It is servicable to the southern peojle in another way, as it feeds very largely upon crayfish, which lumrow into and underminc the levees and dikes. 
Examinations of one hundred and twenty-six stomacins of Mallards, made at the Biological Survey, revealed 17 per cent. animal food and 83 per cent. vegetable. The most jmportant items

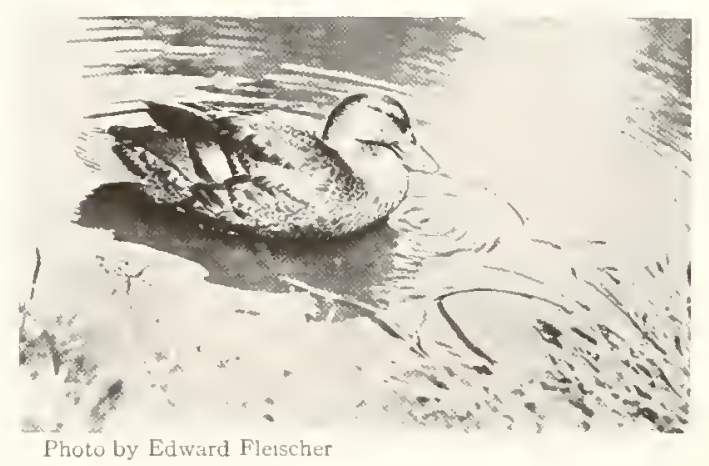

FEMALE MALLARD of the animal food were dragon-fly nymphs, fly larve, grasshoppers, beetles, and bugs. Nollusks, carthworms, and crustaceans were found. The principal elements of the vegetalote food, as found by the experts of the Biological Survey, were the seeds of the smartweeds, seeds and tubers of pondweed and of sedges. Other items of importance were the seeds of wild rice and other grasses, of burr reed, hornwort, water shield and widgeon grass. A great many vegetable substances of less importance were included in the Mallard's diet, of which the following are worthy of note: wild celery, alga, roots of arrowhead; fruits, such as grapes, dogwood, sour gum, and bavberries; and the seeds of such small aquatic plants as millweed, horned pondweed, and mermaid weed." (Forbush, in Game Birds, WildFoal and Shore Birds.)

\title{
BLACK DUCK
}

\section{Anas rubripes Browster}

\author{
A. O U. Number 133 See Color Plate ra
}

Other Names.-Dusky Duck: Black Mallard; Dusky Mallard; Red-legged Duck; Summer Black Duck; Spring Black Duck.

General Description.- Lengtli, 22 to 24 inches. Color, dusky-brown. Darker than female Mallard and not so much white in the wing.

Color.-Gencral plunaye, dusky-brown, paler helow: crown, darker than sides and throat, being quite blackish with pale brown streaks: ground color of neck. grayishbrown with dark streaking; wing-coverts, dusky-gray, the lesser ones varied with light edges; greater coverts, tipped with black and edging purflish-blue speculum; below. the lighter edgings of feathers in excess of

The Black Duck and the Mallard are in certain ways supplementary each of the other. The former is the common Mild Dnck of the eastern half of North Anerica; the latter, of the western half, thoush they overlap considerably. They are enough alike in form, size, and habits to be called popularly "Black" Mallard and "Gray" Mallard. There is, nevertheless, a decided difference in temperanent. Though the wild Mallard is a very shy bird, it soon loses this fear in captivity, as is seen in the fact that it is the progenitor of the domesticated Mallard. The Black Duck, under restraint, remains the sane shy, timid skulker it always was. In fact I know of no Duck more implacably wild. darker centers; above, the reverse; bill. olive; feet, orange-red with dusky webs: iris, hrown.

Nest and Eggs.- NEST: On the ground; a rather large well-made structure of weeds and grass with a deep cup; lined with down and feathers. EgGs: 6 to 12 , very pale buff or pale greenish-buff.

Distribution.- Eastern North America: breeds from central Keewatin and northern Ungava south to northern Wisconsin, northern Indiana and southern Mtaryland: winters from Nova Scotia south to southern Louisiana and Colorado; in migration west to Nebraska and central Kansas; casual in liermuda; accidental in Jamaica.
In the eastern half of the United States it breeds, in suitable localities, in the Middle States and as far north as well up into Labrador. The locations chosen for its nesting are thick, bushy swamps, reedy loogs, the higher edges of meadows, tracts of weeds or low brush on small islands, and the like. As with all Wild Ducks, the nest is hard to discover, except by accidentally flushing the female from the eggs. My first experience was in plodding through the thick of an alder swamp. when a big bird suddenly shot from the ground almost into nuy face, revealing a dozen large yellowish-white eggs under the vegetation.

Nesting is quite early in Connecticut, sometimes 
as soon as the first lays of April, but more generally from about April 20 to the first week in May. The broods keep very close in the thick swamps, and seldon show themselves on open water, minless it be close to thick aquatic reeds or grass. During August they take to wing, and the number of them reared in the vicinity can be judged somewhat by their evening flights. They are crepuscular and considerably nocturnal, flying and feeding during the night and at dawn and duck.
The planting of wild-duck fonds has become a real art. Captured birds are induced to breed in marshy enclosures. The eggs are griven to domestic poultry, which raise the young somewhat tamer. These hancl-reared birds breed much more readily than the wilk parents. Nany of the roung are allowed to go wild, and these, through " the homing instinct," return in spring to breed in the locality. Hlerbert K. Job.

"In the interior the fond of this species is largely vegetable, particularly in the fall. In

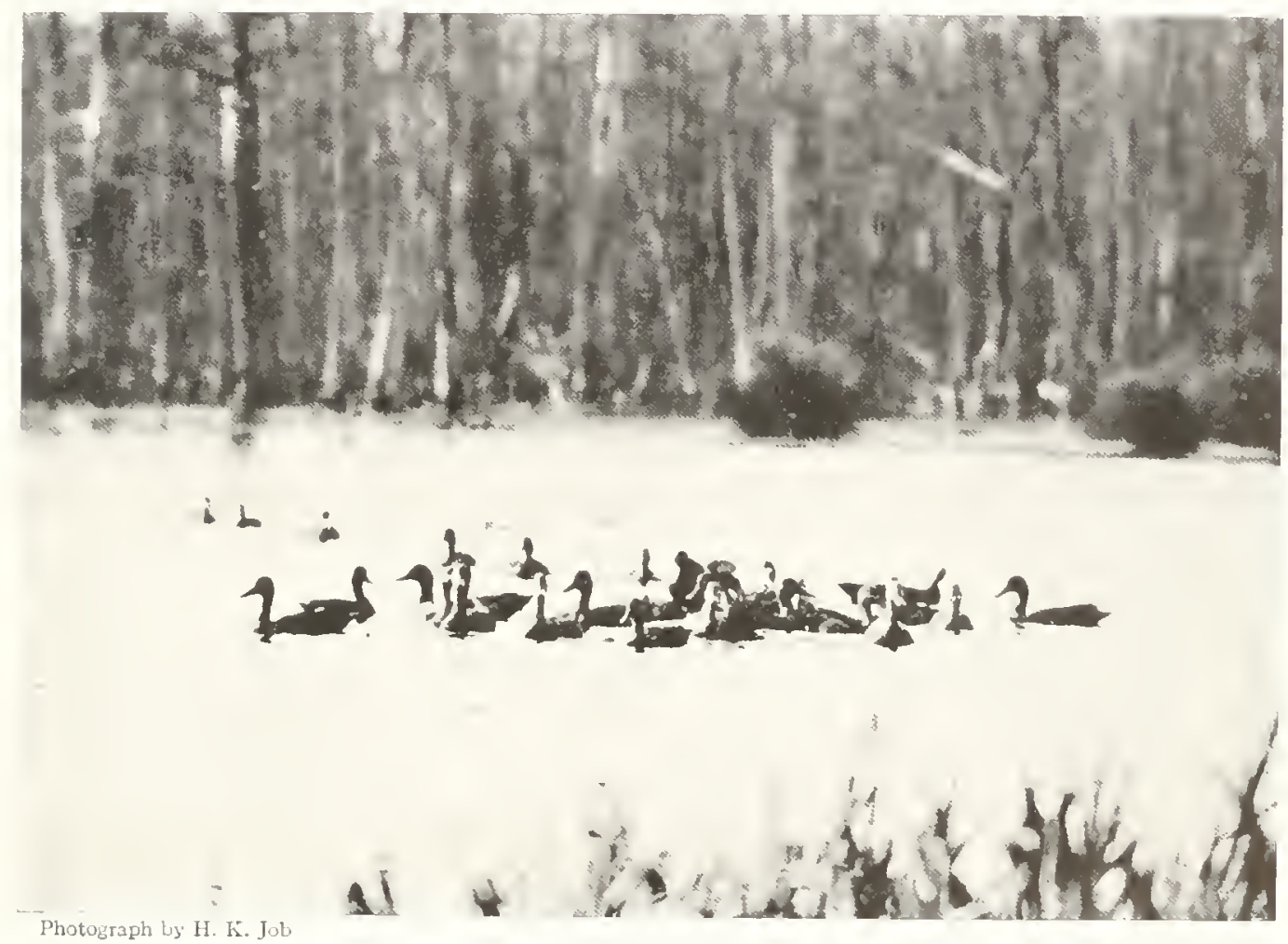

BLACK DUCKS

Just after alighting

The Black Duck is notally hardy, and can endure almost anything in the line of cold, so long as it can find open water in warm springs or small streams, where its food of aquatic anmals or plants is accessible. I have seen it in wooded swamps in mid-winter, where there was open the merest little channel of a small stream. At times, in regions along the sea-coast, it flies out on the bays, or the open sea in daytime, to take refuge from disturbance.

Important practical projects have been carried ont by private enterprise to estahlish the breeding of this and other species of Wild Ducks in large tracts of swampy land, where there are ponds. the spring more animal food is taken. The vegetable food includes grass ronts taken from meadows, roots, and shoots of aquatic plants, wild rice, grains, weed seeds, hazel nuts, acorns and berries. The animal food includes small frogs and toads, tadpoles, small minnows, newts, earthworms, leeches, and small shell-fish. The food of the Black Duck has the same practical interest for the game preserver as has that of the Mlallard, for the Black Duck is closely related to the Nallasd, thrives almost equally well on grain, and when grain fecl, becomes a very excellent bird for the table." (Forbusls, in Game Birds, Wild-Fonl and Shore Birds.) 


\title{
FLORIDA DUCK
}

\section{Anas fulvigula fulvigula Ridgreay}

\author{
A. O. U. Number 134
}

Length, -22 inches.

Color.-Lighter colored than the Black Duck, the buff markings in excess of the dark ones, giving a lighter general tone: cheeks, chin, and throat, plain pale buffy; bill, olive; nail, black and dark spot at base;

feet, orange-red; iris, brown.

Nest and Eggs. - Similar to the Black Duck.

Distribution.- Northwestern to southern Florida.
The Florida Duck is one of our little-known species of water-fowl because its range is very limited and nowhere does it seem to be abundant. It closely resembles the common Black Duck of the northern States, practically the only difference being the absence of streaks on the neck and also the fact that it is of smaller size. So far as known at the present time it is confined to Florida and the coast country of Louisiana. On the palmetto prairies of Hillsboro County, Florida, I discovered some one summer swimming about with their young in the small sloughs and grassy ponds of the region. When pursued the fenale would flutter away with a great splashing and giving every evidence of a highly nervous state of mind. The young meantime scampered for cover, with bodies raised high out of the water, propelling themselves forward at a most astonishing rate. The male bird was in no case seen in company with his family. Another time I came upon several of them at Lake Flint and again at Lake Hicpochee in the Okechobee country. Here they were feeding in the shallow water in company with numerous Coots which abound in the region. They are great birds to dabble and seem thoroughty to enjoy the sensation of muddying the waters. Frequently they quacked to each other, but their notes seemed to me to be indistinguishable from the call of the Black Dnck.

Along the Louisiana coast there exist extensive salt and brackish water marshes through which wide creeks or bayous wind their serpentine way to the open sea. This is a haven for the myriads of Ducks and Geese that repair here to spend the winter. Upon the approach of spring, however, they depart for their northern breeding grounds and the deserted marshes are left to the mosquitoes, the snakes, and the alligators. And yet a few scattered birds tarry and brave the discomforts of the sweltering summer days. Should you at this season quietly paddle a pirogue along the smaller bayous, there would be a chance of coming upon the rare, elusive Florida Duck and her brood, and you might get a glimpse, or even a quick photograph, of them before they hurry into the marsh and disappear. T. Gilbert Pearson.

The Mottled Duch (Anas fulitigula maculosa) is a geographical variation of the Florida Duck and is resident in southern Texas and southern Lonisiana. The two forms differ but little.

\section{GADWALL}

\section{Chaulelasmus streperus (Linnaus)}

\author{
A. O. U. Number 135 See Color Plate I2
}

Other Names.-Gray Duck; Gray Widgeon; Creek Duck: Bleating Duck; Speckle-belly: Blarting Duck; Red-wing.

General Description.-Length, 22 inches. Males are brownish-gray ahove and gray below; females are like female Mfallards, but smaller and wing-patch is like that of the male. The only River Duck with a pure white, black-bordered wing-patch. Wings, long and pointed; tail with 16 feathers.

Description.- Adult itale: Wide low crest on top of head. Head and neck, grayish-brown, darker on crown and nape; sides of head, throat, and neck, speckled with dusky; lower neck, breast, sides of body, and foreback, dusky with erescentic hars of whitish on breast and waved with lighter along sides; lower back, dusky shading into black on rump and upper tail-coverts; shoulders, tinged with brown; lesser wing-coverts, gray; middle cozerts, chestuut; speculum, achitc, formed by outer webs of secondaries, framed in velvet-black of greater coverts and bordered behind with black and ash; abdomen, white minutely zig-zagged with gray; under tail-coverts, velvet-black. Adult Female: No crest. Above, variegated with dusky and tawny-brown, very similar to female Mallard, without any crescentic or wavy marks of male: breast and abdomen, white with dusky spotting; wing as in male, without chestnut coverts.

Nest and Eggs.- Nest: A slight hollow in a bunch of grass or reeds; usually near water; constructed of dry grass; lined with down and feathers. EGGs: 8 to 12 , creamy or buffy-white.

Distribution.- Nearly cosmopolitan; in North Amer- 


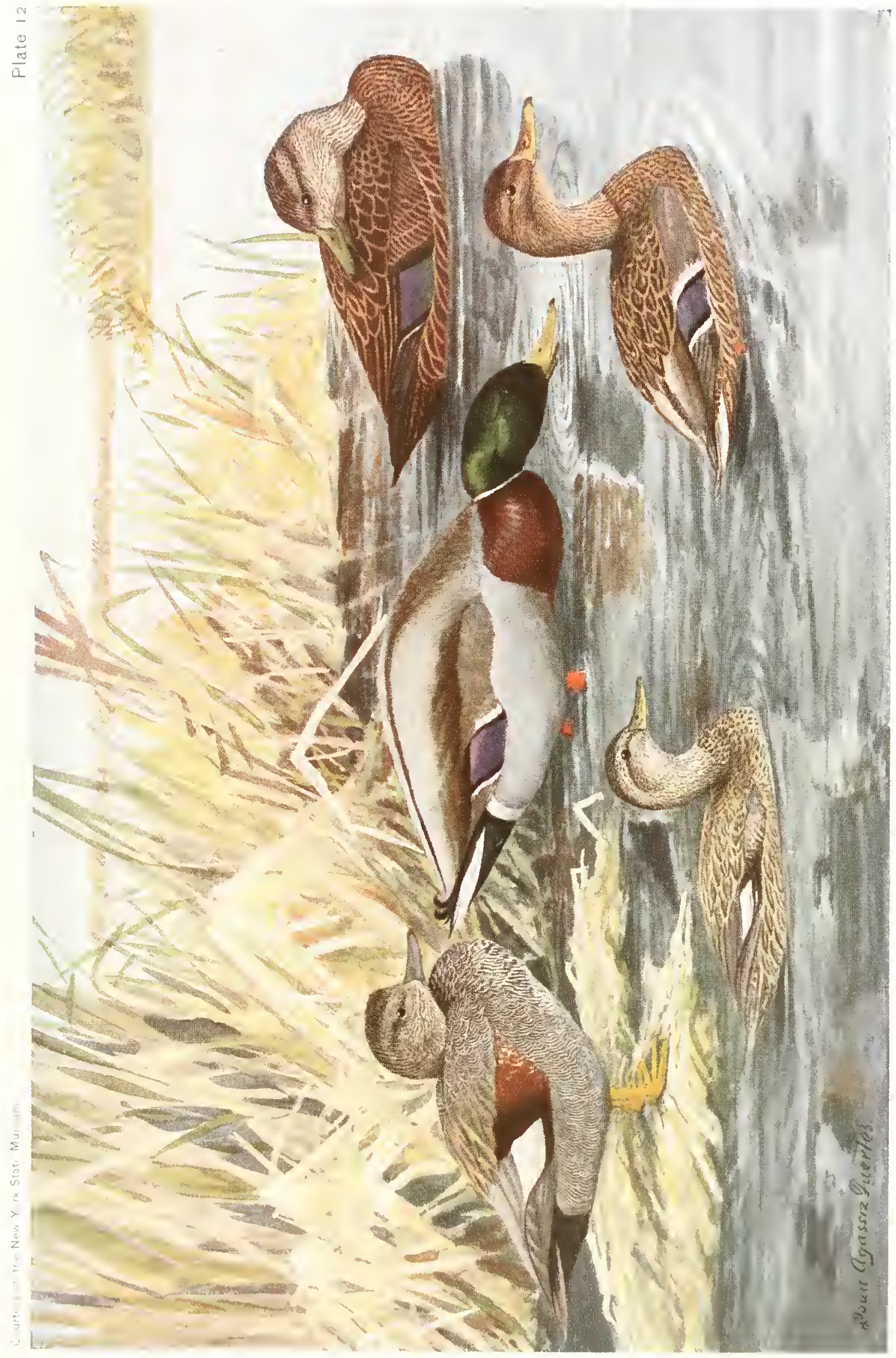



ica breeds irom southern Britich Columbia, central Allerta and central keewatin south "s southern Caliiormia, southern Cotorarlo, northern Nehraska and southern Wisconsin; winters from southern liritish Columbia, Arizona, Arkansas, sonthern Illinois, and
North Carolina south to Lower Califorma. central Mexico, and Florida; accidental in Permuda. Culsa. and Jamaica; rare in migration on the Atlantic coast of the Middte and New England States north to Newfoumblan!.
In North America this almost cosmopolitan species, the Gadwall, breeds mainly, if not entirely, in the western provinees. There is reason

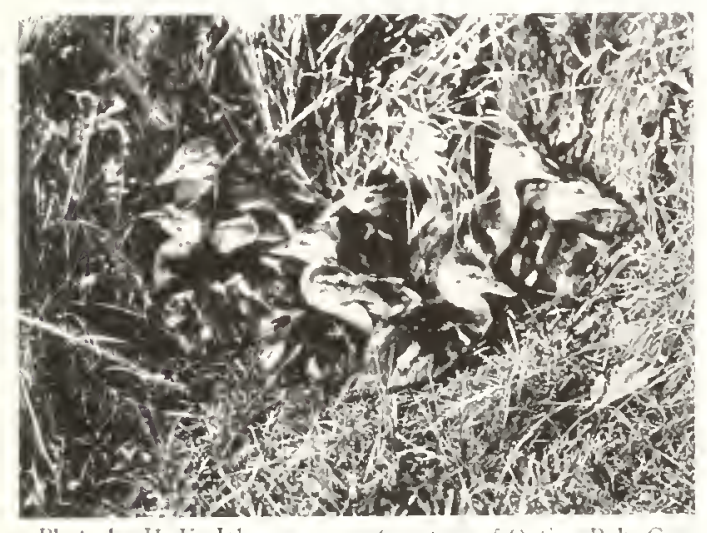

Photo by II. K. Jol

GADWALL DUCKLINGS

to believe that the Gadwall was once not unconmon in New England; but within the last half century not many specinens are known to have been taken. Wilson believed it to be rare in the "northern parts of the United States," and it was probably always less common in the $N^{\top}$ ew England States than in the II est and South; but I am comrincerl, by the statements of the older ornithologists and by de:crijtions given me ly some of the older grinners, that the Gadwa!l was more often seen in the carly part of the last century than it now is, ani that some of the socalled Gray Ducks which were then killed here were of this species.

The Gactwall is a swift Aler, resembling the Baldpate or IVidgeon when in the air. It is quite distinctly a fresh-water fowl, and gets much of its living along the shores of lakes and rivers, concealed by the reerls, zrasses, and bublues that grow near the shore or overhang it. It is a goud diver at neerl, and is secen ustually in pairs or sulall "bunches," often in company with other Duchs

When approached from the land they usually make no attempt at concealment, but swim toward open water and take wing, making a whistling somncl with lleir wines, that is not so lond as that male by the Baldpate. This is an excellent hird for the table, which accounts larely for its present rarity $1 t$ is fond of grain and is easily domesticated. It lireeds naturally in the latiturle of Massachusetts, and it might prove a great acouisition to the game preserve or to the lamm-yard if it could be jropagated in sufficient munluers. It seems a promising species with which to experiment with this end in riew.

The food of this bird consists of the tender shonts of grasses, hlades and roots of aquatic

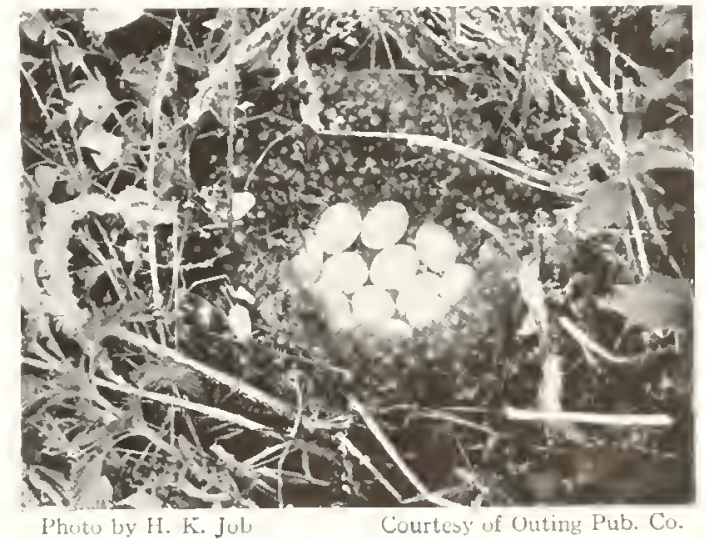

NEST OF GADWALL

plants, secels, nuts, acoms, inserts, mollusks and wher small forms of aquatic life. including small tish.

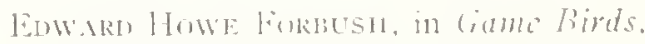
llibl lionl and Shore libds.

\section{EUROPEAN WIDGEON \\ Mareca penelope (Liminus) \\ 1. ก IT. Xumber 136 See Color Thate 1.3}

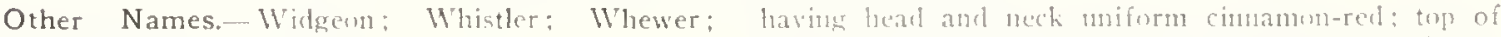
Whew: Whim.

Length. - 18 th 21 inches.

Color. Ampr Mate: liffers from the balfpate in

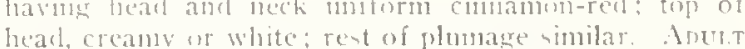

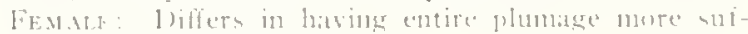
fused with yellowish-lrown. 
Nest and Eggs. - Similar to those of the Baldpate.

Distribution.- Northern part of the eastern hemisphere; occurs in winter and in migrations rarely in
Wisconsin, Michigan, New York, Nova Scotia, Newfoundland, and Greenland south to Nchraska. Missouri, Indiana, Ohio, North Carolina and Florida, and in Alaska, British Columbia, and California.
The Enropean Midgeon is an Old World species which occasionally appears in the western hemisphere. Normally it breeds among the grassy swamps and lakes of Norway and Sweden and is accounted the most abundant of the Ducks in Lapland. Sometimes it breeds on the lakes of northern Scotland but it is always an abundant winter visitor" to southern Scotland and throughout England. In size and general character it closely resembles the Baldpate.

\section{BALDPATE}

\section{Mareca americana (Gmelin)}

$$
\text { A. () U. Number ras sice color Plate } r_{3}
$$

Other Names.-American Widgeon: Pald Widgeon; Green-hearted Widgeon: Snuthern Widgeon: California Widgeon; White-belly; Bald-hearl; Bald-crown; Ballface; Smoking Duck; Wheat Duck; Poacher.

General Description. - Length, Is to $2 \mathrm{I}$ inches.
Males are brownish-gray ahove, and brownish-red and white below. Females are yellowish-hrown above, and brownish anrl white below. Iill, small, widlest near the base: tail with It feathers.

Description.-Adult Male: Heal with short crest.

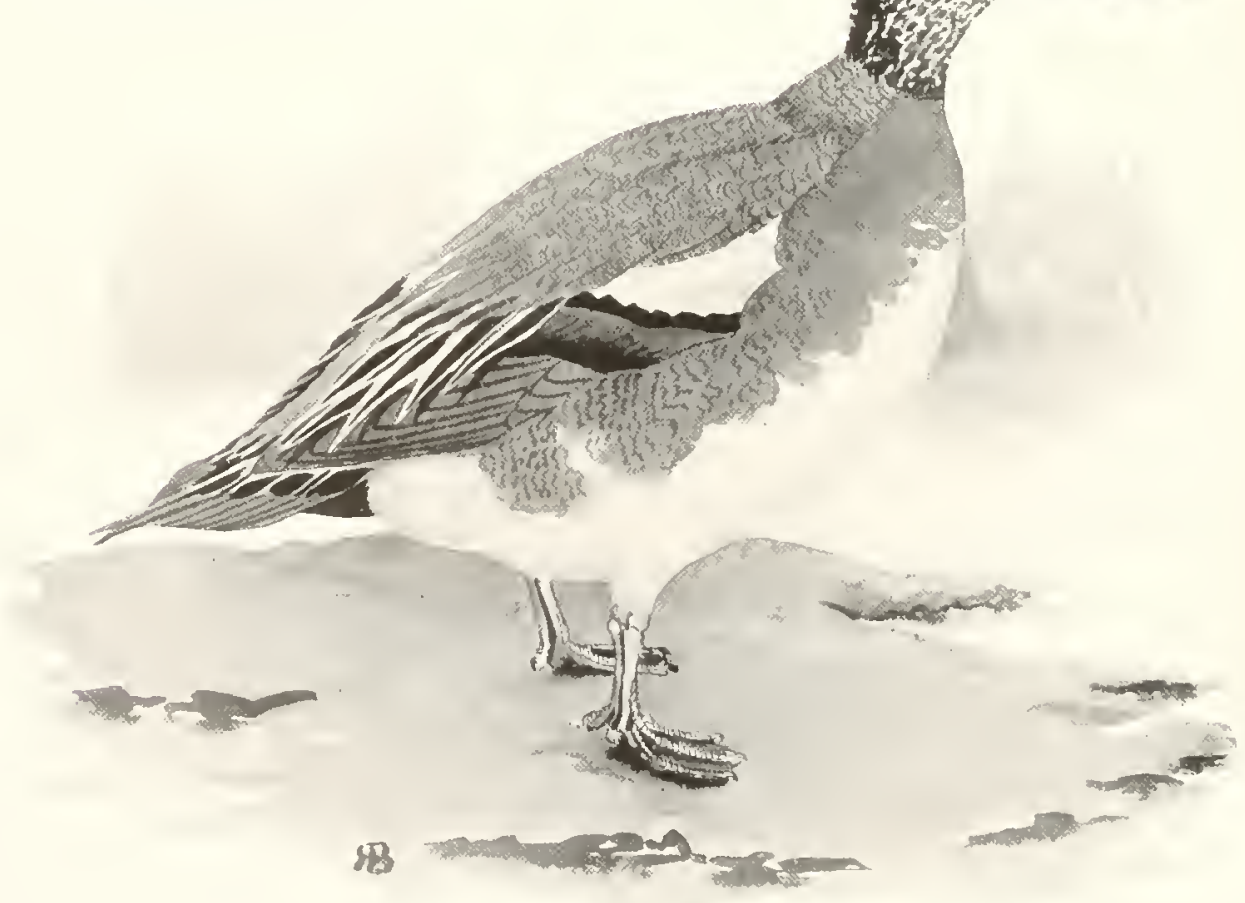


Forihiad. rawn and back of hid, ahteri a broad fatch of glosin yrich on side of hod extending around and luwn back of neck where it mets its fellow; checks and rest of neck, whitish with dunky spots; thruat, dunk; back, shoulders, and rump, pale brownishgray linely waved with dusky; breast, light brownishred with pale gray edgings on feallers: sides of body, the same color waved with dusky; rest of lower parts, pure white except under tail-coserts which are biack; lesser wing-corerts, plain gray; midlle and greater coverts, pure white forming a large area, edged behind by black tips of the sreater curerts; speculum. ulossy "yre'n bordird bihind by black: long inner secontaries, black with sharp white edges; rump and upper tailcoverts. White: the outside feathers of latter, dusky. primaries and their coverts, and tail, pale brownishgray; this perfect plumase seen only in old drates; bill, grayish-blue, black at tip and base helow: fect, the same with dusky webs: irts brown; usually the whole head and neck are pale brownish-yellow speckled with greenish and dusky. ADE.T JEMIIE: Hearl and neck all around, pale grayish; crumn and back of neck, more lirown with dusky spots; upper parts, yellowsh-brown barred on back witl dusky : shoulders sputted with the same; rump and uprer tail-everts, mixed brownish and white; tail, grayish-liruwn, the feathers white edged: wing, as in male but white area mottled with srayish; breast, bruwnish; rest of under parts, white bill, feet, and eve, as in male.

Nest and Eggs. - NEsT: On the ground in marsher a neat well-built structure (for a l)uck) of uran and weets; lined with feathers and down from the breat oi the bird. Fogs: 8 to 18 , vale buffy

Distribution. - North America in general; breeds irom northwestern Alaka, northern Mackenzie, and central Keewatin south to Oregon, Nevarla, L'tah. Colorado, Kansas, sunthern Winconsin, and northern Indtand: Winters from southern British Colnmbia, sunthen Jllinois. Maryland, and Delaware (casually Massachusets and Rhode Island) south to southern Lower Caliornia, the West Indies, and Costa Rica; rare m migration to northern Ontario, northern Quebec, and New ioundand; accidental in IIawaii, Bermuda, and Enrope.
In the East the Baldpate or Ameriean Widgeon is a shy and wary bird and a great tell-tale. Quick to take the alarm itself. it is not slow to communicate it to others: and whenever a few Baldpates mix with a flock of other Ducks the sportsman must "nind his eye," or all his stratagems, disguises, and concealnents will fail. In the Far llest it is less wary.

Wild isolated lakes and rivers not nuteh frequented by other Ducks often are chosen by the Baldpate as favorite mesting spots. Here they nest, usually among bushes or trees amid the dead leaves, often on high ground and not always near the water, hut the eggs are well concealed and covered with their blanket of down. While the ienales are incubating, the males gather and, like the males of other River Ducks, go into the "celipse" plumage, which closely resumbles that of the fema!e and leaves them inconspicuots in color during the stmmer while they molt and grow new wing quills.

As the season of migration approaches the Baldpates begin to move southward and many are shot in the northwestern States while flying from pond to pond: but they soon become shy, fying high over marshes and leeping well out of range of strpicious points, and by the last of October when they appear on the Atlantic coast they are difficult to kill.

The usual note of this hird is a soft whistle which is repeated often when the flock is on the wing. The llight is either in a line nearly abreant or in a group much like a flock of pigeons. Whenever anything alarms one of the flock a lonler whistle warns all the others to shy off or climb the air.

The species is very fond of wild celery, but is a ponr diver and depends sonewhat upon the flocks of Redheads, Canras-backs, Scamps, ancl

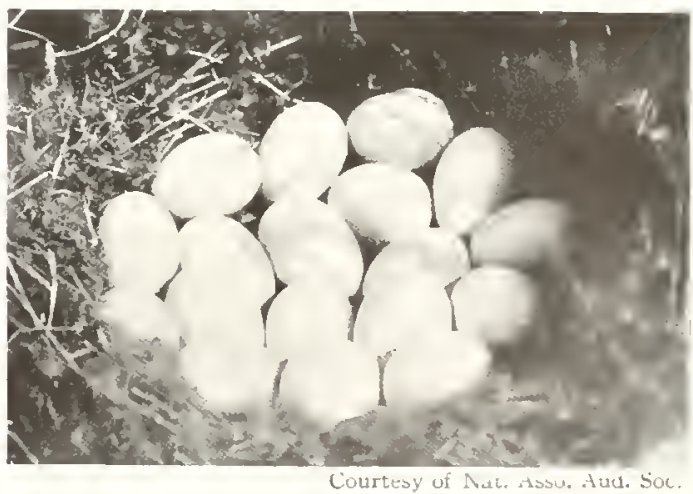

NEST AND EGGS OF BALDPATE The largest families are found among Ducks, Grouse, and Quails,
the young of which are able to leave the nest as soon as the natal covering is dry

Coot to dive for its food which it steals from their bills the moment they appear ahove water. The male may be recogrnized by the conspicuons white of the forchead and wing-coverts.

EDWAKD Howe Forbush. 


\title{
GREEN-WINGED TEAL
}

\author{
Nettion carolinense (Gmelin)
}

A. O. U. Number I39 Sice Color llate I3

Other Names.-Green-wing; Red-headed Teal; Winter Teal: Mud Teal.

General Description. - Length, I 4 inches. Males are gray and red above, and whitish and red below; females are brown above, and whitish below.

Description.-- Adult MALE: Head, slightly crested. Head and uper neck, rich chestunt with a glossy green patch behind $c y c$, blackening on lower border and on back where it meets its fellow, bordered below by a whitish streak; upper parts, grayish, very finely waved with dusky; speculum, aclet-black on outer half, rich glossy grean on incr; prinaries and wing-coverts, grayish; greater coverts with chestnut tips margining the speculum in front; breast, warm brownish; rest of lower parts, whitish speckled with round dusky spots on breast; sides, grayish, finely waved witl dusky; a white crescent in front of wing; bill. dusky lead color, darker below; feet, bluish-gray; iris, brown. Adult Fenale: Head (no crest) and neck, light warm brown, whitening on throat and darkening on crown, spotted with dark brown; upper parts, dark brown. each feather with distinct tawny edgings; sides of body, the same; rest of lower parts, whitish; wing as in male but speculum duller. Young of THE YeAR: Resemble aduit female.

Nest and Eggs.- Nest: On the ground, usually in a thick growth of grass or among willows; constructed of dry grass; lined with feathers and down. Egas: 8 to II, sometimes I2, pale buff.

Distribution.- North America at large; breeds from the Aleutian Islands across British America to Newfoundland, south to central California, northern New Mexico, northern Nebraska, northern Illinois, southern Ontario, Quebec, and New Brunswick; winters from Aleutian Islands, British Columbia, Nevada, southern Nebraska, northern Indiana, western New York, and Rhode Island (casually Nova Scotia) south to southern Lower California, the West Indies, and Honduras; accidental in Hawaii, Bermuda, Greenland, and Great Britain.
Teals might be called the bantams of the duck tribe, as regards size. Their swiftness of flight is in inverse ratio to mere bigness, and probably there is nothing more rapid that flies. The celerily with which a Teal can vatt into the air

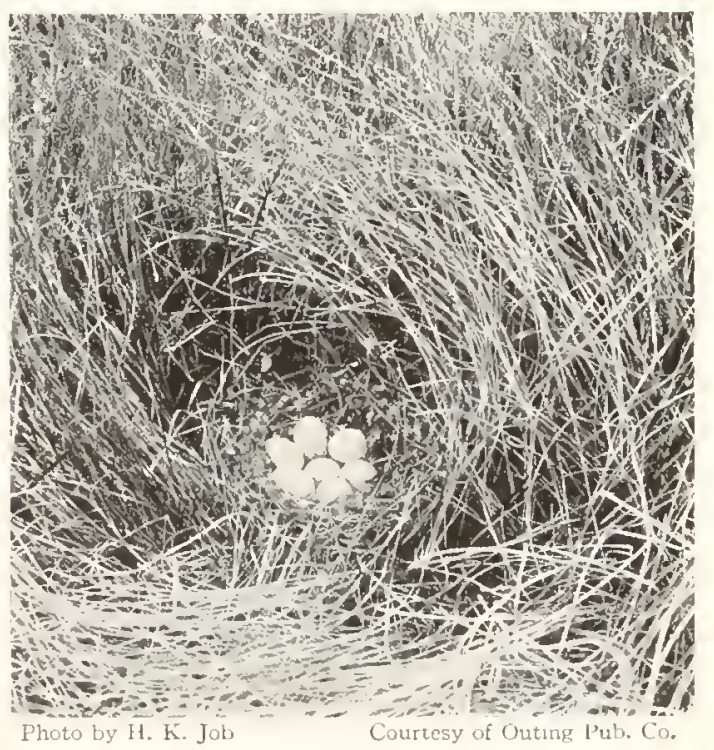

NEST OF GREEN-WINGED TEAL

when alarmed is astonishing. In all its movements it evinces a real grace, a peculiar charm. From the culinary standpoint, surely there is nothing more luscious in the realm of waterfowl, no, nol even the vannted Canvas-back.

The Green-wing and the Blue-wing are the
Lwo Teals of North America which are well known and widely distributed. Of the two the Green-wing is the hardier, lingering in the northern States late in the fall and even at times well into the winter, as long as there is any open water at all to be found in the ponds or at warm springholes. It is also, on the whole, the more northerly of the two, both in its winter range and in its breeding.

Of late years both species have been growing regrettably scarce in the eastern districts of the country. When found al all it is usually only a single bird or a pair. But in parts of the central and westem districts there are still good flocks to be scen.

The nesting of the Green-wing is mostly in the Northwes1, not so commonly on the sloughs of the open prairies of the Dakotas and southern Manitoba as in the more brush-grown regions further west and north. It grows more numerous as one penetrates into northern Manitoba and western Saskatchewan. In the latter it likes the alkaline ponds, and in the former the poplar forest lakes. The nest has seemed to me one of the most difficull of Ducks' nests to discover, in that it is usually located well back from water, sometines near the edge of meadow and forest. These Teals frequent the open marsly pools, but my search for their nests in the grass nearby was ustally in vain. They were generally discovered by accident. One was found near the cabin of an Indian half-breed by the edge of a cattlepasture, amid grass, weeds, and low brush. 
$\frac{n}{\frac{m}{a}}$

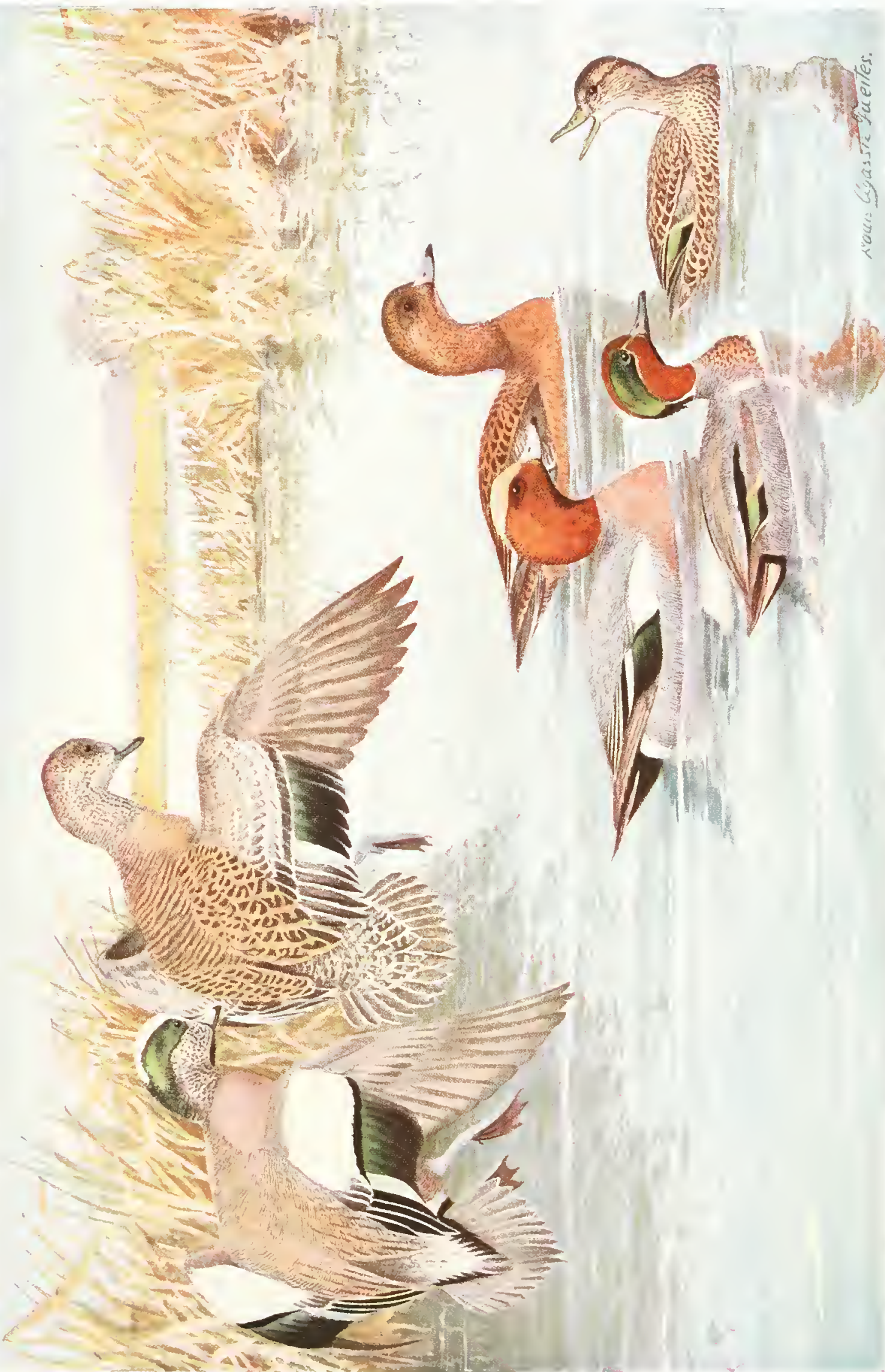



Others were under low bushes at the drier edges of meadows, back from the lake almost to the forest.

On a large island of a big alkaline lake in Saskatchewarn it was my good fortune to discover my first nest of this species, which made the twentieth kind of Duck whose nesting I had discovered. The island was high and dry, opren, overgrown with prairie grass and tracts of low brush. Nany kinds of Ducks were nesting lere and they kept Hushing from their egss close in front of me as I tramperl about - P'intails, Gadwalls, Shovellers, Mallards, both Scaups, Bluewinged Teals, and others. Suddenly up fluttered a small duck with green on the wings. In the thick of the grass was a nest lined witl soft down. containing a complement of eggs.
I have hatched and reared the young and find them hardy and casy to manage.

Heriert K. JoB.

"The Green-winged Teal is fond of wild oats and rice, and tales seeds of varions grasses and weeds, also cliestunts, acorns, wild grapes, berries, insects, crustaceans, worms, and smalı snails. Audulon states that he never found water lizards, fish, or even tadpoles in stomachs of this Teal. He regarcled it, when fed upon soaked rice or wild oats, as far superior to the Canvasback, and considered it the most luscious food of any American Duck. Possibly it might be domesticated to advantage, as it has heen bred in captivity in a snlall way." (Forbush, in Game Birds, II ild-Fowl and Shore Birds,

\section{BLUE-WINGED TEAL}

\section{Querquedula discors (Linnaus)}

iก $T^{\top}$. Nimber sto See Color l'late it

Other Names, - Blue-wing: White-faced Teal: Summer Teal.

General Description. - Length, 16 inches. Males are variegated dark and light brown above, and purplishgray and yellowish-gray helow with spots of black.
Females are dark brown ahove, variegated with lighter, and whitish below, mottled with hrown.

Color.- Anth MILE: Crown, grayish-black; a large white blackedend crescent in front of cye' rest of hear. purpliali-gray: lower hind-neck and fore-back,

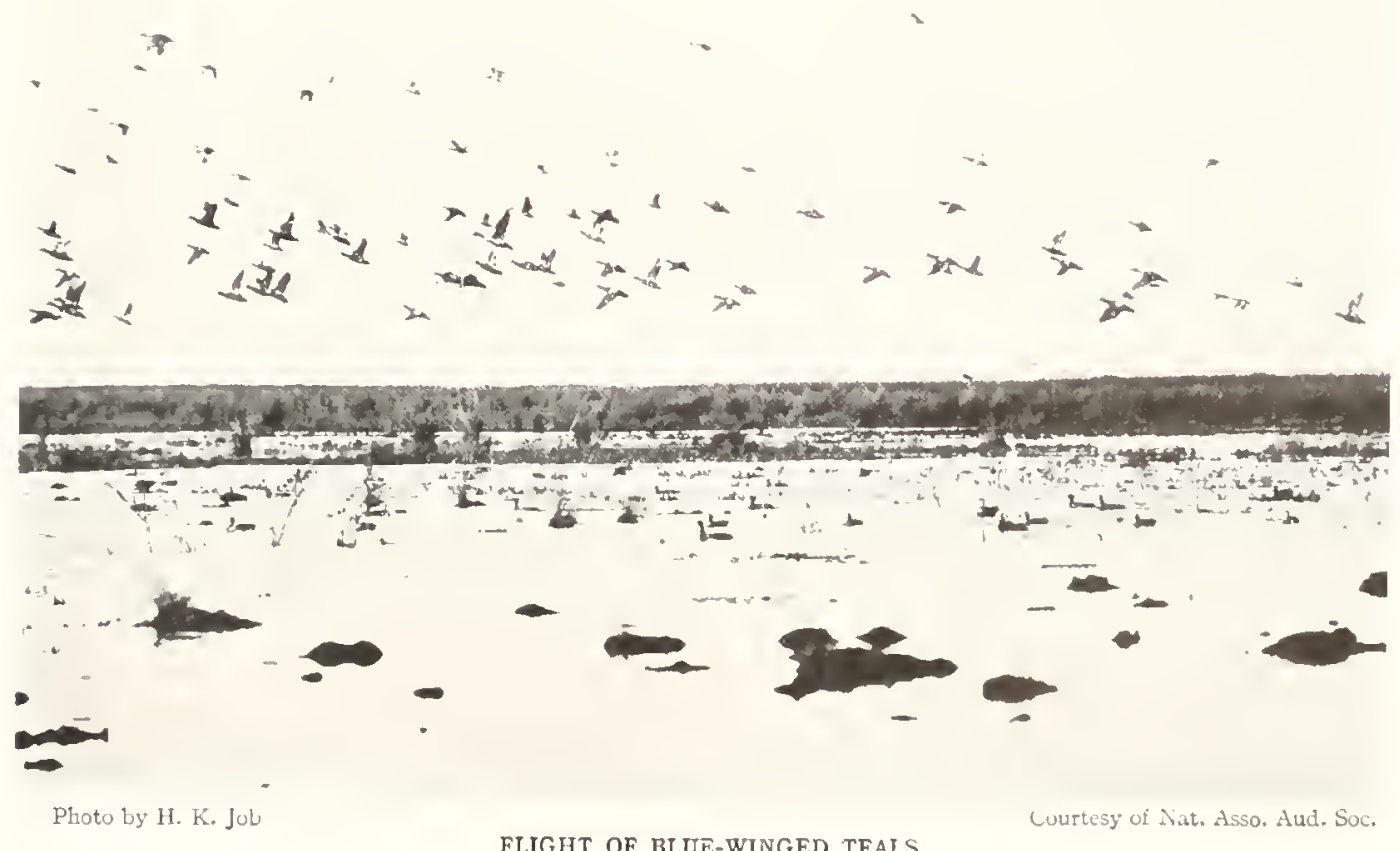

FLIGHT OF BLUE-WINGED TEALS

Louisiana 
variegated with brownish-black and yellowish-brown; lower back and rump, dark brown with a greenish tinge: aing-conerts and outer webs of some of the shoulder feathers, dull cobalt blue; speculum, rich mallard grin enclosed by white tips of greater coverts and secondaries: some inner secondaries, greenishblack on outer web, greenish-brown on inner, striped lengthwise with reddish-buff; breast, very pale purplishgray; rest of under parts, yellowish-gray with innumerable round black spots on breast, sides, and below, changing to bars on flanks behind; under tail-coverts, black; a patch on each side of rump, pure white; bill, ashy, darkening on ridge and tip; feet, yellow, webs duller; iris, brown. Anult Fenale: Head and neck, dull buff; crown, brownish-dusky streaked with brownish-black; cheeks and chin, whitish, markings small or obsolete; upper parts, dark brown with pale yellowish- brown edgings to all feathers; below, grayish-white, slightly more brown on breast, mottled on breast with dusky spotting and on sides and flanks with V-shaped brownish marks; wings as in male but speculum duller; bill, greenish-dusky; feet, paler yellow. Young of THE IEAR: Resemble adult female.

Nest and Eggs.-Nest: In marshes or on dry ground; constructed of grass and weed stems and lined with feathers and down. EGGs: 8 to 12, pale buffy.

Distribution.- Western hemisphere; breeds from central British Columbia, across British America to Newfoundland, south to Oregon, Nevada, New Mexico, Missouri, Indiana, northern Ohio, western New York (occasionally Rhode Island), and Maine; winters from about the parallel $36^{\circ}$ south to the West Indies and South America as far as Brazil and Chile; accidental in Bermuda and Europe.
The Blue-winged Teal is quite similar to the Green-winged in many of its ways. One difference is that it is less able to endure cold. Before the heavy frosts of late autumn arrive, it is well to the sonthward. I have been told by lunnters in Louisiana that in late October and November large columns of them pour along the Gulf coast and pass on into Texas and Mexico. However. a good many remain in Louisiana on the great reservations for the winter. In the winter of I9I5-16 I saw there considerable numbers of this species, associating with the Green-wing, sometimes in flocks of several hundreds. Both kinds became quite gentle under protection, and would swim up within a few feet of blinds and of our cabin window and feast on rice which was scattered for then1.

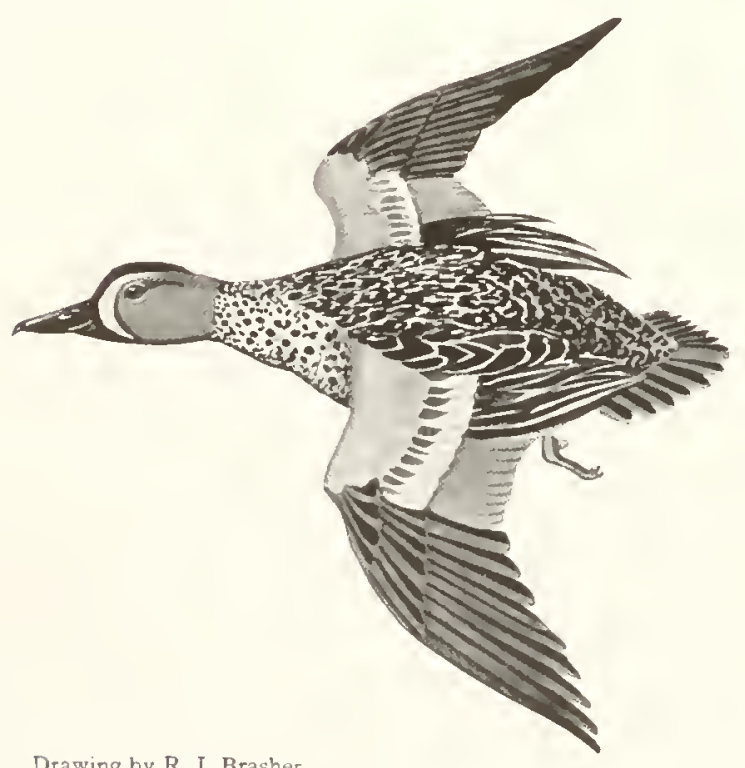

Drawing by R. I. Brasher

BLUE-WINGED TEAL (⿳亠丷厂 nat. size)

1t becomes quite gentle and tame under protection
Quite a number of the Blue-wings remain each sunnmer to breed in Louisiana. The general impression seemed to be that this is a rather new

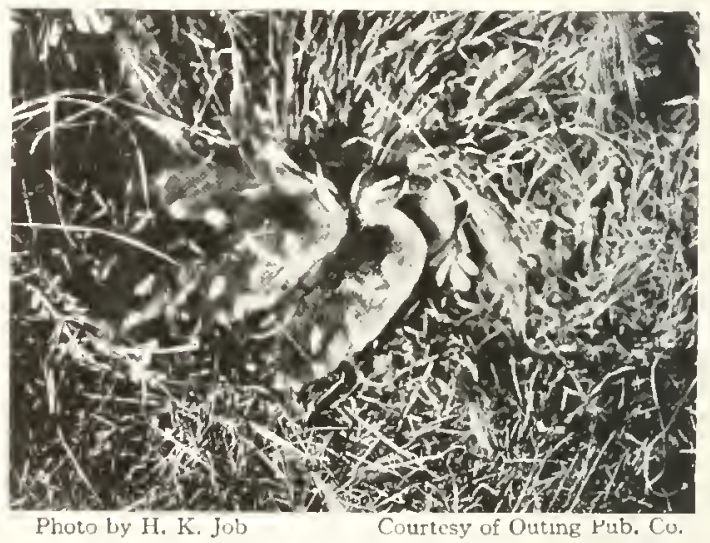

BLUE-WINGED TEALS

About one month old

thing, and that they are breeding further south than usual because of protection. For the same reason, since the abolition of spring shooting, they are said to be nesting more and more in the central-western States. The Green-wing, however, still elects to go well to the nortl.

The Blue-wing is the connon summer Teal of the open prairie regions of the northwest. In selecting its nesting-site it does not retire as far from the water as the Creen-wing, hut generally chooses the thick growth of prairie grass of the preceding year's growth, only a few rods back from the shallow marshy sloughs. Sometimes, however, it is placed on the dry prairie, half a mile from water.

The mother Bhe-wing always approaches her nest with great caution, not flying directly to it, but, alighting at a distance, she snealis through the grass and weeds. In leaving the nest she 
pulls over it the blanket of gray dowts which she las plucked from her breast as a lining. entirely concealing the egers. and making the ne it bractically invisible. After returning she sits very close, allowing herself almost to he stepyed on before she will leave. Confilent of her powers of concealment, she seem ; more apt than most other Ducks, except perhaps the other Teals, the Pintail, and the Shoveller, to nest carelessly near the haunts of man, in the prairic regions of her choice. The nests of thene confiding low mothers may be placed beside a path or road, in a cattle-vard, or near a house. One smmer 1 was at a lunter's camp just lack from lake Manitoba. and nuny times a day we followed a little path to the water. One day a boy walked a little off the trail, and came tearing back to camp to report having flushed a luck from her eggs. It was a ne-t of this species. only a dozen feet from the path, in the prairie grass.

The Blue-wing prefers little shallow marshy ponls, or meadows and bogs. w the larger open waters. Its food in the ponds inclucles much vegetable matter, heeds, grasses, pondweels. etc.
It also at times devours smails, tadjoles, and many insects.

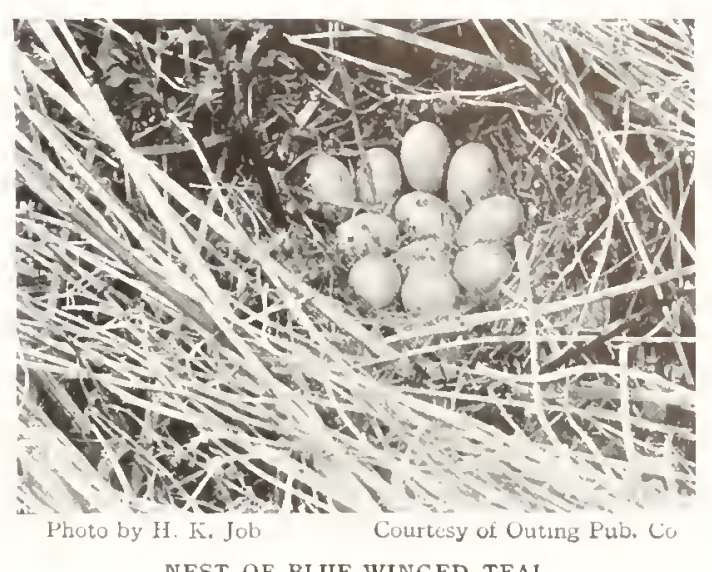

NEST OF BLUE-WINGED TEAL

Formerly in North Dakota I used to see it. often with the Shoveller or the I'intail, almost wherever there was the merest pridde by the roadside, in spring and early smmmer. Let us lope that it may continte alundant and intimate on the western farm. Herbert K. Job.

\title{
CINNAMON TEAL
}

\section{Querquedula cyanoptera (I"icillot)}

\author{
1. $0 \mathrm{~L}$. Number IfI
}

\begin{abstract}
Other Names. - South American Teal: Rerl-breasted Teal.

General Description.-1,engtl], I; inches. Males have the head and under parts chestnut, and the upper parts hrown. Females are dark brown ahove, variegated with lighter, and whitish below, mottled with lrown.

Color.-Adult Male: Head. nick, and cntirc under parts, rich purplish chestuut, browner on crown and chin, blackening on center of abdomen: under tailcoverts, dark brown: fore-back, a lighter shade of same colur crossed by brown curved bars; lower hack and rump, greenish-brown, the feathers edged with paler; wing-cuverts, cobalt-blue: some of the shoulder feathers, blue on onter web with a yellow center stripe; others, dark green, also with center stripe; speculum, bright "l'ith franed between white tips of greater cuverts and white ends of secondaries; bill, disky: feet, urange,
\end{abstract}

There are several curious facts concerning the Cimamon Teal. It seems to have been first described from a specimen taken in the faraway Straits of Magrellan early in the inth century. Its first recorded apjearance in the webs, darker; iris, brown. ADrLT Female: Quite imilar to female Plue-winged Teal, but larger with longer bill and under parts with some tinges of the chestnut color of the male: bill, dusky, paler below and along edges: feet dull yellowish: iris, brown.

Nest and Eggs.- Nest: In tall grass, usually near water; very well constructed of woven grass and lined with feathers and down. Fogs: 9 to 13. creamy-white.

Distribution.- North and South Anerica: breeds in North America from southern Kiritish Columbia, southwestern Alberta, Womingr and Western Kansas south to northern Lower California, southern New Mexico and southwestern Texas: winters from southern California, central New Mexico and southern Texas south to southern Lower California and central Mexico; rare east of the Iooth meridan; occurs in South America from Peru and brazil south to the Falkland Islands.

United States apparently was in Lotiviana near the town of Opelousas in 1849 , but strangely enough it is now seldom seen in that State. At about that time, indeed, it appeared frequently in the lower valley of the Mississippi, but its 
normal range now alpears to be much further to the west and south, for reasons which are not apparent. It is now essentially a bird of the W'est.

A flock of Cinnamon Teals in the water are likely to present an enlivening spectacle, as the males often engage in some sort of play not unlike the boy's game of leap-frog.

"The Cinnamon Teal nests very commonly in the lake region of southern Oregon. I liave seen it nesting all through this section from Klamath Lake to Malheur Lake. In some places in southern Oregon it is more abundant than the Mallard or the Pintail. I think sportsmen often mistake the female for the Blue-winged Teal, because of the blue wing-narkings." (W. L. Finley, as.)

\section{SHOVELLER \\ Spatula clypeata (Limaus) \\ 1. O 2 , Number 142 see color Plate 14}

Other Names.-Spoonbill; Spoonhill Duck; Spoonbill Teal: Broaly: Bltwe-winged Shoveller; Red-breasted Shoveller; Shovel-bill; Swaddle-bill; Butter Duck; Cow-frog.

General Description.- Length, 17 to 21 inches. Males have the colors green, white, blue, black, grayishbrown, and red in patches, while the females are pale brownish-yellow with spots and streaks of dusky. Both sexes have the bill long and clumsy and broadened at the tip.

Color,- Adult MALE: Head and neck, dark glossy green; lower neck and fort-briast, pure white, extending almost around body; a narrow line from green of head down back of neck and back, dark grayish-brown shading into black on rump and upper tail-coverts; shoulders, broadly white: aing-cos'erts and some outer fiathers of shoulders, dull cohalt; speculum, rich green set hetween white tips of greater coverts and black and white tips of secondaries; the long inner secondaries, greenish-black with white stripe; lower brast, ablomon. and sides, purplish-chestumt. lightening behind, followed by a white space: center tail-feathers, dusky: outer ones, white: under tail-coverts, black: bill, purplish dusky feet, vermilion or nrange: iris, orange or yellow. Adelt Female: Ground color all over, pale brownish-yellow closely and narrowly streaked on crown, finely spotted on sides of head and neck all around with dusky; feathers of back and sides, broadly brownish-black, leaving only narrow edges of the lighter color; wing as in male but coloration duller; bill, yellowish shading to dull greenish at tip with some orange below and at base; iris, yellow; feet, dull orange.

Nest and Eggs.- NEST: Located in the marshes or in dry grass or under bushes: constructed of grass and leaves, and lined with feathers and down. EGas: 8 to 14 , olive-greenish or buffy.

Distribution.- Northern hemisphere; in North America breeds from Alaska. Nackenzie and southern Keewatin south to southern California, central New Mexico, northern Texas, northern Missouri and northern Indiana: winters from southern British Columbia across the United States on about the parallel $35^{\circ}$ south to the West Indies, Colombia, and Hawaii : in migration occasional in Bermuda, and north to Nova Scotia and New foumdland

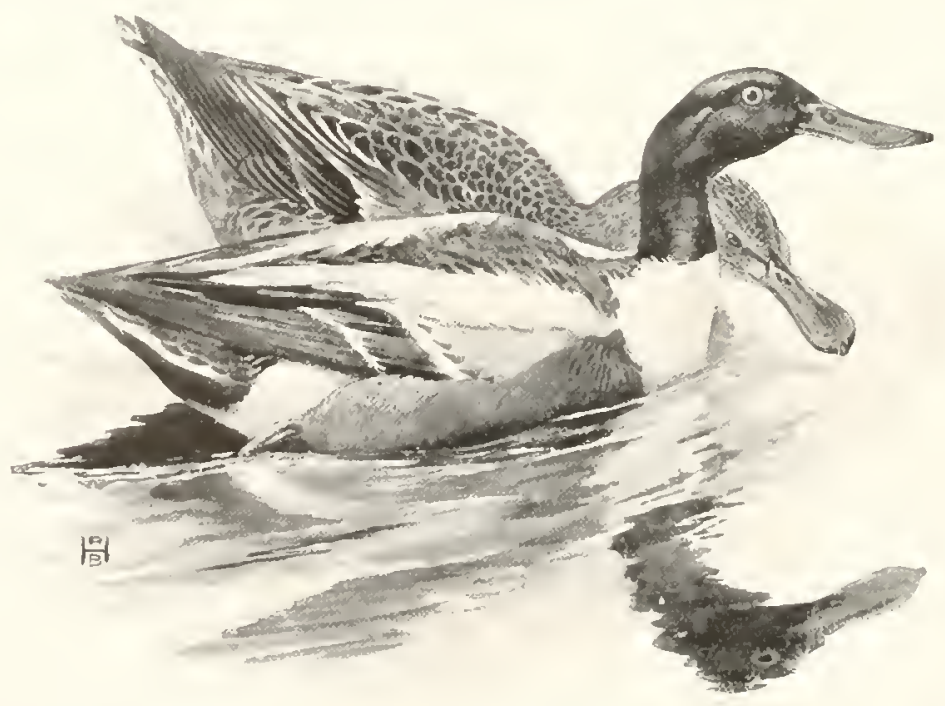

Drawing by $\mathrm{R}$. Bruce Horsfall

SHOVELLER (? nat. size)

A quaint Duck, always carrying with it a prodigious spoon 


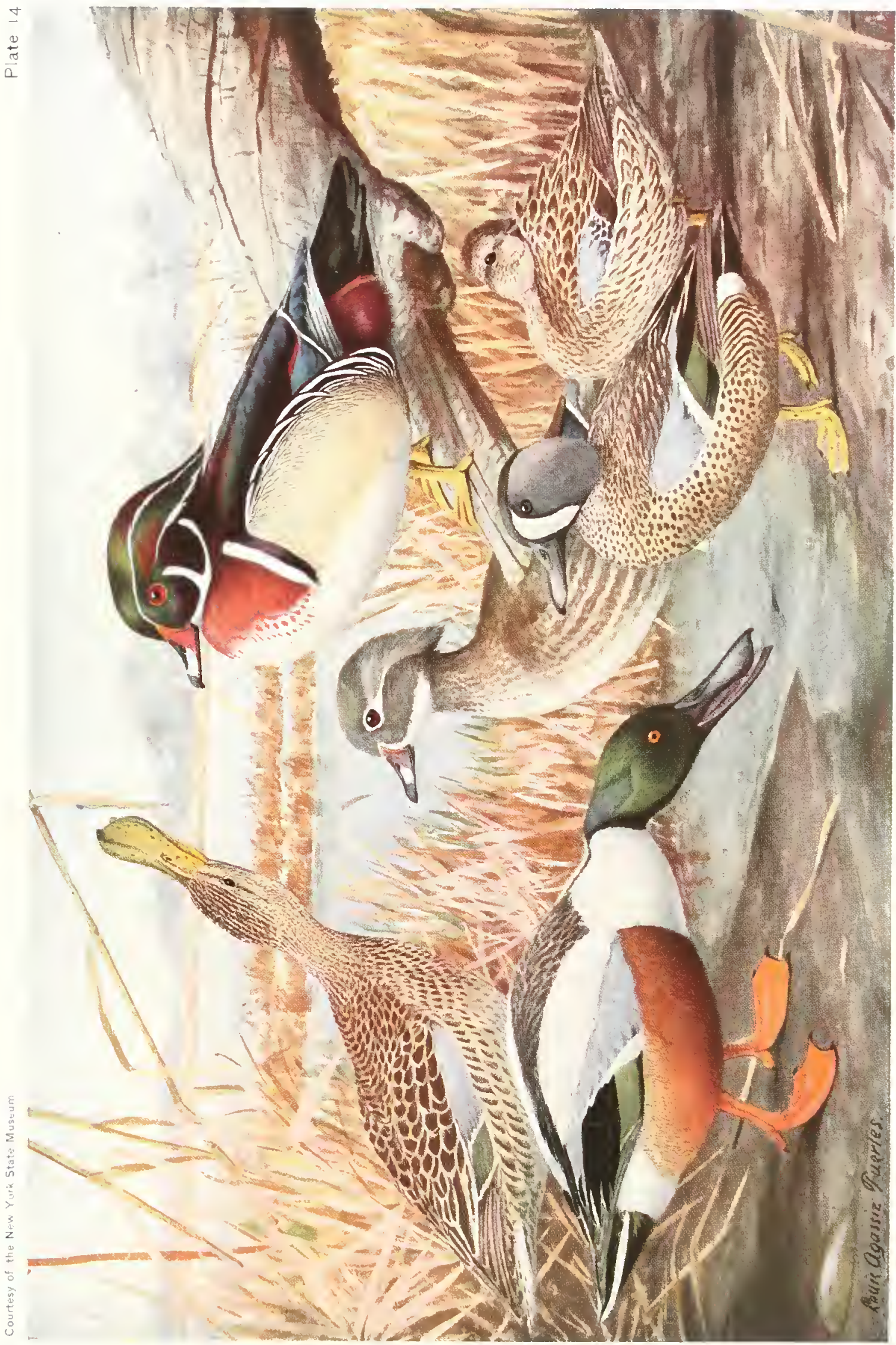



Though it is the wise practice to try to estalylish only one vernacular name for each species, I think that this louck is better known as "Spoonbill " by the average hunter and out-door person. Nor is this name absurl, as is sonetimes the case with popular names. The bird certainly carries quite a prodigious spoon with it upon all oceasions, and is never at a luss to use it deftly in its natural haunts. A popular name for it might well have been "mud-sucker." The great bill is edged with a long fringe of bristles, and the quaint little Duck, almost top-heavy in appearance, paddles through the slough, constantly dabbling in water and ooze, which it takes into its bill, and, ejecting the refuse through its "sieve," retains whatever nutritions matter there may be.

This is another fresh-water Duck which is scarce in eastern districts but common in the West. There it frequents the shallow sloughs and bogs. It scems to be more strictly insectivorous than some of the other Ducks. Though they were abundant in Lonisiana in winter, and were associated with the many l'intails and Teals which ate the rice put out for them, the Shovellers seldom touched it, not that they were particularly shy, but apparently because they preferred the natural fare of bugs and aquatio growths.

I have watched the Shovellers a good deal, as they nested in the prairie sloughs of the Nortlwest. In spring the ma!e is a very gandy creature, far ontshining lis plain little wife as they swim in the slough. They are then quite tame and easy to observe, and $i$ have seen them in roadside pools, and even in swampy barnyarrls. where it seemed that they must be domesticated Ducks, until suddenly they flew away.

Nesting is usually in rather thick grass, frequently only a short distance hack from the edge of the slough, or even in a tussock on quite moist ground. Yet, on the other hand, it is often far lack on the dry prairie, quite a distance from water. Really there is no accounting for the tastes of individual Ducks.

Speaking of taste, in another sense, many people have the idea that the Shoveller is a lean, scrawny sort of bird, always thin and poor eating. My experience has been that. on its winter grounds in the Soutl, it is fat and luscions, quite as good as one of those delicious little morsels, the Teals.

It is a rather delicate bird, and does not stand

$$
\text { inI.. I - IC }
$$

the cold ats well as many other l)ueks. Hence it migrates fairly early and goes well to the Sunth. If kejt in captivity over winter in the North, both it and Teals should have some shelter from the worst of the winter weather. I have known them, in very bitter coll, to have their bills accummulate balls of ice as the water trickled down the bristles and froze. J'robalbly no hetter plan could be employed for wintering these delicate Ducks than the model aquatic house which we have adopted for this purpose at the experiment station of the National Audubon Socicty at Amston. Conn. It is a small house built out in

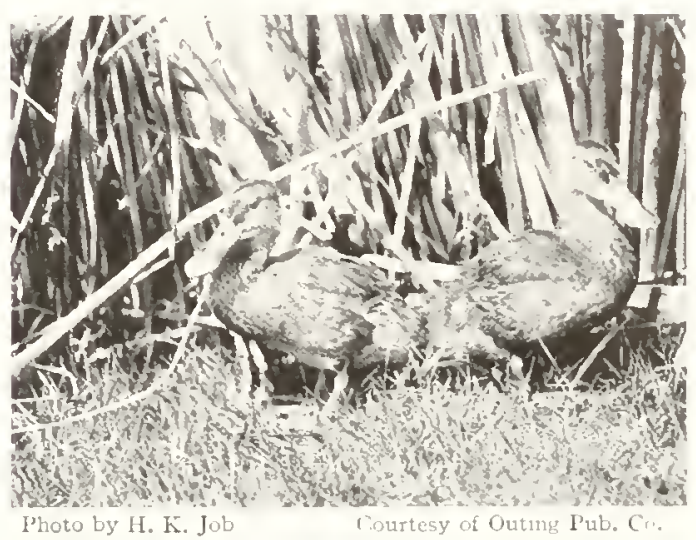

YOUNG SHOVELLERS

the water on posts, the inside being a swimming pool and a float, with large frame windows to the south and west, to utilize all possible sunshine. There the Ducks thrive in comfort alt winter, without having the water freeze, even when $5_{5}$ degrees below zero ontside, and in spring they are not reduced in vitality, and are in fine condition to breed. HEReERT $K$. Jor.

"Audubon states that repeaterl inspections of stomachs of these species disclosed leeches, small fish, earthworms, and snails. It feeds also on aquatic plants, grasses, grass seeds, and hulbs, which it procures along the shores of small ponds which it frequents. It often feeds by wading and dabbling in the mud, straining mud and water through its peculiarly constructed bill. Dr. James P. Hatch states that it feeds on aquatic insects. larve, tadpoles, worms, etc., which it finds in shallow, mudely waters; also crustaceans, small mollusks and snails." (Forlush, in Game Rirds, Wild Foal and Shore Rirds.) 


\title{
PINTAIL
}

\author{
Dafila acuta (Linnows) \\ A. O U. Number 143 See Color l'late 15
}

Other Names.-- Male: Sprig-tail: Split-tail; Spiketail; Picket-tail; Peak-tail; Sharp-tail; Sprit-tail; Spring-tail; Spindle-tail; Kite-tail ; Pigcont-tail; Pheasant-dock; Sea-pheasant. Female: Gray Duck; Pied Gray Duck: Pied Widgeon. Either SEx: Winter Duck; Lady-bird; Long-necked Cracker; Ilarlan; Smee.

General Description.-Length, 24 to 30 inches. Males are gray above and whitish below: females are brown, varied on body with ocher and dusky. Both sexes have the head small and not crested, the neck long, and the tail long and pointed with 16 feathers: in the male the two contral tail-feathers are from 5 to o inches in length.

Color.- Adult Male: Head and neck above, dark brown glossed with green and purple; back of neck with at stripe shading into the gray color of back; back, finely waved with dusky and white; shoulder-feathers and long inner secondaries, striped lengthwise with velvetyblack and silvery-gray; lesser wing-coverts, plain gray; "reater conerts, tipped with rufous or cinnamon, edging front of speculum: speculum, greenish in front, bronzy with violet reflections behind where edged with the white tips of secondaries; tivo lony central tail-feathers, black; the remaining fourteen tail-feathers, gray; throat, white running up behind back of head in a narrow stripe : breast, abdomen and sides, whitish, hinely waved with black on sides; under tail-coverts, black; bill and feet, grayish-blue; iris, brown. Anult Female: Ilead and neck all around, warm yellowish-brown with indistinct streaking; rest of plumage, varied with ocher, plain brown, and dusky; tail without long central feathers; wing, as in male but much smaller; bill, dusky bluish; feet, dull grayish-blue : iris, hrown.

Nest and Eggs.- Nest: On the ground, usually in tall bunches of prairie grass, near water: made of dry grass, snugly and warmly lined with down. Egas: 7 to 10 , pale greenish to olive-buff.

Distribution.- Northern hemisphere; in North America breeds on Arctic coast from Alaska to Keewatin and south to southern California, southern Colorado, northern Nebraska, nurthern lowa, and northern Illinois; winters from southern British Columbia, Nevada, Arizona, southern Missouri; southern Wisconsin, southern Ohio, Pennsylvania (rarely), and Delaware south to Porto Rico and Panama, and in Hawaii; in migration occasional on the Atlantic coast to northern Ungava, Greenland, and Newfoundland, and in Bermuda.
In other writings I have characterized the Pintail as the greyhound among waterfowl. It is an interesting, agile, swift-flying, hardy species, the male being wonderfully garbed in a most effective blending of gray, white, and lirown, surpassing many other birds of more gaudy hues.
Though shy enough ordinarily, it lecomes readily accustomed to man. The young are easy to rear and grow up very tame. I predict that the time is not far distant when the domesticated Pintails will be almost as faniliar as tame Mallards, and will be raised on preserves and estates
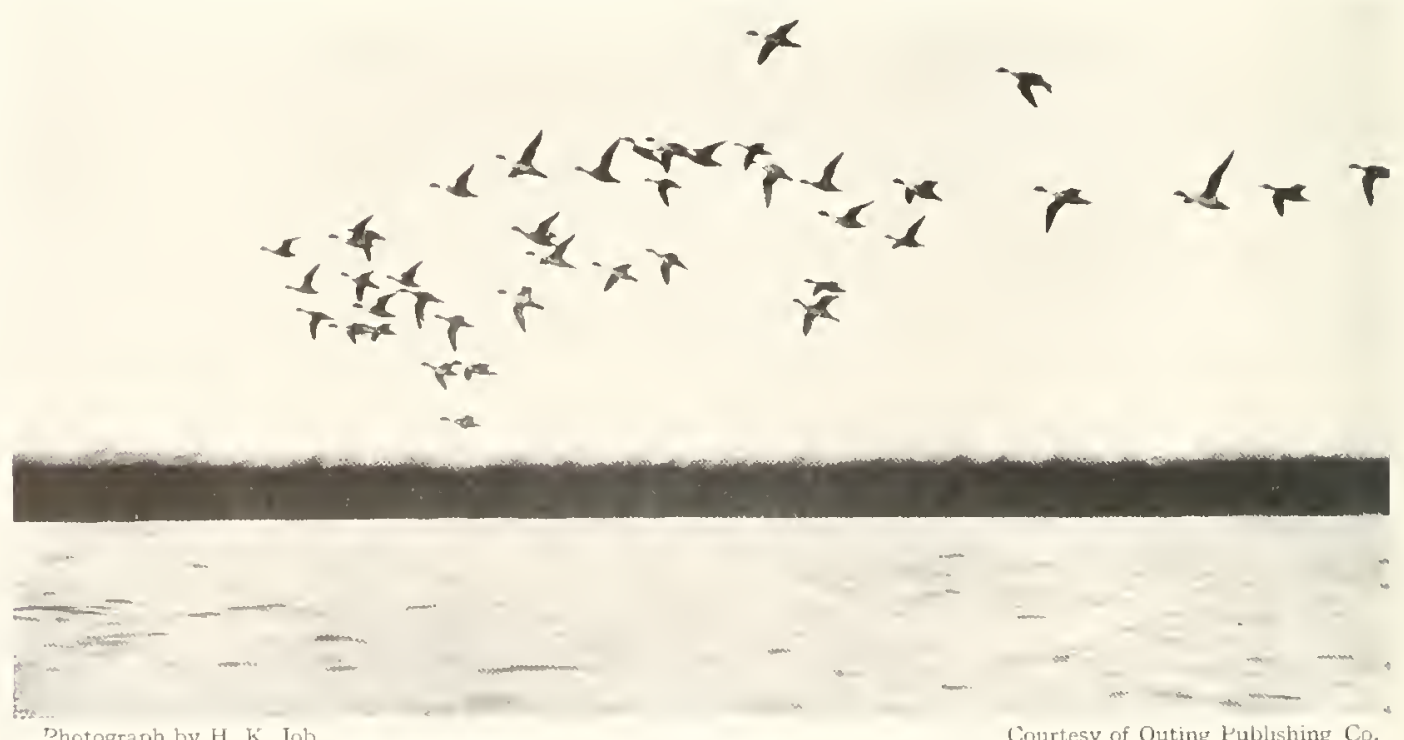

PINTAILS 

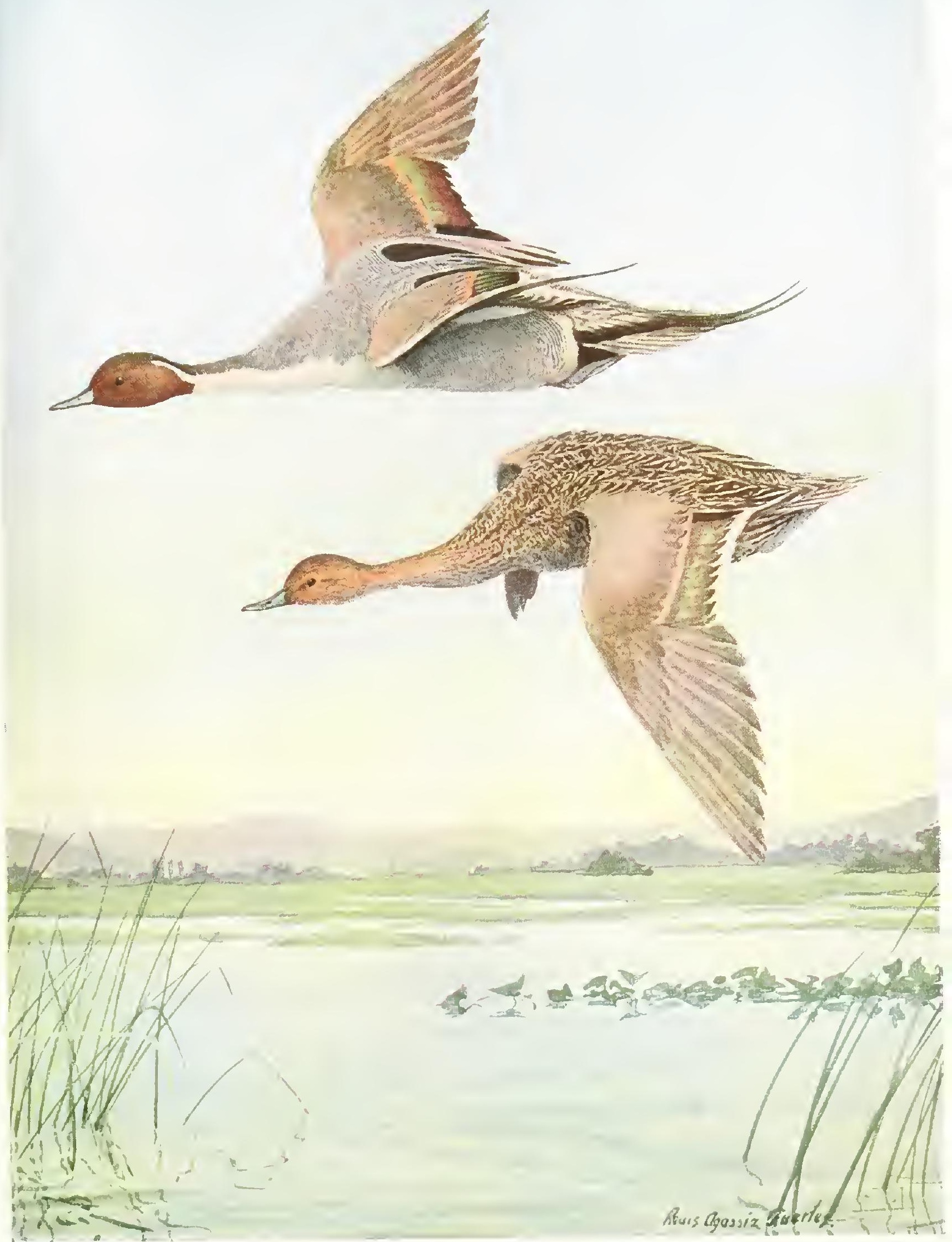

for surting prirjoses, for food, or for ormamenent.

Though l'intails breed in the northerly parts of the cuntinent, they also do so in ont northwestern States. They are hardy and early, arriving in spring often before all the ice is ont of the lakes, In norther"11 Manitroba I have seen young on June 25 that were futly Hedgerl except that the primaries were not yute loms enomgh jor flight. The egas must have heen laid in late March or April when conclitions there are deciderlly wintry. The nest is usually in dry grass or in a clump of weels. Small dry islands are favorite locitions. (otherwise it seems to be placed gute regardless of proximity to water. Frequently I have found it far back on the dry prairie, probably a mile from the nearest slough. lt is perhaps more tlinsily lunilt than with most other 1)ucks, and often has rather less down than the average. The nmmber of egrs in a clutch has seemerl to me, in my experience, to run slightly less than with other species, seven or eiglit being most common, and seldom over nine or ten.

11 migration it is not at all common in eastern waters. but in the Mississippi valley and west it is probably next to the Mallard in abundance. It prefers shallow ponds and marshy areas where grass and sedge grow from the water. In the sloughs where it breeds, the nated pairs swim- ming about make a beantiful sight, liven in antumn when the male has lost for the time his distinctive plumage, the bircls are (puite distinct, wring to their slender forms and long necks, and their movenents alwaly have the air of grace and sood breeding. In fact the l'intail is one of my special favorites. Though l prefer it alive. I must admit that it is very fone on the table, and that I had just as soun eat it as any uther 1)uck. ()n one of my winter jatunts in Lumsiana, the hunters of the party proviled many a Pintail, and it was considered that one Dnck at a meal for each man was just the right anomnt.

By November the Pintails are aloundant on the marshes of lonisiana where, in some localities, they winter ly thomands. In the winter of IoIs 1 fomd it the general testimony that this species had increased wouderfully in abundance during the last few seasons, which result was attributed directly to the stopping of spring shooting - that outrage against reason and conservation, now made an offense by Federal Law and by our International Treaty. They were fond of grain. and, on putting this ont, various Ducks, but chiefly Pintails, wonld assenhle in large numbers to feast upon it, becoming so loold that I was able to film and to photograpla large numbers of them from blinds, and even from the windows of our calin on the marsh.

HERERT K. Jor.

\section{WOOD DUCK}

\section{Aix sponsa (Limnceus) \\ A. O L. Number 144 See Color Plate if}

Other Names.-Summer Duck; The Bride: Bridal Duck: Wrood Widgeon; Acorn Duck; Tree Duck.

General Description.-1,ength, 20 inches. Males are green, blue, and purple ahove with white streaks, and red, yellow, and white below. Females are brown above, and yellowish-brown and whitish below. Both sexes have long, full crests; the bill narrow, higher at base than wide; the tail long with soft, hroad feathers.

Color.-Anult Itale: Head, including crest, iridescent green and purple; a narrow white line from bill over eye to rear of crest; another commencing behind eye and running to nave: a broat white patch on throat forking behind, we streak curving upward behind eye, the other curving an sirle of neck; above, lustrous violet and bronzy green: shoulders and long inner secondaries. velvet-black glossed with purple and green: a grcenish-blue speculum hounded by white tips of secondaries hehind: primaries. white-edged and frosted on webs near end: upper tail-coverts and tait, leep dusky black: sides and front of loa'er neck and breast, rich purplish-chestuut "a'thly marked asith small $I^{\prime}$ shaped awhiti spots; a large black crescent in front of wing preceded by a white one: sides, yellowish-gray waved with fine black bars; rest of under parts, zhite; lengthened flank feathers falling in a tuft of rich purplish-red below wing; bill, white in center, black on ridge, tip, and below, with a square patch at base of lake-red; feet, yellowish-orange; iris and lids crimson. ADUlt Feamale: Crest small: head and neck, grayishbrown, darker on crown: feathers at base of bill n̂ârowly all around, chin, upper throat, and a broud circle uround coc ruming into a streat behind, pure achite: upper parts, brown with some sloss: fore-neck and cides of body, yellowish-brown streaked with darker: breast spotted indistinctly with brown: abiomen. white: hill, grayish with a white spot in center, redush at base: feet, dusky yellow; iris, brownich red.

Nest and Eggs.- Nest: In a bollow tree from 20 to 40 feet from ground, lined with feathers and down. Ersis: 8 to 14 , creamy-white.

Distribution.- Temperate Nortl America: breeds from southern Britisl Columbia eastward on about the parallel $40^{\circ}$ to New Brunswick and Nova Scotia, sonth in central Califurnia. Texas and lilorida: winters chiefly in United States from about $37^{\circ}$ southward; accidental in Bermuda. Atexico, Jamaica, and Europe. 
The Wood Duck is one of the most richly and beatufully colored birds of the United States, and, for a nigratory bird, is peculiarly

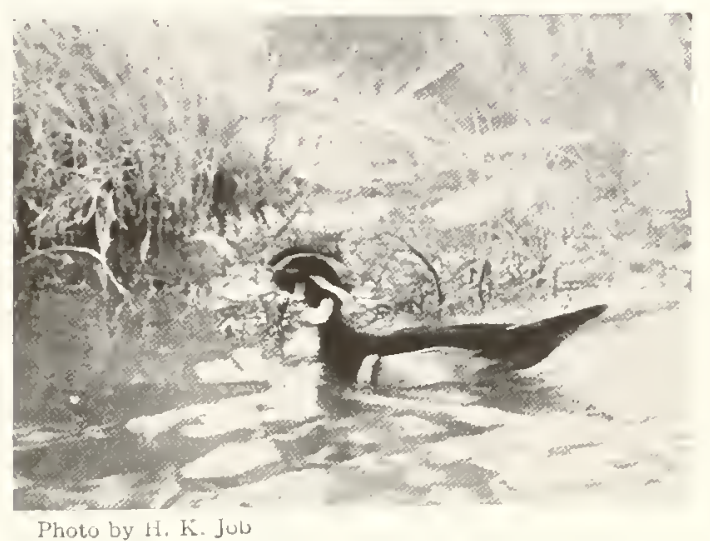

MALE WOOD DUCK
In one case which I witnessed, a Golden-eye, emerging from quite a narrow slit, had fairly to wriggle from side to side to force its way out.

After the nesting season the lNood Ducks are seen in snall flocks, probably family parties. They frequent the wooded swamps, and fly out to the more open ponds and streans about dusk. Where dead trees or branches have fallen into water, a typical sight, to be witnessed by creeping very silently through the bushes, is a row of these beautiful Ducks standing on the fallen timber enjoying the sunshine, some asleep, with bills under the wing-coverts, others preening their feathers, but all appearing very well contented with their lot in life.

This bird was classed by the Government as one of our vanishing species. This aroused widespread concern, and caused a number of States to prohibit shooting for terms of years;

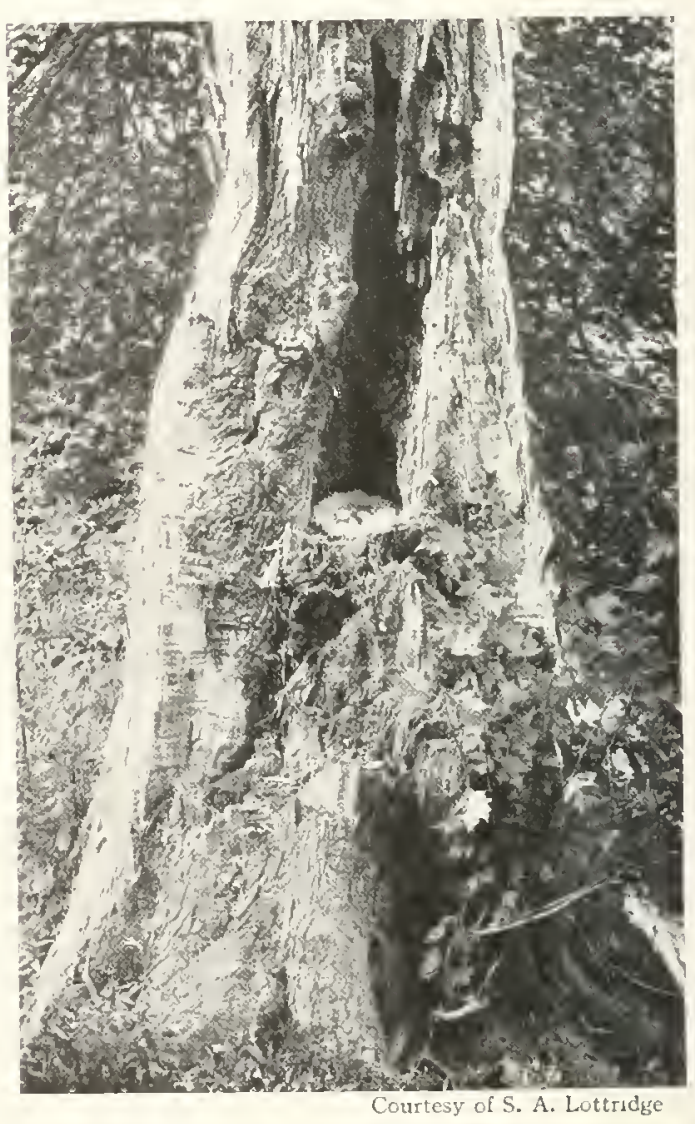

NEST AND EGGS OF WOOD DUCE

The regular nesting site is in a hollow tree, preferably in the woods, and is often a distance from water

the same action was adopted also by Federal regulations. There seems now to be a marked change for the better, in which result artificial 
propagation is playing an important part. It had been found that this Duck, throngh somewhat peculiar lut perfectly practicable methods, can be bred and reared in captivity, birds thus raised bringing high prices. Onite an industry arose in breediner American Woorl loucks in Holland and selling them in America. Now we have learned the process ourchelve, and anyone who desires can breed these beantiful birds in almost any small fencerl pool or pond. To those who desire it, the National Association of Andubon Societies, throush its lepartment of Applied Ornithology, imparts detailed information and furnishes literature. HlikBERT K. Tur.

\title{
REDHEAD
}

Marila americana $(E y / 0 n)$

\author{
1. O [T. Number 146 See (nhr l'late 16
}

Other Names.-American Pochard or Poachard; Red-hearled Broadbill; Raft Duck; Red-hearled Raft Duck.

General Description.-Length, 23 inches. Males have the head red, the neck and fore part of the body blackish, and the remainder of the body silver-gray above and on the sicles with a center line below of white: females have the head clulter and paler and the back browner. Both sexes have the bill short, the skull rounded and high-urched, the feathers on the head presinting a puffy appiance, and the hind toe with a web or lobe.

Color.- Anula Male: The entire head and the ncck all around, rich purc chostnut with bronzy reflections; back, white crossed with fine black wavy lines, the colors about cqual in amount, producing a distinct silvery-gray shade; sides of hody, the same; lower neck and fore-parts of body with rump and tail-coverts above and helow, blackish; wing-coverts, gray finely dotted with white: speculum, ash, bordered insirle with black; center line of body below, whitish; bill, dull blue with a hack band on end; feet, grayish-blue with

In the kedhead we have the comnterpart of the Canvas-back. The young of either can hardly be distinguished save by the shape of the lill, especially in the downy stage. Later they grow more apart, yet they retain many resemblances. Many a person who thinks he has eaten Canvasback has very likely dined instead on Redhear.

It is usual to find the Redhead the more numerous of the two, though along the Gulf coast of Touisiana, where Audubon found liedheads in plenty, I have found them now to lie rare, even in sections where the Canvas-back is abunrlant. Like lhe latter. it is found mostly on the sea-coast or on the larger borlies of water inland. It fecds much by diving, catcling small fish and other aquatic life. Also it is partial to roots and shoots of aquatic plants. I have ducky webs; iris, yollowish-oranut. Apult Feust. Head and upper nick, dull brownish-red, fading to whiter on cheeks, chin, and a space hehind eye; npper parts, brownish, the feathers with fraler edges; breast and sides, brownish, remainder of lower parts, white; bill, dull grayish-hlue with brown belt near end; feet and iris, as in male

Nest and Eggs.-. Nest: On ground near water or in a clump of deal reeds nver the water; bulky but well-constructed and hined with down. EgGs: 7 to 10 , pale olive or light buff.

Distribution.- North America; hreeds from southern British Columbia, central Atherta, central Saskatchewan, and southwestern Keewatin south to southern California, Utah, southern South Dakota, southern Minnesota, and southern Wisconsin; winters from southern liritish Columbia, Utah, New Mexico, Kansas, Ilhinois, Maryland, Delaware, and Massachusetts sonth to Lower California, central Mexico, and Florida; accilental in Jamaica; in migration casual in Alaska and regularly on the Atlantic coast north to southern Labrador.

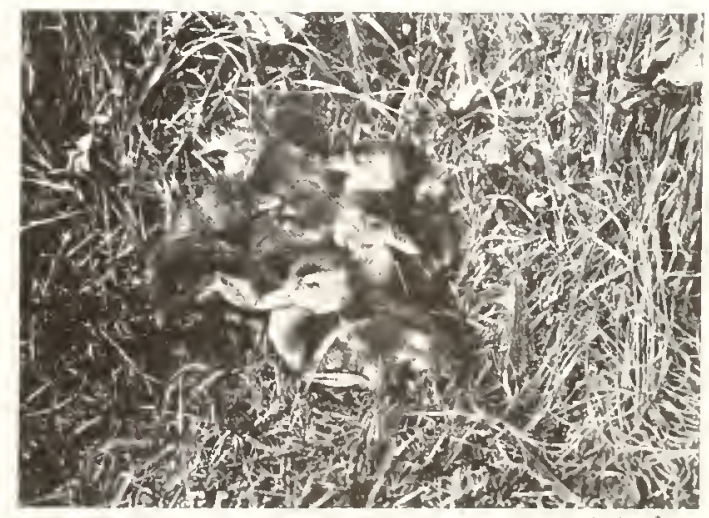

I'hoto by H. K. Job Courtesy of Outmg Pub, Cu.

YOUNG REDHEADS

Eighteen days of age 
watched both species together diving, and both exhibit the sane skill and celerity in this pursuit. with no noticeable difference.

This species, like the others, breeds in the sloughs and marshes of the Northwest, in about the same localities, but is generally the more common. Wherever I have found the Canvasback breeding. the Redhead has been there too. whereas the converse is not true; there are many sloughs in which Redheads breed where there are no Canvas-backs. If there is any distinction in the choice of nesting-sites, I should say that the Redhead is even more apt than the other to build out in reeds or canes growing in quite deep water. In northern Manitoba, on Lake Winipegosis, in places where the Canvas-back was nesting in meadows in the sedge, with water not knee-deep. I found Redhead nests among the outer reeds on the margins of boggy ponds. where one needed a canoe to reach them.

Perhaps the Redhead is not more prolific than any other Duck, but I have found larger numbers of eggs in some of their nests than is at all usual with others. the maximum number being twentytwo, the most I ever found in a wild Ducli's

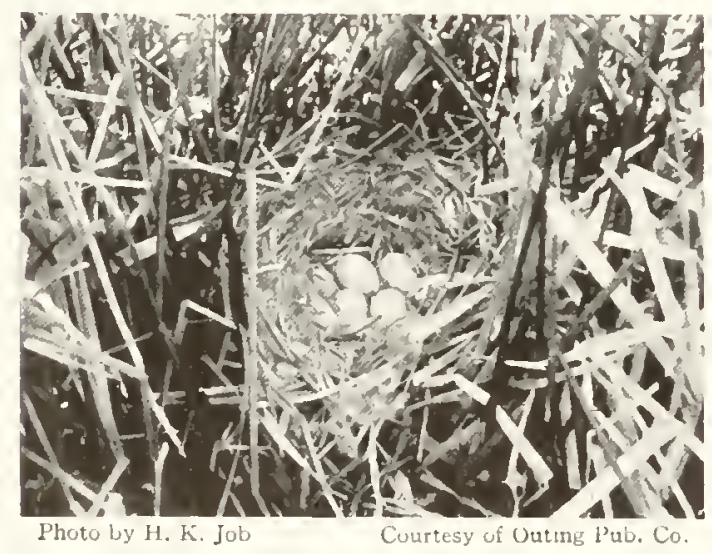

NEST OF REDHEAD

Built over water on edge of channel in a clump of flags and

nest, and all fertile and advanced in incubation. The eggs are quite different from those of the Canvas-back, being yellowish-white in color, and "ith a very smooth glossy surface, almost like billiard balls, and easy to recognize.

In the Northwest where wild Durks nest in abundance, it is not uncommon for individual

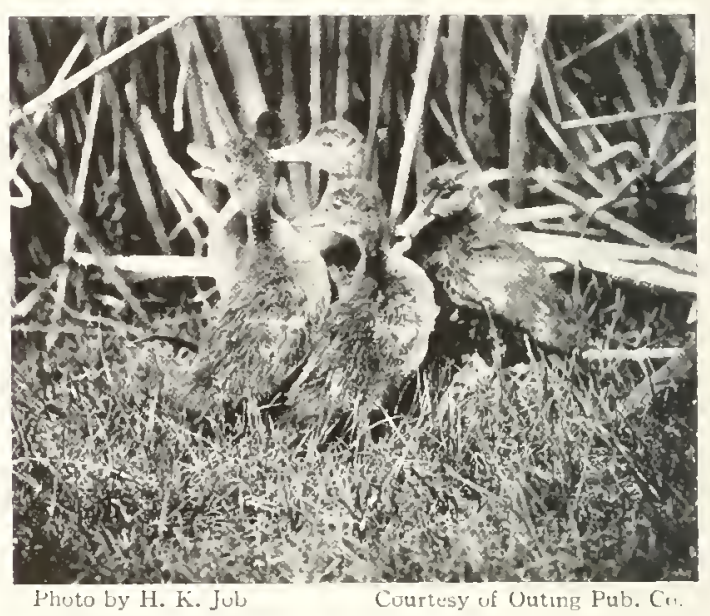

HARDY AND DOCILE

Some more young Redheads

Duclis to lay in each other's nests. The Redhead and the Ruddy Duck seemed to me to be especially addicted to the practice. They laid rather freely in each other's nests, and frequently palmed off their offspring thus on the unsuspecting Canvas-back.

Both kinds have been kept and studied in captivity. I have reared both from the egg to maturity, and under my direction have had both kinds breed. Though the young of both were quite easily reared, the Redhead presents fewer difficulties than the Canvas-back. It breeds more readily under favorable conditions, and the young are especially hardy and docile, though the young Canvas-backs, too, are quite manageable. Most experimenters, in time past, have had much less difficulty in keeping Redheads than Canvas-backs under artificial conditions.

As a result of this line of experimental research, I an confident that in the not distant future both kinds will regularly be propagated on estates where there are suitable ponds.

HeFHERT ki. Jor. 


\section{CANVAS-BACK}

Marila valisineria (I'ilsum)

1. () $t^{\circ}$. Immber 1.5

Other Names.- White-back: Bull-neck; Can

General Description.-- Length, 24 incles. Malea have the head red, the lower part of the nect and the fore part of the hody blackish, and the remainder of the body grayislo-white above with a center line luelow of white; temales have the head aml neck velhorishbrown and the body grayish-brown. Puth sexes have the profile lone and sloping llines of hood and bill nowly on ). bill three times as long as wide, and hind toe with web or lobe.

Color.- AduLT MILE: Feathers of entire head and upper neck (all around) dark reddish-brown. whemred un the crown and in frout of ese ann thruat in dusky: typer parts, white sery finely waved with narrow hlack rigzag bars, the gencral effect much lighter than in the Redlead: rest of plumage substantially as in that bird but upper tail-coverts and rear parts in general, uraver: bill. plain dusky blush, not handed: ieet. arayish-hlue: iris, red. Anct Female: Very similar to the female

\author{
See talor l'late 10
}

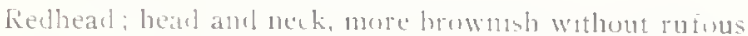
shade tut easily distinguinlued from that hirel by the maih lonere and differntly shaped bill: iris, redilingbrown: bill and feet, as in the male Canras-back.

Nest and Eggs. - Nest: Usually in tall rushes or reeds near water: bulky: conutruted of dry grass amt reeds: lined with domn. Elicis: o to no, pale nlive greets

Distribution.- Whule uf North America, hreedins from Oregon, Nevala, Nebraska and southern Minnesota northward to soutluwesten Keewatin. Great Slave Lake, Fort Yukon, and entral liritich Columbia; winters from southern British Columbia. Nevada, Colorado. Illinois, Penusylvania, and western New York sututh to central Mexico and Culf coast; in winter fomerly abundant in Maryland. Virsinia, and North Carolina. now rare: occasional south to Hlorida, and casual in the Nest Indies, Permuda, ind Cuatemala; in migration north rarely to Niw Brunswick and Nova Scotia

CANVAS-BACK (t) nat. Size $)$

The king of waterfowl, famous for the flavor of its flesh

Drawng by R. I. Brasher

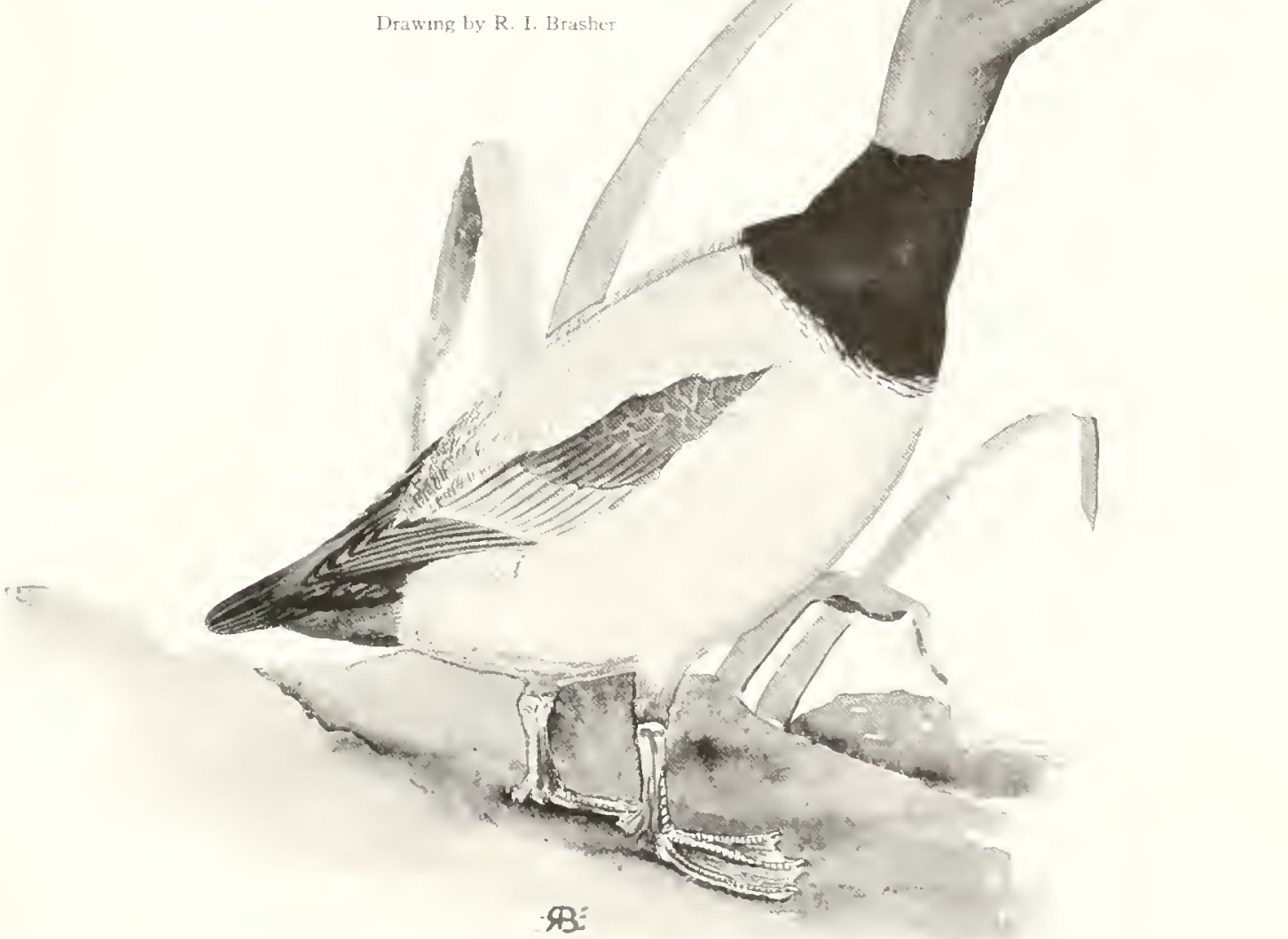


Though the Canvas-back has acquired a great reputation for the flavor of its flesh, it is probable that this characteristic taste depends upon

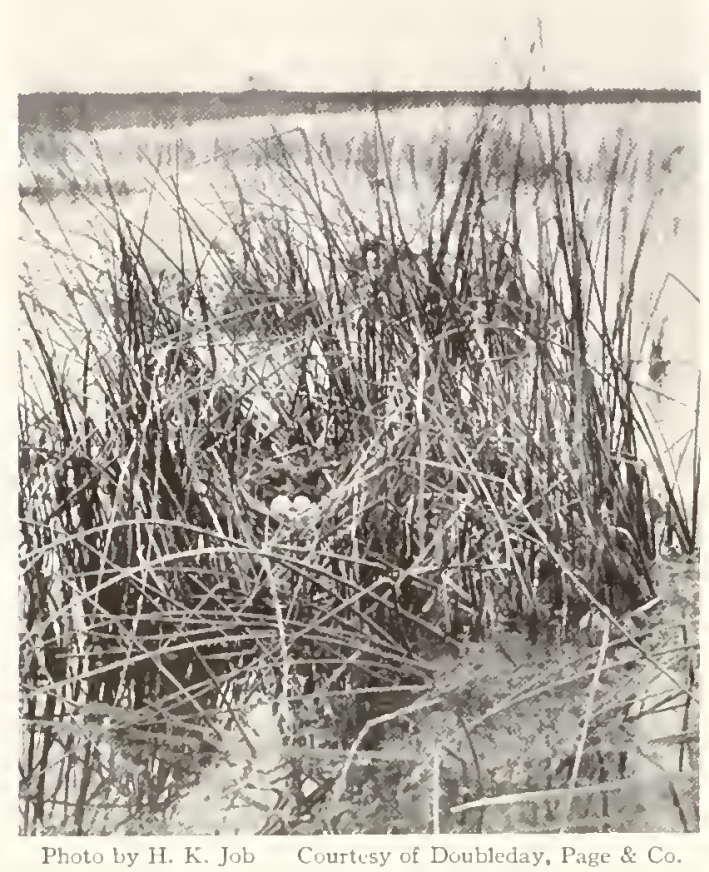

TYPICAL NEST OF CANVAS-BACK

the local food supply. Various water-plants besides the spicy wili celery please His MIajesty, the assumed king of waterfowl. so he is not always spiced up. At various tines when I have eaten Canvas-back, I really could not distinguish it from other good-meated wild Ducks. In northern Nanitoba the local hunters, I was tuld, when shooting, ustually single out Mallards first, finding then meatier and fully as tasty.

None the less is the Canvas-back a most fascinating waterfowl. Swifter than the proverbial arrow, the flocks fairly sing like bullets, as they pass down wind. Wonderfully agile and graceful are their movements in the water, especially when they leap, headlong for the dive, leaving one to guess where they may reappear. I once watched two Indians in the Northwest, each in a canoe, out on a large lake, try to catch a large young Canvas-back not yet quite able to fly. It took them about an hour of the liveliest sort of work before the bird rose, winded, to the surface and let one of them pick it up.

Its breeding-grounds are the marshes and sloughs of the interior Nortluwest - Nortl Dakota, Manitoba, Saskatchewan, and on up into the trackless wilds. There I have often found its nest, a semi-floating pile of dead stems, usually anid a clunp of reeds or rushes, or else in long sedge, but always in vegetation growing from water usually at least linee deep. The nest is a sort of deep wicker-basket. lined with dark gray down, in contrast with the white down of the Redhead. The eggs usually number eight to eleven, and are of a peculiar lead-bluish color, with some olive tinge, differing from that of any other Duck. The ducklings are of a decided yellow-olive color. From the first they may be distinguished from others by the straight profile of the upper mandible, always characteristic of the Canvas-back.

A most hardy species, it is driven southward only by the actual freezing of the lakes. Numbers of them stay in Lake Caynga. New York. and other similar bodies of water, till they sometimes freeze in and perish. One of their principal lines of migration is southeast across country from the breeding-grounds of the Northwest out to the Atlantic coast at Chesapeake Bay - a noted winter resort of the species.

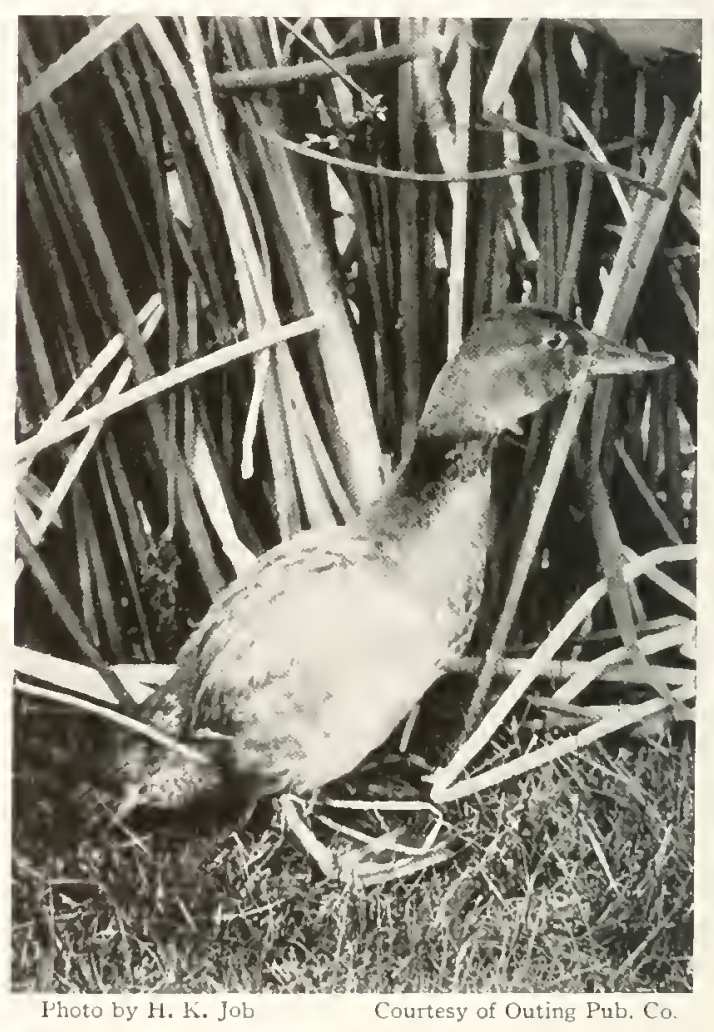

CANVAS-BACK

About six weeks old

Despite incessant persecution, I think that the Canvas-back is on the increase, owing to the stopping of the suicidal practice of spring shoot- 
7
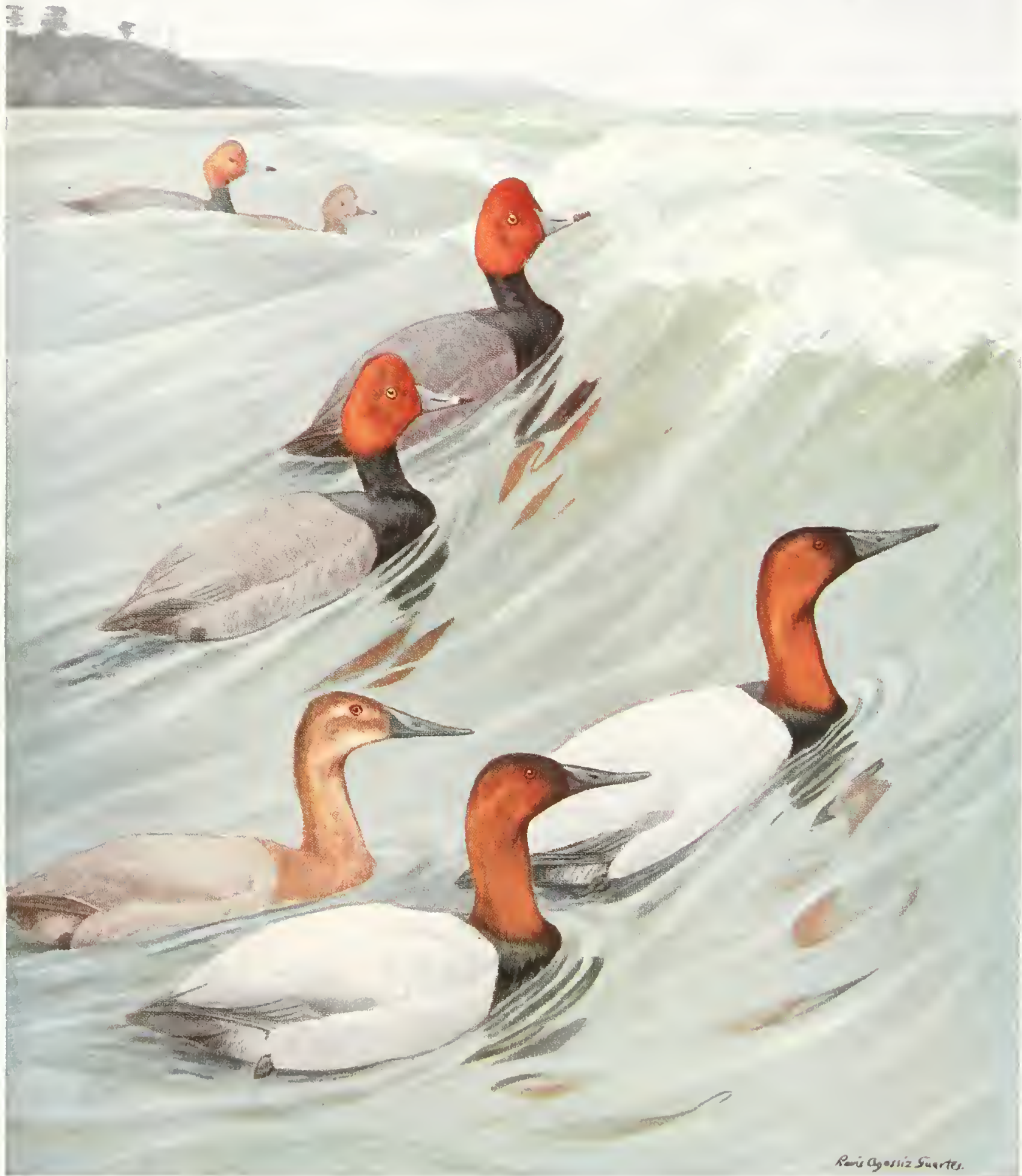

(
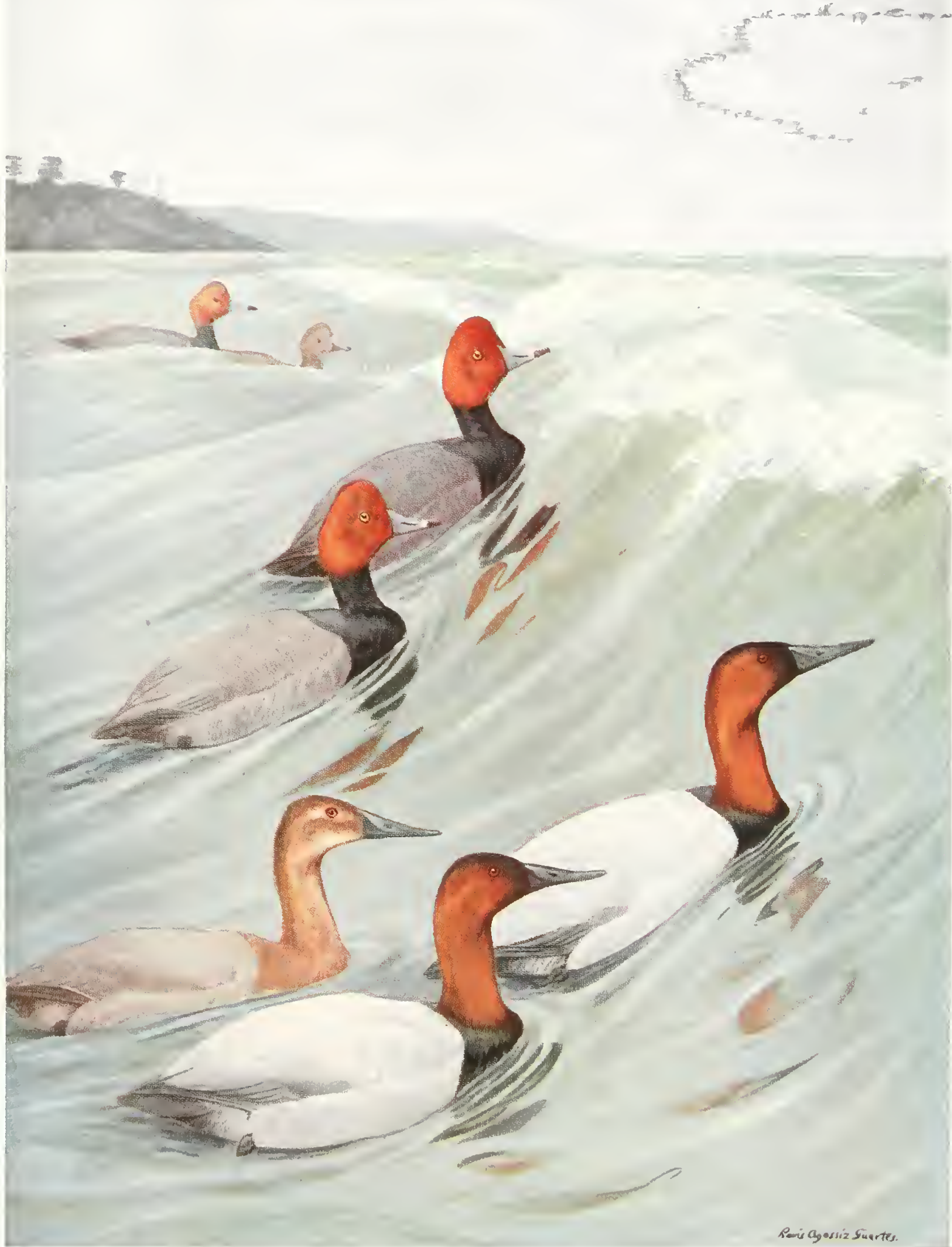

REDHEAD 

ing. Recently, I was studying waterfow] in the Mississippi Delta country, and was anchored off the exit of l'ass, in a dense log. This suddenly lifted, and we saw, stretched out before us, a solid "bed" of Ducks, surely half a mile long and one hundred yards wide. The guide and I estimated that there were thirty-five thousand, over one-lialf of whicl were Canvasbacks. And this was but one of many such hordes along that coast. (heer up, friends of wild birds, the "King" still lives!

\section{HEKBERT K. JoR.}

\title{
SCAUP DUCK
}

\author{
Marila marila (Linncus)
}

A. O. U. Number 148 See Color I'late 1 -

Other Names.- Mussel Duck; Green-head; Blackneck; Gray-back; Blue-bill; Greater Blue-bill; Bluebilled Widgeon; Broad-bill; Rait Duck: Flock Duck; Shuffer: Black-head: Big Black-head; Floating Fow?; American Scaup Duck; Greater Scaup Duck; Troopfowl.

General Description.-1ength, 20 inchea. Males have the fore parts black, and the rest of the boly white marked with black; females are dusky-brownish above and yellowish-brown below. Both sexes have the bill short and wide, and the hind toe with web or lobe.

Color.-ADelt Mile: Entive head, neck. and fore parts of body, black with green and bluish riflections; middle of back, shoulders, and most of under parts, white, everywhere except on flanks and abdomen marked with fine transverse zigzag lines of black; wingcoverts similar but more obscurely waved: greater coverts, tipped with black; speculum, white fromed in black of greater coverts and ends of secondaries; primaries, brownish-black; bill, dull bluish-uray with black nail; feet, bluish-gray: webs, dusky; iris, yellow. ADUlt Fenale: I bolt of pure white arownd face at hase of hill: black parts of male replaced by duskyhrown: upper parts in general. dusky-brownish without black marking; wing, as in male; below yellowishbrown, duskier on hreast and along sirles; center line of body, whitish: bill, legs, and eyes as in male.

Nest and Eggs. - NEST: In marshy ground, made of weeds, grass and lined with down. Egrs: 9 to 12 , pale buffy-olive or olive-gray.

Distribution.- Nothern part of northern hemisphere; in North America breeds from about the parallel $48^{\circ}$ northward, rarely on Magdalen Islands, in Ontario, and Michigan; winters from Maine to Flurida and the Bahamas, and from Alaska. Nevada, Colorado and Lake Ontario south to southern California, suuthurn New Mexico, and southern Texas; in migration rare in central Ungava, Newfoundland, and Nova Scotia.

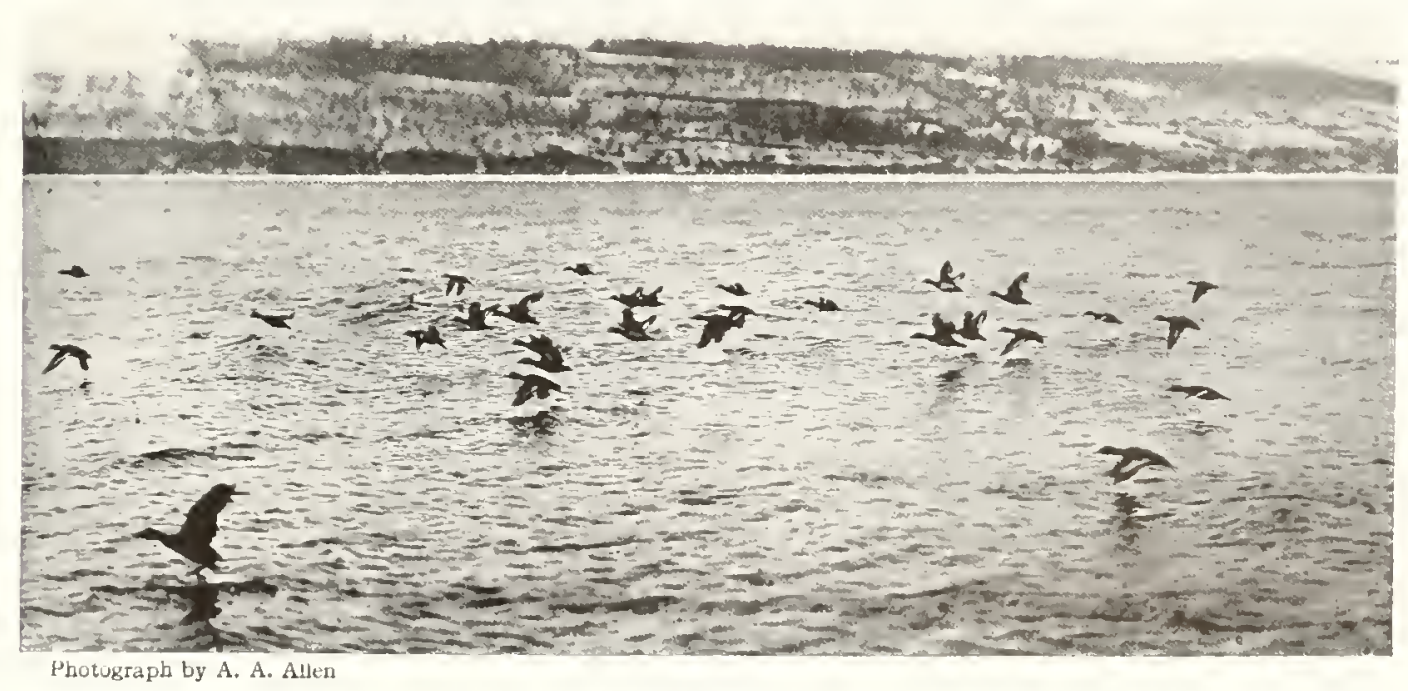

SCAUP DUCKS

Flying over Cayuga Lake 
Scanp is the European name of this bird but it will hardly be recognized uncler that title by American gunners. Here it is known as the Broad-bill, Blue-bill, Blue-billed Widgeon, Widgeon, etc. It seems more inclined to migrate to salt water than does the lesser Scaup, but this may be because its winter habitat is more northem and it is more likely to be driven to the open sea by the freczing of the fresh water. It $i$. conmon in winter in the unfrozen marshes and lakes of central New York, but if these freeze it muist go to the sea or starve. Therefore, the species is of ten more numerous in the late winter and early spring on the coastal waters than it is in the autumn and early winter while the lakes remain open.

These birds breed mainly in the Northwest in marshes and about numerous small ponds. Those that migrate to the Atlantic coast winter chiefly from Massachusetts to Chesapeake Bay, while farther south their place is taken mainly by the
Lesser Scaup. They are swift flyers, showing a stripe of white on the wing as they pass in a characteristic waving line. The male may be distinguished from the male lesser Scaup, which he closely resembles, by the color of the hearl which has a greenish luster in contrast with the purplish cast common on that of the lesser bird. At a distance both appear black: therefore, they are called Black-heads, indiscriminately. The white faces of the females of both species are very conspicuous.

The Scaup is an excellent diver and when it has been feeding in the interior on the roots of the wild celery (vallisneria) and other water plants, its flesh is fit for the epicure, and even when it feeds on the eel grass and other vegetation on salt marshes and flats it is fairly well flavored, but after it has fed for a time in salt water on crustaceans and mollusks it grows fishy and is not highly prized for the table.

Edward Howe Forbusi.

\title{
LESSER SCAUP DUCK
}

\author{
Marila affinis (Eyton) \\ A. O U. Number 149 Siee Color l'late 17
}

Other Names.-Black Jack; River Broad-bill; Creek Broad-bill; and names of the Scaup Duck with or without qualifying terms.

Length.- I7 inches.

Description.-Auult Male: Varies principally from the Scaup Duck in size; iridescence of head chicfly purple; flank feathers finely marked with black in a zigzag pattern; otherwise similar. Adult Female: Very similar to the female Scaup Duck but smaller and with breast and sides more inclined to rufous-brown.

The species of marine Duck which is probably under more general observation than any other is the Lesser Scauy. These are the Ducks which are seen in great "rafts" or "beds" just offshore in harbors or bays in winter and early spring nearly all along the Atlantic coast, from Long Island Sound to Florida. They feed, by diving, largely on mollusks or other sluggish marine life.

A flock settles on the water over some musselbed or clam-flat, and the members are soon diving actively. Another passing flock sees and joins it, and so on, unti] there may be several thousands. These usually stretch out
Nest and Eggs.- Similar to Scaup, eggs averaging smaller.

Distribution.- North America at large; breeds from the northern borders of the United States northward; more rarely to southern Montana, Colorado, northern Iowa, northern Indiana, and western Lake Erie; winters from southern British Columbia, Nevarda, Colorado, Lake Erie, and New lersey south to the Bahamas, Lesser Antilles, and Panana; rare in migration in Newfoundland, New Brunswick, and Nova Scotia.

into a long column, and keep swimming to windward, after satisfying their hunger, the whitepenciled backs of the males glistening britliantly in the sunshine.

In some localities, where they are not persecuted, these flocks become quite tame. At Tampa, Florida, they swim up right among the vessels lying at the wharves. The greatest sight is at Palm Beach, Florida, in Lake Worth. There flocks of them swim close up to the boat-landings back of the hotels. Guests throw out bread and are wonderfully amused to see wild Ducks fight for food within six to ten feet of their benefactors. Sometimes they even take food from 


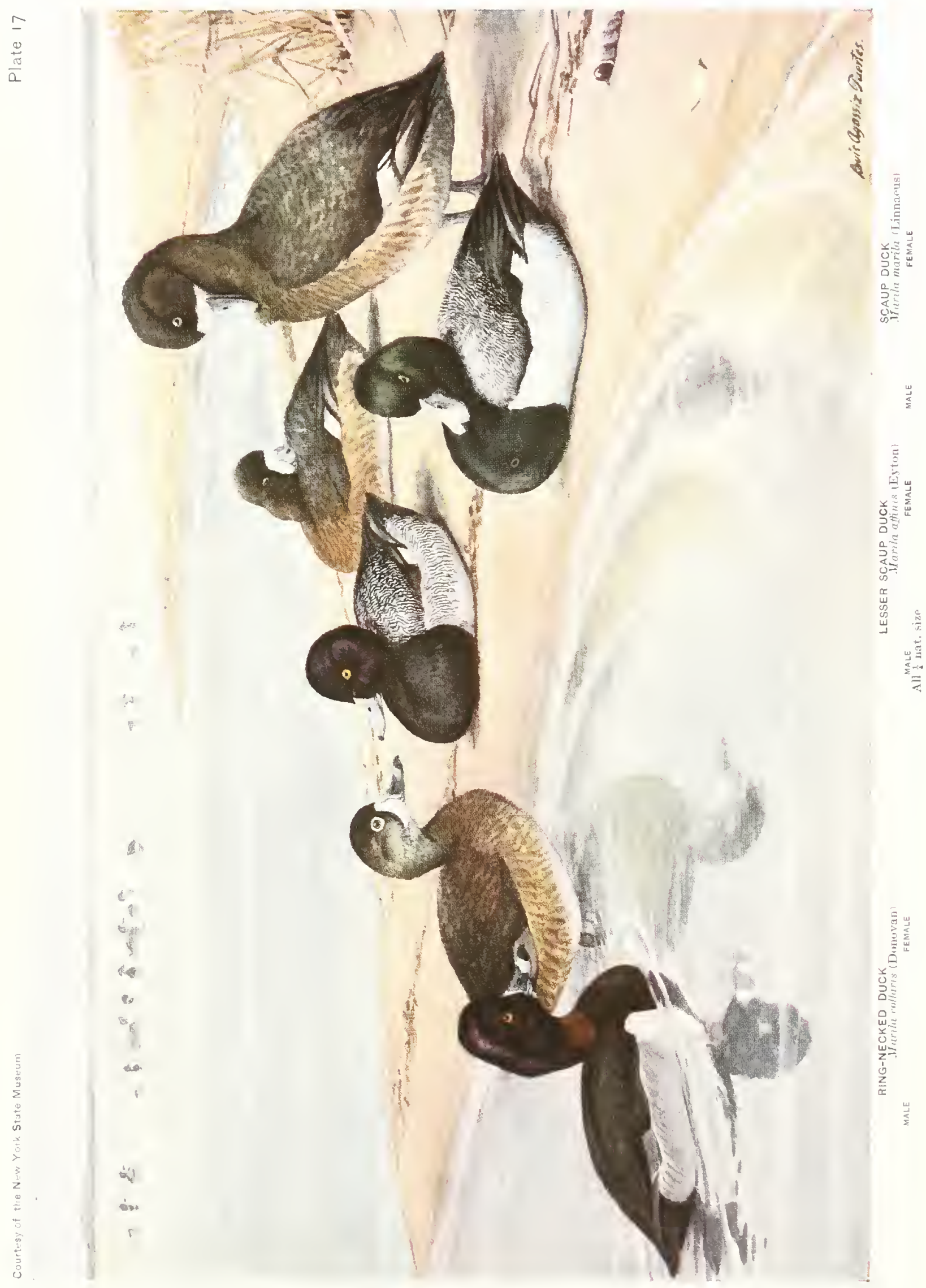



the outstretched liand. lihe strangest part of thes is that when they fly outsisle the protected area they lectome as shy ats ever.

Hardy, like all the marine bucks, they are especially late in arriving in antumn along the Atlantic const of the [nited States. Iittle is seen of them till November. It first they seem inclined to keep out un the open seat, and the sunners get little chance at them before severe cold drives them in.

One reason for this talliness is that, next to the Vhite-winged Senter, the Sean is ordinarily the last Duck to breed. They nest in the same of July. Is it is ten or cleven wetes before they can $f l y$, the young are not a-wing before late Sejutember or early October.

The nents are not wamally built mut over the water like those of the Cinvas-back and kedhead. hut either in weeds or grass un a dry slore. a little back from the water's edge, or telse in it firm tussock of meirlow rrass, riglit at the margin of a bogng slengh. where the female can slup into the water from the nest.

1 have raised the young by hand, and find them especially interesting. At lirst they are rather wild. great on jumping, but soon they become

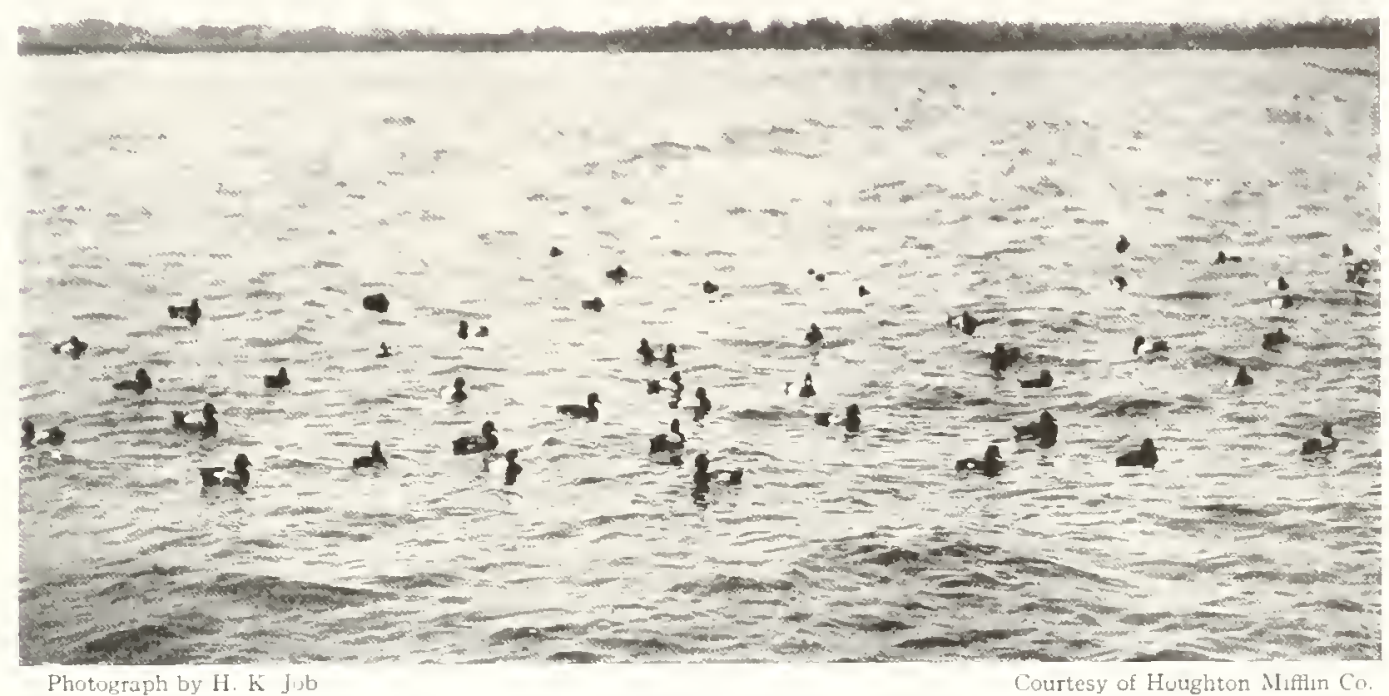

LESSER SCAUP DUCKS

At Palm Beach, Florida, in March

prairie marshes of the Northwest as do the Canvas-back and Redhead. There I have found that their layings are not complete until about tle middle of June. The first young broods are generally seen in the sloughs toward the middle very docile. Their soft flowny suits are of rich dark olive-brown color, and they erect their crown-feathers somewhat under excitement. which gives them quite a striking appearance.

HERBERT K. JOB.

\section{RING-NECKED DUCK}

\section{Marila collaris (Donor'an)}

$\therefore$ O U. Number 150 see Color l'late :

Other Names.-Rirg-bill: Moon-bill; Marsh Bluebill; Plack Jack: Bunty: Ring-billed Hlackhead: Pastard Froad-bill: Ring-necked Scaup Duck: Ring-necked Scaup: Ring-neck; Ring-billed Duck.

General Description.- Length, 18 inches. Males have head, upper parts, and breast black, and remaining lower parts white: females have upper parts brown, and lower parts yellowish-brown and white.

Color.- Anut MaLE: llead and neck all aronnd lustrous black with purple reflections; extrene chin, white: chestmut ring around loa'er neck: fore-breast and upper parts, black; speculum, bluish-gray: under 
parts from breast, white: lower abdomen and sides, finely marked with black; tail and under tail-coverts, black; wings, dark brown; bill, black a'ith bluish-gray base and a band of sane color ncar tip; feet, grayish blue with dusky webs; iris, yellow. Adult FEMALE: Forehead, narrowly, sides of face more broadly, pure white: rest of head, umber-brown, lightening on cheek and throat; a white cye-ring; upper parts, duskybrown; breast, sides of body, brown, variegated with lighter; abdomen, white; wing as in male; speculum, duller, bill, legs, similar to male; iris, brownish-yellow.
Nest and Eggs.- Nest : On the ground in marshes; made of dry grass and leaves and lined with down. Eggs: 6 to 12, usually 9 or 10 , rarely 15, grayish-white to buff.

Distribution.- North America in general; breeds from northern California, North Dakota, northern Iowa and southern Wisconsin northward; winters from southern British Columbia, New Mexico, northern Texas, southern Illinois and New Jersey south to Porto Rico and Guatemala; occurs in migration north to Newfoundland, Nova Scotia, and Quebec.
Distinctive peculiarities about the king-necked Duck are that it is almost never seen in large flocks, and seldom in open water. It swims buoyantly, and is much given to raising its head with a swan-like movement of its neck, and to erecting the feathers on the back of its head. It rises readily, from water or land, its wings whistling faintly; its flight is swift and direct.
It is expert at diving and in that way captures many minnows, crawfish, snails, tadpoles, and frogs, though a considerable portion of its food consists of the roots of aquatic plants and seeds.

Nowhere is this Duck recorded as very common. It resembles the Lesser Scaup in appearance, size, and habits, and the two species mingle together.

\title{
GOLDEN-EYE
}

\section{Clangula clangula americana Bonaparte}

\author{
1. O. U. Number 15! Siee Color I'late 18
}

Other Names.-Golden-eyed Duck; American Goldeneve; Garrot; Whistler; Whistle-Duck; Whistle-wing; Brass-eyed Whistler; Whifler; Jingter: Merry-wing: Great-head; Bull-head; Iron-head; Cub-head; Copperhead; Cur; Spirit Duck.

General Description.- Length, 20 inches. Males have the head greenish-black, the fore part and sides of the body white, and the back and tail black; females have the head and back brown and the under parts grayish. Both sexes have fluffy crests, and bills that are short high at the base, and narrowed near the tip.

Color. DuLT MALE: liead and neck, glossy grecnish-black; a large oral spot in front and bilow eye. white; lower neck, under parts, middle and greater wingcoverts, most secondaries, and some shoulder-feathers, white: long inner secondaries, edge of wing, primary coverts, primaries and back, black; tail, ashy; some flank feathers with narrow dusky streaks on top edge; bill, dusky with yellow tip; feet, orange, dusky webs; iris, yellon'. AdUlt finale: Chin, upper throat and head all around, brown; neck and entire lower parts, dull whitish, shaded on breast and sides with ashy; upper parts, brownish; some feathers of upper back with lighter edges; upper tail-coverts, tipped with pale brown; bill. feet, and eye as in male; wlite wing spaces much more restricted.

Nest and Eggs.- Nest: In hollow tree, made of grass, leaves, and moss and lined with down. Egas: 9 to 12 , light greenish.

Distribution.- North America; breeds from central Alaska, across British America to Newfoundland, south to southern British Columbia, southern Montana, northern North Dakota, northern Michigan, northern New York, and northern New England; winters from about the parallel $43^{\circ}$ south to southern California, central Mexico and Florida.
The Golden-eye is commonly known as the Whistler because of the peculiar penetrating whistle made by its wings in flight. There are times when these cutting strokes can be heard even before the bird itself can be clearly made ont. The Whistler breeds from just above the latitude of Massachusetts northward to the limit of trees, making its nest in a hollow tree near some fresh-water pond or river. It breeds in the interior of Alaska, but is very rarely seen on the coast. It is found almost throughout the interior of North America, and is distinctively a fresh-water bird until the frosts of winter hegin to close the ponds and rivers, when most of the Whistlers in New England go to the salt water. Some, however, still remain in the unfrozen fresh waters of the North, South, and West.

The Whistler is a remarkably active bird, 


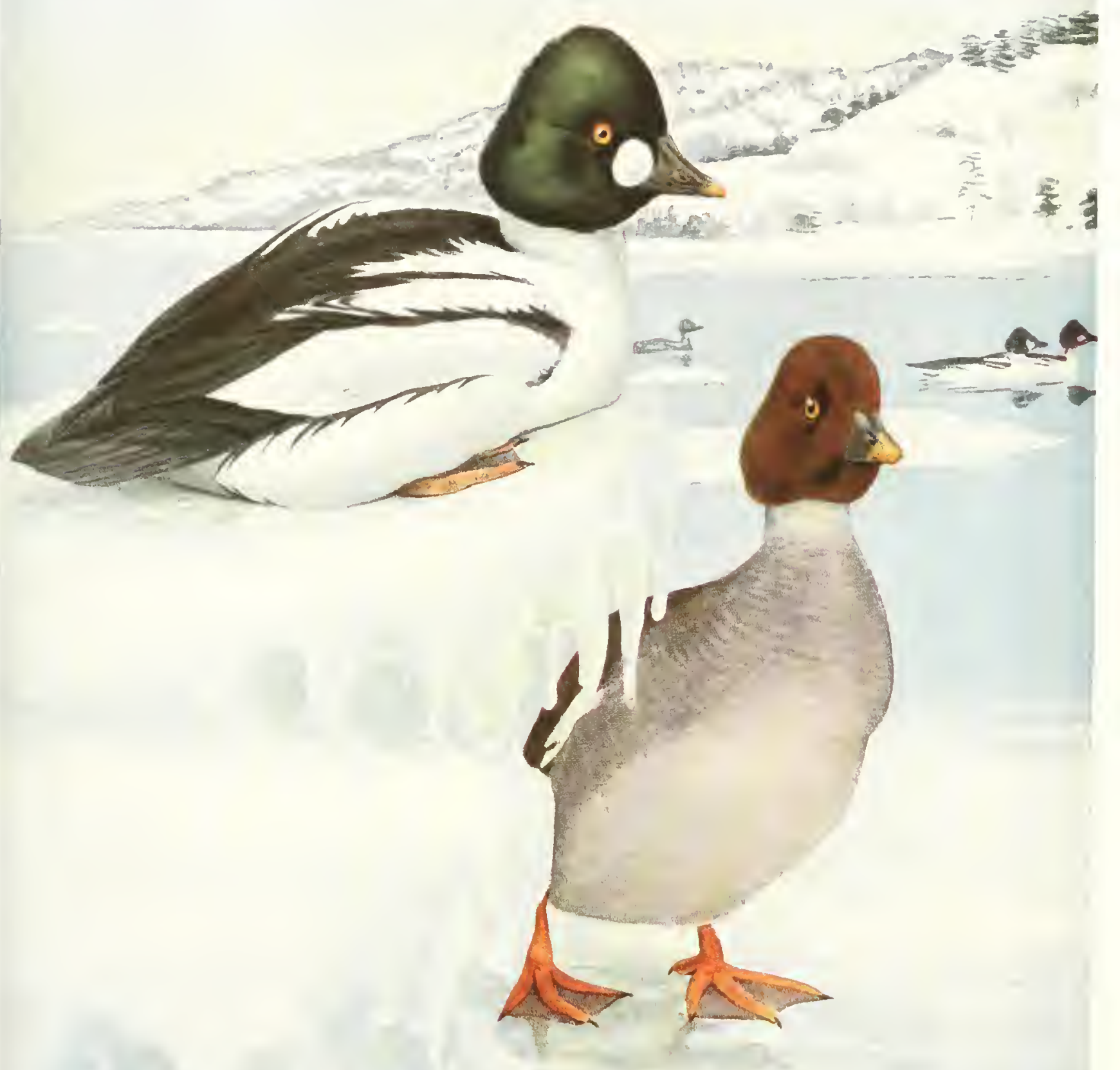

Rours aqussie Exurtes. 

dives like a flash, and rarely comes well to decoys. It has learned to be extremely wary and cautious, but in stormy weather it often kecjs close to shore, which gives the shore gumner his chance. It does not always dive for its lood, but sometines dabbles in the mud along the shore with Blue-bills or other Duclis. Offshore it feeds largely on mussels. which it dislodges and brings up from the botton. Audution found it feeding on crawtish on the Ohio River. Wayne says that in Soutl Carolina a small mussed of salt or brackish water is its favorite fond. Knight has observed it feeding on these and also on some vegetable substances. He states that it eats small fish and fry also, and along the coast it feeds on mussels and wher mollusks; but Elliot belicves that in the interior the Whistler feeds on vegetable matter, such as grasses and roots.

When feeding there and when it first comes to the salt watter, in alutumn, the young are fairly tender and well-liavored, being about on a par with the filuc-bill as a table delicacy. Some of the residents of lape (ond consider it superior to the Scoters. Nuttall says that it eats fresh-water vegetation, such as the roots of Equisetums and the seerls of some species of Polygonums.

Edward 1 lowe forbush, in Game Birds, W'ild-Fowl and Shore Birds.

\section{BARROW'S GOLDEN-EYE}

\section{Clangula islandica (Gmelin)}

1. O U. Number $1 \$ 2$

Other Names.-Rocky Mountain Garrot; Rocky Mountain Golden-eye.

Description.-Anuto Male: Coloration exactly as in Golden-eye except that the whito spot in front of oye is trimele-shaped and white of wing is divided by a dark bar formed by bases of greater enverts: averages larger than the Folden-eye; hill, differently shaped, being shorter and deeper at hase. Adult Fenule: Indistinguishable from the female Golden-eye in color but separable by shape of bill.

Nest and Eggs.- NEST: In hollow trees; made of grass, leaves, and weed stems and lined with feathers and down. Eocs: 6 to in, dull greenish.

Distribution.- Northern North America; breeds from south-central Alaska and northwestern Mackenzie to sonthern Oregon and southern Colorado, and from northern Ungava to central Quebec: winters from southeastern Alaska, central Montana, the Great Lakes, and Gulf of St. Lawrence south to central California, southern Colorado, Nebraska, and New England; accidental in Euroje; breeds commonly in Iceland, and is a rare visitor to Greenland.

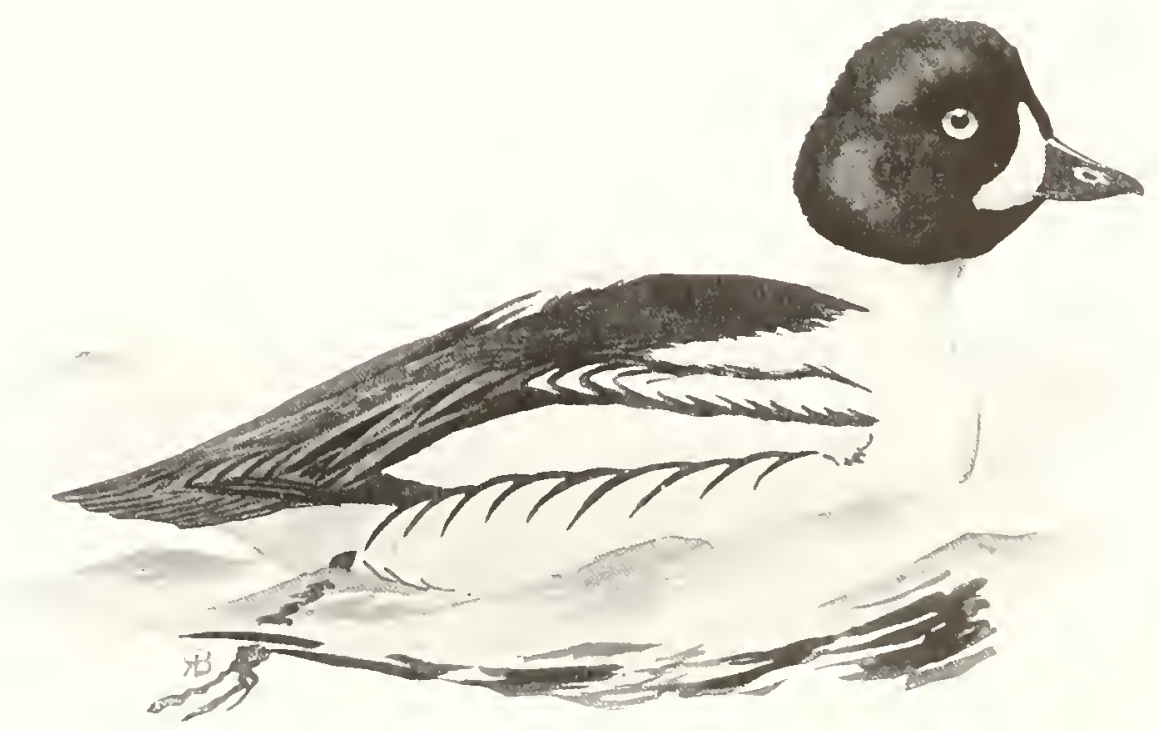

Drawing by R. 1. Brasher

BARROW'S GOLDEN-EYE ( $\frac{1}{8}$ nat. size)

An active bird, diving like a flash, and rarely coming well to a decoy 
Barrow's (jolden-eye closely resembles the Anerican Golden-eye. It is not easy to distinguish between the males at a distance and it is impossible to tell with certainty to which species the females and young belong. Their habits are also similar but the Rarrow's breeds farther south and winters farther north. Its note is a low croaking sound.

\title{
BUFFLE-HEAD
}

\section{Charitonetta albeola (Limaus)}

\author{
1. O. U. Number 153 See Color I'late to
}

Other Names.- Buffle-headed Duck; Diuffalo-headed Duck: Bumblebee Duck; Butter Duck; Butter-ball ; Butter-box; Butter-back; Spirit Duck; Wool-head; Hell-diver; Conjuring Duck; Narionette; Dipper; Dipper Duck; Dapper; Dopper; Robin Dipper; Little Black and White Duck (male); Little Brown Duck (female).

General Description.- Length, 15 inches. Males are black above, and white below; females are grayishbrown above, and whitish below.

Color-Adult MAle: Head, puffy and crested, and iridescent, purple, and green; a large white patch on each side behind cye, runing some distance below eje and joinm its fillow os'er top of head; neck all around, under parts, shoulders, nearly all wing-coverts, and most secondaries, pure white; some shoulder feathers edged with black, forming a narrow length-

This little Duck is widely known on fresh waters, for it is by nature a fresh-water bird, which in autumn and winter frequents the seashore. It was named Buffle-head (or Buffalohead) because of its large fluffy head, which looks particularly big when its feathers are erected. The Buffle-head was not much sought by gunners until within recent years. Its great weakness is a fondness for decoys.

The male is a handsome bird; its bright contrasting tints are highly ornamental, but, as is usual among Duclis, the female is full and inconspicuous in color and much smaller. My youthful experience with the 1)ipper luck convinced me at the time that it could dive quickly enough to dodge a charge of shot: but its immunity from danger probably was due more to my inexperience and to the inferior quality of the gtm and ammunition used than to the quickness of the bird. However, it dives like a flash, and is very likely to escape unless the gunner, warned by experience, uses a close shooting gun, judges well his distance and holds exactly right. When a few are together one usually keeps watch when the others are muler water and warns them of danger by its short quack.

In flight it hurls itself througl the air with tremendous speed, its rapidly moving wings almost forming a haze about its glancing form, which buzzes straight away as if bound for the other wise line: back and upper parts, black; tail, grayish; bill, dull bluish-gray with black tip and base; feet, pale flesh color; iris, brown. Adult Female: Head, thinly crested, dusky-gray with a lighter patch on side; upper parts, grayish-brown; wings the same zeith small white arcas; below, whitish shaded on sides of neck and body with ashy; bill, feet, and iris, as in male.

Nest and Eggs. - NEST: In hollow trees or stumps ncar water; lined with down and feathers. EGGs: 9 to 14 ; from creamy-wite to buff or dull olive.

Distribution.- North America; breeds from Maine, Ontario, Iowa, northern Montana, and British Columbia north to Alaska; winters from British Columbia, Aleutian Islands, Idaho, Colorado, Missouri, southern Michigan, western New York, and New Brunswick suath to northern Lower California, central Mexico, Louisiana, and Florida.

end of the world. It alights on the water with a tumultuous splash, sliding along for a little distance over the surface. When it has once alighted it seems to prefer the water to the air, and will often dive, rather than fly, to escape langer. It is sometimes so fat that in the 11 iddle States it is known as the Butter-box or Butter-ball, but the flesh is not usually of a very good quality. As with all Ducks the quality of its flesh clepends largely on the character of the food it has recently eaten, and this species, like others, is much more palatable when killed in the interior than when taken on the sea-coast.

In February the males begin their mating antics, when they have a habit of stretching forth the neck and erecting the glossy feathers of the luead as it is moved back and forth, so as to display their beaties to the hest adrantage in the sunlight. They are quite quarrelsome in the mating season and fight furiously for the possession of favored females.

Nuttall says that the Buffle-head feeds principally upon fresh-water and submerged vegetation, and that it sometimes visits the salt marshes "in quest of the laver (Clada lactuca)," as well as crustacea and small shell-fish. Iudubon states that it feeds on shrimps, small fry, and bivalves in salt water, and on crawfish, leeches, snails, and grasses in fresh water. It also takes locusts, grasshoppers and many other insects. 
When it is considered that the minnows on which the Buffle-head feeds to a considerable extent eat egers of trout and other food fishes. it secms probable that it is a useful biril, and certainly it is a very interesting one. Its dimimution on the Atlantic sea-board has been deplorably rapid. In Is-o Samuels regarder it as a "very common and wel! known birl" in New Encland and abunlant in migration. At its uresent rate of decrease, another century will see its extinction as surely as the last century saw that of the Great Auk and the Labrador inack. Its rate of decrease should be watcherl, and, if necessary, a close season should he declared for neveral years in cvery State and prosince where it breeds or which it visits in its annual migrations. It is unsafe to procrastinate in matters of this kind.

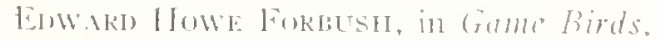
l'ild-Fond and Shome firds.

\section{OLD-SQUAW}

\section{Harelda hyemalis (Limncus )}

1. O I Number 154 see color Itlate 20

Other Names.- Long-tailed Duck: Long-tail : Swallow-tailed Duck; Sunth-southerly; Old Wife: Old lnjin; Old Granny: Oll Molly; Old hilly: John Connolly; Uncle Huldy; Coween or Cowheen ; Calloo; Cotkawee: Scoldenore: Scolder: Quandy: Squeaking Duck; Winter Duck: Hound.

General Description.- Length, male 23 inches: female 10 inches. In summer the males are black and brown above, ant white below: in winter they show more white and less dark: fumales are grayinh-brown above, and whitish shaded with rlark below. Poth sexes are without crests, have comparatively short necks, and short bills; males have long slender tails, the two central feathers of which are elongated.

Color.-Adtit Ml.me in SUMmer Plumage: Hures broadly, space abuat eye sides of head and cheles. sitery aray: forcheat, cromen, and back of had. Hackish-brath: rest of neck all around, upper hack, and breast, dark chocolate-brown: upper parts and long tailfeathers, blackish; shoulders, yellowish-brown striper] with darker; shorter tail-feathers, whitish; wing. dusky: under varts, white: hill. fleh color with black tip and base; feet, hluish-gray with dusky web; iris, yellow, orange, or red. Adult MaLe in WIAter: Houd. nock. fore-back, and uppor hrost. athite; a may patch commencin! in front of ele, includin! chects and side of houl, crtendin! down side of neck in a point, chang- ing to rufous: upper larts, including long tail-feathers. black: shoulders, broadly white: lower breast with a large patch of deep brown rounded behind, ruming up and meeting black of back: rest of under parts. pure white. Adut lemile in Sum mer: Head, neck, and upper parts, dark grayihb-brown, paler on throat, with a grayish-white patch around eye and another below on side of neck: under parts, white shaded across breast and on sides with arhy-brown; hill, mostly duky with a light space in center. ADELT FEM.ME I. WINTER Crown, back of head, and back of neck, mottled grayinh and bruwn: rest of head and neek, white with a dusky patch back of eye; upper parts, ducky-brown: thonlders, mixed with lighter brown and gray; breast thared with grayish: rest of under parts. white; bill. dusky.

Nest and Eggs.- Nest: Placed under bushes or urass near water: constructed ni grasses and dry weed tems and lined with feather and down. Eas: 5 to y. from dull pea-green 20 light olive-huff.

Distribution.- Northern hemisphere; in North Inerica breed from Alaska across British America to Labrador. principally heyond the tree limit: winters from the Alentian Islands to Washington aus from the Gulf of St. Lawrence suuth to the Great Lakes and North Carolina and rarcly to Colorath. Texas, Louisiana. and Florida.

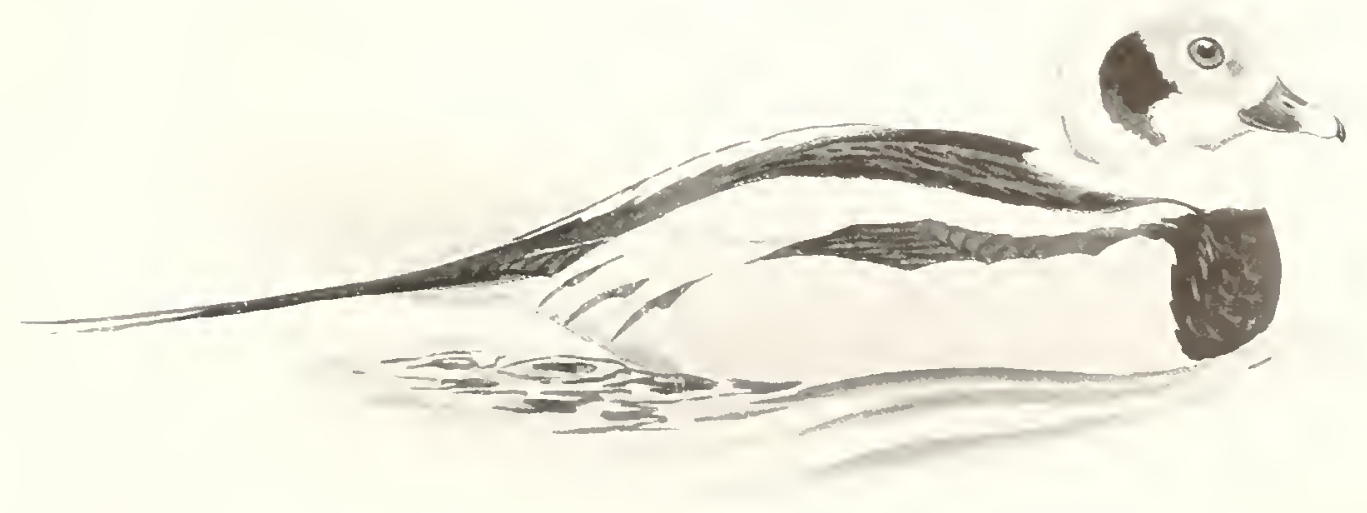


We class the Old-squaws among the Sea Ducks and seemingly they do prefer to live about sea-water. They occur inland, however, on many of the larger rivers and lakes. On the Pacific side of the continent, California is their southern limit, and on the Atlantic coast they go down to North Carolina and sometimes to Florida. The summer home is in the high northern latitudes. Their food consists mainly of shellfish and crustaceans. Wayne reports finding them in company with Surf Ducks feeding on mussels along the South Carolina coast.

As they are not regarded as good for the table. market-hunters seldom kill them, and only the less experienced sportsmen shoot them if other Ducks are within reach. Their habits, including their manner of flying, feeding, and diving, are very similar to those of the Scoters, with which birds they much associate.

Along the North Carotina coast the Old- squaws assemble in large focks, especially in the spring. At this time they are often very noisy; in fact no wild Duck in North America has so much to say to his fellows as this handsome species. This propensity for ceaseless chattering is given as the reason for naming the bird "Old-squaw." Many hunters call it "Old South-southerly," through some fancied resemblance between those words and the notes of the bird. Another local name is "Longtail." the extended tail-feathers of the male, especially in the spring plumage, giving point to this name.

Old-squaws are said to indulge in a variety of interesting aerial evolutions during the mating season. At great speed they chase one another through the air and often dart down to the water and disappear, as they carry on the chase for a bricf time beneath the surface.

T. Gilbert Pearson.

\section{HARLEQUIN DUCK}

\section{Histrionicus histronicus (Linnaus)}

\footnotetext{
1. O. [T. Number I5s Sec Color l"late ig
}

Other Names.-Painted Duck; Mountain Duck; Rock Duck: Lord-and-Lady; Squealer; Sea Mouse.

General Description. - Length, 17 inches. Males are deep bluish-slate; females are brown above, and grayishbrown below. Both sexes have small crests, short bills, and long, sharp tails.

Color.-Adult Male in Futh Plumage: General color deep bluish-slate with a purplish tinge blackening on top of head. lower back, rump, and tail, a darker shade on head and neck than on breast and back; a white patch between bill and eye curving upward and backward, changing to chestnut along nape; a round white spot on side of head, a long white streak on side of upper neck, a white collar around neck, complete or not - all these marks with black borders; a white crescentic bar in front of wings; two white streaks on hack; outer webs of inner secondaries and a bar across end of greater coverts and some of the secondaries, also white; speculum, dull purplish ; sides and flanks, broadly chestrut with a small white spot at root of tail; bill. dull olive, lightening on sides; feet, grayish-blue with dusky webs; iris, brown. Three years required to reach this perfect plumage; male usually seen intermediate between this and plumage of fernale. Adult Female:
Ilead, neck, and upper parts, dull dark brown, deepest on head and rump; lower parts grayish-brown whitening on abdomen: a lighter spot in front of eye, another larger one below it and still another one further back on side of head, all obscure whitish; bill, dusky; feet. dull leaden-gray; iris, brown. Young: Similar to adult female in summer.

Nest and Eggs. - Nest: In hollow tree or stump, under driftwood or in crevices of rock, usually near swiftly rumning streams; constructed of weeds, grass, and leaves and lined with down and feathers. EGGS: 6 to 8, pale cream or buffy.

Distribution.- Northern North Anerica and eastern Asia; breeds from Alaska, on the Arctic coast, to Greenland, south to British Columbia, central Mackenzie, northern Ungava, and Newfoundland and in the mountains to central California and southwestern Colorado, northeastern Asia, and Iceland; winters on the Pacific coast from Aleutian Islands to California, in the interior to Colorado, Missouri, Lake Michigan, and western New York, and on the Atlantic Coast from Gulf of St. Lawrence regularly to Maine, rarely to New Jersey, and accidentally to Florida; accidental in Europe and not rare in Asia south to Japan.
Harlequin, well named! fantastically decorated. but still a thing of beauty. Delightful in color, elegant in form, graceful in carriage, rightly are its little companies called the "Lords and
Ladies" of the waters. This is the loveliest of the Sea Ducks, but its beauty is reserved mainly for the cold and inhospitable North, and the wave-lashed rocks of isolated ledges in the 
wintry sea. It breeds principally in the Far Nurth alomg the coast of the Arctic (kean. let. strange as it may seem, some inclividuals prefer the slacial treans in the mountains, and follow the higher ranges as far south as California. where they rear their young anicl snow-clarl peats and disport themalves in the framing mountain torrents mntil the rigors of approaching winter drive then tor the sea.

Nests have been fomml on the eromnd, in holes in rock am lonks, and in hollow trees. The downy youne take to the water as sonn as they become strong and then they tmulle abont anong the rocks and rmahing waters perfectly at homc as are their parents on the sea. In the breeding season the llarleduin is quite a solitary hird but there apprear to be many mmated or infertile ones or posilly those that have finished breeding,
Which may be fomm on the sea in Nity and the stmmer montlis. Such little flocks, often led by a full-plumagerl male, enjoy themsedves on the waters of l'nget Sombl among the unter islanele, diving platying alwut on the -urface and dressing their plumase, apparently without a care in the world. On the Atlantic colst they are scarcer now in 11 aime and rarer still to the southwarl hut in some severe winters flocks are seen south of Nantucket and Marthas V'ineyard off the cuast of Massachusetts. They are fond of swift waters, mad surrents, tide rips and flowing seas; are tremendunsly tomsh and harly, and feed largely on mussels, which they get by diving, often to considerable depths. When mesting along momtain streams they eat many insects.

Edward Huwe Forbush

\title{
LABRADOR DUCK
}

\section{Camptorhynchus labradorius (Gmelin)}

\author{
1. (1) 1 . Vumber 150
}

Other Names.-Pied Duck: Skunk Duck.

General Description.- Le'ngth, 29 inclues. Males were black will white heads and marking : ienales were grayish-lown ahore, and graysh-white below.

Color. Ancit Mnle: Hearl and upper neck. white with a longitudinal black stripe on crown and nape: lower neck, ringed with black continuous with that of wpper parti; helow this a white half-collar continuous with that of sloulders: rest of under parts, black: wing-coverts and sccondaries, white, some of the latter marmined with black; some long shomker-feathers, pearly-sray; primaries, their coverts, and tail-feathers,

The most remarkahle fact about the Labrador Duck. Which seems to have been common on the - Atlantic coast one hundred years ago, is that it is now extinct and no one knows why. If it is a fact that it bred only on rocky islands about the Gulf of St. Lawrence and the coast of Labrador, the feather hunting of the eiglnteenth contury and the ecrging and shooting of the nineteenth probably resulted in its extinction. but no one. now living, kwows to a certainty that it bred in Librator. John W. Andulum was shown nests at Blane Sablon that were said to be those of this species. Newton writes that it was common in summer on the coast of Lilorador until alont r.42. Major ling writes (18, so) that it was common on the northern shore of the (inlf of St.

$$
\text { Vi31.. } 1 \text {-I I }
$$

brownivh-black; bill, black with urange base and edlues: ieet, grayish-blue with dusky webs; iris, chestnut. Antht Fiew.ale: Almse, grayish-brown : several secondaries white, forming a speculum, but no white on wingcoverts or houlders; below, gravish-white barred with dull brown: a spot on side of head and anuther in iront of eye, white; bill, feet, and iris, as in male.

Nest and Eggs.- Lnknown.

Distribution.-Formerly along the northern Atlantic Cuasts: supposed to have brest in Lahrador and to have wintered from Nova Scotia south to New lersey: now extinct.

Lawrence and bred there, but gives 120 dates. I have seen no other eridence of its breeding in Labrador. There are no definite records of its nesting, and not one of its egers is in existence. It may have liresl much farther north hut so far the recorls show that no one has ever seen it to the northward. We must be satisfied, then, with the probable explanation that, like the Great Auk, the species breal more or less locally. and was exterminated in much the same way. l'robably the exact fates never will be known.

The history of the bird is lorief. It was lirst made known to scicnce ly. Fmelin in r - RS, nearly thirty vears alter the New England feather hunters had ceased to raid the islands where it was believed to breed, the birds having become 
so reduced in numbers that feather hunting was no longer profitable. Audubon never saw it alive, but asserted that it remained off the coast. of Maine and Mĩassaclusetts all winter and was nnknown south of Chesapeake Bay. Dekay (is 44 ) averted that the hivel was well known to gumners on the New Tork coasts, but Giraud, writing about the same time, regarded it as rare there. Elliot says that between is6o and IS70 he saw a considerable number of the species in the New York marliets, but that a full-plumaged male was excedingly rare although no one inagined that the species was on the verge of extinction. The last Labrador Duck on record died by the hand of man near Long Island. New
Little is known about the habits of this Duck. ]t frequented sandy shoals off the New England coast and was so tame and confiding that it was not difficult to shoot.

It was said to feed largely on shellfish, and Audubon relates that a bird stuffer at Camden, New Jersey, had many fine specimens taken with hoolis baited with mussels. It was a strong flyer and a good diver and, as is the case with most Sea Ducks, its flesh was rank and fisly. It was hardy and in every way well fitted for the battle of life but was not able to cope with civilized man. It is significant that its extinction occurred in the nineteenth century when marked improvements in firearms were

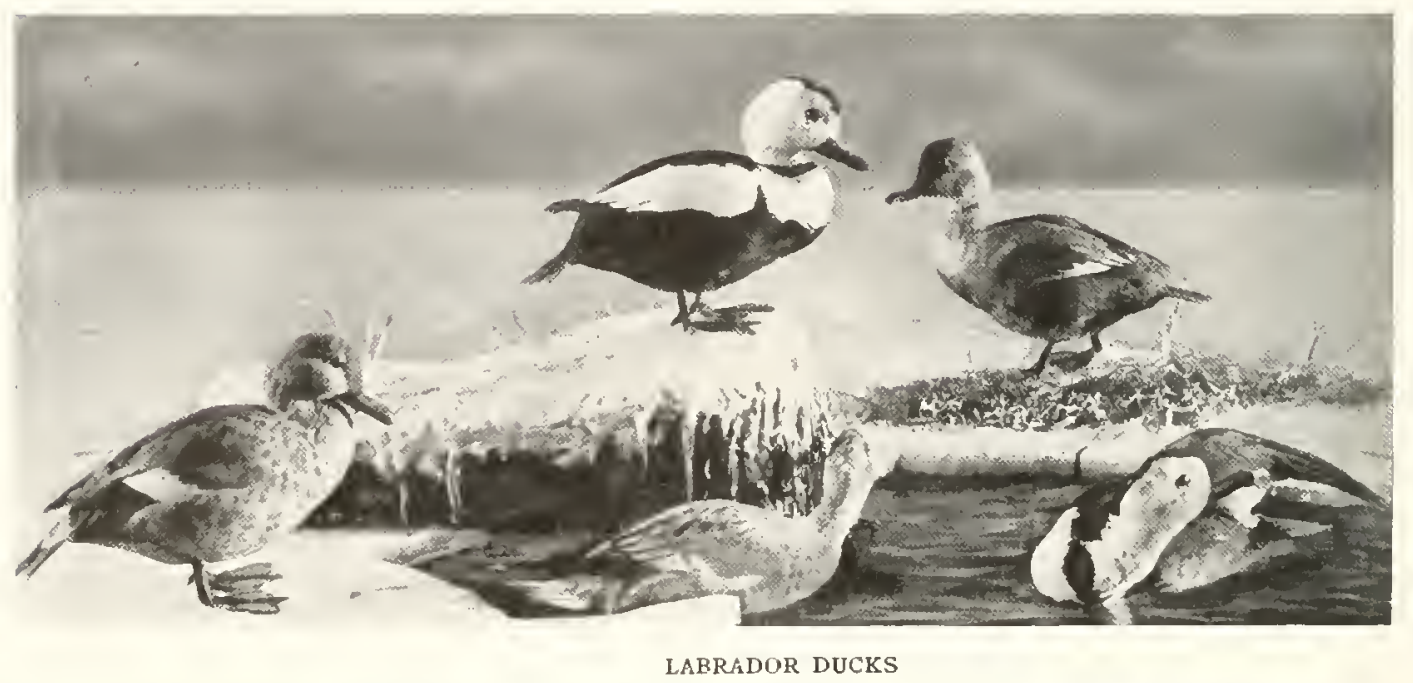

A group of mounted specimens in the American Museum of Natural History, New York City

York, in $18,5$. According to Dutcher's summary, there are only forty-two recorded specimens in existence in the museums and scientific collections of the world. accompanied ly the extermination of far more species of hirds than in any other century since the dawn of history.

Fin.IR1, l lowe FoBRusi.

\section{SPECTACLED EIDER}

\section{Arctonetta fischeri (Brandt)}

$$
\text { 1. () U. Number } 158
$$

Other Name.-Fischer's Eider.

General Description.- Length, 22 inches. Males are white above and grayish-black below; females are yellowish-brown, streaked and barred with darker. Both sexes have dense patches of velvety feathers around the eyes, outlined with black, suggesting spectacles; very fine, stiffened frontal feathers: and crown feathers lengthened into a short hanging hood in the male, slightly indicated, or not, in the female.
Color.-Anult Malf: Most of head. neck all around. most of back, lesser and middle wing-coverts, long inner secondaries and a patch on side of rump, white: frontal feathers on head, nape, and cheeks strongly tinged with pale sea-green; spectacle area pure silverywhite framed as aforesaid, with black: rest of plumage, including wings, grayish-black; bill, orange; feet, yellowish: iris, white surrounded with a light blue ring. Adult Female: Varies as do all Eiders; general colora- 
tion, vellowish-brown, streaked on hearl and neck, and larred on body, except alulomen, with hlack and hrown.

Nest and Eggs.-Nest: On the ground amoug rucks; made almost entirely of feathers and down from the bird's breact. Eugs: 5 to 8 , light olive.
Distribution. - Very locally distributed on coast of liering Sea and adjacent Arctic Ocenn: breeds in Alaska from Point liarrow to mouth of the Kuskokwim and on the northern coast of Siberia west to mouth of Lena River: winters in Aleutian L hlands.
The Spectacled Eirer is essentially an Maskan Duck, as far as its habitat on this continent is concerned, and is most commonly seen in and near Norton Sound, where it breels. Ils principal winter home seems to he on the islands of the Aleutian Archipelagn. I ike the Emperot Gnose, this Duck is likely to $\mathrm{Al}$ near the surface of the water or the land: it mormal progress on the wing is very swift and stealy. Dur- ing July and dugust the birds motergo a severte molt which deprives them even of the use of their wing-feathers. When they are thus luelpless the Eskimos kill them wholesale with sticks and clubs. The natives also make caps of the heavily feathered skins of this Eider, and use the briglit green plumage for headdresses of varimis kinds.

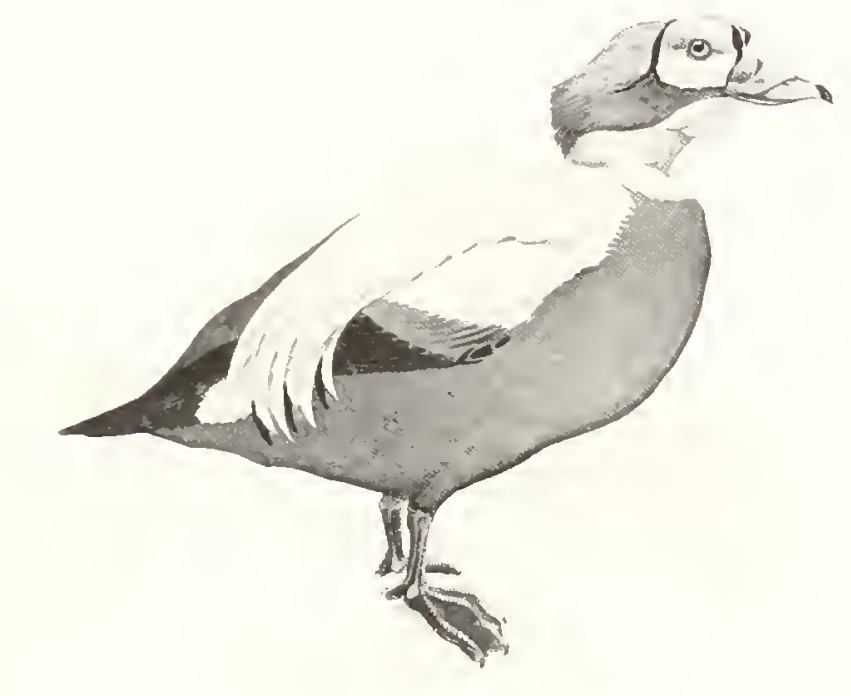

Drawing by R. I. Brasher

SPECTACLED EIDER ( $\frac{3}{6}$ nat. size)

The Eskimos make caps of its skin

NORTHERN EIDER

\section{Somateria mollissima borealis (Brehm)}

1. O. [T. Number 159

General Description.- Length, 24 inches. Nales are whte above, and hlack helow; females are pale rufousbrown, variegaterl with darker.

Color.-ADult MAE: Crown. gluesy hlue-black. including eyes, and scparating behind to receive white of hind neck; hrad, neck all around. fore-breast, most of hack. most of ainu-costerts, lon! inner srondaries, and sides of rump. ahite tingerl with creany-pink on breast; sides of hearl washed with pale sea-green; middle of rump, upper tail-coverts, tail, lower back, and umler parts from breast. deep sepia hack; bill, yellowish, brownish in center with white tip: legs, yellowish; iris, brown. Anelt Fen.ue: Ground color of entire plumage, pale rufous-brown. darker on crown, streaked on side of head and nech and variegated clsewhere with transverse has of black and chentnuthrown: abdomen, plain grayish-hrown.

Nest and Eggs.- NEST: Retween stones, on rocks 
or banks, or any suitable hollow; made of seaweed and lined with down plucked from the hreast of the bird: additional down is added as incubation proceeds, and the quantity is often so great as to conceal the eggs entirely. Egcs: 6 to ro, greenish-drab.
Distribution.- Northeastern North Anerica; breeds from Ellesmere Land and Greenland south to nortlwestern Hudson Bay and southern Ungava; winters in southern Grecnland, south rarely to Maine and Massachusetts.
The Northern Eider is a North American race of the common Eider of Europe and is amost identical with it. It nests on islands off the northern coast of Labrador.

This bird furnishes much of the eider-down that is gathered by the Cireenlanders, and it is not improbable that it was one of the species sought by the feather hunters on the coast of Labrador in the eighteenth century.

Edward Howe Forbush, in Game Birds, Hild-Fonl and Shore Birds.

\section{EIDER}

\section{Somateria dresseri Sharpe}

A. O L. Number 160 See Color Plate ig

Other Names.-American Eider; Common Eider: Eider Duck; Dresser's Eider: Drake (malc): Sea Duck (female); Black and White Coot (male); Iste of Shoals Duck; Squam Duck; Wamp; Canvas-back.

Description.- Length, 24 inches. This Eider differs from the Northern Eider in shape of bill: in latter base of bilt extenils along each side of forehead between the narrow pointed extension of crown feathers, this lateral extension being very narrow and ending in a point, whereas in the Eider the processes are more than twice as broad witl obtuse rounded ends; the sides of head are more extensively greenish but otherwise the coloration is similar.
Nest and Eggs. - NEST: On the ground, in grass, in crevices between rocks, or in any sheltered locality; made of moss, seaweed, and lichens and lined with gray lown from breast of the bird, the lining being added gradually during the month of incubation. EGGS: 6 to Io, usually 6, plain dull greenish-drab.

Distribution.- Northeastern North America; breeds from southern Ungava and Newioundland, on the southern half of Hudson Bay to southeastern Maine; winters from Newfoundland and Gulf of St. Lawrence south on Atlantic Coast to Massachutsetts, rarely to Virginia, and in interior rarely to Colorado, Iowa, Wisconsin, Ohio, and western New Iork
Eiders are native to both Europe and America but the European and Northern Eiders differ from the American in the shape of the processes of the bill, which extend upward and backward toward the eyes. These maxillix are less attenuated and more rounded at the ends in the American species than in the European and the Northern. This is one of the famous species that arc responsible for the greater part of the eiderdown of commerce. The female plucks from her own brcast the down to line her nest and. as is the case with other species, she felts this down into a blanket or mantle which not only lines the nest but extends up so that she can cover the eggs with a flap or coverlet of the same warm substance. In Iceland, Norway, and some other parts of Europe the down is considered so valuable that the birds are conserved, tended, and protected, so that they become almost as tame as domesticated fowls. Nesting places are made for them in the turf or among the stones, and some of then even nest on the sod roofs of the houses, where sods are removed or arranged for their accommodation. In some places the nests are so numerous that it is impossible to step anong them without endangering the sitting birds. Some birds become so tame while on the nest as to allow the inhabitants to stroke their feathers. When the first downy lining and the eggs are removed from the nest by the down gatherers, the female phucks her breast again, rencws the lining, and lays more eggs. If her treasures are removed a second time, it is said that the male denudes his breast for a third lining. The down and eggs taken are not sufficient to interfere with the breeding of the 


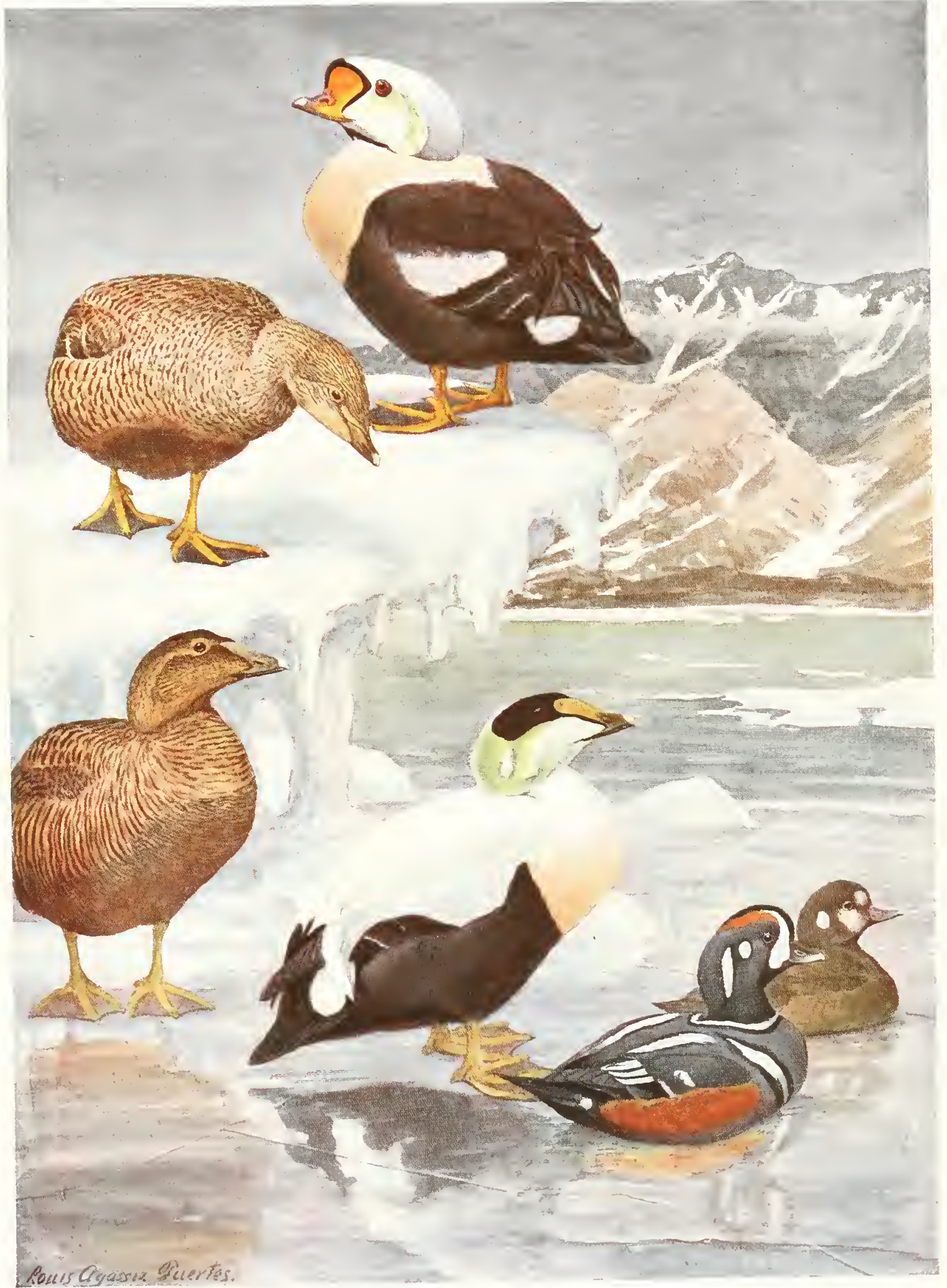



birds, and both the birds and the inhabitants jureper in the partnership.

$11 \mathrm{e}$ do it differently in America. The coast of labrador jormerly was a great breeding ground oi the Eider Ditcli. Defure the year 1,50 , vessels were litted out in New England for the Labrador coast for the express purpose of collecting feathers and cider-down. The crews lancted on the coasts and islands when the young birds were still unfledged and while the parents were molting their flight quills and mnalile to fly. They surrounded the birds, drove them together and litled them witl clubs, thus destruying " millions" for their feathers alone, as there was no market for their flesh. This was continued until not lung after 1,60, when the birds had becone su reduced in numbers that feather hunting becante unprofitable and was griven up. In the meantine, and ever since, eggers, fishermen, and settlers have destroyed both birds and eggs, until the vast Eider nurseries of the labrador coast are little more than a memory, and now we import rider-down sathered by the wiser and more humane people of the Old Morld.

However, the Eider is by no means exlinct in this country. It still breeds in the more inaccessible regions of northern Ungava and alout Hudson Bay and a few are preserved in Maine under the protecting care of the National Association of Audubon Socicties. The nests are hidden away carefully under thich shrubbery on rocky islands where the waves of the Atlantic break ceaselessly on jagged rocks and the birds when not on their nests keep at sea.

The only note I have ever heard from one of these birds was a hoarse croak when the female was suddenly startled from her nest, hut the male is said to have a soft note in the breeding season.

In migration they seem to he rather silent bircls, flying in long undulating lines and alternately flapping and sailing. The Massaclusetts gunners call them Sea Ducks for they seem to prefer the outer ledges jutting into the sea.
Numbers frequent the islands south of Cage Cod in winter where they feed largely on muselo for which they dive sometimes in at least ten fathoms of water. They are harly and handsome. Their flesh is lishy and mattractive. If

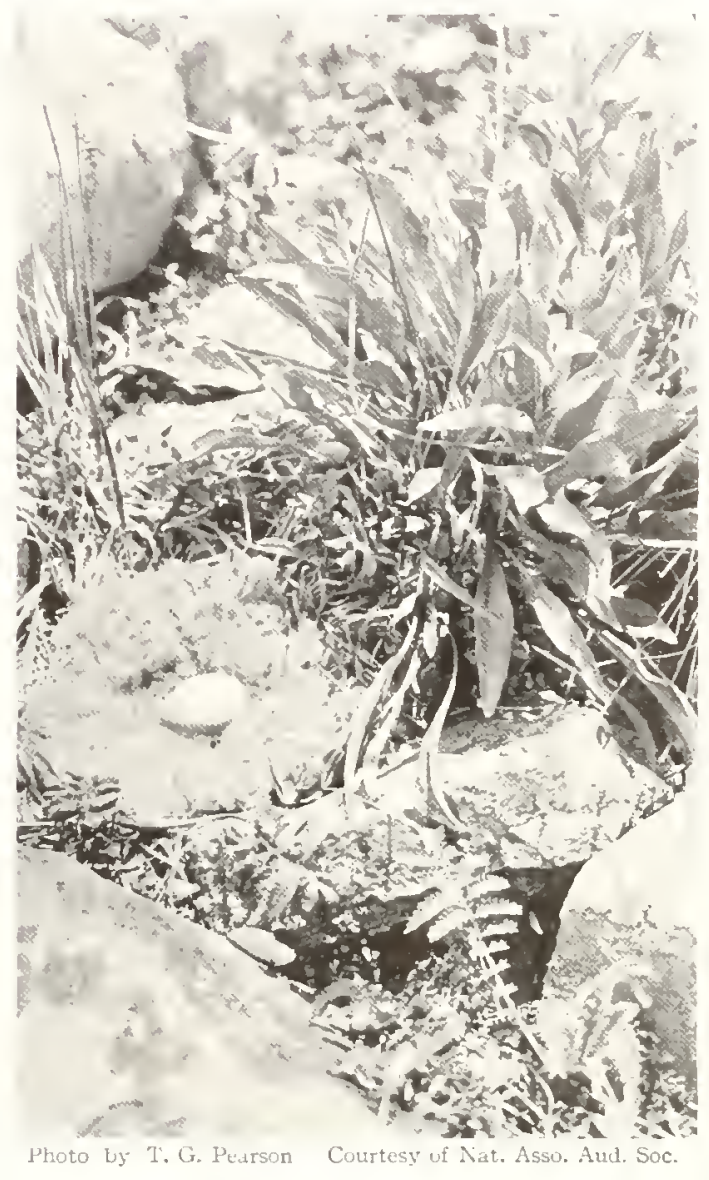

NEST OF E1DER

At Way Ledge, near Isle au Haut, Maine

frotected on their breedines srounds they might hecome in time a great sutree of revenue to the leople of the northern coasts.

EIMARU J] ME FuRBUSH,

\section{KING EIDER}

\section{Somateria spectabilis (Limaus)}

1. O U. Number 1uz see Color I'late 19

General Description, - Length, 2z inches. Males are white above and hownish-hlack helow: females are light brown. streaked and larred with darker. Males have the hill with immense sruare irontal processes bulging high above rest of bill : bill of females are less developed hut retain the ame general outlines.

Color.-ADtr.T Mille: Fore parts, most of wingcoverts, and a spot on each side of rump. white, tinged 
on sicle of head with pale sea-green, and on breast with creany-brown: top of head and back of neck. pearlgray: cyclids and spot below eye, black; rest of plumage, deep brownish-black, including the long inner secondaries; a black $V$-shaped mark on chin; bill, reddish-orange, the enlarged part surrounded in front, on top. and rear with a black border; tip, white: feet, yellowish-orange with dusky webs; iris, brown. Anult FEMALE: Hardly separable from other female Eiders in coloration, but easily distinguished by the shape of bill; the bill, yellowish, dusky at end, with white tip).

Nest and Eggs.- Nest: In depressions of ground or among rocks: composed entirely of down. EGGS:

The King Eider is an aretic species and its habits resemble those of the common Eider. It is a deep-water Duck, feeding mostly on mussels. The female lines her nest with down, as do the other species, and it forms part of the eiderdown of commerce. which is gathered by the matives in fireenland.

The raised irontal processes at the base of the bill, which adorn the head, develop immensely in the hreeding season, bulging high above the rest of the bill. These processes are soft, and are
Usually 6, but sometimes more, light olive-gray to grayshis-green.

Distribution.- Northern part of northern hemisphere: breeds along the whole coast of northern Siberia, lering Sea, and Arctic coast of America from Icy Cape east to Melville Island. Wellington Channel, northern Greenland, northwestern Hudson Bay, and northern Ungava; winters on Pacific coast from Aleutian Islands to Kodiak Island, in the interior rarely to the Great Lakes, and from southern Greenland and Gulf of St. Lawrence south regularly to Long lsland, rarely to Georgia: accidental in Calitornia and lowa. supported upon a mass of fatty substance. They shrink and become more depressed in winter, when the general formation of the beak is not much different from that of other Eiders. The female, however, does not resemble the male, and is not easily distinguished in the field from that of the American Eider. When in luand, the general resemblance of the bill and the head feathering to that of the male may be noted. EDward Howe Forbusif, in Game Birds, II ild-Foal and Shore Birds.

\section{SCOTER}

\section{Oidemia americana Sarainson}

1. O L. Xumber 163 See Color I'late 20

Other Names - M ALES: Bfack Scoter: Sea Coot: Black Coot: Black Sea Coot: Fizzy : Broad-billed Coot: Hollow-billed Cnot; Pumpkin-hlossom Coot: Booby; Butter-hill: Black Butter-bill : Butter-hilled Coot: Butter-nose; Copper-bill; Copper-nose; Yellow-bill. FEMALEs: Brown Coot; Gray Coot; Smutty Coot.

Description.- J.ength, male 2I inches; female it inches. AduLt M.M.E: Entirly hlack, less glossy below; bill, black, with a yellow protuberance at base: feet. dusky; iris, brown. Antet Female: Sooty-brown, paler below, lightening on ahdomen, with dusky speckling: sides and flanks waved with dusky; throat and sides of hear, distinctly whitish; hill, dusky and not peculiar; feet, dull olive with black webs; iris, brown.
Nest and Eggs.-NEST: On ground near water; made of coarse grass, feathers, and down. EGGs: 6 to 10, pale buf:

Distribution.- Northern North America and eastern Asia; breeds in northeastern Asia and from Kotzebue Sound to Aleutian 1slands, including Near Islands; also on west shore of Hudson 13ay, Ungava, and Newfoundland; winters on Asiatic coast to Japan and from islands of Bering Sea south rarely to Santa Catalina Island, California; in the interior not rare on the Great lalies, and casual or accidental in Missouri, Louisiana, Nehraska. Colorarto, and Wroming; on the Atlantic coast abundant during migration from Newfoundland and Maine south, but rarely as far as Florida.
We have no means of hnowing the early history of any one of the Scoters as they all were generally grouped together as "Coots" or "Plack Ducks" by the early historians. The Scoters or "Coots," as they are called by the munners and fishermen, are typical diving Ducks. They are very muscular and powerful in build. The bony framework is strong, the skin tough, and the feathers strong, coarse, and very firmly attached to the skin. The whole structure scems to be formed to resist the tremendous water pressure that they encounter while diving at great depths. Fishermen, both along the Massachusetts coast and in the lake region of $M$ isconsin, have told me that they have taken these diving Ducks in nets set from 50 to 100 feet 
helow the surface. This may be an exaggeration. Cnder water they use both legs and wings for propulsion, and are even nore at home there than in the air. If threatened with danger they are as likely to dive as to fly, and sonetimes, when in full flight, they have been seen to dive The Scoters are universally known as Coots along the New England coast, a mane derived probably from the firench fishermen who first established the fishing industry on the banks of Newfoundland. The true Cnot, however, is a lobe-fonted fresh-water bird.

As fond. Ducks of this genus are regarded as nourishing but not very appetizing. Some writers have gone so far as to stigmatize them as ahominable: hut the people of Cane Col are able. quite as likely to mix with flocks of the otluer Scoter: The flight of the Seoters is swift. I have heard it estimated at 200 miles an hour with a strong wind, hut this is probalily exaggerated. They may possibly fly at the rate of over ino miles an hour uniler farorable enditions, but this is a high rate of speed for any lirel. This biri] usually flies in lines at some distance from the shore, and the flocks are often led by an old experienced male, who will lead his following high in air while passing over the boats where gumers lie in wait.

In migration this hird is often seen in flocks of roo or more, and in smaller gronys at other times, hut it associates with the other two species. Little is known alout its early abuntance, but it

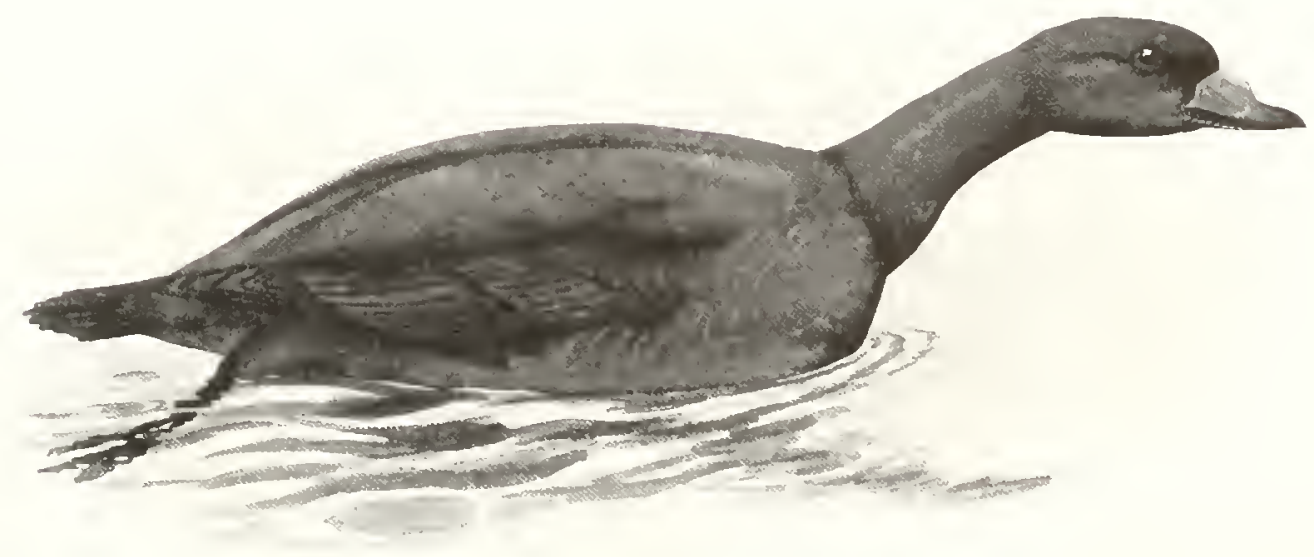

I) T.14irg by R. I. Brusher

SCOTER ( $\frac{1}{6}$ nat. size)

As food, this Duck is nourishing, but not very appetizing

by parboiling, ete., to make a dish of eren the old birds, which, thongh it may "taste a little like crow" to the minitiated, serves as an agreeable variant to a cliet of salt fish.

A cultured loston lady assures me that when she attempted to conk a Coot it drove everybody out of the house, and that she had to throw away the kettle that it was cooked in. Nevertheless, I have found the young palatable if properly prepared, though hardly equal to the celery-fed Canvas-lack. Many Scoters are shot for food and sold in the markets, but large numbers are killed merely for sport, and either left to lie where they fall or to trift away on the tide.

The American Scoter, Plack Coot, or Little Gray Cont, as it is commonnly called, while a common lird, is the least numerous of the three Senters. While at times it keeps by itself it is is probable that on the Atlantic it has decreased nore in proportion to its former numbers than the other two commun species. It is far more numerous now on the lacific coast than on the Atlantic. So little is lnown of its breeding grounds in northeastern North America that J'rofessor Cooke is obliged to reason, by exchsion, that as we have no record of its breeding west of Indson Bay until we reach the Yukon valley, nor in labrador south of about latitude 52 degrees, the multitudes seen in winter on the Atlantic coast must breed east of Hurlson Bay, in northern Ungava. As this is one of the least explored regions of the world, it is quite possible that vast numbers of Scoters and Nergansers breed there. It breeds mainly in fresli-water marshes and ponds in the north and also upon islands in the sea. It is a very expert diver, and 
is often able to get so nearly under water at the flash of a gun that the shot injures it very little if at all.

Its food consists largely of mussels, and when feeding on fresh water it prefers the fresh-water clams to most other foods. Thirteen Massachusetts specimens were found to have eaten nearly 95 per cent of mussels; the remaining 5 jer cent. of the stomach contents was composed of starfish and periwinkles. It is a common belief that all Scoters feed entirely upon animal food, but this is not a fact. Along the Atlantic coast they appear to subsist mostly on marine animals. but, in the interior, vegetable food also is taken.

Edwata Howe forbush, in Game Birds, IFild-Foal and Shore Birds.

\title{
WHITE-WINGED SCOTER
}

\section{Oidemia deglandi Bonaparte}

\author{
1. O $[$. Number tos sice cinlor Plate 20
}

Other Names.- Velvet Scoter; Velvet Duck; lake Huron Scoter: White-winged Surf Duck, or Sea Coot or Scoter: Black White-wing: Plack Surf Duck; Piedwinged Cont; Uncle Sam Coot; Bell-tongue Coot: Bull Coot: Brant Coot: Sea Brant: May White-wing; Eastern White-wing: Assemblyman.

General Description.- Length, male 23 inches: female 20 inches. General color of male, hlack: female, brown above and gray below. Bill swollen at hase over nostrils and on sides; feathers of lores come close to nostrils.

Color-Adelt Male: Rlack, paler below, more brownish on sides: a small white spot under ansl behind eve; spculum athiti, formed by tips of greater coverts and most of secondaries; bill, black at hase and on knob, a white space in front of knob: sides of bill reddish shading to orange on tip; feet, orange or red with black webs and joints; lris, pale yellow. AnuLT FEM.SLE: Sooty-brown ahove; pale grayish below; a large space in front of and below eye, and another hack of it on sirle of head, whitish: closely resembles the other two female Scoters but can always be distinguished by the

The White-winged Scoter, the largest of the three dark-colored marine Ducks commonly called "Sea Coots" along the Atlantic coast and readily distinguished from the other two by its white wing-bars, is very familiar to gunners. Toward the end of August flocks of adult males, flying southward, begin to be noticed along the New England coast. The lighter-colored females and young are not due till about the middle of October and later. Then there is a great procession of them past the headlands, flying swifty and low over the water. They stream by in single files, in wedge-shaped formation, or in irregular columns, the three kinds being often intermingled.

The "coot shooters," starting out at the first glimmer of dawn, or before, anchor their boats in a line straight out from some headland, ahout white speculum; hill smaller than in male and grayishlusky ; feet, dull Hesh color with black webs ; iris, darkbrown

Nest and Eggs. - Nest: Usually concealed under werhanging bushes, small spruces, or willows: sometimes near salt water, at other times 2 or 3 miles from the sea: a depression in the ground, lined with a littie grass and, after the clutch is complete, with a little down. Erics: 5 to I4, usually 7 or 8, pale salmon-buff or flesh color.

Distribution.-- North America; breeds from the coast of northeastern Siheria, northern Alaska, northern Mackenzie, and northern Ungava south to central British Columbia, Alberta, northern North Dakota, and southern Quebec; winters on the Asiatic coast to liering Island, Japan, and China, and in North Anerica from Unalaska Island to San Quintin Bay. Lower California, the Great Lakes (casually to Colorark, Nebraska, and Louisiana), and the Atlantic coast from the Gulf of St. Lawrence south (rarely) to Florida: non-hreeding birds occur in summer as far south as Rhode laland and Monterey, California

a gunshot apart. and lie low. after anchoring out woolen decoys in front. The Scoters, coming swiftly on, may swing around the boats further nut to sea, or rise higher in the air. Often, however, trusting to their swiftness, they dash through the line. Then the guns speak. On some mornings when there is a big flight it sonnds like a regular battle. Scoters are thiclily armored, however, witl feathers, down, fat, and a tongh hide, and many a time I have heard the impact of the shot on their bodies when there was not the least visible effect. They fly more especially carly in the morning, but on lowery, windy days, particularly when a storn is brewing, I have watched them pass loy thousands all day long.

Such big thick-set birds, floating rather high on the water, make thenselves quite conspicuous. and are easily recognized. They like to gather 


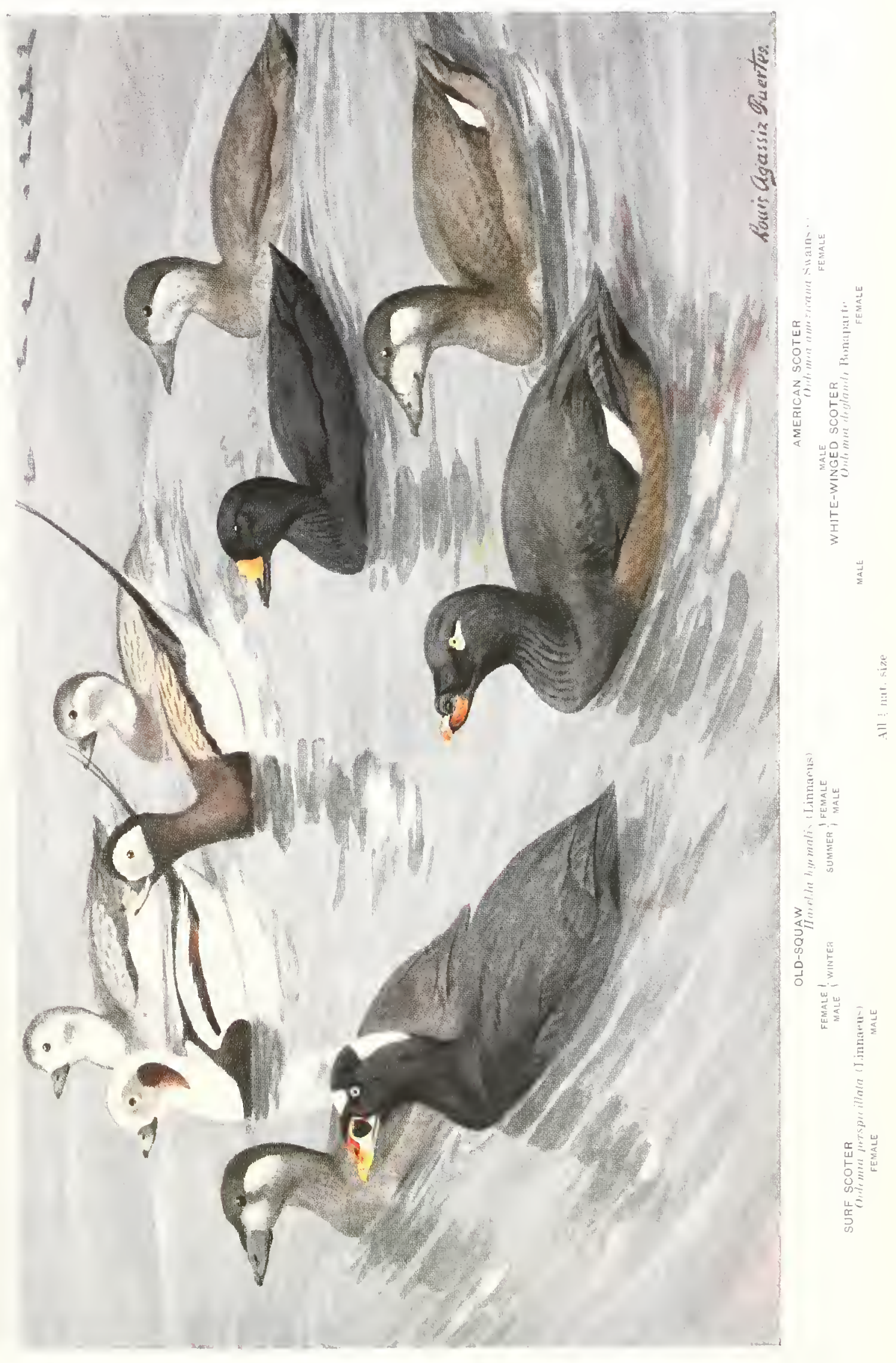



urer stumerered beds of mons.els and other hivalles, and feed mon them hy divings. Beins rery hardy birds. they do not go as fatr south in winter as many of the l ncks. Jarge numbers of them remain in the winter about Nantucket and long lslancl. Few get is far ats the southern Stiltes.

This Scoter is the must sotutherly of the three in its breeding range. I have fommel gutes a ntmeber of their nests in North lodiutat and Manitoba. Fhongle so hately, they are the list wi the water-birds to breed. Lsually they finish latying from June 20 to July I. Whan lecginning to lay. the female swims ashore, prelerably on an island. and creeps into the thickint werels or hrush she can find near by. There she scratches a hollow, lays a very big creany-m lite eng. and rakes the soil over it. Next dis she diss it out, alds another, and buries both. When the set is nearins completion she plucks lown from her heast and lines the nest. Examining a nest of exgs before incubation begins is like disuing potatoes.

She sits very close, and when almost stepped on tries to seury through the weeds to the water. Once l canght a Scoter leaving her nest. She did not act frightened, but gazed quictly at her captor. Suddenty she gave a violent Hitp, slipped to the ground, and managed to wet to the water first. The young are large for ducklings, clarl in black and white suts of doun, and walli almost erect. reminding one of little men. Il EkBERT K. Jor.

The stomachs of nine Il'hite-winged SenterIrom Mas-achusetts waters, eximined by $11 \mathrm{r}$. II L. Nedtee, of the liological Survey, contained

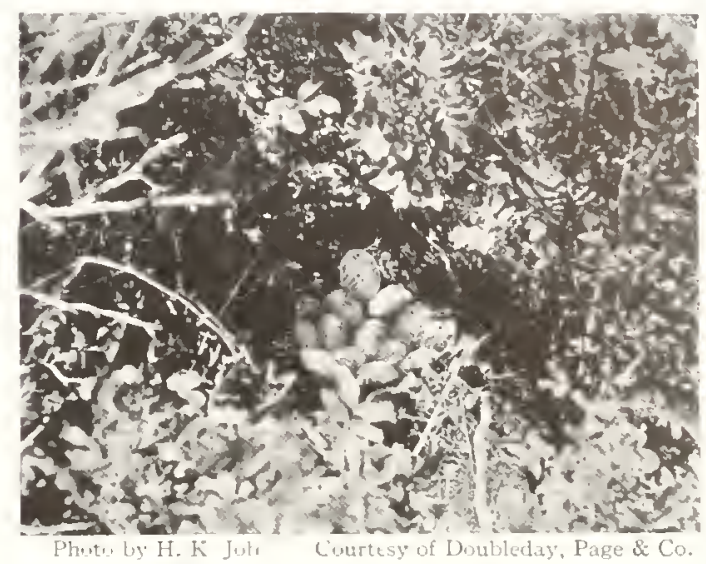

NEST OF WHITE-WINGED SCOTER

of mussels, abunt it jer cent, quobogs, 22 per cent. : periwinkles. 19 jer ecnt. : hermit crabs, o per cent.: the remainder was caddis larve and alge and other veretalile matter. Three birds from Nantucket had eaten only the common inussel.

\section{SURF SCOTER}

\section{Oidemia perspicillata (Limious)}

\section{A. O. [. Number 166 See Color Plate 20}

Other Names.- Surf Duck: Surf (unt ; Surier: Sea Coot; hay Cout: Gray Coot : Brown Coot; Box Coot; spectacle Cont; Butterboat-billed Cont: Flollow-lilled Cout: Speckle-billed Coot: Plosmom-billed Coot: Ilorselead: Horse-head Coot; Patch-head; Hatch-head Coot; Patel-polled Coot; White-head; White Scop: Baldpate: Skunk-head: Skunk-hearl Coot: Skmb-top; P'ictured-bill; Plaster-bill; Moroceo-jaw; Gogsle-nose; Sinufittaker.

General Description.- Length, 25 inches. Predominating color of male, black; fenale, sooty-brown alove, gray below.

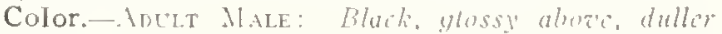
letera: a trimendar white putch on forched pointing

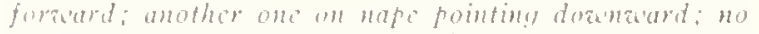
white on stimes: lasal half of bill, white with a large round syot of black, this bordered above and hehind by reil and yellow in a very narrow line; front half, yellowish-orange crused by a white band: upper half, crimson and orange; fect, orange-red with dusky webs and joints; iris, whitc. Antet Fenal.e: Above, sootybrown: below, gray: two whitish ratches un side of head, thus scarcely different from females of other two species. Distmguished from female Seoter by larger bill, and from female White-winged Scoter by absence of white speculum.

Nest and Eggs.- Nest: On the ground in a bunch of marsh grass: more rarely in the low branches of dwarf spruces; conntructed of grans and plant stems. and lined with down. Eutis: 5 to \&, cream color.

Distribution.- North America; breeds on the Pacific coast from Kotzebue Sound to Sitka, and from northwestern Mackenzie and Huthon Strait to Great Slave Lake, central Keewatin, an! northern Quebec; nonbreeding birds oceur in summer in northeastern Siberia and suth on the Pacifie coast to Lower California. and in Greenland and south on the Atlantic coast to Long lstand: winters on the Pacilie coast from the Aleutian Islands south to San Quintin Hay, Lower California. on the Great Lakes, and south casually to Colurain, Kansas, Iowa, Illinois, ant Lomisiana. and on the Itlantic coart from Nowa Seotia to North Carolina. rarely to Florida: casual in the Bermudas; irequent in Europe. 
The Sea Coots are birls of the ocean and the larger lakes of the interior during the period of their sojourn in the United States. Now and then a few may be seen on some of the more inportant rivers, but one need not look for them on small ponds and in marshes where many other wild Ducks love to dwell.

From the studies which economic ornithologists have made of their feeding habits we learn that about So per cent. of the food of coastwise specimens consists of mussels which they procure by diving. They also eat periwinliles, algre, and eel-grass. The flesh of few, if any, birds whose diet consists largely of fish or shell-fish is really palatable; and it would seem that this fact alone would protect the Scoter from gunners. Nevertheless they are extensively shot, particularly where the supply of other Duclis is not very great. This is partially true along the New England coast.

Here they are liunted in a communal faslion. The gunners of a locality agree on a day when they will go Coot slooting. At least fifteen or twenty boats must go, if success is to be attained. The boats are anchored in line offshore from some headland that separates two bays where the birds are accustoned to feed, and are stationed at a distance of about one hundred yards from each other. All this is done very early in the morning for by sunrise the companies of Coots will begin to pass. They fly swiftly and the man who secures many must be a good shot.
Speaking of the Seoter as an article of food, Walter 11. Rich in Feathered Game of the Northcast says:

"They are unusually tough customers either in life or at the table. Most of our cooks believe it impossible to so prepare this bird as to make it decent food for any but a starving man. The best recipe I have seen runs somewhat as follows: First, skin your fowl and let it parboil in saleratus water at least one day, or until it can be dented with a fairly sharp ax. If your courage holds out, the game is now ready to stuff and bake as you would any other Duck, except that you must prit enougl onions into its inside to take away all Coot Havor. Arriving at this stage of proceeding there are two lines of retreat yet open to you; either throw your delicate nursel away or give it to someone against whom you hold an ancient grudge - on no account should you try to eat it."

The summer lome of the Surf Scoter is in the Far North: none is lnown to rear its young in the United States. Those occasionally found within our horders in stmmer are either cripples, as the result of winter shooting, or are nonbreeding individuals. Andubon describing a nest lie fotnd in Labrador writes that it was hidden among tall grasses and raised about four inclies above the gromnd. It was made of weeds and lined with down of the bird in a manner similar to the nest of the Eider Duck.

T. Gilbert Pearson.

\section{RUDDY DUCK}

\section{Erismatura jamaicensis (Gmclin)}

\section{A. O. U. Number 167 siee Color l'iate to}

Other Names.-Dumpling Duck: Daub Duck; Deaf Duck; Fool Duck; Sleepy Duck; Butter Duck; Brown Diving Teal; Widgeon Cont; Creek Coot; Sleepy Coot; Booby Coot: Ruddy Diver; Dun Diver: Sleepy Prother: Butter-ball; Batter-scoot; Blatherskite: Bumhlebee Cont; Quill-tailed Cont; Heavy-tailed Coot; Stiff-tail ; Pin-tail ; Eristle-tail ; Sprig-tail ; Stick-tail; Spine-tail: Dip-tail: Diver: Dun-bird; Dumb-bird Alud-dipper; Spoon-billed Butter-ball; Spoonbill: Broad-billed Dipper; Dipper; Dapper: Dopper; Broadhill; Blue-bill; Sleepy-head; Tough-head; Hickoryhearl; Steel-head; Hard-headed Lroarl-bill; Pull-neck; Leather-back; Paddy-whack; Stub-and-twist; Lightwood-knot; Shot-prouch; Water-partridge: Dinky; Dickey: Paddy; Noddy; Pooby: Rook: Roody; Gray Teal: Salt-water Teal; Stiff-tailed Widgeon.

General Description.- Length, I6 inches. Males are red above and white below; females are brownish-gray above and grayish below. Both sexes have the forehead rather low; the neck thick; the bill long and broad and curving unwarl, but tip overlanging and curved dowmward: and the tail composed of 18 stiff feathers, often spiny-pointed.

Color.-Antti Mire in SPRing: Forehead, crown, sides of head to below eye and mape, dusky-black; face. lores, chin, and sirles of head, pure white; neck all around, upper parts, and sides, rich glossy chestnut; lower parts, silvery-white, "watered "with dusky; wingcoverts, primaries, and tail, blackish-brown; under wing-coverts, white; bill and feet, rather bright bluishgray, latter witl dusky webs; iris, brown; eyelids, bluish. Male in Fall, and Adtht Female: Upper farts, brownish-gray, spotted and traversed with dusky ; below, pale gray and whitish, with darker transverse 
marks on sides: crown and nape, dusky-brown, with ww indistinct dusky streaks alongside of head; under tail-coverts, white: bill, feet, and eyer, as in spring male but much duller.

Nest and Eggs.- Nest: In the ahandoned homes of Coots or on the shores of lakes, ponds, or streams; a bulky structure of dry reeds, rushes, and grass, so large and buoyant that it will float. Eors: " to 14. creany or light bufi

Distribution.- North America: hreerls from central British Columbia, Great Slave Lake, southern Keewatin, and northern Ungava south to northern Luwer California, central Arizona, morthern New Afexico, northwestern Cebraika, southern Ifimesota, southern Michisan, southern Ontario, and Maine, and rarely and locally in southern lower California. Kansas, Massachusetts, Valley of Mexico, Lake 1)ueñas, Guatemala, and in Cuba, Purto Rico. and Carriacou; winters from southern British Columbia. Arizona, New Atexico, southern Illinois, Maine, Pennylvania, and south to the l.esser Antilles and Costa Rica; rare in migration to Newfoundland and liermula.

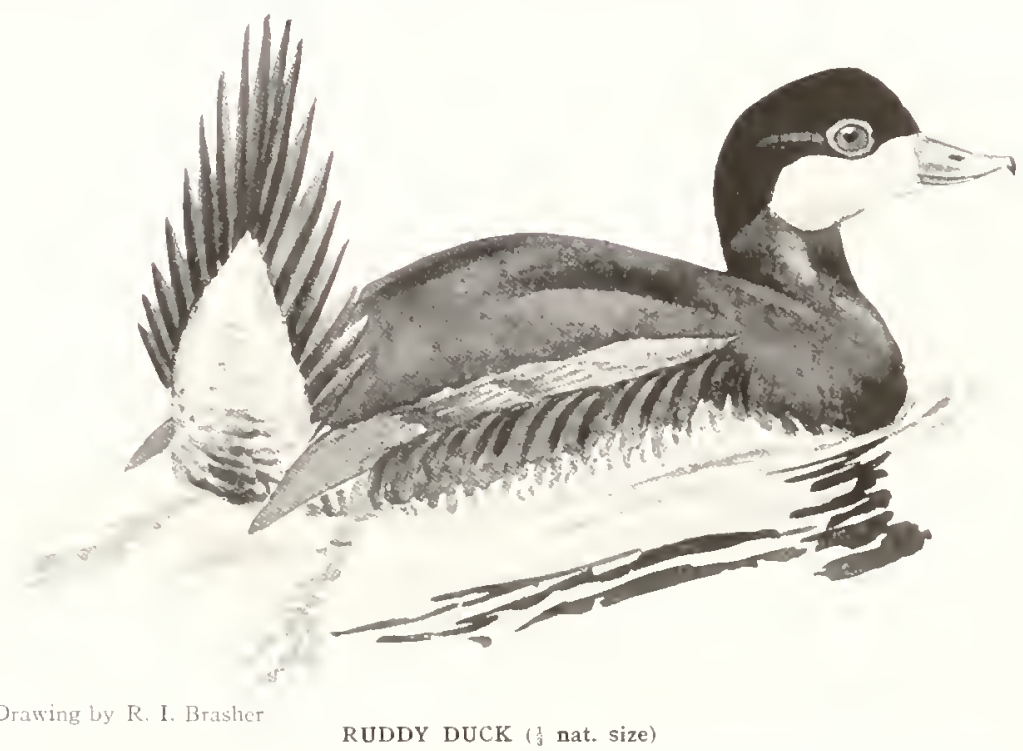

A sprightly, comical little Duck, whose flesh is a passable substitute for that of the Canvas-back

The sprightly, conical little Ruddy Duck is a distinctly North American species and is clistributed widely over the continent. It is perfectly at home on or under water and dislilies to leave it. often preferring to attempt escape ly diving rather than by flying. This makes it easy game for the gunner, as a flock will sonetimes remain in a salt pond so small that any part of it may be reached from the shore with a shotgun, diving at every shot until those left alive essay to fly and most of them pay the penalty of their simplicity with their lives. They can dive so "quickly that they often escape mharmed. Like the Grobes they possess the pown of sinking slowly down hackward out of sight, lut like then also they rise from the water with some hahor and difficulty. They are extremely toush, hardy little birets and gunners know them by such names as Tough-hear, Hard-head. Stecl-head, etc. (ther loeal names, such as Booby. Noddy, and Foul Duck, indicate a lack of respect for the lirds' perspicacity.

When the famous Camras-lack frist showed signs of scarcity on the Atlantic coast, a price

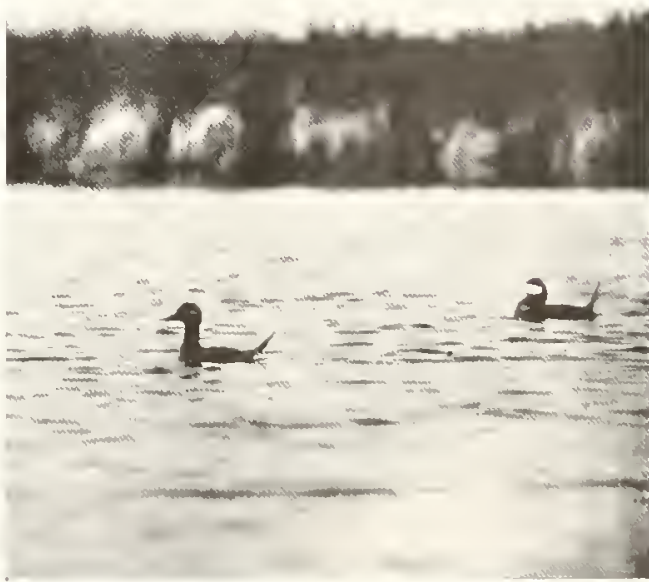

I'h ut: by H. K. Job

A PAIR OF RUDDY DUCKS ON BREEDING-GROUND 
was put upon the head of the Kundw Duck to mect the marliet demand. Unfortunately for its safety it feeds upon delicate grasses and other vesctable aliment in preference to sea-food. Therefore, its flesh is a passable substitute for that of the Canvas-back. So the market gunners have pursued it until its numbers are no longer legion and its cliances for extinction are good.

The male is a handsome birl in the breeding season but presents rather a ridiculous appearance in mating time, as he swims pompously about with his head lifted proudly and drawn away back toward the spread tail, which is ralsed and thrown forward as if to meet it.

This Duck nests in prairie sloughs, where the broods remain until after all the other breeding Ducks have departed. Old and young are regular gourmands and, according to Gurdon Trumbull. sunners near the moutli of the Matumce River told of finding then floundering helplessly fat, on the water and in some seasons floating about dead or dring in numbers. But this was before the days of the market demand for their flesh. They do not have so much time to get fat now.

EDWARD HOWE Forbush.

\section{GEESE}

Order Anseres; family Anatida; subfamily Anserina

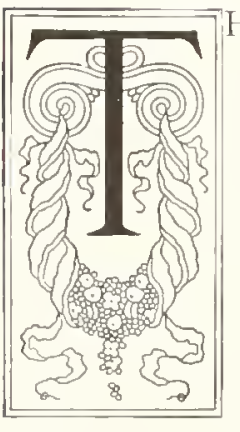

HE Geese in scientific terminology constitute the subfamily Anserinc, of the family Anatida (Goose-like swimmers), included in the order Anseres-(Water for.1). They comprise nine or ten genera and about forty species, of which ten or twelve occur in the United States. Of these, however, only two or three species are actual residents of this country, and the remainder are no more than migratory visitants south of the Canadian boundary.

The group are closely related to the Swans, from which they differ in having the neck shorter than the body, and the lores feathered; they are also closely allied to the Ducks, from most of which they differ in having the tarsus enclosed in small, hexagonal scales, and in the similarity in color of the sexes. They also lack the cere, or soft swollen surface at the base of the upper bill, which is characteristic of the Ducks. Still another marked difference is shown in the feeding habits of the Geese, which often take them into fields far away from water. This habit is due to the fact that Geese walk much more readily than do Ducks, because of their legs being set further forward on their bodies. Their fond is almost wholly vegetable. In the water they take seeds and roots of aquatic plants, which they get by searching the vegetation below the surface, an operation which they accomplish by completely immersing the head and long neck, tipping the body meanwhile so that the tail points straight upward. On land they feed in the spring on sprouting grain, and in the fall on corn, oats, wheat, and barley, taken from the stubble fields.

Geese nest invariably on the ground and usually line their nests with their own down to which sometimes soft grasses are added. The eggs, from four to six or cight in number, are white. The coloration of several species of Geese varies greatly according to their habitat and the seasons.

Owing to their great powers of flight the Geese cover inmense distances in their annual migrations, many species nesting well within the Arctic Circle, and ranging far to the south in winter. 


\section{SNOW GOOSE}

Chen hyperboreus hyperboreus (Pallas)

$$
\text { 1. () } 1 \text {. Number : }
$$

Other Names. - Navey; Common Wavey; Little Havey: White Brant: Leser Hnow Gowe; Common Suow Guone; Whate Gume: Nexican Gouse.

Length. -25 inches

Description.-Bill, short and high at hase. Anuts: Pure whit, the head washed with ruty brown: primaries, groy at base, blach at mis; hill, pale carmine-red with white tip and black cutting edge: feet, pinkish-red: cyen, dark brown. Yu['Nı: Entire phlumage, gray, linhtening below: streaked on hearl and neck very taintly with darker: more or lens waved on back with same; secondaries and primaries. dusky, the former with lighter ergen; bill anl leet, much darker than in ariult.

Nest and Eggs.- Unknuwn

Distribution. - Nurth America: loreeds from mouth of the Mackenzie eant probably to Coronation Gulf and Netville Island; occurs on the Arctic coast of mortheastern Asia, but not known to hreed there: winters from southern Pritish Columbia, southern Colorado, and southern Illinois south to nortsern Lower California, central Mexico (Jalisco). Texas, and Louisiana. and on the Aniatic coast south to Japan; generally rare in eastern United States.

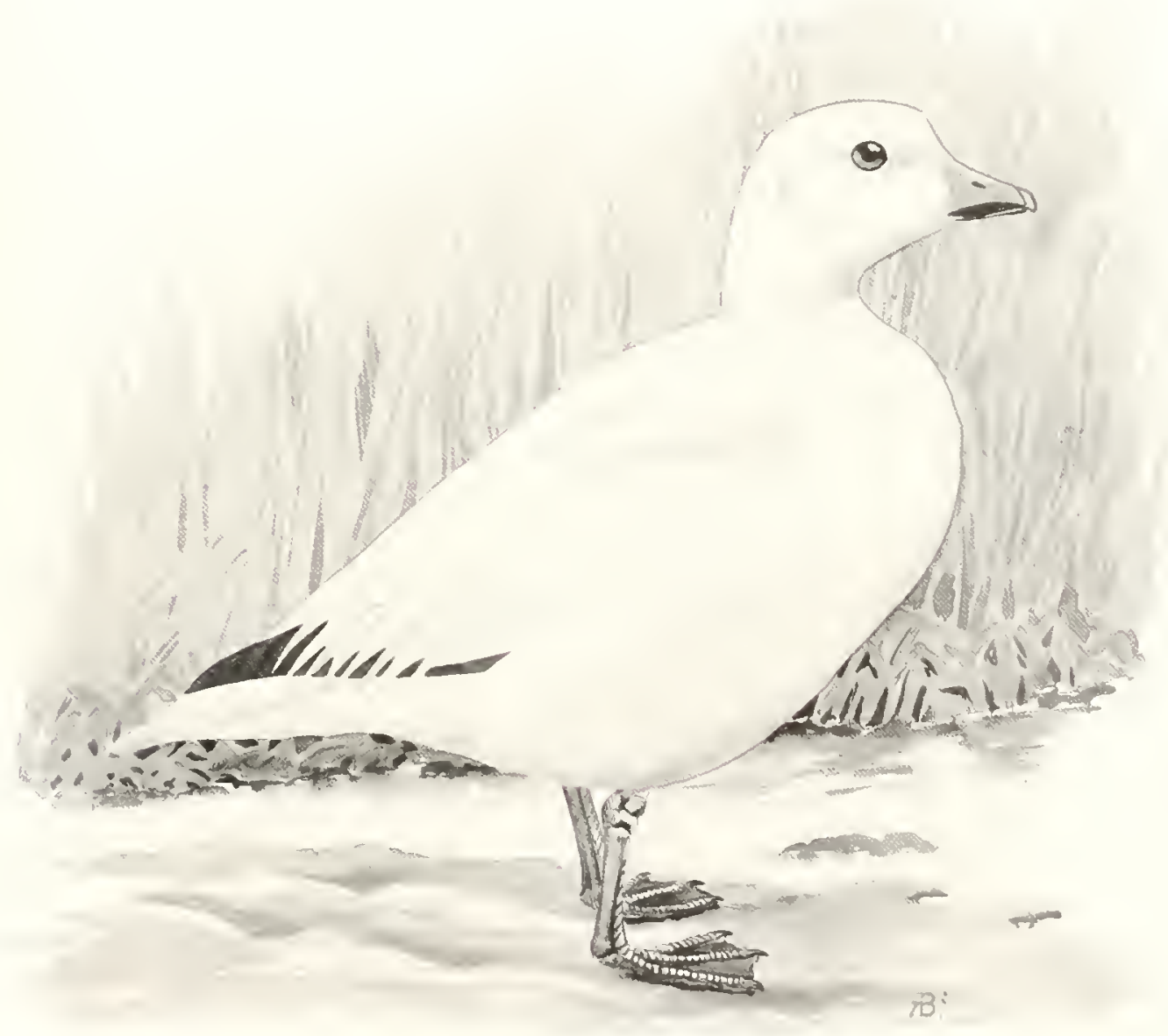


The Snow Goose is a western bird, closely resembling the Greater Snow Goose, which is confined mainly to eastern North America. In the old days, about which the ancient hunter loves to tell. great Hocks of White Geese, resting upon the western prairies, appeared like banks of snow. The enomons numbers of the past are gone, but the white birds are more or less abundant still in migration in the Far West and they are numerous in winter along the Pacific coast of the United States.

This hird breeds bevond the Arctic circle and reappears in the Lnited States in September. The flocks like to rest on some lake at night and to feed by day in the open fields. Farms where they can pick up waste grain are favorites, and they are destructive to young grain just sprouting from the soil. As the migrating flocks come in at night they present a beautiful and impressive sight. They $\mathrm{fly}$ in a wide rank presenting a curved front not so angular as the $V$-shaped flock of the Canada Goose. Winging steadily along, high and serene, their extended pinions barely moving, their snowy forms borrowing rosy tints from the sumset sky, they seek a harbor of security: but as they seem alout to pass on, and leave the placid lake far behind, the tlock lengthens, turns upward at an angle of fifty or sixty degrees, and then, hanging on down-bent rigid wings, floats softly down and down, drift- ing and still falling a thousand feet or more and at the end, with a few quick flaps, dropping to the water, and so they come to rest. Sometimes when near their goal they zigzag down more like a falling Canva-back. The young are easily distinguished from the adult birds by their grayish plumage.

The Snow Goose is difficult to approach and is not highly regarded by the epicure. Were it not for its taste for sprouting grain it might maintain its numbers for many years.

\section{Enward Howe Forbush.}

The Greater Snow Goose (Chen hyperborcus nizalis, color plate 2I) is similar in color to the Snow Goose, but larger in size. It breeds on Whale Island, in Ellesmere Land, and in North Greenland. but its full breeding range is unknown. In the winters it is found from southern Illinois, Chesapeake Bay, and Nassachusetts (rarely) south to Louisiana, Florida, and the West Indies. Sometimes during migration it is seen west to Colorado and east to New England and Newfoundland.

Audubon said he found this Goose in fall and winter in every part of the United States that he visited and other early writers record great flocks on the Atlantic coast. Its numbers have been sreatly reduced: this is probably due not only to its conspicuonsness, but also to the superior Havor of its flesh.

\title{
BLUE GOOSE
}

\section{Chen cærulescens (Limurus)}

\author{
A. O. U. Number I69.I See Color l'late a I
}

Other Names.-Blue-winged Goose; 13lue Wavey: lihe Brant: Blue Snow Goose; Mhite-headed Foose: Bald-headed Brant: White-headed Bald Brant: Brant.

General Description.-Length, 28 inches. Head, white; hody. gray. Pill, short and high at base.

Color.-Aduts: Hod and upper neck, achite: face stained with rusty: neck below, back, and hreast, dusky-gray fading into whitish below, into fine bluishyray on zings, and into whitish on rump and upper tail-coverts, broadly-barred across the hack and on sides with dusky-gray; wing-coverts, pale grayishbrown; most of secondaries. dusky edged with gray; primaries, black: bill and feet, pinkish-red: cutting edges of hill, hlack and tip white; iris, dark brown. Young: General color, brownish. streaked on side of neck and harred on back with pale gray; under tailcoverts whitish; wing as in adults; bill and feet, dusky Hesh color: iris, brown.

Nest and Eggs.- Unknown.

Distribution.-Eastern North America: breeding range unknown, but prohably interior of northern Ungava; winters from Nebraska and southern Illinois south to coasts of Texas and Louisiana: rare or casual in migration in California, and from New Hampshire to Florida, Cuba, and the lialnamas.
Cutil within a very few years the Blue Goose was generally considered a rare species. In a winter trip to the delta of the Mississipli River, in 1909-10, I was astonished to find that the immense concourses of Geese, by scores of thousands, which were said to be "Brants," were in 


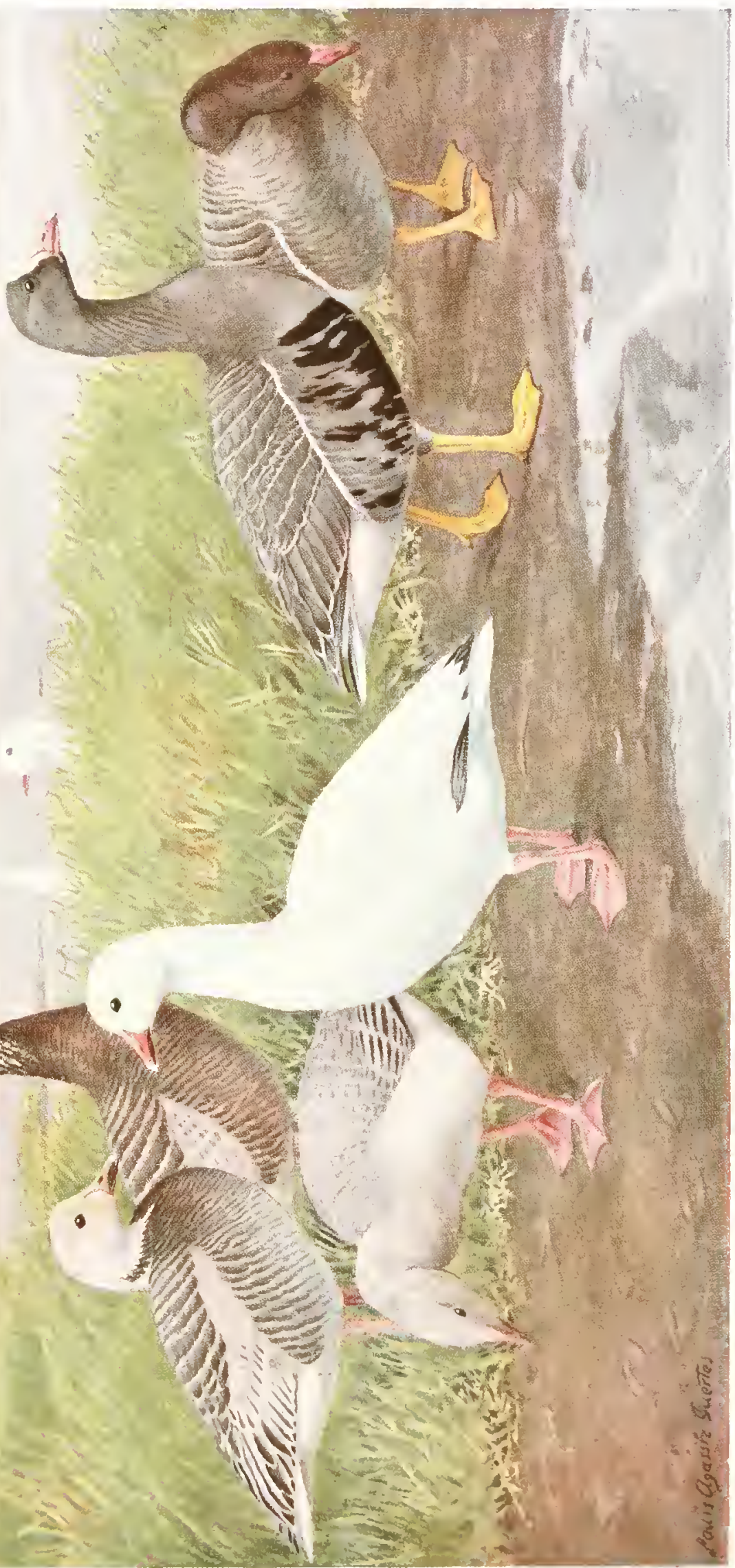



reality, nume-tenths of then, Bine reese. The Camalia ciesese did not consert with thene, and there were only a few White-fronted and Snow Cuese in their company.

It daybeak they comld always be foumd out on the thats off from the exits of certain "patsese" into the ciulf. They kept aly a tremenduns elamor which comkl be hearel a couple of miles away. lieing exceulingly shy, they would rise and disapsear up or down the coast if anyone approached within halt a mile of then : consequently even the narket gumners get very few. Farther wesward, on the Mild life kefuges, they make rendezvous for the night in
Texas, humdreds of thousands henes concentrated within a (emparatively short eosht-line.

In January, noto, I hat a remarkable experience with litue Geese. (In at extain puint on the shore of Termilion liay, lat., there is a rather small gravel-spit, linown as "the gouse-bank," to which from time immenorial. speat numbers of Geese have always resorted doring the winter to eat gravel for digesting their foud. Wishing to secure photosraphs and nution pictures of bilue Geese. we lunitt a lolind at one end of this sput, scattereal cortu, and returned some four weeks later. The weather was hat and the Geese dirl not show up. Nfter fire ditys of dreary wating

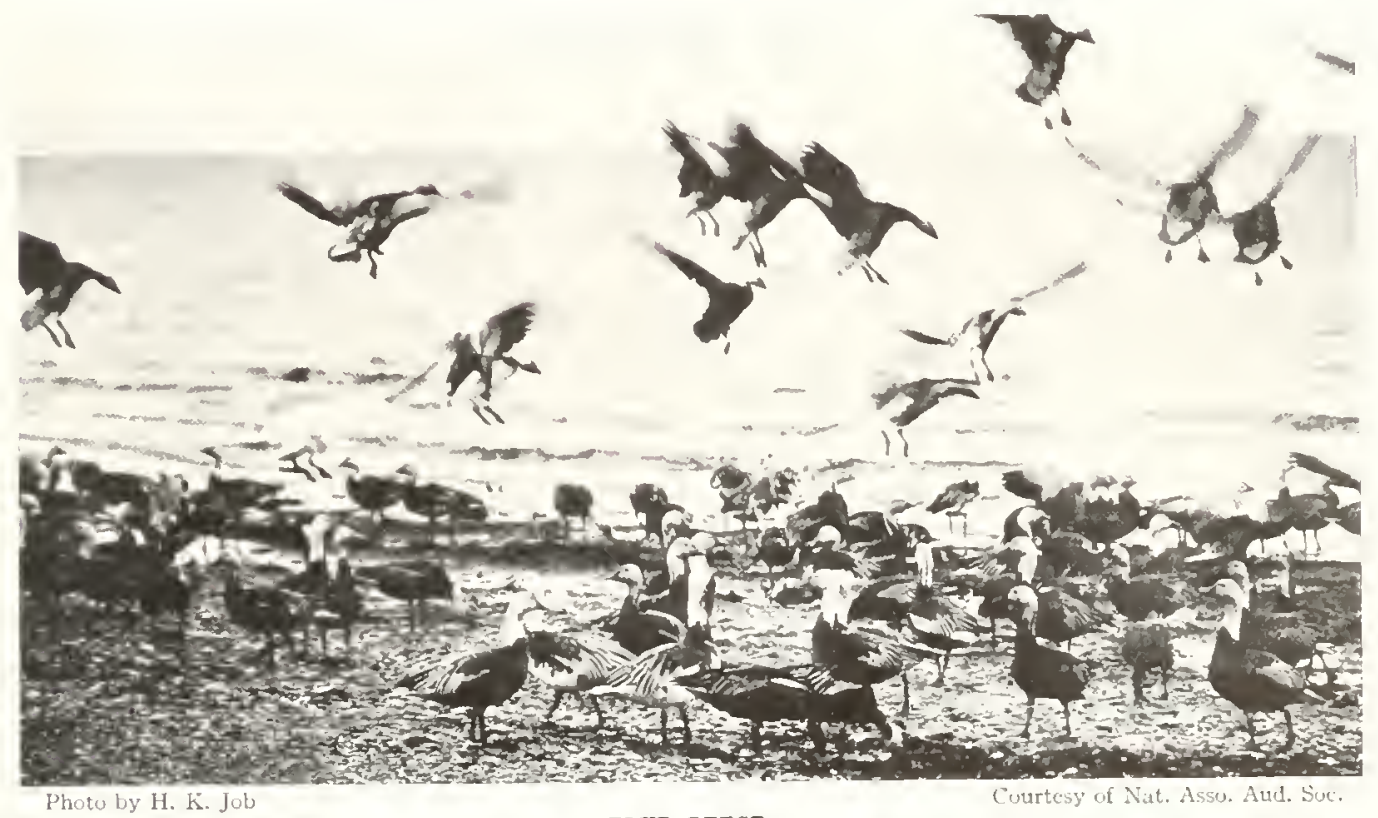

BLUE GEESE

The photographer waited five days to get this picture

certain localities on the marshes. At Cheniers at1 Pigres the cattle men complatined that these great hordes of Geese, spendins the nights, and sometimes days, on the marshes used for pasturing cattle, milled 11] every root of the grass from many acres, creating depressions which filled with water and hecame ponds. The cattle men actually had youthe emponed to ride about on horscback and shont at the Creese to drive them nif.

They breed very far north, perhaps on the Aretic islands north of the Anerican continent Very little is known abont its breceling halnits. It is a remarkable fact that in winter nearly the whole of the species in a body seems to resort to the Gulf coast of Lonisiana, or not further than amirl fog and hosts of mosrpuitoes, patience had its reward

Jardly was I hidden in the blind that morning before the rieese began to come. After considerable circling they alighted on the shore ancl came up to got the sravel. The "seance" lasted four homes. and furing that time I had 11pwarts of a throssand Blue Greese, and a few snow Geese, within as near as six feet. They ate, drank, bathed, and dozed, withont any suspicion of my presence. Noisy fellows, they talked so much that they soemed not to hear the clattering of the picture machine, even when only a dozen feet away. It was one of the most thrilling exjeriences of a lifetime.

IIERBERT K. JOB. 


\title{
WHITE-FRONTED GOOSE
}

\author{
Anser albifrons gambeli Hartlaub
}

$$
\text { 1. O. [T. Number 17ra See Color l'late } 21
$$

Other Names.-American White-fronted Goose; Laughing Goose: Harlequin Brant: Gray Prant: Pied Brant; Prairie 13rant; Spectacled Brant; Speckled Brant; Yellow-legged Goose: Speckle-belly:

General Description.-Length, 30 inches. Plumage. uravish-brown with rlark patch on lower breast. Bill, comparatively low at liase.

Color.- Lares, forthed, and fore-crown, ahite, bordered behind by blackish; head, neck, breast, and upper parts in general, dark grayish-brown, feathers of back with lighter edges, forming regular and distinct transverse bars; upper tail-coverts, white; secondaries and ends of primaries, dusky, ashy at base: greater coverts and secondaries bordered with whitish; sides of body helow, grayish-brown; a large patch more or less broken oi deep hlackish-brown on lower breast and ahdomen: bill, pink with white tip (the bill is yellow in breeding seasun ) ; feet, chrome-yellow ; iris, dark brown. Young: General tone of color browner, no black below; no white on head; tip of bill, black or dusky; otherwise similar.

Nest and Eggs.- NEst: A shallow depression in the ground, lined with grass, feathers, and down; usually near fresli-water lakes. Eiggs: 5 to 7 , creamy-white.

Distribution.-Central and western North America: breeds on and near the Arctic coast from northeastern Siberia east to northeastern Mackenzie and south to lower Yukon valley; winters commonly from southern Britisl Columhia to southern Lower California and Jalisco, and rarely from southern Illinois, southern Ohio, and New Jersey south to northeastern Mexico, southern Texas, and Cuba, and on the Asiatic coast to China and Japan; rare in migration on the Atlantic cuast north to Ungava.
The White-fronter Goose was formerly an uncommon spring and atutumn migrant on our coast (Howe and tllen). Dr. T. A. Allen $(18-0)$ terns it a rare migrant, spring and fall, and says that Dr. Brewer states that it was more common thirty or forty years ago, as was the case with many of our other Ducks and Geese. It is now regarded as a mere stragsler on the entire Atlantic coast.

it is known as a lirant in some of ont western States, where it is abundant in migration.
Furmerly it was common as far east as the Ohio kiver.

The flight of the White-fronted Goose is similar to that of the Canada Goose. There is the same $V$-shape formation, and at a distance it might be readily mistaken for that of the Canada Goose. Audubon states that in Kentucky this Croose feeds on beechnuts, acorns, grain, young blades of urass, and smails.

EDwakn Howe Forbush, in Game Birds, ll'ild-Fon'l and Shore Birds.

\section{CANADA GOOSE}

\section{Branta canadensis canadensis (Limaus)}

$$
\text { A. } O \text { (T. Number I } 2 \text { See (olor I'late } 2=
$$

Other Names.-Wild Goose: Common Wild Goose; Cravat Gonse; I3ig Gray Goose: Bay Grose: Reef Gonse; Black-hearled Goose: Canada Brant; Honker; Long-necked Goose.

General Description.- Length, 35 to 43 inches. Head, black; hody, hrownish-gray. Neck, long and slender.

Color.-Head and neck, hlack: a broad circular patch crending from upter side of head around throat to an cqual distance on ather side, not reaching lower bill, leaving chin black: rest of plumage, brownisli-gray, more achy helow; all feathers with paler edges; upper and under fail-coacrts, athite; bill and feet, black; iris, brown.

Nest and Eggs.- Nest: Usually on a mound in marshes: constructed of grass, reeds, and leaves and lined with down; rarely old nests of Hawks or Eagles are appropriated. EgGs: 6 to 7 , dull white.

Distribution.- North America; breeds from limit of trees in valtey of the lower Yukon, northwestern Mackenzie, and central keewatin south to southern Oregon, northern Colorado, Nebraska, and Indiana; formerly bred casually south to New Mexico, Kansas, Tennessee, and Massachusetts; winters from southern British Columbia, southern Colorado, southern Wisconsin, southern Illinois, and New Jersey (rarely southern Ontario and Newfoundland) south to southern California. Texas, and Florida: accidental in Bermuda and Jamaica 


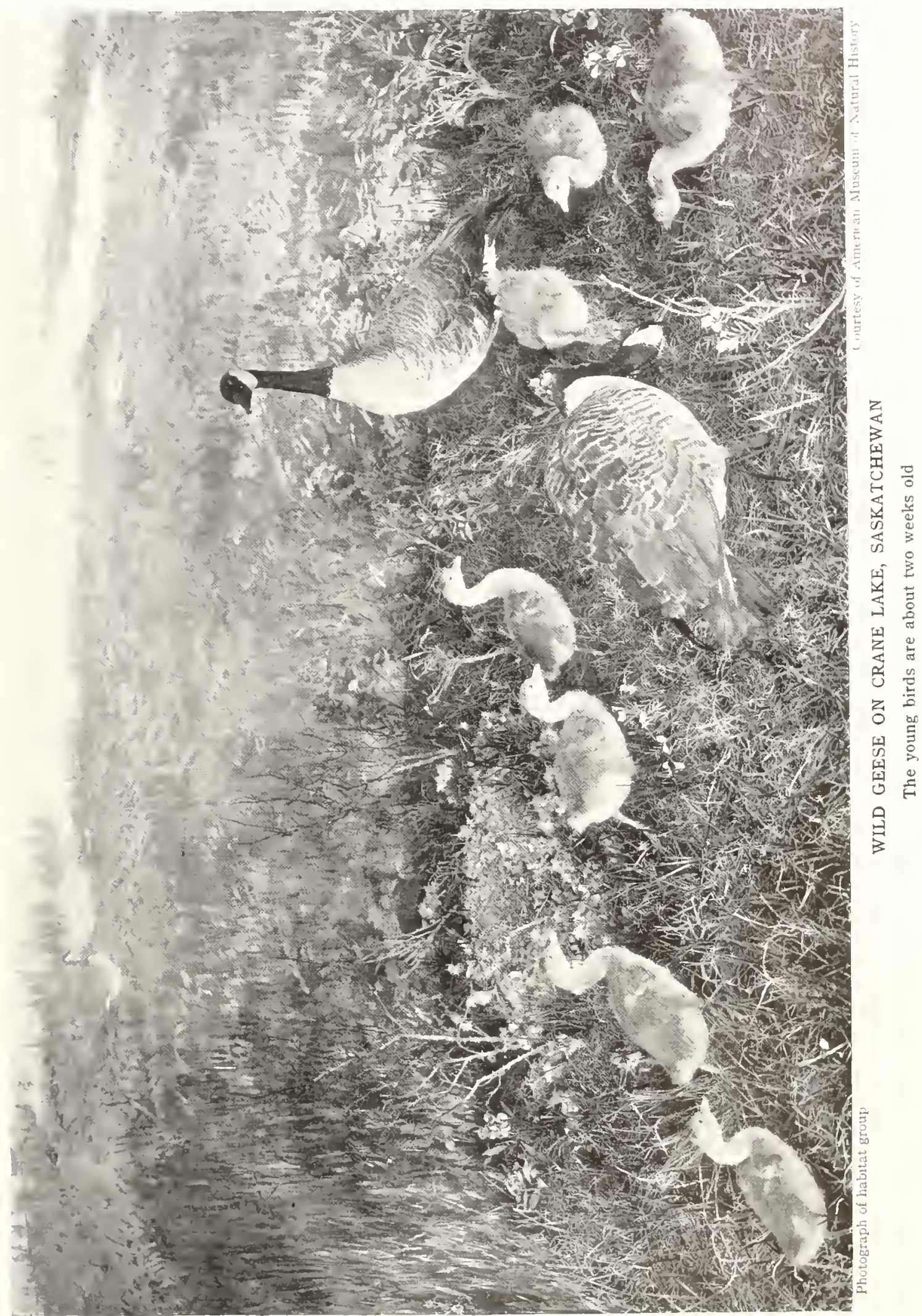


The Canada Goose is the best known member of the subfamily Anscrinc in eastern and central North America. Nearly everyone is familiar with the sight of the $V$-shaped bands of these

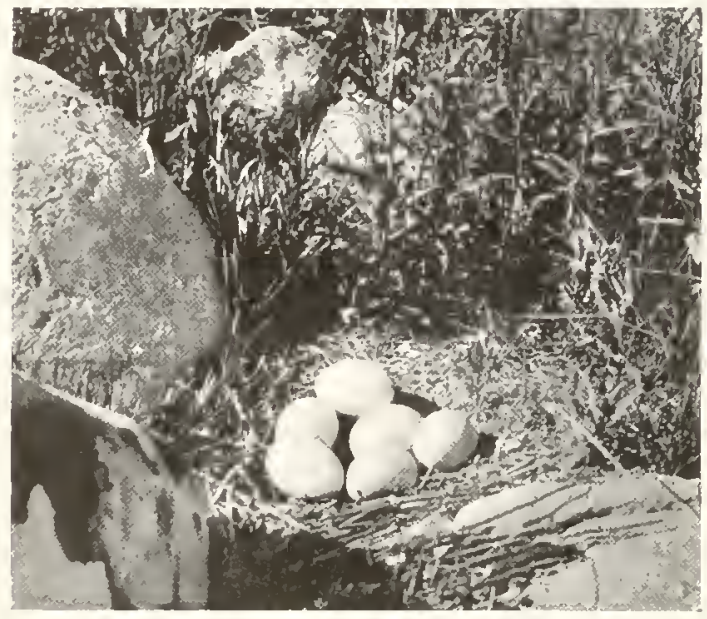

Photo by T. G. Pearson Courtesy of Nat. Asco. Aud. Soc.

NEST AND EGGS OF CANADA GOOSE

Stump Lake, North Dakota

s)lendid birds as they nuigrate southward in autum, or in spring when they again turn their wing-beats toward the frozen pole. The great breeding grounds of thi, Goose are in the liritish provinces, few, if any, of the eastern flight pausing in spring soutl of the Canadian border. In the western States, however, they breed contmonly in many localities. Thus, I have found their eggs on islands in lakes of North Dakota, and come upon the young attended by the parents in Oregon and northern California. It is a rather curious fact that shortly after the young have hatched, the parents begin a mo?t of feathers which is frepuently so extensive that the birds lose the power of flight. At this season they nust of course repend entirely upon their wonderful ability to swim, when in search of food, or endervoring to escape their enemies.

Canada Geese are not flesh eaters. the grainfields of the great Northrest being their special delight. During the fall migration they often come here in great numbers and feed on the grain scattered among the stubble at harvest time. Along the lower Missis ippi River they may often be seen in the fields of Tennessee and Arkansas. Like most Ceese, while feeding, they have one or more sentinels constantly on the lookout for danger. Furthermore the members of a feeding flock are continually rising $u$ p and looking about. so that there are always a number of hearls in the air
These birds assemble in enormous numbers on favorite feeding gromeds in Chesapeake Bay and in the sounds of North Carolina. In Currituck Sonnd I have seen one flight that was two hour's in passing a given point. They came in one long wavy rank after another, from twenty to thirty of these extencled lines of Geese being in sight at a time. The Canada Goose is highly esteemed as an article of food, and when one stops to think of the incessant gun-fire to which they have long been subjected, it is hard to understand why their numbers lave not materially decreased.

T. Gilbert Pearson.

The Canada Geese " feed largely on vegetable matter, the roots of rushes, weeds, grasses, etc., grass, and many seeds and herries, and swallow guantities of sand as an aid to digestion. Ceese either feed on shore. when they pluck up grass ancl other vegetation, or they bring w1 food from the bottom in shoal water by thrusting their heads and necks down as they float on the surface. Like the Brant, they feed on eel-grass, which grows on the flat 3 in salt or brackish water. in tirlal streans, and marshy ponds. Sometimes they are destructive to young grass and grain." (Forbush.)

Hutchins's Goose (Branta canadensis hutchinsi) is precisely like the Canada Goose in everything except size; its length is but 25 to 34 inches, and its weight is generally three or four pounds, rarely exceeding six pounds. It breeds in the Arctic region of North America and migrates south in winter chiefly through western

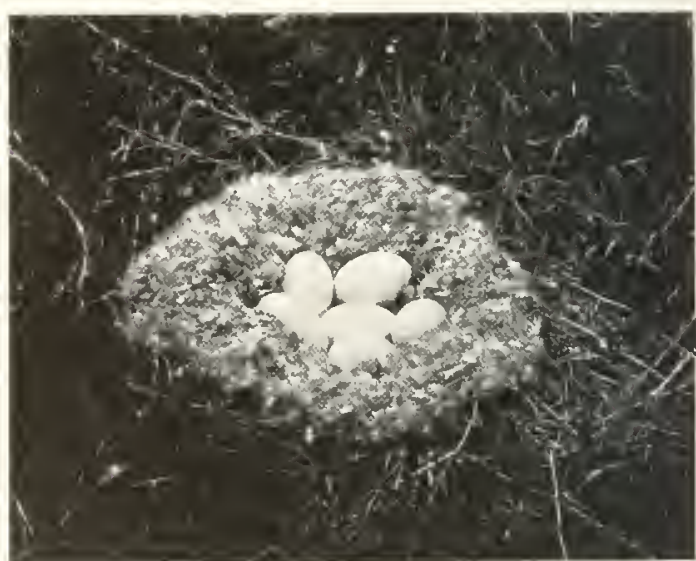

Photo by If K. Job

NEST AND EGGS OF CANADA GOOSE

Saskatchewan

Linited States and the Mississippi valley. Sonetimes it visits northeastern Asia. Throughout its range it is variously known also as Goose-brant, 
$\frac{a}{2}$
$\frac{2}{2}$
5
5

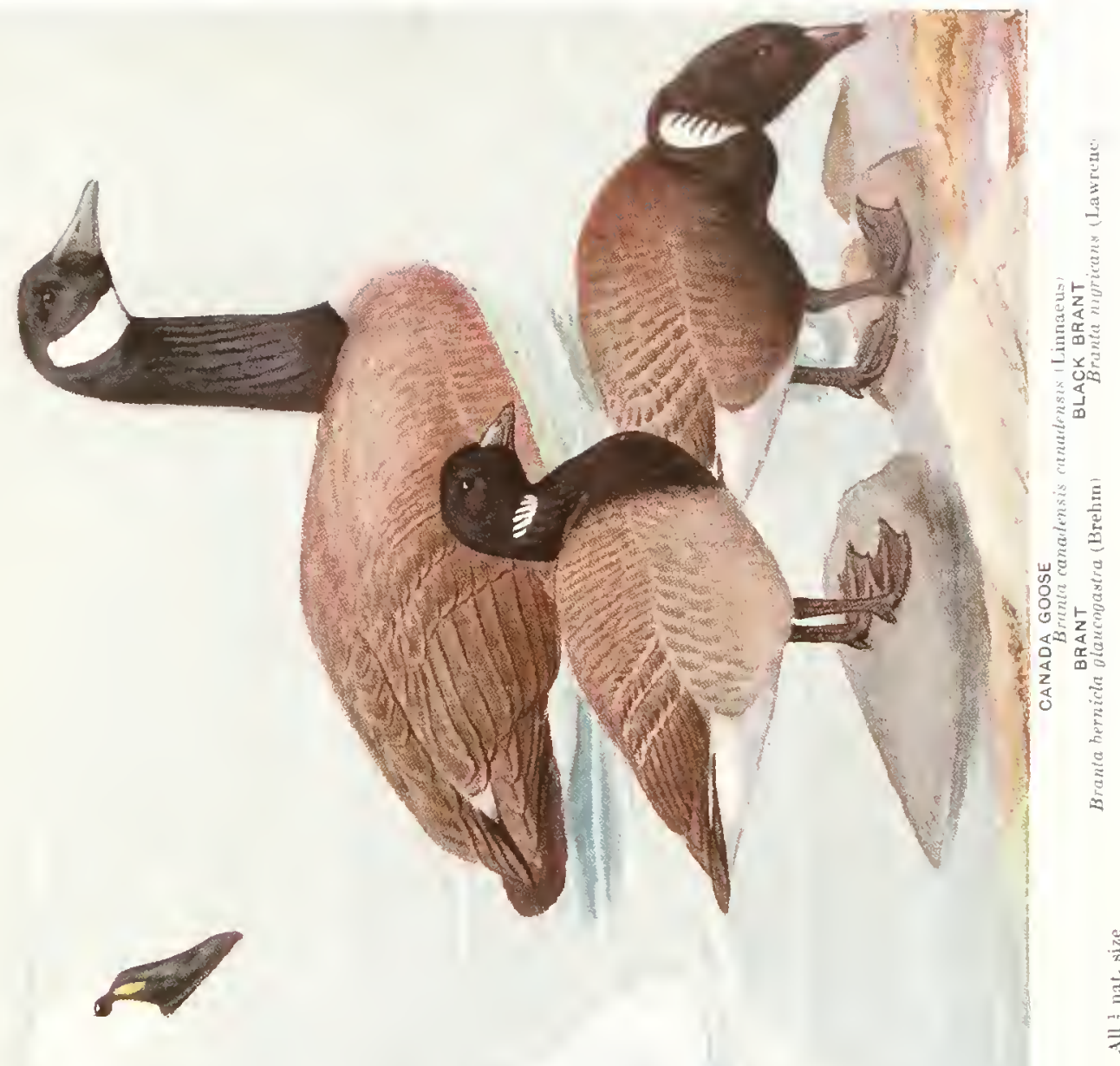

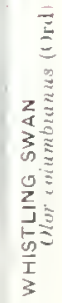



Little Camada Croose, Iittle IVild Coose, Small Ciray lioose, little Gray Goose, Short-necled Gnose, or Mud Goose.

The White-cheelied Coose ( Branta canadonsis occidentalis) and the Cackling Conse (Rranta canadensis minima) are other geographical varieties of the Canada roose. The former is found in the l'acific coast district of Nortl America. breeding from Prince William Sound and Mitkof Island south in northeastem California, and wintering from Washington to south California.
It is like the Canada, but the under parts are darlier and the white cheek patches are usually separated by a liack throat patch. The Cackling roose is like the White-cheeterl lout smaller in. size. It breeds in the western Aleutians and Norton Sound south to the northern coast of the Alaskan peninsula. In the winter it may be foums from British Columbia soutl to San Diego county, California; it has sometines heen reported from Colorado, Lowa. Wisconsin, and Illinois.

BRANT

Branta bernicla glaucogastra ( $\mathrm{Hr}$ chm $)$

\author{
1. 1) (1. Number 1 ;3a see color f'late 2:
}

Other Names.-Common Brant: Fastern Prant; White-bellied Brant; Light-bellied Hrant; Brant Grose; Clatter Goose: Crocker; Quink: Plack Brant: Brent Guone: Burnt Gouse.

General Description.-Length, It inches. Color abue, brownish-gray: below, ashy-gray and white. Neck, long and slender.

Color.-AnelTs (SEXES At.1KE): Head, neck, throat, and breast. black; on cach side of nock a sories of 5 or 6 ahite streks; upper parts, brownish-gray, the feathers lighter edged; rump. darker; upper tail-coverts, white; primaries and seconlaries, dusky; lower breast, pale abyy-gray fading on abdomen and lower wingcoverts to white; biil and feet, black: iris, brown. IM MATURE: Similar, but not so much white on sides of

neck and wing-coverts, and the secondaries tipped with white.

Nest and Eggs.- Nest: A lepression in the gromud on marsny gromul or sambly heaches: made of grass, moss, and feathers and linel with down. Egrs: + to 0 , grayish-white.

Distribution.- Northern hemimplere; breeds on Arctic islands north of latitule 7 and west to about longitude 100 , and on the whole west coast of Greenland; winters on the Atlantic coast from Massachusetts, south to Nortb Carolina, rarcly to Florila: has been recorded in the interior from Manitoba, Ontario, Colorado, Nebraska, Wisconsim. Michigan. Indiana, and Louisiana: accidental in British Columbia and the Piarbarlos.

\title{
BLACK BRANT
}

\section{Branta nigricans (Lazernoc)}

\author{
1. (1) 1. Number 124 See Color Plate $2=$
}

Description.- Like the Brant, but black of head and breast extending over most of under parts, fading on abdonen and under tail-coverts into lighter; white neck patches usually larger and meeting in front.

Nest and Eggs. - Nesting similar to and eggs indistinguishable from the Brant's.

Distribution.- Nestern North Imerica: breeds on the Arctic coant and islands from Foint harrow east

to near mouth of Anderson River, north probably to Mielville Island; common on Siberian coast, Chukchi I'eninsula, and west to New Siberian Islands; winters un the Pacitic coast from Pritish Columbia sonth to San Quintin Bay, Lower California, in the interior of Oregron and Nevala, and on the Asiatic coast south to Japan; recorded as a straggler to Massachusetts, New lork, and New Jersey.

The Frant is the smallest of our wild creese and is known to the United States only as a winter visitor. Its summer home is heneatl the very shadow of the frozen pole, for its nest is built well within the Arctic circle. When the lirst breath of autumn sweeps over our southland the wild water-fowl begin to appear, and every. successive grale from the North brings its teeming thousands. Not among the first arrivals lut soon to follow comes the lirant. It does not visit the 
rivers and lakes of the interior like most of its hin, lut follows down the coast to feed principally in the salt and hrachish waters of the bays and sounds of Virginia and North Carolina. Here it may be fommin in thousands and tens of thousands. I recall once sailing through Panlico Sound from Ocracoke to Cape Ilatteras, a distance of thirty miles, and there was not a minute during the entire trip but what newly startled flocks were in the air before us.

When the weather is fair Brants gather in very large companies to feed on the eel-grass grow- come ; they " draw to the idols," the local gunners say. They are awkward. slow-flying birds and poor indeed is the marksman who cannot make a good scole with a shotgun under such conditions.

Another popular way of hunting them is by means of a battery. This may be described as a coffin with canvas wings. It is anchored on the Prant's feeding grounds and when the gunner lies down in it he is effectively concealed unless to a bird almost directly overhead. This is probably the most deceptive device used by man to

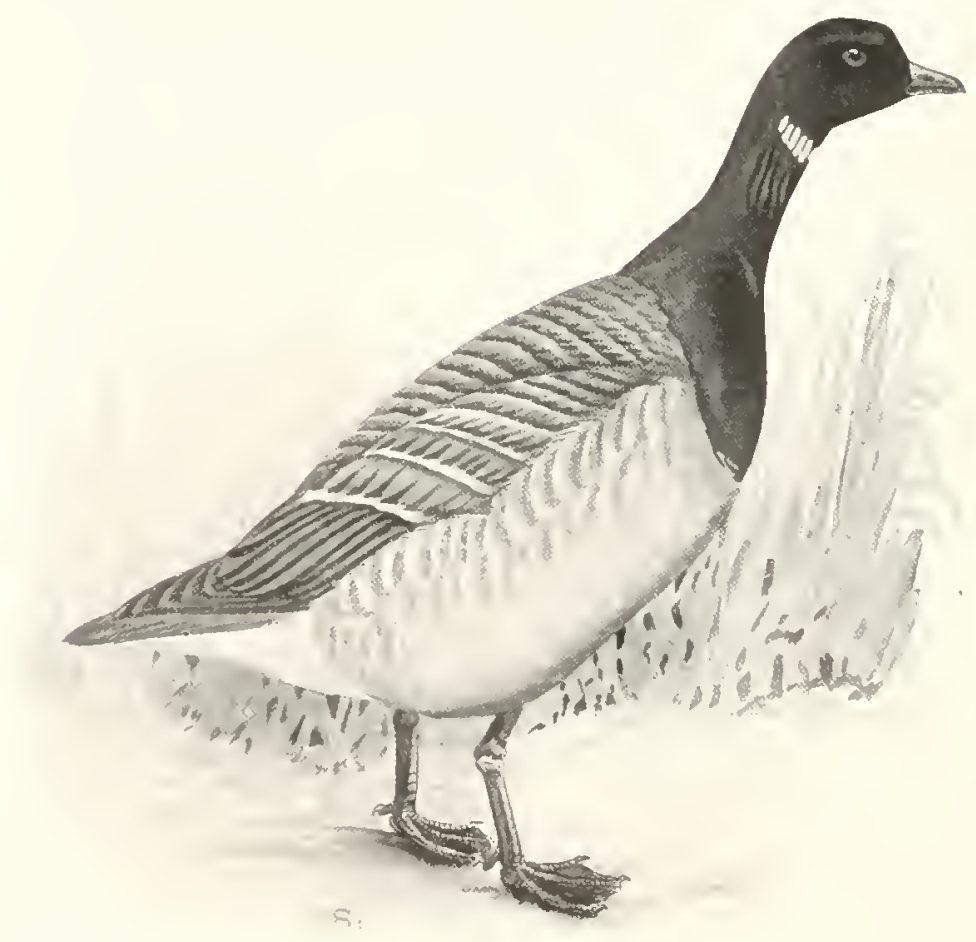

Drawing by R. I. Brasher

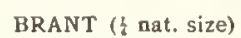

The smallest of the wild Geese

ing in the shallow water of the shoals, or at high tide to drift a chattering host upon the bosom of the slow-heaving sound. Then strong winds blow these large "rafts" are loroken up and small companies of from two to a dozen fly about seeking companionship. It is then that the gunners get in their deadly work. In a small hlind crected on four posts standing on a shoal. often three or four miles from land, the hunters take their stand. Anchored in the water about them are from fifty to one hundred wooden decoys representing Ducks and Brant. It is to these dimmy sirens that the small flocks of Brant outwit the wary wild fowl. I have known bags of one hundred Brant to he made from a single battery in a jay. In viewing such sights one is led to woncler that any of these game-birds have been able to escape the terrific slanghter to which they have long been subject by the hand of man.

On the Pacific coast of North America the Black Brant is found. It is very similar to the eastern species, but has more black on the underparts and the front of the neck as well as the sides has white markings.

T. Gilbert l'earson. 


\title{
EMPEROR GOOSE
}

\section{Philacte canagica (Sirasticuoff)}

\author{
A. $O$ U. Number $\$ 76$
}

Other Names. - Painted Goose: Peach Goose.

General Description.- Length. 28 inches, 1 lead and tail, white; body, bluish-gray. Lill, small and but little elevatel at base.

Color-Anurs: Head, sides and back of neck, and tail, white, the first two tinged with amber-yellow; throat, blachish; rest of plumage, bluish-gray; feathers above and below with black subterminal crescents whitetipped, producing a scaly appearance; bill, Hesh color witl white tir; feet, orange-yellow; iris, brown. Younc: Head, dusky speckled with white on top ; stherwise similar to adult.
Nest and Eggs.- Nest: A feprescion on marshy islands bordering the sea, at first withus semblance of nesting material. but an tire number of exges to he laid nears completion, the depresuion is lined with yrass. leaves, aml down. Eigs: 5 to 8, rutt whitish.

Distribution.- Coasts of Alaska; hreeds from Kotzebue Sound south to mouth of Kuskotwim, on St. Lawrence Island, and alio on Chukchi Peninsula. Siberia, near East Cape; winters from the Commander and Near islands eant throngh the Aleutians to Brintol Bay and Sitka: casual in British Columbia and California; accilental in Hawaii.
Edward II. Nelson, who mate a special study of the Emperor Coose in Alaska, and prepared for the National Association of Audubon Societies a leaflet in which be records some of his interesting observations, says that this is the "least known and the most beatutiful" of all the wild geese which make their summer honc in the Far North, in both the ()h, and the New worlds. For these reasons it seems proper to give here sone account of the hird, even thotigh its visits to the United States proper are confined to oceasional appearances in northern Californa.

The main wintering place of the Emperor roose, according to Mr. Nelson. appears to be on the sunthern side of the Peninsula of Alaska and the Aleutian Islands, where the Alents know it as the "Beach Goose." The Eskimos of the Inkon delta Mr. Nelson found wearing "parkies" or outer garments made of the slins of Enperor Geese, sewed together. Their native name for the bird is " nachau-thluk." As to his observations of the bird's habits in the Intion region Mr. Nelson writes:

"At first the Emperor Geese were difficult to approach, but as their numbers increased they became less shy. When on the wing, they were easily distinguished from the other Geesc, even at considerable distances, by their proportionately shorter necks and heavier bodies, as well as by their short, rayjicl wing-strolies, resembling those of the Black Brant. Like the latter, they usually flew near the ground, rarely more than thirty yarrs high, and commonly so close to the gromind that their wing-tips almost tonched the surface on the down stroke. While flying from place to place, they give at short intervals a harsh, striclent call of two syllables. like kla-ha. kla-ha, kla-ha, entirely different from the note of any other couse 1 have ever heard. Ther are much less noisy than either the White-fronted or Cackling Geese, which often make the tundra resound with their excited cries.

"Alnost at once after their arrival on the islands, the Emperor Geese appeared to be mated, the males walking aromd the females, swinging their heads and nttering low love notes: and incoming flocks quickly disintegrated into pairs which noved abont together, though often congregating with many others on flats and sandbars. The male was extremely jealons and pugnacions, however, and immediately resented the slightest approach of another twwird his choice: and this spirit was shown equally when an individual of another species chancel to come near. When a pair was feeding. the male moved restlessly about, constantly on the alert, and at the first alarm the pair drew near one another, and just before taking wing tottered a deep, ringing u-lugh, u-lugh; these, like the flight-notes, having a peculiar deen tone impossible to describe. At low tide, as soon as the shore ice disappeared. the broad nutu-flats along shore were thronged with them in pairs and in wrouss. They were industriously dabbling in the mud for fond tntil satisfied, and then congregatted on hars, where they sat dozing in the smo or lazily arranging their feathers.

"Early in June, they hegan repositing eggs on the flat, marshy islands borlering the sea. The nests were most numernus a short distance back from the mudrly feeding-grnumb, lut stray pairs were found nesting here and there farther inland. One must have lain with neck ontstretched on the ground, as I afterward found was their 
custom when approached, for the Eskimo and I passed within a few feet on each side of her; but, in scanning the ground for nesting birds, the general sinnilarity in tint of the bird and the obvious stick of driftwood beside her had completely misled our sweeping glances.

"The same ruse misled us several times; but on each occasion the parent betrayed her presence by a startled outery and hasty departure soon after we lad passed her and our backs were presented. They usually flew to a considerable distance, and showed little anxiety over our visit to the nests. When first laid the five to eiglut eggs are pure white, but they soon become soiled. When the complement of eggs to be laid approaches conuletion, the parent lines the depression in the ground with a soft, warm bed of fine grass, leaves, and feathers from her own breast. The males were rarely seen near the nests, but usually gathered about the feeding-grounds with others of their kind, where they were joined now and then by their mates.

"The young are hatched the last of June or early in July. and are led about the tundras by both parents until August, when the old birds molt their quill-feathers and with the still unHedged young become extremely helpless. At this tiuse, myriads of other Geese are in the same condition, and the Eskinuos made a practice of setting up long lines of strong fish-nets on the tundras to form pound-traps, or enclosures with wide wings ?eading to them, into which thousands were driven and killed for food. The slaughter in this way was very great, for the young were killed at the same time. Fortunately, in Igog. President Roosevelt made a bird-reservation covering the delta of the I'ukon and the tundra to the southward, which includes the main breedground of the Emperor Goose, and thus took a long step toward perpetuating this fine bird."

\title{
SW A N S
}

\section{Order Anscres; family Anatida: subfamily Cygnina}

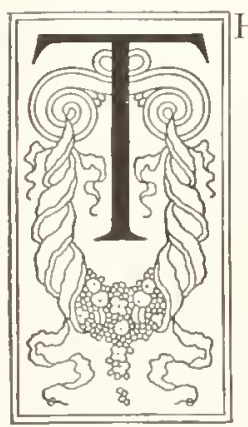

HE Swans constitute a subfamily (Cignina) of the family Anatida, and may be considered as comprising two genera, which include about eight species. The "true" Swans English ornithologists group in a single genus, Cygmus, while by American scientists they are called Olor from the Latin, meaning Swan. They are large, and almost exclusively aquatic birds and are characterized by the length of the neck, which may be even longer than the body, the number of vertebra ranging from twenty-three to twenty-five, while the Geese have less than twenty. The Swans are famous for their statcly appearance in the water, due largely to the constantly changing but always graceful arching of their necks. The plumage is generally pure white, though the head is sometimes marked with rusty hues.

Like the Geese, the distribution of the Swans is very wide, their range including much of the Arctic regions, where they build their rude nests, composed chiefly of reeds, in which are deposited about six eggs of a greenish hue. Their food consists mainly of the seeds and roots of water plants, though they are accused of destroying great quantities of fish-spawn.

\section{WHISTLING SWAN}

\section{Olor columbianus ( $\mathrm{rrd}$ )}

\author{
1. 1 IT. Tumber I 80 See Color I'late $2=$
}

Other Names.-Swan : Common Swan; Wild Swan; American Whistling Swan.

Length.- $4^{1 / 2}$ feet.

Description. - Nostrits nearer the tip of the bill than the eyes. Adults: Entire plumage, pure white; bill, black with a yellow spot at base in front of cyc; feet. black; iris, brown. Young: Plumage, ashy-gray, darker on neck where washed with pale rufous; bill, party flesh color; feet, yellowish flesh color.

Nest and Eggs. - NEST: On the ground in or on the borders of marshes; a large structure of grass, moss. weed stalks, and herbage of different kinds. EGGs: 3 to 6 , dull white.

Distribution.- North America; breeds from north- 


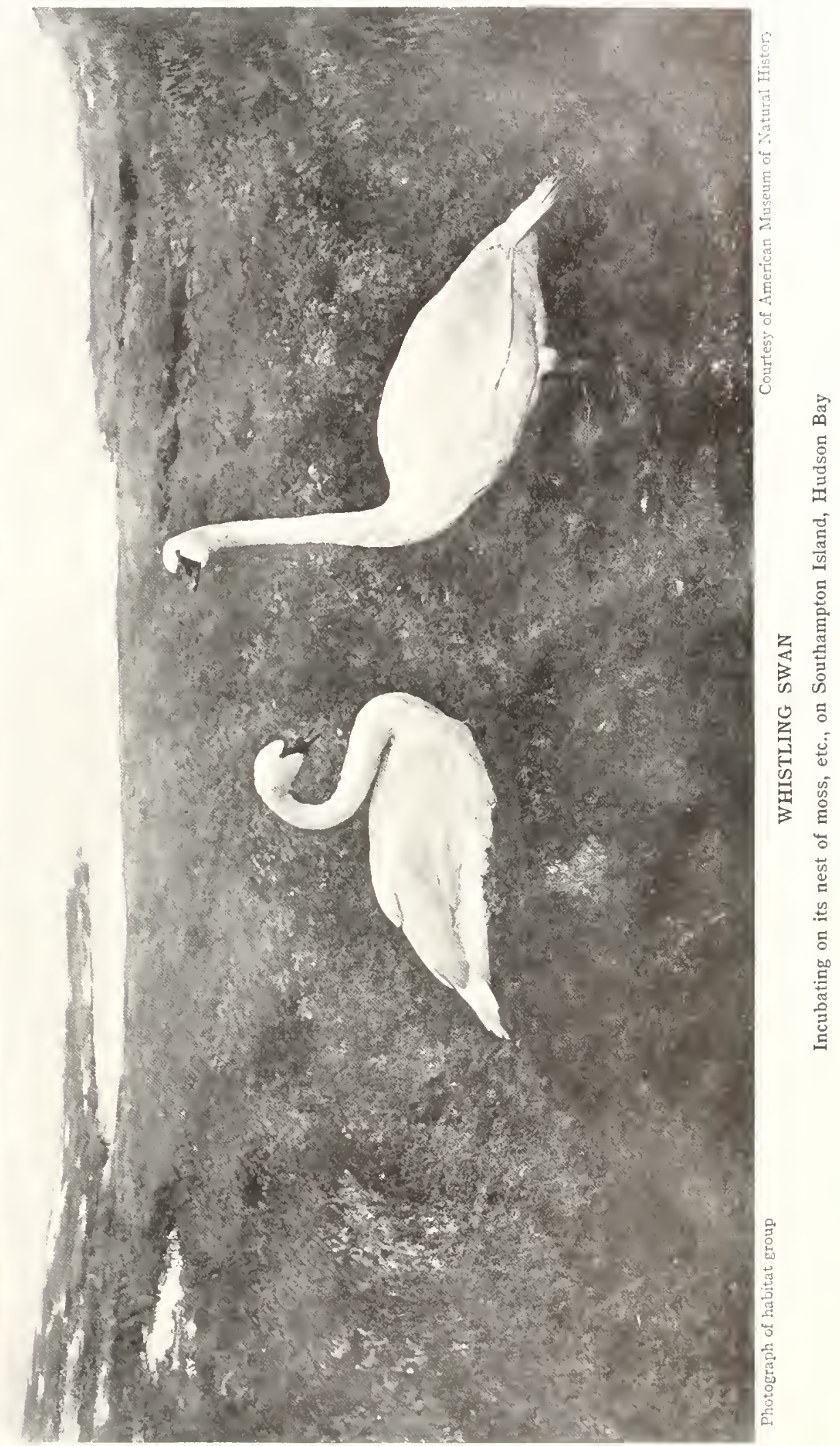


ern Alasha south to Becharof Lake, Alaska Penirisula, and on Arctic islands from about latitude 74 "south to northern Mackenzie and northwestern Hudson Bay: in migration occurs west to Bering Island: winters on the Pacific coast from southern British Columbia, rarely south to southern California, and in the interior from
Lake Erie and southern Illinois to coast of Louisiana and Texas, and on Atlantic coast from Delaware and Maryland to South Carolina, rarely north to Massachusetts and south to Florida; casual in northern Mexico; accidental in the British Isles and in the Bermudas.
On the coasts and islands of the Arctic Sea, in far-off archipelagoes of the great frozen North. the Whistling Swan builds its huge nest. When the mother leaves it she covers the egos carefully with the mossy nest lining to insure warmth and safety. The eggs are hatcher hy the last of June and the cygnets are led to the water where some high-keyed notes may cone from the vounger birds but the old males sound the bass horn. As the flock passes over, high in air, the leader utters a high note like that of a flageolet which Elliot describes as sounding like whor-whowho and this, repeated hy flock after flock, may have given the bird its name.

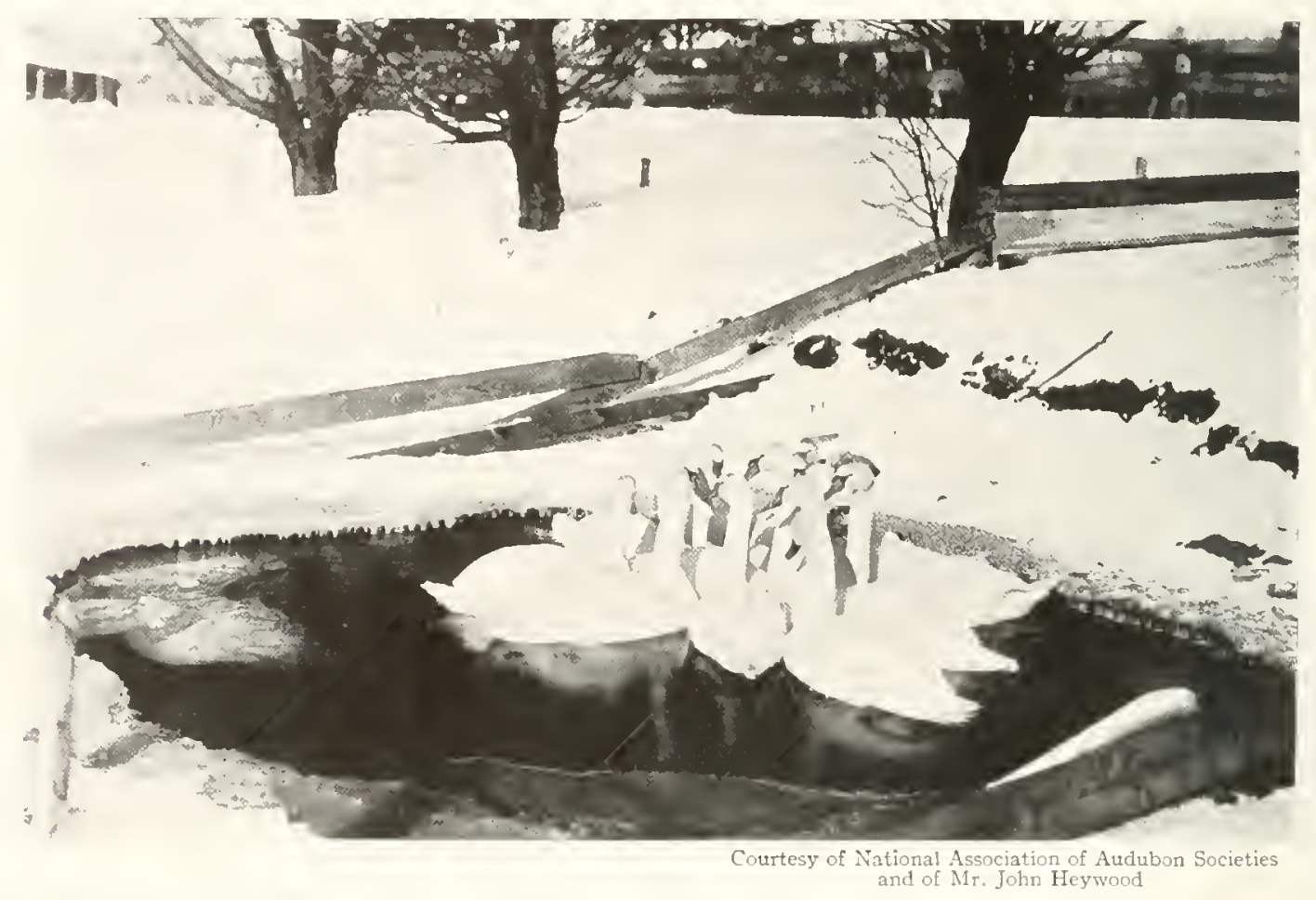

SWANS IN WINTER ON HEYWOOD ESTATE, GARDNER, MASSACHUSETTS

Showing how waterfowl keep open a hole in the ice

they feed and grow under the midniglit sum. Soon the parents molt out all their flight-feathers and, as the whole family i: then mable to fly, they often fall victims to the natives who hunt them remorselessly at this season, but native tribes are few; the comtry is a wide wilderness and many of the birds escape the dangers of the north. Late in September or in October they are on their way southward where they are to face greater perils.

It is hard to see just why this bird is called the Whistling Swan. Its calls have great variety:
The flight seens to divide into three sections: one following the Atlantic coast: another the Mississipin valley, and a third the Pacific coast. The flocks pass mainly overland in an unwavering line at great heights. In fair weather they seem to avoid civilization, flying so high as to be unmoticed by human eyes and making but few stops, therefore they are considered scarce in most of the northern States of the Union. Tery rarely, when canght in storms and over-weighted with sleet and snow, they are forced to come to the ground. 
Such a catastrophe occurred to the flocks in northwestern l'ennsylvania on March 22, IS-4. Swans came down in many places in four counties, in ponds, streams, fields, or villages. Large numbers were killed by men and boys with guns, rilles, and chuls. Twenty-five were captured alive in one village, as they were worn out and hehpless after their battle with the stom. Most of those that alighted within sight of human habitations were slaughtered wantonly. (George B. Sennett, in Bull. Nuttall Om. (lub, 1880.) In some cases the Great Lilies are their refuge. if they can reach those waters, and often they are saved by alighting under the lee of sone point or island. but now and then a flock comes down in the Niagara River and is carrierl over the falls. Whenever this happens and the wearicl and often injured birds are cast up against the ice bridge or along the shores, penple come in croweds and kill with guns or clubs the birds that have passed alive through the fury of the elements.
There is no safety for a Swan in this comtry except it he high in air or far out on open water Such refuge is found on the broad waters of the Sonth. The great flocks that once frequented the coast in winter from Massachusetts to Soutl Carolina are gone, but the species still winters in large numbers on the Carolina coasts.

The song of the dying Swan has been regarded as a pleasing myth for many rears, but Elliot asserts that he heard it once at Currituck Sound, when a Swan, mortally wouncled in the air, set its wings and, sailing slowly down, began its leath-song, continuing it until it reached the water "nearly half a mile away." The song was mlike any other Swan note that he had ever heard. It was plaintive and musical and souncled at times like the soft rumning of an octave. Inquiry among local gunners revealed the fact that some harl heard similar sounds from Swans that had been fatally hurt. Need we wonder that the Swan was a favorite hird of mythology? EDward Howis Forrush.

\title{
TRUMPETER SWAN
}

\section{Olor buccinator (Richardson)}

\author{
1. () $[4$. Number 18 :
}

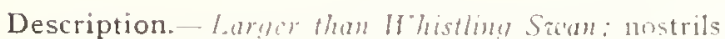
midway between tip of bill and eyes. Antuss: Flumage, pure white or with wash of rasty on lead: bill. lores and feet, blach: iris, brown. Vouso: Bill and teet. not perfeclly black; plumage, srayish; head and upper neck, rusty, Length, 5 feet.

Nest and Eggs. - NesT: On an elevated knoll near water: constructed of grass, stalks, feathers, and down. EgGs: 5 to 7 , dull white.

Distribution.-lnterior and western North Anerica: breeds from the locky Mountains to western shore of Hudson Bay and from the Arctic Ocean to about latitude $60^{\circ}$ : frumerly bred south to ludiana, Missouri. Nebraska, Montana, and Idaho, and custually west tn Furt Yukon and British Columbia: winters from southern Indiana and southern Illinois south to Texas, and from southern British Columbia to southern California: casual in migration in the Kocky. Monntain region of United States; accidental in New Jork and Delaware. Now of rare occurrence nearly everywere.
The Trumpeter Swan. the largest of North American wild fowl, represents a vanishing race. In nost parts of North Anerica it is a bird of the past. Formerly it ranged over the greater portion of the continent. Today it is seen rather rarely in the willer regions of the interior.

Great flights of Swans were ohserved by the early settlers on the Atlantic seaboard from Maine to Genrgia. No one knows what proportion of these were Trumpeters, but, as the Trumpeter was recorded on the Atlantic coast as late as the last half of the nineteenth century, there is some reason for the belief that some of the early flocks were of this species, 1t was once the prevailing Swan of California and was abundant in Oregon and Mashington, but it has now practically disappeared from the Pacific coast. It always was a bird of the fresh waters and did not, like the IThistling Swan, often frequent salt water hays and estuaries. When the country was first setted the Trumpeter hred in the northern United States, and from there northward to the fresh-water lakes and ponds in the vicinity of Hudson Bay, where it was very numerous, and even to the shores of the Arctic Ocean.

Little is known alout the breeding lobits of 
this bird, but, like the Canada Goose, the male guards and defends the female, eggs, and young.

In autumn when the grip of the frost congealed the surface of its native lakes and streans the Trumpeter gathered in mighty flocks, circled high in air and moved southward in great flights using the $\mathrm{V}$-shaped formation so characteristic of migrating Canada Geese. This is written in the past tense as there are no longer any great flights of the species. Then, as now, the Mississippi valley was a highway of bird migration and there, at times, in autumn, when the icy north wind blew, the sunset sky was overcast by clouds of waterfowl moving in dim strata near and far, in varying lines, crossing, converging, ascending, descending, but all trending southward toward waters as yet untunched by the frost. The rushing of their wings and their nusical cries filled the air with a chorns of unrelated sounds, blending in rough harmonies. Above them all, in the full light of the setting sum great flocks of Cranes passed along the sky, and higher still in the glowing firmanent rode the long "baseless triangles" of the Swans. sweeping across the upper air in exalted and unswerving flight, spanning a continent with the speed of the wind, their forms glistening like silver in the sumset glow. They presented the most impressive spectacle in bird life ever seen in North America. When at last they found their haven of rest they circled with many loarse trumpetings in wide spirals from that giddy height reconnoitering the country as they swung lower and lower until, their ap- prelnensions at rest, they sailed slowly down to drink, bathe, feed, and rest on quiet, peaceful waters.

Swans feed almost entirely by reaching down in shallow water and pulling up the vegetation from the bottom with the bill. Animal food such as shellfish is taken to some extent, mainly in the spring.

The reason for the rapid decrease of the Trumpeter is not far to seek. It is the largest and most conspicuous of waterfowl. W'herever, in settled regions, Swans were seen to alight, every kind of a firearm that could do duty uas requisitioned and all men turned out to hunt the great white birds. They were not much safer in the almost unimhabited North, as the demands of civilization pursued them there. The records of the traffic in Swans' down tell the story of decrease in the teritory of the Fludson Bay Company. Just previous to the middle of the nineteenth century about five hundred Swans' skins were traded annually at Isle à la Crosse and about three hundred were taken yearly at Fort Anderson. These were mainly skins of the Trumpeter Swan. The number sold annually by the Company slowly decreased from I3I 2 in 1854 to 122 in 1877 . In 1853 Athabasca turned ont 25I, in I889 only 33. In I880 and I890 Isle ì la Crosse sent out luut two skins for each outfit. (Preble, North American Fanna.) So the demands of fashion and the blood lust will follow the Trumpeter to the end.

EDWARU Howe forbUsil.

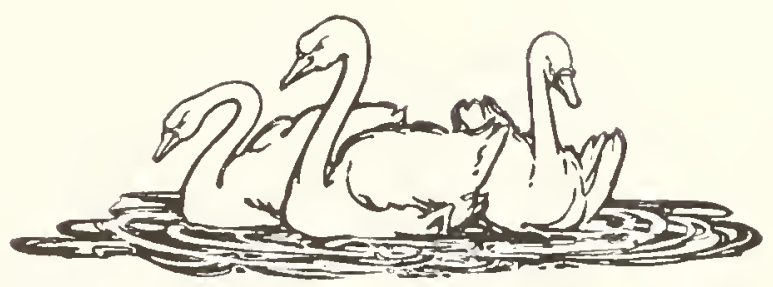




\title{
ORDER OF LAMELLIROSTRAL GRALLATORES
}

\author{
Order Odontoglosse; family Planicopteride
}

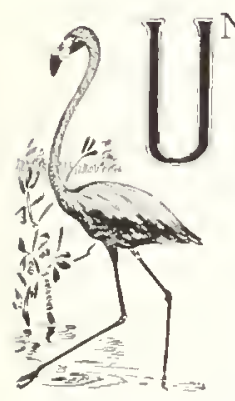

NTIL comparatively recent times the Flamingoes were associated by ornithologists - as they still are by many others - with the Storks and Herons. It is now known that they constitute an order which is the link letween the order of Lamellirostral Swimners and that of the Herons, Storks, and Ibises. The Persians recognized this relationship to the Geese when they gave to the Flamingo the name of $\mathrm{K}^{\prime}$ aj-i-surkh, or Red Goose.

Of the seven species comprising the Flamingo family, five oceur in this hemisphere, but only one comes within the borders of the United States. The family has several peculiar and interesting eharacteristics. In the first place, the plumage of all Flamingoes is very beautiful, the prevailing colors varying from rosy pinl to bright scarlet. Again (and unlike the Herons, Cranes, and Ibises) the Flamingo's long neck is not due to multiplication of the vertebra, of which there are but eighteen, but to the lengthening of the separate bones. Furthermore, the bird's bill is quite distinct in its structure: the lower mandible is a boxlike affair, broad and deep, into which the upper mandible, which moves freely, closes like a lid, and the sides are fitted with gill-like processes, which act as sieves, while the whole is bent sharply downward near the tip. This curious organ is thrust into the mud in an inverted position, the point being directed backward. In this manner the bird seeks its food, which consists of frogs, shellfish, mollusks, and aquatic herbage, strained from the mud by the sieve apparatus.

Any bird or beast of strange appearance and unusual habits is likely to be eredited with almost any weird practice. The Flamingo furnishes an illustration of this in the accounts of its nesting habits which long passed current, and some of which are still believed by many. For probably the oldest and one of the most graphic of these accounts we are indebted to William Dampier, the seventeenth-century English freebooter and explorer, who thus described the nesting of the Flamingo (near Curaça) in his famous book, A Ner' l'ojage Around the llorld:

"They build their Nests in shallow Ponds, where there is much Mud, which they serape together, making little Hillocks, like small Islands, appearing out of the Water, a foot and a half high from the bottom. They make the foundations of these Hillocks broad, bringing them up tapering to the top, where they leave a small hollow pit to lay their Eggs in; and when they either lay their Eggs, or hateh them, they stand all the while, not on the Hillock, but close by it with their Legs on the ground and in the water, resting themselves against the Hillock, and covering the hollow nest upon it with their Rumps: For their Legs are very long; and building thus, as they do, upon the ground, they could neither draw their legs conveniently into their Nests, nor sit down upon them otherwise than by resting their whole bodies there, to the prejudice of their Eggs or their young, were it not for this admirable contrivance, which they have by natural instinct. They never lay more than two Eggs, and seldom fewer. The young ones cannot fly till they are almost full grown; but they will run prodigiously fast ; yet we have taken many of them."

Of course, neither Dampier nor anybody else ever saw Flamingoes incubating their eggs in this manner; what he wrote was what had been told him, or what he conjectured would have to be done by a bird with stch tremendously long legs; for we know, as a matter of fact, that Flamingoes cover their eggs very much as other birds do, that is to say, by sitting on them with their legs doubled up and the knees stretched out backward and coming about under the end of the tail. Yet undoubtedly by a great many ornithologies, or by detached articles still in circulation, this absurd invention is still perpetuated. 


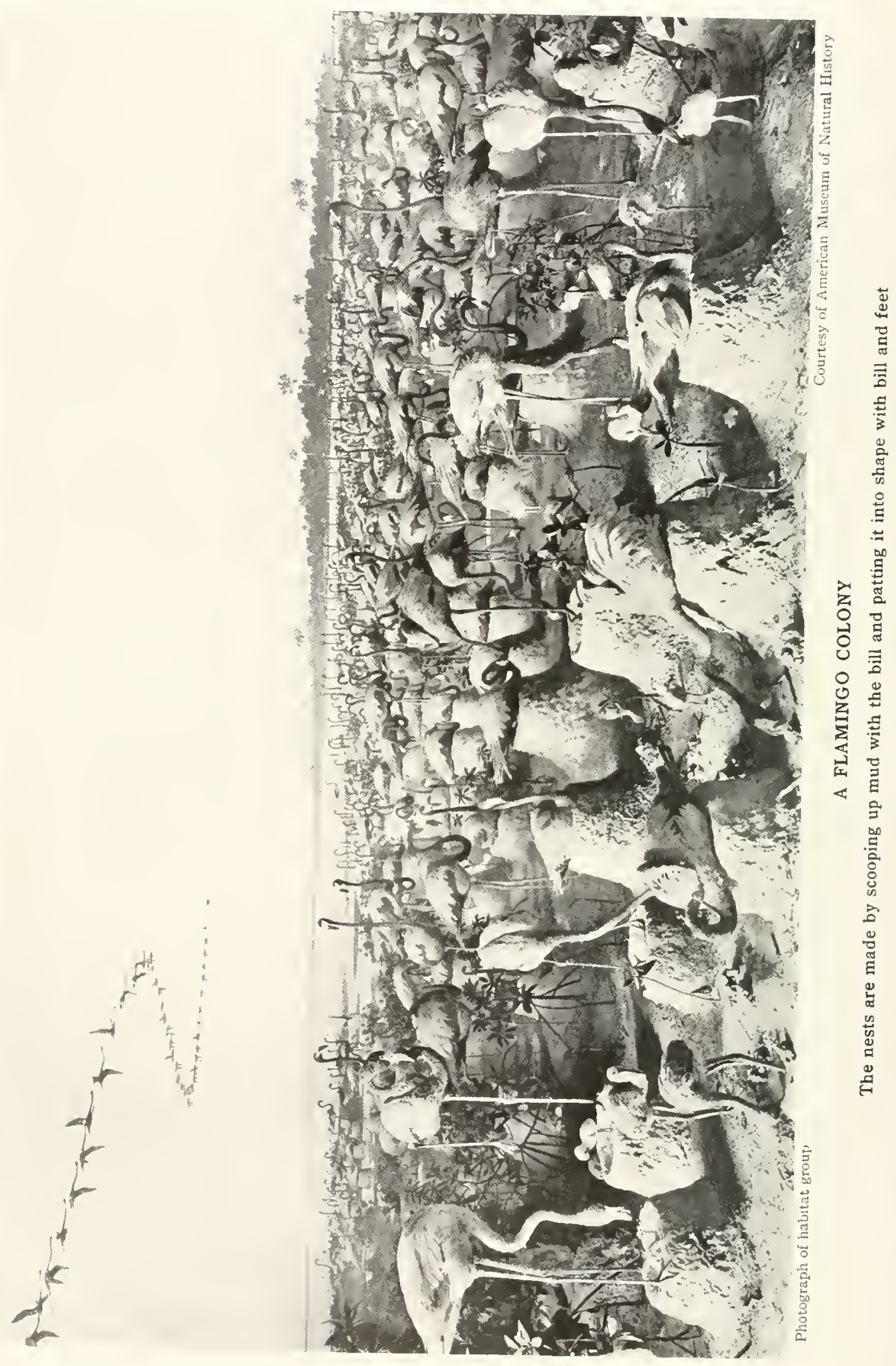

[170] 


\section{FLAMINGO}

\section{Phœnicopterus ruber Limusus}

$$
1 \text { : } 1^{\circ} \text { Sumber } 182
$$

Other Names. - Scarlet Flamingo: American Flamingu.

Description.-Anuls: Plumage, scarlet: primaries and most secondaries, black legs, litke rell; hill, black on end. orange in middle, base and lare shin of hearl. yellow. This perfect shmage ratre: birls as ustually seen are mostly dull pink with vermilion and scarlet only on wings. Votwi: The punng are hatehed in white down with a straight bill, which gradually acquires the crook. First plumage, grayish-white with dusky wings; this passes through pink, royy, and red to its full scarlet,

The great Scarlet Flamingo is a rare birct in the Lnited States. ()ecasionally a few are seen at the extreme southern end of filoricla and there was undoubtedly a time, many years agu, when they bred in that region. I saw a specinen at Palm lieach in mos that had bech recently killed near there, but they jrobab!y never wander much north of this point. They frerpent shallow lagoons or flooded mud flats, ancl are usually found in flocks.

In igot Dr. Frank M. Chapman found and stutdies a colony of perhaps two thousand pairs that were nesting on the ishand of Andros in the Bahama Islands. Hlis intimate photographic studies made at this time were the sreatest wrnithological trimmph in birs photography that had then been attained. It may be added that his pullished notes constitute practically all we know today of the nesting habits of this bird. The nests in this Flamingo city, he tells us, were pillars of rlried mutd, a foot or nuore in height. that had feen scraped up by the birds from the immerliate vicinity.

On each of these one white challiy egg was laid. While incubating, the ofrl biris do nut sit astride the nest as shown in many old illustrattions, but double their less under them. There was no cover in the way of trees or bushes for a long distance, but here on the semi-floorled. marl-covered flain the birds were fairly secure from human intrusion, as the region was isolated and particularly difficult to approach.

Upon first entering his photographic blind which he har erected near the field of Flamingoes' nests. Dr. Chapman liar grave apprehensions as to whether the birds, all of which had flown to a distance, would return to their eggs. bercial sears being required to perfect the plumage. Lemeth of arlult, 4 feet.

Nest and Eggs.- Nest: I conical structure un remute inacessible islands, of mus or marl scraped ni by the birl's bill. about is inches in diameter at the bance and abut a foot across the top: from a few inches to more than a fout high. Erigs: I or 2, white

Distribution.- Atlantic coant of subtropical anil tropical America, from the Bahamas, filorida Keys, ansl lucatan to lirazil, and in the Galapagos: accidental in South Carolina.

In Cimps and Cruises of an Ornitholonist he tells us something of their behavior. when, aftet his companion had departed from the neigborhood, le eroucherd in his blind and waited.

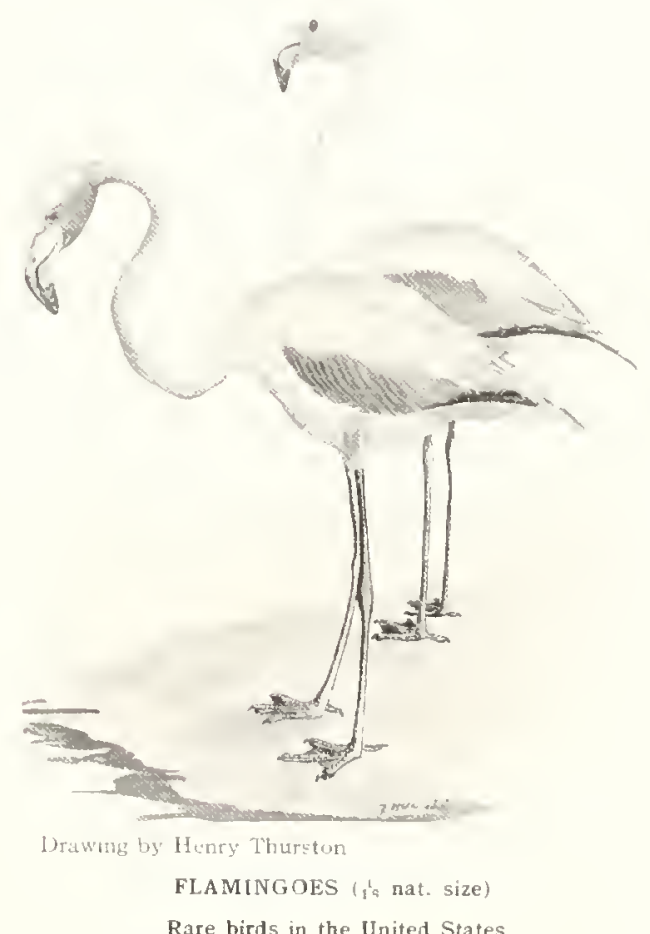

Rare birds in the United States

"Without further delay, the birds returned to their hrmes. They came on foot, a great red cohort marching steadily toward me. I felt like a spy in an eneny's camp. Night not at least one pair of the nearly four thonsand eves detect something unnatural in the newly grown bush 
almost within their city gates? No sign of alarm, however, was shown; without confrision, and as if trained to the evolution, the birds advanced with stately tread to their nests. There was a bowing of a forest of slender necks as each bird lightly touched its egg or nest with its bill; then, all talking loudly they stood up on their nests; the black wings were waved for a moment and bird after bird dropped forward on its egg. After a vigorous wriggling motion, designed evidently to bring the egg into close contact with the skin, the body was still, but the long neck and head were for a time in constant motion, preening. picking material at the base of the nest, dabbling in a nearby puddle, or perhaps drinking from it. Occasionally a bird sparred with one of the three or four neighbors which were within reach, when, bill grasping bill, there ensued a brief and harmless test of strength."

T. Gilbert péearson.

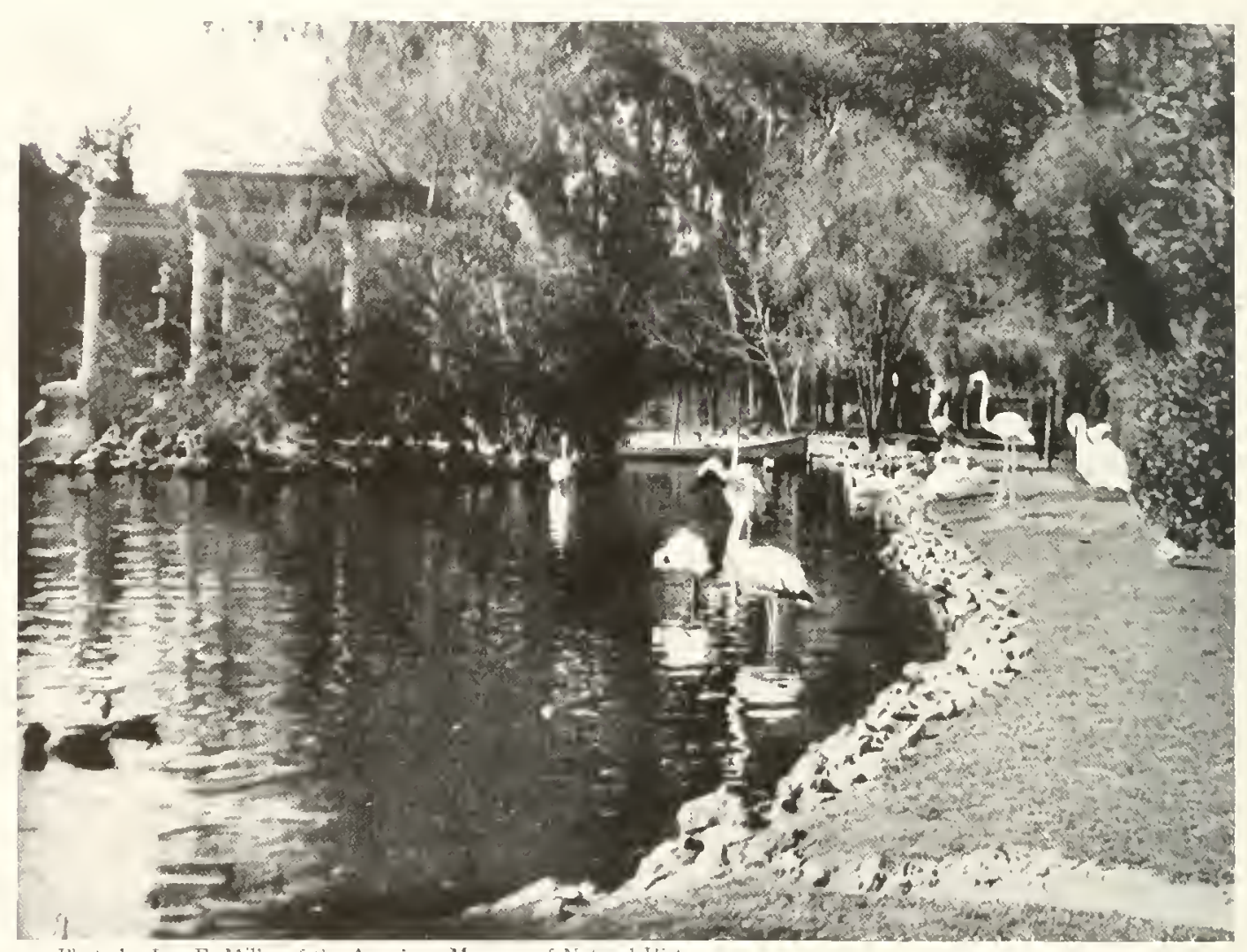

Photo by Leo E. Miller of the American Niuseum uf Natural History

FLAMINGOES IN THE ZOOLOGICAL PARK, BUENOS AIRES 


\title{
ORDER OF HERONS, STORKS, IBISES, ETC.
}

\author{
Order Herodiones
}

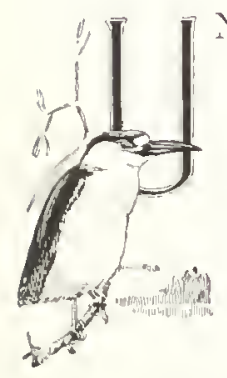

NDER this order are grouped the long-legged wading lirds generally found along shores or on muddy flats. Their necks are long, but are easily lient into a strongly curved S-shape. Their wings are rounded, long, and broad, and the tail short. The toes are four in number, all on the same level, long, slender, and without webs. The head is more or less naked with small, elevated nostrils, and the slitll shopes gradually to the base of the bill. "The bill is rariable and divides the order into three suborders: the Spoonbills and Ibises (Ibides) have the liil grooved along the side from nostril to tip, a peculiarity not found in the other members of the order; the Storlis and ITood lbises (Ciconic) have the bill very thick at the lase and curved near the tip which is rather blunt: the Herons, Egrets, Bitterns, ete. (Hcrodii) have the bill straight and sharp-pointed. The first of these suborders, as its name indieates, enntains two families, and the others one each.

Their food is prineipally fish, reptiles, amphibians, mollusks, and other aquatic animals. The food is seized by a quick, straight thrust of the bill. Becanse of the structure of their feet, they are naturally good perchers and generally nest in trees. The nests are clumsy and crude, the eggs few. The young are naked, or nearly so, when hatched, and are fed and cared for in the nest by the parents.

\section{SPOONBILLS, IBISES, AND STORKS}

Order Herodiones; families Plataleida, Ibidida, and Ciconiida

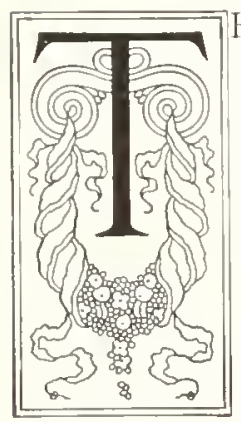

HE Spoonhills are distributed quite generally throughout the tropieal and subtropical regions and are grouped in three genera including five or six species, of which the only American representative is the Roseate Spoonbill. As a family they are gregarious, especially during the breeding period, when they gather sometimes in very large colonies in marshes and bayous and build platform-like nests in low trees or bushes. The eggs number from three to five, and are white, spotted with varying shades of brown.

Structurally the Spoonbills are similar to the Ibises, exeept in their possession of the enrious spoon-shaped bill which gives them their name. This is plainly a special adaptation, and is made use of by the bird in obtaining its food, which consists of frogs, aquatic insects, shellfish, mollusks, and small fish, and which the bird captures by submerging its bill and swinging it from side to side in a semicircular sweep imparted by a corresponding movement of the body. While thus feeding the birds stalk about with grave and dignified mien, seldom making long pauses, as do the Herons, to wait for their prey to approach. While resting, either in a tree or on land, they often stand for an hour or more on one leg, after the manner of many of their kind. Their flight is accomplished by an easy flapping operation, and is accompanied by some soaring, with head and legs ontstretched meanwhile.

The plumage of the Spononills varies from almost pure white to the beautiful conbination of white and rose or pinkish tints which characterize the species found in this country. During the breeding scason the adults develop a fine erest, which depends from the nape of the neck. Spoonbills have no true vocal organs, though the windpipe is very 
long, and at the lower end coils approximately in the form of a figure eight, somewhat after the manner of that of the Cranes. The common call is a harsh quack, and the birds often make a clattering sound by snapping their mandibles together.

As the Spoonbills differ from the Ibises in the peculiar structure of their bill, so the Ibises are unlike the Storks, their close relatives, in the differentiation of the same organ, which is evenly curved, somewhat slender, more or less cylindrical, and comparatively soft, except at the tip, while that of the Storks is generally straight, rigid, and hard. Of the eighteen or more members of the Stork family scattered over the warmer parts of the earth, only one, the Wood Ibis, is regularly found in America north of the southern boundary of the United States.

Certain of the Ibis species are gregarious in the breeding season, while others are rather solitary. The nests may be placed in low bushes, on trees, or occasionally among reeds, or even in holes in ledges or cliffs. They are composed of plant-stems and sticks, and may or may not be lined with straw, roots, or herbage. The eggs are from two to four in number and may be greenish-blue, pale blue, olive-green, greenish-white, or sometimes brownish, while sone of the lighter-colored forms may show brownish or reddish markings. The range of the Ibis is virtually cosmopolitan. About thirty species are linown, and these are referable to about twenty genera. About one-third of the species are of New World occurrence.

Remarkable variation in both proportions and coloration are shown in this family; some species are graceful in their outlines and others are clumsy and uncouth, while plumage colors range from nettral or dull tints to gaudy and brilliant hues. Most of the species walk with marked grace and deliberation, while the flight is generally like though perhaps rather more rapid than that of the Spoonbills. The Ibises' diet includes aquatic insects, shellfish, mollushs, worms, small fish, frogs, grasshoppers, beetles, and lizards. In their search for their food, when it is in the water, the birds sweep the bill to and fro, though they also use it frequently for probing in mud or soft sand.

The Ibis was one of the most sacred birds of the ancient Egyptians, and as such was the subject of many myths and superstitions. Even to-day it is one of the characteristic birds of the Nile valley, and in lower Egypt it is called Abou-mengel," Father of the Sickle," the reierence being, of course, to its curved bill. Herodotus credited the bird with being a destroyer of snakes, and Cuvier recorded finding the remains of a reptile in the stomach of a mummied Ibis, but it seems clear that such creatures do not form part of the bird's normal diet.

\title{
ROSEATE SPOONBILL
}

\author{
Ajaia ajaja ( Linneus)
}

A. O U. Number 183

Other Names.- Pink Curlew; Rosy Spoonbill.

General Description.- Length, 32 inches. P'lumage. white with some pink or red. Adults have the head and throat bare.

Color.-Upper neck and back, white, sonetimes tinged with pink: zoings and under parts, delicati rosemadder; plumes of lower foreneck, lesser wing-coverts, upper and under tail-coverts, rich carmine: shafts of wing-and tail-feathers, carmine; tail, brownish-yellow with a patch of same color on sides of breast; the skin of the bald hearl varjed with dull green, orange, and black: bill, with various shades of green, blue, yellow. and black; legs, lake red; iris, carmine. Young: Head, feathered; general plumage, white tinged with pink on wings, tail, and abdomen; edge of wing, dark brown. Three years are required to reach the perfect adult plumage.

Nest and Eggs.-Nest: A platform of sticks in dense tropical marshes, usually in cypress trees or mangrove bushes, from 8 to 20 feet above ground. EGgs: 3 or 4 , white or buffy, blotched and spotted with various shades of brown.

Distribution.- North and South America, from Texas. Louisiana, Florilla, and Georgia south to Patagonia and the Falkland Islands; formerly casual north to Pennsylyania and the lower Ohio valley (Indiana and Illinois): accidental in California, Colorado, Kansas, and Wisconsin. 
There is no large wading bird of North America that bears such brilliant feathers as the koseate Spronbill. The general plumage is pink with the lesser wing-coverts of the adult a bright carmine color. This part of the plumage $i$. known as the "drip." The bill is long and flatly. syoun-shaped. The bird gets its food hy wading. swinging its opened bill from sicle to side through the mud and water, as it minnces. Formerly the suonbills, or "l'ink Cirlewn," a. the Florida hunters know them, were extensively shot and their feathers shipued to Jatisonville where they were made into fans to sell to winter tourists. Today the bircls are extremely rare, thanke to the enerey of the plume-hunter and the bird-shooting tourint. But for the warkens cuployed by the National Association of Auclubon Societies they would probalily now be extinct in Florila. I few are sometimes sevn in lonisiana and possibly a thousand are left in Floricla. but mless pullic sentinent in that Sitate should receive a radical and sudden slift toward conservation, the bird will probably not long survive.

Spoonbills travel in Alucks, sometimes in company with lbises. They Hy in long diagonal lines, each bird heing behind and just to one sicle of the one in front. When seen among the dark green foliage of the mangrove trees, or while in flight, their wings reflect the smlingt and they show to advantage and make an mustral apleal to the birl-sturent. For the most part they are silent, although when feeding or when ahout their nests a low croaking note is constantly uttered, as though the birds were conversing among themselves.

1)r. Frank M. Chapman, speaking of the actions of the yomng in a nesting colony he visited in Mexico. says

"When their parents returneil they were all attention and on the alert for food. On such occasions they usually stood in a row on the edge of the nest facing the old hirds, and in a nost comical manner swung the head and neck wl and down. I have seen halancerl nechancal toys which would make almost exactly the same motion. The tors, however, were silent, while the little Spoonbilis all joined in a chorus of tremuloms, trilling whistles, which grew lomder and more rapid as the parent approached

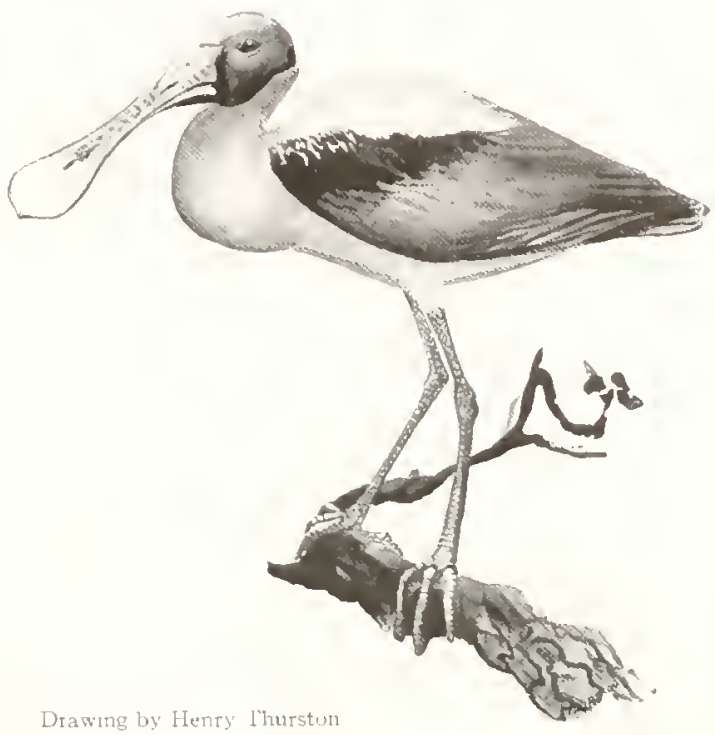

ROSEATE SPOONBILL ( $\frac{1}{4}$ nat. size)

One of the rarest and most brilliant waders of the South

" What their parent brought them I could not see, nor for that matter, could they. But with a confidence burn of experience, the luird that had first opportmity pushed its bill and head far down into its parent's mouth to get whatever was there. This singular operation sometimes lasted as long as ten seconds, and it was terminated only by the parent which, much against the will of its offspring, disengaged itself: then after a short rest a second youngster was fed and thus in due time the whole family was satisfied."

T. Gilbert Priarson.

\section{WHITE IBIS}

\section{Guara alba (Linnciss)}

$$
\text { 1. 1) L. Numler } 184
$$

Other Names.-- Spaniah Curlew; Stone Curlew (young): White Curlew

Length.- 2f inches.

Color.-Anults: Plumage, pure white; tips of sereral outer primaries, ylossy hlack; hare face, bill. and legs, orange, red, or carmine, the bill tipped with dusky: iris, pale bluskl-white. Yousr: Dull grayishbrown; rump, hase of tail, ald moler parts, white: bare space on liearl, restricted and dull yellowish: bill, vellowish-orange; legs, blush-cray; iris, brown. 
Nest and Eggs.-NEst: Usually in mangrove thicket: constructed from twigs of those bushes. Eurs: 3 to 5, gravish-blue or whitish, blotcherl and spotted with dull yellow, rufous, and umber-brown

Distribution.- North and South America, from
Lower California, Texas, and South Carolina south to West 1ndies, Brazil, and Peru, and casually to Great Salt Lake, South Dakota, Illinois, Vermont, Connecticut, and Long Island; winters from Gulf of Mexico southward.
Some years ago the National Association of Audubon Societies purclia ed as a bird-reservation a portion of Orange Lake, Florida, that con-

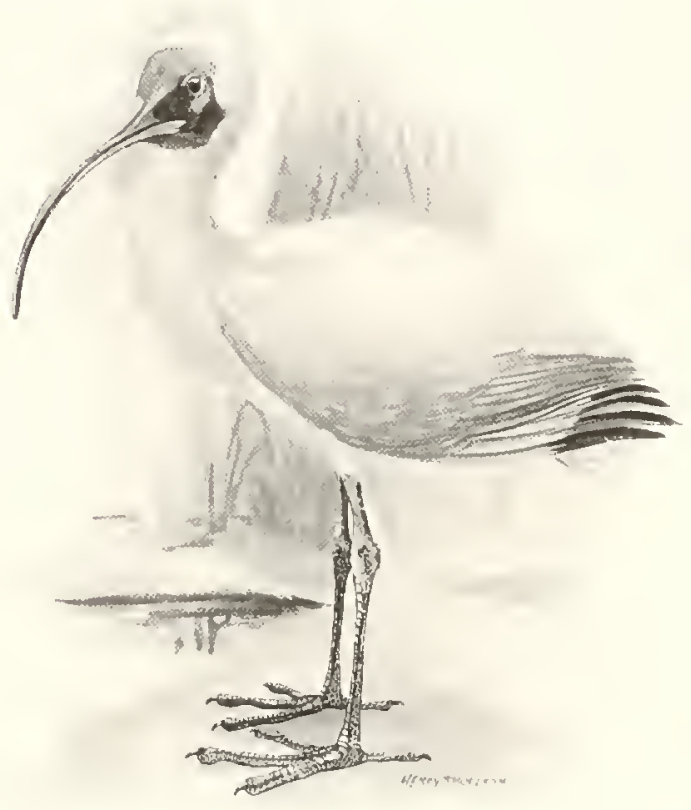

Drawing by Henry ' 1 tumsion

WHITE IBIS ( $\frac{1}{9}$ nat. size)

A flock returning to their nests at evening is a pretty sight

tains an island which has ing heen the breeding place of innumerable water-hirds. Those years when the water is not two high to cover their food White Ibises to the number of alyout ninc thonsand yairs come here to breed, as do the Egrets, Herons, and VIater Turleys that are preant every season. Their nests are built in the low alder trees that cover the island and are p'aced at all lreights from one to fifteen fect. They are bulky and their weight added to that of the heavy litds plays sad havoc with the branches. The eggs are beatifully spotted; the young are crested with black down. It times the trees are so covered with White Ibises that at a listance they appear to be weighted down with : now.

The birds, of course, have their natural enemies. This island literally swarms with water moccasins in summer. They take many of the eggs and perhaps some of the newly hatched young. Vultures roost on the island and they devour many young. The most annoying of all the creatures that disturb the lbises, however. are the Fish Crows. Numbers of them are on the island all day long and the quantities of eggs they consume is astonishing. When the nest is robbed these birds will lay again, and the Crows keep then producing eggs for many weeks. The warden in charge estimated that in the summer of I9I3 every female Ibis laid an average of eleven eggs, although four is the normal number for a bird eacli season.

These birds fly in long ranks and make a very pretty sight when towards evening they begin coming in from their feeding grounds which are often many miles away. Low over the water to avoid the wind they come into view, rank after rank as far as the eye can see. With black-tipjed wings sweeping up and down with never a pause the birds advance nntil near the island when they rise in union and scatter about anong the trees to spend the night.

In the United States the White Ibis breeds as far north as the swamp country of southern Illinois and the rice regions of Soutl Carolina. I lave seen then on the coast as far north as

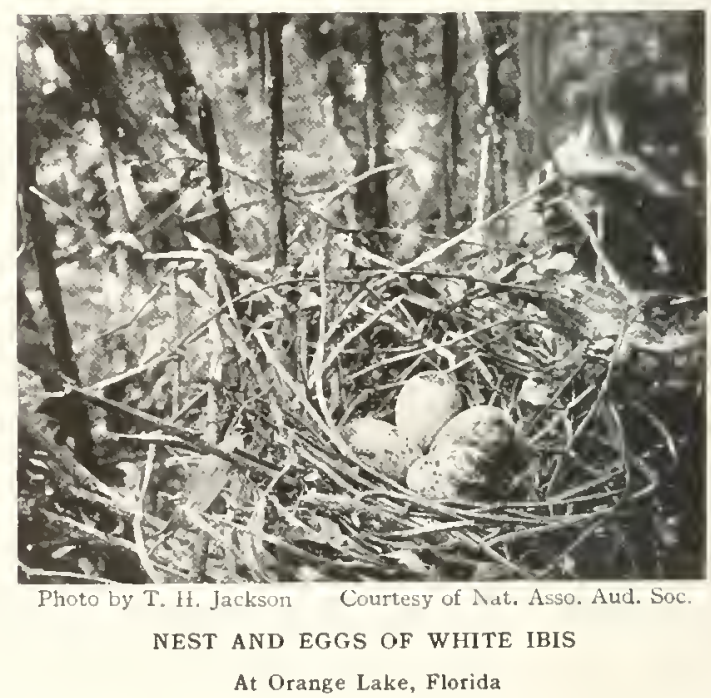

Beaufort. North Carolina, lut only in the late summer, and only then the inmature birds who exhil)it the same wanderlust as the young of some 
species of Herons. The young hirds before they assume the adult plumage are called "Stone Curlews" by the fishermen, and the old birds, which are popularly supposed to he of a different species. are usually referred to as "Spanish curlews" or "White Curlews." "The White lbis is in no sense a Curlew. but its lome. rouncled, curved bill has doubtless sugsested this name to many interested but unscientific observers.

\section{GLOSSY IBIS}

Plegadis autumnalis (Linncus)

1. O. UT. Number $180^{\circ}$

Other Names.- Bay Ibis; Green Ibis; Ord's Ibis; Liver; Black Curlew.

Description.- Length, 24 inches. Aputss: Rich fuplish-chistnut shading on head, back, wings and tail, to glossy purplish-green; silles and nniler tail-coverth dusky-green; primaries, greenish-hlack: hare skin around eye slaty-blue; no white fiathers on face: bill. dusky; legs, dark grayish; iris, brown. Yousi: llearl and neck, grayish-brown streaked with whitish: upper parts, dull dusky-green; below, grayish-browt

Nest and Eggs.- Nest: In marshy ground or low bushes; constructed of dearl reeds, plant stems, etc.; rather well built and well cupped. Ecosis: 3. reep dull bluish-green.

Distribution.- Tropical and subtropical regions, mainly of eastern hemisplece: rare and local in sutheastern United States from Louisiana to Florida, and in the Wrest Indies; casual morth to Missouri, Wisconsin, Michigan. Ontario, and Nova Scotia.

\section{WHITE-FACED GLOSSY IBIS}

Plegadis guarauna (Limncus)

$$
\text { 1. } 0 \text { I. Numlier 18; }
$$

General Description, - Length, 24 inchea. Predominating color, rich purple.

Color.-Anums: Head, neck, and entire under parts. rich purplish-chestnut tinged with irirlescent violet on hearl and nape; back and wing, iridescent violet-green and purple; shoulders, rich wine-red. lens lustroun than wing: primaries, green with brassy luster; rump, toper tail-coverts, and tail, green with purylish reflections: lower tail-coverts, similar, contrasting witl chestmut abdomen; bare ara on head. lake red; a marain of white feathers surrounding hare spaci on head. including chin: bill, dusky. reddening on tip ; legs and

The Glossy lbis and the White-faced Glossy this are identical in appearance, except that the former does not possess the small patch of white feathers in the region about the base of the bill.

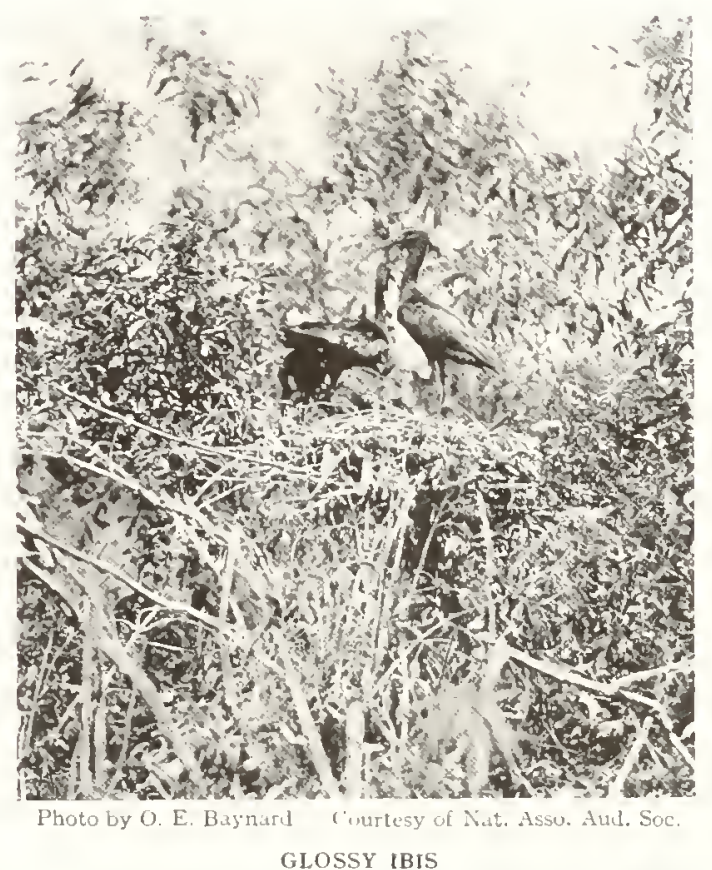

Two adılt birds, one nest, and four young, Bird Island, Orange Lake, Florida

feet, Aull reddish; iris, red. Youns: Plumage, entirely green; bill, dusky, blotehed or banded with pinkishwhite: legs, black: this coloration changing through brownish or grayish to the mature iridescent plumage.

Nest and Eggs.- Nest: On reed beds; constructed of dead reeds attached to upright stalks of living ones; very well and compactly built with a well-shaped cup. Egrs: 3 or to deep bluish-green.

Distribution.-Temperate and trofrical America from southern Oregon, Arizona, Texas, and Florida south through Mexico to southern south America: casual north to British Columbia. Wyoming, and Nebraska.

Both birds are inhabitants of tropical and subtropical America. They are extremely rare in eastern United States and appear to be confined largely to Florida. The only place they have 
been known to nest in that State in many years is on the Audubon Society's bird-island in Orange lake. As many as seven pairs have built their nests here in a season.

In April, roit, I hid in the top of a willow

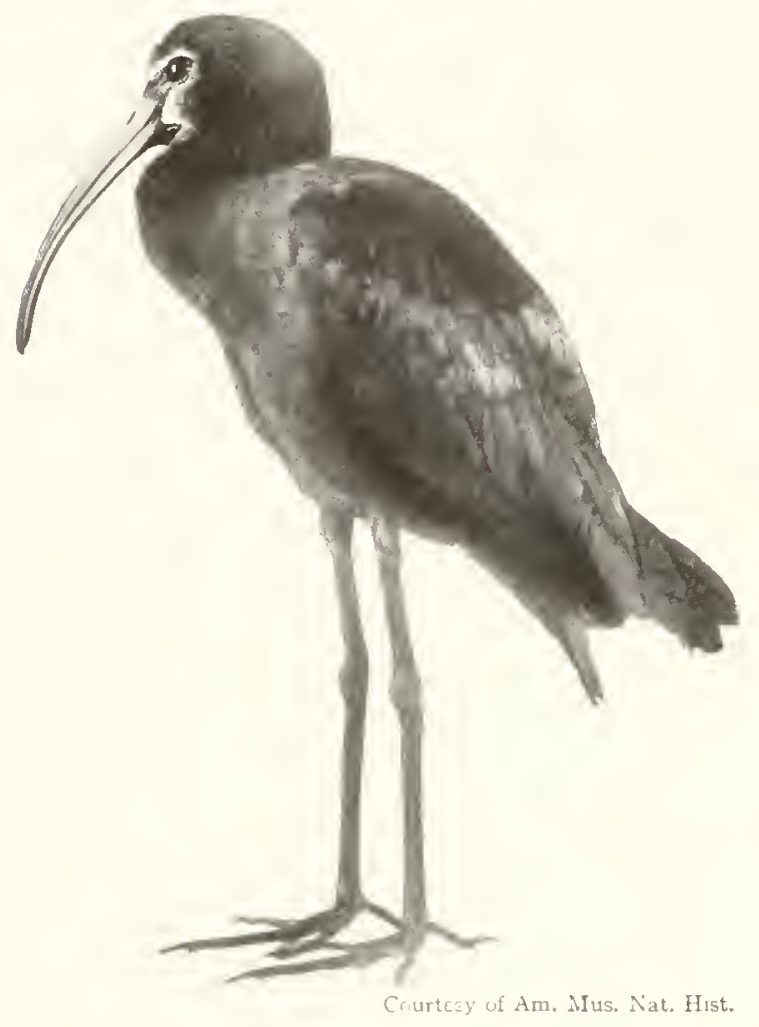

WHITE-FACED GLOSSY IBIS (1 nat, size)

He is capable of a flight of ten or twenty miles in search of breakfast

tree on this island to watch the actions of the thousands of nesting Herons and White lbises in the bushes below and about me. While thus concealed ] had the grood fortune to see six of these rare birds. At a distance they appear to be dull black, but upon coming closer the plumage was seen to possess a rich metallic luster that shone with various hues of green and purple as the hirds tumed in the sunlight. One that lit in a bush nearby had a white face which marked it as a Thite-faced Glo:sy. The nests were built in the bushes in a manner similar to that of the other Herons and lbises. They were very substantial structures of sticks and twigs.

The Glossy Ibis is the species most generally supposed to be found in the West Indies and Florida, the White-faced Glossy on the other hand being regarded as a western bird. The latter breed in the extensive marshes of Malheur lake in southeastern Oregon, making their nest 3 in the interminable jungles of the tule reeds that here cover the marshes far and wide.

They are gregarious birds at all times and after the nesting season wander about from one feeding ground to another. The people of the Malheur country esteem them highly as food, and despite the law they are at times killed and eaten. In the coastal regions of Texas these Ibises are met with in various sections and here also they are shot. "Blach Curlew" is the name by which gumners usually know them. They frequent the low, moist grounds about lakes, or over-flooded meadows. Often the feeding grounds are long distances from their nests, but the Glossy Ibis is a good flyer and quite capable of taking a flight of ten or twenty miles to get its breakfast. The food consists of crustacean;. especially crawfish, and water insects of various kinds. Frogs at times fall heneath the lightning stroke of the long curved bill. There should be a strong law in every State where this elegant wader is found, making the deed of killing one a misdemeanor punishable by heavy fine-and the law should be rigidly enforced. T. FILBERT PE.ARSON.

\section{WOOD IBIS}

Mycteria americana Limorus

1. O IT. Number 188

Other Names.-American Wood Stork: Colorado Turkey: Goard, or Gourd, Head: Iron Head; Gannet. Description,- Length, 4 feet. Antr.rs: Irhitc; aingquills, primary coscrts, and tail. nlossy grecnish-black: the hald head and neck, grayish-blue, creamy, and yellowish; bill, dusky along ridge, dingy yellowish on sides and below: legs, bluish-gray ; iris, dark brown. Young: Dark gray with blackish wings and tail; head and neck, downy feathered, becoming bald after first molt.
Nest and Eggs.- Nest: A platform of sticks in trees, sometimes 100 feet up; the same sites are occupied every year and the nests sometimes hecome very bulky from the addition of material each season. EGGS: 2 or 3. white.

Distribution.--Temperate and tropical America from southern California. Arizona, Texas, Ohio valley, and South Carolina south to Argentina: casual north tc Montana, W'isconsin, New York, and Vermont. 
Of all the various species of Storks known to inhabit the earth, only two are found in North America. (one of these, the Jabiru (Jabime micteriu of tropical America, occasionally wanders north to Texas. but the other species. the Nood Itrs, is with us in goodly numbers. They hreed in the southern United Sitates, chietly in Florida. They are gregarious at all times. althougl now and then small bands wancler away from the main flock. I once saw at least five thousand of these birds in a drove feeding on a grassy prairie of central Florida. When disturbed by the report of a gum they mose, a vast white and black mass, and the roar of their wings coming across the lake rescmbled nothing so much as the rumbling of distant thunder.

They breed in colonies mmbering lumdreds or thousand of pairs, and they always select the tallest trees for nesting sites. For several years the Audubon Society has been gruarding a colony in "Big Cypress" swamp of south lorida. In the rookery nearly every tree has its nest and some of the eypresses with wide-s]reading linbs hold six or eiglint of them. This colony occupies an area of from two humber to five hundred yards wide and about five miles in length. Here. as in other rookeries. Fish Crows are a great scourge. All day a stream of Crows can be seen flying from the pine woods to the swanly, or returning with eggs stuck on the end of their bills.

I had the opportmnity to witness the rather odd manner in which these birds sonetines get their prey. The water was low at this season and in the pine flats various ponds, which ordinarily cover many acres, were partially or entirely dried wy. One of these, now reduced to a length of about one hundred feet and with a width jerhaps half as great, contained many small fish crowded logether. Thirty-seven Mood Ibises had taken possession of this pool and seemed to be scratching the bottom, evidently for the purrpose of making the already thick water so mudily that the fish would be forced to the surface. The mumerous downward strokes of the bare, bony heads fully demonstrated the effectiveness of their enterprise. "Coard Hear," "Irnn Head,"

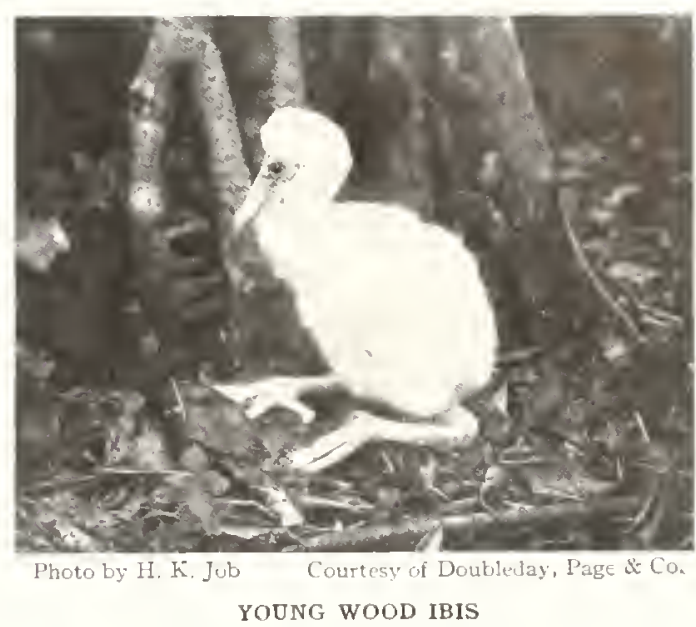

and " (iamnet" are the apjellations given to these birds by many swamp-dwellers to whom the name llood Ibis is unknown.

After the breeding season these Storks wander north as far as Pennsylunia and Michigan. Often one may find then on the wide marshes. either salt- or fresh-water, standing perfectly still for an hour or more at a time, the long heavy bill pointed downward and resting on the skin of the thick, naked neck. On such occasions they seem to represent the personification of dejection.

T. Giliert P'EARson 


\section{HERON FAMILY}

\section{Order Herodiones; stborder Herodii; family Ardeida}

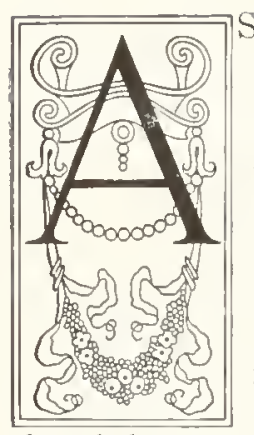

S hungry as a Heron" is a simile which should mean much to a student of birds, for Herons as a class are gaunt and voracious creatures who always seem to be half famished, and actually are more or less emaciated, no matter how plentiful is their food supply. Structurally the family is characterized by the possession of four toes, with the hind one on the same plane as the three front ones, and the claw of the middle one equipped with a comb-like process on the inner side; a slender body, long neck, and a long and sharply pointed 1)ill; comparatively long but noticeably rounded wings; and a bare space about the eyes and on the sides of the head. There is great variation in the plumage, which is free and pliable, and is likely to be extended on the back, as in the case of the beautiful nuptial plumes of the Egrets. On the abdomen, rump, and certain other parts are curious patches of down which are characteristic of the family.

Several of the American Herons are gregarions during the breeding period, when large colonies place their bulky nests near together in tree-tops; but in their feeding habits they usually are solitary. Some species capture their prey by standing motionless and waiting for it to come within reach; others pursue on foot frogs, crawfish, and the like in shallow water. Their flight is deliberate, but powerful and certain, and is accomplished by incessant flapping, and little or no sailing or soaring. Unlike the Cranes and Ibises, the Herons in flight carry the neck folded and the head drawn in near the shoulders. Their eggs number from three or four to six, are unspotted and are whitish or bluish-green in color. Of the true Herons there are about twelve species, which are from one foot to four feet and more in length. The family is represented in virtually all parts of the North American continent excepting the regions of continuous cold or drought.

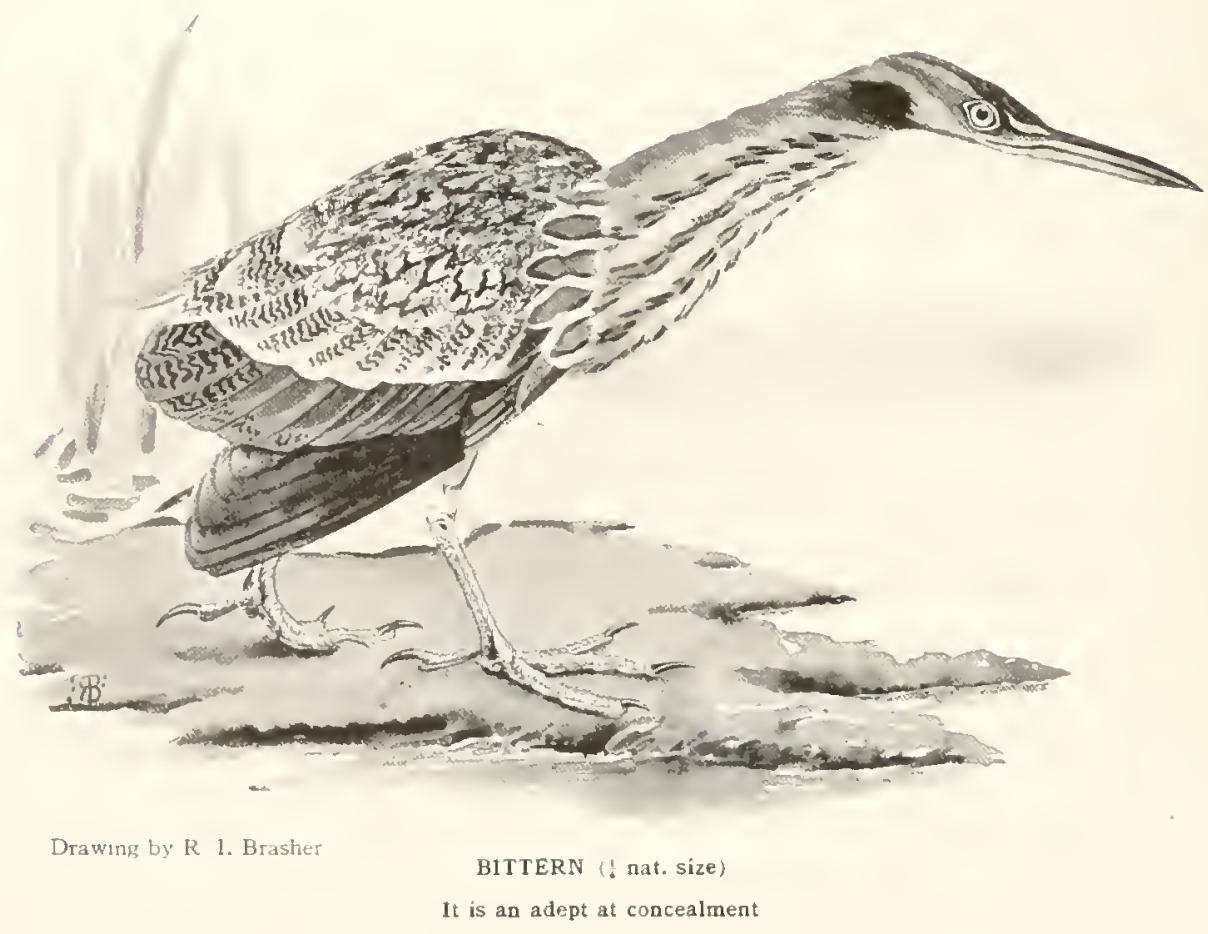


Plate 2

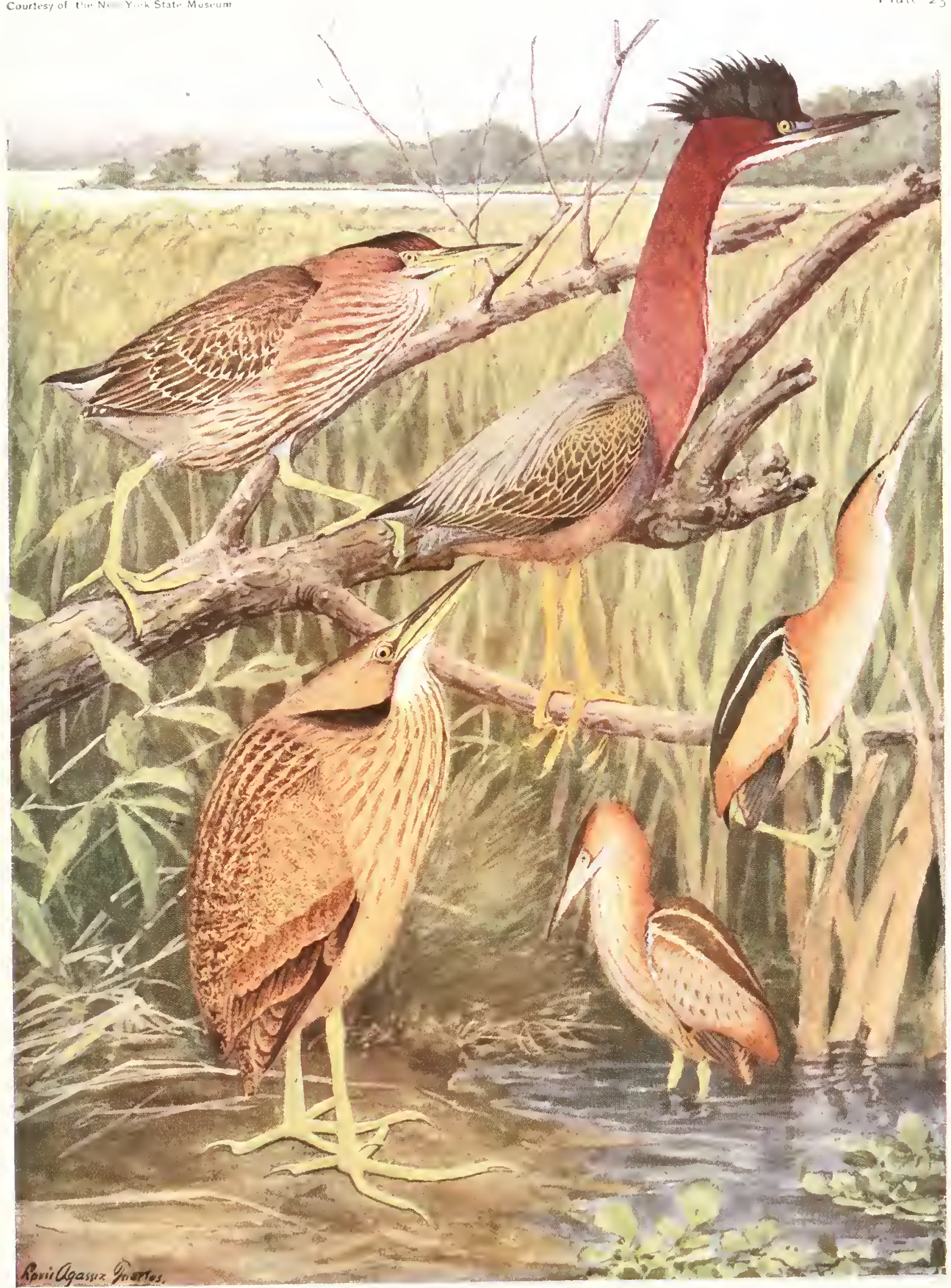





\section{BITTERN}

Botaurus lentiginosus (Monla! $/ u$ )

A. 1) I' Vumber 190 tee color I'late 23

Other Names.-American Bittern; Stake Driver: Thumler Pumper; Jutterbump; Atire Drum: Bog Bull: Indian Hen: Marsh Hen; Puke.

General Description.- Lengtl, if to 34 inches. Culor above, brown, blackish, white, and tawny mixed: below. yellowislr.

Color.-Crown, dull brown with bufty stripe over eye; rest of unper parts, streaked and minutely frockled anth brown. blackish, ahite, and taring; chin and uppes throat, whitish; under parts, yellow and tawn-white, each feather with a bruwn darker-elged stripe; center of throat and neck, white with brown streaks; a lorown mustache on sicle of throat; wing-guills, greenish-black with a glancous shade and tipped with brown: tail, lrown; bill, galte gellow watl dusky ridge; legs, dull "llowish-yelloa"; iris, yellow.

Nest and Eggs. - NEst: On the ground among reeds in a swamp: roughly ansl loustly constructerl of dead runtres. Eugs: 3 310 5 , brownish with a gray shade.

Distribution.- North America; breeds from central Enotish Columbia, suuthern Mackenzic, central Keewatin, southern Ungava, and Newfouncland south to suthern California, nurthern Arizona, Kansas, the Ohio valley, and North Carolina, and less frerpently in southern Lnited States; winters from California, Arizuna, sonthern Texas, the Ohio valley, and Virginia south to Cuba and Guatemala, and casually to the Pahamas, Porto Rico, Janticia, ansl Great Britain.
Thoreau says that the Bittern is the genius of the bog. It irecuents the ouze, and delights in the quaking false bottom where the first unwary step may plunge the adventurer into slimy depths. Here it stealis about, hidden among the rank marsh growth; here it makes its nest and woos its mate. lint it is not confined to the marsh; it is common in large meadows and may even bx seen hunting grasshoppers in nearly mpland pastures. The Bittern is an adept at concealment. It has a habit of standing annong the grass or reeds with its bill cocked up at such an angle that even when in full sight it remains umoticed because of its close resumblance to a rail or a stake. Its penciled foreneck initates the reeds and all its colors are inconspicuous. It has learned the art of moving almo it as slowly as the minute hand of a clock so as to escape observation while changing position.

The most remarkable characteristic of the Bittern is its song, but the result of its efforts can hardly be called musical. While producing the sound the bird looks as if trying to rid itself of some distress of the stomach and the resulting melory sounds much like the sucking of an oldfashioned wooden pump when some one tries to raise the water. The bird sudelenly fowers and rai.es its head and throws it far forward with a convulsive jerk, at the same time opening and shutting the bill with a click. This is acconpanied by a sound which resembles a hicough. This is repeated a few times, each time a little louler than before, while the lird seems to be swallowing air. This is succeeded by the pumping noises which are in sets of three syllables each resembling flunk-a-lunk or, as sme people will have it, plum pudd' $n$. The lower neck seems to dilate with the air taken in and remains so until the periomance is over, when the neck is deflated.

There is a preculiar acoustic property about the sound. Its distance and its exact location are very hard to gage. The volume seems no greater when near than when at a consider-

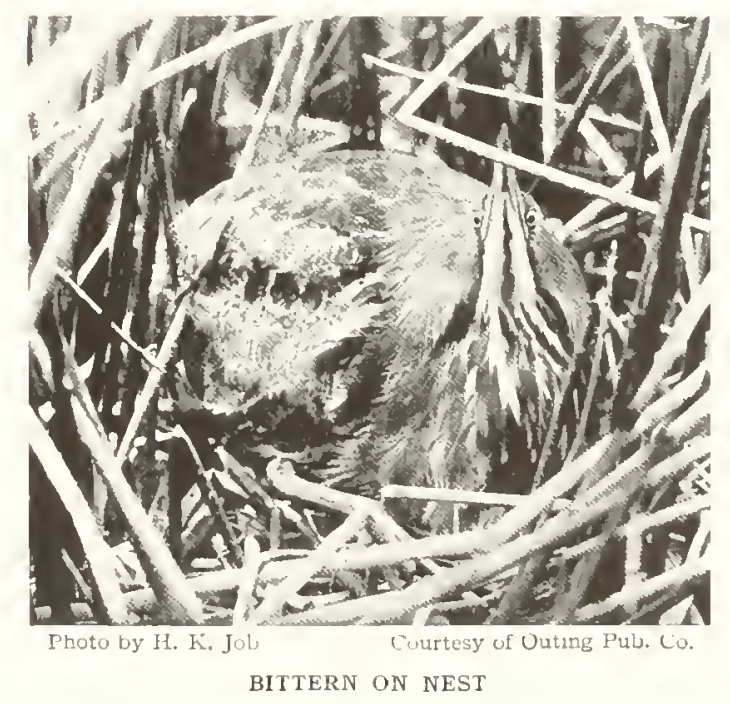

able distance, but as the distance increases the sound is no longer heard and in the place of each set of syllables there comes to the ear only a single note closely rescubling the driving of a stake, which can be heard from afar. Hence the name "Stake Driver," often appllied to this hird. These notes, although conmon in spring, particularly at morning and cvening, are not noticeable and their resemblance to pumping and stake-driving is a protection to the bird.

Another remarkable characteristic consists of white nuptial plumes upon the sides of the neck 
or breast, which appear to be always concealed, except when the birds are performing their mating antics, when a plume is raised on each side high above the shoulder and becomes conspicuous against the darker plumage of the upper parts. The young - helpless, homely, and awkward are exposed to many dangers in their lowly nest. Ninks, muskrats and water snakes roam about them; keen-sighted Hawks, Eagles, and Owls sweep over the marsh; but the watchful mother is ever ready to defend them, and with hes dagger-like bill and long neck she is no meat! antagonist. When danger threatens she bristles to twice her usual size and with glaring eyes and ready, open beak becomes a dauntless defender. Edward Howe Forbush.

\section{LEAST BITTERN \\ Ixobrychus exilis (Gmelin) \\ A. O L. Number ig see Color J'late 23}

Other Names.- Divarf Bittern; Little Bittern; Least Heron.

General Description.- I.ength, is to 14 inches. Color above. greenish-blick; helnw, hrownish-yellow.

Color.-Anelt MALE: Crown, back, and tail, glossy greenish-black; a streak down back of neck; most of wing-coverts, and outer edges of inner secondaries, pure chestnut; other wing-coverts, brownish-yellow; primaries, dusky, tipped with chestnut; front and sides of neck and under parts in general, brownish-yellow;

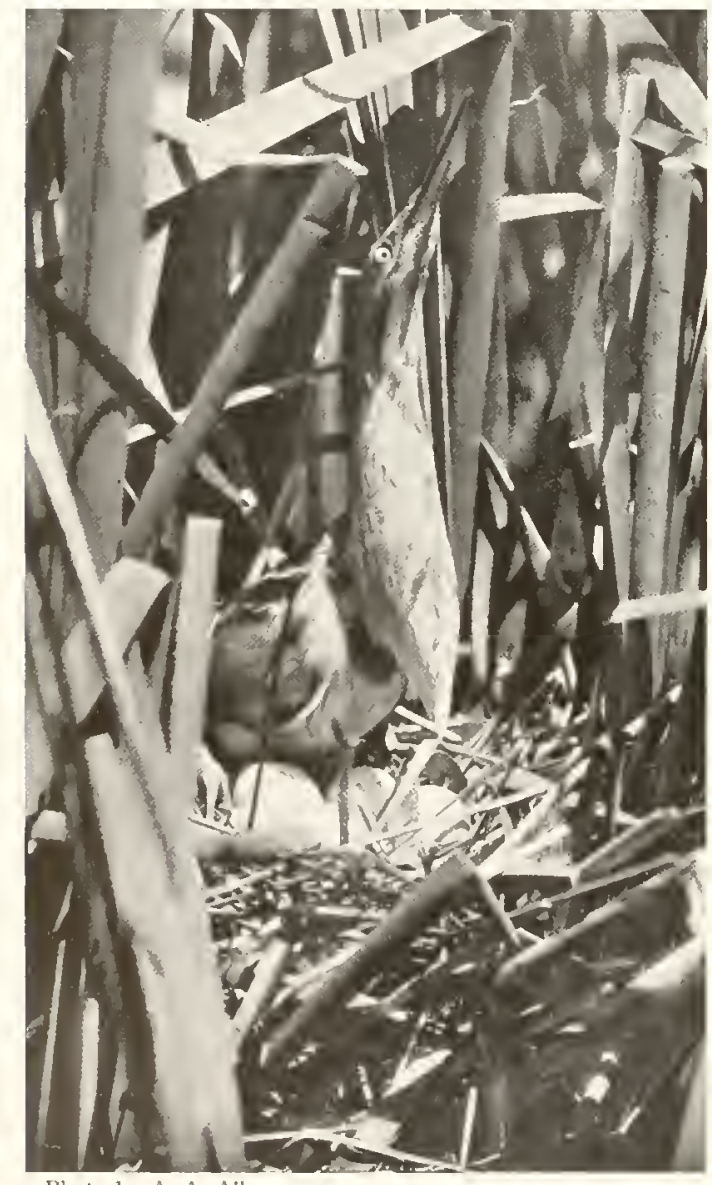

Photo by A. A. Ailen

LEAST BITTERN

On its nest in the marsh white streaks along throat line; sides of hreast with a broken brownish-black patch; a whitish streak on upper side of shoulder-feathers; bill, pale yellow with dusky ridge; skin of lores, light green; legs, dull greenish; iris and toes, yellow. Adult Female: Crowa, brownish; back, brownish-chestmut with 2 white streaks along shouiders; wings, similar, but coverts more spotted with brown.

Nest and Eggs.-NEST: Usually in a bunch of cattails; a rough platform of dead reeds, raised above the water on a bed of decayed rushes. EGGs: 3 to 6, bluishwhite.

Distribution.- Temperate North America and northern South America; breeds from southern Oregon, southern Saskatchewan, southern Manitoba, southern Qucbec, and Nova Scotia south to the IVest Indies and Brazit; winters from Florida and Gulf of Mexico southward.

Reed-grown ponds, grassy margins of lakes, and expranses of fresh-water marshes form the abiding places of the Least Bittern. Only a little over a foot in length, it is the smallest of all our Herons. Because of its retiring habits and secretive disposition it is known to few besides the inquisitive ornithologist, whose enthusiasm for the subject learls him into the forbidden haunts of the Bittern. Even then it is rarely seen until suldenly it springs from its hirling, at times almost beneath your feet, and in an awkward and laborious manner flies away a few rods and drops again into the marsh. More rarely it may be seen clinging to the stem of some rush or reed much in the manner of a Wren. It has not been given to many to hear the soft cooing spring notes of the male, but most summer marshwaders are familiar with the startled qua with which it begins its flight when disturbed.

Although the Least Bittern is found in summer as far north as Maine and Manitola, it is much more abundant in the southern States. A few pass the winter in Florida, but the bulk of these birds migrate farther south. In spring they arrive in the Carolinas and Arkansas by middle April, and a few weeks later their summer dis- 
position in the northern States is complete. A fairly compact platform of plant stems and grasses serves as a nest, on which from three to six elliptical pale bluish eggs are laid. It is usually situated in clusters of tall grass or reeds and at a distance varying from one to four feet from the water.

In many of the fresh-water ponds of Florida certain small areas, near the shore, are coverest with a thick growth of buttonwood bushes. These are popular places for small colonies of the Boat-tailed Grackle, the big shiny Blackbircl of the country. In the midst of these Blackbird villages one may often find a Least Bittern's nest. They do not assemble in colonies like most members of the family, the two or three nests sometimes found in the same neighborhood evidently having been placed close together nore because the different pairs chanced to likic the location. than from any desire for the compranionship of their kind. Although 1 have ahwas found these Bitterns partial to fresh water in the summer, Arthur T. Wayne states that in South Carolina they atso breed regularly in salt marshes, and that during migration they constantly frequent such locations.

To find a nest full of young Least Bitterns is an event to remember. Standing at their full height with bills pointed skywart they remaits as mationless as though cast in lironze. The alternate light and dark strealis on their breasts and throats blend perfectly with the coloring of the reeds about them. Eridently they know that so long as they are still they are perfectly hidden.

A rare and closely allied bird variously lnown as Cory's Least Bittern (Irobrychus neorents). Cory's Bittern, or Cory's Dwarf Bittern, has been found in Florida, Ontario, Michigan, and perlajs elsewhere.

T. Gilbert Pearson.

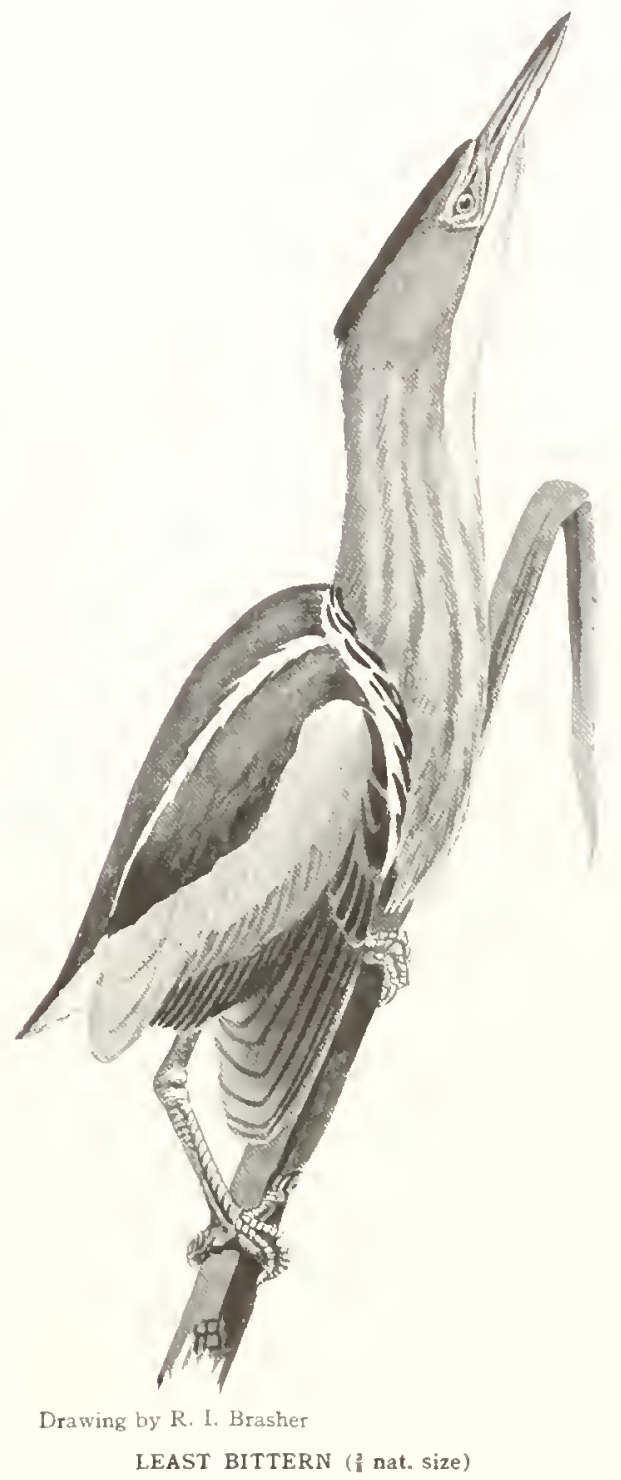

The smallest of the Herons in "the frozen position"

\section{GREAT WHITE HERON}

Ardea occidentalis Audubon

1. () U. Number 192

Other Name.-Florida Heron.

General Description. - Length. 4f to 54 inches. Head not crested, but in breeling season witl a few feathers long and flowing; plumage, pure ahite; bill, yellow, greenish at bane: legs and feet, yellow; iris, chrome yellow: hare space around eye, bluish and green.
Nest and Eggs.- NEST: In low buslues or high trees: a cimple platform of sticks. Encs: 3 to 5 , bluish-green.

Distribution.- Region borlering Gulf of Mexicn from southern Florida south to Cuha, Jamaica, and Yucatan: casual north to Anclote River and Micco, Flerisla. 
The Great White Heron is equal in size to the conmon and well-known Great Blue Heron. It is not the prond possessor of beautifnl aigrette-

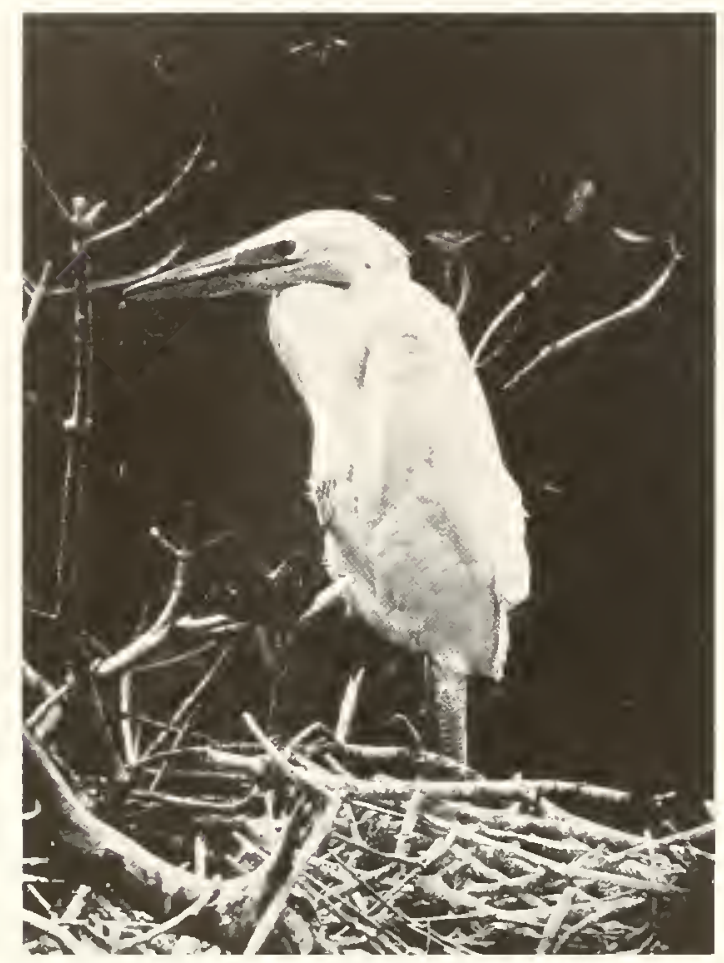

Photo by H. K. Job Courtesy of Hougliton Miftin Co. YOUNG GREAT WHITE HERON

In nest, Florida Keys plumes, such as adorn the Egrets, and consequently has not been so extensively shot. It occurs mainly on the islands of Jamaica and Cula, but is not uncommonly found along the coast of Florida. In 19I I I discovered a colony of seven pairs breeding on the island in Tampa Bay, on the Gulf coast of Florida. This appears to be the northern limit at which they lave thus far been found in the nesting period. The nests were about twelve feet above the water and rested anong the stronger topmost limbs of mangrove trees. They were huge affairs, made of sticks, and those examined contained either three or four eggs. The little colony covered a territory about eighty feet in dianeter. One hundred feet away a number of Florida Cormorants and Louisiana Flerons were beginning to build their nests. Apparently the three species were dwelling together in harmony.

Cruising among the Florida Keys and coral reefs near Cape Sable one may of ten see these giant Ilerons feeding in the shallow places which everywhere abound. They haunt such localities in south Florida, but one need not look for them inland. Their great size and white plumage render them conspictnous marks which may be seen for a long clistance. I have always found the Great White Fleron extremely shy and difficult to approach. Its judgment seems never at fault in determining what is the exact range of a hunter's rifle. T. Gilbert Pearson.

\section{GREAT BLUE HERON}

Ardea herodias herodias Linnaus

\section{O. U. Number I9t see Color Plate 24}

Other Names.- Red-shouldered Heron: Blue Crane; Crane: Commun Blue Crane.

General Description.- Length. 42 to 50 inches. Color above, slaty-blue: below, black. Head, crested and with long plumes.

Color.-ADLtTs: Forehead and top of head, white; sides of cron'n and crest, black; neck, pale gray, marked on throat with white, rusty and black streaks; chin and cheeks, white; upper parts. slaty-blur; shoulders, grayer; tail, slaty-blue: inner wing-quills, slaty-blue shading into black prinaries; plumes of lower neck and hreast, gray; abdomen, black with white and rufous streaking; under tail-coverts, white; bill, yellow with dusky ridge; legs and feet, dusky, soles yellow; bare space around eye, greenish and blue; iris, chrome yel- low. Youva: No crest or lengthened feathers on head; entire crown, blackish; general color above, hrownishslate, the feathers edged with rufous; lesser wingcoverts, reddisb-brown; below, ashy.

Nest and Eggs.- NEST: Usually in tall trees along river banks; a large and bulky structure of limbs, twigs, and some dry grass. EGis: 3 to 6 , blue or greenisbblue.

Distribution.- Western hemisphere; breeds from southeastern British Columbia, central Alberta, central Manitoba, northern Ontario, and Prince Edward Island south to southern Lower California, northern Texas, and Snuth Atlantic States (except Florida): winters from Oregon, the Ohio valley, and Middle States south to the West Indies, Panama, and Venezuela.
The Great Bute Heron is the largest of the truly American herons, and is known as a stately, dignified, and interesting lird 1, those who have observed it in other ways than over the sights of a shotgun or rifle. This pursuit is legalized in certain regions where the bird is believed to be even more destructive to the spawn and young of game fish than to its other prey of frogs, craw- 
fisl, small snakes, salamanders and varions water treatures which are more harmful than usetul, nut to mention grasshoppers and meadow mice. Lnder these conditions it heeomes diffenlt to a) even to within field-glass range. I stalk of this hind is. however, well worth while if it hringe the observer to within observation distance, for his reward will be an exhibition of steilthy and skillful fishing which $\mathrm{i}$; bound to command his acmiration.

Nuch of this fishing the Heron does withont stirring from the pusition he takes in shallow water anlong reeds or near the shore. Mutionless as a statue lue stands. his lons neck donbled into a flattened $S$ and his lecen eyes searching the water nearby. As a fros or fish ayproates he bolls his rigid position until the creature comes within striking range, and the Jeron linows what that is to a small fraction of an inch. Then suddenly the curved neck straightens ont and simultaneously the long, rapier-like bill shoots

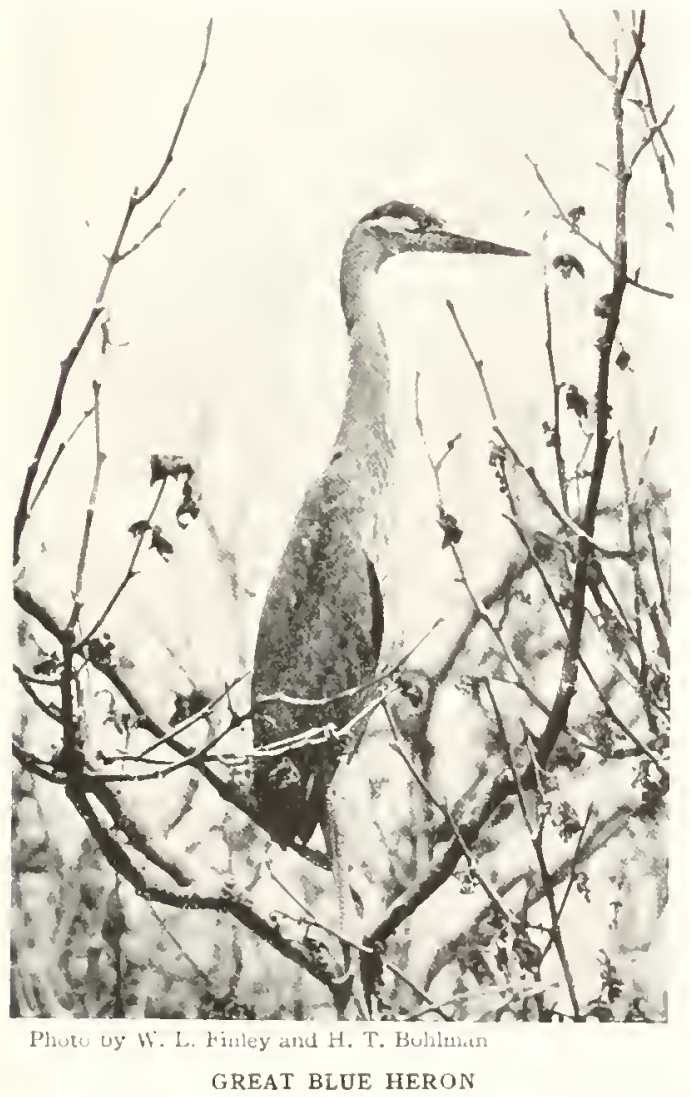

downward with a stroke which is quicker than the eve can follow and seldom misses its mark. In a second the fish or frog has disapreared, and the fisherman has resmmed his statuesque pose. Again, the creat hirel may be reen stalling slowly through shallow water, lifting each foot above

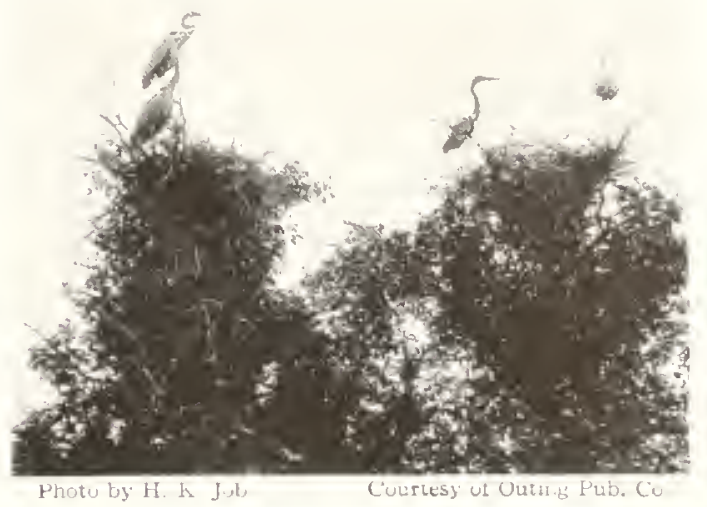

A COLONY OF GREAT BLUE HEROYS

the surface, and sliding it into the water again so genty as to cause hardly a ripple: and woe to the crawfish or salamander that does not observe that approach.

Like most Herons, the Great Blue is a solitary bird in its habits excent during the breeding season. Then the birds show a strongly marked gregarious instinct by fommon colonies, generally in isolated swamps, where they build their huge nests and bring up their young, which are fed by regurgitation. These heromries are nost interesting institutions for the bird-student. ocasionally several nests are placed in a single tree. and frequently colonies are found which include I 50 or more nests. L'nless the birds are seriously molested they are likely to return for many successive vears to the same nesting-site.

It is well linown that members of the Heron fannily feel to a great extent on fish and other forms of aguatic life, and consequent?y do not live far from water. The Great Bhe Herons at times depart from this family trait and visit hillsides, cultivated fields, and drier meadows in search of pocket aophers, ground squirrels, and field mice. which they greedily devour. Pellets collected in an inland ne ting colony of these Herons showed that a very large proportion of the food of the voung is made up of these injurious rodents. The Flerons, like other flesheating birls, rligest their food rapidly and are disposed to sorge themselves when opportunity offers. It is fair to assume as a low average that a pair of Herons with four or five young will consume twelve to fifteen gophers per day.

GEORGE GLADDEN. 


\section{EGRET}

\section{Herodias egretta (Gimelin)}

A. O. U. Number 196 See Color l'late 24

Other Names.-American Egret: White Heron; White Egret; Greater Egret: Great White Egret: Great White Heron; Long White.

Description.-Length, 4 I inches. No crest, but a magnificent train of long plumes springing from back and extending a foot or so beyond tail in breeding season; plumage, intircly ahit?; bill, yellow; legs and feet, black; lores and iris, yellow.

Nest and Eggs.- NEST: Merely a platform of sticks in mangroves or in trees. EgGs: 3 to 5, plain bluishgreen.

Distribution.- Temperate and tropical America; breeds in Oregon and California, and from North Carolina, Florida, the Gulf coast, and Mexico south to Patagonia: formerly bred north to New Jersey and Wisconsin; winters from the Gulf of Afexico southward; casual in Manitoba, Quebec, New England, and Nova Scotia.
The treatment which man has accorded the Egret is not only an evidence of his power over weaker animals, but stands as a blot on this country's history. The long white plumes, which this bird bears on its back in the mating and nesting season, have long been sought as adornments for women's headwear. The only way to get these "aigrettes" is to shoot the bird, and shoot it at the time it is engaged in the care of its nestlings. At other seasons it is wild, and only with great difficulty can one approach to within shooting distance, before it takes wing.

The plumes are acquired early in the year but not until the hirds have accumulated in colonies. and laid their eggs, can the hunter hope for success. Even then the wise millinery agents wait until the rookery is ripe. By "ripe" they mean when the eggs have hatched. If the shooting begins in a colony before this time, the birds will frequently desert their nests and eggs. Thus in order to get the most satisfactory results the phume-hunter must be content to wait until the young appear, and the instinct of parental care is so aroused that the old birds will return again and again despite the fact that they see their companions falling all about them before the guns of the inhuman hunters. This method of attack on any species if long continued means its doom. When old and young atike perish no chance remains to perpetuate the species.

In the far West a few Egrets still are found, but very rarely. They appear never to have reached the abundance there that they did in the Southern States. At one time the lake-shores of Florida teemed with tens of thousands of these elegant, long-legged white creatures. Several years ago I visited rookeries containing great numbers of thems, but even then the work of destruction was going on. While visiting a phune-hunter's camp in $1886 \mathrm{I}$ was told that the New York feather dealers paid ninety cents for the plumes of every bird. Since that time the price has gone up and up until recently tourists at Miami and Palm Beach have been paying \$10 and more for the scalp of each bird brought in by the white hunters and Seminole Indians of the Everglade comntry.

For several years past the National Association of Audubon Societies has been employing guards to protect the few remaining breeding colonies as far as they are known. These nesting places are distributed from the coastal region of North Carolina southward to the Florida Keys, but it is debatable whether the species can be saved, although without the efforts of the Audubon Society the bird would probably have disappeared entirely by this time.

This member of the Heron family often associates in the nesting season with other Herons. The loose nests of twigs are placed in the top of bushes or on the limbs of cypress trees high above the waters of the sequestered swamps into which these birds have long since been driven. T. Gilmert Pearson. 


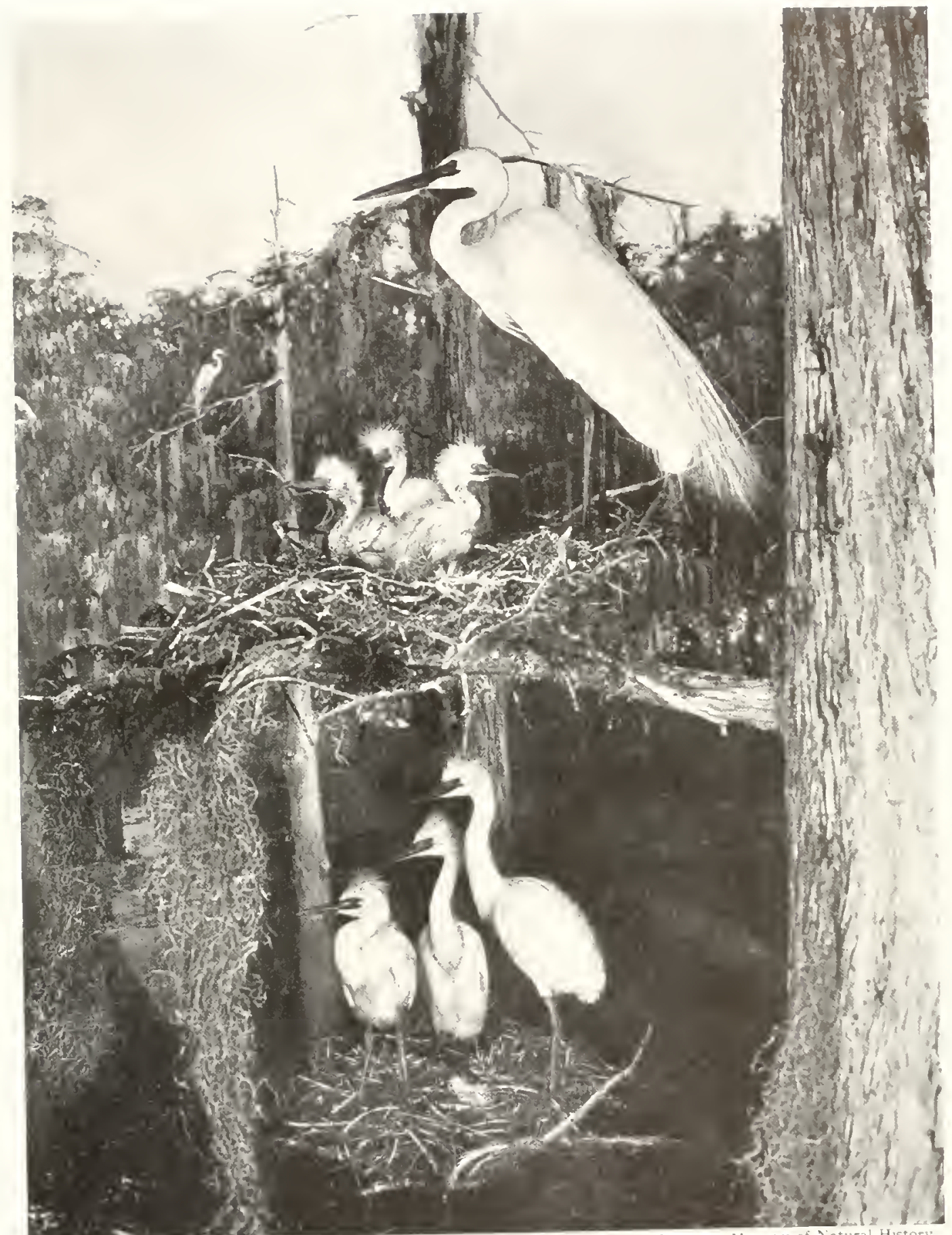

Photograph of habitat group

EGRETS

These birds have been brought to the verge of extinction by plume hunters

$[187]$ 


\section{SNOWY EGRET}

\section{Egretta candidissima candidissima (Gmelin)}

1. O. [T. Number 197

Other Names.-Little Egret; Lesser Egret; Common Egret: Snowy Heron; Little Snowy; Little White Egret; Little White Heron: Bonnet Martyr.

Description.- Length, 24 inches. Plumage, pure white: bill and legs, black: toes, yellow: bare space around eye, greenish-yellow; iris, chrome yellow. A long crest on crown, another from back of about 50 feathers, the latter recurved, and another on lower neck.

Nest and Eggs.- Nest: Usually among mangroves or in swampy willow ponds; a simple platform of sticks. Egas: 2 to 5, pale bluish-green.

Distribution.- Temperate and tropical America : formerly bred from Oregon, Nebraska, Indiana, Illinois, and New Jersey south to Chile and Argentina; now breeds locally in the United States from North Carolina to Louisiana; winters from Florida southward; casual in British Columbia, Ontario, Massachusetts, and Nova Scotia.
Much smaller than the Egret, the Snowy Egret is nevertheless adorned in the breeding season with "aigrettes," growing on the back between

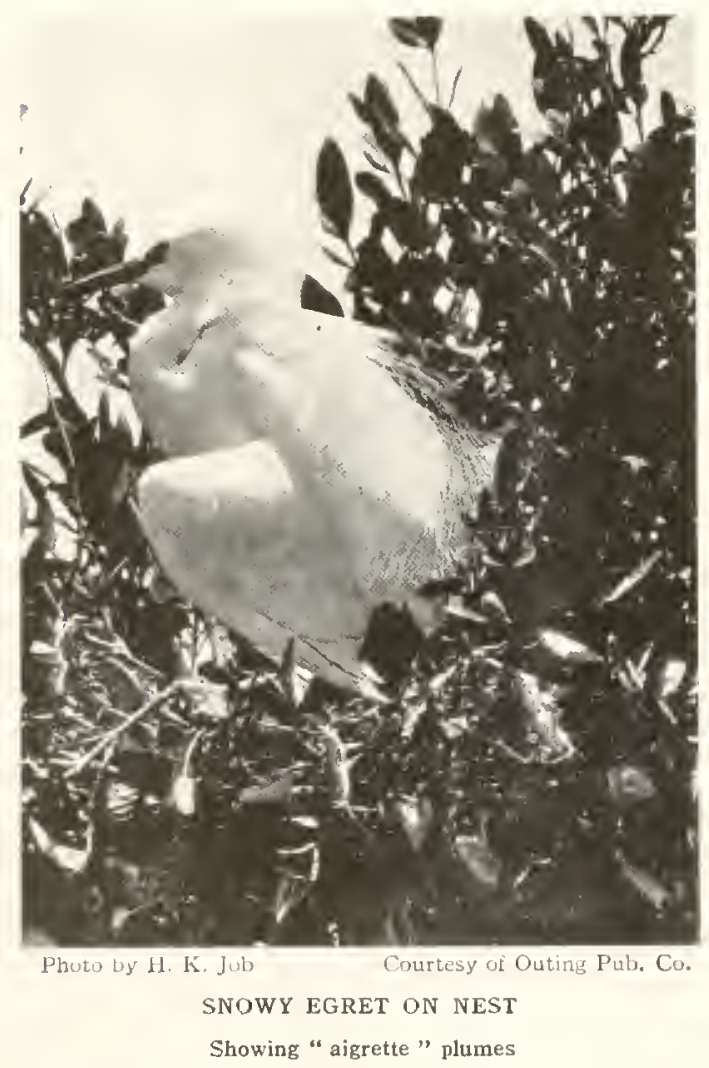

the wings, that are quite as valuable in the market as those produced by the larger bird. The jhume-feathers are much shorter, more delicate, and are recurved at the end. They are the "cross aigrettes" of the millinery trade. To the plume- hunters the bird is known as the "Little Snowy," to distinguish it from the larger species called by them the "Long IV'hite."

Snowy Egrets once bred as far north as New Jersey, but now their northern breeding limit is North Carolina. Although found inland in Florida, they are elsewhere in their range in the United States more distinctively inhabitants of the tide-water regions. Owing to protection afforded them from the millinery feather hunters of recent years by Audubon Society wardens. they appear to be increasing in a few sections, notably about Charleston, South Carolina. Apparently the largest gathering of breeding birds is in a splendid Heron colony that has developed under the special care of $E$. A. Mcllhenny at Avery Island, Louisiana. The rookery is in the trees and bushes of a small artificial pond within 200 yards of MIr. Mc Ilhenny's house, and among the many interesting entertainments he gives his guests is to take them out to the edge of the yard of a spring evening that they may watch the Herons and Snowy Egrets coming home to roost or to relieve their mates on guard at the nests.

Like that of other Herons the food of this bird consists of such small forms of life as inhabit the sloughs and marshes of their territory. The voung are fed extensively on small fish that are regurgitated into their throats by the parent bird. The Snowy Egret has a plumage of spotless white. The legs are black and the feet are bright yellow. By observing the coloring of the feet and legs one need never mistake it for the immature Little Blue Heron, which, except for the absence of "aigrettes," it much resembles

\section{T. Gilbert Pearson.}




\title{
LOUISIANA HERON
}

\section{Hydranassa tricolor ruficollis ( Gossc)}

\author{
1. () I. Number 199
}

Other Names-Lady of the Waters; Denuriselle.

General Description.- Length. 27 inches. Color above, slaty-purple; below, white. The longthened feathers of head and neck, sharp with weli-defined edges; the hack train-teathers, iringe-like.

Color. AntLTS (SEXES hlLE): (ruwn, hiles of head, most of neck, back, and wings, slaty-purple: chin and thruat. white, broken behind with color of head: the long teathers of crest. white: lower back and rump, white but concealed by feathers of train which extends beyond tail: lower parts. mostly athite: bill, black bluer toward base; legs, grayish; iris, red: bare space around eye, light lilac. Young: No crest or plumes.
Neck and back, hrownish-red: rump, center of throat. and under parts, white: wings and tail, pale lavenderblue: legs, dusky green. ludividuals show variations between this and adult plumage but are neter athite.

Nest and Eggs. - NEST: In mangrove or willinw swamps; in communities or in company with other Herons; a frail platform of sticks. EGgs: 3 to 5. bluish-green.

Distribution.- Southern North America; breeds from North Carolina and the Gulf States to the West Indies, Mexico (both coasts), and Central America: winters from South Carolina southward; casual in Indiana, New Jersey, and Long Island.
Though characteristically a southern species. the Lomisiana Fleron ranks among the most abundant Herons in this country, since in the Southern States it is decidedly the most abundant of the ntmerous Herons. In every way it is a beautiful bird, distinct and ditinguished in its royal purplish garments contrasted with sharply defined white under parts. It is graceful and gentle, not shy, and is quite well known, feeding along the edges of swamps and meadows, or on the horders of streams and ponds.

Of social disposition, its nesting is mainly in rookeries, sometimes of large size. In E. A.
McIlhenny's celebrated Egret and Heron colony at Avery Island, La., this is the most abundant species, many thousands of them nesting in this forty-acre tract. Reasons for their abundance are primarily that the plumes which grow from their backs at the nuptial seasnn, though quite pretty, fortunately have not been in demand for millinery purposes. Then, further, they are tamer in disposition than some others, and apparently are not so easily frightened from a locality by human intrusion.

The rookeries are usually in a wooded swamp. generally among low, rather thick trees, and par-

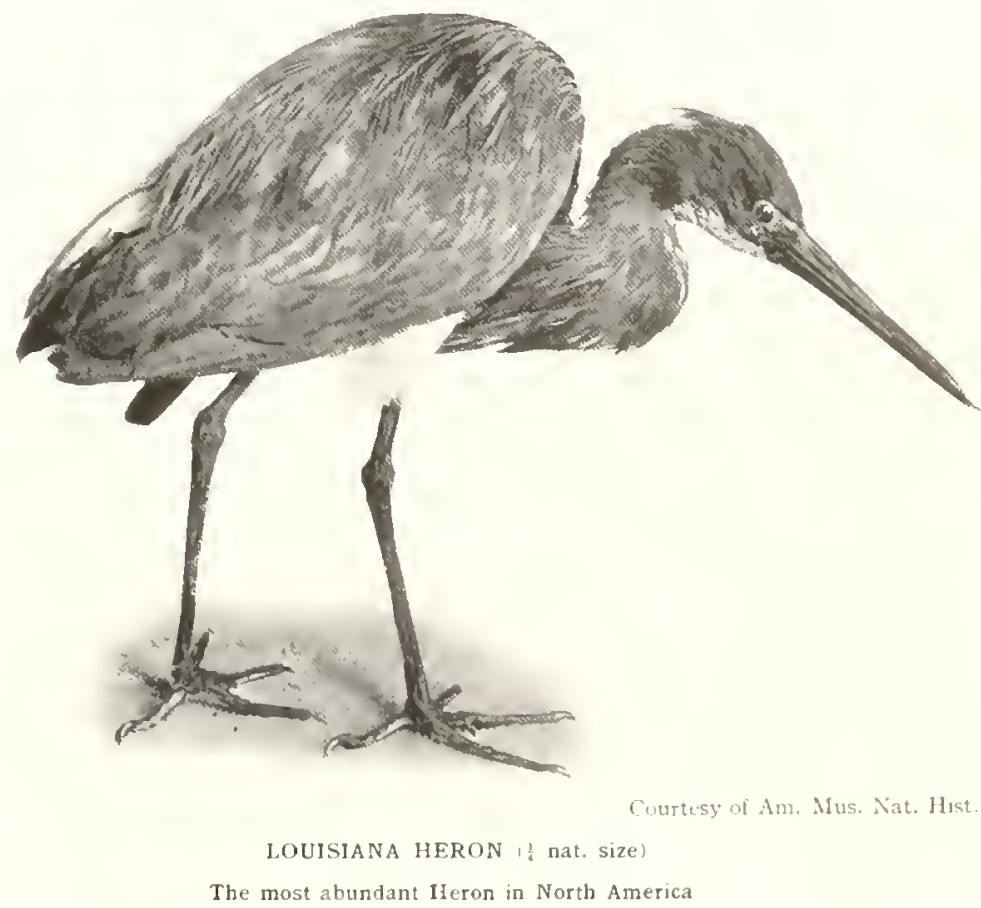


ticularly on small wooded or buslyy island; where such can be found. On the Louisiana Coast reservations, where the islands were treeless, these Herons were content to nest directly on the ground, or on the smallest of bushes, sometimes hardly a foot up. The nests are frail platforms

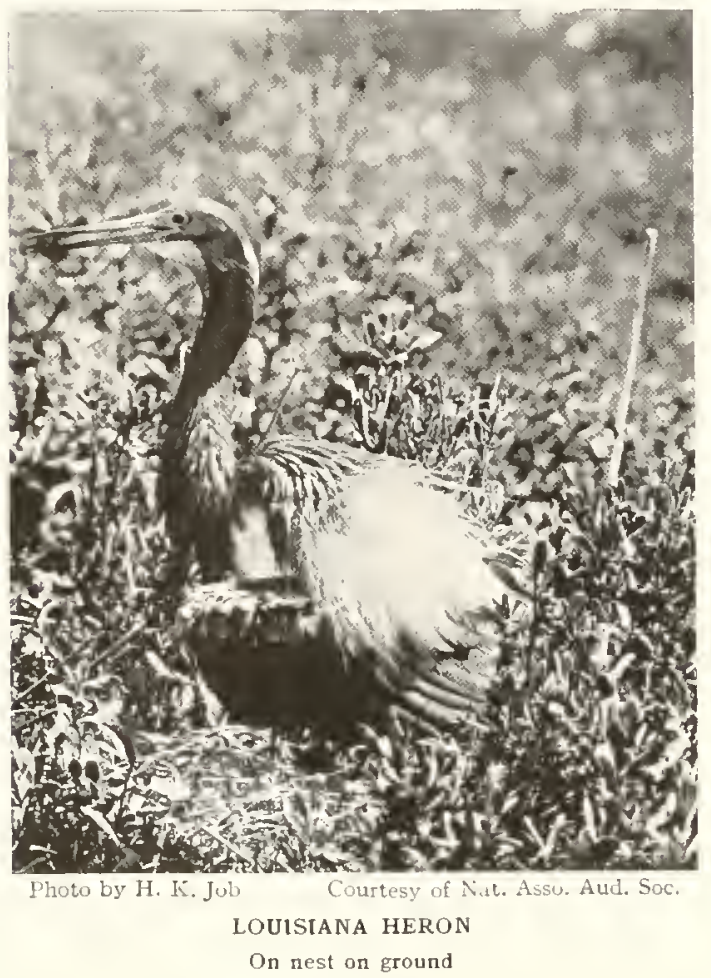

of sticks, and are similar to those of most other flerons, as are their eggs, which are blue, rather small, and from three to five in number.

On various occasions I have pitched my little photographic tent annong their nests, preferably at night, leaving it till morning, when I would enter it and have a companion withdraw. The birds had soon becone accustoned to it as a part of the landseape, and, not leing alle to "count noses," would soon return and settle down to brood their eggs or small young, or would cone to feed the latter. It was most interesting and exciting to sit there, as though a member of the tribe, and watch all the singular, remarkable ways and actions, selecting the quaintest of these for photographic records.

These rookeries are the more interesting in that it is usual for various sjecies of Herons to congregate together. In such colonies I have found, besides representatives of this species, the Snowy and American Egrets. Black-crowned and Yellow-crowned Night Hlerons, Little Blue and Great Blue Herons - certainly a lively assortment. Since, however, the Lousiana Heron is the most abundant of all, there are plenty of rookeries, especially the smaller ones, where it is found alonc. In such places there is the wildest of confusion when one enters. The larger young climb from the nests from branch to branch, using both bills and feet to aid them. The less said about cleanliness and odor the better. Yet despite their slovenly ways it is remarkable how clean and trim the Herons look! They spend hours preening their feathers, so that, after all, in their own peculiar way they are orderly.

Most of them retire beyond our borders in winter, but on the Gulf coast I have seen a few of them at that season, still wading in the shallows and striking swiftly with their sharp bills at the small fish and other aquatic forms which constitute their bill of fare. Herbert $K$. Job.

\section{LITTLE BLUE HERON}

\section{Florida cærulea (Linnous)}

A. O. U. Number 200

Other Name.- Blue Egret.

Description.- Phumes on shoulders and throat. OLd Aituts: Gencral plumage, lark slaty-blue shading to purplish-red on neck and head: bill, black shading to bluish at base: legs and feet, black; iris, yellow. Young Aututs: In perfect plumage, pure white, but usually showing traces of blue, especially on end of primaries. Length, 24 inches.

Nest and Eggs.- NEST: In trees or bushes over or near swamps; constructed like those of the rest of the genus. Eras: 2 to 4 bluish-green.

Distribution.- North and South America; formerly bred from Missouri, Indiana, Illinois, and New Jersey to western Mexico and soutl to Argentina and Peru: in the United States now breeds locally on the coast from North Carolina to Texas: wanders casually to Nebraska, Wisconsin, Ontario. New England, and Nova Sentia; winters from South Carolina southward. 
In that portion of the United States that the Little Blue Heron inluabits it is one of the most common members of the Heron amily. It is generally seen in flocks, inluabiting the shallow ponds and grassy lake-sides of the Soutlern States. With slow deliberation they wale carefully along, their bright rellow eyes scanning the shallows in quest of the fish, water-insects, or frogs itpon which they subsist. Upon the approach of evening they take flight and with measured wing-strolies pass across the country, sometines for several miles, to a favorite roosting place in the trees of a swamp. or om smme island. In spring they assemble in colonies, often by hunclieds, and huild their nests in the small trees or bushes of some isolated and favorite pond These "rookeries" are usmally inhabited also by other species of Ileroms and sometimes by other varieties of water birds.

The young are first covered with white down which later is replaced by white feathers. Not until two years of age do they assume the blue plumage of the adult. During the second summer individuals may be seen representing all stages in this change of feathers. Some are white with only a few blue feathers showing. while others, further developed, are entirely blue excert for scattering spots of white. The Little blie Heron is one of the comparatively few birds that mates and rears young while yet clothed in the feathers of youth. I recall visiting a colony of perliaps forty pairs on one occasion. every hird of which was still in the white phase of plumage.

Because of their white appearance they are often mistaken for Egrets and many times these rarer birds are reported as heing seen in a neighborhood, when a closer inspection by a competent observer would easily reveal the mistalie.

Itter the nesting season the Jirds wander alt over the country hunting for good feeding grounds. It is an odrl fact wortly of mention, that the young take trips farther afield than do their parents; and thus it happens that in the late summer inmmature Little Blue Herons are constantly recorcled far to the north of their breecling sounds, where the adult hirds are seen only at very rare intervals, if at all. Old llerons

$$
\text { Vot. I }-14
$$

possess a very pretty tuft of long plumes on their backs in stmmer. but these lecorations never appear on the hird while in the white plumage.

Being fish eaters their Hesh is not at all esteemed as a table delicacy. Lut in remote regions the colonies arc often railed for their eggs for which some people profess a fondness. Their

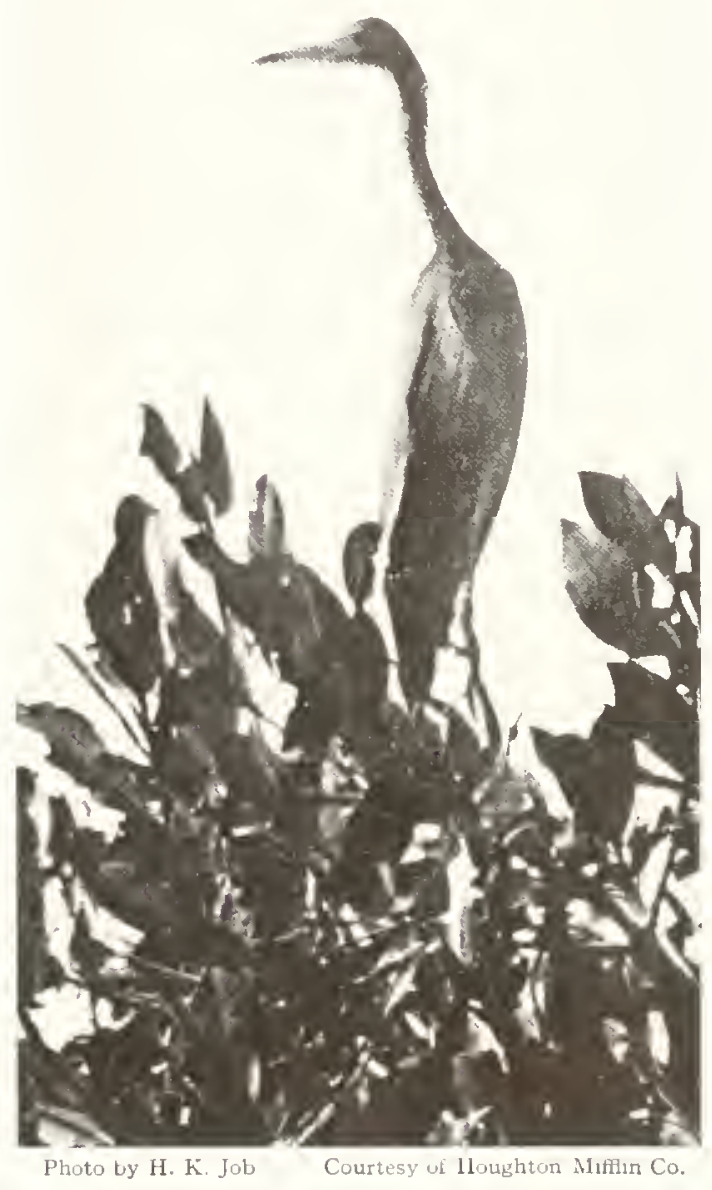

LITTLE BLUE HERON

chief natural enemies appear to he water moceasins and alligators. with which most rookeries are infested. The former climb into the trees and swallow the eggs, the latter devour the young when they fall from the nest.

T. Gilbert pearson. 


\section{GREEN HERON}

\section{Butorides virescens virescens (Limmitus)}

$$
\text { 1. O L. Number } 201 \text { tee (wior l'late } 23
$$

Other Names.- Little Green Heron: Green littern: Fly-up-the-creek.

General Description.-Length, 18 inches. Color ahure, dark green; below, dark hrown.

Color-Adurs: Crown (including a long noft crest), lengthened feathers of back and shoulders, lustrous dark aren: the hack plumes with a glaucous cast; aing-torerts, mon with well-defined tawny edges: neck, rich dark purplish-chestnut: center of thruat, white with dusky streaks; below, lark brownish: abdomen, streaked with white; primaries, secondaries, and tail, greenish-dusky; erlge of wing. white: bill, dusky-greenish, yellow at base below: bare space around eye hluish-green; legs, yellow; iris, yellow. Young: No crest; top of head, brown; sides of neck and hody

Though a comparatively small Ileron, the Green Heron is perhap, the best known nember of his family in this country, and probably most people who see him dismiss him as a gawky, awkward, and rather stupid bird with habits which are not exactly tidv. This is becauce he brownish itreaked with lighter: thrnat and center line of neck. White with rlusky streaks; back, plain greenishhrown; wing-coverts and secondaries, with white edgings and white tips: under tail-coverts, grayish-white: hill, greenish with dusky ridge; legs, pale greenishgray; iris, yellow.

Nest and Eggs.-NEST: Frequently in the woods but usually near water; a frail platform of twigs in a tree or bush. Eccs: 3 to 6 , pale greenish.

Distribution.- Eastern North America; breeds from southern South Dakota, northern Wisconsin, southern Ontario, southern Guebec, and Nova Scotia south to the West Indies; winters from the West Indies southward, and rarely in southeastern United States: casual in Colorado.

is unually seen when he utters his harsh alarm note and flops clumsily along to a nearby perch. where he stretches his neck, jerks his tail, and wazes around in a fuddle-headed manner.

Those who really know the hird, however. realize that when he is about his business of

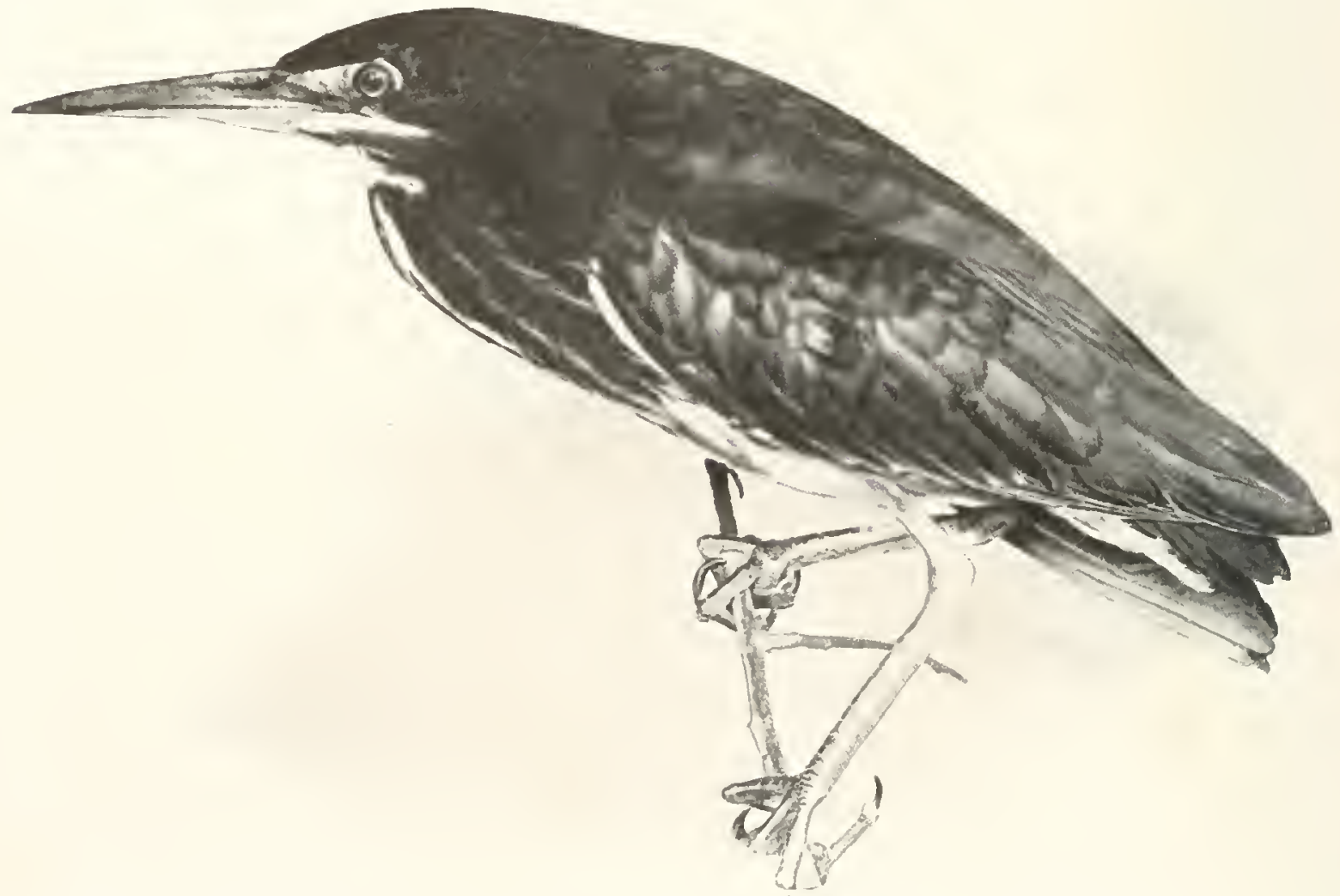




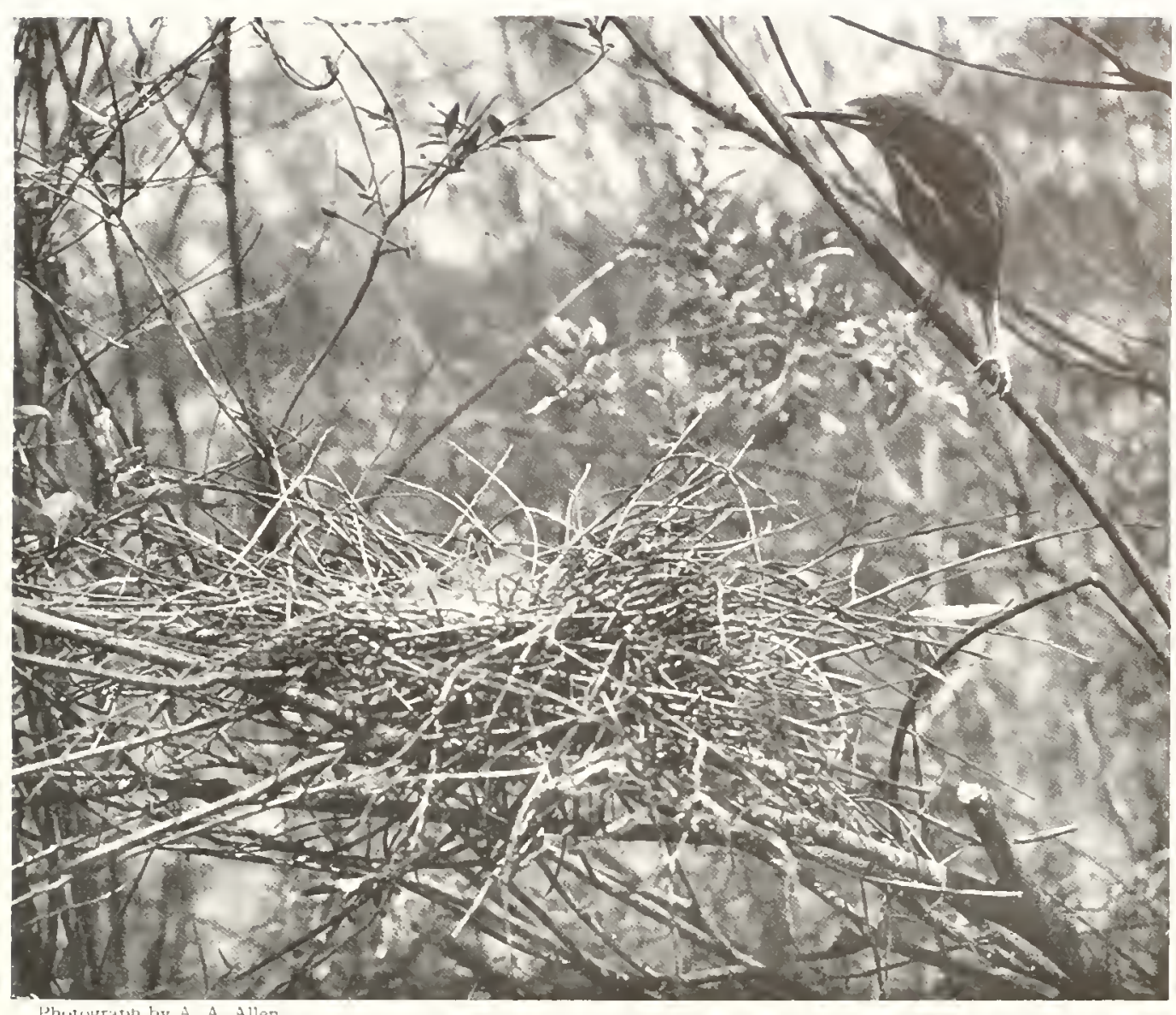

GREEN HERON

At its nest in the willows fringing a pond

catclingr fisb, frogs, salamanders, and the like, he is very far from stupid or clumsy. Then lre steps along in the shallow water or through the weeds with true Heron stealth, and the thrust of his long bill, as he seizes his prey, is as accurate as and a greeat deal quicker than that of an expert sworlsman. When flushed to a perch, the bird has a curious halit, if it sees it is olserved, of sudelenly becoming absolutely rigricl, or " freezing." to we the term commonly employed. This apprarently is clone for the purpose of escaping further observation. It is an interesting fact that young llerons, at a signal from the old hird, often employ the same ruse, and stand as motionless as statues, sometimes until the intruder has approached to within a $f(w$ feet.

Lnlike other members of its family, the Green Heron is not gregarious in its breeding habits. Occasionally a few hirds place their nests near together, but this apparently is accidental, for there are no true rookeries of Green llerons, and the birds lead a clistinetly lonely life

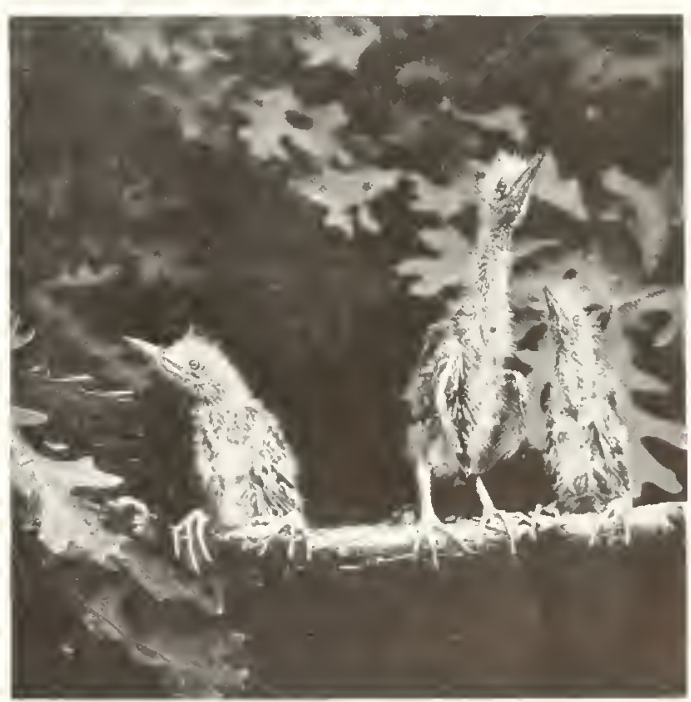

Photo by S. A. Luliritke
YOUNG GREEN HERONS

Removed from the nest by the photographes 


\section{BLACK-CROWNED NIGHT HERON}

Nycticorax nycticorax navius (Bodd(tert)

Other Names.-Night Heron; American Night Heron: Qua-bird; Quawk: Squawk; Gardenian tleron.

General Description.- Length, 26 inches. Color above, black and ashy-gray ; below, white. Head crested and, in breeding plumage, with a few long white cordlike plumes from back of crown.

Color.-Adults: Croan, back, and shoulders, black; rest of upper parts, wings, and tail, pale ashy-gray; forehead, sides of head, and throat, white shathing into vary pale lavender on neck; rest of under parts, white: bill, black: legs, yellow; iris, red: bare space around eye, yellowish-green. Young: Entire plumage, grayishwhite, streaked on head, breast, and beneath with dark see color I'late 24

brown; streaked and spotted on back with rusty and whitish; wing-coverts, brown with conspicuous white triangular tips; primaries, dusky-brown; bill, dull yeilowish: feet, pale greenish-yellow; iris, brown.

Nest and Eggs.-NEST: In trees, bushes, or on ground; a large but loosely constructed affair of branches and twigs. Elics: 3 to 6 , pale sea-green.

Distribution.- North and South America; breeds from northern Oregon, southern Wyoming, southern Manitoba, northern Quebec, and Nova Scotia south to Patagonia; winters from northern California and Gulf States southward; casual in winter north to Massacluusetts and southern lllinois.
Though not strictly a nocturnal bird, as it moves about more or less in the daytime, the Black-crowned Night Heron feeds chiefly in the evening or after the night has fallen. As the twilight deepens it may be seen flying heavily toward its favorite feeding places, and now is most frequently heard the loud and raucous quark from which is has received one of its popular names.
The bird's preferred hunting grounds are slaallow tidal creeks, the edges of ponds, and swamps which include pools. Here it hunts, usually alone and often at a distance of several miles from its breeding place, so that the feeding of the young frequently involves long flights from the hunting ground to the nest.

Its bunting methods differ from those of its relalive, the Great Blne Heron. Instead of

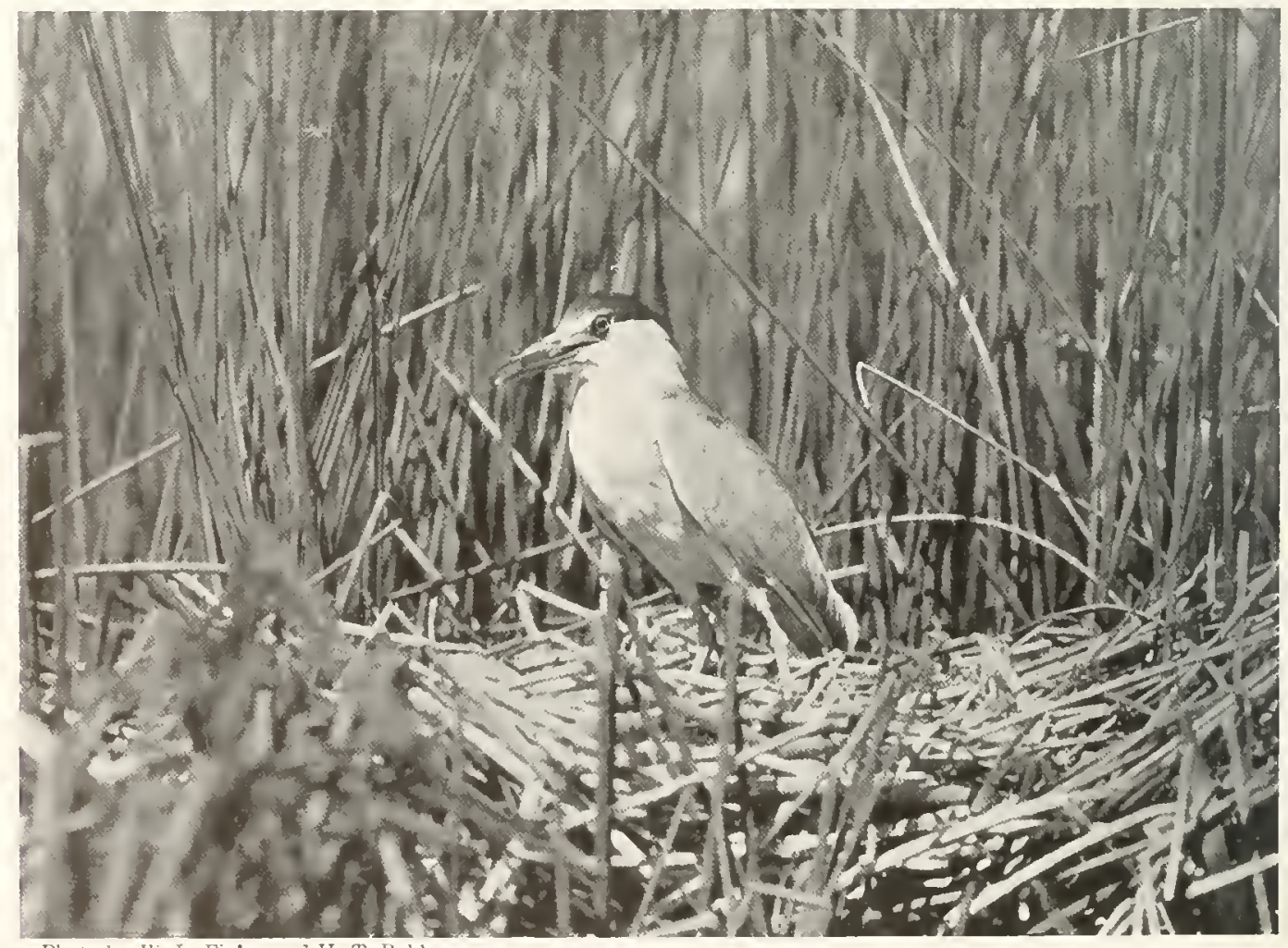

Photo by W. L. Finley and II. T. Bohlman 


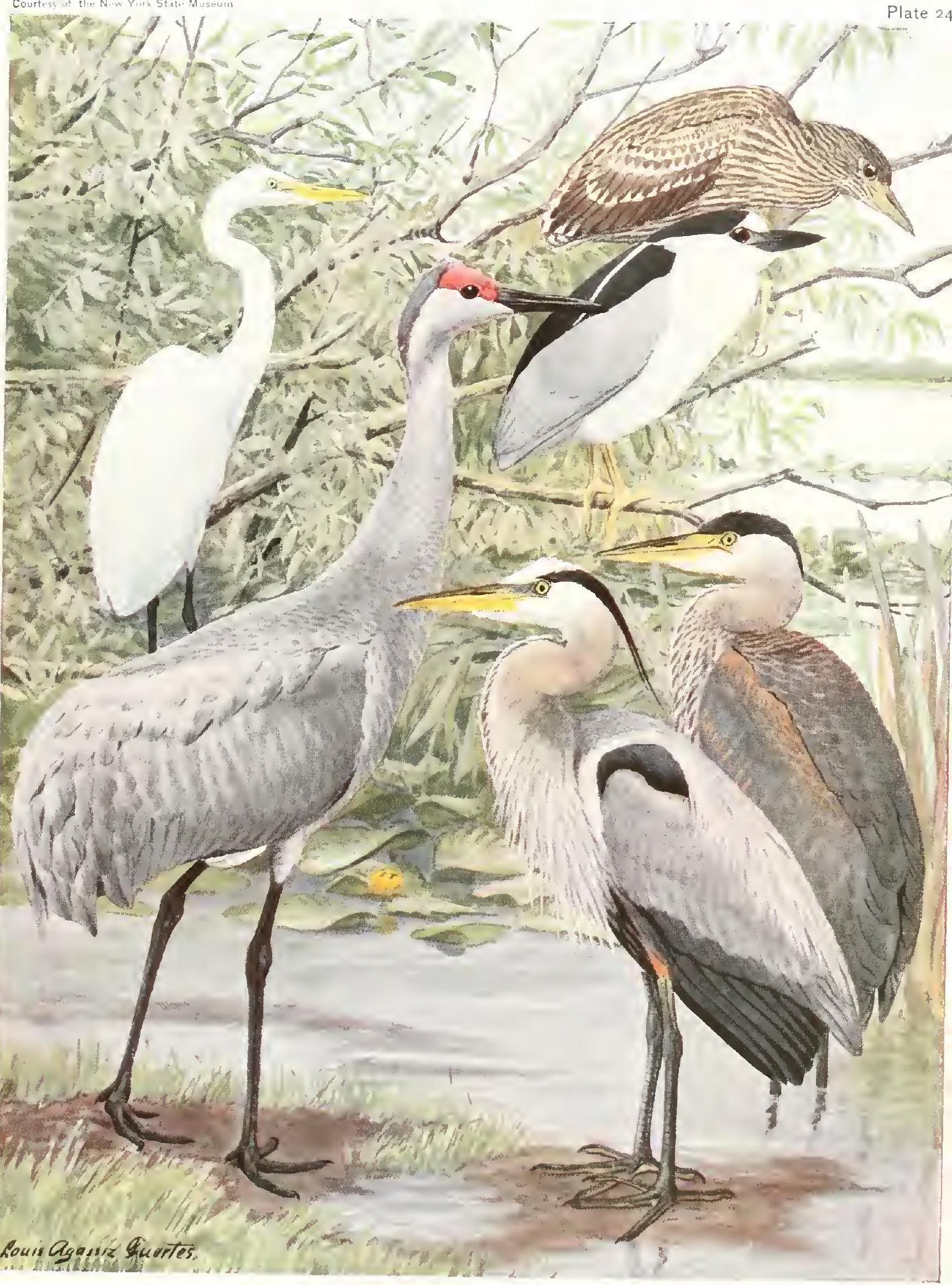



standing rigid, and knee-deep in water, its that big fisherman does, the Night Heron moves

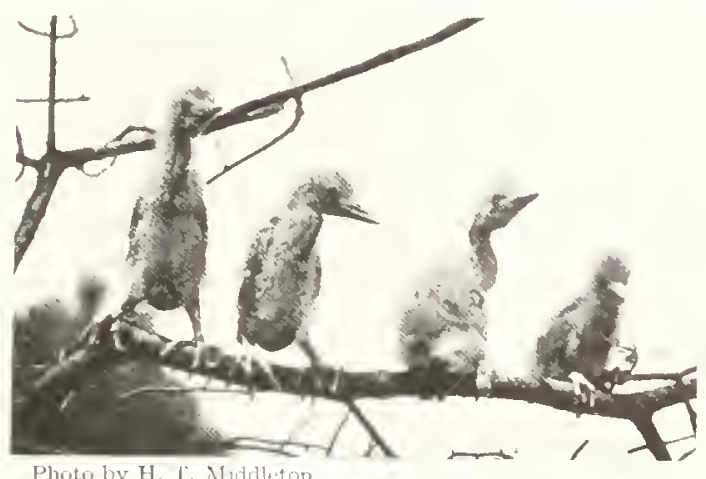

YOUNG NIGHT HERONS aloun briskly, holding its heall lowered and its neck curved, all reatly for the guice stroke which means death to the from or fish alt which it is ainimal.

This lieron's most interesting charateterintit is its gregarionsness, which callses it to collect in labere colonies doring the nesting periol. Thene hermries ustally are situated in an isulated patch of wouds, and their jupulation naty include severall humded pairs of lirds, not to mente tion as many eromps of fout or five yomes hirely Ineleet, as a pair will frequently rase two boude in a season, it is mot uncommmons to find the arlult birrls feeding at the sime time two sets of yomesters, me composed of fledglings in the nest and the other of hirds alle to clamber ahout in the branches.

\title{
YELLOW-CROWNED NIGHT HERON \\ Nyctanassa violacea (Linnirus)
}

\author{
1. O [". Vumper 203
}

General Description.- Length, 24 inches. Plumage, bluish-gray, lighter below. Head, crested and, in breeding fllmage, with a few lomg white cord-like plumes from back of crown.

Color.-ADtLTS: Top of heal and patch uncler eye, creamy white; sides of heal and chin, black; rest of Ilumage. bluish-gray, datker on back, the feathers with hlack centers and pale edges: lighter below: head and neck, and most of crest. White tinged atith r'ery pule tan'n; wings and tail, dusky-slate; bill, black: teet. hlack and yellow; iris, urange; lores and space around eve, greenish. Yousi: Abese. brownich-gray with a strong ulive tinge, streaked and yotted with brownishvellow: below, streaked with lorown and white: sicles

Although the name of Yellow-crowned Night Heron sugrests that this bird is a "night " bird, in reality it is quite as dinnual in its habits as any of the more cummon llerons. Nany times I have come ulon it in the fresly-water marshes or on mud flats by the sea where it was evidently feeding and it woukd fly awily with all the assurance of a bird whose sight was minupaired by the sunlight. It is a solitary species and is little known to many bird-students. Rarely are more than two or three found at a time and generally they are seen singly. It is a southern species and frobably never breeds north of Illinois and North Carolina. Wayne states that they "breed only in small colonies of two or three pairs." This refers to the South Carolina bircls of which lee writes, lont in Filorida I have found the facts to be otherwise. In that State I have examined several of their colonies and they numbered from twelve to twenty pairs in each instance. Ap- of lical and neck, yellowish-hrown streaked with clarker: top of head and neck variegated with white; bill, black with much greenish-yelluw below; lores and legs, greenth-yellow; iris, yellow.

Nest and Eggs,- NEsT: A platform of sticks in trees of swampy areas. Finis: $t$ to i, dull himinh

Distribution.- Narm icmperate and tropical - America; breels from southern Lower California, Fanas, sututhern Illinois, southern Imliana, and Sunth Carolina sunth to Prazil and l'eru; casual morth to Colorado, Ontario, Massadnusets, Maine, anel Nuva Seotia: winters from southers Lower Califurnia and southern Florida suuthward.

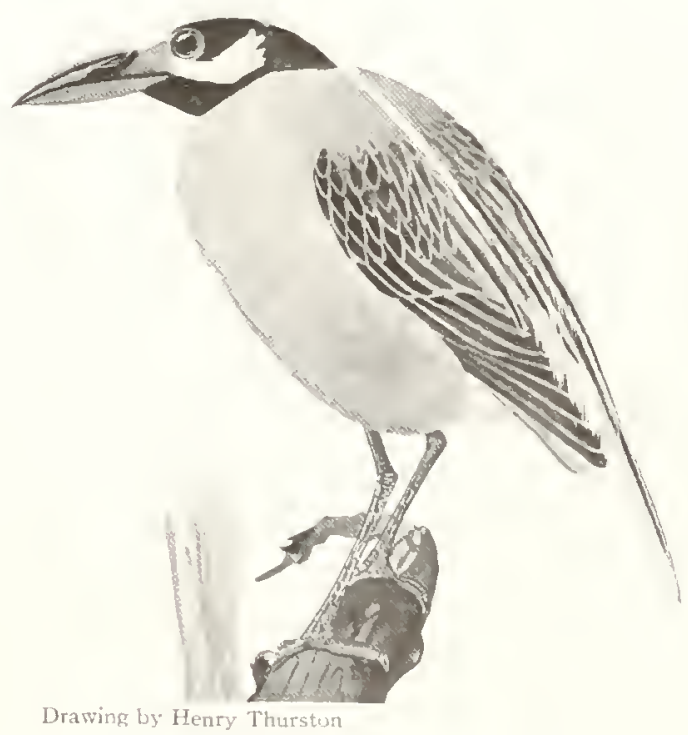

YELLOW-CROWNED NIGHT HERON ( ${ }_{6}^{2}$ nat, size)

A solitary and little-known species 
parently they do not associate in colonies with other Jerons, but always form their own village.

In Hillsboro County. Florida, sone years ago, I waded out in a large pond thickly grown with trees through the foliage of which the sun rarely

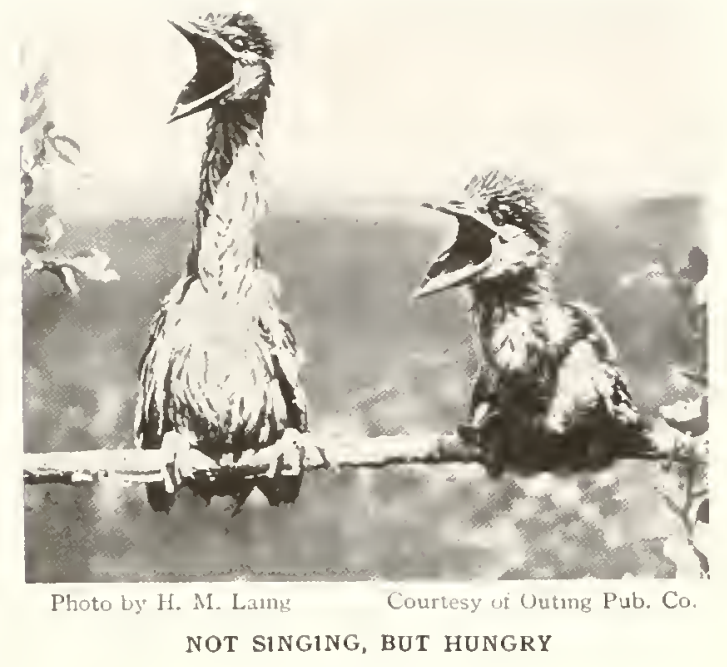

Young Night Herons

pierced to the dark scum-water beneatly. The object of my venture was to diseover whether any Egrets were breeding among a company of
Herons, whose squawks told me they were nesting in the trees surrounding an open place in the center of the pond. Submergerl logs, fallen limbs and aquatic moss made the going difficult. The place was infested with water-moceasins and alligators, and the nervou; strain soon began to tell. Upon reaching a point perhaps sixty yards from shore where the water and slime was breast deep. I was startled beyond all description by a sudden hoarse cry and leavy fapping directly srerhead. Unknowingly I had waded into the midst of a colony of Tellow-crowned Night Ilerons.

While occupying the same pond with the other Herons, they were at least two hundred feet from the nearest nest of any other species. Before leaving I counted sixteen nests, all of which appeared to be occupied.

These birds are supposed to feed largely upon mussels and crawfish and along the coast many small crabs are consumed. They retire to the far south in the autumn ancl do not reappear in the northern part of their range until March. Hfter the nesting season many of the young wander far inland and in North Carolina I have seen them rluring the month of August nore than two hundred miles from the coast.

T. Gilbert Penrson.

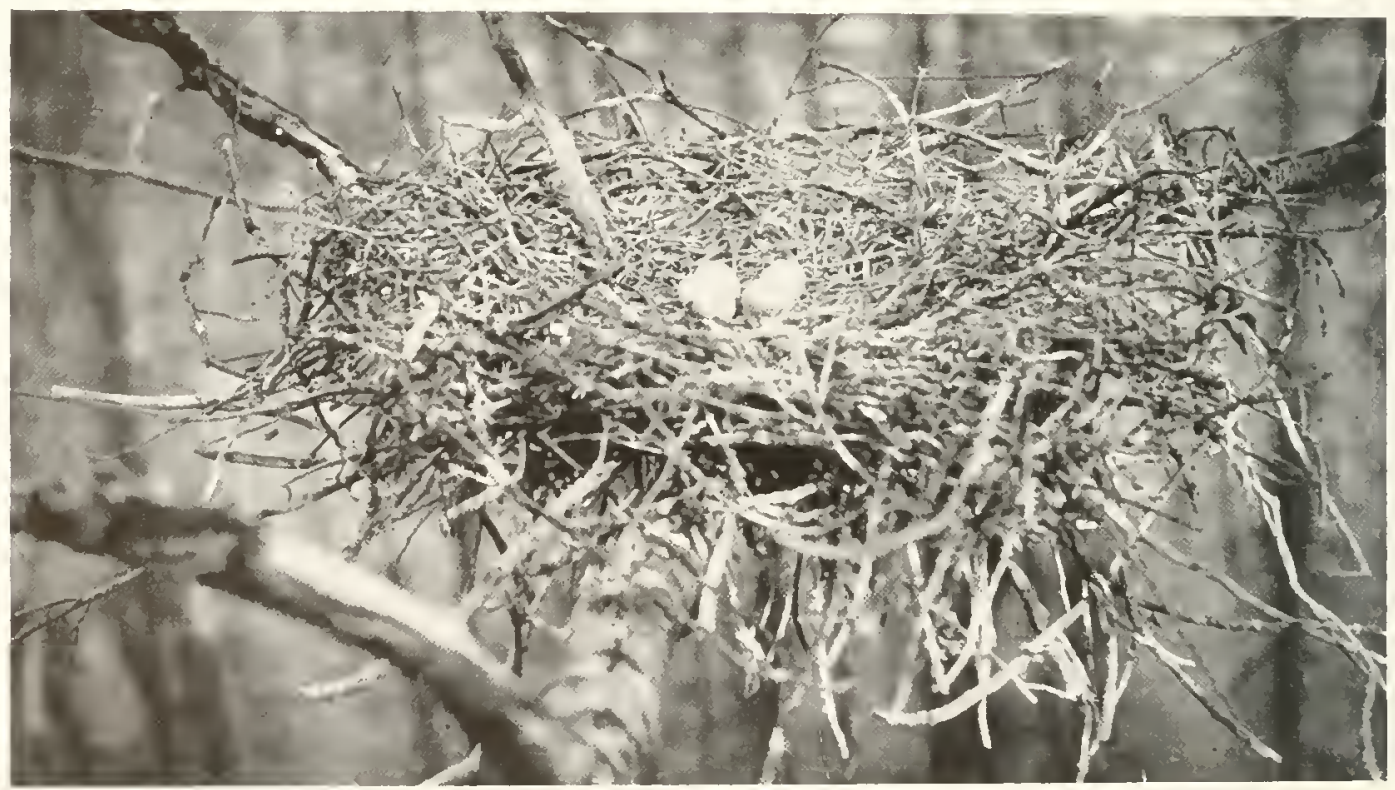

Photo l.y S. N. Leek

NEST OF GREAT BLUE HERON

Showing the four hluish eggs 


\section{ORDER OF MARSH-DWELLERS}

Oriter Paludicole

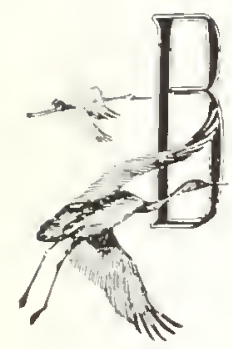

IRDS of this order viry sreatly in size and appearance the Little Black Rail is but five inches long, while the Cranes average about four feet. Strueturally all are alike in having the hind toe clevated. Two habits are common to the entire order. The first of these is that of dwelling in marshy places, and the scond is that of always flying with the neck extended. The roung are hatched with a covering of down and are able to rum ahout soon after leaving the shell, athough requiring more or less attention from the parents.

The order is divided into two suborders: the Long-legged Marsh-dwellers (Gruts), which includes two families, the Cranes and the Courlans; and the Henlike Marsh-dwellers (Ralli), which consists of the single family of Rails. Gallinules, and Coots.

\section{CRANES AND COURLANS}

Order Paludicola; suborder Gmes; families Gruide and Aramide

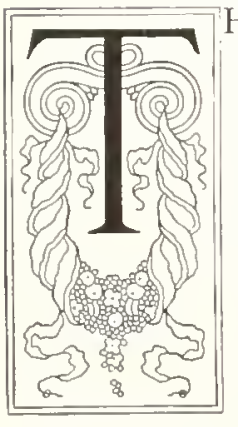

HOUGH superficially similar to the Herons in some respects, the Cranes constitute a distinct group in a different order. They are the family Graida of the Marsh-dwelters and are really more chosely related to the Rails than to the Herons. When in flight they may be distinguished from the Herons by their habit of carrying the neck extended at full length. But they are similar to the Ferons in having the head more or less bare, while they differ from them in that their plumage is dense and compact, rather than loose. The family includes about twenty species, of which only three occur on this continent. Their favorite habitats are narshes and plains, and their dict includes not only frogs, snakes, field mice, and lizards, but grain and consideraßle vegetable food. Most of the Cranes have singularly loud and resonant cries, this being especially true of the Sandhill Crane. This resonant quality of the Crane's cry is due probably to the curious peculiarity and great length of the bird's windpipe. Though this organ is ahout normal in the chick just hatched, it becomes elongated and coiled as the bird matures, and is accommodated in the keel of the breastbone. In the Whooping Crane, when this development is complete, nearly thirty inches of the trachea may be thus packed away, and the entire length of the organ, from the throat to the lungs, may be fully fire feet.

Another distinguishing characteristic of the Cranes is the fact that the chicks are covered with down when they are hatched, and are able to run about a few hours after they leave the shell. The American spccies range over the cntire continent as far south as Cuba and Mexico. They are migratory from the northern portions of their range, but less so or not at all in the south.

The Courlans comprise another family, the Aramida, of the Marsh-dwellers. But two species are known: one found in South America, and the other, the Limplin, in Central America, Mexico, the West Indies, and Florida. 


\title{
WHOOPING CRANE
}

\author{
Grus americana (Linneus)
}

\author{
A. U. $\mathrm{I}^{\mathrm{r}}$ Xumber 204
}

Other Names. - White Crane; Great White Crane; Garoo.

General Description.- Length, $4^{\prime \prime} 2$ feet; sprearl of wings, $\gamma^{I / 2}$ feet. Plumage, white. Head with bare spot on each side below eyes, crtendiny to a point on back of crozm and sparsely covered with short hairs.

Color.-Adurts: White; primaries and coeterts, black; hare part of head, carmine; bill, lusky-greenish; legs, black; jris, yellow. Young: Entire head, feathered. General plumage, whitish, variegated with rusty-brown.

Nest and Eggs.- Nest: On the ground; a well- built structure of marsh grass and reed stems, from one and a half to two feet in diancter and eighteen inches high. EGis: 2, olive or buffy, blutched with large irregular spots of lirown.

Distribution.- North America; bred formerly from northern Mackenzie south to Illinois and lowa; now mainly restricted to southern Mackenzie and northern Saskatchewan; in migration formerly not rare on the Atlantic coast from New England to Florida and casual west to Colorado and 1daho; winters from the Gulf States to central Mexico.
The Whooping Crane was named and described by Linne in the eighteenth century. I'revious to that time all three American species were lumped tugether as Cranes.

Many of the narratives of the early voyagers and settlers tell of Cranes migrating and nesting along the Atlantic coast. During the first century after the discovery of the country. Cranes evidently were more or less numerons all along this const, from Florida to New England, but the word has been used so frequently to denote the larger llerons that one might be inclined to place little faith in the statements of sailors and colonists were it not for two facts: (I) In those days Cranes were well-known and conspicuous birds in England and other countries of which these voyagers were natives, or which they had risited, and undoubtedly they were familiar with these birds, and could distinguish them from Herons. (2) In the lists of birds given by these early adventurers, Herons, "Hearnes" and "Hernshaws," "1Bittems," and "Egrets" or "Egreples" are also referred to. showing that they distinguished the Cranes from the Herons. The common European Heron was a large species (resembling the Great Bhe Heron of America) which, at that time, was called the Hernshaw, Hearneshaw, or Heronshaw. It is often inpossible to determine which species of Crane was referred to in these early narratives and lists of bircls, as usually no description is given; but now and then we find a reference to a bird that must have been the IVhooping Crane.

The Whooping Crane is the only bird of North America that can be clescribed as "almost as tall as a man." The Whooping Crane stands about five feet high when stretched to its full height, but being white it appears taller, while the
Sandhill Crane is not so conspicuous on account of its color and does not appear so large.

Probably there were few Cranes inhabiting Massachusetts when the Pilgrim Fathers landed at I'lymouth, except along the coast, on the islands, and on the meadows and marshes of the river valleys, for most of the State was then covered with primeval forest; and while Cranes are sometimes found in open woods, they are shy and wary birds, and prefer the open country, where they can discern their enemies from afar.

The fact that they sometimes ate the corm proves that they were actually Cranes, not Herons, and also helps to explain their early disappearance from $M$ assachusetts. They paid with the death penalty for eating the corn. Also, as these birds occupied the only natural open lands - those that were first sought by settlers - they were driven out within a few years after settlement began. Even had they not attacked the corn they must som have succumbed because of their large size, their white color, and their general conspicuousness. In the early days the Indians used to steal upon the Cranes and shoot them with arrows. Now the few survivors of this species in the West will hardly come knowingly within a mile of the white man.

John Lawson, in his History' of Carolina, says that Cranes are sometimes "lred up tame" and are excellent in the garden to destroy frogs and other vermin.

This birl is long-lived and grows wary as the years go by; it now frequents prairies, marshes. and barren grounds, over which it stalks, always alert and watch ful. It flice low, its wings sometimes almost lirushing the grass tops, lut in migration it rises to such tremendous heights that it may pass over a large region mnoticed by man. 


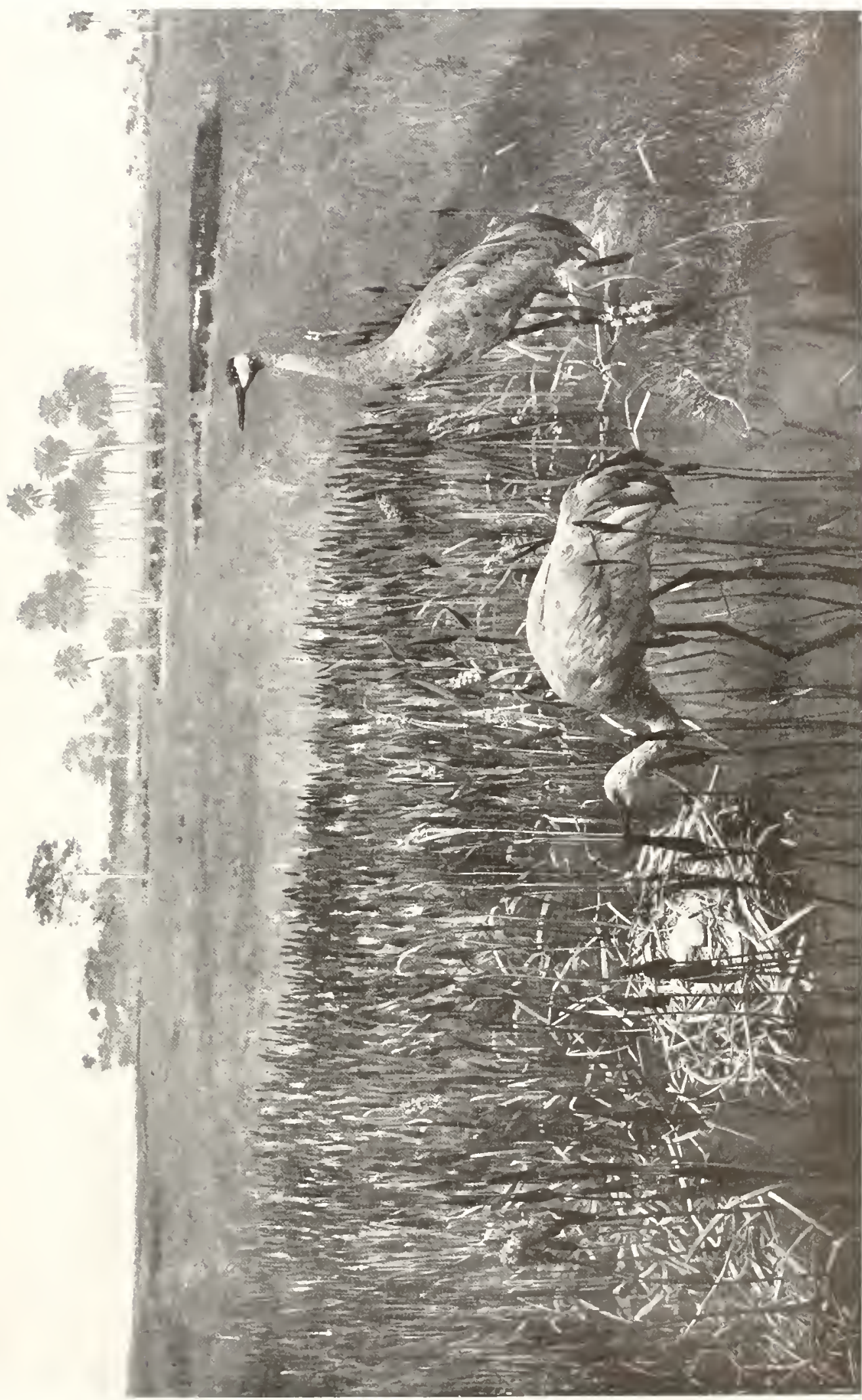

$r$ 
It feeds on irogs, fish, small mammals, and insects, and is said to take corn and other cereals and the succulent roots of water-plants.

Nutta!l, describing the flights of the II'hooping Crane up the Mlississippi valley in December. I8II, says, "that the bustle of their great migrations and the passage of their mighty armies fills the mind with wonder." It seemed, he says, as though the whole continent was giving up its quota of the species to swell this mighty host. and the clangor of their numerons legions, prassing higl in air, was almost deafening. His state- ment, that this great host of Cranes was passing nearly all night, will give sone idea of the inmensity of this great flight

The $/ 1$ hooping Crane is doomed to extinction. It has disappeared from its former habitat in the East and is now found only in uninhabited places. It can hardly he said to be common anywhere except perhaps locally in the far North. Only its extreme watchfulnesi has saved thus far the remnant of its once great host.

Edwakd Howe Forbusil, in Game Birds, l'ild-Fozd and Shore Birds.

\title{
SANDHILL CRANE
}

\section{Grus mexicana ( Miiller)}

\author{
A. 0 [. Ximber 206 siee color l"late 24
}

Other Names. - Brown Crane: Upland Crane; Field Crane; Southern Sandhill Crane.

General Description.- Length, \& leet: spread of wings, 6\% feet. Plumage, slaty-gray. Head awith have spot forking behind, wot reaching on sides below eyes, and thinly sprinkled with hair.

Color-Aduts: Plumage, slaty-gray: primaries and their coverts, ashy-gray but little darker than general color: cheets and throat, lighter inclined to whitish; bill and teet, black; iris, brows. Younk: Head, feathered. l'lumage, variegated with rusty and brown.

Nest and Eggs. - NEst: On tise ground, tisually (n) a slight knoll of open grassy flats: generally a mere depression in the ground. lined with dry grass and weed stems. Esics: 2, from pale olive to buffy-brown. marked over entire surface with spots of burnt-umber.

Distribution.- North America; resident in Louisiana and Florida; bred fornerly from southern British Columbia, Saskatchewan, Nanitoba, and western Ontario south to California, Colorado, Nebraska, Hllinois, and Ohio; formerly in migration east to New England: now rare east of the Mississippi, except in Florida, and rare as a breeder in the southern half of its former breeding range: winters from California. Texas, and Louisiana south to Mexico.
The virtual extermination, or at best the extrence rarity, of the great Whooping (rane, leaves the much smaller Sandhill crane by far the largest representative of that interesting family in America. For it should be remembered that the varions Herons - notally the Great Blue Heron - which are connmonly called "Cranes." not only are not Cranes at all, but differ radically from them in both disposition and habits.

If not in size, then in its conspicnous and striking characteristics, the Sandhill Crane is a fit suecessor to his towering relative, whose days seem to be numbered. Nor is the bird a wealiling at that. for the height of the mate when he stands erect is nearly that of a man of average stature, while the bird's great wings carry his compact and numscular body with perfect ease and at a high speed. The bird's wariness bespeaks intelligent cantion rather than weakness or fear.
Indeed, when the Sandnill Crane is crippled by a broken wing or otherwise, he may becone an exceedingly ugly antagonist for the man who attempts to overpower him, because of the skill, strength, and quickness with which he will then employ his long and dagger-like bill in defending himself. Many a hunter's dog has been blinded or otherwise bady injured by the vicious thrusts of this very dangerous weapon, which the Crane does not hesitate to use when he is at bay and lighting for his life.

Unlike the Herons, this Crane spends much of its time, and gets the food which it seems to relisli most, on dry land. Hence it is often found on the plains and prairies, sometimes in small flocks but oftener in pairs or singly. Its diet includes a large percentage of roots, bulbs, grains, and the like; and it is especially fond of corn which it takes from the shock. Insects, frogs, lizards, snakes, and mice are also included in its bill of 
fare, but not in sufficient numbers to make its Hesle "strungr" as is that of the Herons and oher walling hirds. In fact, this Crane's flesh is cxcelknt for the table, and it has been persistently hunted for foud

Oil the fonceless prities and the treeless marshes, where its keen eyes can detect af ar ont the alprosich of an enemy, the demeanor and habits of this fine, bave lird challenge the admiration of the man who appreciates alertness, contige, and strength in wild life. Not for an instant is the great lirel off his guard. Moving in deliberate and dignified strides he pituses oceasinnally and lowers his head to thrust his long bill into the soft carth, or to seize a druing frog or an mowatehful insect; lut in a few secombls up again comes his head, and his eves search the surrounding conntry. If the approach of his chiet enemy, man, is discovered, the Crane smoveys the intruder for a few minutes and then, with a few long, rumning strides takes to his
Wings, at the satme time sommlung his wilci and detiant ery.

This cry of the Sandhill Crane is a veritable voice of Nature, mutamed and unterrified. Its uncanny quality is like that of the Loon, but is more pronouncel because of the much greater volume of the Crane's voice. Its resonance is remarkalle and its carring power is increased by a distinct tremolo effect. Often for seviral minutes after the bircls have ranishel, the moearthly sound drifts back tu the listener, like a taunting trumpet from the minder-world.

Geurge Giladnen.

The Little Brown Crane (Gmis canadonsis) in like the Sandhill Crane except for its smaller size. It breeds from northern Alaska, Melville Island, and Boothia l'eninsula sonth to central Maska, sonthern Nackenzie, and central Keewatin. During migration it occurs through the interior of the United States and winters south to Texas and Mexico.

\section{LIMPKIN}

\section{Aramus vociferus (Latham)}

1. O U. Number 207

Other Names.-Courlan: Crying-bird; Clucking-hen: Carat.

Description.- Length, is inches. Color, nlive-brown, paler on face, chin, and throat, streaked or spotted everywhere with white: hill, dusky: legs, greenishdusky: iris, brown. The young are pater and dulter than the adults.

Nest and Eggs.- Nest: On the grounl near water. sometines a short distance ahove ground in a maze of vines or thick bushes : constructed of grass, leaves, dear vines, moss, and other old vegetation. Eirs: 4 to 7 . usualty 5 or 6 , varying from pure white to buffy, spotted and splashed with brown and gray.

Distribution.- Florida, Greater Antilles, and both coasts of Central America: casual north to South Carolina; accidental in Texas. ()f the Courlan family only two species are known, one of these leing the I implkin of Central America, Mexico, the West Indies, and Florida. It may be lescribed as a very large Rail with many of the habits of an Ibis. In the Everglarles of Florida it is a common bird and while crossing that vast waste in the month of Nay I found many flocks, some of which numbered as high as forty inclividuals. Their flight is peculiar. With dangling legs the bird springs from the glades and goes off on wings that have a jerky motion, strongly suggestive of the morements of the wings of a mechanical beetle. In aligliting the wings are held ligh above the back and in this attitude the bird drops from sight. The food consists largely of the big fresh- water snail found in many parts of the State. These smails in places abound in the sluallow waters and are easily procured by this longlegged wading bird. In the cypress swanys I have come upon piles of empty shells from which the snails had been extracted by these birds. In doing this the shell is rarely hoken.

In the swamps along the Oklawaha River, lumbermen of recent years have cut much of the timber. Stumps, from fon to ten feet in lieight, are everywhere leit standing. The jungle hates a bare place and soon these stumps are covered with vines. Here, on the top of these vine-clad pillars, the Limpkins often build their nests. Farther south you may find them in tall bunches of saw-grass or isolated custard-apples bushes in 
the glades. The nests are made chiefly of such varieties of twigs and leaves as are obtainable in the neighborhood. From four to seven brown splotted eggs are laid.

Linl kins at tines are very noisy creatures. Their usual call possesses a quality of unutterable sadness, as though the bird was oppressed beyond measure by the desolateness of its surroundings. For this reason the name "Cryingbird" is usually given them by the natives. In the spring and early summer they largely haunt the swampy shores of streams and lakes, but in the autumn they gather in great numbers in the more open savannas. Thousands thus pass the winter months on the pond-covered prairies about the headwaters of the Caloosahatchee River, west of Lake Okechobee. The Limplin is highly esteemed for food, but owing to the difficulties of hunting them in their retreats there is strong likelihood of the species persisting in Florida for many years to come.

A few years ago many were to be found in the swampy country of northern Florida, within fifteen or twenty miles of the Georgia line, and two or three specimens have even been taken in South Carolina. T. Gilbert Pearson.

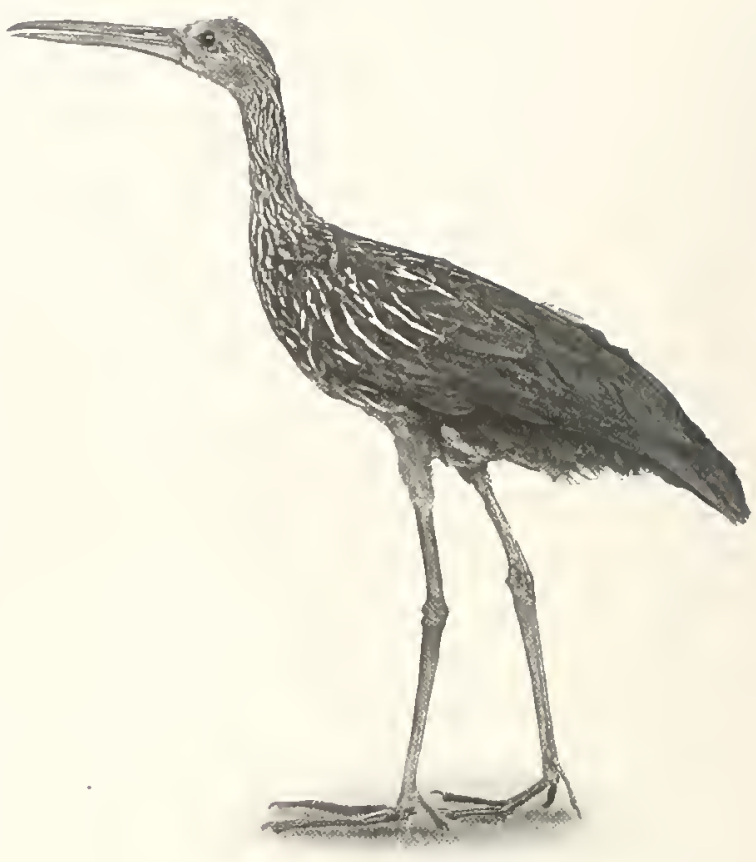

Courtesy of Am. Mus. Nat. Hist.

LIMPKIN

A long-legged wading bird of Florida and tropical America

\section{RAILS, GALLINULES, AND COOTS}

\section{Order Paludicola; suborder Ralli; family Rallida}

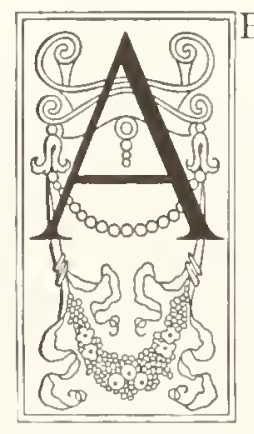

BOUT fifty genera, embracing one hundred and eighty species constitute this family, the Rullida, which includes the Rails (Rallina), Gallinules (Gallinulina), and Coots (Fulicina). The distribution of these birds is virtually cosmopolitan, and about fifteen species occur, regularly or casually, in North America. They are from small to fair-sized birds, with noticeably compressed bodies, - well adapted to rapid progress through thickly growing reeds and rushes, - long necks, small heads, short, ronnded wings, short tails, and long, strong legs and feet. The bill is short and henlike in the Coots and Gallinules, but long and slightly curved toward the end in the Rails. The plumage is subdued and blended in color. A family peculiarity is that of running, rather than flying, to escape danger, a trait apparently responsible for the extermination of certain species which had lost the power of flight throngh disuse of the wings, and the steady diminution of others for the same reason.

"Rails and Gallinules are marsh birds, very secretive in habits, keeping well under cover of the dense rushes and grasses, except at night or in the twilight, when they venture out on the muddy shores. When silently floating along the marshy stream, one may of ten see them standing motionless near their favorite coverts, or walking deliberately along the margin flirting their upturned tails and bobbing their necks in henlike fashion. Their cries are also loud, and remind one of the different notes of our domestic fowl. Consequently all our species of the family, from the Virginia Rail to the Coot, have received the common name of Mud Hens. The flight of Rails and Gallinules is feeble and hesitating. They usually take wing as a last resort, and then proceed with dangling legs, in a direct conrse, low over 


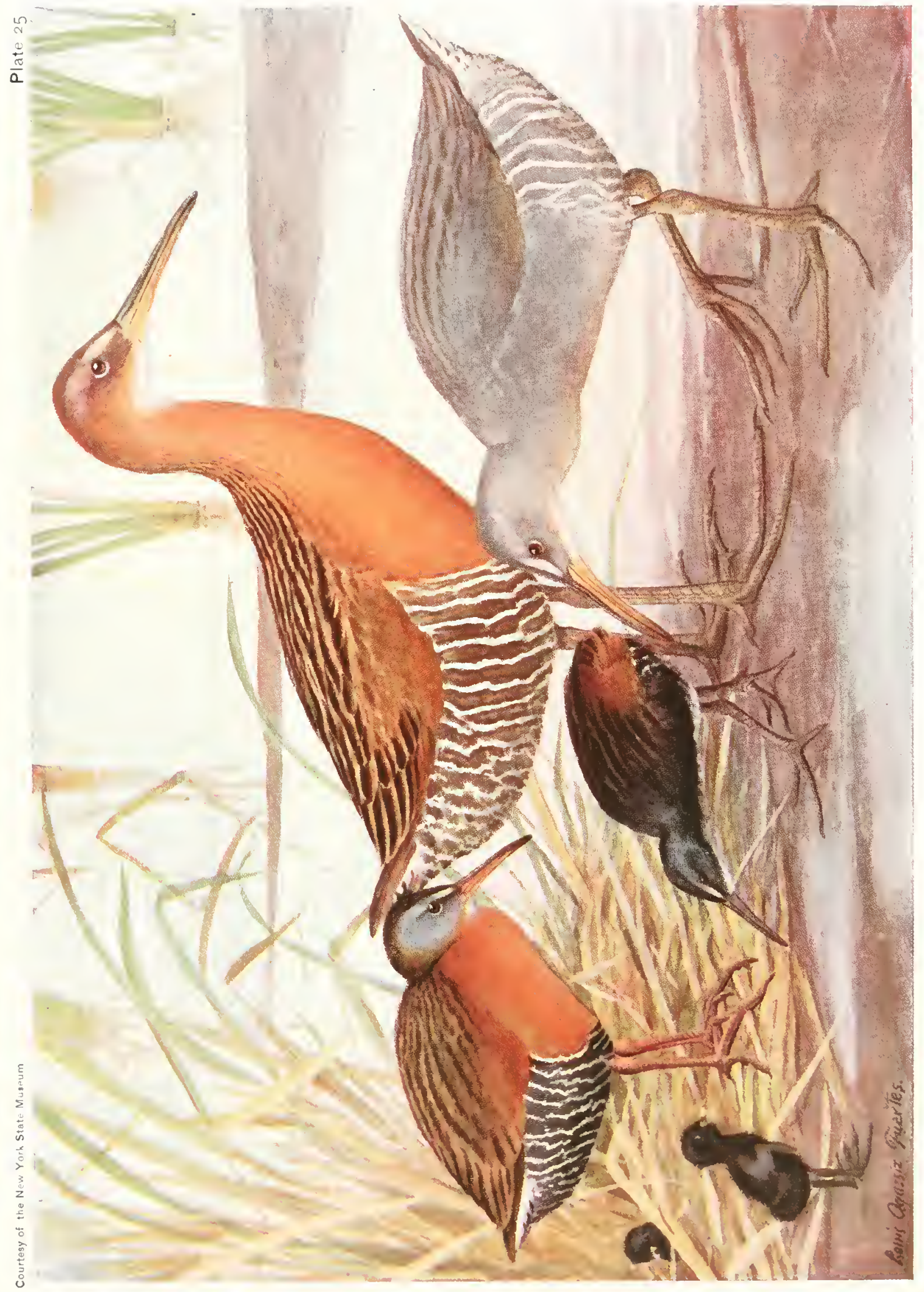



the tops of the rushes, dropping abruptly in a few rods amidst the grass, as if exhausted by their unwonted exertion. "They are perfectly at home on the ground, and dart among the dense weeds with marked freedom, the long toes keeping them from sinking in the mud or submerged vegetation, their thin bodie's gliding easily between the reeds." (Eaton.)

All of the Rails, Gallinules, and Coots nest on the ground, and as a rule lay large sets of eggs. The young are covered with down when hatched, and are able to run about very soon after leaving the shell.

\title{
KING RAIL
}

Rallus elegans Audubon

\author{
A. O U. Number zo8 sce Color l'late 25
}

Other Names.-Fresh-water Marsh Hen; Great Red-breasted Rail: Murl Hen.

General Description.- l,ength, Iq inches. L'pper parts, tawny-olive streaked with darker: lower yarts. chestnut. Furehead entirely feathered down to hase of bill: bill leng and slenter.

Color.-Adets: Crown, sides of head, back of neck, and rest of uppir parts. tan'ny-oliz' streaked from center of neck to tail with blackisb-hrown; an indistinct whitish lue from bill over and behind eve: chin and upper throat. White; neck and brest. rich chestunt; rest of under parts, white traversed by broad bars of olive-bruwn : wing-coverts, olive-brown : secondaries, dusky-brown edged with lighter; primaries, plain

This large and handsome Rail, the King Rail. closely resembles the Virginia Rail excent in size. Its retiring habits probably account for our lack of knowledge regarding it. Little seems to be known of it except that it apprears to prefer fresh marshes to salt marshes. I have nover seen it allive.

Dr. Bachman, in South Carolina. seems to have harl a better opportunity of ohserving its habits than any one else who has written about it. lle states that he found twenty pairs breeding within a space having a dianeter of thirty vards, and that the nests were placed on the gromed, being raised up six or eight inches by means of withered weeds and grasses; but Wavne, who has also found numerous nests, finds them in rushes or buttonwond hushes, from eight to eighteen inches over water. He noted that the female laid an egr each day after is A. M. and on laving the twelfth began at once to incuhate. This Rail frequents the swampy borlers of rivers and fresh-water ponds oversrown with vegetation. The stomach of one specimen was filled with seeds of Arundo tecta; that of another contained a quantity of oats.

EAM.ART Howe Forbusi, in Game Birds, Wild-Fond and Shore Birds. dusky-brown; a narrow white emi-circle below eye bill, yellowish, dusky on ridge and tip ; legs, prale duskygreenish: iris, reddish-brown. Down: Young: Glossy black.

Nest and Eggs.- NEST: On the ground in marsh grass: built of deas reeds and grass, well concealed irom above by interlacing of surrounding urass. EGgs: () to 12, dull white to pale buff, thinly spotted with redidish-brmw and lilac

Distribution.-Fastern North America: breeds from Nebranka, southern Minnesota, Ontaris. New York, and Comecticut south to Texas, Florida, and Cuba: winters mainly in the southern part of its breeling range: raswal noth to South Dakota and Maine.

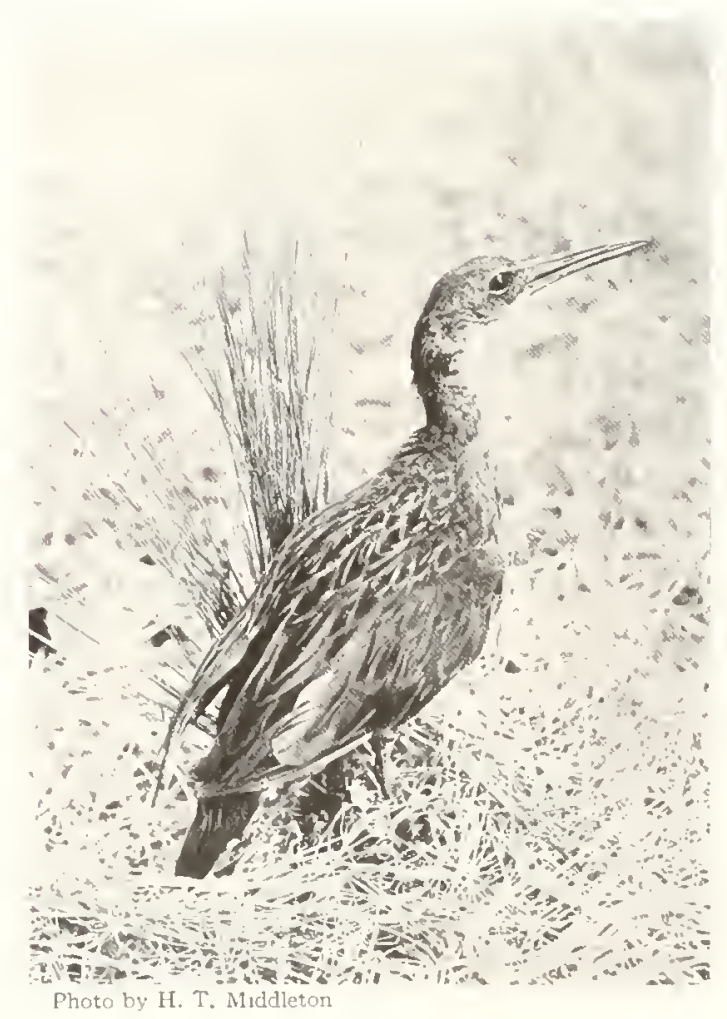

KING RAIL. 


\section{CLAPPER RAIL}

\section{Rallus crepitans crepitans Gmelin}

A. O. U. Number 2 II

Other Names.-- Common Clapper; Mtarsh Clapper; Mud Hen; Sedge Hen; Meadow Hen; Salt-water Marsh Hen.

General Description.-Length, 16 inches. Color above, brownish-gray; below, lighter. Forehead entirely feathered down to base of bill; bill, long and slender.

Color.-ADults: Forehead, dusky; crown, sides of head, neck, upper parts, and lower parts as far as abdomen. pali olice-ash streaked on back, shoulders, and rump with olive-brown; lores and throat, whitish; abdomen and under tall-coverts, pale brownish-white traversed with broad indefmite bars of brownish-gray;
See Color l'late 25

wing-quills and tail, plain dusky-brown; bill, yellow, dusky on ridge and tip; feet, pale greenish-dusky; iris, reddish-brown. There is much variation in the shades of plumage, tall and winter birds being much darker and with browner shates. Downy Young: Glossy black.

Nest and Eggs.-NEST: A platform of dead reeds and grasses on the ground in meadows. EgGs: 0 to 15 , white to buff, dotted and blotched with chestmut and some lavender.

Distribution.- Salt marshes of the Atlantic coast; breeds from Connecticut to North Carolina: winters mainly south of New Jersey; casual north to Maine.
Grassy salt marshes are the haunts of the Clapper Rail. From Connecticut southward to the Florida Keys they are undoubtedly more numerous than any other species found in these marshes. (Jne does not find them everywhere in their range but in the localities they like best the grass seems to swarm with them. It is ordinarily very difficult to flush them and one may wale or push a boit through the marsh for hours and never see one while all the tine their tantalizing calls are heard near and far. Their facility in keeping out of sight is most remarkable. From Virginia southward they are much hunted during the months of September and Octoher. They are shot from small boats when the tide is high and the flooded marshes afford no shelter wherein the birds may hide. While one man poles the boat a second stands in the bow and fires at the

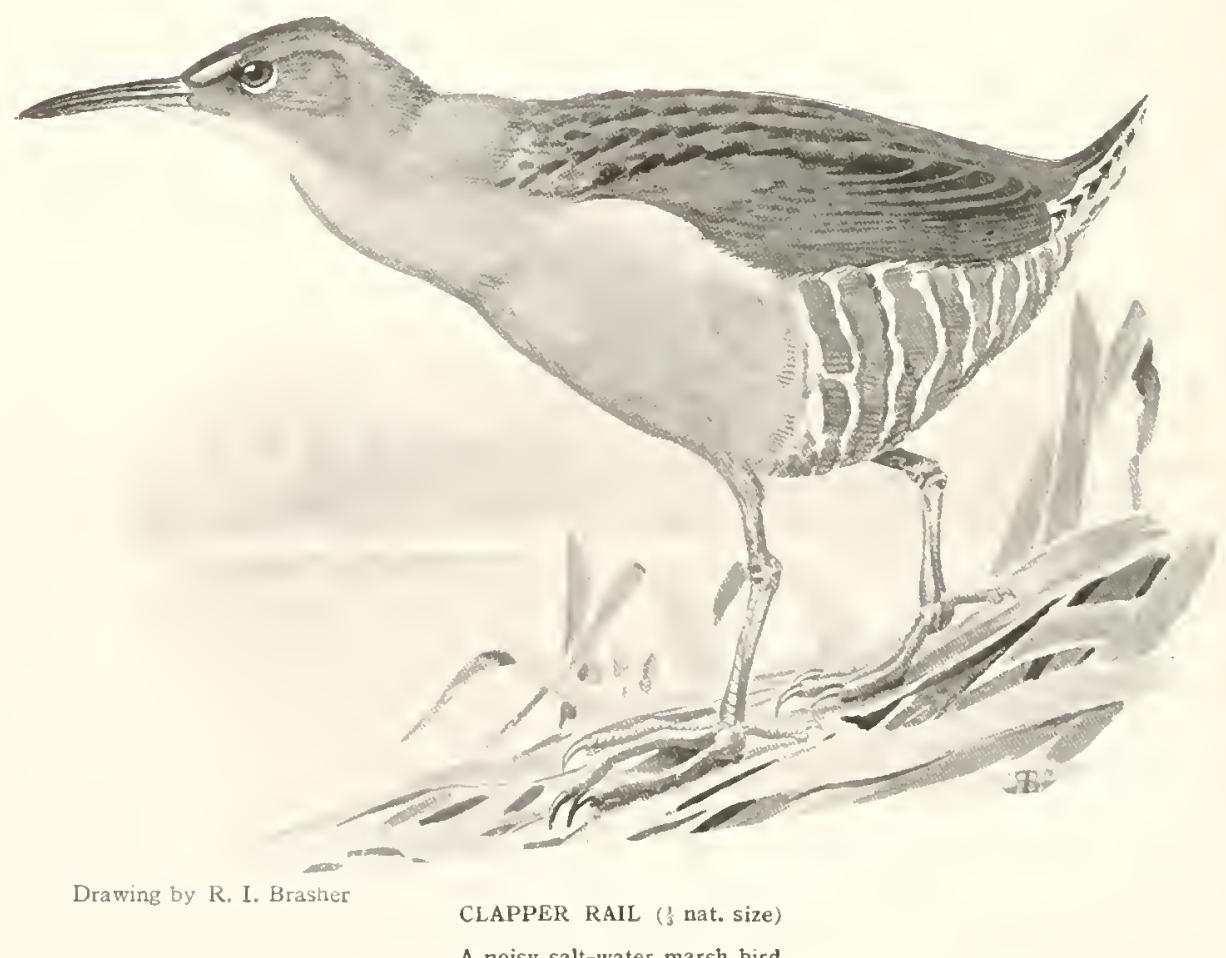

A noisy salt-water marsh bird 
show-fling game as it rises from the scant cover of the exposed tops of the grass.

buring the breeding season one may find many nests within a small area. The following description of one of their favorite nesting colonies is quoted from my notes male at the time of my visit :

"Jacks Grass' is a low islamel of perliaps twenty acres on the North Carolina coast near New inlet. It las no trees. lout is covered senerally with grass eiglit or ten inches long. Small clumps of rushes srowing rarely wer three teet high are scattered ore the island, and in nearly. every one of these a Clapper Rail's nent was found. These were composed of marsh-grass bades and stalks, and were built from six tu eisht juches above the wet sod. The iragnents of grass used varied from four to six inches in length, shorter pieces heing employed for the top layers. The nests measured about eight inches acros the top, and were of minform widtli from the bottom. On May I 3 two of the nests examined each held eight slightly inculated eggs. and one nest of ten exgs was seen. (Jne was found with two freshly deposited egrs, and another had four incubated exus. Eurs-shelly from which the young had but shortly departed were found in one instance. L'sully the nesto were not screened from view hy any arching of the rushes above them. Hlong the banks of the tide creeks that traversed the island the marsl grass was often two or more feet in lengtl. Here were many covered runways of the birds, some of which were several yards in length."

Three distinct subspecies, or climatic varieties, of this Clapper katil have heen recompized by naturalists. One is the Louisiana, or IJensluaw" Clapper Rail (Rullus crepitans saturatus), chiefly distinguished by having its feathers darker colured than the common variety: the Florida Clapper Rail (Rallus crepitans sentti), a form that is still darker: and Viane's Clapper Rail (Rallus irepitans coluri). found from North Carolina southward. Two closely allied but distinct precies occurring clewhere in North America are the Califormia Clapper Rail (Rollus

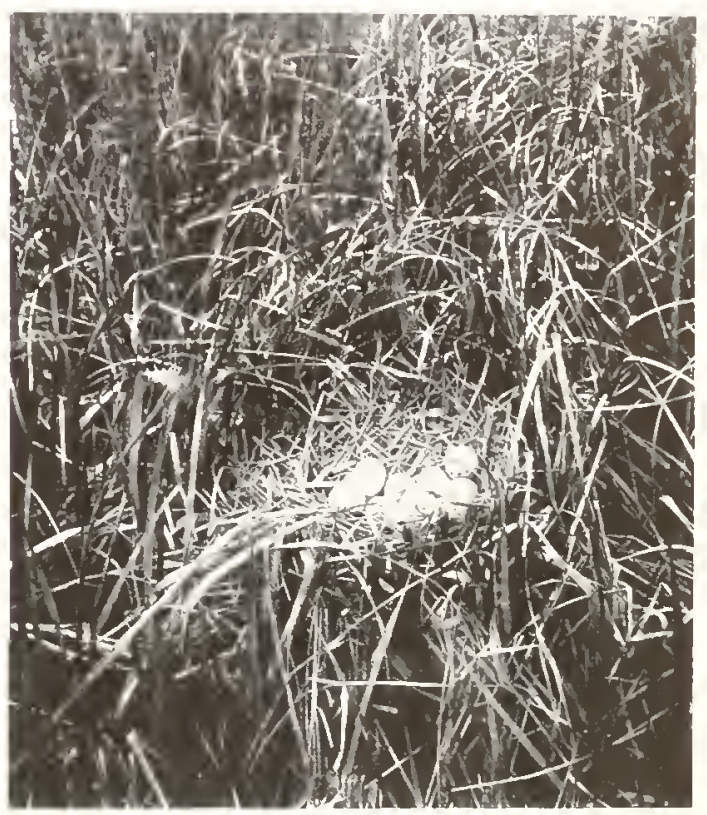

photu by 1. B. Lhilipp Courtesy of Nat. Asso. Aul. Soc. NEST AND EGGS OF CLAPPER RAIL

Stone Harbor, New Jersey

ubsoletus), of the salt marbes of the Pacific coast, and the Caribbean Clapurer Rail (Rullus longirostris curlocus), found in Texas and the Vest Indies. The general halnits of all are very similar to the more familiar eimtern bird.

T. GILAERT PEIRSON.

\section{VIRGINIA RAIL}

Rallus virginianus Limnatus

\footnotetext{
A. O. [T. Xumber 212 siee folor I'late 25
}

Other Names.-1 Little Red-hreasted Rail: Small Mud Hen; Fresh-water Marsh Hen: Long-hilled Rail.

General Description. - Length, I I inclues. Like the King Rail except for smaller size.

Color-Anti.ts: Crown, back of neck, and upper parti. pale olive-hrown, streaked on back and rump with dark brownish-black; sides of head and chechs, ashy: lores and a narrow semi-circle below eye white: chin and upper throat. White; nick and brast, rich chestunt. abdomen and under tail-coverts. dusky with narrow white traverse hars: wing-coverts, chestnut : secondaries, brownish-black edered witl olive: primaries and tail. 
[1ain brownish-black; bill, flesh color, dusky on ridge and tip: legs, dark flesh color: iris, reddish-brown. ImMATURE: Darker above than adults: under parts, blackish. Downy Young: Sooty black with yellowish hill. Nest and Eggs. - NEST: In a tuft of grass or reeds in meadows; rather compactly constructed (for a Rail) of dry reeds. EGGs: 6 to I2, cream or huffy, thinly spotted with chestnut or lavencler.

Distribution.- North America; breeds from British
Columbia, southern Saskatchewan, southern Keewatin, Ontario, southern Quebec, and New Brunswick south to southern California, Utah, Kansas, Missouri, Illinois, New Jersey, and eastern North Carolina, and in Toluca valley. Nlexico; winters from Oregon, Utah, and Colorado to Lower California and Guatemala, also in the lower Mississippi States, and from North Carolina (casually Massachusets) to Florida; occurs casually north to northern Quebec and Newfoundland.
In general habits I have not noticed any very distinctive difference hetween the Virsinia Rail and the Sora, unless it be that birds of the former species are more inclined to keep by themselves in solitude or in pairs, whereas a good many photographs. Despite all my care I found it next to impossible to see the bird on the nest before pulling the thread attached to the shutler. So I laid my line of communication further off and pulled at a venture, after waiting a reasonable

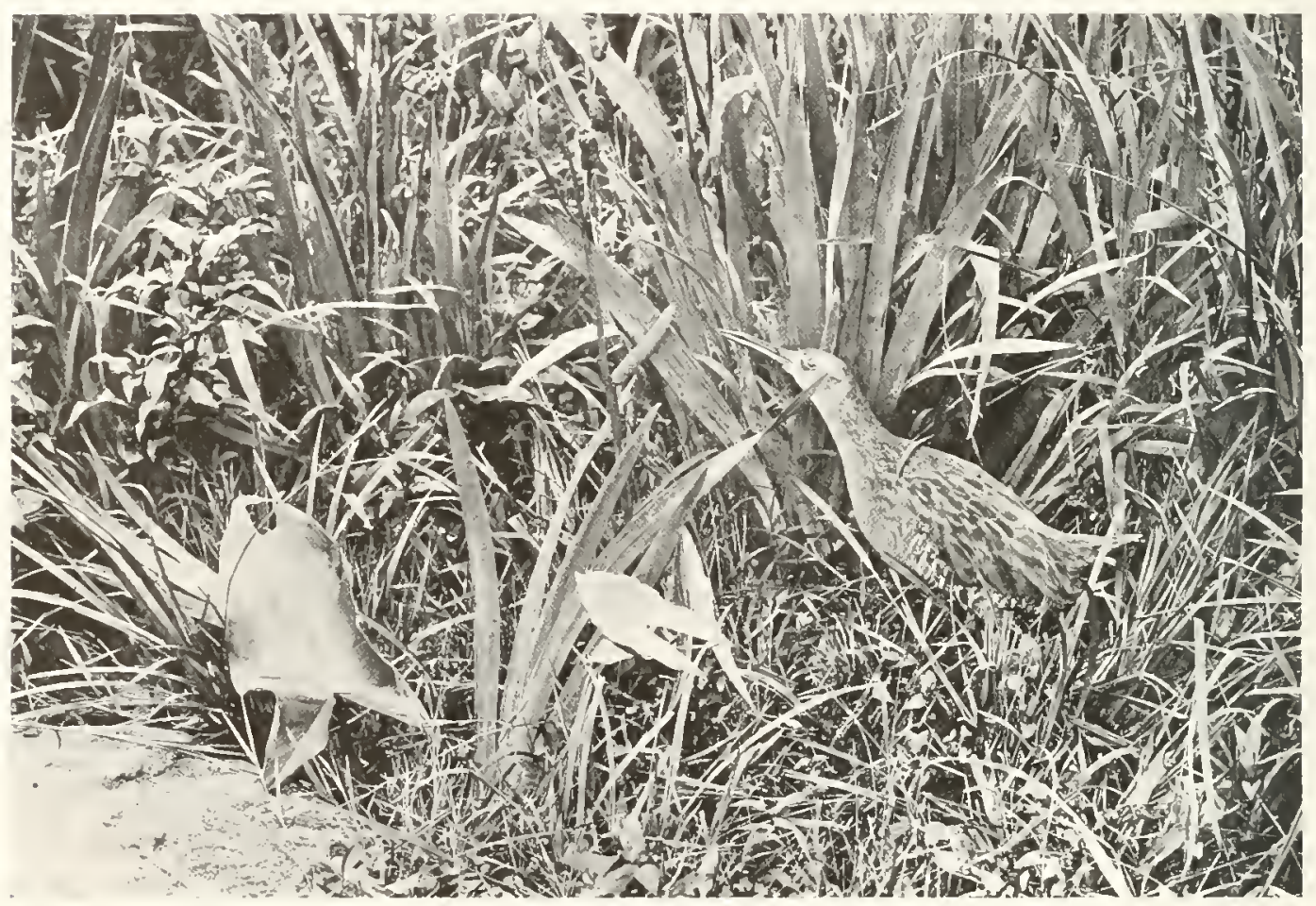

VIRGINIA RAIL

Courtesy of S. A. Lottridge

It hides away in marshes and is little known

Soras may be found, even during breeding time, in the same bogr. The nesting is entirely similar. With neither species, as a rule. can one flush the sitting bird directly from the nest, for it slips off upon hearing the approach. In a few cases. where I came up very silently, I have seen them slip off through the grass, especially when I approached with caution nests already located.

On one occasion, by concealing my camera in a bower of rushes near a nest, I secured some time. In each case except one I seculed my subject.

The young, as with other kinds, are tiny black creatures, which have a most amazing way of chisappearing in a bog. Seeing the sprite in the grass, we may do our best to make a grab, but the reward is likely to be only a handful of grass and black slime.

Though it is hard to see the nesting bird for identification, the egess of both the Virginia Rail 
and the Sora are distinct and characterintic. Thougl of the sime size, thuse of the former are lighter in ground color, being yellowish-white. whereas thone of the Sora are a more deciled buff in hue. The lirds. tow, are distinct, the tortat having a little short bill, while the subject of cur sketch has quite a long bill and a redder shade of plumbage.

This bird is one of the coterie, always to be associated together. which are found in the bogs and neadows - Virginia Rail, Sora, keel-winged Blackbird, both Marsh Wrens, littern and leenst Bittern, sometimes Swamp Sparrow, anu, in the West, the Coot and Yellow-headerl Blackhird, as well as Redlead. Rudrly Duck, Canvas-hack. and others. It is a most interenting fratemity, and the fascination of their company has made and keeps me at regular "log-trotter,"

Hergert K. Jor.

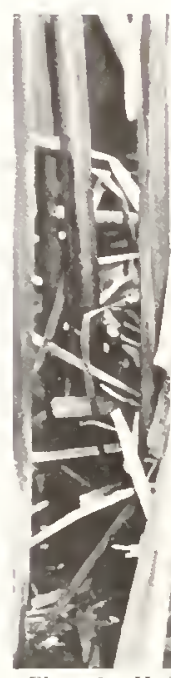

Photo by H. K.

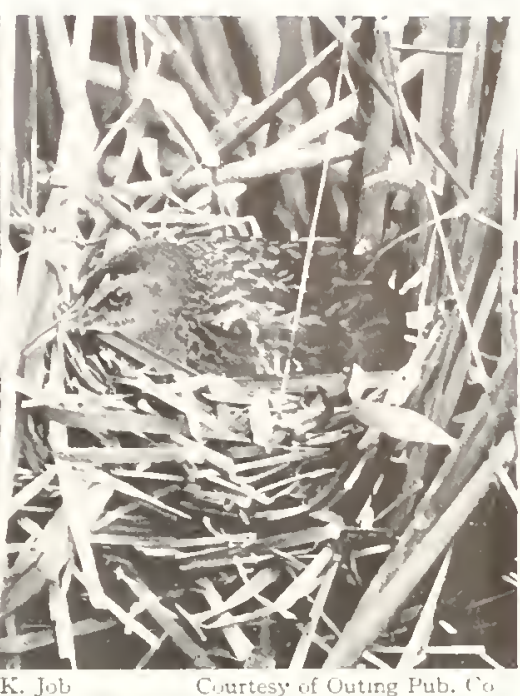

VIRGINIA RAIL ON NEST

\title{
SORA
}

Porzana carolina (Limnerus)

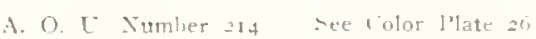

Other Names. - Carolina Rail: Common Rail : Soree; Meadow Chicken; Carolina Crake; tittle American Water Hen; Chicken-billed Rail; Chicken-bill; Railbird: Ortolan: Wud Hen.

General Description.- Length, o inches. Color above, olive-brown; below, gray. Bill short and stout; forehead entirely feathered down to base of bill.

Color.-ADulss: Forehead, lores, face, chin, and throat (narrowly'), black; crown, neck, and upper parts. including tail, olize-brown; back with dark-brewn traverse bars and streaked narrowly with white; line over eye, sides of head, and under parts, pure oray. more olive on sides of body where barred with white transversely; abdomen barred with white; tail-coverts, whitish, tingerl with rufous; bill, yellow, with extreme tip black; feet, light yellowish-green; iris, carmine.
lMaATlRE: No black on foreparts: throat and abdomen, whitish: neck and broast, aushed with cinnamon. Jow Focng: Glosy black, with a tuft of orangecolored bristly feathers on the breast.

Nest and Eggs.- NEST: (1n the ground in meadows; a carelessly constructed affair of grass ancl weeds Ecos: 7 to 13. nure rarely 16, pronounced drab, spotted with chestnut and lavencler over entire surface.

Distribution.- North America: breeds from central British Columbia, southern Mackenzie, central Keewatir, and Gulf of St. Lawrence south to southern Califurnia, Utah, Colorado, Kansas, Illinois, and New Jersey; winters from northern Calfornia, lllimois, and South Carolina through the West 1ndies and Central America to Venezuela and Peru; accidental in Bermuda, Greenland, and England.
The Soras are curious birds, which remind one of very tiny dark-colored bantam hens. They spend their lises mainly in slipping through the tangles of the fresh-water bogs, in the universal search for something to eat. Success in their mission is demonstrated by the fact that, though slenderly built, supposedly" "thin as a rail." by autumn they are quite generally loaded with tat. From their arrival in May until their final departure south in October they live in close retirement and are seldom seen. But throw a stone into one of these seemingly tenantless bogs, and it is surprising what a chorus of yells and cackling sounds may arise, as though its coverts sheltered a sizable poultry farm.
During my boyhood I had constant opportunity to study Soras and Virginia Rails in an almost bottomless "eat-tail" bog, in the suburbs of Boston. Mass., on the edge of the town of Brookline, now groomed ipp into a fine city park and lake. It was my delight to flomuler through it with boy companions, and find many sorts of nests. I shall never forget how one day a boy tried a short cut to a nest, contrary to my advice. got in all over, and finally, in tears, floundered ashore, swimming through black ooze of the consistency of New Orleans molasses. His return home through the city was a constant ovation, as may be imagined.

Here I found many a Sora's nest, including one

$$
\text { Vol. I - I5 }
$$


whicls contained sixteen eggs, the largest number that I ever found in a Rail's domicile, eight to ten being usual, and thirteen not infrerquent. The

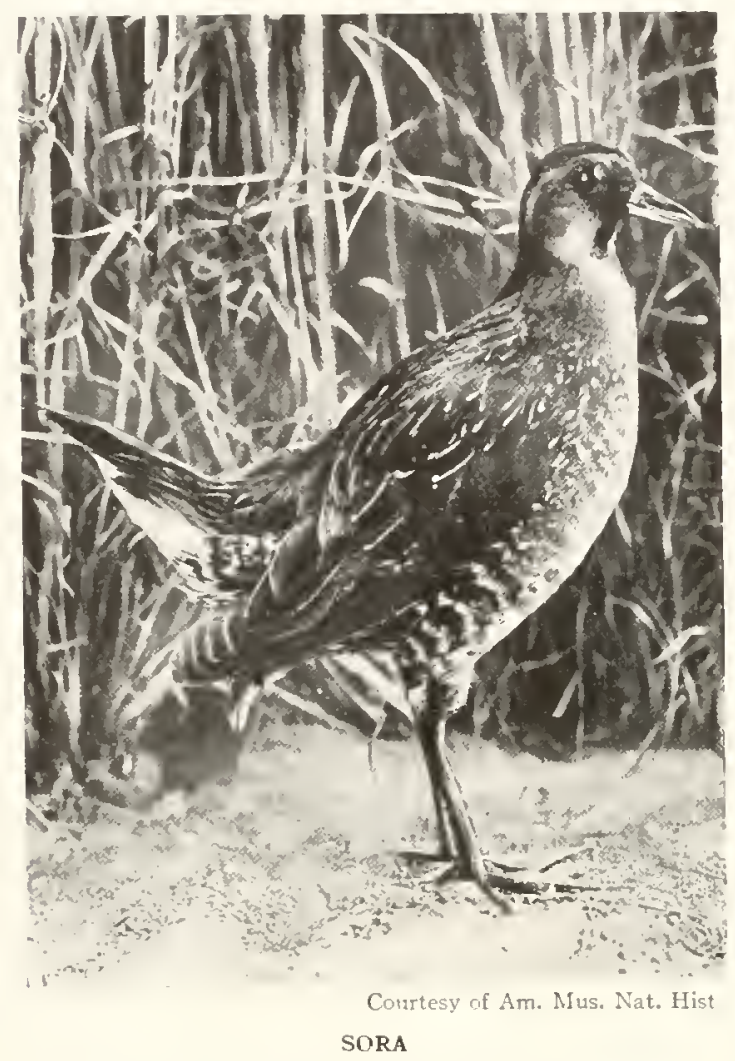

Their peculiar flight makes them easy targets for gunners

nests are little platforms of dry grass or rush leaves, quite well hollowed. Sometimes they are in a cluster of reeds or rushes, a little above the level of the water, or under a thick tussock of meadow grass. But, after much searching. I found that the more typical location, both for the Sora and the Virginia Rail, was just out of the bog, in open meadow, where, on comparatively. firm ground, rather short meadow-grass grew from just a little water. There the Rails constructed a little pile or island of grass, raised slightly above the water. The stems of the rather sparse grass held it together, and the ends were twinted and tied by the birds to form over it a sort of rounded canopy. In walking over the meadow I learned to find nests by noting this arching of the grass, eren at some distance. Rails are nocturnal, and toward dusk one may watch them at the edges of the bog trotting out to feed. Their migrations are quite mysterious. Some frosty monning the neadows suddenly are found to he alive with them. Then the gunners get their innings. In some localities, such as the meadows along the Connecticut River, near its mouth, Rail shooting becomes a regular industry. At high tide boatmen pole flat skiffs through the grass. The Rails flutter up with their characteristic flight, making easy marks.

In Louisiana I found this species common in winter on the marshes hack from the Gulf coast. on the reservations. Toward evening I could watch them from the windows of our camp, a well as during cloudy days. They came out from the reeds and fed on the rice which we scattered. sometimes venturing even under the house.

Hertert K. Job.

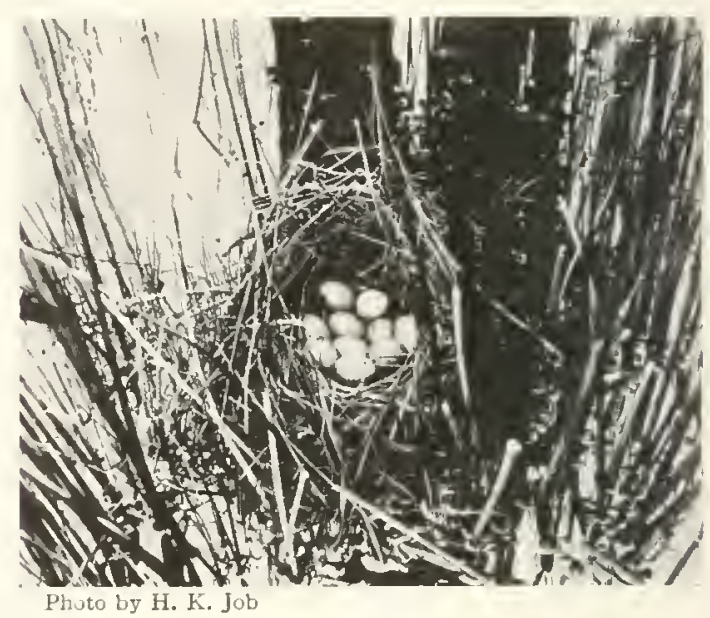

NEST AND EGGS OF SORA

\section{YELLOW RAIL}

Coturnicops noveboracensis (Gmclin)

\section{A. O. U. Number 215 See Color I'late 26}

Other Names. - Little Yellow Rail: Yellow Crake.

General Description.- Length, 7 inches. Prevailing color, brownish-yellow, paler below and streaked above with dark. Forchead entirely feathered to base of bill; bill short and stout
Color.-Anults: Crown (narrowly), neck, and upper parts, broadly and regularly streaked with yclloz'ish brown and burnt umber, this fusing on crown and shading on sides of neck and sides of breast into reddish-brown spots; the dark streaks of back and wings, 


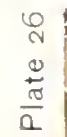

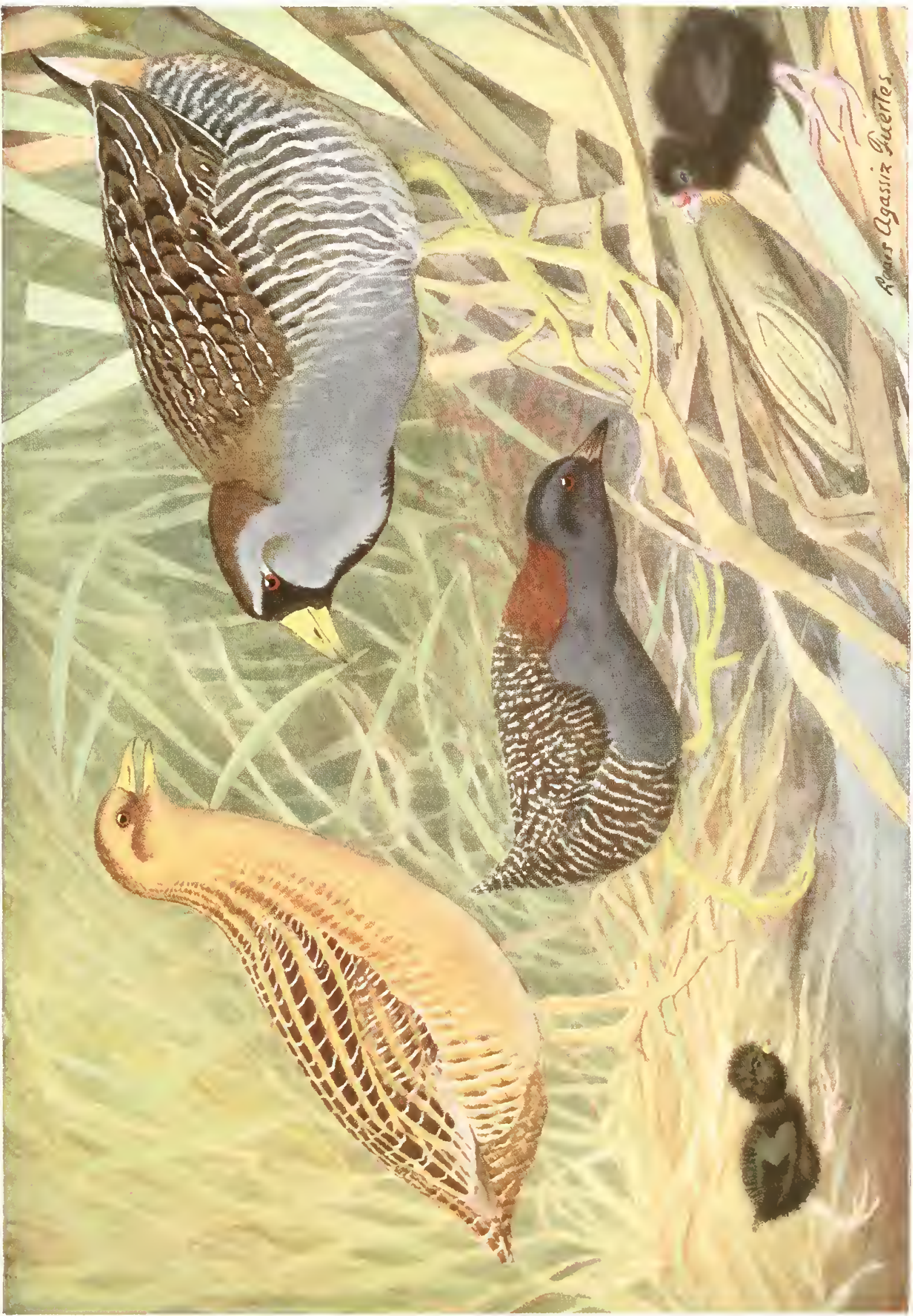



crossed by narrow white semi-circles, the winns, show' ing considerahle white in flight; sides of head and neck. chin, throat, breast, and ablomen, vellowish-brown; under tail-cuserta, flain brownish; siden of body, with some traverse spots of brown and white: lores and a streak below eye extenling on sicle of face, brown: bill, yellow: feet pale yellowish flesh color: iris, brownish-reel. Down Yoling: Black.
Nest and Eggs. - NeST: On the armund 11 meachows:

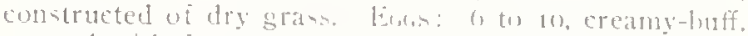
unotted with fine rusty-hrown

Distribution.-Chietly eatern North America; breeds from southern Mackemzie, contral keewatin, and south('ru Lingasa wouth to Munesota and Mane: winters in the Gulf States, rarely in Califorma. Illimois, and Nurth Carolina; canual in Nevala. Utah, and liermula.
The lellow Rail is seen wather rarely in Mastachusetts. I have met witl it alise only once. It probably is more common in migration than is helieved generally, as it is very small and its habits are secretive. It is even more reluctant than the other Rails to take wing ; hence it is seen rarely, but is sometimes caught hy dogs and cats. When forced to take wing it flies in the same hesitating, fluttering manner as the other" Rails, but rather swifter and sometimes to a comsider- able distance. It can swim and dive well in case uf neces-ity.

IVayne states that in South Carolina he found it nearly impossible to flush these frirls with a rog when their only cover was short deat grass. Ilis dog causht nine and flushed hut one. Freshwater smails were found in their somachs.

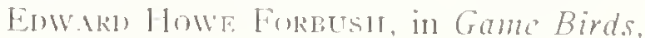
IT'ild-Fon'l and Shore lirds.

\title{
BLACK RAIL
}

Creciscus jamaicensis (Gmelin)

\author{
A. ค. 1T. Number afo sce tolur llate 20
}

Other Names.- Little Flack Rail: Filack Crake.

General Description.- Length, 6 inches. Upper parts, black barred with white: head, throat, and chent, slate color. Forehead entirely feathered down to base of bill; bill short and stuut.
Color.- Inelts: Forehead and crown, dusky; hindneck and fore-back, dark chestnut; rest of uppr\% parts. dow browish-black, finely harres with white; head. neck, and breast, dark slate; abrhmen and under tailcovert, deep blackish-hrown, traversed with narrow

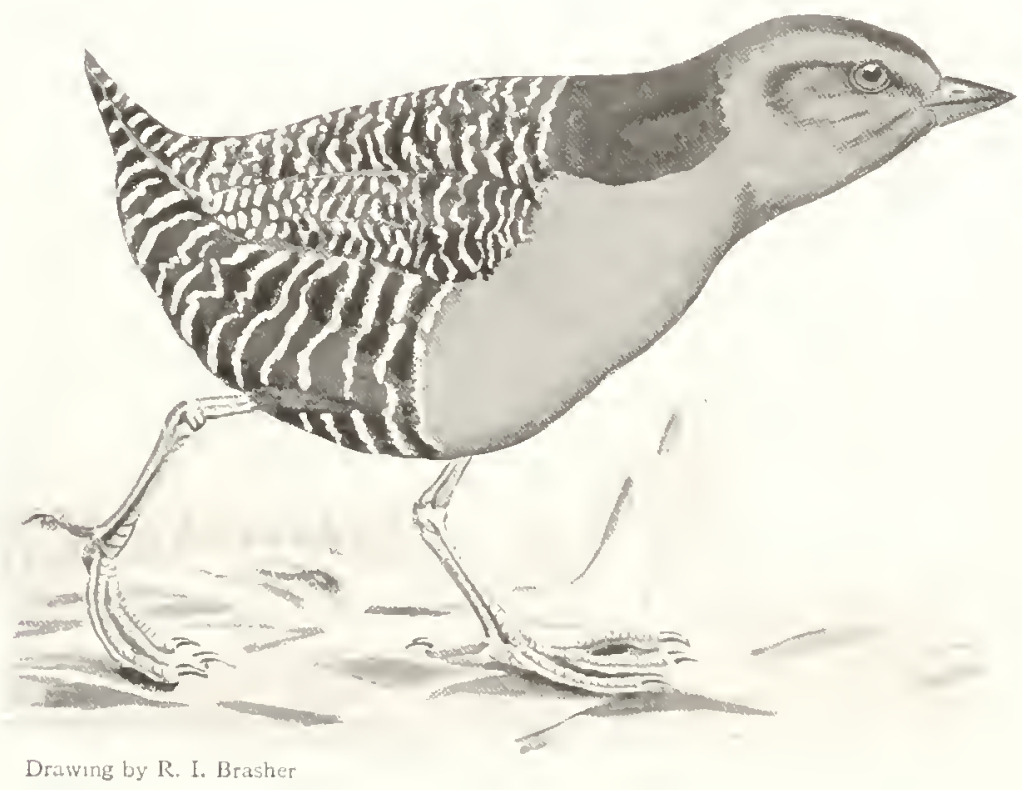

BLACK RAIL (1 nat. size)

The smallest of the American Rails 
white bars; lores and a line through and hack of eye. dusky" wing-quills and tail. dusky with some white spots. Doll Ny Young: Black

Nest and Eggs.- Nest: A very well-made and deeply cupped structure of fine grasses and weed stems: well concealed in a depression of the gromind. EGGS: 6 to 9 , white, sparsely spotted with small chestnut dots.

Distribution.-Eastern North America; breeds from southern Ontario and Massachusetts south to Kansas, Illinois, and South Carolina: winters from Texas east through the Gulf States and south to Jamaica and Guatemala; casual in Bermuda

The Black Rail, the smallest Rail in America, is believed to be a very rare hird in New England, where it has been recorded only from Maine, Connecticut, and Massachusetts, in which States it possibly breeds. So far as our present information goes, Massachusetts appears to be near the northern limit of $i$ ts breeding range on the Atlantic coast, but it may go farther north.

Records are received with caution, as the black, downy young of larger Rails are mistaken for Black Rails. Wayne appears to be the first observer who has actually seen the female Black Rail on her nest in the United States, and recorded it. The nest was in an oat field, and the standing grain, where the nest was, had been cut. The bird is so secretive that, as related by Wayne, two men and a dog searched four hours for the male in the oat field before it could be secured, althongh it was calling incessantly. This bird may not be as rare as it is rated.
The Black Rail runs swiftly, like a mouse. through the herbage, and seldom flies, although in migration it has reached the Bermuda Islands. Gosse quotes a Mr. Robinson who says that in Jamaica it is so foolish as to hide its head and cock up its tail, thinking itself safe, when it is easily taken alive.

Enwakd Howe Forbusi, in Game Birds, Wild-Fon' and Shore Birds.

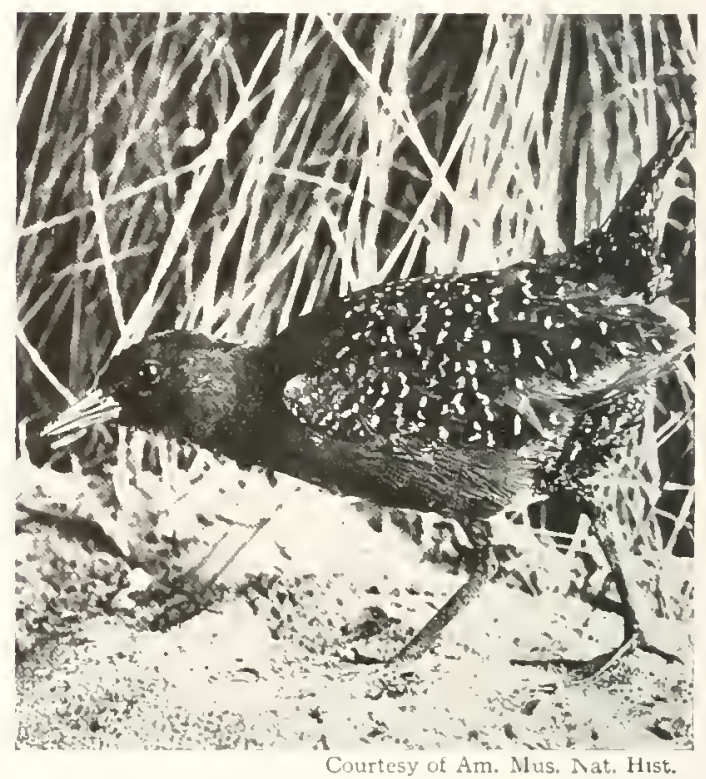

BLACK RAIL

\title{
PURPLE GALLINULE
}

\author{
Ionornis martinicus (Linncus)
}

A. O. U. Number 218 see Color l'late 27

Other Name.-Sultana (Jamaica).

General Description.- Length, I4 inches. Head, neck, and nunder parts, purplish; upper parts, olivegreen. Head with frontal shieid extending from base of bill and covering forehead: toes slender and without lohes: bill shorter than head.

Color--Aburrs: Head, neck, and under parts, doep purplish-blue: abdomen black; under tail-coicerts white; back and upper parts in general, olive-green: wing-coverts, blue-edged: wing- and tail-feathers dusky with outer webs huish-green; frontal shield, pale cobalt; basal half of bill, carmine, front half yellow; a narrow white streak on side of face at base of bill; legs, chrome-yellow: iris, red. ImMATURE: Upper parts, washed with brownish: under parts, mottled with white. Dow: Young: Glossy-black with numerous white hair-like feathers on head.

Nest and Eggs.- Nest: Placed in reeds over water: constructed of dead rushes. Egas: 6 to 10, creamy, thinly spotted and dotted with brown and lavender.

Distribution.- Tropical and subtropical America; breeds from Texas, Tennessee, and South Carolina south through Mexico and the West Indies to Ecuador and Paraguay; winters from Texas, Lonisiana, and Florida southward; irregulary north in summer to Arizona, Nebraska, Wisconsin, Ontario, Quebec, Nova Scotia, and New Brunswick; accidental in England and Bermuda. 
The l'urple (iallinule has lecen richly cndowed with beatiful feathers. With the single exceptim of the male Woun Duck it must be regarded as pusesesing the most striking culor of any of our southern water-lirds. () the rice plantations along the Ashler River alowe Charlestom, south Carolina. I found this speciec very alundant and often saw them run across the roarl ahead of our bugegy. There was much water alrout and they seemed to pass frepuently from one pont or ditch to amother, their stout. fairy long legs sending them forward at a gooul speed when haste was desired.

With much vivilness do I recall one spring morning when, while I was fishing from a loat in Lery Lake, Florida, these hirda were much in evidence. It wan during the mating season and they were the personification of activity. There was here an abundant growth of water lilies, and the birds seemed to take the greatest pleasure in walking over the lily pals. their yellow legs twinkling in the sunlight. As they walked, their tails jerked in a mont pert and amusing manner. When springing from pad to lad their wings would be held high above the head. One of them clucking and displaying lis superb plumage to every possible advantage appronched some bushes which grew near shore and climbing the limbs jroceeled with many flutters and loud bursts of suttural notes to climb upitard until it

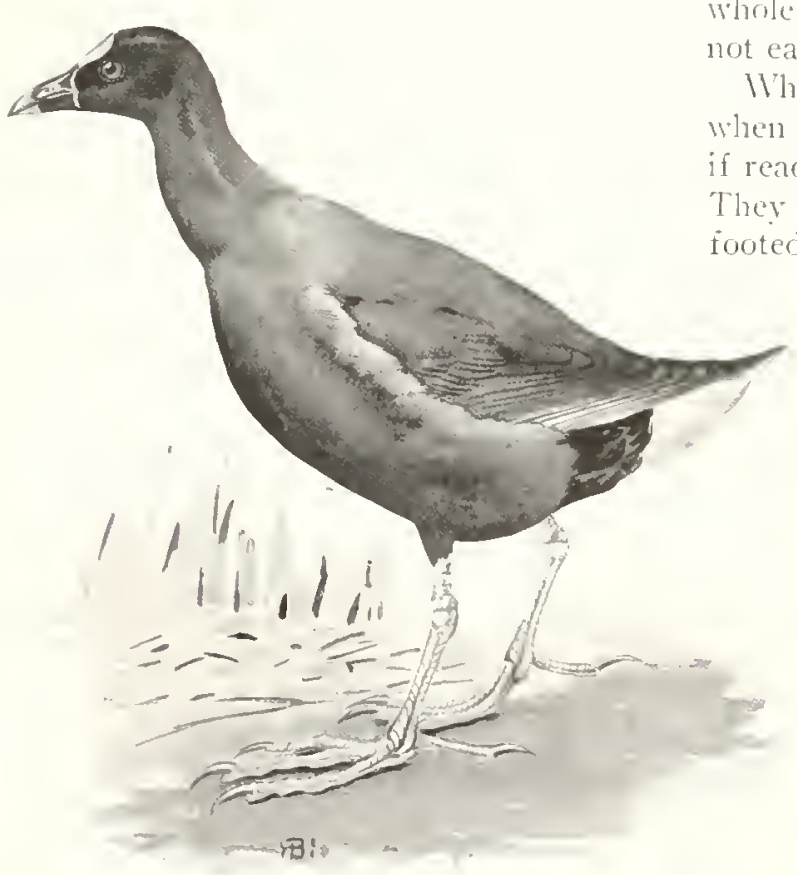

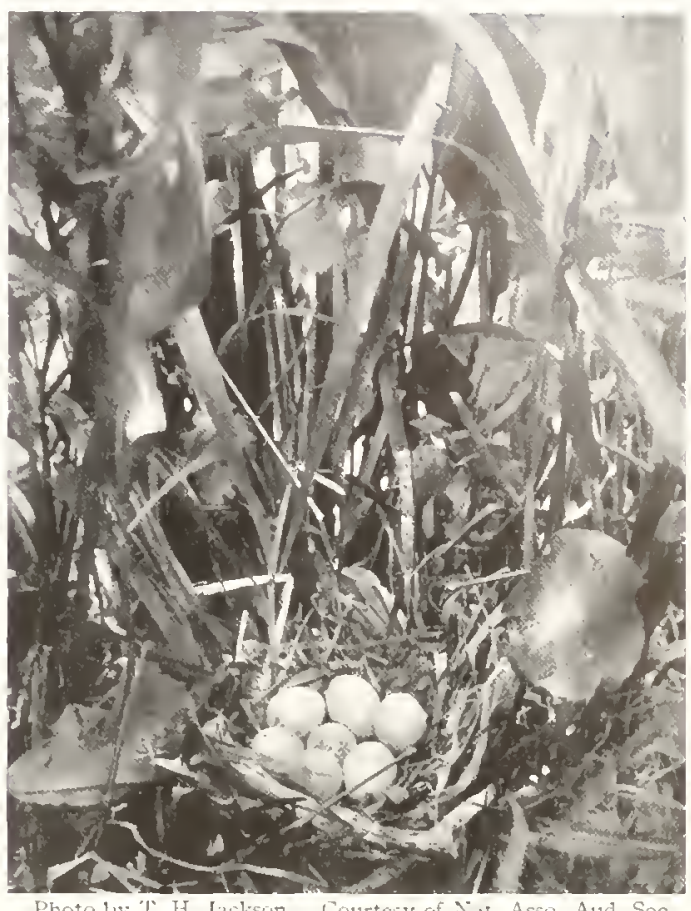

Photo by T. H. Jackson Courtesy of Nut. Asso. Aud. Soc.

NEST AND EGGS OF PURPLE GALLINULE

Orange Lake, Florida

reached the hranches of a dense magnolia tree. Here from a height of twenty feet its purple flumage shone with a mont resplendent leauty under the full glare of the morning sum. The whole performance combined to make a picture not easily forgotten.

When making short flights, and especially When chasing each other, the legs hang down as f ready for immediate use in case of emergency. They swim well although they are not weifooted. The long slender toes must be very 
serviceable in aiding then to run over the insecure pathway paved only with the floating leares of the water lilies or to climb among the timgles of grass and water-plants.

The Purple Gallinule arpears in its summer home in April or May and after a perfectly uroper period of courtship nest building is begun. This interesting receptacle for the eggs is usually huilt in reeds or rushes a few feet above the water. Not long ago I examined six nests in a pond in lower Louisiana. Without exception these were constructed of grass-stems and rushes, each being built in a separate bunch of thick rushes. The surrounding stalks were pulled down in such a manner as to livle each nest completely from view. They were located above the water at heights varying from two to five feet. In the Mississippi valley the Puple Gallinule does not breed much north of Missouri. In the Eist and South (except Florida) it is confined largely to the tide-water sections.

\section{T. Gilbert l'Earson.}

\section{FLORIDA GALLINULE}

\section{Gallinula galeata (Lichtenstein)}

\section{A. O. U. Number =19 See Color l'late 27}

Other Names.-American Gallinule; Common Gallinule: Red-billed Nud Hen: Water Ilen: Water Chicken.

General Description.- Length, It inches. Prevailing color, blackish. Forehead covered by naked shield a base of bill; toes slender and without lobes; bill slender. sharp, and nearly as tong as head.

Color.- Anults: Hearl, neck all around, breast, and under parts, dark slate, duskier on head and neck, and whitening behind; upper parts, brownish-slate; wings and tail, dusky; sides of under tail-coverts, edge of wing, outer web of first primary, and stripes on flanks, white: bill, frontal plate, and a rinu around upper part of ley, red; tip of bill, yellow; a narrow white stripe on face at base of bill; legs, greenish-rellow; iris, red. Fotse: Similar to adults. but duller, with whitish under parts, and brownish bill and forehead

Nest and Eggs.- Nest: In the marshes; constructed of dry reeds; often placed on a buoyant platform of the same material, capable of rising and falling with the water; in some places it is built on dry parts of the meadow. EGGS: 6 to I2, buffy-white, rather sparsely spotted with brown.

Distribution.-Tropical and temperate America; breeds from central California, Arizona, Nebraska, Minnesota, Ontario, New Fork, and Vermont south through the West Indies and Mexico to Chile and Argentina, and in the Galapagos and Bermuda; winters from southern California. Arizona, Texas, and Georgia southward: casual in Colorado. Quebec, Nova Scotia, New Brunswick, and Maine.

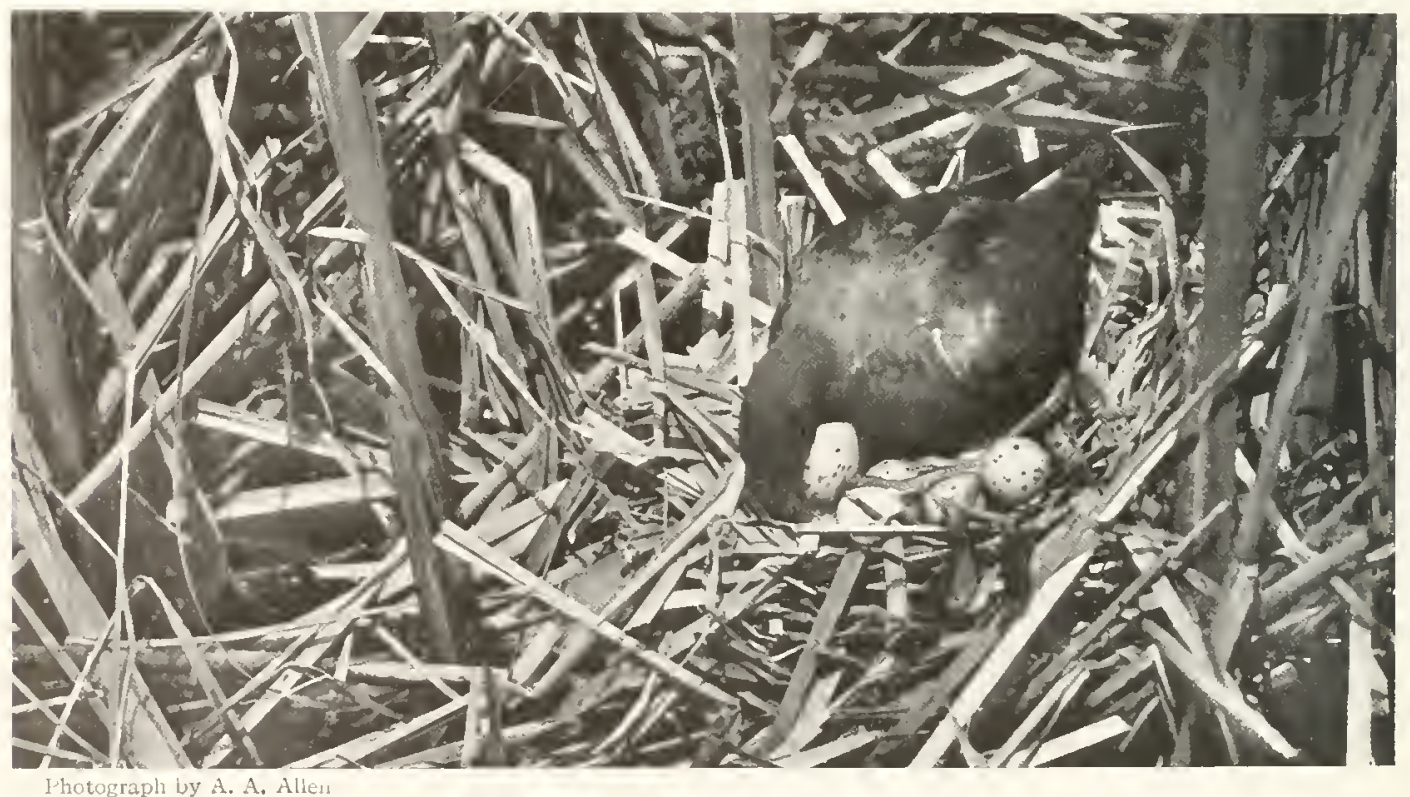

A FLORIDA GALLINULE TURNING ITS EGGS 


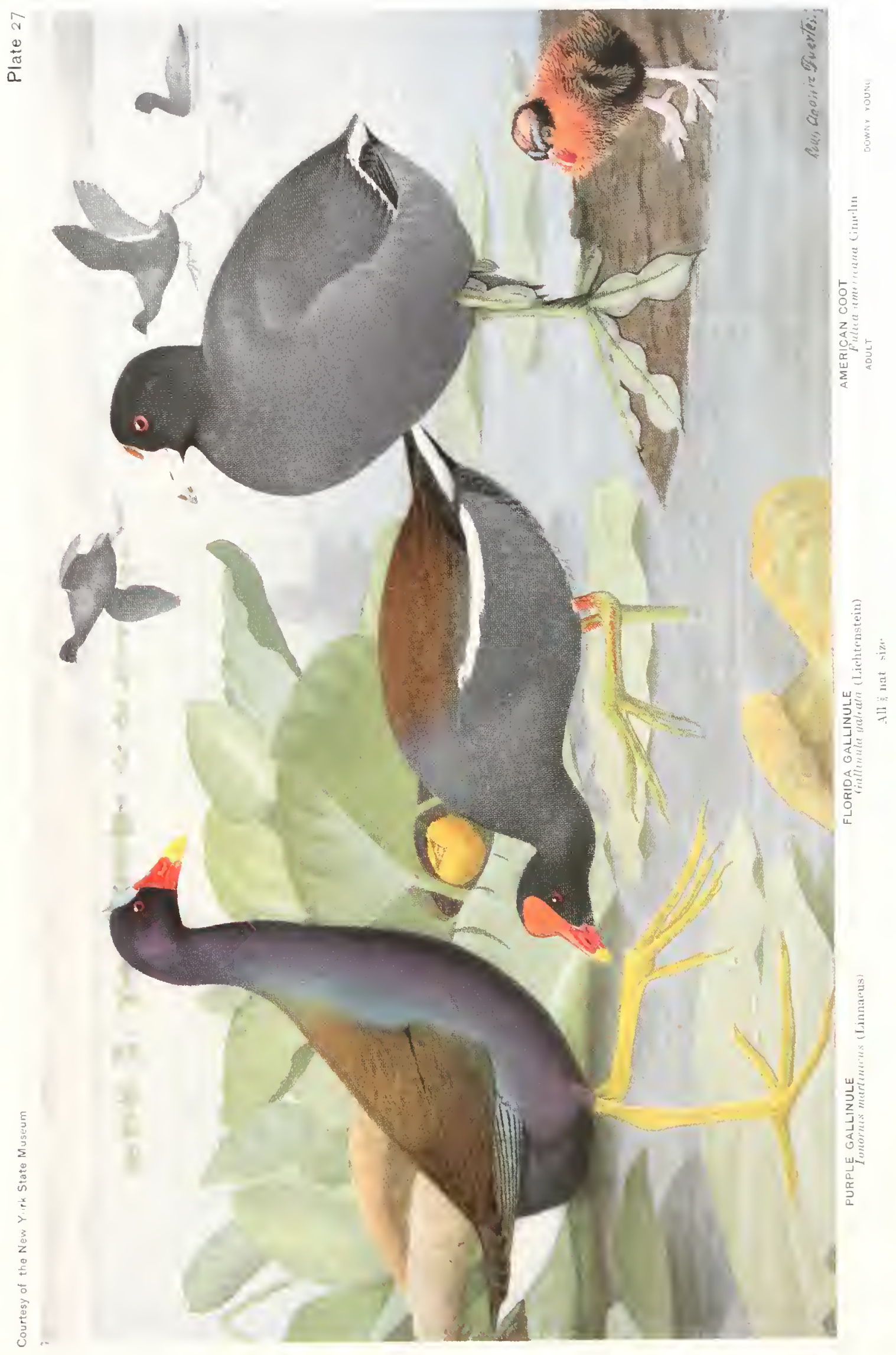



Sor hen-like in many of its movements is the Florida liallinule that one can realily understand why its near relative in Furope should le namerl the Moor Hen. In habits it nuch resembles hoth the King Rail and the Coots. and its lome is in the same character of country occupied by both of these slecies. It is a hird of the ponds and matshes of our southern country, although it occasionally breed as far north as Minnesota and Maine. Like the kabils it often has mote or less favorite pathways through the thick marsh grass, and like the cont is sontetimes seon swimming about in shallow weel-grown waters. When thus recupied the heat bobs back and forth with eatch stroke of the feet. They cannot of respondeney, and the questionner explosive ihuch of inymiry. They ate bery nuing hircl and their notes are among the nust fandiar and constantly hearl calli of the ru-h-srown lakeside. When the incubation of the egos begins, the volume of soumls decreases perceptively. Rarely have I heatul one call at nisht, for this bised is not so nocturnal as the Rails and many of the 1 lerons.

like most hircls, the Gallinule is very cleanly and lathing is one of its frequent diversions. In flight it is most misainly and when Husherl its passage througl the air is attenderl with every indication of extreme weariness.

The Gallinule's nest is worth a wale in the

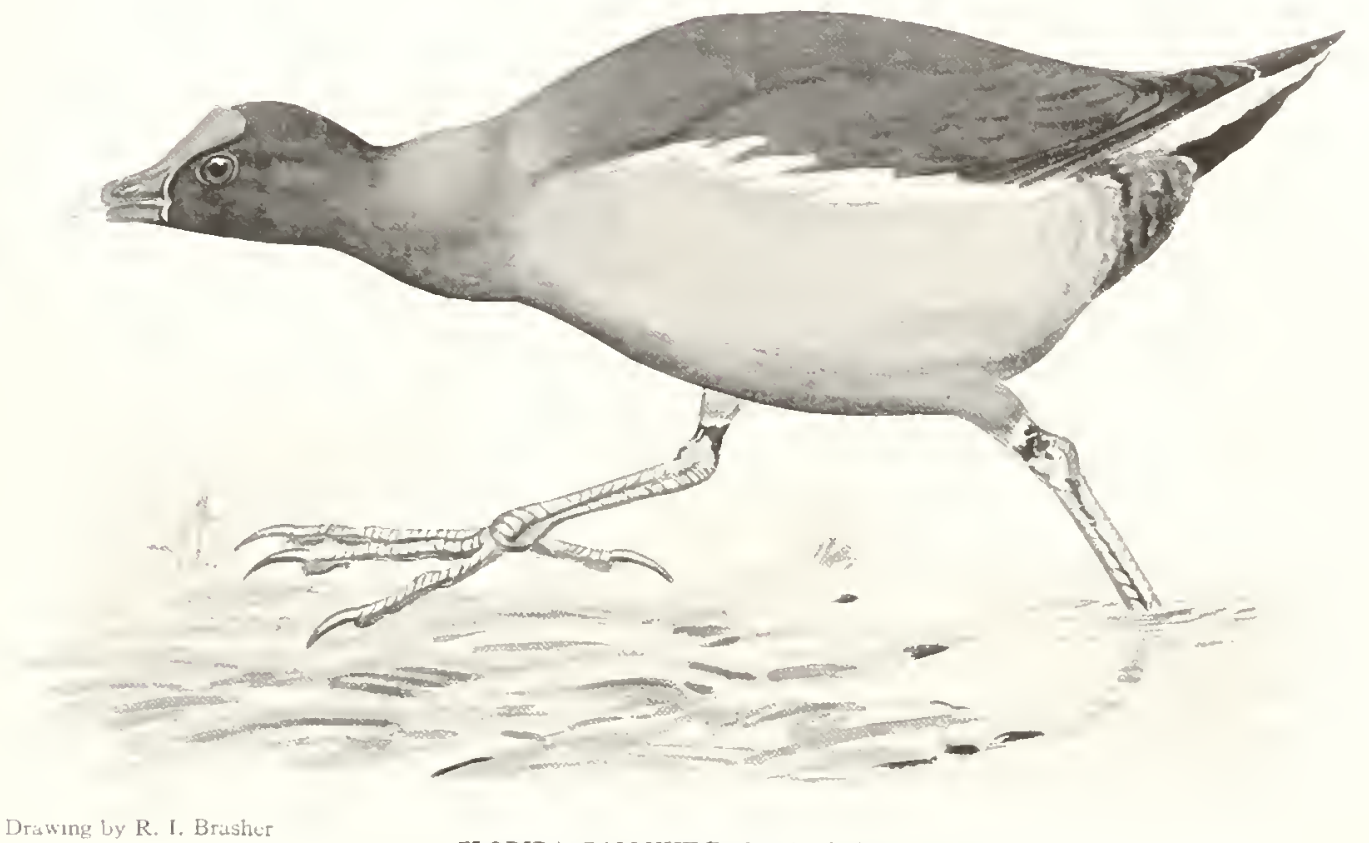

Drawing Ly R. I, Brisher

FLORIDA GALLINULE ('? nat, size)

The source of many of the henlike noises heard in fresh-water marshes

righty he said to assemlole in Hocks, although as many as a dozen are at times seen feeding near together. Often they come on shore for food or assemble in small companies to sun and lest at some favorite rendezwus. It a distance they somewhat resemble the Cont, but a nearer view will reveal the difference. The hringt scarlet liil and hearl-shel is a field mark for identification quite distinct from the white lill of the Cont

Floricla Gallinules poseses a wonderful repertrile in the matter of calls. They are all very harsh, but they sugresent the entire range of passions. For example, there is the appealing tichet. ticket of the lovelorn male. the protulant tuka, tuka pond to discover. It is male of flass or rushes, and is placed from just ahove the water to a leight of a fort or two. It is wedged in among a clump of rushes $01^{*}$ in a rush-hidden bush. Frefuently it is a foot and a lialf in diameter and several inches thick. The central carvity is slightly sumken and is just large enomgh to hold the six to twelve spotted ergs that are laid. Inculation besins as sonn as eso-laying commences, With the result that some young appear from a week to twelve days hefore the others. Imong their enemies may he mentioned the cotinn-mouth moccasin that swallows their egrs and the frogs and alligators that snap up the young when swimming.
T. Culliert Pearson. 


\section{COOT}

\section{Fulica americana (imelin}

A. O. U. Number 221

Other Names.-American Coot; Mud Hen; Nater Hen: Marh Iten: Moor-head; Meadow Hen: Water Chicken: Pond Hen: Mud Coot: Ivory-billed Coot; White-bellied Mud Iten; White-bill; Hen-bill; Crowbill: Sea Crow; Pond Crow: Crow Duck; Flusterer; Blue Peter; Splatter: Shuffler; Pelick; Pull-doo.

General Description.-Length, 16 inches. Prevailing color, slate, dark above and light below; forehead, covered by naked shieid at hase of bill ; bill stout, nearly as long as head: toes lobed along idyes.

Color.- Adults: Entire plumage, dark slate-gray, blackening on head and neck, tinged with olive on back; under tail-coverts, edge ot wing, tips of sicondarics, and ends of some primaries, white; bill, white with small spots of reddish near end and at base of frontal shiek; frontal shield, brown: fiet, palc olicerrecuish: iris, red. Downy Young: Blackish above, whitish he-
See Color l'late 27

low, with numerous orange-colored hair-like feathers on throat and upper parts. IMMATURE: Similar to adults, but lighter below, and bill flesh color.

Nest and Eggs. - Nest: Construeted of dead reeds, grasses, and hits of decayed vegetation: afloat on the water or in the reeds nearby. EgGs: 7 to 16 . creamy, finely and regularly spotted over entire surface with specks of dark brown and black.

Distribution.- North America; breeds from central British Columbia, southern Mackenzie, Manitoba, Quebec, and New Brunswick south to northern Lower California, Texas, Temessee, and New Jersey, and also in southern Mexico, southern West Indies, and Guatemala; winters from southern British Columbia, Vevada, Utah, the Ohio valley and Virginia south to Colombia; casual at Fort Yukon, Alaska, and in Greenland, Labrador, and Permuda.
Many people think that the Coot is a Duck because it is usually seen swimming. Is a matter of lact, however, it belongs to the Rail tribe. Its feet are not wehbed straight across, but each toe has a sort of scallop of lobes, which answer just ahout as well in paddling. Another popular mistake is to apply the name coot to those marine
Ducks which are properly called Scoters, not "Sea Coots,"

The real Coot. while having some limitations, is notably versatile with its feet. Not that it is exactly a feathered I'arlowa, but with marked ability it can rum, walk, swim, and "skitter." In the "Mud Ien skitter," which might well be

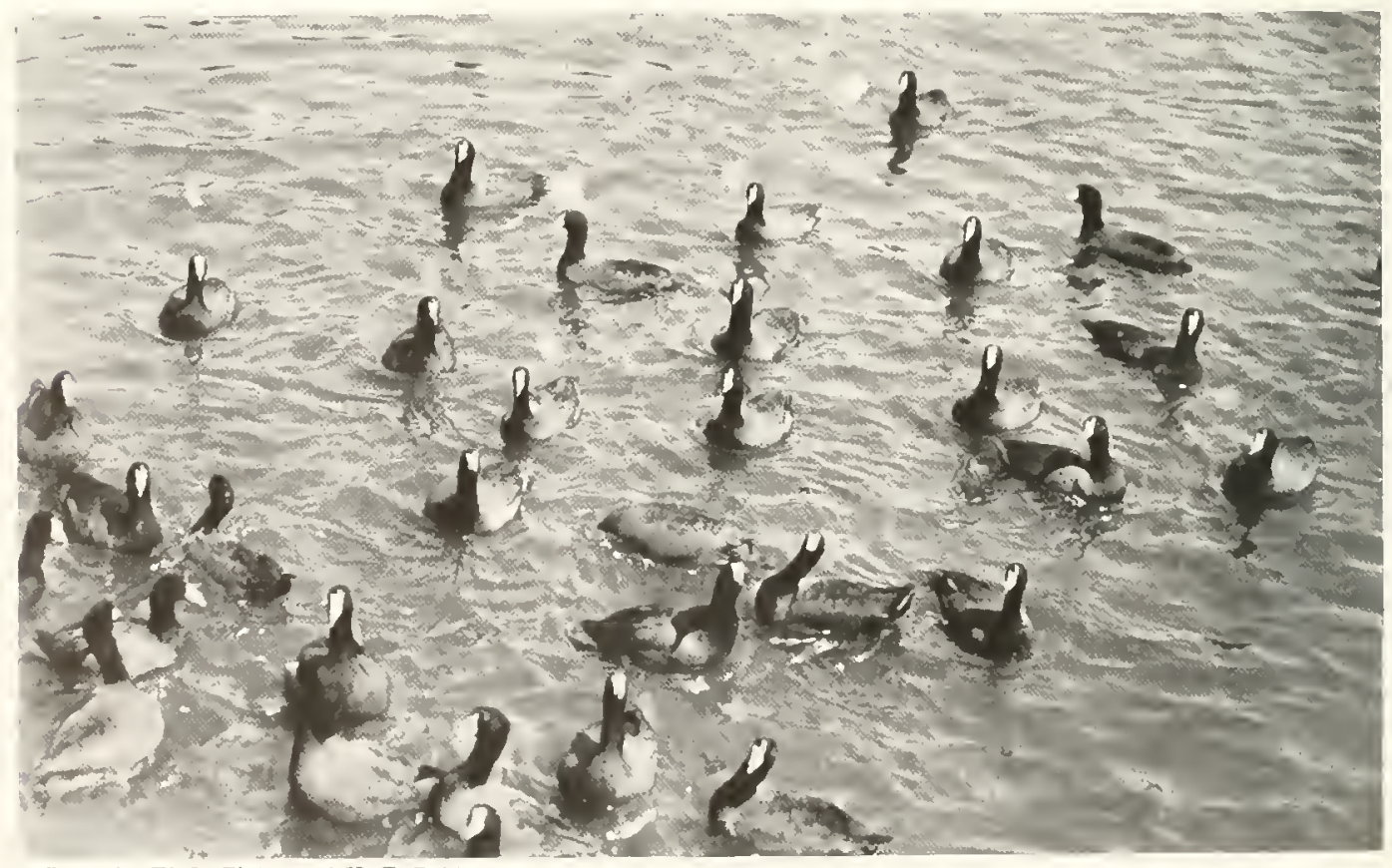

Photo by W. L. Finley and H. T. Bohiman

coots

Their odd ways make one laugh 
made a new dance for suciets, it can beat even the celebrated dancer, for it is juaticel on a veculiar floor, the suriace of the water - as the flock flutter away, pattering with their feet as they go.

The favorite hants of the Conts are the shallow ponds or hogs, where reels or rushes grow from the water. In such places ther make their nests, which are plation of dead stems woren together in a sort oi wicker-haskt fashion, piled wy from the bothm of the water, and partly supported by the stems of the apuatic plants, being rather deeply hollowerl. The egas number from seven or eight to fourteen ur sixteen, and are distinguishable by the small
It there is a more amu-ine lircl anywhere, I should like to sec it!

Though the Coot is rather tame, it is lificult to see it on the nest, but it is easy to watcls it swim away, bobbing its head after the approverl bathion of the skittering fraternity. Number. lreed, scattered alout, in the same slougl. (In migration they are seen montly in small partice, or often singly. They lueed from the nurthern States north, and in winter are abundant in swampy parts of the southern States where they gather in lavge flocks.

In I,ourisina / foumd them in great numbers in winter on the fresh-water marshes. When I "baited a blind," to plotograph wild Ducks, it

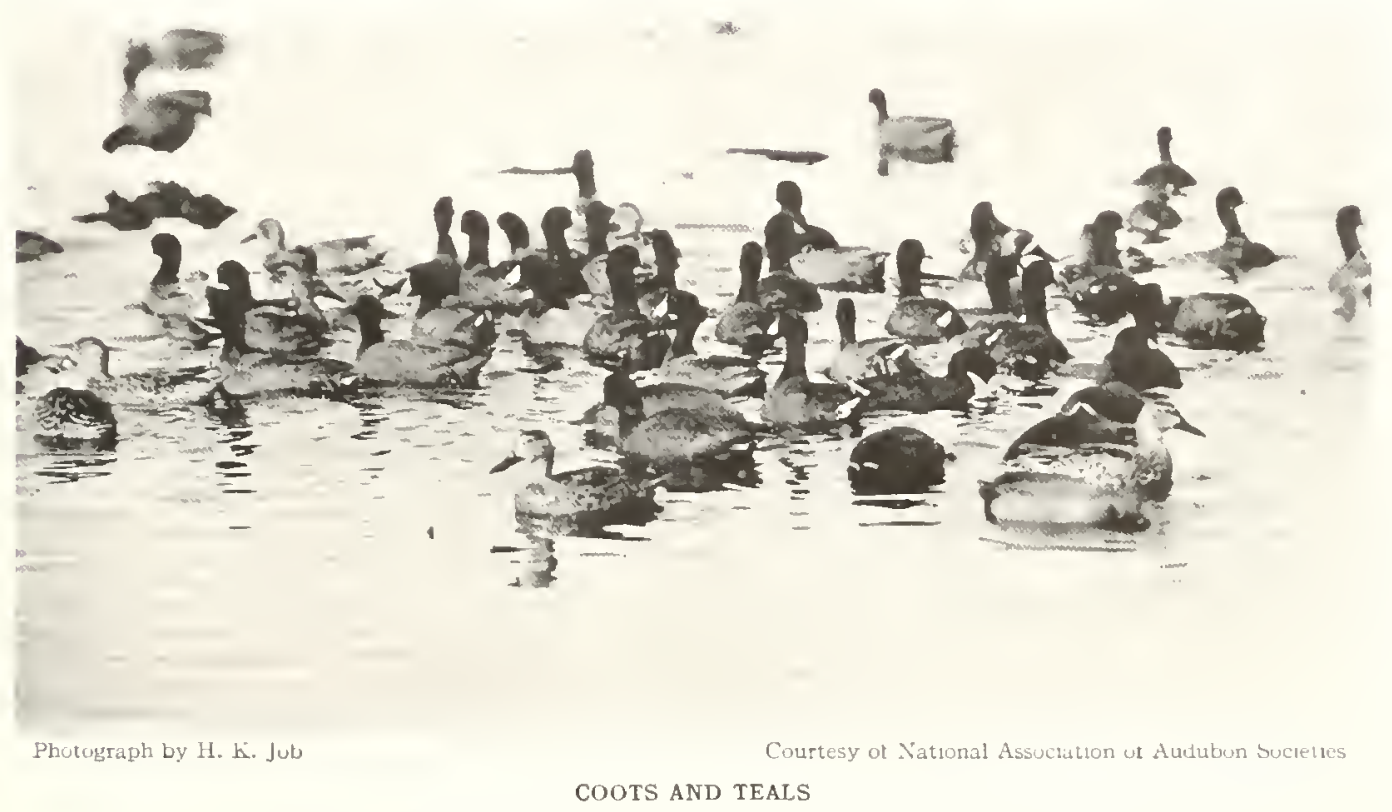

The Ducks used the Coots as buffers for danger

"pepper-spot" markings evenly sprinkled over them. (Jne exg is laid each day and incubation begins with the first egg. Conseguently they hatch one by one, each youngster frompty leaving the nest to swim off, probably to be tencled by the other parent.

The young are singular creatures, covered with a sort of hlack down with orange-colored hairs projecting from the necli and hearl, the latter being hald on top, and the bill and adjacent parts bright red. I have hatched some in inculators and reared them to maturity. At first small and feehle, they hecome active and bold, rushing at me and shrieking for ford with raucous screams. was ahways the Coots which ventured up first to try the fuod. The Ducks used them as buffers for langer, and swam up aiter the Coots proved to them that it was sate. They otten came up on the steps of the camp to set fond, and were known to walk into the house, perhaps thinking they heard the dinner-hell.

Ther are easily kejt in captivity, hut in the beeding season are said at times to make at rather too free use of their sharp bills. However, their odd wass make one latigh, and I recommend the funny Coot as an antidote for "the blues."

HERHERT R. JOR. 


\title{
ORDER OF SHORE BIRDS
}

\author{
Order Limicole
}

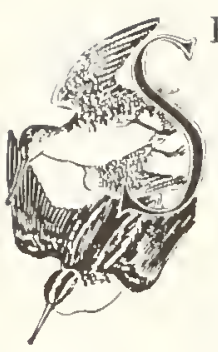

HORE birds include seven closely related families - so closely related that no suborder has been established within this order. The varions species frequent open areas, usually along watercourses, ocean beaches, or marshes. They average small in size, the largest North Ameriean species being the Long-billed Curlew, and the smallest being the Least and Semipalmated Sandpipers, or Peeps, so abundant in the spring, summer, and fall everywhere in the maritime districts. In color they are generally brown or blackish above, mottled and streaked with buff or whitish. The wings are long and pointed, the primaries graduating rapidly from outer to inner, the secondaries reversing this order - this giving a $V$-shape to the open wing. Many speeies are eapable of sustained flight, and perform almost incredible journeys during migration. The tail is short. The legs are long and thin with long, slender, usually unwebbed, toes.

The food of the Shore Birds is the mollusks, crustaceans, and insects, found in the mud or along the moist strand of their habitat. They nest on the ground, usually laying four eggs, which are so well spotted or blotehed with dark colors that they are quite inconspicuous among the grass or pebbles. When hatched the young are eovered with down of a gray or brown color marked with blachish. At the approach of an "enemy" these downy chicks lie flat on the ground in an endeavor to escape detection.

Shore Birds have mellow, piping or whistling, voices, whieh can be heard for some distance. They are greatly prized as game birds and have been hunted to such an extent that it is not uncommon to hear them spoken of as "our vanishing shore birds."

\section{PHALAROPES}

\section{Order Limicola; family Phalaropodide}

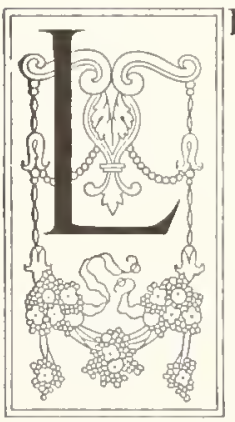

I'T’TLE swimning Sandpipers " the Phalaropes were aptly called by Dr. Cones. They are essentially birds of the northern hemisphere, and all of the three species oceur in North Ameriea, though only one, Wilson's Phalarope, is actually a permanent resident of this continent. A peculiar and interesting characteristic of the family is that the usual differences between the sexes of nost species are reversed in the case of the Phalaropes; which is to say, the females are not only the larger and have the more striking plumage, but they are the aggressors in the courtship performanees and the males do the nest-building and incubate the eggs.

All of the Phalaropes are comparatively small birds - from seven to nine inches long - and have noticeably thick, duck-like plumage to protect their bodies from the freezing waters in which they are often found, and a bill in which the lateral groove is prolonged nearly to the hardened and pointed tip, while the bill itself is as long as or longer than the head. The toes are equipped with marginal webs. The legs are normally long and slender. The wings are long, flat, and pointed, with the outer primaries longest and the inner secondaries elongated, giving the wing in flight a $V$-shaped appearanee. The tail is short, stiff, broad, and rounded.

Dr. Couses's popular name for the Phalaropes is in reeognition of their pelagic, or at least aquatic, habits, which often take them many miles out to sea, even in the dead of winter. The nests are mere depressions in the ground and sometimes are thinly lined with grass. Three or four eggs are laid but only about two young are suecessfully hatehed and raised. 
$\frac{8}{2}$

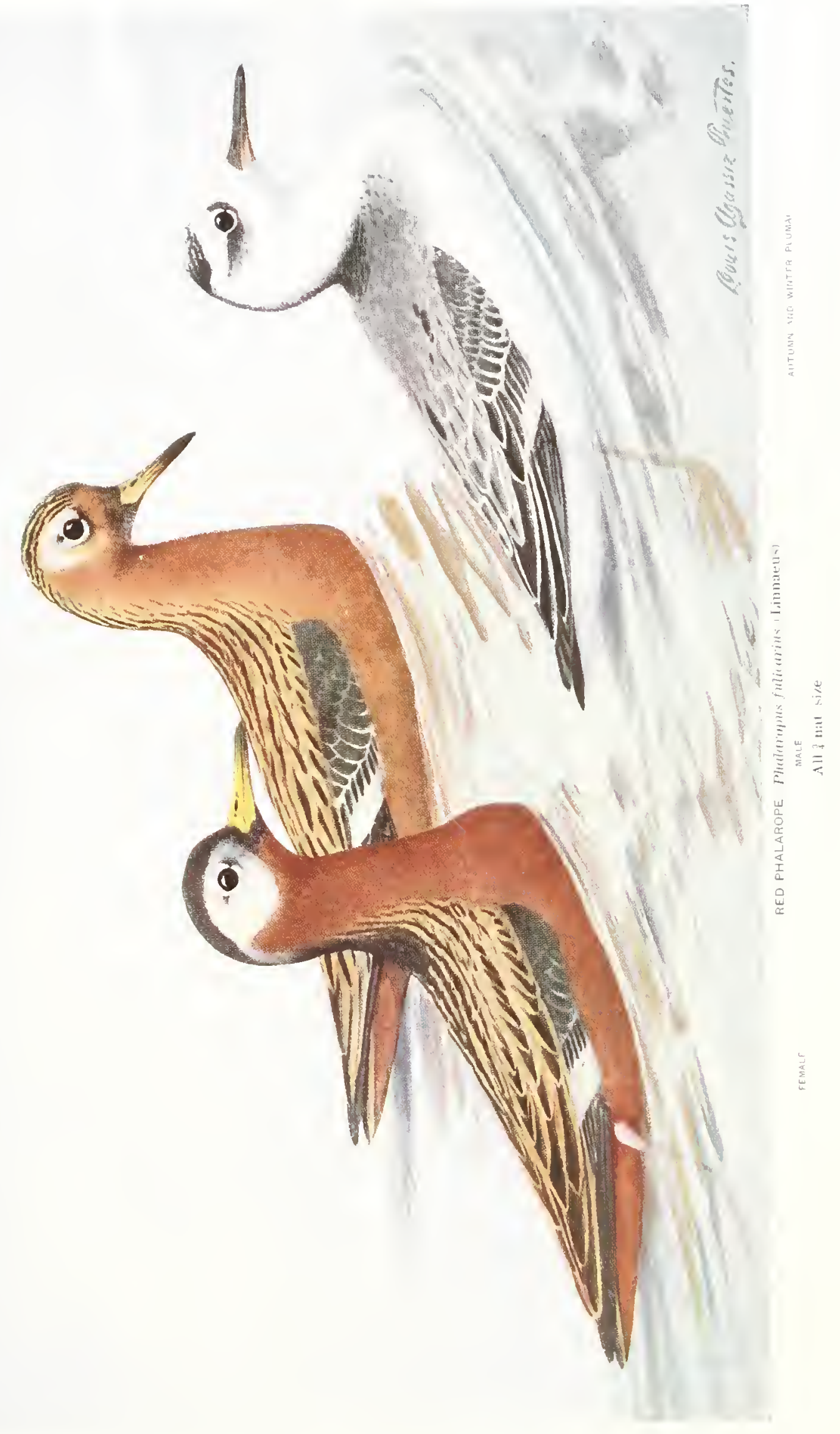



The baby thalaropes are covered with down at birth and within a short time after leaving the shell are able to run about.

The Northern and Wilson Ihalaroles are known to be of great ceonomic value, lecentse they destroy immense numbers of nore or less harmful insects. The investigations of II. 1 . Mcaltee, a Government biologist, showed that 53 jeer cent. of the food of twenty-eight Northern Phalaropes consisted of mosuuito larvie, the insects eaten including the famous muscuito of the marshland of New Jersey. Wilson's Phalarope is known to feed upon bill-bugs, which often do considerable damage to corn. Undoubtedly far more has been done by the Phalaropes and other shore lirds toward the extermination of mosquitoes in New Jersey. than has been accomplished by the Sitate's expenditure of large sums of money. Mr. Medtee's investigations showed that the Phalaroyes also feed freely upon the crane lies " leatherjackets"), grasshopers, the clover-rout cureulio, the wreworms and their adult forms, the click beetles, the diving beetles which are a nuisance in fish hatcheries, and various species of marine worms which prey upon oysters.

\section{RED PHALAROPE}

\section{Phalaropus fulicarius (Limnetes)}

\section{O. L. Number $22 z$ sece color I'late 28}

Other Names.-Whale-bird ; Reri Coot-footed Tringa ; Gray Phalarope; Flat-hilled Phalarope; Sea Snipe; liank-bird; lirown Bank-bird; Guli-bird; Sea Goose.

General Description.- Length. \& inches. 1n summer. upler pats motted and striped with black anel pale brown. under parts entirely red; in winter, gray above and white lelow; but always distinguishable from other Phalaropes ly the short, stout, tapering bill (dagger-shaped). The front toes have lobed or scalloped webs.

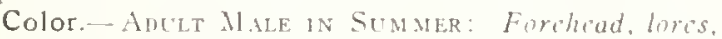
chin, loary shide of head, throat. and ontive under parts. dull cinnamon-brozen; crown, nape, back of neck, and upper [rarts, yellowish-brown; crown streaked witl brownish-black: rest of feathers above. with broall dark centers: wing-coverts dusky, the greater coverts showing white for most of their exposed portions; primaries brownish-black; a white ring around eye and a whitish area alove and hehind eve; hasal half of bill, yellow, encl duiky; feet, yellowish; iris, brown. Anult FFM.ALE IN SUMmer: Forelicad, crowu, chin. mape (narrowly), hack of neck, wings, and middle tail-feathers, sooty-brown: lores, cheeks, wiles of head, over eye and larger part of greater wing-coverts, white; thout, neck (broudly), brewst, and cutire under parts, rich aine-red: back, shulfers, and long inner coverts ochery-white, each feather with a broad center streak of browninh-

It is unfortmate that the ked l'halarope beeerls far in the north, for the chance of studying it habits wothd he musually interesting. Ifter depositing the exgs the female bes her interest in lome-ties and the smaller. more protectivelycolored male meekly perfurms the houselold duties of incubation and assumes all the care of starting the youngsters towarl maturity, while lis mate looks on or gads about the country reking new feeding grounds. black; primaries and wing-coverts, dusky, the latter edget with dull white; bill, vellowish, tipued with black; fect, yellowish-brown; irts, deep brown. Anults in Winter: Forehead, most of crown. sides of head. throat, breast, and rest uf under parts, pure athite; back of head, a spot in front of, another below, and one behind eye. a narrow streak down back of neek, upper hack and prmaries, plain dusky-gray; lesser and midtle wing-coverts, grayish-ash edged with white, center coverts showing white space as in summer; rest uf uplet parts. numly uniform pale yraysh-ash, some of the feathers with darker centers; bill, mostly duaky: feet, dull yelluw; iris, brown.

Nest and Eggs.- Nest: A hollow in grouml : umetimes thinly lined with mons and dry grass. Eusis: 3 to 4. dull greenish or yellowinh-gray, spotted with various shades of brown.

Distribution.- Northern and southern heminheres: in North America breeds from morthern Alaskit. Melville Istand, and northern Ellesmere Land south to mouth of the Yukon, northern Mackenzie, central keewatin, Hudion Strait, and southern Greenland: winter home unknown but probably on the oceans, at least as far south as Falkland and Juan lernandez islancls: migrates along both coasts of United States; casnal in migration in interior south to Coloralo, Kansas, Mllimis. and Maryland.

"When migrating this is a lirnl of the open laters, wsully the sea, where it feerls and rests in flocks, swimming as gracefully and sa fely as a duck, and found along the shore only when driven in hy storms." (Barrous.)

Their food is worms, soft, small marine animalcula, insects, and crustacea, which live in their marshy habitat. In the North it feeds on the animat-life which forms the fond of the right whale - hence its name of IThale-bird. 


\title{
NORTHERN PHALAROPE
}

\section{Lobipes lobatus (Limaus)}

\author{
1. O. [1. Number 223 sce color liate 29
}

Other Names.-- Sea Goose: Mackerel Goose: ITebfooted Peep; Bank-bird; White Bank-bird: Sea Snipe; Whale-bird; Hyperborean Phalarope; Red-necked Phalarope.

General Description.- Length, $\gamma$ inches. Color above, ashy-gray; bill very slender, cylindrical, and sharp (needle-like); front toes with lobed or scalloped webs.

Color- Anuit Mine in SUMMer: Forehead, throat, breast, and lower parts, pure white; crown, sides of head, back of neck, upper back, ashy-gray; forehead and front part of crown, mottled with ashy; lores, dusky; a broad ara of rufous crtendin! from nape doanaiard across upper breast, interupted on uppor broast suith dusky striaks; sides of breast much mottled with ashy-gray and white: flanks and sides marked with arrowhead-shaped dusky spots; shoulders, rufoushrown, each feather with hlackish center and white tipped; wing-coverts and prinaries. dusky, the greater coverts with rear portion white; a white semi-circle ahove and another below eve; bill, hlack; jris, brown; feet, dusky gray. Adult Female in Summer: Head from chin, back of neck, shouklers, and back, plain grayish-ash; throat and lower side of head, white, hordered behind and below with a large patch of rich tawny, this color including upper breast; under parts. white, broken on side of breast, sides, and flanks, with ashy-gray; a broad l'-shaped stripe of yellowish-broan on back; tze narroa oncs of same color on shoulders: wing-coverts and primaries, duskv, the greater coverts broally white on ends, forming a conspicnous bar, a white semi-circle above and another below eve: bill, black: legs and feet, bluish-gray ; soles of feet, greenishvellow; iris, deep brown. Anults in Minter: Forehead, broad line oaer ere running alone side of head and meting white of chin. brast, and loacer parts, pure white: a broad streak behind eve, crown, hack of neck. and upher parts, plain light ash, varied with white ertges of feathers, these lighter edges forming a $V^{T}$-shaped mark on back and more extensive on shoulders, heconing narrower on longer wing-coverts hehind; sides of breast, mottler with ash; sides and flanks, with a faint tinge of gray, thinly spotted with darker; wing as in summer; a wash of pale rufous on sides of neck; a

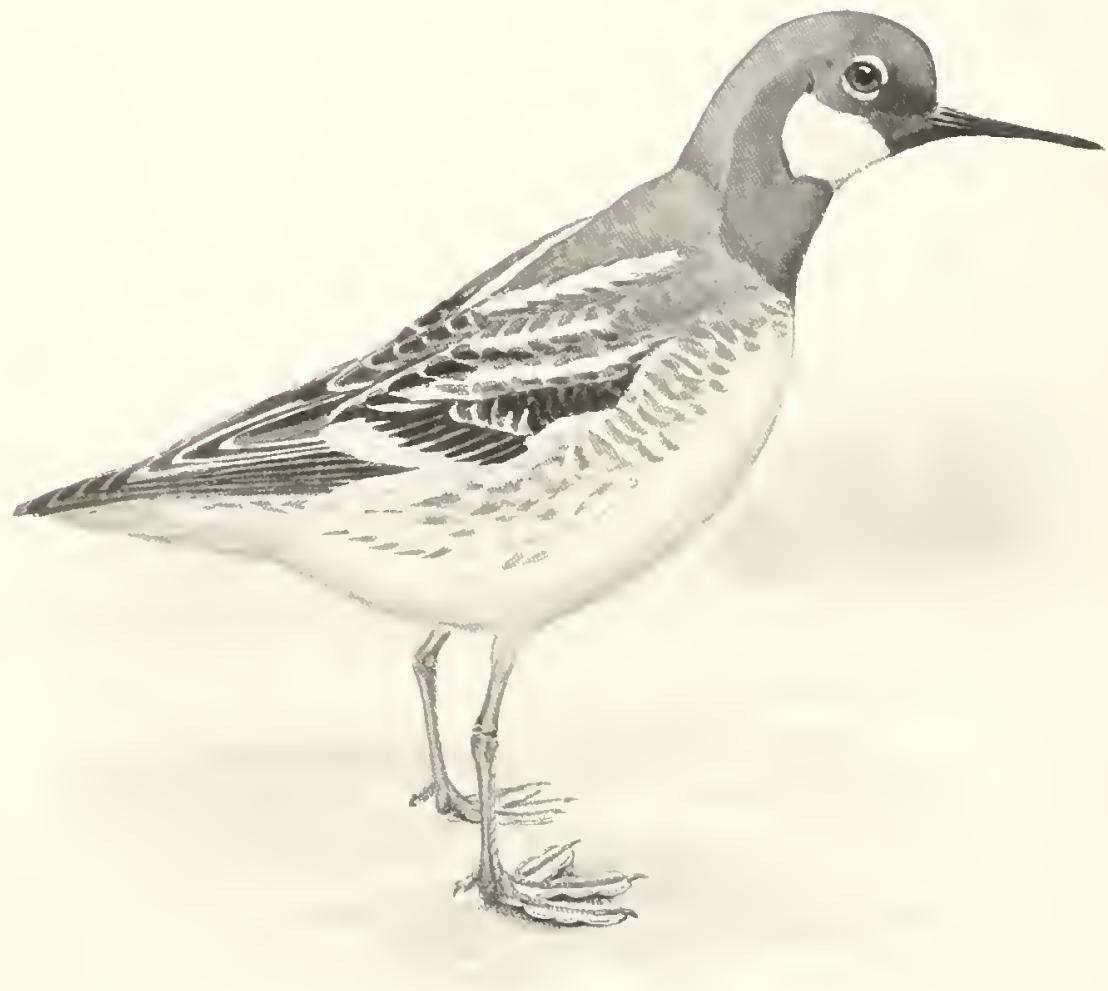

Drawng hy R. I. Brasher

NORTHERN PHALAROPE (female: $\frac{2}{3}$ nat. size)

She leaves all the family duties to the less handsome, more modest male 


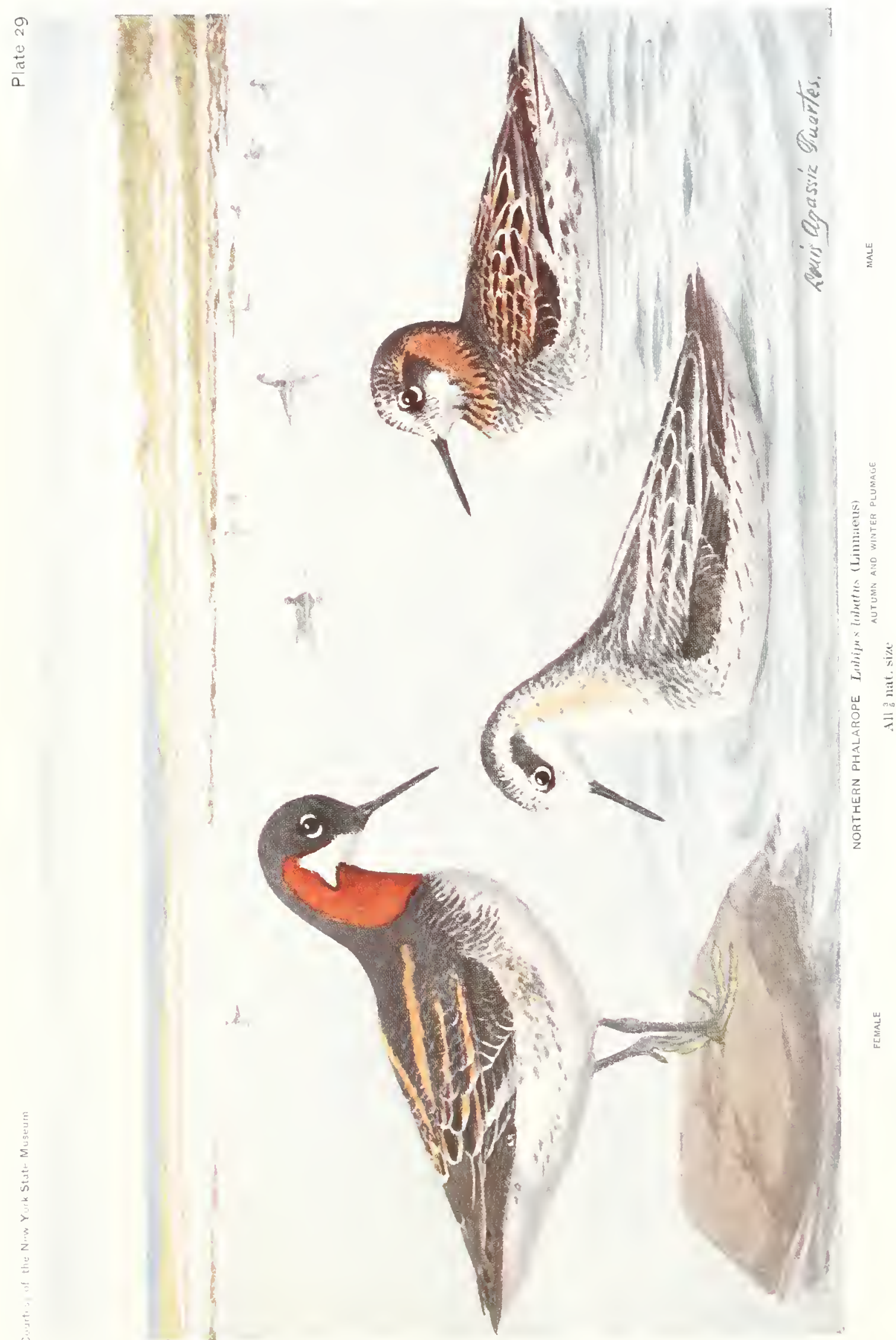



dusky srot in front of ere: eye-rnus. whate mterupted before and behind; bill, blush-black; feet, hivel; iris, deep brown.

Nest and Eggs. Nist: A hollow in groumi lined with srans or leaves leoss: \& greenish or buffy, thickly blotehed woth varsus shates of hrown.

Distribution.- Northern and suthern hemispheres; in Nurth America breets irom northern Alaska, Met-

Like the Red Fhalarope, the Northern I'halarope hreeds in the extreme nurth. It has a curiou halit of whirling around several times in sucesesion on the surface of the water, ereating miniature whirluools, evidently with the intention of stirring up the tiny marine life on which it feeds. I have seen many flocks on the ocean, ville lslant, and central foreenlanel sumth w Aleutian lulands (including Near lands), valley of the upper Sukvo, uothern Nackenzic, central ketwatin, southern Jamen Bay, and northern Lngara: winter bone nnknown, but probably the weans sunth of the equator: in migration occurs nearly throughout the Lniten States and in Mexico, Central America, Bermuda, and llawail.

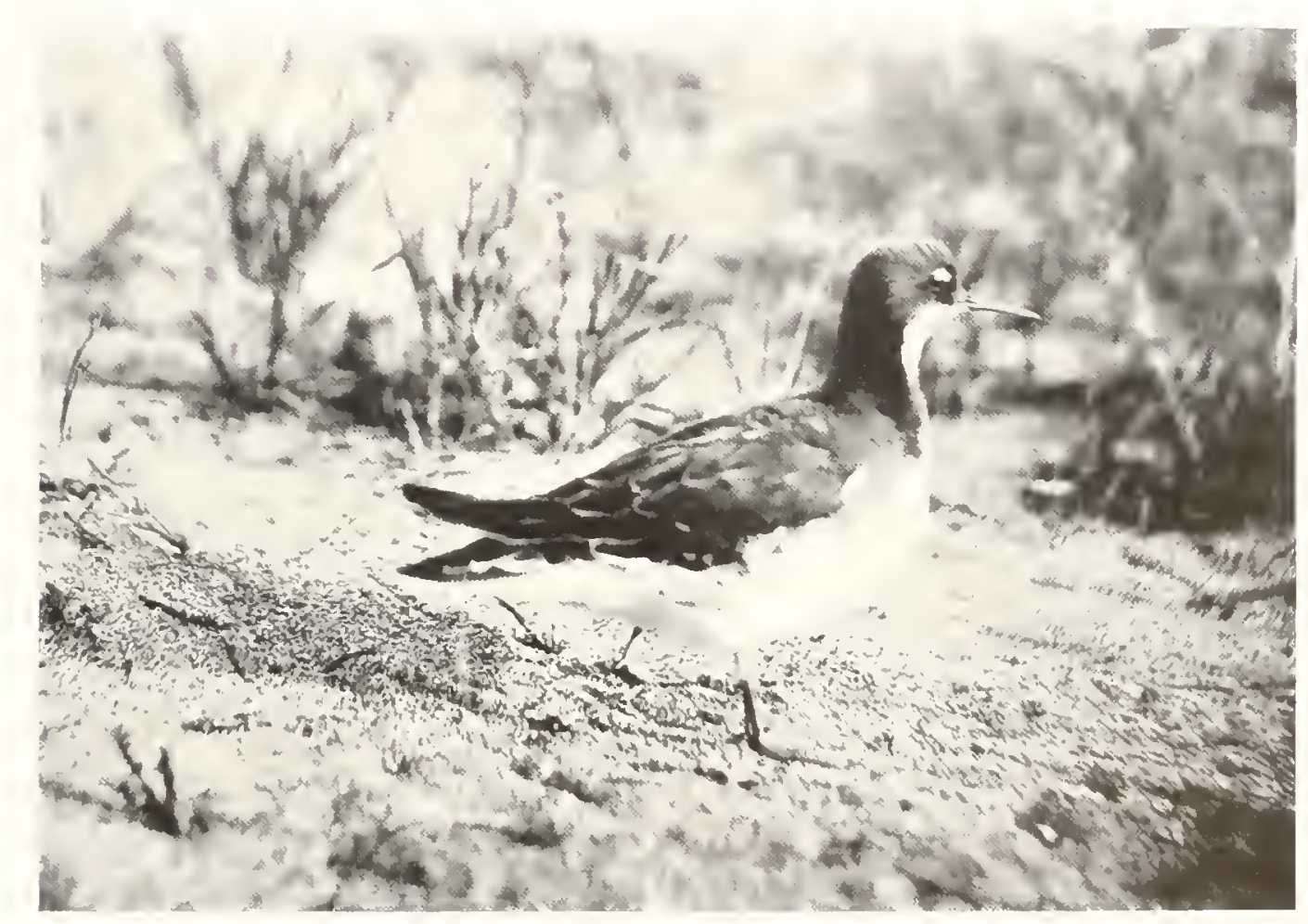

Photo by W. L. Finley and H. T. Bohlman

well off the shore of the New England coast, during lugunt and september, Huating like thistledown but not woing through the grations they perform on the shallow inland jonds, which would indicate that in the latter they find food absent in the former.

R. I. Br.SIIER.

NORTHERN PHALAROPE

Female in summer plumage 


\title{
WILSON'S PHALAROPE
}

Steganopus tricolor licillot

\author{
A. O. U. Number 224 siee Color l'late 30
}

Other Name.-Summer Phalarope.

General Description.- Length, 9 inches. Color above, gray; bill longer than head and very slender; front toes with marginal webs, but the membrane not scalloped.

Color.- Adult Male in Sumaler: Forehead, crown, and upper parts in general, including wings and tail, dull grayish, streaked on back, shoullers, and wingcoverts with darker gray; lures and a bruad stripe over and behind eye, whitish: throat and a patch on nape, white; rest of under parts, dull white, washed on side with pale yellowish; a rusty area on sicle of neck, bordered above with dusky; dusky spot in front of eye and an indistinct one of the same color, hehind; bill, lusky ; feet, dull horn; iric, brown. ADULT Female in SUMMER: Crown, pale ash changing to white on a narrow stripe on back of neck, this color changing again on rack to ash. continuing down and becoming white on rump and upper tail-coverts; a broad black ara commoncing

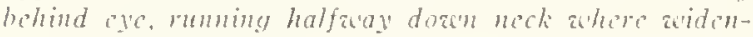
ing and chansing into rich purplish-chestnut, crtending along back in a narroater streak; shoulders, the same color, bordered on each side with grayish; wings, pale grayish-brown; primaries, dusky; tail, mottled with gray and white; chin and throat, pure white; rest of under parts, whitc: sides of neck, breast, and flanks washed with pale rufous; a large white spot over eye, burdered in front with blick streak; a smaller spot of white below eye; bill, dusky; feet, horn blackish; iris, brown; no white patch on awing. ADtLTS IN WINTER: Crown, hack of neck, and upper parts, ashy-gray, each feather usually edged with whiter; wing-coverts and secondaries, dusky-gray edged with pale yellowisl-white; primaries, plain dusky; upper tail-coverts, line over eye, and under parts, white, shaded on sides of breast with grayish; a duaky spot in front of eye: an indistinct streak behind eye uf light dusky; bill, dusky; legs, yellow; iris, brown. Founi: Hrownish-black ahove, this soon succeeded by coloring of winter adult.

Nest and Eggs.- NEST: A slight depression in the ground: lined with grass. Exics: 3 or 4 creamy, buff. or drab, spotted, specked, and scratched with brown of different shades.

Distribution.- Noth and South America: breeds from central Washington, central Alberta, and Lake Winnipeg south to eastern Califomia, southern Colorado, southern Kansas, northern Iowa, and northwestern Indiana; winters from central Chile and central Argentina south to Falkland Islands: casual in migration on Pacific coast from sonthern Pritish Columbia to Lower California and on Atlantic coast from Maine to New Jersey.

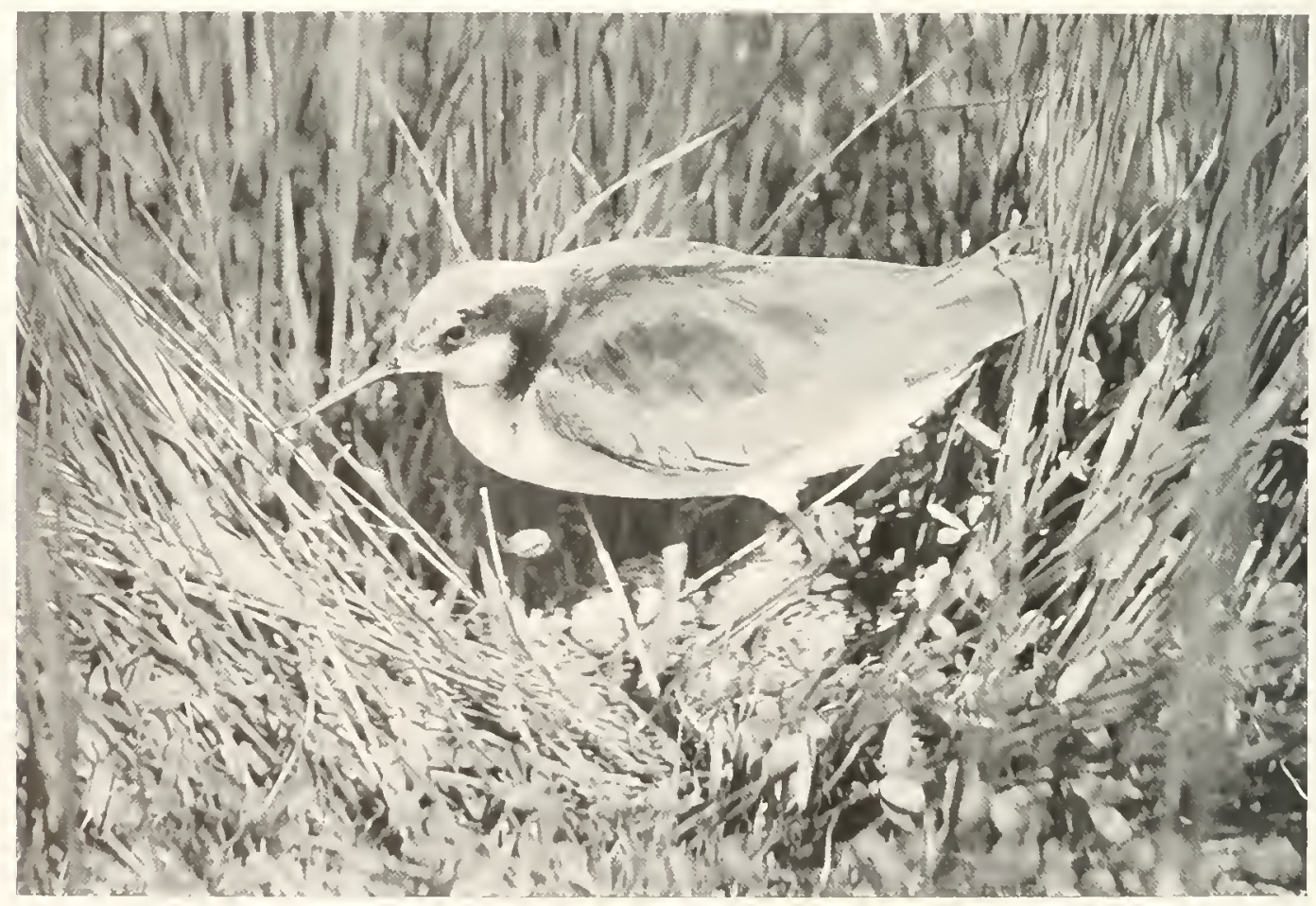

Photo by W. L. Finley and H. T. Bohlman

MALE WILSON'S PHALAROPE RETURNING TO HIS TASK OF INCUBATING 
0
$m$
$\frac{0}{a}$
$\frac{0}{a}$

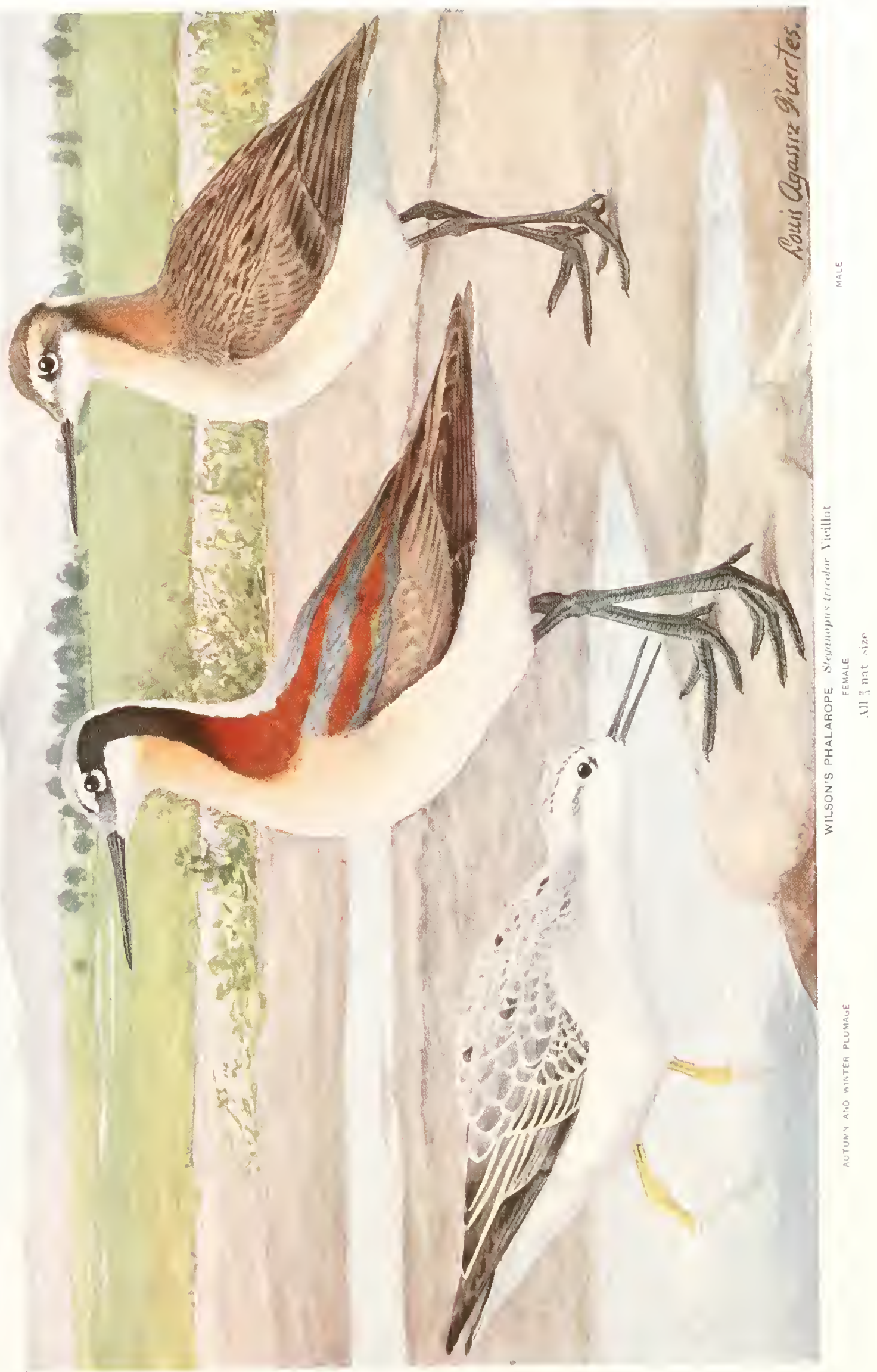



Though 1 have met the other two kimls of lhalanpes ont on the open Atantic well offshore, to tind Wilson's l'halarope one has to journey to the northuest interior. There I have found these beatutiful, sentle linds breeding beside the marshy sloughs of North Dakota, Manitula, and sackatchevan. The hest-known, most widely advertised peculiarity of Phalaropes is their fandy relationship. The female is the lares and brigher-colured, and is said to do the courtine; the demute little male - mere man -inculates the egrs and cares for the young, while the wives fluck tosether in the slouglis as though they had orwanized women's clubs or other social coteries. Thus I have watched partics of these giddy little lavlies sunting alunt, and then, tramping through the meadow grass on the prairie a few rods back from sume wher slutsh, have flushed the male from the nest so well hidelen in the grass. The four eggs are decidedly pointed and are very boldly and thickly streaked with black.

To the credit of the female it must be said that she is not entirely without the heart of the mother. The cries of her huslond, in times of seeming danger, soon bring her to the rescue, and she runs or flies abont witl bim, scolding, though he usually leads in the performance of the various protestations.

On one occasion, during the spring migration, in early June, I met a considerable flock of Northern l'halaropes on a shallow alkaline slough in northern Manitola, but at the most I have only seen Wilson's I'halarope in small par- ties. Like all the trile thene are araceful in every motion, notilly in swimming, bohbine their heads and necks prettily forward as they progress.

Despite the alove reversals of social unge, the female is far from being a viraso. The birels

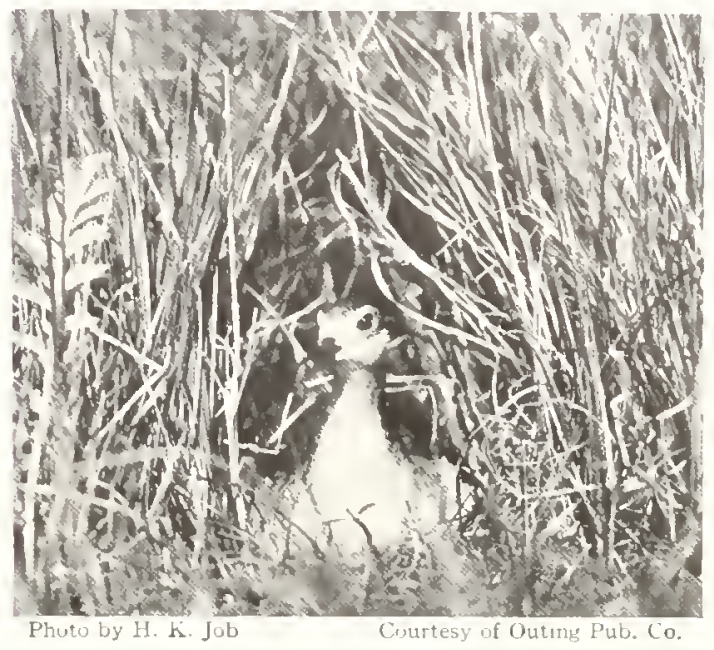

WILSON'S PHALAROPE

The male of this species attends to the work of raising the family

are gentle in manner and incomspicuous, and the average person passing througl their haunts probably woukd not nutice them. Though small, they are, like other shore birds, swift and strong in fight, and in winter they journey as far south as Chile and. Irgentina.

HERBERT K. JOB.

\section{AVOCETS AND STILTS}

\section{Order Limicola; family Recurvirostrida}

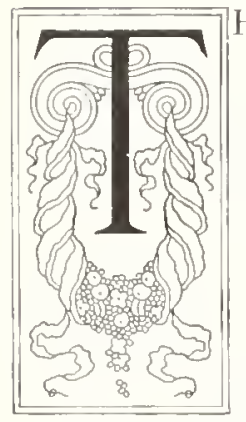

HE Avocets and Stilts include eleven or twelve species which occur, usually in flocks, throughout the warmer regions of the world. As a family they are comparatively large lirds, and have excecdingly long legs, long necks, and long, slender bills, curved more or less upward, in which the nostrils are set within the quarter nearest the base.

Of the Avocets, there are four species, one occurring in North America. another in South America, a third in Europe, and a fourth in Australia. Each of these has a rudimentary hind toe, and the front toes webbed, in which latter respect they differ from most wading lirds. Their wings are rather short and their tails are short and square. Their plumage is thick and duck-like. They feed on aquatic insects, shellfish, and the like, which they capture chiefly in shallow water by sweeping the lill from side to side with a movement which suggests the swinging of a scythe. The Avocets swim easily, when they need to, and usually are comparatively tame. They are from fifteen to eightcen inches long and in coloration are generally black and white, with the legs of a bluish tinge. They build rude nests on the 
ground in swampy places; the eggs are three or four in number, of olive or buff color prof usely marked with dark brown spots.

Uf the true Stilts there are seven or eight species, only one of which occurs in America. The family differs from the Avocets in having no web between the middle and inner toes; in being considerably snaller, with an average length of about thirteen inches; and in having the wings long and pointed. The common American species occurs in both continents and is found most of ten in small flocks on muddy flats, where the bird walks with long, deliberate strides, probing the mud with its long bill or catching fish in the shallow waters. Physically and in their habits, there is considerable general similarity between the Stilts and the Avocets.

The young of both Avocets and Stilts are covered with down at birth and shortly after leaving the shell are able to run about. This natal down is soon replaced by the first or juvenal plumage.

\section{AVOCET}

\section{Recurvirostra americana Gimelin}

A. O. U. Number 225

Other Names.-American Avocet; Plue Stocking: Blue Shanks; Irish Snipe.

General Description.-- Length, is inches. Color. white with some black areas; bill. flattened and upturned; three front toes webhed.

Color.-Avults In Summer: White, changing imperceptibly to chestmutbroan of head and neck: shoulders and wings, black: some secondaries and coverts, white; tail. pearl-gray; bill, black; legs, dull blue; iris, red or brown. Adults in Winter: Head and neck, pearl-gray; otherwise like summer plumage. Yocno: Hearl and neck, washed with chestnut, the black feathers exlged with same color: bill. nearly straight.
Nest and Eggs.- NEst: In the marshes, hidden in the grass and constructed of grass and weed stems. EGGS: 3 or 4. pale olive or buffy, uniformly and thickly spotted with burnt umber and other shades of brown.

Distribution.- North America; breeds from eastern Oregon, central Alberta, and southern Manitoba (rarely north to Great Slave Lake) south to southern California, southern New Mexico, northwestern Texas, northern lowa, and central Wisconsin; winters from southern California and southern Texas to southern Guatemala; casual from Ontario and New Brunswick to Florida and the West Indies, hut rare east of Mississippi River.

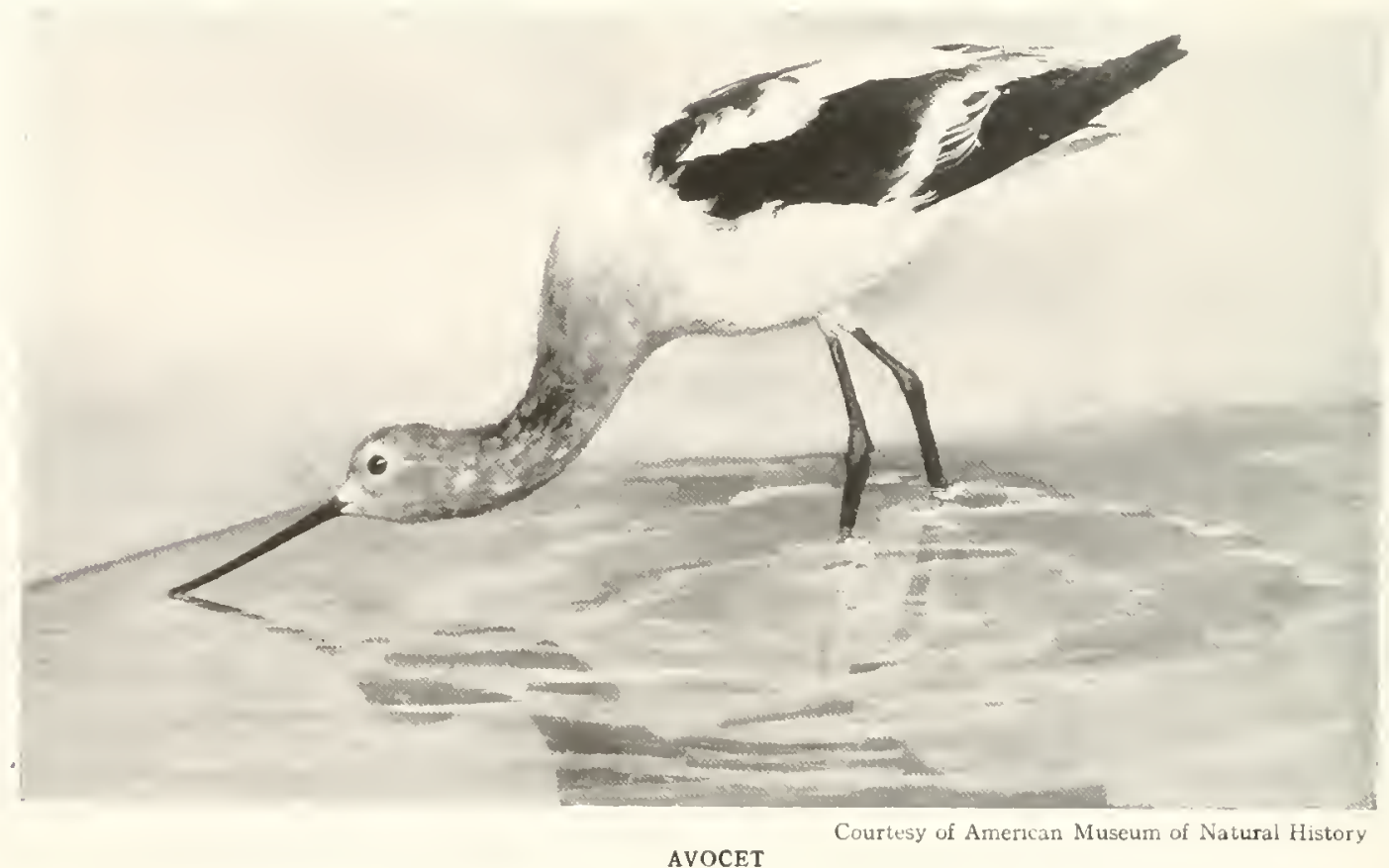

The most showy of North American shore birds 
The Arocet stands out among North . Imerican whore birds as the most showy of them all. Its white londy and black and white-strifed wings reveal its presence at a great distance. It is a large hird, heins about a font and a half long. This, alded to the fact that it makes a most acceptable dish when served on the table, is responsible for the extended jersecution to which it las been subjected by sumers. ()ne of the names by which shooters knom it is "Blue Shanks," the color of its loms, hare leurs being responsible for this. While searching for wild Ducks mests on the marshes of the klamath River in (rewon I first cante nfon these remarkable hirds. Fivlently a snall group Ha nenting in the neighborhood, for trpon our appearance three hirds came into viem and at once set up a great outcry. Unr first view of them was when they came flying toward us giving vent to their alarm and recentment at om approach. They flew overhead and circled about much as is the custom of Willets under like circumstances. Their screaming som brought others, who may lave leen their mates called from the nents by the general alarm. It times they alighted on the ground at a safe distance, or setted in the water of the slough. Here the manewrers of headbobbing and wing-waving were most anusing. Sometimes the body would be all but sulmerged and with head lajd out along the water the bird would swin away just as a wounded wild Goose will often try to escape the fowler.

The Arocet's nest is a depression in the gromnd in the vicinity of water and is lined with grass. The young uyon emerging from the spotted eggs are ahle to rum almost at once.

Audution has this to say in reference to their feeding habits:

"They scarch for fond precisely in the manner of the Roseate Spoonlill, moving their heads to and fro sideways, while their bill is passing through the soft mud; and in many instances, when the water was deeper, they would immerse their whole head and a portion of the back, as the Spoonbill and Rest-brasted Snire are wont to do. When, on the contrary, they pursued aquatic insects, such as swim m the surface, they ran after them, and, on settins up to them, surlrenly seized then fy thrusting the luwer mandible beseath them, while the other was raised a good way abue the surface, much in the manner of the Black Shearmater [13lack Skimmer], which, however, performs this act on wing. They were also exjert at catching flying insects. after which they ran with partially expanded wings."

In the United States the Avocet is to-day confined almost entirely to the territory lying west

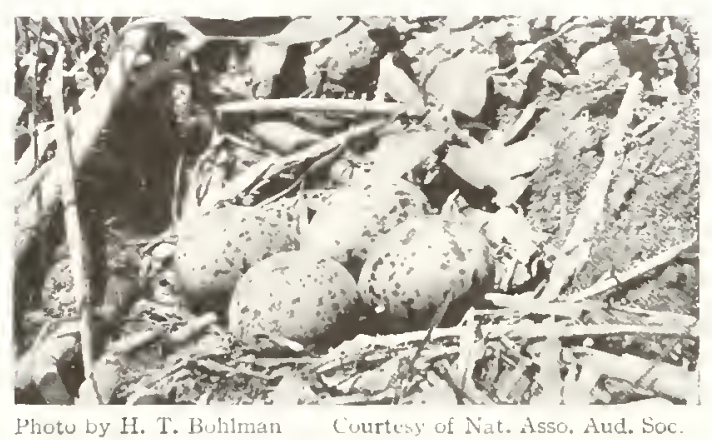

NEST AND EGGS OF AVOCET

uf the Mississippi Kiver. The fiecteral Migratory. Bird Litw extends protection to it at all times, and it is to be hojere this splendid game bird may be spared the melancholy fate of the Eskimo Curlew and the Whooper Swan.

Like several other shore birds, the Arocet makes itself very useful by destroying diving beetles, which are predatory in their habits and do much damage to fish hatcheries by feeding upon insects which are the natumal diet of fishes. It also feeds frecly upon grasshoppers and upon lill-bugs, which injure the corn crops. Snails and marine worms also part of its lifet.

T. Cillebrt JeArson.

BLACK-NECKED STILT

Himantopus mexicanus ( 1 Hiller) $^{-}$

1. ก $\mathrm{U}^{\mathrm{T}}$. Number 226

Other Names.-. Stilt; Longshanks: Lawyer.

General Description.-1.ength. 1,3 incher. Color ahose, black, sharply contrasting with the white of under parts; legs very lomin

Color.-Anutss: Back, shoulders, and arings, glossy Vin. I -16 black, continumin up back of nck, on crown, enlarging on side of hearl, and including the eyes: a spot ower and behind eye, one bencath eye. forchead, forepart of crown, lures, chin. sjoles of head below eye, siles of neck, entire under parts, rump, and upper tail- 
coverts, white: tail, ash; bill, black; iris, red; leura, flesh culor. White of rump covered by the wings in life. In the female the hlack is often dingy. You va: Upper parts, brown, markel with whitish.

Nest and Eggs. - Nast: A repression in the sand or a frail structure of grass and small stems hidden in a bunch of weeds. EGas: 3 or 4 buffy or olive-brown, thickly spotted and blotched with dark brown.

Distribution.- Temperate North America and northern South America; breeds from central Oregon, northern Utah, and southern Colorado to southern Califormia, southern New Mexico, southern Texas, coast of Lonisiana, and in Mexico. and from central Florida and Bahamas throttghout the West Indies to northern Brazil and Peru; formerly bred north to New Jersey; winters from southern Lower California, southern Texas, southern Lotisiana, and southern Florida south through Central America and the West Indies to northern Brazil, Peru, and the Calapagos; casual in migration to Nebraska, Wiscunsin, and New Brunswick.
The Black-necked Stilt has been brought to verge of extemination along the Athantic coast by the spring and summer shooting. It is not uncommon in the West and Surth, being par-

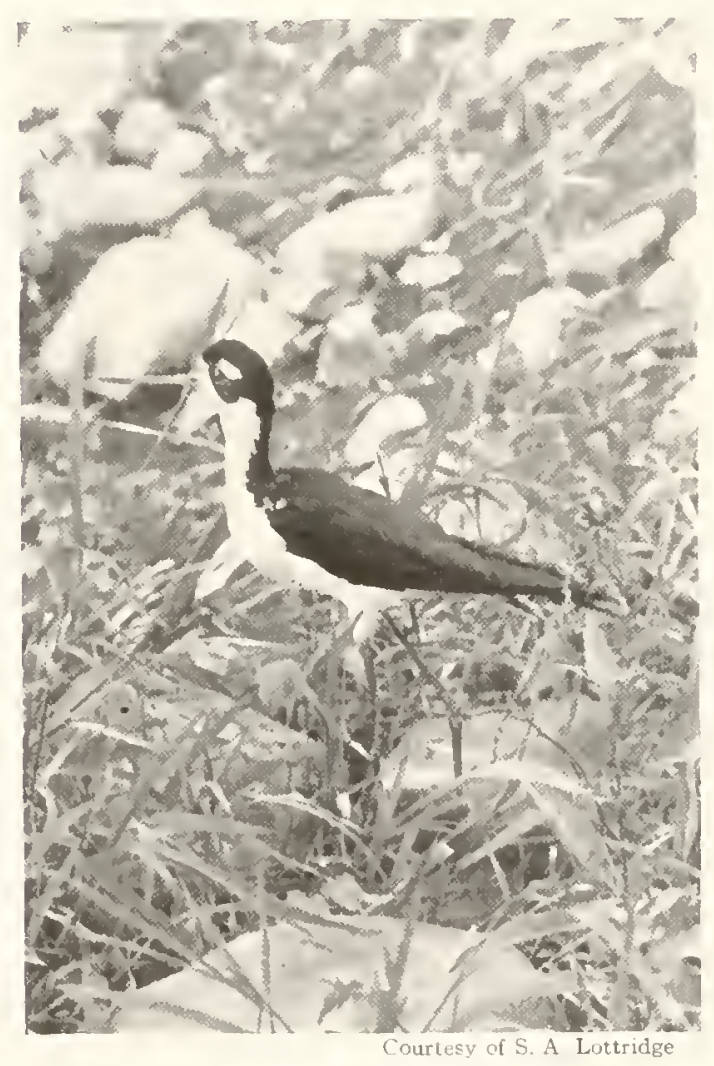

BLACK-NECKED STILT

The bird walks with long deliberate strides ticularly abundant about the alkaline lakes and pools of the Great Basin. where it is often seen in the company of the Avocet.

"On the ground, whether walking or wading, the bird [the Black-necked Stilt] moves gracefully, with measured steps; the long legs are much bent at every step (only at the joint, however) and planted firmly, perfectly straight; exceft under certain circumstances, there is nothing vacillating, feeble, or unsteady, in either the attitudes or the movements of the birds. When feeding, the legs are bent backward with an acute angle at the heel joint to bring the body lower; the latter is tilted forward and downward over the center of equilibritum, where the feet rest, and the long neck and bill reach the rest of the distance to the ground." (Coues.)

When the birds light they raise their wings straight up above the body for a moment, then close them slowly over the back. Many water birds have this same habit; and it is undoubtedly a recognition mark to keep in touch with the rest of the flock as the pose is a very conspicuous one, enabling the bird to be seen from a long distance.

The Black-necked Stilt's diet is known to include in considerable quantities several species of the predacious diving beetles which, because they prey upon insects that are the natural food of fishes, are counted a nuisance in all fish hatchcries. In this respect its economic value is a matter of fact, not of theory. Grasshoppers are destroyed in large nummlers by this bird, and also bill-bugs which feed upon corn.

R. I. Brasiler. 


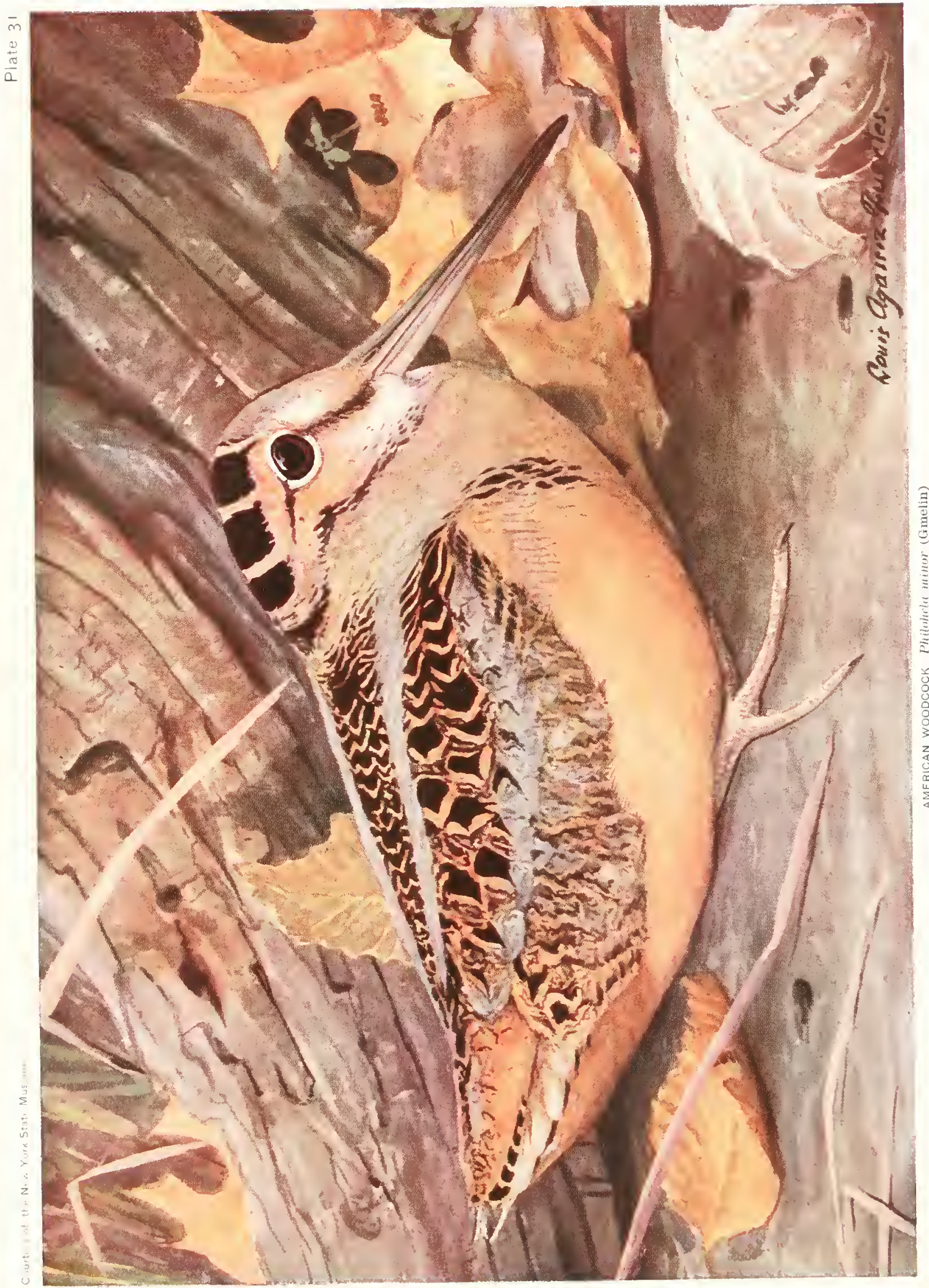





\title{
SNIPES, SANDPIPERS, ETC.
}

\author{
Order Limicole; lamily Scolopacida
}

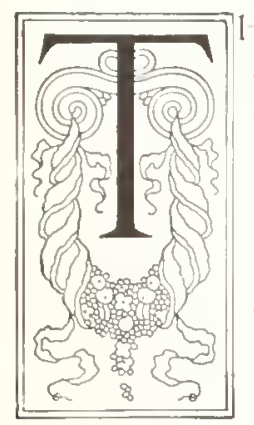

HE snipes, Sandpipers, and the closely allied species which form the family scolopucida of the order of Shore Birds, or Wading Birds, are represented in all the habitahle parts of the world, hut during the breeding season they are found with few exceptions only in the northern parts of the northern henisphere. There are about one hundred speeies in the family, about half of which number oceur regularly or nceasionally in America.

The nembers of this family vary greatly in size, shape, and color, but in general they are of small or medimi size and never reach the average size of Herons. Usually the bill is long and soft-skinned, generally straight, roundish, and slim, but sonetimes curved either upward or downward and in one species, the Spon-bill Sandpiper of eastern isia, the end is spoon-shaped. The head is feathered to the hill. The legs are of moderate length. The wings are normally long, flat, and pointed. The tail is rather short, stiff, broad, and rounded.

As indicated by the name of the group in which this family has heen placed, its memhers are seldom found far from the shores of bodies of water or from moist lands. They migrate and pass the winter in locks, but during the breeding seasnn are not gregarious. Like other shore birds, they all, with the exception of the European Green Sandpiper and the American Solitary Sandpiper, nest on the ground. The eggs usually number four, but seldom does a pair succeed in bringing nore than two young hirds to maturity during a season. The babies are clothed with down when hatched, and are precocial, that is, they are not cared for in the nest by their parents, but are able to run ahout within a very short time after leaving the shell.

Many of the species in this group are greatly prized as game birds, and to this fact is due to a large extent the decrease in their numbers. The development of land for agricultural purposes has restricted their breeding grounds, and this is an indirect, but nevertheless another, cause for their lessening numbers. Not only because of their food value are the birds entitled to protection, but also because of their usefulness. They search out and destroy many creatures that are detrimental to man's interests. Among the pests which they eat are grasshoppers, army worms, cutworms, cabbage worms, cotton worms, boll weevils, rice weevils, Texas fever ticks, horseflies, and mosquitoes.

\section{WOODCOCK}

\section{Philohela minor (Gmolin)}

1. (1) IT. Nunber $2 \geq 8$ See cinlor l'bat 31

Other Names.-American Woodcock: Woodhen: Big-headed Snipe: Fig Mul Snipe: Blind Supe: Whistling Snipe; Woorl Snipe: Night Partridge; Night Peck: Timber Doodle: Hookum Pake: Labrator Twister: liogsucker: Bog-bird: Pewee: Whistler: Bigeyes.

General Description.- Length. II inches; color above, brown; below, pale orange-brown; head, large; neck, short: cles. larme and set far hack and high: hill, zery long and compressed. the lower section shorter than the upper into which it fits at the tip. and the upper section eapable of heing flexerl like a finger: wings. short and rounded: there outer primaries, scythe-shaped; leys, short and stout with thohs fiathered; toes. without webs.

Color.- Abose, finely lilenles and varied with hlack. warm browns, gray, and russet, the brown merlominating. the gray tending to form streakis above and below shoulders; forehead, grayish: thrit squart patches of hack cortendine from top of crown to nape and siparated by narmat orat bars: a lilack stripe from gape to eye; chin, whitish; rent of under morta, pale orange-brown with a few black apots on sides of chent; primaries, plain browninh; bill, brownish flesh color. dusky on ridge and tip; fect, flesh color; eye-ring, white; iris, lark brown. 
Nest and Eggs.- Nest: On ground, on brushy bottoms or in open woods, usually not far from water; a depression in the leaves without lining. EGgs: 3 or 4. buffy to grayish-white, irregularly and thickly spotted with pale reddish-brown.

Distribution.-Eastern North America; breeds from northeastern North Dakota, southern Manitoba, north- ern Michigan, southern Quebec, and Nova Scotia south to southern Kansas, southern Louisiana, and northern Florida; winters from southern Missouri, the Ohio Valley, and New Jersey (rarely Massachusetts) south to Texas and southern Florida: ranges casually to Saskatchewan, Keewatin, Colorado, Newfoundland, and Bermuda.
During the day the Woodcock sits quietly in a shadowy retreat, usually in the swamps, but often in open wpland woods. It may also be flushed in "slashings," where will be found the " form " of old leaves where it had nestled. The swampy coverts which "Mr. Big-eyes" prefers are clean, sweet localities, where alders and willows like to grow. The bird is by no means confined to such resorts for it may be found uesting well up in the hills, thougl even there a favorite resort is generally not far away, to which it travels in the evening and forages for its nocturnal supper. Often in the evening I have seen it against the fading west, bound for its own particular restaurant. Even after night had fallen its familiar scupe could be heard.

Some of our birds are enveiled in mystery and the Woodenck is not the least strange of this coterie. It often lives where its presence is unsuspected. One of the lest Woodcock covers I have known was within the limits of the city of Brooklyn. Fortunately this knowledge was not shared by others, so the birds were little hunted. Into this retreat the birds would come silently some April night, and from it they would disappear sone October day as mysteriously.

The flight is swift though short, sometimes accompanied with a clattering sound, at others as silent as an owl's. I have frequently seen them collide with limbs when flushed. This may be due to the fact that the birds' eyes are placed far back in the head, or it may be because they are watching the intruder and cannot look forward and behind at the same time.

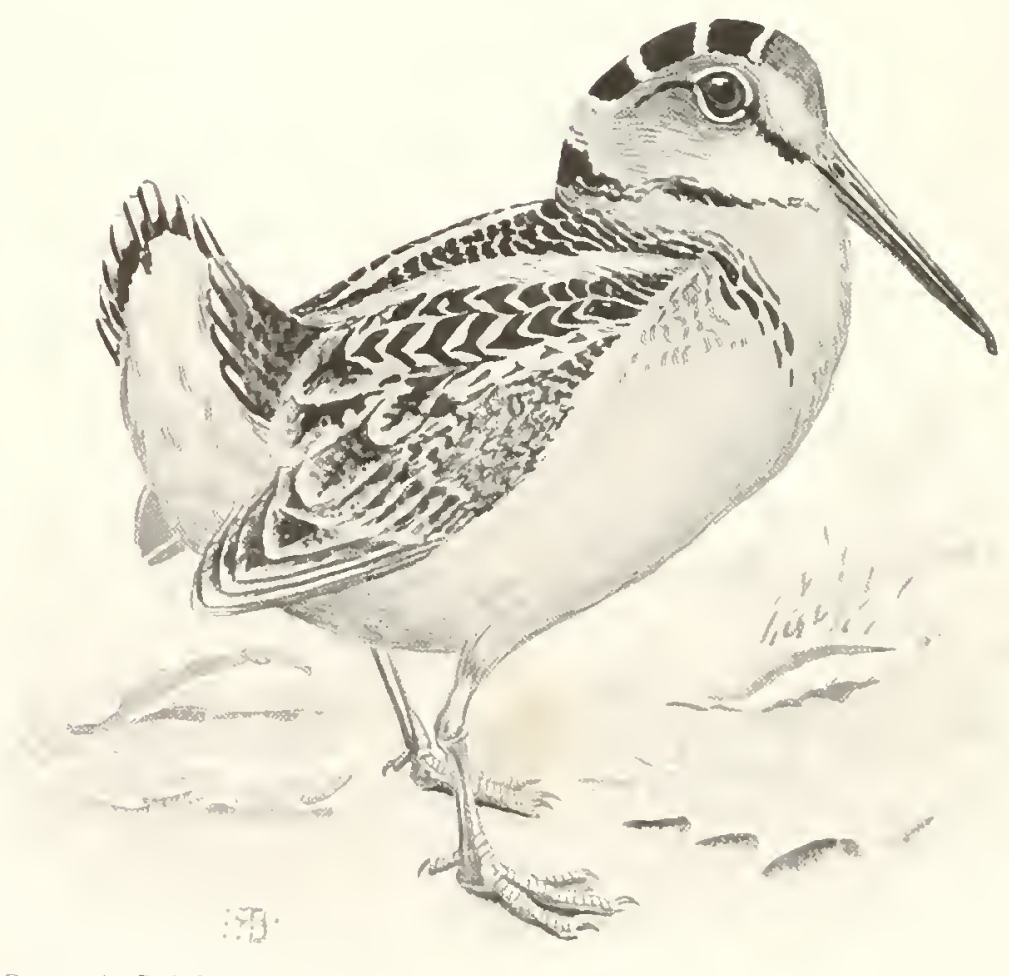

Drawing by R. 1. Brasher

WOODCOCK ( ${ }_{8}^{3}$ nat. size)

A game bird that is not disturbed by the advent of agriculture 
The mother Woodeock has a curious atud interesting habit of Hying off, when disturbed, with a young chick grasped between her feet or between her thigls. If she has an opfortunity, she will convey all her habies, one at a tine, to a place of security.

It conting time, and all throuml the periol of incubation, the male induleses in a curious acrial dance. Soon after sumet he whirls up in spirals. chirping and twittering, to a height of fifty on sixty feet, then circles horizontally and desecurls, giving voice to his eestasy in a continumu "cheeping" until he raches the ground where he struts like a tiny turker-abluler, with dronping wings and upright spread tail, chansing his notes to a series of rather hard faiks. (In moonlisht nishts, I lave listened to this serenade until after " o'clock.

1 dish of anglewnmm can hardly tre considered appetizing; but, transmuted in the Moodcock's interior machinery the is really wlle hundred per cent. angleworm), there seens to be no difference of opinion among epicures when the bird is brouglit to the table on toast.
The Woolcock's diet inclutes also 113 considerable quantities such haminl insects as the crane fly ("leather-jaclet"), and various species

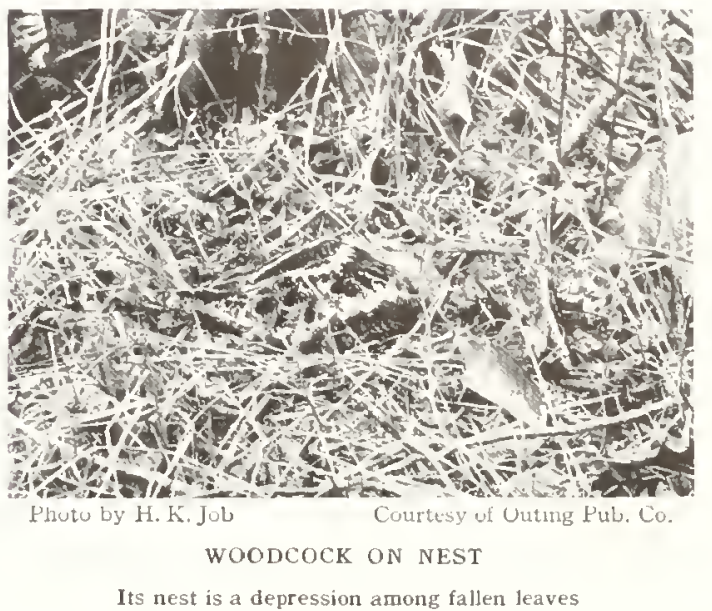

of more or less destructive srashoppers. Tu this extent its feeding halits are of distinct benefit to man.

R. I. BRASHER.

\title{
WILSON'S SNIPE
}

\section{Gallinago delicata $(0, r d)$}

\author{
A. O U. Number 230 tee Ciblor l'late 32
}

Other Names.-Common Snipe: English Sinpe: American Snipe: Meadow Snipe; Marsh Snipe; Bog Snipe; Gutter Snipe: Jack Snipe; Shadbird; Alewifebird: Shad Spirit.

General Description.- Length, 12 inches. Color above, mainly brownish-black; bill lung and slender, upper section overlapping under. Seldom found away from iresh-water marshes.

Color.-Gromind color of head, neck, throat, and brust. pale broznish-zhite; sides of head, neck, and brost. spottid arith palc and dark hooun: two dusky stripes from bill over crown to back of head; another from gape to eye and extending a little behind and a small patch on cheeks: back and shoulders. lorownishhlack mixed with chestnut and hrown; shoulder-feathers, lowally elged with brownish-white, forming two longitudinal stripes on each side; wing-coverts, brownish. feathers edged with whitish, secondarjes with brown spots coalescing along shaft; primarius and their covcrta, dusky-brown, the outer me white-edged; unper tail-coverts, brown with narrow hlack luars; tailfouthirs, black at hase, then bright ruferes a'ith a narvar subtrminal black bar and white-tipped: abdomen, white: sides of hody. shated with brozen. harrad

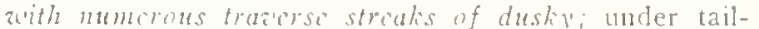
coverts, rufous with dusky bars; hill, brownish fleshcolor, dusky on rielge anul tip : fect, greenish-gray : iris. hown surroundeal by white rins interrupted in front and behind.

Nest and Eggs.- Nest: A grass-lined depression in marshy gromd. Egas: 3 or t. grayish-olive, spotted and streaked with chestnut. burnt umber, and black

Distribution.- North . Imerica and northern South America; breeds from northwestern Alaska, northern Mackenzie, central Keewatin, and northern Lngava south to northern California, southern Colorado, northern Iowa, northern Illinois, Pennsyluania, and New lersey: winters from northern California. Yew Mexion. Arkansas, and North Carolina through Central America and West Indies to Colombia and southern Brazil: remains in winter casually and locally north to Irashington, Montana, Nebraska, lllinois, and Nova Scotia: accidental in Hawaian Islands, liermuda. and Great Britain.
As its scientific name implies, the Wilson's Snipe is truly a delicacy, and in many more ways than from the eulinary standpoint. Every phase of its life assumes a peculiar interest, when one comes to know it well. Surortsmen, naturally. are fond of it, and refer to it familiarly an "Jack Snipe."

In the brecding season its ways are most sin- 
grular and entertaining. It breeds on the northern borders of the United states and north to the Arctic Sea. On the Magdalen lislands I have watched it with both amusement and amazement. The background is of the mossy bogs and marshes, interspersed with shallow ponds and clumps of small spruce. There, in May and June, we may sec and hear the male hird darting about in wide circlings up in the sky, like a sort of feathered meteor, producing with its wings a humming, murmuring sound, not unlike that accompranying the flight of the "Whistler" or Coklen-eye. Then the mode of the performance changes. The singular, long-billed creature now flies low, emitting a vocal yelping or cackling, in seneral form not very different from that of the Yellow-legs, only continuous, lasting for several minutes at a spell. l'resently it alights on a spruce tree or a stub and continues its vociferations.

I'ossibly the female may indulge also in the circling and winnowing performance, for I have seen two or more birds at a time executing this, and in one case we thus traced a hird to its nest. Watching where it alighted, after much flying arouncl, a member of our party flushed it from a nest of four handsomely marked, pointed egss, in the grass near a little bush. I cmbraced the opportunity to set the camera by the nest, with

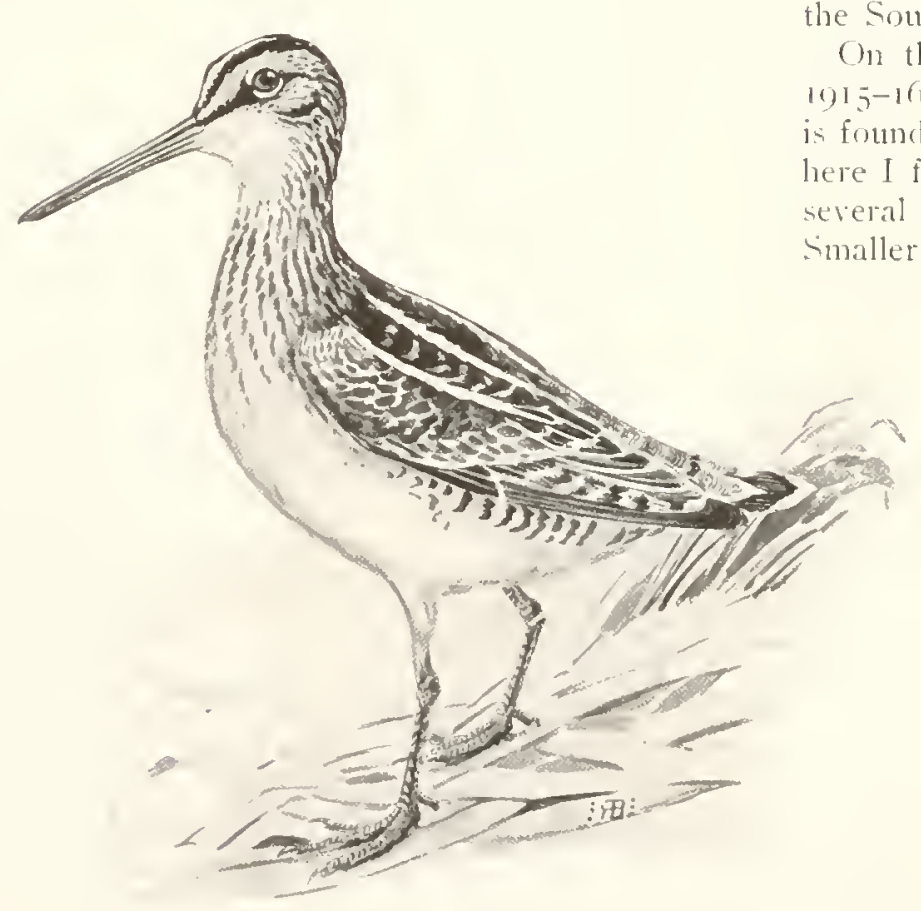

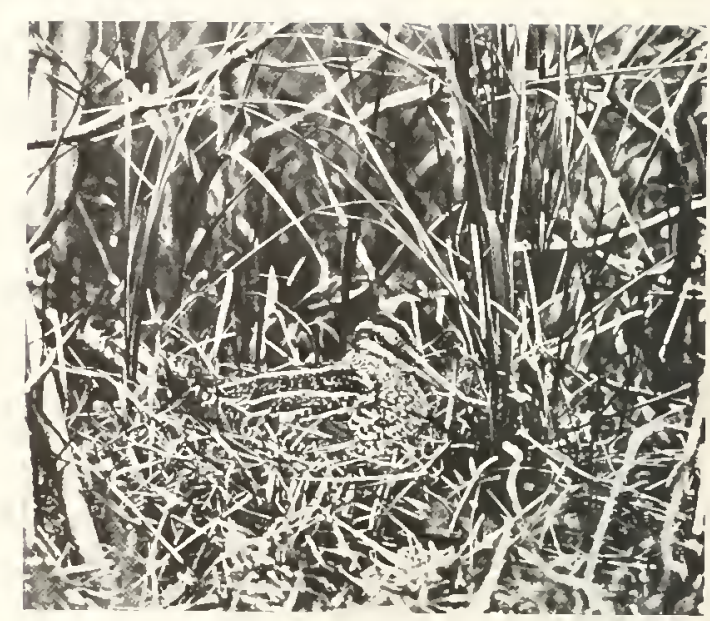

Photo by H. K. Job

Courtesy of Outing Pub. Co.

WILSON'S SNIPE ON NEST

thread attached, ant thus secured some interesting pictures.

The usual haunts of this Snipe are open meadows or fresh-water marshes, where the ground is wet and soft, and where there is grass enough to conceal it. It migrates down across the Lnited States from mirl-September to freezing-up time, and is much bunted. Flushing surldenly from the grass, it darts off with rapid, erratic fliglit, uttering reiterated squeaky notes, commonly represented as scaip, scaip, or cscape, suiting the action to the word. It winters from the Southern States to as far south as Brazil.

On the Louisiana marshes, in the winter of $1915-16,1$ found it very abundant. Usually it is found in scattered parties on the meadows, but here I found it in large flocks, sometimes noting everal hundred in flight in a compact mass. -maller parties, or " "risps," say of twenty to
Drawing by R. I. Brasher
WILSON'S SNIPE ( nat. size)
A favorite with sportsmen 

forty, were frequently dirting almut. expecially toward evening. Near the camp of Messrs. Ward and Nothenny, where I stayed, there were a series of mudely flats, interspersed with bumches or fatches of grass. Which were fairly alive with Snipe. In the morning I could see one or more of them lying leneath many a tuscock dozing. Unless flushed, they stayed there until sundown, or till it became nercast, whereupon they could be scen ruming almut orer the open mud and shallow water, busily probing for worms. By building a blind at the edse of one of these
Hatt and carefully awaiting sulden intervals of sunshine late in the aftermom, 1 secured motion pictures and others of them thus engagerl.

HERTEKT K. JUR.

The foorl of Wilson's Snipe is known to in clucle erane-fles (") kather-jaclicts"), locu-ta, grashoppers, craw fishes, and the preclacious diving beetles which cane troulle in fish hatcheries and destroy much of the nattural inect foorl of fishes. To the extent that it preys upon these insect forms - and that is very considerable it must be reckonerl a useful bird.

\section{DOWITCHER}

Macrorhamphus griseus griseus (Gmelin)

1. O. L. Number 23 I tae (nolur Flate 33

Other Names.- Robin Snope: Sea Pigenul: Driver: Red-hreasted Snipe (summer): Brown Snipe (summer): (Brown-lack (summer); Gray Snipe (winter): Gray-back (winter).

General Description.- Length, ir inches. Color sides, thickly speckled with dusky; a series of dusky specks from gape through and helind eye: hill and feel, dull dusky-greeninh; iris, hrown. IN IVINTER: Forehearl, heal, neck, back, shoulders, anl long imner secondaries, dark gray, the feathers on lack witb ducky

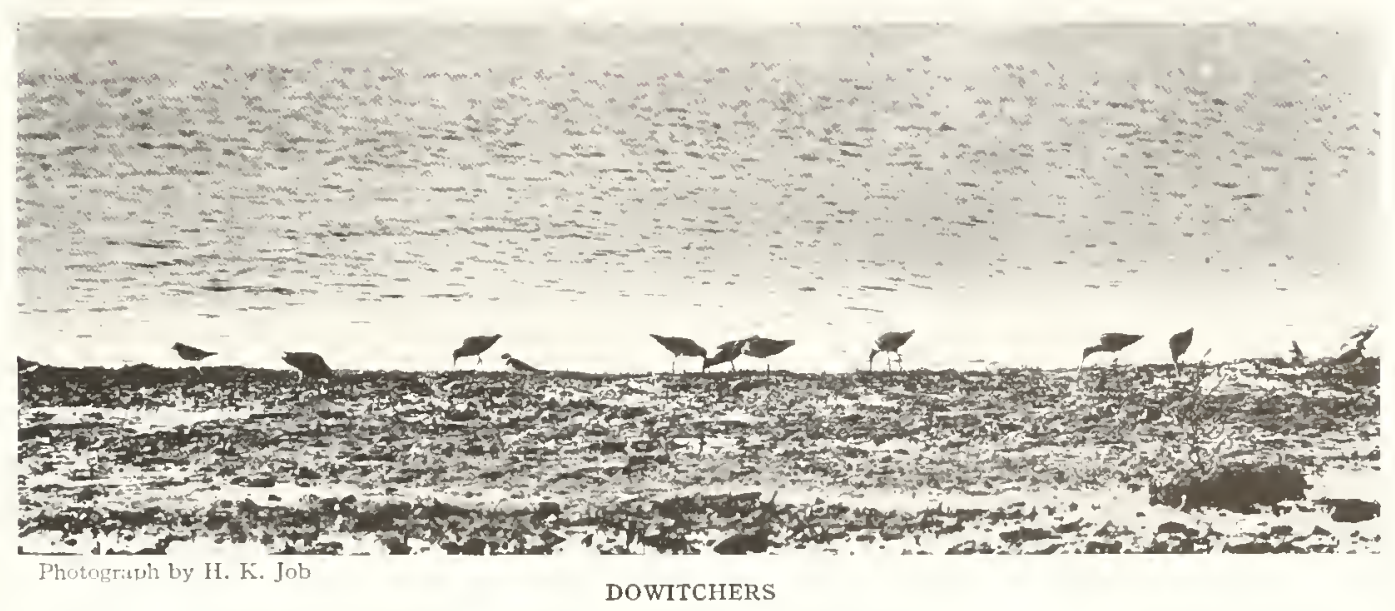

A flock on Breton Island Reservation

aburc, in summer, brownish-cinnamon; in winter, slatefray. Bill long and slender, upper section overlapping unfer. Found on sank bars and mud flats, and not in bogs.

Color.-Is Summer: Ground color of neck, head, breast, and upper parts, brownish-cimmamon; head and neck, narrowly streaked with lusky-brown; icathers of hack, with broall blackish-brown centers: rump.

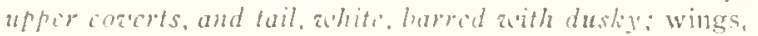
grayish-dusky, the coverts edget with highter: secondaries, broadly elged and tipped with white; suder parts, rufous, paler or whitish behind: breast and centers and paller celges: lower lack, rump. and tail. fure alhit, with romulish sputs of dusky: wing-coverts, like back; secomlaries, white-edged and -tipped: primaries dusky-brown: under parts, while; throat, sides of breast, and sides, strongly slualed with gray: a dusky stripe from gape throush and hehind eye: the white stripe between this and crown, pronounced; cheeks and sile of head. mottlest with pale dusky: lower tailcoverts with roundish dusky spots; hill. dusky, greenish at base; legs, dully greenish-gray; irin, brown with white crescent below.

Nest and Eggs.- Nest: A depression in the ground 
on borders of marshy lakes and ponds; a loose structure of grasses and leaves. EGGs: 4. greenish-olive to light clay-color, spotted with dark brown.

Distribution.-Eastern North and South America: breeding range unknown, but probably northern Un- gava; winters from Florida and the West Indies south to northern Brazil; in migration regularly on the Atlantic coast, and occasionally in Illinois, Indiana, and Ontario: accidental in Greenland, Bermuda, Great Britain, and France.
The Dowitcher's regular food includes several species of destructive grasshoppers, diving beetles which do much damage in fish hatcheries besides destroying insects which are the natural food of fishes, and various marine worms which prey upon oysters. Its usefulness to man, therefore, is very considerable.

It is a bird of the open meadows, feeding along marshy shores and on sand bars bared by the receding tide, in flocks, and often in the company of other waders. This gregarious instinct, combined with its gentleness, is a fatal trait, and enables gunners to slaughter them unmercifully and sometimes to exterminate every individual in a "bunch." To turn a 1 2-gauge " cannon " loose among these unsuspicious birds, winnowing in over the decoys with friendly notes of greeting, is about as sportmanslike as shooting into a bunch of chickens. To catch them with a camera requires skill and patience, and herein lies the hope for future existence of our disappearing wild life-substitution of the lens for the gun!

The call of the Dowitcher is a rather lowpitched series of whistles:-pheu-phou-pheuphen-pheu, without the diminuendo of the Yellow-leg's notes.

The Long-billed Dowiteher (Macrorhamphus yriscus scolopaceus) differs from the common Dowitcher in its larger size, richer coloration, and longer bill. But the two can only be unerringly separated by a close comparison with the specimens in the hand. The Long-billed Dowiteher is known locally as the Greater Longbeak, the Greater Gray-back, and the Redbellied Snipe. It is found in western North America and South America; it is "supposed to be rare or casual on the Atlantic coast and declared to be the only representative of the genus in the west - which would be important if it were a fact. Nesting and habits same as stock form." (Coues.)

\title{
STILT SANDPIPER
}

\section{Micropalama himantopus (Bonaparte)}

\author{
A. O. U. Number 233 See Color Plates 33,34
}

Other Names.- Long-legged Sandpiper: Frost Snipe: Mongrel; Bastard Yellow-legs.

General Description.- Length, 9 inches. Upper parts, in summer, mottled with blackish-brown, white, chestnut, and dusky: in winter, ashy-gray. Under parts, whitish barred with dark. Legs long and slender; toes webbed at base: bill long, slender, and slightly cured.

Color.-In Summer: Forchcad, crown, a line from atpe throulh eyc broadening on side of had. mfous: center of crown, dusky: a whitish streak from bill over and back of eye: upper parts, blackish-brown, each feather edged and tipper with white or chestnut; upper tail-coverts, harred with white and dusky: tail. mottled white and ash; wing-coverts, grayish, the feathers edged with lighter; primaries and secondaries, grayish-brown, latter edged with white; under parts from throat, whitish, sometimes with a pale rufous wash. spotted on breast, bared cacryzhere beloz' with brozonish: bill, dusky-greenish, darkening at tip; legs, dusky yellozish-grein: iris, brown with a white crescent below. IN WINTER: Above, ashy-gray, crown nar- rowly streaked and feathers of back more broadly edged with lighter; wing-coverts, brownish-ash, the feathers lighter-edged; primaries and secondaries, dusky, the latter edged with whitish; a dusky streak from bill through and behind eye; under parts from chin, white. narrowly and thinly barred with dusky; bill, dusky; legs, dull brownish-yellow; iris, brown with a white crescent below.

Nest and Eggs.-- Nest: A depression in the ground lined with a few leaves and grass. EGas: 3 or 4 . grayish-white or light drab, boldly marked with spots of chestnut, brown, and lavender, more numerous at the large end.

Distribution.- North and South America; breeds neat the coast of Mackenzie and probably south to central Kecwatin: winters in South America south to Uruguay and Chile; casual in winter in southern Texas and Mexico; in migration occurs in western Mississippi valley, West Indies, and Central America; less common on the Atlantic coast, and casual in British Columbia, New foundland, and Bermuda. 
Alhourh considered rare, the Stilt Sandpiper is more numerous along the Ithatic coast than is supprosed, since it is frequently mistaken for the lellow-legs by gunners ur by thone not trained to close observation. The similarity of the two species is acknowledged by the populat name. "Bastari letlow-legs," which the sportsmen of I.ong Island have given w the sitilt Sandpiper. The different color of the long legs will always be a distinguishing mark, hwever, botween these collins.

It thies in focks, or individuals mily join forees with other species, $A$ Stilt Sindpiper among a number of Semipalmater Sandpripers is instantly noted, his long less raising his body conspicuously above his smaller companions. Its gentral habits of feerling are similar to those of the smaller sanduiper.

\section{KNOT}

\section{Tringa canutus Limaus}

\section{1. () U. Number 234 see folor Plates 33,34}

Other Names.- Red Sandpiper: Red-breasted Sandpiper: Rerl-breasted Plover; Freckled Sandujuer: Ashcolored Sandpiper: Canute's Sandpiper: Gray-back: Silver-back; Robin Snipe: White Robin Snipe; Robinbreast; Reach Robin; Red-breast: Buff-breast: Buffbreasted Plover: Horsefoot Snipe: White-bellied Snipe; Mfay-bird; Blue Plover; Silver Plover.

General Description.- Length, Io inches. In summer, color of upper parts grayish-brown and the breast rufou-brown; in winter, plain gray ahove and white below. Bill straight, longer than the head, and flattened and enlarged at tip: toes slender and not webherl at base.

Color.-Aduts iN Summer: Upper parts, grayish-brown narrowly streaked on crown and back of netk wh dusky; feathers of back and shoulders, tipperl and edged with graysh-white, those of shoulders, tinged with yellowish-brown; rump and uppr tailcorerts, white with traverse hars of dusky-brown: tail, arayish edged witl ashy-white: line over and hack of eye, sides of head, chin, throat, and under parts, plain rufous-brom shading into lighter on flanks, into white on under tail-coverts: latter with arrowhead spots of dusky; wing-coverts and secondaries, grayish edged with ligbter; primaries, plain dusky gray: bill and feet. greenish-flack: iris, brown. ADULts iN WINTER: . Hooce, plain grayish; crown, streaked with darker gray, feathers of back, wing-coverts, and secmdaries, erlged. or not. with whiter; rump and upper tail-coverts. white with dusky spots and hars; primaries, dusky, lighter

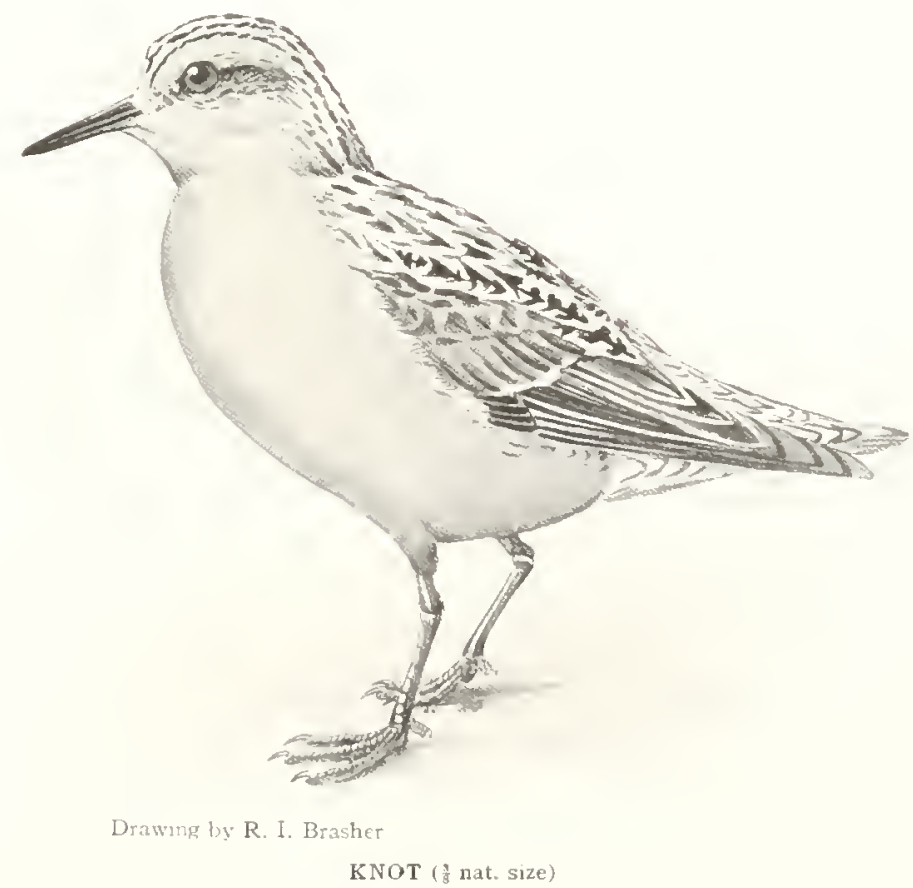

$A$ bird that is known on the shores of every continent 
timped: beloat, white: sides of breast and sides, with dusky markings more distinct and wedge-shaped on sides; an inclistinct dusky line from gape through and back of eye; legs and bill, dusky-greenish; iris, brown.

Nest and Eggs. - NEST: A depression in the ground. lined with grass. Eugs: 4, light pea-green, speckled witl brown.

Distribution.- Northern and southern hemispheres: breeds from northern Ellesmere Land south to Melville Peninsula and fceland, and also on Taimyr Peninsula, Siberia; winters south to southern Patagonia, and from the Afediterranean to South Africa, fndia, Australia, and New Zealand; casual in winter on the Atlantic coast of the United States; in migration uccurs on the Atlantic coast of North America and over most of the eastern lemisphere; rare in the interior of North America and on the Pacific coast.
A flock of Kinots tripping along the leach in their spring plumage with rufous breasts gives the observer the impression that some Robins have acquired nautical propensities and come down to the ocean for a change of food. While following the retreating surges gleaning minute crustacea left stranded by the recession of the waves they talk in soft low notes to one another and are so preoccupied that they often come within a few leet of a motionless watcher.

After nesting in the extreme North they return to the coast in the attumn with an entirely different dress, no longer with the robin's breast, but with a soft gray above and white below.

Like some other maritime birds, individuals oiten remain as far south as Long Island, New lork, all summer, being apparently not interested in marital duties - wise bachelors or old maids who prefer a good table and comfortable climate to the long journey and inclemency of the Arctic
Circle, where those with a proper sense of domestic responsibility settle down for a few weeks and raise a family.

When not harassed by gumners they are remarkably gentle and unsuspicious, and I have laid in a hollow scoopred out of the sand while a flock fed all around me, one or two actually peeping over the edge of the pit, within three feet of niny face!

The Knot is an industrious eater of grasshoppers which are injurious to crops, and of crawfishes which do much damage in rice and corn fields in the South and to levees by boring into and weakening them. It also feeds upon the marine worns which are destructive parasites of the oyster, and upon the diving beetles which prey upon the natural insect food of fish. For these services it is entitled at least to such protection as will guard against any decrease of the species.
R. I. Brasiter.

\title{
PURPLE SANDPIPER
}

\section{Arquatella maritima maritima (Brïnnich)}

\author{
1. 1) U. Numler 2.35 See folor l'late $3 t$
}

Other Names. - Rock Sandpiper; Rock Snipe: Rock Plover: Rock-lind: Rockweed liird; Winter Rockbird: Winter Snipe.

General Description.-1,ength, 9 inches. Principal colors, black and white. Legs short and strons. General build, sliort, thick, and squatty.

Color.-ADULTs in SUMMER: lpper parts, black: crown, streaked with yellowish or grayish-white; back and shoulders varied with chestuut, pale huff, or whitish, the reddisl color on sides, the paler colors tipping the feathers: sides of head, with a rufous wash, separated from the crown by a whitish line: under parts, white shaded on throat and breast with tawny and here and there streaked with blackish; rest of lower parts with dusky-gray markings: rump and upper tail-coverts, plain dusky; wings, dusky; lesser wing-coverts, narrowly tipped with white; greater coverts, broadly tipped with the same; secondaries, mostly white increasing in size toward the inner feathers: inner tail-feathers, dusky: outer ones, gray. ADELTS IN TVINTER: Entire upper parts, soft blackishfrown with purple reflections, each feather lighter borlered; greater and lesser wing-coverts, inner secondaries, and shoulilers, edsed and tipped with white; secondaries, broadly tipped with white: primaries, deep dusky: upper tail-coverts and middle tail-feathers, like color of hack; outside tail-feathers, light ashy; throat and briast, broanish-ash shading into the white of rest of under parts; feathers of side, with wedge-shaped light dusky centers: lores, dusky : eye-ring, whitish ; bill, yellow with dusky tip; feet, dull orange-red.

Nest and Eggs.- NEST: Slight depression in the ground, thinly lined with dry grass. Ergs: 4. grayish ulive, boldly and distinctly marked with rich burnt umber over the entire surface.

Distribution.- Northern hemisphere: breeds from 
$m$
$m$
$\frac{5}{\pi}$
$\frac{\pi}{n}$

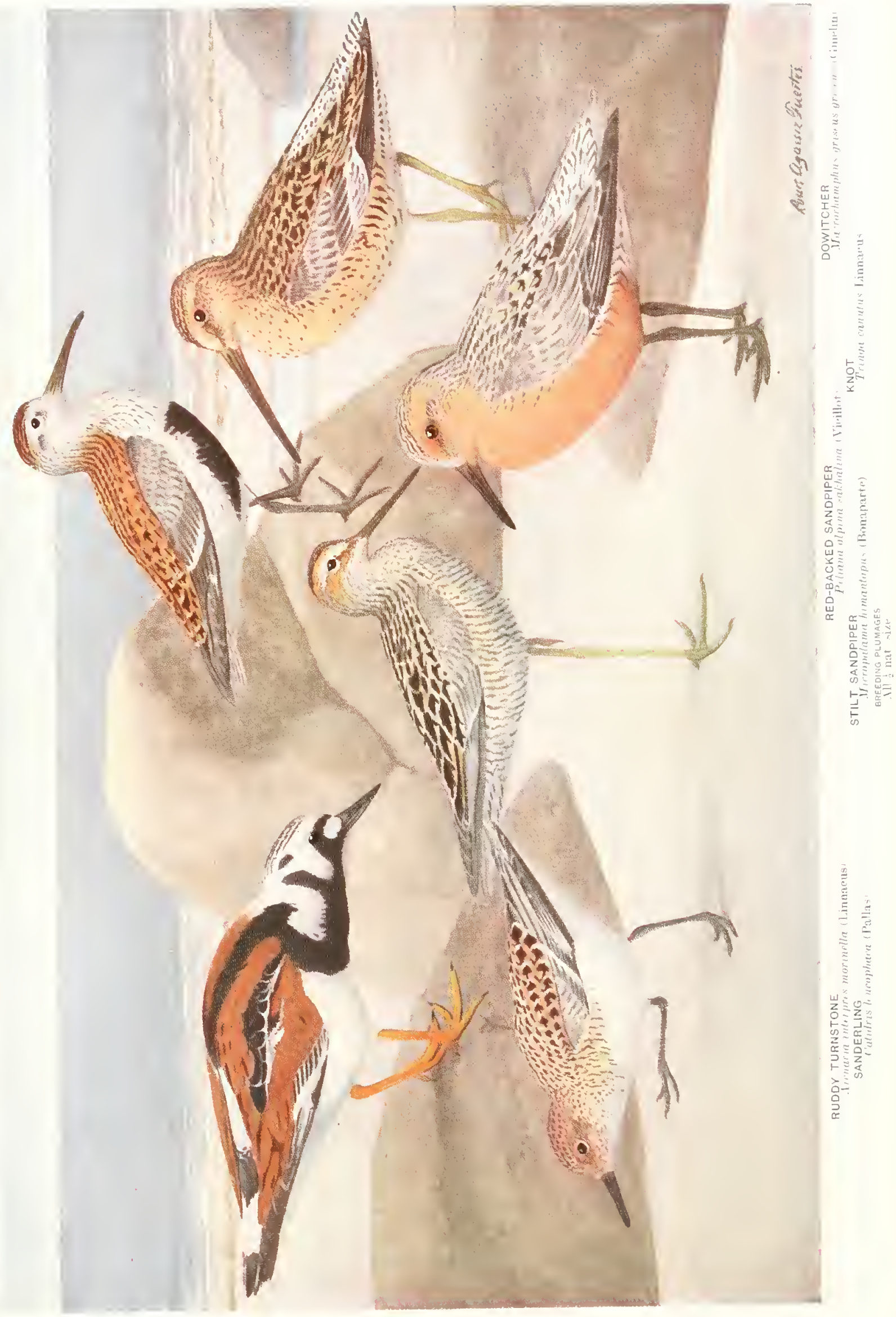



Melville 1sland, Ellesmere Land, and nurthern Greenland somth to Melville l'emmala, Cumberlinel sound, ancl sonthern Greenland, and in Nurway, Rusia, Siberia, Iceland, and Farue [nlands; winters from somthern
Greenland ant New lirunswik to Loner l sland; caunal in migration to the Great Lakes, Georgia. Florila, and liermuda, and in the Eistern Hemisphere south to Great Liriain and the Metiterranean. $\triangle$ member of the Snipe family feeding on the wintry beach seems almost as much out of place ats a Hummingbird and the ob-erver is likely to think the birl's jumrney hals leen interrulted by injury.

I have secn I'urple Sandpipers min the rocky Maine coast in becomber, seatching carefully in seaweed for their fond and ajplarently indifferent to the colld. Is nearly an I coulit make unt they reemed to le feeding on imall mussels and clams, which they swallowed shell ancl all.

Although nowhere common in . Inerica, since its principal line of migration follows through Norway into other fart of Europe, it can be found during the winter nonthe as har south as Long lslanul, $\mathrm{N}$. Y., where, like the Ipsurich Sparrow, it is less rare than is generally supposed because few observer brave the onren wind-swept dunes in winter.
Two varieties of the f'urple Simdpiper occur in Alaska. These are the Nleutian Sandpiper (. Hequatella maritima anesi) and the I'ribilof

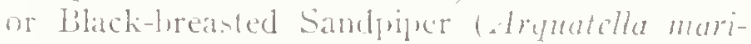
tima ptilocnemis). When first describerl these two subspecies nere supposed to be separate species from each other and from the l'urple Sandjiper, aluhough a close relationship between the three was acknowledged. Careful study has established their exact status. In their respective winter plumages the Aleutian and I'urple sandpipers ate not distinguishable and in the other seasons there is very little real difference between them, but the Aleutian both lineed. and winters within the houndaries of Mlaska, occasionally straying over to Plover Bay, Siberia. The Pribilof sandpiper breed on the St. Jawrence, St. Matthew, and Pribilof islands and winters on the coast of southeastern Alaska.

R. I. BR.ASHER.

\section{PECTORAL SANDPIPER}

\section{Pisobia maculata (licillot)}

1. () U. Number 239 tee Color I'late 35

Other Names.-Grass Snipe; Jack Snipe: Grassbird; Meadow Snipe; Cow Snipe; Prownie: Mrownback; Triddler; Hay-bird: Fat-bird; Short-neck; Squat Snipe: Sinatter; Krieker: Marsh Plower.

General Description.- Length, 9 inches. Color above. browni-l1-black: leclow, white marked with dusky

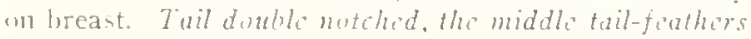
pointed and lonere than all the ollers.

Color-Crown, streaked with blacki-h-brown and chestnut; sides of head, nech, and brast, pali yellowish-

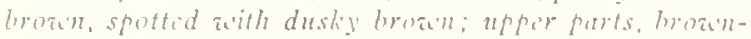
ish-hlack, wach fouther edged wilh ashy or chistnut, shovlder feathers with lighter margins; outer npper tail-coverts, white with arrowhead spots of dusky; lesser coserts, bruwn with hroad hrownish-ash edges; secondaries and greater coverts, brownish, elferl and tipped with white: primaries, dusky black; contral tailfiathors, broanish-black with lighter edges; rest of tail-feathers, anhy, margined with white; throat, abdomen, and under tail-coverts, white; sides, yellowishbrown spotter with dusky; bill and legs, dusky-greenivh; broad, indistinct stripe above, and a ring around, cye, whitish.

Nest and Eggs.- NEsT: On the ground; a mere ilepresion, sparsely linerl with grass. Eocs: 4. greenish-trab, spotted and blotched with brown.

Distribution.- Nurth and South Anerica: breets on the Arctic coast from morthern Alaska to mouth of Yukon and northeastern Nackenzje: winters in South America from Peru and Bulivia to northern Chile, Argentina, and central Patagonia; in migration very rare on P'acific coast sonth of Pritish Columbia, except in Lower California: common in fall migration in Mississippi valley and on the Atlantic coast, rare in spring: casual in northeastern Siberia. Unalaska, and Greenland: accidental in Hawaii and Englani.
"During the mating season the male Pectoral Sandipiper develops a sreat pouch, formed of the skin of the throat and breast, which he is able to inflate until it is nearly as large as the body. Ile now becomes a song bird. and flutters upward twenty or thirty yards in the air, as if 
emulating the famous Skylark, and, inflating his great pouch, glides down again to the ground; or he flies slowly along the ground, his head raised high and his tail hanging straight down, uttering a succession of booming notes. Is he struts about the female his low notes swell and die away in musical cadences." (Forbush.)

Alhough migrating in flocks the "Krickers" scatter when a good feeding meadow is reached, and are generally flushed from the grass singly. They prefer the bayside meadows, and are seldom seen along the margins of ponds or on the beaches. It is probable that they "fatten up" on some favorite food further north, for they are extremely fat when they arrive on the Long Island (N. Y.) marshes in September. They "lie" well, flushing within easy gunshot range with a flight similar to that of Wilson's Snipe but less rapid. The zigzags are shorter, the course rapidly straightens out, and if the "sportsman " waits a few seconds after they spring, it is not difficult to add them to the "bag." When the early morning mists of September hang low over the meadow's Pectoral Sandpipers, magnified by the fog, apjear nearly as large as Wilson's snipe.
R. I. BRASHER.

\title{
WHITE-RUMPED SANDPIPER
}

\section{Pisobia fuscicollis (I Ticillot)}

\author{
1. O U. Number 2 .
}

Other Names.- Bonaparte's Sandpiper; Schintz's Sandpiper: Sand-bird; Bull Peep.

General Description.- Length, 7 inches. In summer. the upper parts pale brownish with dusky stripes and the lower parts white with brownish markings: in winter, brownish-ash above and whitish below. Middle tail-feathers pointed and longer than others.

Color.-Adults in Stumer: Crown and upper parts, pale brownish, each feather with a large dusky center, forming stripes on back; crown, striped with dark brown ; shoulders, more chestnut; rump and upper tail-cozerts, ahite; central tail-feathers, brownish-black, the rest light grayish, broadly edged and tipped with white; sides of head, neck, and breast, washed with pale yellowish-brown, spotted with darker; an indistinct dark brown streak from bill through and behind eye; wing-coverts and secondaries, grayish-brown edged with lighter; primaries, dusky; chin and throat. white: abdomen and rest of under parts, white; bill and feet, dusky-greenish; iris, brown surrounded by a white ring. ADtuts in IVINTER: Crnain, back of neck. back. and shoulders, brownish-ash, indistinctly streaked with darker; rump and upper tail-coserts, white; central tail-feathers, dusky; the rest, light ash: some feathers of shoulder and back, deep chestnut edged with white; wing, as in summer; a broad streak over eye, chin, throat, and under parts in general, whitish faintly spotted with pale brown; a streak from bill through and behind eye, dark brownish-ash: bill, dusky horn, lighter at base; feet, dusky-greenish; iris, brown surrounded by a white ring.

Nest and Eggs.- Nest: A depression in the ground. lined with a few leaves. Egos: + light olive or olivebrown, boldly spotted and marked with deep sepia. chiefly at large cnd.

Distribution.- North and South America; breeds along the Arctic coast from northwestern Mackenzie to Cumberland Island: has occurred in summer west to Point Barrow and east to Greenland; winters from Paraguay to southern Patagonia and the Falkland Islands; in migration most abundant in the Mississippi valley, less so on the Atlantic coast; casual in the Bermudas, Great Pritain, the West Indies, and Central America.
The While-rumped Sandpiper is usually found among the Least and Semipalmated Sandpipers tripping over awash seaweed or running along the shore. They seldom associate with flocks of their own kind, but prefer the company of other species. In autumn plumage they can be easily confused with the smaller Sandpipers, but close scrutiny will reveal the white upper tail-coverts - a conspicuous identification mark. Their habits are similar to those of other members of the family and they are naturally unsuspicious unless repeatedly disturibed.

An important part of the diet of the Whiterumped Sandpiper consists of grasshoppers of species known to be injurious to crops. This is a real service to man which should not be overlooked when measures for the adequate protection of the birds are considered. 
$\frac{+}{2}$
$\frac{1}{a}$

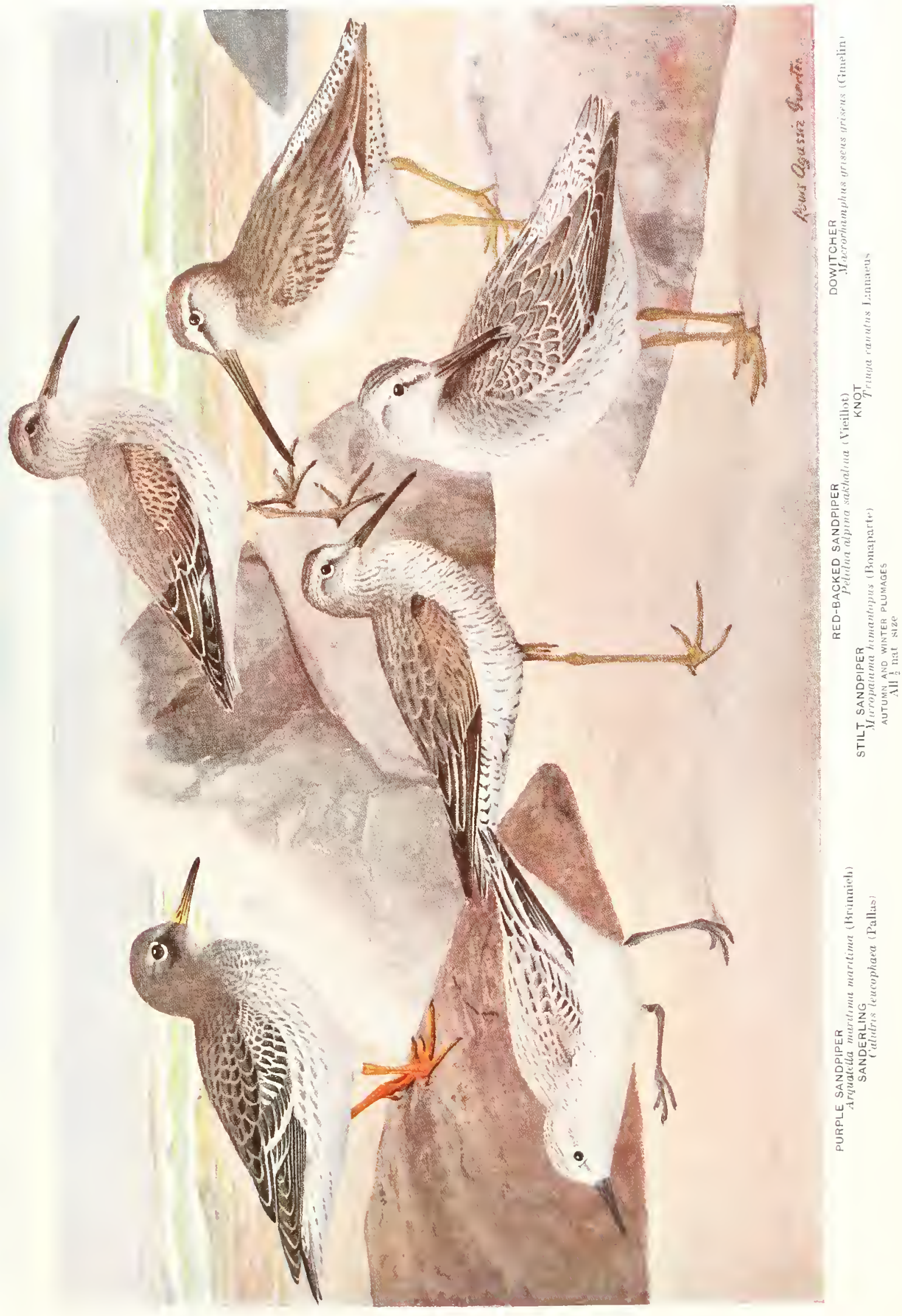





\title{
BAIRD'S SANDPIPER
}

\author{
Pisobia bairdi ( (omes)
}

\author{
1. O [. Number z+t See lolor fliate 35
}

\section{Other Name.-Grass-bird.}

General Description, - Length, 7 inches. Color above, brownish-black: below, white with pale lurownish un breant. Resemblea the Pectoral Sandpiper but smaller and breast less heavily streaked.

Color-Anciss: Entire upper parti, hrownishblack, each feather horlered and tipped with light redish-yellow, these tips broader and nearly pure white on shonlders: coverts and secondaries like back, latter lighter tipped: central tail-feathers, brownish-black: remainder, successively lighter, all narrowly borrlered with white: breast fole broanish ath faint spots and streaks of dusky; throat and under parts, white: bill and legs, dusky : iria, brown. Young iN Autums: Sides of head, throat, breast, and upper parts, including wings, nearly uniform pale yellowish-hrown, each feather darker centrally: crown (atrongly), sides of head, throat, and breast (more faintly), streaked or spotted with brown; rest of under prarts, white: bill, rlusky, lighter at base; legs, dull olive.

Nest and Eggs. - NEST: A depression in the ground tmiler shelter of tuft of grass, lined with a few leaves and grasses. Eacs: + buffy, spotted with shades of chestnut-browin.

Distribution.- North and South America: breeds along the Arctic coast from Point Barrow to northern Keewatin: wintera in Chile, Argentina, and Patagonia; wecurs regularly in migration from the Rocky Mountains to the Miscissippi River, and in Central Anerica anl northern South America, and irregularly in autumn in the Pacific coast from Alaska to Lower California and on the Atlantic coast from Nova Scotia to New lerey: casual in summer in Ginerrero. Nexico; accidental in England and South Africa.
Mthough it is slightly larget than the J ceast and Semipalmated Sandpipers it is not easy to distingush the Bard's Sandpiper from those species. Its general color in the field is more yellowish-hrown and it is found almost exclu- sively along the prairie sloughs and lagroons of the Middle West. Its hahits are similar Io other small Sandpipers; it runs along the shore in the same confiding way, and unless frightened will sometimes feed almost at the observer's feel.

\section{LEAST SANDPIPER}

\section{Pisobia minutilla (I icillot)}

1. O C. Number 242 see Color l'late 35

Other Names.-Peep: Wilson's Stint; Ox-cye; Alur-peep: Sand-peep; Little Sand-peep.

General Description.- Length, 6 inches: the smallest Sandpiper. and not heavier than an English Sparrow. Color above, gravish-hrown; below, white with the breant darker. Much like the Semipalmated Sandpiper, but the feet with mo wobs.

Color - Anelts $1 \mathrm{~N}$ Sirmer: Entire uppor ports. dusky broan striped on head and neck with chestnut, each feather on back and houlders edged with chestnut and tipped with whitish; center tail-feathers, hlackish edred with chestnut, others, gray edged with white; wing-coverts and secondaries, brownish edged with hay; necomdaries, tipped with white: prinaries, dusky ; hreast, washed with pale rusty and spotted with hrown: a diffuse streak from bill through anci hack of eye, dusky: hill and leys, dusley grenish; iris, hrown with white eve-ring: throat, ahdomen, and rest of under parts, white. ADULTs IN WiNTER: Entire upper parts, pale grayish-brown, each feather darker centrally: secondaries and primaries, white-tipped; hreast, shated with very lale brownish-gray, spotting olsulete: bill as in stmmer: fiet. jolloaish-strien.

Nest and Eggs.-Nest: Near water; a mere ilepression in the ground. lined with leaves and grass. Eors: 3 or 4 creany-huff to light drah, heavily spotted with chestuut and lavemler.

Distribution.- North and South America: breeds from northwestern Alaska, southern Arctic islands, and northern Ungava to Yakutat Bay. Alaska, valley of the Unper Yukon, northerm Mackenzie, central Keewatin, southern Ungava, Nova Sootia, and Sable lsland: winters from California, Texas, and Nortl Carolina through the IVest Indies and Central America to Brazil. Chile, and the Galapagos: in migration necurs throughout the Lnifed States and west to northeastern Siberia and the Commander Islands, north to Greenland, and in Bermurla: accidental in Eurne. 
To the lover of unspoiled Nature our grand open sea beaches would not seem like the real thing were it not possible at times to see flocks of innocent little Sandpipers running gracefully along the margin, chased by the advancing waves. The tiniest atom of its tribe, the Least Sandpiper, accompanied by several other linds, is still with 11, and is perhaps increasing, thanks to the outlawry of shooting them under the Federal
It was my good fortune to be ahle to study its nesting halits when I found it breelling on the Magdalen Islands, Gulf of St. Lawrence. Ticture there, on these islands, lroarl expanses of meadowy country, carpeted with short grass and moss, interspersed with patches of low spruce and juniper, and dotted with small shallow ponds. Here, in early June, we may listen to a sweet, twittering little songr, and spy the author.

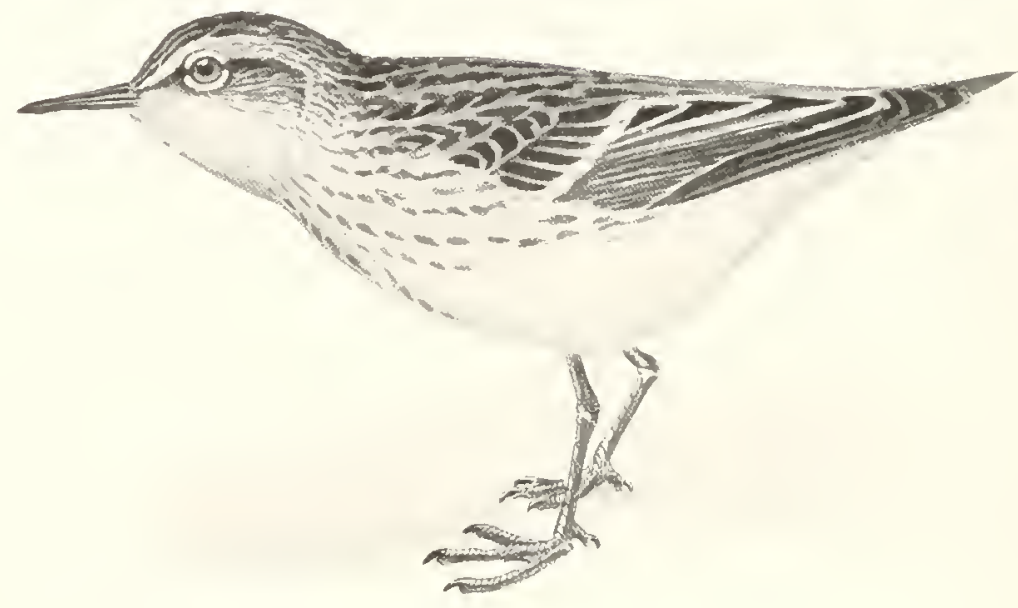

Drawing by R. I. Brasher

LEAST SANDPIPER (3 nat. size)

The baby among shore birds

Law. It will be a sorry day when we need such tiny things for food, each one affording lut a mere taste.

This species and the Semipalmated Sandpiper cunsort together and resemble each other so closely that it is hard at a clistance to tell them apart. There is a slight distinction in halit, in that the Least Sandpiper is more ast to be found on marshes, while the other prefers the heach. though there is no certain distinguishing of them in this way. As things go, they are comparatively common in May and again in August ant the first part of September quite generally over the country, wherever there are any consiclerable bodies of water, particularly on both our seacoasts, also in the Mississippi valley, and (n the shallow prairie sloughs of the Northwest.

Whereas most of the larger shore birds cross to the interior of the continent to lueed, the Sandpipers as a class seem not to avoid the northern Atlantic coast in the spring flight and in the nesting season. This is true of the Least Sandpiper. Though it breeds in the far Northwest, it also does so on our castern coasts, well to the north. not a Warther lont our little Sandpiper, the male bird, circling about on quivering wings, singing to his little mate who loiters on the edge of a

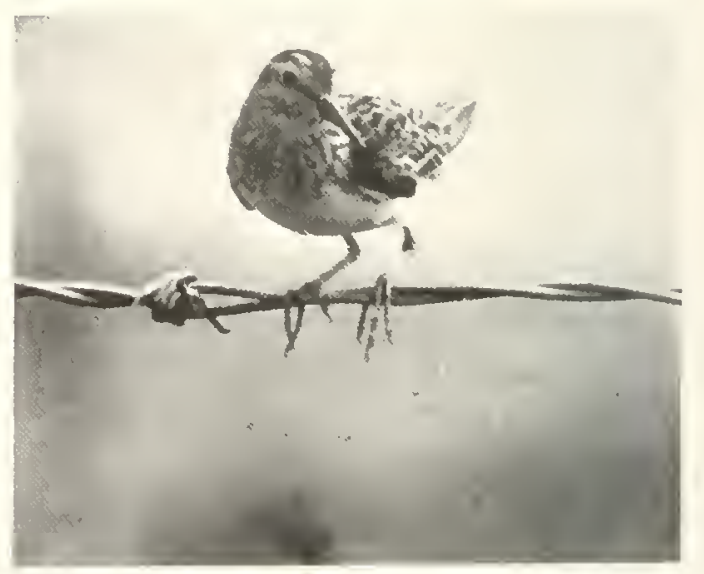

Photo by H. K. Job Courtesy of Houghton Miffin Co.

\section{AN ANXIOUS MOTHER}

Least Sandpiper watching the photographer near her babies

( )ne day, a June 13 , a tiny hird fluttered almost from beneath the feet of my companion, and 
llere was otr first nest of the Least Samdpiper, a litlle hollow in the northern moss, lined with dry bavberry leaves, and holding four eggs, large for the size of the bird, and wide across, thomsly somewhat pointed. The tiny owners trailed around at our feet in abject despair. Finally we compromised by persuading the female to allow ne to photograph her on the nest, after which we parted company.

(1) another occasion, beside the crurle cartroad leading to the fisherman's house where we were staying, a pair of these hirls appeared greally worried over our passing. They ran about, alighted on the wre ience, and scolded plantively. This set tus to searching. but it was some time before I discovered the fotr tiny voung, very recently hatched, huddled together on the gromul among the sparse grass of the adjoining pasture, and a tell-tale egor-shell near liv. Little lufi-colored lulls of down, ormanented with black spots, they were as pretty bird-babies as I have ever seetr. Somehow, these episodes with breeding shore linds of Arctic proclivities. in this crisp northern clime, appealed to me with very special fascination.

HLRBERT K. JOB.

\section{RED-BACKED SANDPIPER}

\section{Pelidna alpina sakhalina ( $/$ icillot)}

A. O. U. Number $243 \mathrm{a}$

Other Names.-American Dunlin: Black-leellied Sandpiper: Brant-bird; Red-back; Red-backed Dumlin ; Lead-back; Ox-bird; Fall Snipe; Crooked-billed Snipe: Crooked-hill; Little Blackbreast: Winter Snipe: Simpleton; Stib; Black-heart Plover (Ontario).

General Description.- Length, g inches. In summer, upper parts chestnut and the luwer parts white with a black patch; in winter, upper plarts lark a hhygray, under parts pale ashy-white. Bill, rather long and terminal third bent slightly downward.

Color.-Adults in SuM MER: Crozen, back, shoulders, rump, and upper tail-cozerts, chestuut, crown, streaked wilh dusky, rest of feathers of upper parts with rlusky centers, many with whitish tips (especially behind): tail, wing-coverts, and secondaries, anhy-gray: seconduries, broadly athite-tipped, coverts with darker centers; primaries dusky, some inner ones edged with white at bare; sides of head, back of neck, chin, throat. and rest of tuder parts, white; abdumm, with a broad arelety-bluck putch: other whitish parts above, streaked with pale dusky; bill, dusky-yellow; legs, dark horncolor; iris, brown with a dusky spot in front. ADuLrs IN VInTFR: Entire upper parts, dark ashy-gray, lightening over eye and streaked with whitish on back of neck:

\author{
See Color I'lates 33.34
}

feather, of back, faintly ontlined with lighter: wingcovers and secondaries, more brumish: feathers. darker centrally, secondaries narrowly white-tipped: primaries, deep dusky, the inner unes whitish at base forming a constricusus zthite spot; chin, throat, and rest of under flarts, fale ally-white; black area of smmmer plumage entirely ahent; under parts from throat, obsoletely streakell with dusky; bill and legs, dtrisky-greenish; iris, brown.

Nest and Eggs.- NEsT: A hollow in the ground, in or near salt marshes or frem-water lakes and ponds. FGos: 4, pale greenish to bruwnish-buff, spotted with dinll umber, chestmut, and sepia.

Distribution. Nurth America and eastern Asia: breeds on the northern cuast w Silheria west to month wi lhe Yenisei, and from Puint Barrow to mouth of Inkon, and in Poothia and Melville peninsulas, and nurthern Lngava: winters on the Pacific coast from Washington to southern I. ower California and from New Jersey (rarely Massachuretta) south to Louisiana and southern Texas, and in Asia from China and Japan to the Malay Archipelago; rare in migration in the interior of the United States except about the southeru (x)d "if Lake Michigan.
- Ilthotigh the Red-backed Sandpijer is found often in the interior of North Imerica, in New Fingland it is confined mainly to the neighborhood of the sea and largely to the salt marshes, but also frequents sand bars and metrl flats. It is an active little bitd ustally keeping in companies, which run about nimbly and fly very rapidly. profoming varied evolutions in concert, as if drilled to act logether. In the breeding season it has a rather musical flight song. which never is heard except in its northern home, so far as 1 know. IVhen frightened or flying it has a hoarse, srattines note.

There seem to be two well-delined migration routes of this species: one from. Maska and Siberia down the Pacific coast of North . Imerica. and one from IIndson biay. Lnemal, and the lands to the north clown the Itantic coast. 
The Atlantic birds winter mainly in the United States, and the Pacific birds are common in winter only as far south as southern California. The future of this species, therefore, is in our hands. It can he protected or exterminated by the people of the United States and Canada. In spring the eastern migration passes more to the west- ward, and the species appears in numbers on the Great I akes, becoming rare to the northeast of Massachusetts.

The Red-backed Sandpiper feeds largely on worms, crustaceans, and insects.

Edward Howe Forbusn, in Game Birds, Itild-Fozel and Shore Birds.

\section{SEMIPALMATED SANDPIPER}

\section{Ereunetes pusillus (Linnaus)}

1. O. U. Number 2.46 See Color l'late 35

Other Names.- Peep; Little Peep: Sand-peep; Black-legged Peep; Ox-eye; Sand Ox-eyc.

General Description.- Length, 61/2 inches. Principal color above, chestnut; below, white with spots on breast. Toes, accbed at base; bill, straight and enlarged at tip; tail, double-notched.

Color.-Abults in Summer: Above, varied with black, pale chestnut, ashy, and white, each feather dusky centrally with a reddisl edge and whitish tip: rump and upper tail-cozerts, dusky, more whitish on sides: central tail-feathers, brown, others, ashy-gray; wing-coverts and secondaries, brownish and rufous, edged with lighter; primaries, plain dusky: a dusky line from gape through and behind eye and a white line above; lower parts, pure white tinged with palc rufous on breast, where spotted with pale dusky; bill, black; legs, disky grecn; iris, brown. Adults in Winter:
Above, plain ashy, the feathers lighter-tipped; light ends of secondaries, less conspicuous as is also the line through eye; under parts, pure white with dusky spotting very faint; bill, legs, and iris, as in summer.

Nest and Eggs.- Nest: A hollow in the ground, lined with dry grass. EGGs: 3 or 4. from grayish to olive, nsually boldly spotted and splashed with brown or chestnut, but sometimes finely dotted over entire surface.

Distribution.- North atd South America; breeds from the Arctic coast of North America south to mouth of Yukon and to sonthern Ungava; winters from Texas and South Carolina through West Indies and Central America to Patagonia ; migrates mainly east of the Rocky Nomntains; casual in British Columbia, Pribilof Islands, and northeastern Siberia; accidental iil Europe.

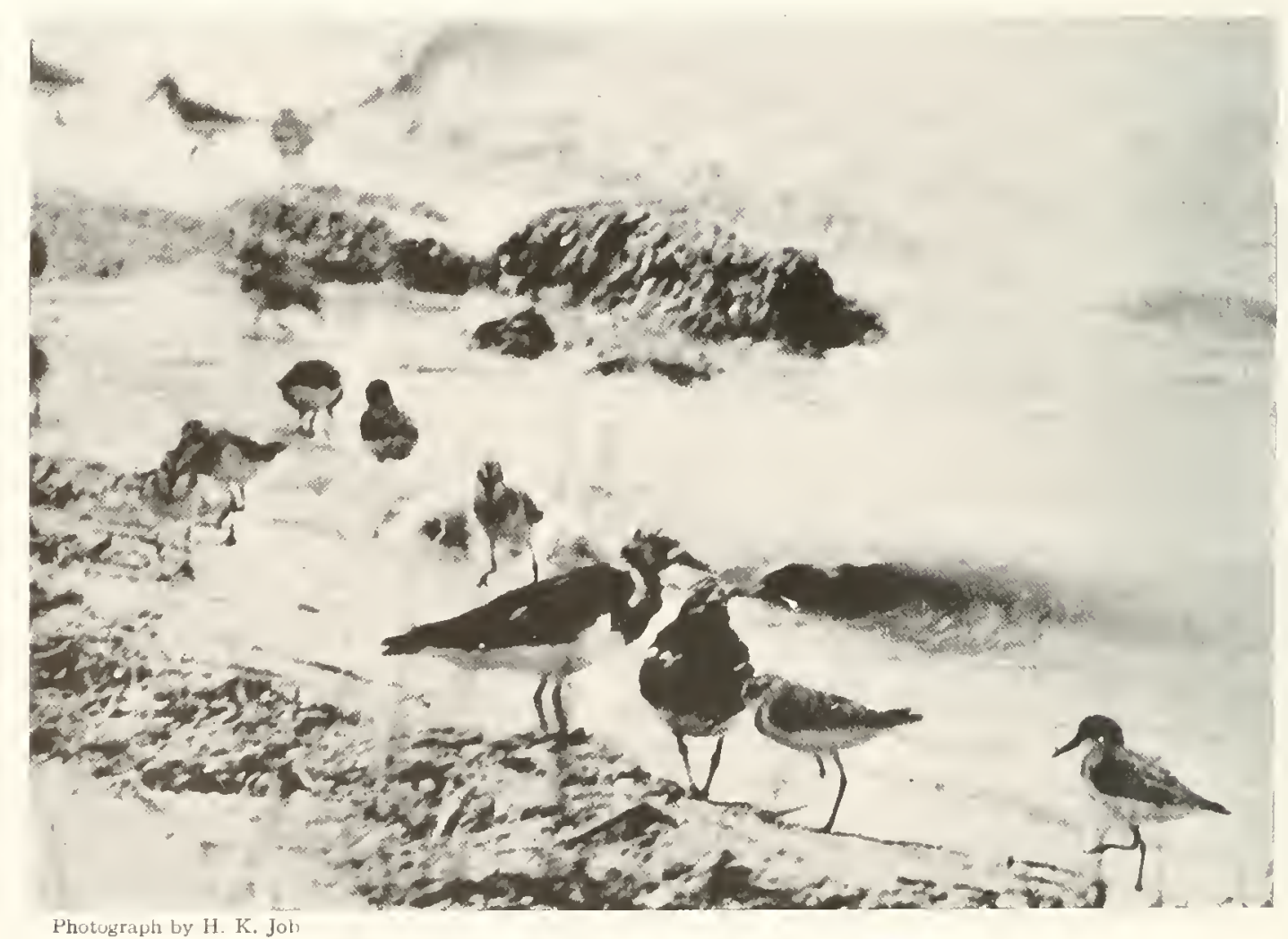

TURNSTONES AND SEMIPALMATED SANDPIPERS 


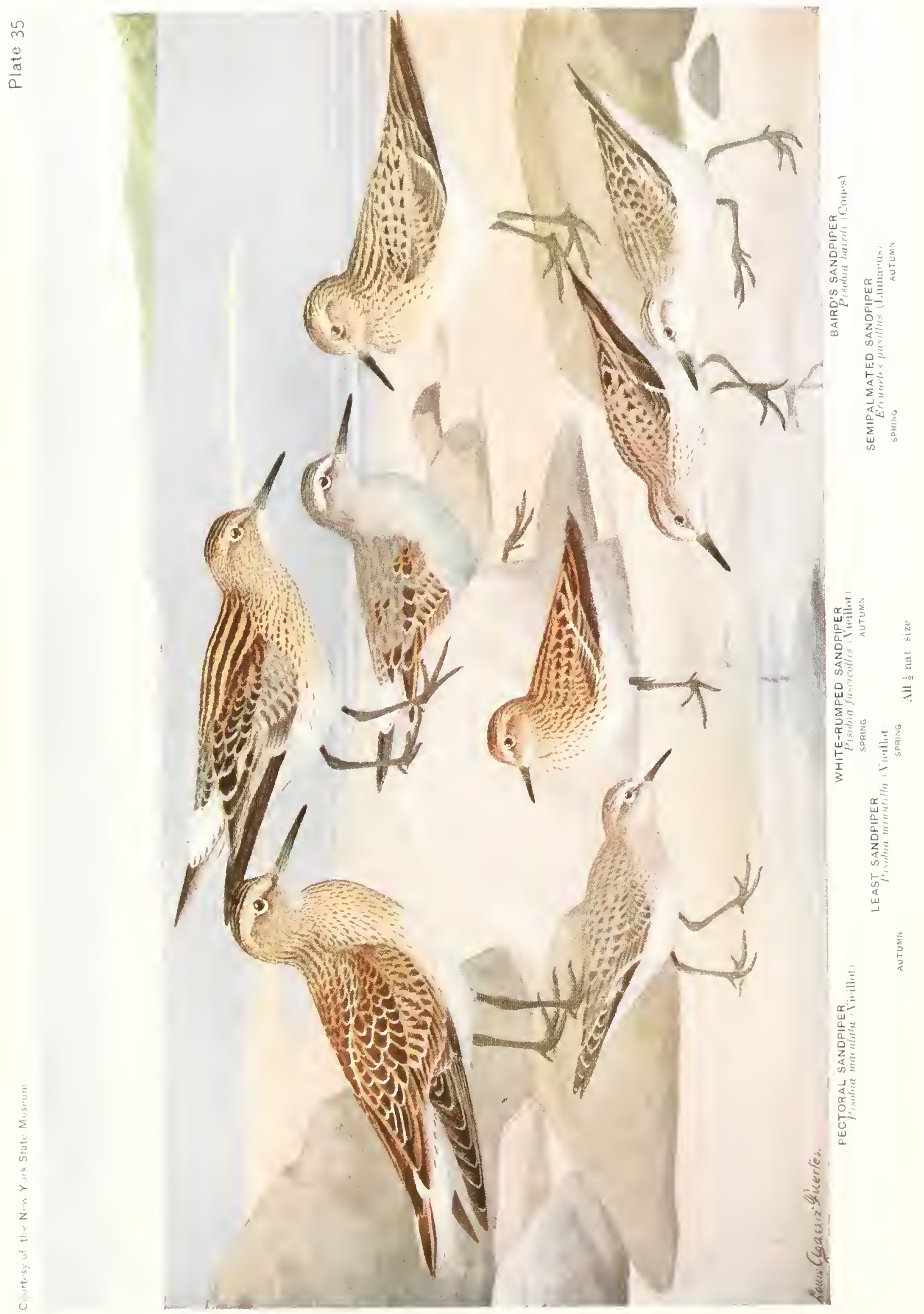



The semipalmated sandpiper is a socialle little bird usually found in complany with other small Sandpipers, enpecially in that of the least Sondpiper to which it is similar in general habits and appearance. It in partial to the open sand beaches - following the receding waves, seizing its minute crustacean food from the lackwash, and cleverly chuding the returning surf. It is more of a sant lird and less of a mud hird than the Least Sandpiper. Positive identification in life is imposible unless a very close view is obtained, enabling the observer to sec the semiwelibed feet.

It is constantly on the move, but, notwithstanding its great activity, it becomes very fat when food is abundant. (On a winly day I have seen little groups of then settle down under the lee of a marsh tuscock, preening their feathers and indulging in a siesta of repletion, heeping up a continuous peeping of contentment. These loafing spells hecome more frequent ats the autumn days wane, and they are loatl to leave a sumny nook under a liank sheltered from the strong northwest wind. I have sailed a sharpie within ten feet before they would take wing with querulous th-ateds lu-aicets of resentmuent.

In its winter plumage the Wentern Sandpiper (Erinnetes manri) can only be distinguished from the Semipalmated by its longer lill: in the summer the colur of its upler parts is richer and more rusty with stronger markings. The curious and remarkable thing about this bird is that while it breeds in a narrow strip of territory along the northwestern coast of Alaska, it is a common winter resident in the sontheastern United States from North Carolina to Floriela and Lounisiana.

This long journey across the continent is not paralleled by any other shore bird; it is, however, comprarable to that of several species of ducks. Just what route this migration follows is unkimon as there are no records from the interior to show which waly the hirds passed. The llestern Sandpiper also winters from Lower California to Venezuela. The individuals that pass the winter in eastern South America prohably migrate over the seas from filoridi.

R. I. Brasher.

\title{
SANDERLING
}

\section{Calidris leucophæa (Pullas)}

\author{
1. O C . Number 248 See Color Plates 33,34
}

Other Names.-Ruddy Plover: Reach-hird; Surf Snipe; White Snipe; Beach Phver; Whitey; Bull Peep. General Description.-Length, 8 inches. 1n summer, principal color above, chestnut: in winter, pale bluishash. Under parts always white, but the breast finely spotted in summer. Only thrie toes (hind toe missing); front toes with narrow marginal webs.

Color-Aduts in Summer: Entire upper parts. varied with black, ash, and chestnut, on back and slioulders each feather black centrally, broadly margined with reddish and tipped with white: wing-coverts, secondaries, and primaries ashy, the feathers lighter on edges of coverts, secondaries, white-tipped, and a athite sput at base of primarics; rump, upper tail-coverts, and central tail-feathers, clusky, tipped and edged with ashy white: rest of tall-feathers nearly white; under parts, white, fincly spotted with dusky and chestnut on sides of throat and breast: bill and legs, lusky: iris, brown. ADCLTS IX WINTER: Upper parts, pale bluich-auh, the crown narrowly streaked with darker and the feathers (m) back fading into white on edges; shoulders and inner secondaries, with darker centers; wing-coverts. like back; secondaries, largely arhite; primaries, dusky, whitening at base; an indistinct dusky line from bill through eye; line above eye, cheeks, and entire under parts, pure white; bill and legs, black; iris, browil.

Nest and Eggs.--NEst: A depression in the ground, lined with grass or leaves. Eacs: 4. light olive-brown, speckled and spotted with different shades of brown, chiefly at large end.

Distribution.- Northem and southern hemispheres; breeds from Mtelville Island. Ellesmere Land, and northern Greenland to Point Barrow, Alaska, northern Mackenzie, Iceland, and in northern Siberia: winters from central California. Texas, Virginia, and Bermuda to Patagonia, and casually to Massachusetts and Wasliington: also from the Mediterranean, Burma. and Iapan to Sonth Africa and various Pacific islands. including Hawaii.
In the sumny days of September, where the White-maned horses of the sea, urged onward ly the winds, charge in long rows and thunder down

$$
\text { Vor. } 1-I y
$$

upon the sands of Cape Cod, the Sanderling is in its element. Malching the very sand in color it is almost invisible while spuatted on the upper 
beach at high tide, waiting for the recession of the waters; but as the ebb begins, the little flock scatters along the shore, retreating before each wave, following down the backwash, until sometimes forced to fly by the onconing surge, intent upon the flotsam and jetsam of the sea washed up for their delectation, spread for a brief moment upon the sloping sands and then carried back into the deep. The Sanderling neglects no opportunity. It follows its prey at times until up to its breast in the wave but always nimbly aroids immersion. Because of this habit, the Sanderling is beter known to many as the Surf Snipe. If disturbed the little flock rises, flies out over the surf and turns, flying up or down the beach, now low in some great sea loollow. now just skimming the crest of a foaming breaker, but they soon swing in again and drop- fring upon the sands resume their absorbing occupation.

The Sanderling's common note is a sharp chit. The bird may be distinguished from the little "Sand-peeps," which it much resembles, by its larger size, and from other Sandpipers by its light color and whitish head. When in flight it shows a line of conspictous white spots on the wing. When in hand it may he readily distinguished from all other Sandpipers by the lack of a hind toe - a characteristic of the Plovers. In the swring and autumn nigrations the Sander-ling is not uncommon on the Great Lakes and is recorded from varions parts of the Mississippi valley, but the sea is its first love. Its flights are largely made over the ocean and it can rest on the water if necessary and swim with the ease of a duck.
EDWard I Howe Forbush.

\title{
HUDSONIAN GODWIT
}

\section{Limosa hæmastica (Linnaus)}

\author{
A. O. U. Number 251 See Color l'late 38
}

Other Names.-Red-breasted Godwit: Ring-tailed Marlin; Spot-rump; Field Marlin; Goose-bird; Blacktailerl Godwit; Black-tail: American Black-tailed Godwit: White-rump: Smaller Dough-or Doe-bird.

General Description.-- Length, if inches. In summer, color of upper parts brownish-black mottled with lighter colors, under parts, chestnut: in winter, upper parts plain dull ashy, under parts lighter ash shaded with buffy; always a white spot just above the tail.

Color.- Antets in Summer: Upper parts brownish-black with greenish gloss, variegated with rufous, vellowish, or white, lighter colors scalloping edges of feathers; rump, blachish; upper tail-cozerts, conspicuously ahite; tail, black, white at base and white-tipped: head and neck, streakerl with dusky; under parts, rich chestnut crossed with numorous black hars, these bars tending to spots on breast and neck: rear under parts, crossed also with white bars; bill, oale reddish, terminal third black; legs, bluish-gray: iris, brown. ADULTs in Winter: General plumage, plain dull ashy lightening on head, neck, and under parts where shaded with pale buffy; tail, as in summer: upper tail-coverts, conspicuously zhite; bill, flesh-colored with dusky tip; feet, bluish-gray. Plunages intermediate between the two are common.

Nest and Eggs.- NEsT: A hollow scooped out of the ground, lined with a few leaves and grasses. EGGS: 4. dark olive-drab marked with still darker brownish sharle of the ground color.

Distribution.- North and South America; breeds from the lower Anderson River sontheast to central Keewatin; winters in Argentina. Patagonia, and the Falkland 1slands; in migration occurs principally east of the Great Plains, most commonly on the Atlantic coast in autumn and in the Mississippi valley in spring; casual in Alaska.
The Codwits constitute a genus (Limosa) of the Snipe and Sandpiner family, and include about half a dozen species of which two are American hirds. Two others, the Pacific rodwit (Limosa lapponica baucri) and the Black-tailed Godwit (Limosa limosa), are included in checklists of North American avifauna - the first becatse a few individuals have straved from Siberia to the islands off Alaska and there reprorluced their kind, and the second because of its acci- dental occurrence in Greenland. The Godwits are characterized by a very long and slightly upward-curved bill, which is grooved nearly to the tip; the shanks are partly bare; the middle or outer toes are partly webhed; the wings are long and pointed: the tail in length equals or somewhat exceeds the wing. Their prevailing color is reddish or brownish, but there is considerable variation of color according to age, sex, and season. 
Marked peculiarities of the genus are that the females are larger than the males. and that incubation is performed by the males. The birds are found in marshes, salt-water meatows, and along the shores of bays or lakes. They place their nests on the grount, lut not invariably near water, and lay three or four eggi, of a generally drab hue, marked with lark loown. Their food, which consists of acuatic insects, shell-fish, worms and the like, ther cajture by probing the sand or mud with their long bills, or by following retreating waves and watching wp the mall creatures thus leit stramled.

Of the Iludsmian (iodwit Mr. Forhush ats: "During my boyhond I irequently hearil blal gunners atrout Boston tell their tales of the Goose-bird which was well and farorably knum all alone our coast. Lut it is impositile now to tell with certaints whether these tales referred to one or both of the forlwith. The Hudionian Godwit is now less rarp than the larger specios. but few are seen or taken regularly on the Massitchusetts cuast. It is shy, like its larger relative, lut a good bird caller finds no difficulty an luring it to his decors.

"The breeding range and migration of this species are more or less shrouled in my-tery. The egrs have leen found once hy MacFarlane in the Anderson River region, which proves that the birds loreed near the coast of the Arctic sea, and that is about all we know of its breeding range, exeept that it summers in lieenatin. We must assume that the species wres to south Imerica by sea, like the Eskimo Curlew, and lands on Cape cind and Long luland in numbers mly when driven there by stoms. It was conwilered rare by Milom and Iudubon, as it probably never was seen on the coast of the Middle and Southern states in any numbers unless driven in by a severe storm." (Gume Birds, ll'ild Fon'l and Shore Birds.)

The lludnonian fodwit feeds to at considerable extemt upon mosequiteres and horse-Hies, as examination of its stomach has amply proved. It is therefore to be connted a useful bird, since the insects it destroys are known to be hamiul.

\title{
MARBLED GODWIT
}

\section{Limosa fedoa (Linncus)}

\author{
1. O. U. Number 249 See folor l'late 38
}

Other Names.-Great Marbled Godwit: Great Godwit; Ked Curlew: Brant-bird; Marlin: Red Marlin: Brown Marlin: Spike-billed Curlew; Spike-bill; Badger-bird; Dough- or Doe-hir l.

General Description.- Lengtl, 21 inches: largest shore bird, except the Long-billed Curlew. Prevailing color, reddish. darker above: no white spot at base of tail. Bill eurved slightly upward

Color.-A light dull yelluwish-rufous, browner and richer ahove but rarying much in intensity with individuals; broad line over eye. sides of head. chin. and upper throat, more whitish; an indistinct dusky line from bill through and behind eye: crown, brownish: neck all around, spotted with dusky: upper parts with brownish-black center on each feather: rump, tailcoverts, and tail. barred with blackish and brown: primaries, rufous, outer webs and ends of a few outer ones dusky; throat, breast, and sides, tracersily barred with broan. the markings narras'; hill, flesh-colored. luaky on ridge and terminal half; legs, bluish-ash; iris, brown.

Nest and Eggs.- Nest: On the ground in a dry field but not far from water; a depression, lined with srass. Eros: 4. creamy-buff to light oliwe-drab. thickly spotted with various hasles of umber hrown.

Distribution.-Nurth America: hreels from valley of the Sakatchwan south to Xorth Dakota formerly to Jowa and Irisconsin): winters from sonthern Lower California, Louisiana. Florita, and Georgia to Guatemala and Belize: castal in California in winter: in migration occurs on Pacific coast north to British Columbia, and on the Atlantic coast to the Maritime Provinces (formerly) and south to the Lesser. Antilles: accidental in Alaska.
My first acquaintance with the Marbled rodwit was one beautiful June day in North Dakota, when I was wading in a large slough, deep not only in mud and water. hut in the delights of insplecting nests of Canvas-back, Redhead, Ruddy
Duck, and various other interesting water hirds. All at once I hegan to hear loul outcries, and a flock of about twenty hig brown hirds with long straight bills swept past me and alighted in the grass just back from the shore. In great excite- 
ment I followed, and with my binoculars had a splendid view of them as they strode about on their stilt-like less and caught insects.

Not until l visited Saskatchewan did I locate their breeding-grounds. There I found them nesting in scattered pairs, very commonly over the dry prairies. Like the large Curlew, they are partial to an alkaline country. Though they are always in the general vicinity of some slough, their actual nesting is back on the dry prairie.

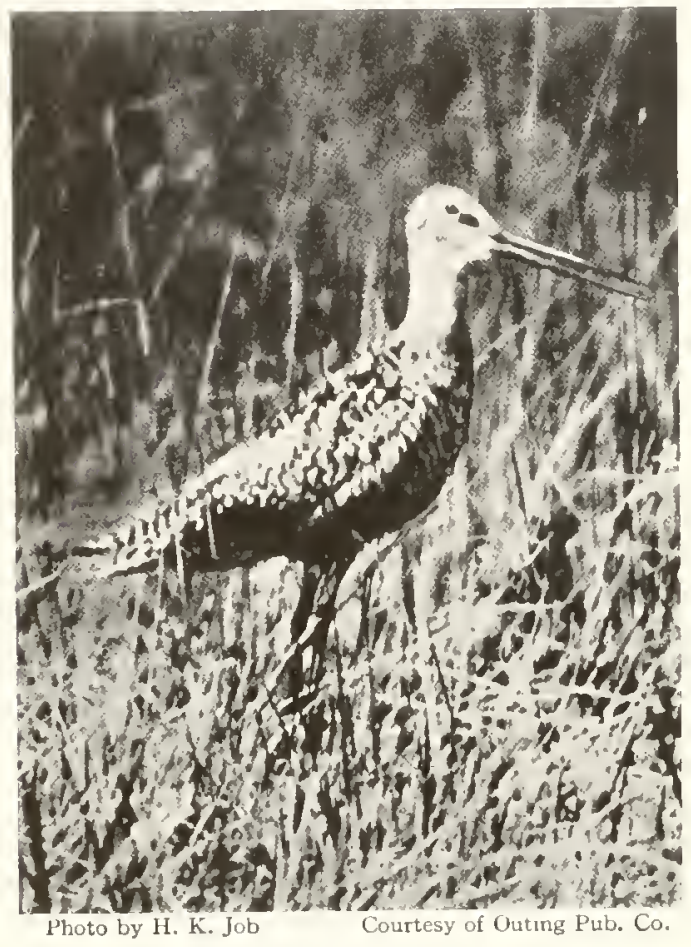

GREAT MARBLED GODWIT

On Saskatchewan prairie

Amid the rather shont dry prairie grass a slight hollow is selected, a frail nest of grass constructed, and four large handsome eggs are deposited the latter part of May or early in June. The nest is not especially concealed, except by the vastness of the surroundings and the blending coloration of the brooding bird. Who sits fuite cluse, so that the nest is found largely by accident. One day while driving our team and outht over the trackless prairie, we were startled by an almost human scream, as a large brown bird futtered from under the feet of the horses. Lucky it was that the nest was not trampled, so I was able to take photographs of it. My companion on the trip, A. C. Bent, afterwards found another nest on which the female sat so persistently that actually he lifted her from it by hand without having her make the slightest effort to escape.

When the young are hatched, the birds become almost as violent and noisy in their demonstrations as the IVillet. They follow one around on the prairie, flying about, alighting nearby, and trotting off, ever shrieking that incessant din of god-ait, god-ail, from which 1 assume their name may have been derived. On one occasion a cundwit followed me nearly all day and kept up this scremming, until in the afternoon it got so hoarse that its voice wonld break into a sort of gasp or croak, as though it had a bad coid. Hence I nicknamed this absurd creature ny "Catar"l-hird." L'nder these circumstances they were so tame that I was able to take with a reflecting canera all the photographs of them that I neerled.

Formerly this species was quite abundant along the Atlantic coast on its migrations, whereas now it is only an accidental straggler. I have seen a few in winter in Louisiana, but most of them migrate beyond our borders to warmer climes. It is a handsome, interesting species which, like nearly all the larger shore birds, is in danger of extermination unless the radical measures already enacted are rigidly enforced.

\section{Herbert K. Jor.}

The Marbled Godwit is of very real service to farmers by reason of the fact that it feeds freely upon varions species of grasshoppers which are very injurious to crops. It should, therefore, receive adequate protection, especially during its breeding season.

\section{GREATER YELLOW-LEGS}

\section{Totanus melanoleucus (Gmelin)}

$$
\text { A. O. U. Number } 254 \text { See Color Plate } 36
$$

Other Names.-Big Tell-tale: Greater Tell-tale: Tell-tale Godwit: Yellow-shins; Winter Y'ellow-legs; Big Yellow-legs: Big Yellow-legged Plover: Greater Yellow-shanks; Cucu; Big Cucu; Long-legged Tattler; Stone-bird; Stone Snipe; Yelper.
General Description.- Length, 15 inches. Color above, blackish-brown: helow, white with brown spots on breast and neck. Bill longer than head, slender, and either straight or with end half very slightly curved upward; legs and toes long and slender. 
Color-Anelts. Head, neck, breast, and lower parts, white streaked with dusky brown on forehead, crown, and back of neck, spotted with arrowhearl marks on front of neck, breast, and sides; chin, throat, and sides of head, with small dusky markings; a conspicuous white eye-ring with a dusky spot in front: lores, whitisli: upper parts frem nock, wing-corots, and secondurics, blackish-brown, each feather l,roully edged and tipped with lighter, sreater coverts and secondaries. barred; quills, plain dusky brown; rump and tail. ahthite, the latter narrowly streaked with light hrowu; bill. greenish-dusky, lighter basilly; legs, light throme gelloa: Vouns: Similar to adults, but lighter above, the streaks beluw limited to the neck and upner breast. and the legs yellow.

Nest and Eggs. - Nest: I mere depression, usually unlined, in the ground. Ebcs: th mayish or deer buff. spotted with rich dark brown and lavender over the entire surface but more thickly at larese end.

Distribution.- North and South America; breeds from Lake Iliamna, Nlaska, and soulhern Mackenzie to suthern Britisla Cilumbia, Ungava, Labrador, and Anticusti Island: Wmters irom sunthern California, Texas, Lumisiana, and Georgia (castally North Carolina) south to Patagonia; occurs in lermuda in migration.
O) Hatteras Island, North Cambina, ahout five miles north of its famous lighthouse, there is, in ordinary seasons. an extenderl series of slallow, grassy beach-fronts. Juring the montl] lookout at all times. They watch and listen and are first to give the alarm. With slurill cries they leap upon the wing and go fying away, generally collenting into a company as they proceed.

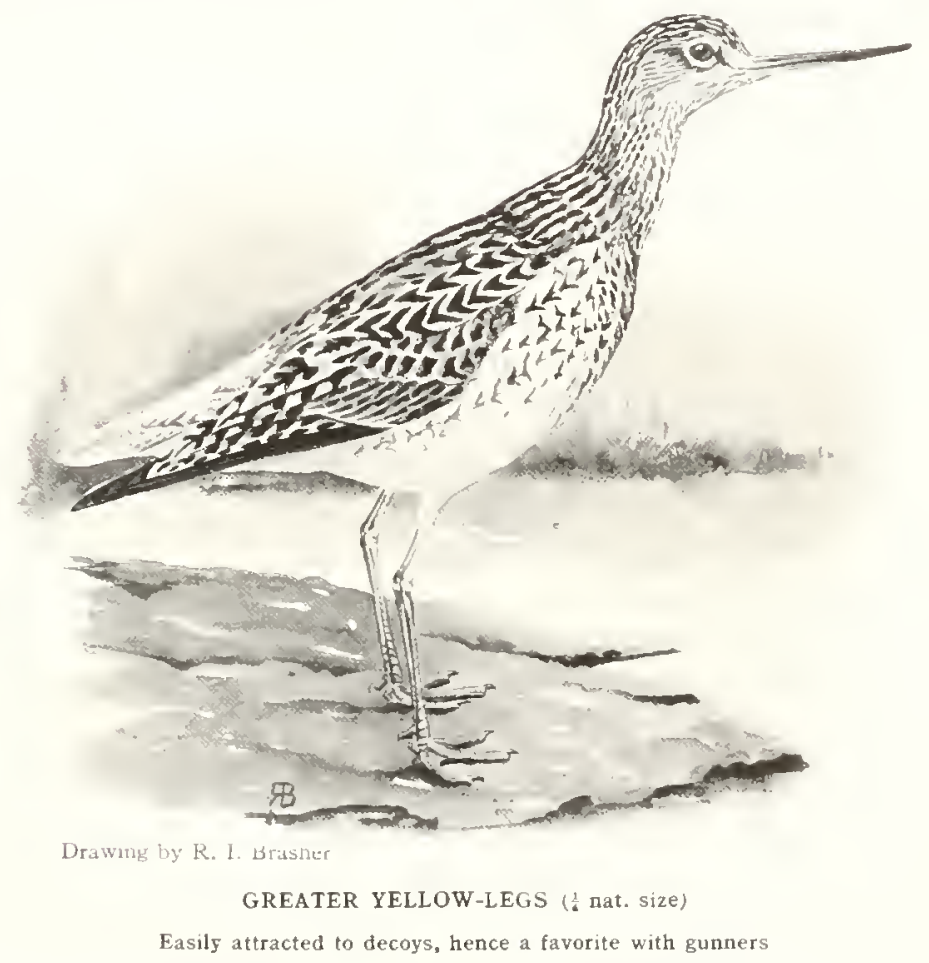

of May, these are inhalited ly lare numbers of shore birds of many kinds. I have seen here at least ten thousand on the wing at at time when disturhed from their feeding by the discharge of a gun.

Anmong the feathered squatrons there are alwass many Yellow-legs. Ithen Hudonnian Curlews are absent the Greater Vellow-legs is the largest bird among them. This gathering place at cape Hatteras is similar to many others all up and down the coast. Yellow-legs are the sentinels of such assemblies, and keep a sharp
Sometimes they do not go far, fut circle lack and fly about in the offing, rarely ceasing to call. In motion their wing-beats are deliberate, and, when approaching others amomg which they are preparing to settle, they have a way of slowly sailing on extended wings that renters them an eas shot for the gumer.

Yellow-legs are extensively hunted, although as food their flesh does not rank so high as some others of the Sandpiper family, as for example Nonlcock and Tpland J'lovers. Ther are shot chichly over wooden molels cut out and painted 
to represent the bird and stuck up in the mud near a shooting blind. To these decoys they often come with little hesitation, especially if to this deception the hunter adds an additional lure fy imitating their call with a fair degree of accuracy.

There is a widespread idea that these birds afpear later in the autumn than the Lesser lellow-legs, so they are much called "Winter Vellow-legs." "Tattler" and "Tell-tale " are also popular names for this species. The breeding grounds are mainly north of the United States, to which territury they retire in May, but 1) July many individuals are back. In fact, the tide of the ningration of the lellow-legs that ebbs and flows along our coast and interior waterways, seems never to cease, for every month in the year they are found in many. Southern States. One reason for this is the fact that not all are mated any one season and numbers of the unpaired birds do not go north at all. In the Gulf States many Greater Yellow-legs pass the winter, but the great bulk go farther afield and scatter throughout the lands to the south as far as Patagonia.

Their food consists of minnows and such insects and other small form of life as are obtainable in and about the water. Where bars and mud flats are exposed at low tide, there the Jellow-legs are wont to come. Along the shores of ponds, lakes, and rivers of the interior they are found, and in fact, few, if any, shore birds have so extended a range.

\section{T. Cillakt Peaksion.}

\title{
YELLOW-LEGS
}

\section{Totanus flavipes (Gmclin)}

\author{
1. (). U. Number 255 See Color I'late .36
}

Other Names.-Common Yellow-legs: Lesser Yellow-legs: Little Tell-tale; Lesser Tell-tale: Lesser Yellow-shanks: Y'ellow-legged Plorer: Summer Yellowlegs: Little Yelper; Small Cucu; Little Stone-bird; Little Stone Snipe: Lesser Long-legged Tattler.

General Description.- Length, I Inches, An exact miniature of the Greater Yellow-legs, from which it differs only in size.

Nest and Eggs.-Nest: A depression in the ground under shelter of tuft of grass or bushes, or in the open. EgGs: 4, creamy, buffy or clay-color, usually boldly marked, splashed, or hlotched with hurnt umber, blackish, and lavender, but sometimes with small spots iver entire surface.

Distribution.- North and South America: breeds from Kotzebue Sound, Alaska, northern Mackenzie. central Keewatin. and southern Ungava to the valley of the upper Yukon, southern Saskatchewan, and northern Quebec: winters in Argentina, Chile, and Patagonia, and casually in Mexico, Florida, and the Bahamas; in migration occurs mainly east of the Rocky Mlountains (rare in spring on the Atlantic coast) and in the Prihilof Islands, Greenland, and Bermuda; acciiental in Great Tritain.

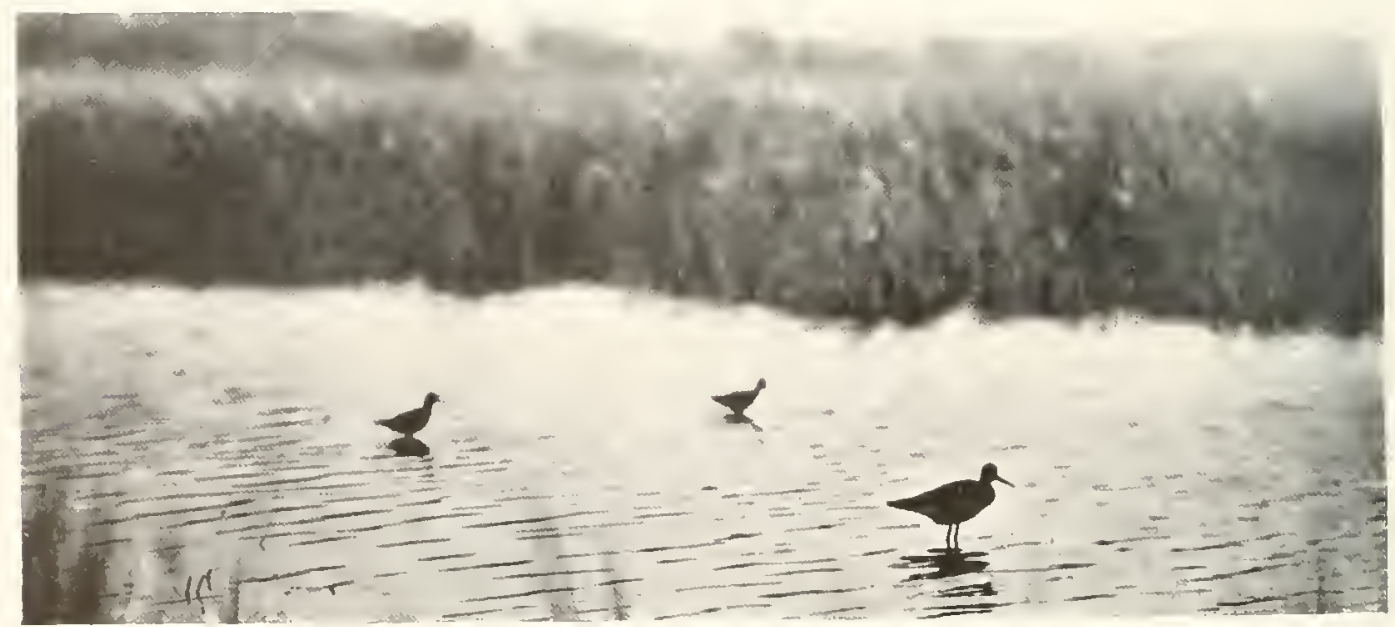

Photograph by H. K. Job

\section{YELLOW-LEGS IN MANITOBA SLOUGH}




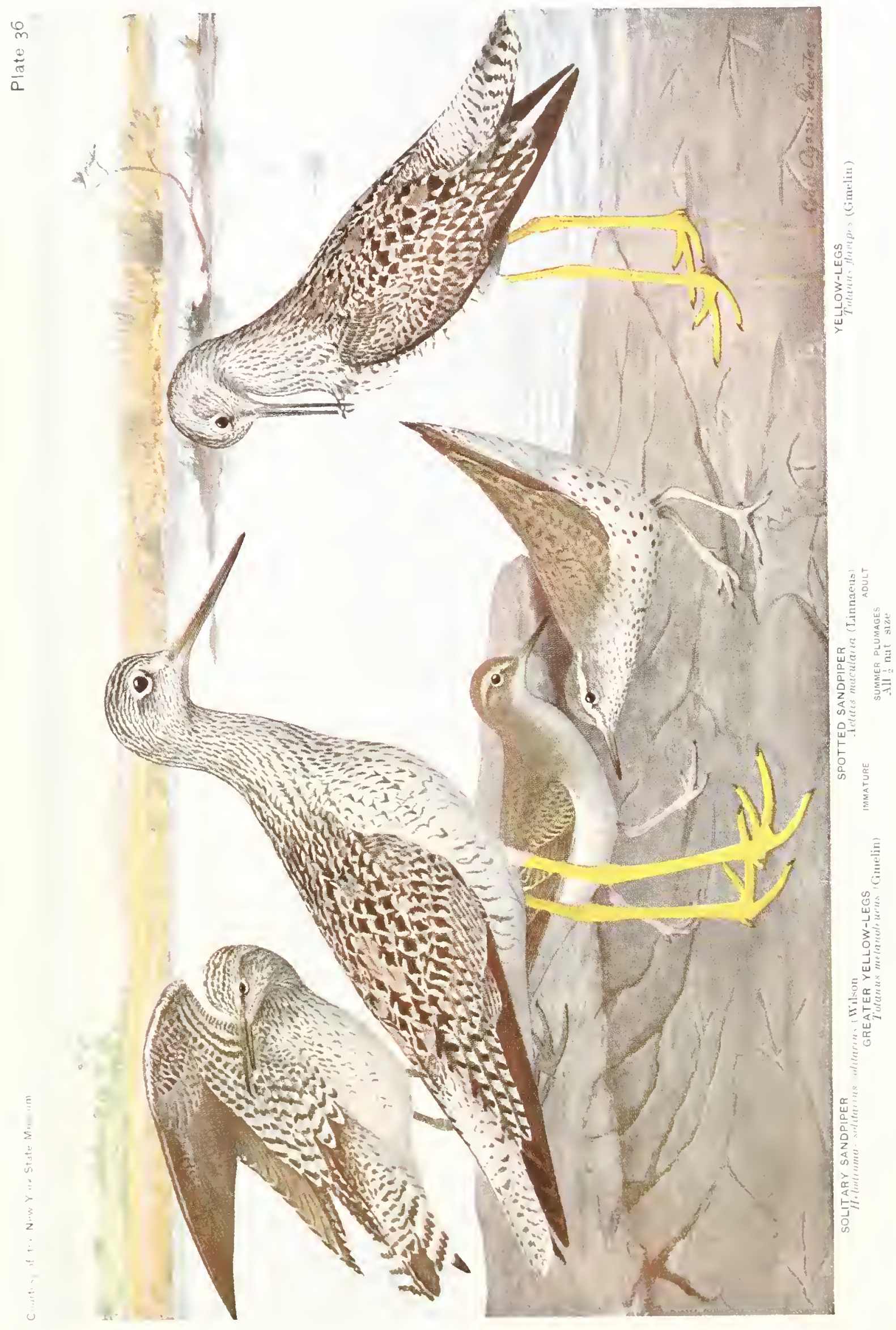



The Lesser Iellow-legs formerly was one of the most numerous of all the shore birds of Sorth . Imerica, and still holds its numleres hetter than many other species.

No longer ago than Is-o the flocks were quite numerous about some of the inlanil punds and lakes in Nassachusetts in Augunt, particularly in dry seasons, when the fonds were low. I remenber that they were alwas watchin, lnt they were readily attracted by a whisted imitation of their call, and if even one was shot unt of the flock the others hovered about antil many had pail the penalty of their symathetic comcent. (of bate vears at those same ponis, a single bird or a pais is seen accasionally, but the flucks are sone, frerlnaps never to return. Its habits are similar to those of the lireater Vellow-legs. and it feech larerely on innects, inclurling ants. EDWARn Hume forbusin, in fame Birds, II ild-liowl and shore firds.

\title{
SOLITARY SANDPIPER
}

\section{Helodromas solitarius solitarius (I'ilson)}

\author{
1. O $\mathrm{L}^{+}$. Number 250 see Color I"lat.
}

Other Names.-Green Sandpiper; American Green Sandpiper: llood Sandpiper: Anerican Woud Sandpiper: Solitary Tattler.

General Description.-Length, n inches. Color above, dark olive-brown, spechled with white; helow. white with dark spots on breast and neek: the harred tail-feathers are very conspicuous in flight. Fill, slender. straight. and lonige than head. Sethum found elsewhere than near intand laken and moolland streams.

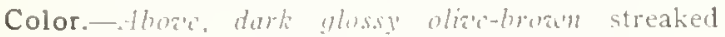
with whitish un head and neck, elsewhere finely speckled with white; upper tail-coverts, whitich, heavily spotted with color of back; middle tail-feathers. hrownish- ulive, remainder, ahite, bared with 3 or 1 bands of olic'tusky; biloa: ahitr: breant and sides of neck. shaded with brownish, streaked and spotted with dusky; sides, with some hars of dusky; bill, dusky-greenish; legs, dull greenish: iris, brown, rarely white.

Distribution. - Nurth ant South America; smmmers from central Keewatin, nuthern Ungava, and Newfoundland south to Nehraska, Illinois, Indiana, Otro, and Pennglvania: proliahly hreeds regularly in the northern part of its range, locally and casually in the southern part: winters from the lVest Indies to Argentina: recorded from Greenland, Bermuda, and Great Britain.
That dark and dainty sprite, the Solitary Sandpiper, is almost the only Sandpiner of the wooded wilderness. It is a bird of mountain, forest, hill, and plain, hut is rarely, if ever, seen on the sandy beaches of the sea. Where other sandpipers jlay. It is not so solitary as its name would imply lut it freutuents solitary places where other Sandpipers seldom or never appear. It is seen singly or in small scattered companies of a few individuals about nountain lakes or streams, near little ponds, ditches, or muldy, stagnant pouls, almost anywhere throughoul its range, and even occasionally on tirlal streams and in salt marshes. At times it freepents the sane feeding groutnd with Yellow-legs or Sprotterl Sandpipers, but may he distinguished from the former ly it much smaller size and dark legs and from the latter by the great quantity of white on its spread tail and its darker apper parts. Its notes, peot-atect. peet-a'ent, are very similar to those of the Spotted Sandpiper and it has the same habit of nodding or bowing its head but its hinder parts are not quite as active and expressive as are those of its spotted congener.
There is some uncertainty about our knowledge of the breeding habits of this bircl. It has been reported as nesting wn high mountains, on the ground, in the nests of other bircls, and in hollow trees, all of which may he true, hut at the present time we have little reliable dati resarding its home life. In the breeling season it is seen singly or more rarely in pairs and then it is linown to alight upon the tree-tojs and to emit a rather weilk and ineffective flight song. It is graceful and elegant, noves lightly and easily and flies swiftly and often wildly, erratically, and high in the air like a snipe. When the ponds and lakes are low during a long frought in August or September, the Solitary Sandpiper may he scen along the exposed muil thats and sandlars, often going into the water up to its belly. In the autumin it has a halit of wading in stagnant ditches and stirring up the bottom by adrancing one foot and shaking it rapidly. This is done so delicately that it does not roil the water. but it starts from their hiding places the minute organisms that lie concealed there. and the lirel, plunging in its bill and head, often clear to the 
eyes, catches them deftly as they flee from the disturbance. This hird secms to feed very largely on aquatic insects, small mollusks, etc., but it destroys grasshoppers, moths, and other destructive land insects, some of which it pursues and catches easily on the wing.

Edvaro Howe Forbush.
The Mestern, or Cinnamon, Solitary Sandpiper (Holodromas solitarius cimamomeus) is not always distinguishable from the eastern Solitary Sandpiper. It averages larger and the spots on the upper parts are or approach a cinnamon brown. It occurs in western North and South America, breeding north of the United States.

\section{WILLE'T}

\section{Catoptrophorus semipalmatus semipalmatus (Gmelin)}

Other Names.- Semipalnated Snipe; Spanish Plover; Stone Curlew; Duck Snipe: Will-willet; Pillwill-willet; Bill-willy; Humility; Pied-wing Curlew.

General Description.- Length, it inches. Color, gray, light below and dark above, with dark markings: a good deal of white on wings, and the rump and upper tail-coverts white. Bill, slender, straight, and longer than head; toes. acebed at base.

Color-ADUtTs in Simmer: General color, ashy, lighter below; crown and back of neck streaked with dusky; shoulders and back with spots and sprecks of the same color; rump, upper tail-cozcrts, and tail, white, the tail barred with narrow traverse streaks of brown; primaries, dusky-brown with a large ahite space at base, this color invading secondaries; primaries beneath, blackish, the white showing two conspicuous areas in fight; lores, whitish; a dusky streak from bill to eye; throat, narrowly streaked; breast and sides, thickly
See Color Plate 37

marked, with narrow traverse arrowhead bars; bill. bluish-lorn, blackening toward tip; legs, pale lavender; iris, brown. Aututs in Winter: Above, light ashy with a tinge of brown, with little or no darker marking; upper tail-coverts. white; wing, similar to summer plumage: below, pale ashy or white sladed with gray on breast and sides; sides of head, pale brown; bill, paler than in summer; a white eye-ring.

Nest and Eggs.- NEST: In a tussock of grass or weeds, close to the water, in fresh- or salt-water marshes; a carelessly built structure of small reeds and grass. EGus: 4, greenish-white or dark brownish-olive, boldly marked with spots in various shades of brown and lavender.

Distribution. - North and South America: breeds from Virginia (formerly Nova Scotia) south to Florida and the Bahamas; winters from the Bahamas to Brazil and Peru; accidental in Bermuda and Europe.

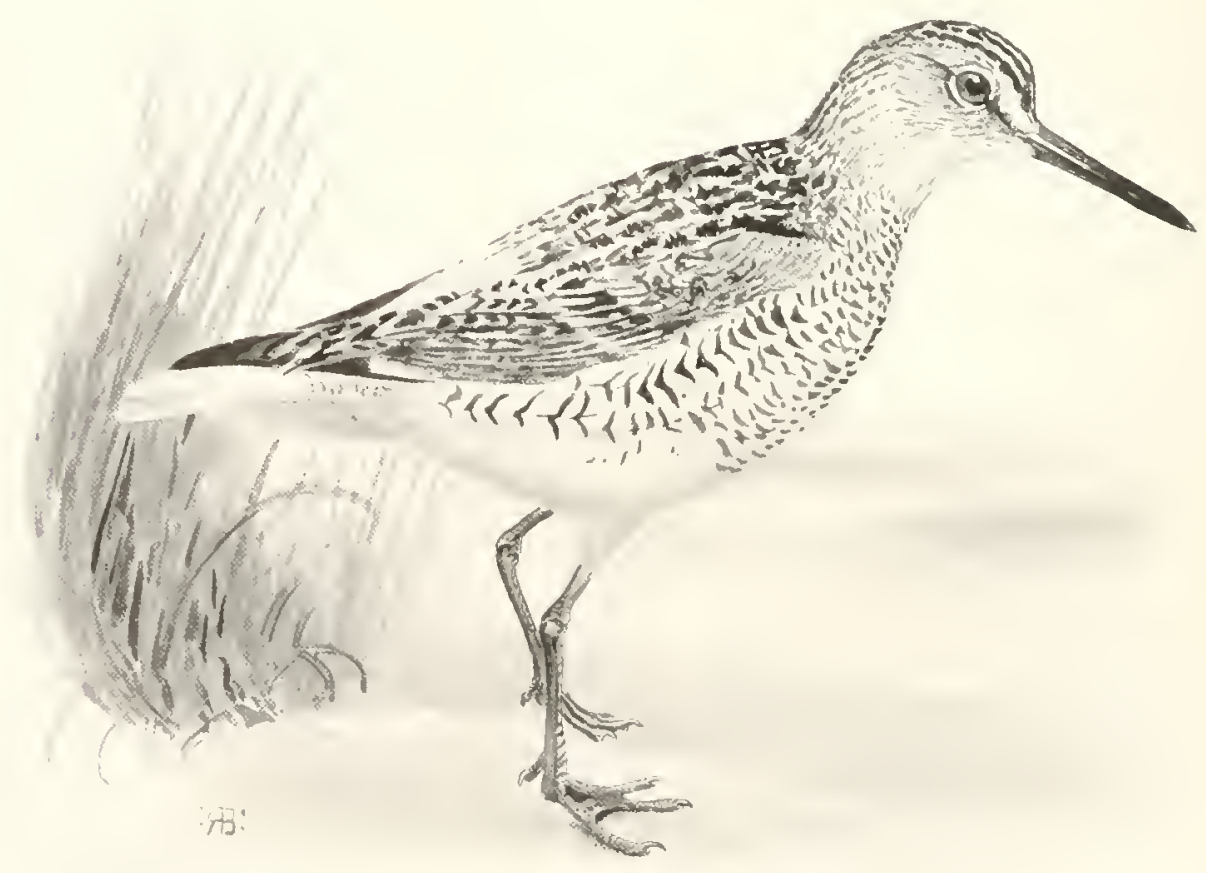


Here is a moist, self-assertive lind, if there ever was one. Willet life, literally, is a perfect "screan." Inrl yet this forward creature has been nicknamed "Ilunility", hecause it probes for worms in the humlice mud in the intervals hetween the priods when it lifts up the voice on high. Constitutionally, the bird seems unable to keep its month shut, as thongh it had blown off the safety valie and was complelled to keep going, from sheer inability to stop, with a compelling motor power behind. Its relatives, the two specics of Yellow-legs, have somewhat the same inquisitive and ascertive dispositions. though apparently in lesier legree. Crumers have frequently lodged complaint that the noisy Willet warns away their game.

The acme of its fantastic verformance cones during the nenting season, particularly when the young are abroal. Then as long as one is mincled to remain on the marsh, the lirds, fairly beside themselves, fly about yelping and screaming. () Snith's Island. Va.. i watched one, perched on the lead fork of a lush out on a lroad marsh. With absolute mechanical precision, for a quarter of an hour at a stretch, with hardly an apparent pause to get loreath. the bill would open and shut, like clock work, to the tune of yip, yip, yip, and so on, rapidly reiterated. When it took to wing it would start up its pill-aillet eries.

Lusully the nest is hard to fiml. I have watched the birds on the marshes of the southern coast and by the sloughs on western prairies, but never had the luck to locate a nest till about May IO, 1904. When I was on a cruise atong the coast of South Carolina. We landed on an uninhabited island, mostly marsh, but with a beach in front, backed by a narrow ridge of sand lietween beach and marsh. Clumps of coarse beach grass grew all along this ridge, and from nearly every other clump, as we advanced, a Willet sprang from her four large dark mottled eggs. until on that one island we had examined over fifty nests. These were trail structures of dry grass, lining hollows scratched in the sand under the grass clumps.
It need not be assumed from this that the Villet is an aldundant bird, for it is another of our rapilly. " ranishing shore hirds." lomerly" it was common along our Itlantic coast, lut now the signt of one is a rarity.

During the fall migration, it is seen casually in muddy loughs or on the flats and marshec of the sea-coast more reserved than is its wont, as

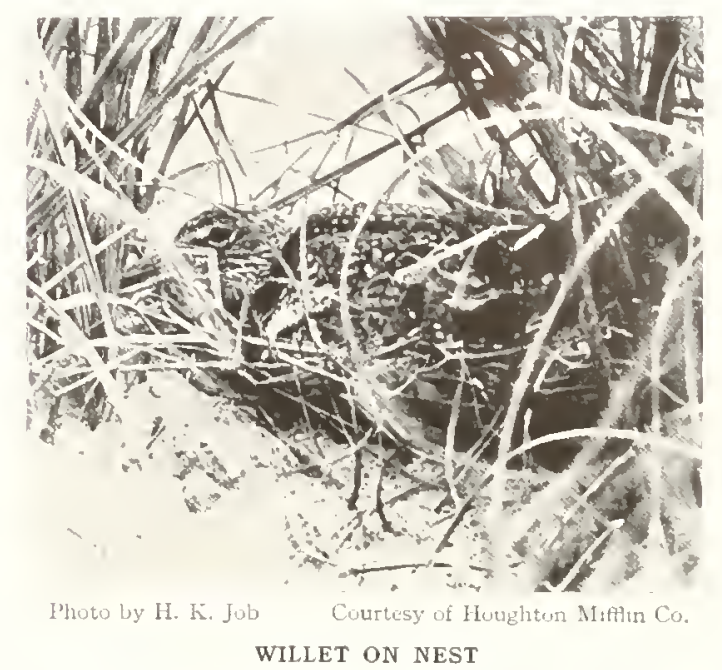

though sobered by the thought of exile from the fields of its vocal exploits. During winter it is absent on its annual junket to raried southern scenes as far remote as Brazil and Peru.

HERLERT K. Toli.

The Western Willet (Catoptrophorus semipalmatus inornatus ) differs from the eastem Willet in larger size and in shades of color, but its general apprearance and habits are the same. This geographical variety breeds from central Oregon, southern Nherta, and southern Manitoba. south to northem Califormia, central Colorado, southem South Dakota, and northern lowa, and on the coasts of Texas and Louisiana: in winter it occurs from central California, Texas, Louisiana, and the Gulf coast of Florida to Nexico and Lower California. It is sometimes found in the Atlantic State during migration.

\section{UPLAND PLOVER}

\section{Bartramia longicauda ( $B c c$ hstein)}

Other Names.-Bartramian Sandpiper: Bartram's Sandpiper: Bartram's Plover: Upland Sandpiper: Uplander; Hili-hird: Field Plover; Highland Plover :
Seet (olar l'laze 37

Pasture Plover: Grass Plover: Prairic Plover: Prairie Pigeon; Prairie Snipe: Palabotte: Quaily

General Description.- Length, 12 inches. Color 
above, blackish-brown; below, grayish-white. Bill, shorter than head; sape, aide; neck. lonty; tail. lony and uraduated; onter and middle toes webbed at base; inner toe free. Found mainly in pastures and old fields away from water. even at the sea-shore.

Color.-Above, hlackish-brown, all feathers edged with tawny or whitish, the brown prevailing on crown and hack, the ligliter edgings of latter producing a streaked effect; on long inner seconlaries, the dark color mere small bars; wing-coverts marked with whitish; primaries, dusky, outer one barred aith white; rump and upper tail-coverts, plain brownish-black: middle tail-feathers, dark brown with rufous edges and irregularly barred; rest of tail-feathers, orange-brown with numerous broken bars or spots of black and a subterminal llack har: line over eye and under parts, grayish-white, tinged with yellowish-brown on breast and sides of head: breast and sides, with each feather marked by a brownish arrowhead-shaped spot; bill, yellowish-green, dusky at tip: legs, yellowish-olive; iris, brown.

Nest and Eggs.- Nest: A slight depression in open rry prairies, lined or not with grass. Egrs: 4, pale huffy or cream. spotted with dark brown and lavender.

Distribution.- North and South America; breeds from northwestern Alaska, southern Mackenzie, central keewatin, central Wisconsin, southern Michigan, southern Ontario, and southern Maine to southern Oregon, northern Utah, central Oklahoma, southern Missouri, southern Indiana, and northern Virginia; winters on the pampas of South America to Argentina: in migration occurs north to Newfoundland and in Europe: accidental in Australia.
My early recollections of the Upland Plover, once a familiar game bird, are of open rolling grassy tracts on Cape Cod, Mass., interspersed with patches of hayberry bushes, in late July and August, and some very shy brown birds that, despite most of my attempts to stalk them, would rise wildly well out of gunshot and with shrill cries fly on to the next hillside, alighting and watching in an erect attitude, their heads projecting from the short sparse grass.

Upland Plover shooting is now becoming a thing of the past, under the protection of Federal Law. This is as it should be, for here we have another species which is in great danger of extermination. Little by little, both through excessive shooting and by the destruction of nests in cultivated areas, it has been growing more and more scarce. Once it was a common bird in the Eastem States, but now only an occasional tone pair is found there. The grassy prairies of the Northwest are now its principal breeding ground, but owing to their increased reclamation for agricultural purposes, it is being further pushed out. This is a lamentable declension from the davs when in New England it was comparable in abundance to the Meadowlark, and pairs were nesting in nearly every field.

Classing it as a "slore bird," is only on the basis of structure and relationship, for otherwise there is no bird which is less fond of the vicinity of water. Its haunts are dry grassy fields, where it lives chiefly on insects injurious to the fields, such as ctitworms and grasshoppers. Here is where it nests, the last of May and early June. The female sits closely, and on the prairies of North Dakota, Manitola, and Saskatchewan I have found nests only by flushing the brooding bird, which allows one almost to step upon her before she will leave. The nest is in rather thick bunches of prairie grass, a simple affair of dry grass leaves. Four is the invariable number of eggs which I have found. The bird is almost exactly the color of dead grass, and even when the nest has been found and revisited. it is astonishing how hard it is to discern the brooding bird. In one case she allowed me to open by hand the grass which covered her. set up the camera and photograph her within two feet of the lens. Shy as the birds hecome under persecution, they are gentle in nesting time. On the western prairies they are much less shy than in the East.

As soon as the young are able to fly, in July, they all begin to migrate south, and most of them are gone before August is far advanced. This was the reason why the older laws allowed $\mathrm{Up}_{\mathrm{p}}$ land Plover shooting in July. In the summer of 1912 I was in Manitoba. At the opening of this early hunting season, a gunner came out near our camy, and shot nearly forty Upland Plovers, while his boy picked up little downy chicks and carried them in his pocket. I reported this to the head authorities, who are excellent conservationists, and the law was changed. It will need the lest of care, by every State and Province, and the coöperation of public sentiment, to save from extinction this beautiful and valuable species.

Herbert K. Job.

The investigations of the Government biologist show that the Upland Plover is naturally an industrious destroyer of many different species of noxious insects. There can be no doubt that the bird feeds upon the highly destructive locust, and also upon grasshoppers, the cloverroot curculio, linil-hugs (which destroy much corn). crawfish. which are a pest in corn and rice fields and also weaken levees by their burrowing, and various grubs which damage garden truck, corn, and colton crops. 


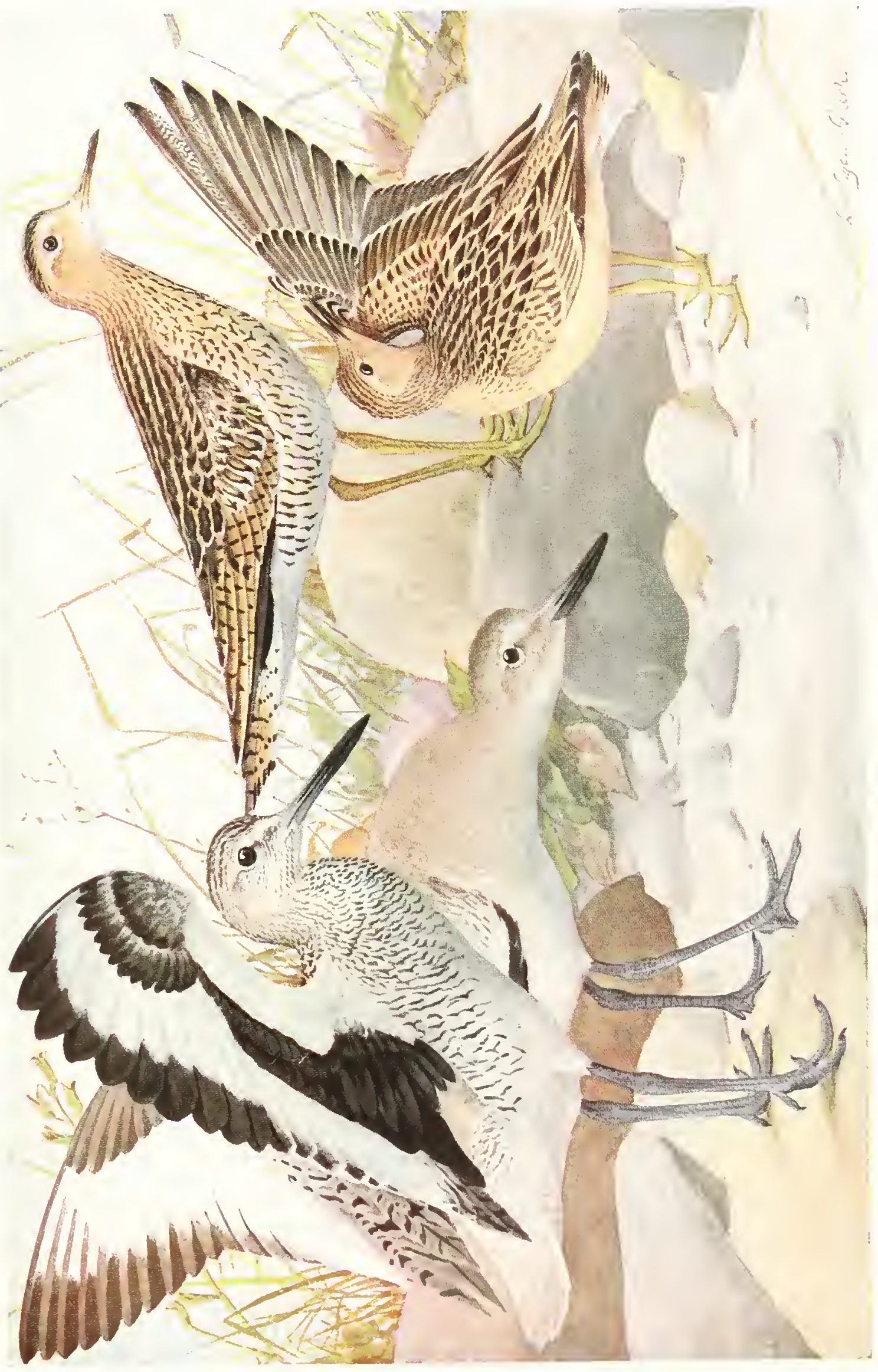





\title{
BUFF-BREASTED SANDPIPER
}

\section{Tryngites subruficollis (I'leillut)}

\author{
A 0 l. Number 202 sece folor l'late 37
}

Other Name.-IIll Grass-hird.

General Description-Lengtlı, 8 inches. Color below, buff; above. dusky brown. Bill shorter than head. slender, hard at tip: sape wide: tail rounled, central feathers projecting; tos not a obbed Prefers dry upland fields and is rarely seen on the shore.

Color-ADelts IX SiMMER: Bbove, duhy-brown. finely streaked on head with pale vellowish-buff, this streaking running down back of neck to feathers of back and shoulders which are edged and tipped with tawny primaries, seeondaries, and coverts, grayishbrown, the last two with lighter edges; inner wobs of primaries and both aths of secondaries. fearly white marblid atith back: lores, sides of head to above eye, throat, breast, and all under [arts, plain buff unmarked except by a few hrowuiah spots on side and ehest;

The Buff-breasted Sandpiner is rather a rare bird uron the Atlantic coast, and possibly always has been, as it lueeds in northern. Maska and its main migration route Joes not touch the Atlantic coast.

lormerly it was very abundant in lexas, and still is common there, but decreasing. The reports of its decrease in the 11 est are very impressive. Apparently it is on the way to extinction.

It is usually a very gentle and confiding bird central tail-teather, hrown; whers, rufums with a subterminal dusky bar; bill, duky: legs. dusky-greenish:

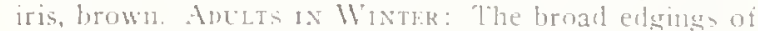
feathers above, narrowed to whitish semi-circles; under parts, whiter: wing and tail, a in summer.

Nest and Eggs.- Xest: A depression in the ground, sparsely lined with gras and withered leaves. Eocs: 4. grayish or pale olive-buff, sharyly spotted with rich burnt umber.

Distribution.- Nurth and South America; breels along the Arctic coast from northerm Alaska to northern Keewatin; winters in Argentina and Urugruay; most abundant in migration in the Mnsisaipni valley: occasional on the Atlantic coast in fall; easual on the Pacific conat mortl to St. Michael. Alaska, and to northeastern Siheria; straggles to Hermuda and Europe.

and pays little attention to the hunter. Il is valuable as an insect eater, particularly in the West, but in its pursuit this fact is overlooked and its fond value only is considered. lootor Hatch found it living upon crickets, arasshoppers, ants and their" "eggs," and other insects, and on minute nollusks taken from the shores of shallow ponds in the warmest part of the day EnW Ard I Iowe Foneush, in Game Birds, II ild-Foa! and Shore Birds.

\section{SPOTTED SANDPIPER}

\section{Actitis macularia (Linncus)}

\section{A. O U. Number 263 See Color l'late $3^{\mathrm{h}}$}

Other Names.-Peep: Peetweet: Teeter-peep; Teeter-tail: Tecterer; Tip-up: Tilt-up; Sand Lark; See-saw; Sand-peep: Sand Snipe; River Snipe.

General Description,- Length, T inches. Color above, ashy-olive: under parts pure white. unspottel in winter, but in summer witl round black spots. Jill straight, slender, and about as long as hearl: outer and middle toes, webtsed at base; inner toes, free; tail. rounderl and half an fong as wing. This is the only. Sandpiper which las largo and distinet spots on its under parts; it nearly always teeters when alarmed: and in fight shows a white line on the wings. Found most often near streams and ponds.

Color--Aderts iN Sumarer Crown and upper parts, including wings, soft ashy-olive, finely varjed with dusky in streaks on head and neck. elsewhere in wayy irregular crosshars: line from bill to eve and back of it, olive-dusky: a line over eye and entire under parts, pure white: under parts, as far as undor tailcoverts, aith numerous sharp, circular black spots, more crowded on the female; primaries and secondaries. brownish-black, largely white at hase, not showing in folded wing; feet urayish fleah color; hill, Hesli colur with black tip: iris, brown surrounded with a white ring. Authts in linter, Axo Youns: As in summer, but without marking above or below: breast, slightly urayish and wing-coverts more strongly untined with lighter.

Nest and Eggs. - NEst: A derression in the cround in the vicinity of water; rather well constructed oi grass, leaves, and weed stems. Egos: 4 creamy, huffy, ur grayish. hlotched with blackish and purplich-gray.

Distribution.-North and South America: hrceds from tree limit in northwestern Alaska, northern Mackenzie, fentral Keewatin, northern Ungava, anil Newfoundland sonth to southern California, Arizona. southern Texas, southern Louisiana, ant northern South Carolina: winters from California. Loujsiana. and Sonth Carolina to southern Prazil and central Peru; straggles to Creat Britain and Helgoland. 
l'robably there is no shore bird more widely and intimately known all over the country than the Spotted Sandpiper, which is popularly nick-

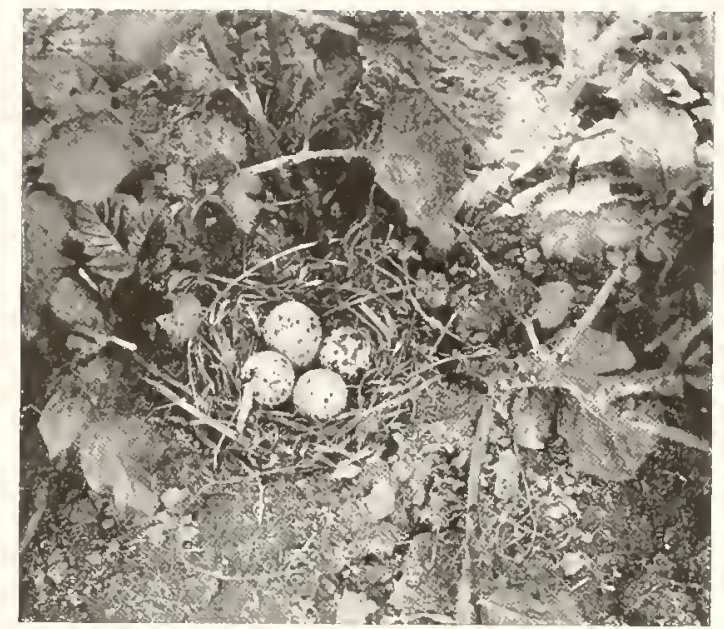

Photo by S. A. Lottridge

NEST AND EGGS OF SPOTTED SANDPIPER

named "Teeter " or "Tip-up," from its nervous habit of constantly tilting its body, and "Peetweet" from its notes. As typically seen, it runs along the shore of a pond or stream, stops and wags its head and borly up and down several times, then runs again, and, if further approached, flies out over the water with a peculiar quivering flight, the wings being held straight out, with alternations of quivering downward beats and brief intervals of snaring. Usually it circles back and alights not far from the same place. It is not hy any means, however, confined to the vicinity of open water. but is often seen in meadows, and even on dry uplands, particularly in cultirater fields where crops are growing.

Nost shore birds breed far to the north, but here is one species which is remarkably impartial in its topography. Though it breeds in northern Alaska, it also does so nearly all over the United States, even down on the Gulf of Mexico, alike on seaboard and interior. In this praiseworthy originality it is entirely unique, surpassing even the Robin, which does not breed so far south.

In the northern States I have usually found fresh egos during the last week of May, generally four in number. The nest may be found in many sorts of situations. Probably that most preferred is just up from the shore of a pond or stream, under a bunch of grass or a clump of weeds. Usually nests are quite well hidden, but 1 have seen them easily visible, under sparse weeds on open gravelly shore. However, they are often placed quite a distance from water, in pastures or among crops, quite often in fields of corn or potatoes.

Some shore birds "act up " to draw away intruders from their nests, when these are being approached. The Spotted Sandpiper makes no such attempt until after being flushed, when both birds appear and rum about anxiously.

The female is a close sitter, and discloses her sccret by fluttering out when closely approached. Owing to this habit, I have inspected dozens of nests, whereas, if the bird would discreetly withdraw, the well-hidden nest would seldom be found, except when placed in cultivated fields.

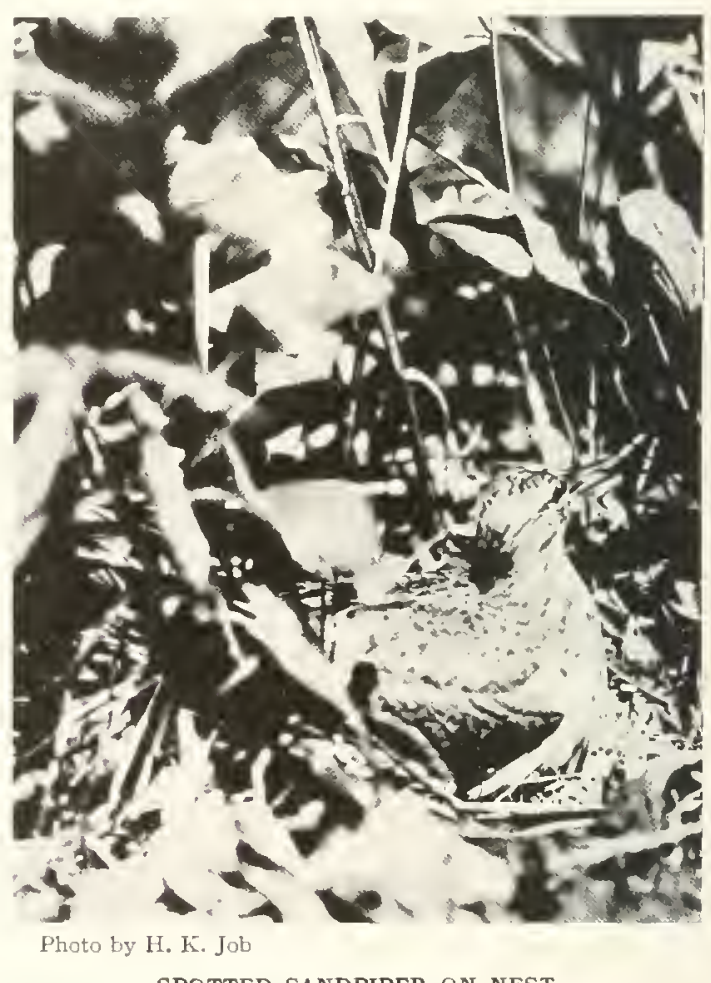

SPOTTED SANDPIPER ON NEST

Some of these birds winter on our southern coasts, but the majority pass on further, penetrating into Brazil and Peru. Herbert K. Job. 


\section{LONG-BILLED CURLEW}

Numenius americanus Bechstin

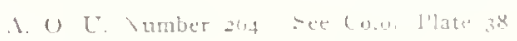

Other Names.- Big Curlew: Hen Curlew; Uld Hen Curlew; Sickle-bill: Sickle-billed Curlew: Sabre-bill; Smoker.

General Description,- Length, 20 inches. Prevailing color red, darker above than below. Its appearance is similar to that of the Mlarbled Godwit, but it is easily distinguishable from the fatter by its longer and cured bill, the upper section of which is longer than the luwer and slightly knobber at the tip. Toes, webleel at base.

Color--Crown, rufous-brown witl blackish streaks: back and shoulders, brownish-black variel with cinnamon-brown, each feather having several indentations of this color; wing-coverts, with more rufons and whitish: secondaries and tail-feathers, [ale brownish barred with dusky; inner primaries, rufons-brown, changing to dusky un outer ones; entire under parts. varying from vellowish-brown to rtifous, usually deep- ening to chestnut under wunge and fadng to whitish on throat and sides of hearl hreant, with dusky streaks tending to arruwheads; bill, dusky above, pale Heshcolor below: legs, huish-gray. Very constant in plumage irrespective of age, sex, or season.

Nest and Eggs.-Nest: A grass-lned depression in the ground on open prairies. Euss: 3 or 4. pale buffy to grayish-buff, sputted with darker lorown and laventer.

Distribution.- North America: breeds from central Iiritish Colmmlia, suthern Sa-kiatchewan, an I Mantoba to northeastern California, nurthern New Mexico, and northwestern Texas: winters from central California and southern Arizona south to Cinatemala, and on the Atlantic coast from south Carolina to Florila, Louistana. and Texas; formerly a regular migrant north to Mlassachusetts and rarely to Newfoundland, now a straggler east of the Missisappi, noth of Florida: casual in the Went Indiev.
From being an abundant species on the south Atlanlic coast a century ago, this interesting, spectacular species, the Long-billed Curlew, is now almost unknown in the eastern United Stales. The only time I ever saw it in the East was about 1886, in August, over the marshes of Marshfield, Nass., when I saw a single wedgeshaped flock of these great birds with alsutrdly long down-curved bills. Audubon found them coming to roost at night by thousands, on November IO, I83I, on an island off the coast $0 \hat{i}$ Soutl Carolina. Seeing that, in May, root, prolsably on the same island. I saw some ten thousand Hudsonian Curlews come to roost at dusk, I could not but wonder if he could have been mistaken in the species. Al any rate, where it was once well known it is now unknown. The specien is in real danger of extinction, and it is well that the Federal Law now places them unde: absolute protection.

$\mathrm{M}_{y}$ personal experience with this great Curlew has been chiefly in sumner, in the nesting season, on the prairies of Saskatchewan. Evidently it is gradually disappearing, for luring extended explorations in North Dakota, from May to (c)tober, I failed to see a single ont. Variotte settlers told me that it had been common in " the eighties" and previously, but that it has sinec become rave. It seems to frefer those pratic recrons where the soil has an allialine tinge and the loughs are surrounded ly the typical bare alkaline flats. In such regions in Saskatchewan

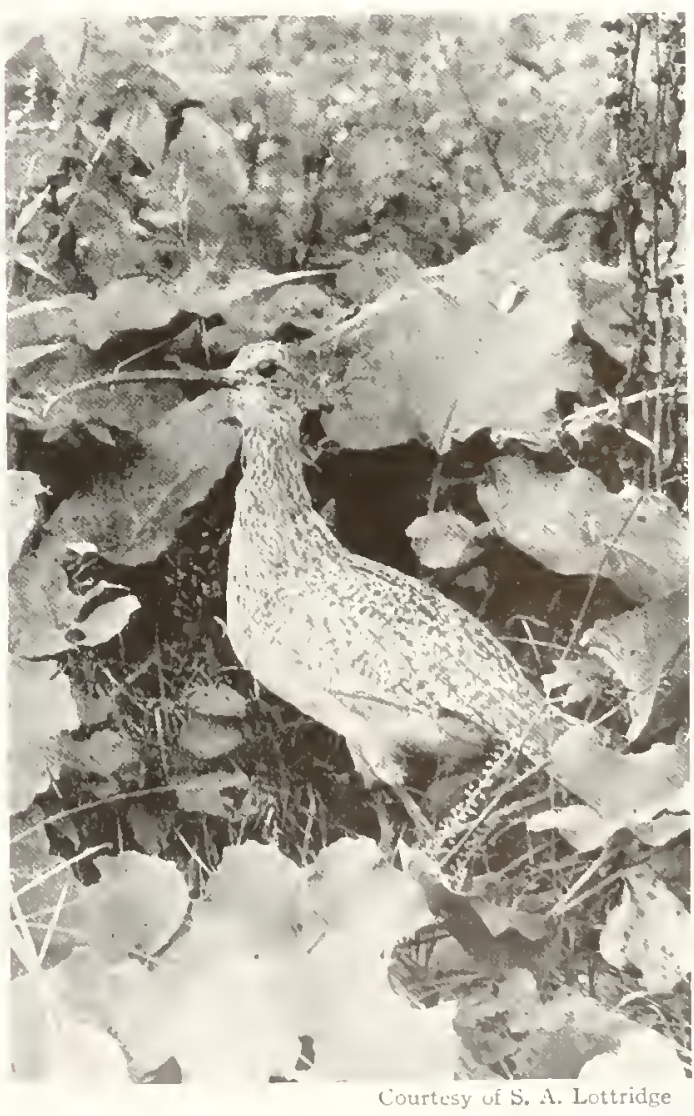

LONG-BILLED CURLEW

This interesting species is now almost unknown in the eastern United States 
I found them in scattered pairs. Conspicuous in size, they also make themselves so by their reiterated loud, high-pitchad, trilling cries, especially when they have young or eggs in the vicinity. They are shyer than the Marbled Godwits which share with them these alkaline plains.

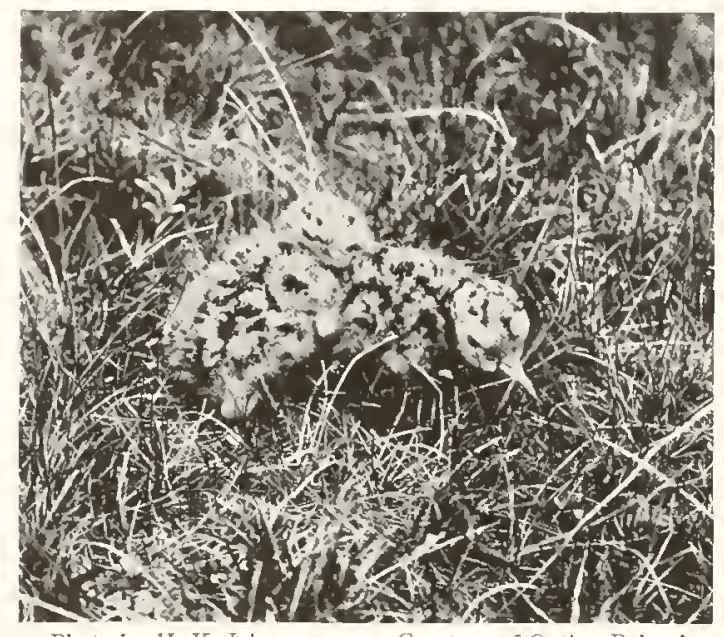

Photo by H. K. Job

Courtesy of Outing Pub. Co.

YOUNG LONG-BILLED CURLEWS

The nest is a simple hollow in the prairie, anid rather sparse grass, lined with dry stems. Three or four very large egrs make the usual complement. It is hard to find, as the male bird gives the alarm when an intruder approaches, and the female joins him. Perhaps they become some- what accustomed to the cowboys who ride around after the cattle, since all of the nests which I knew about were liscovered by cowboys on horseback through flushing the bird from the nest. Though the anxious parents are in evidence, Hying or trotting about at a distance and whistling, they give no definite clue as to the direction in which the chosen spot is located.

One evening at sundown aiter a forty mile drive over the plains, we were approaching a ranch, in rolling prairie country, when we noticed two birds squatting together in the short grass. They proved to be young of this species, quite large, yet still in the downy stage, very pretty and interesting. There was just enough light to take photographs of them by time-exposures. Meanwhile the prarents were flying about, swooping angrily past us at close range, screaming most vociferously. Altogether it was a spectacle which I would not have missed for a good deal.

1 IERRERT $\mathrm{K}$. jor.

The Long-billed Curlew is evidently a persistent eater of the highly injurious locust, as is shown by the fact that ten stomachs of the bird were found by Government experts to contain forty-eight locusts each. This would be sufficient reason for giving it a place among the birds of great economic value to man. But the bird's usefulness does not stop here, for it is known to feed freely also upon various injurious grasshoppers, and it is more than likely that its diet includes other noxions insects, so that its usefulness is beyond question of a doubt.

\title{
HUDSONIAN CURLEW
}

\section{Numenius hudsonicus Latham}

\author{
․ (). U. Number 265 Sec Color l'late 38
}

Other Names-Jack Curlew: Jack; Striped-head; Crooked-billed Marlin: American Whimbrel; Shortbilled Curlew

General Description.- Length, I 8 inches. Can be distinguished from young Long-billed Curlews only at close range.

Color.-Top of head, whiform blackish-brown with acell-defined whitish contral and side stripes; a distinct streak of dusky from bill through and behind eye and a pronounced broad whitish streak above it; upper parts, blackish-brown variegated with white, ocher, or pale brown in the same pattern as the Longbilled Curlew but tone less rufous; primaries and their coverts, dusky, the former broken-bared with pale; tail, ashy-brown with a number of narrow blackish bars; beneath, very pale brownish-white; breast, with dusky streaks changing to arrowheads or broken bars on sides: bill, dusky, yellowish below for about onethird its length, darkest at tip; feet, grayish-blue; iris, dark brown.

Nest and Eggs.- NEsT: Like that of Long-billed Curlew. Egos: 4, creamy to pale olive-gray, boldly marked with shades of umber-brown.

Distribution.- North and South America; breeds on the coast of Alaska from mouth of Yukon to Kotzebue Sound, and on the coast of northern Mackenzie; winters from Lower California to southern Honduras, from Ecuador to southern Chile, and from British Guiana to month of the Amazon: migrates mainly along the Facific and Atlantic coasts; rare in the interior: castual on the Pribilof Islands and in Greenland and Bermuda; accidental in Spain. 


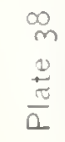

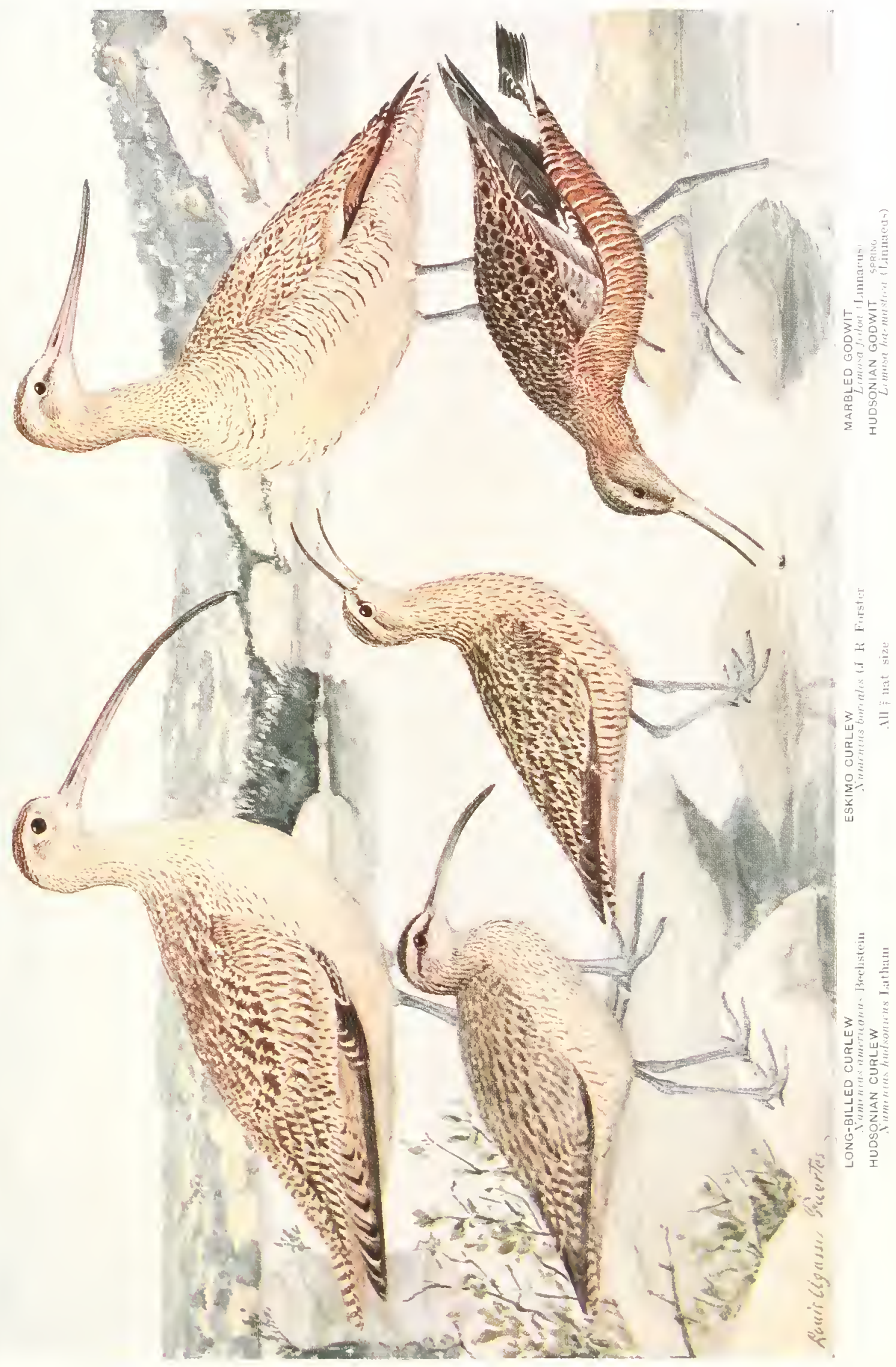



Why shomll the long, slemder bills of the Curlew and the lhis be hent downward? ( ne miglst as well ask why the similar hills ot the frolwit and the lrocet hould he hent upwarl and those of the Nooldock and the Snipe remain almost straight. These questions never have been satisfactorily answered. They remain anong the fascinating problems of ormitholosy yet to be solved.

The Hudsonian Curlew, or Jack Curlew, as it
Iugust and reach their maximum numbers there late in the montl.

When feeding they usually seatter about over the ground, moving slowly and selately, except when in pursuit of some particularly lively prey. Berries they pick from the lushes with their hills. They feed in fields where urasshoppers abound and in lineberry patches. Along the coasts. Where the suecies is most common. the flocks frequent thats, beaches and low grassy

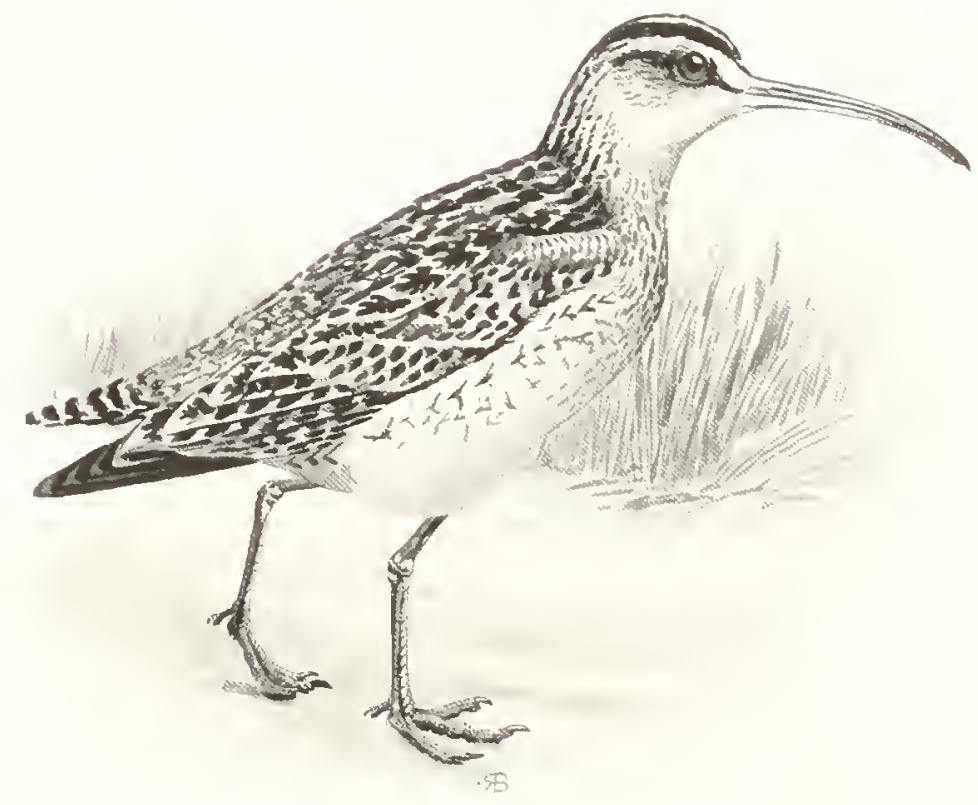

Drawing by R. I. Brasher

HUDSONIAN CURLEW (a nat. size)

It is extremely shy and difficult to stalk

is commonly called by gumners, is an illustration of the Darwinian theory. It has survived, while other species have disappeared, hecause it was fitter - better able to aroid the hunter. No bird is more exposed to jersecution, as it migrates the entire length of North and South Anerica, from the Arctic Ocean to the Straits of Magellan, but it frequents places rather remote from the centers of civilization, breeds in the Far North, is extremely shy amd difficult to stalk, and so perpetwates its race.

The main lines of its migration ate down the east and west shores of both continents but there is also a seattering flight through the interior. Little is known about the hird's hreeding habits lut as som as the young are grom the slow migration hegins. The main fliwh moves from the west coast of Hulson Paly th the shores of New England and southward. The birds appear on the islands of the St. I, awrence River early in hills not far from the sea. When flying to or from their feerling yrounds they usially jass about thirty yards high, except on windy days, when they fly close to the gromml or water. In New England they feed at the enlge of the water or wade in shallow prols picking up their food with the head apparently held sirlewise. Fiddley crabs and the large gray sand spiders form an important part of their diet. These Curlews also consume June bugs and rither beetles and some womms. They are sometimes seen singly, flying and circling ligh in air, and oceasionally a small flock is noted migrating like a flock of Geese or Ducks. Formery they were numerous on Cane Cod and Nintucliet, but now-a-days most of them pass out to sea, though nany still visit the marshes of the (atrolinas. In spring they have a soft, rather mournful call. cur-lead, and the alarm note is pip-pip-pip-pip. EMWARD HWWE FuRUSH. 


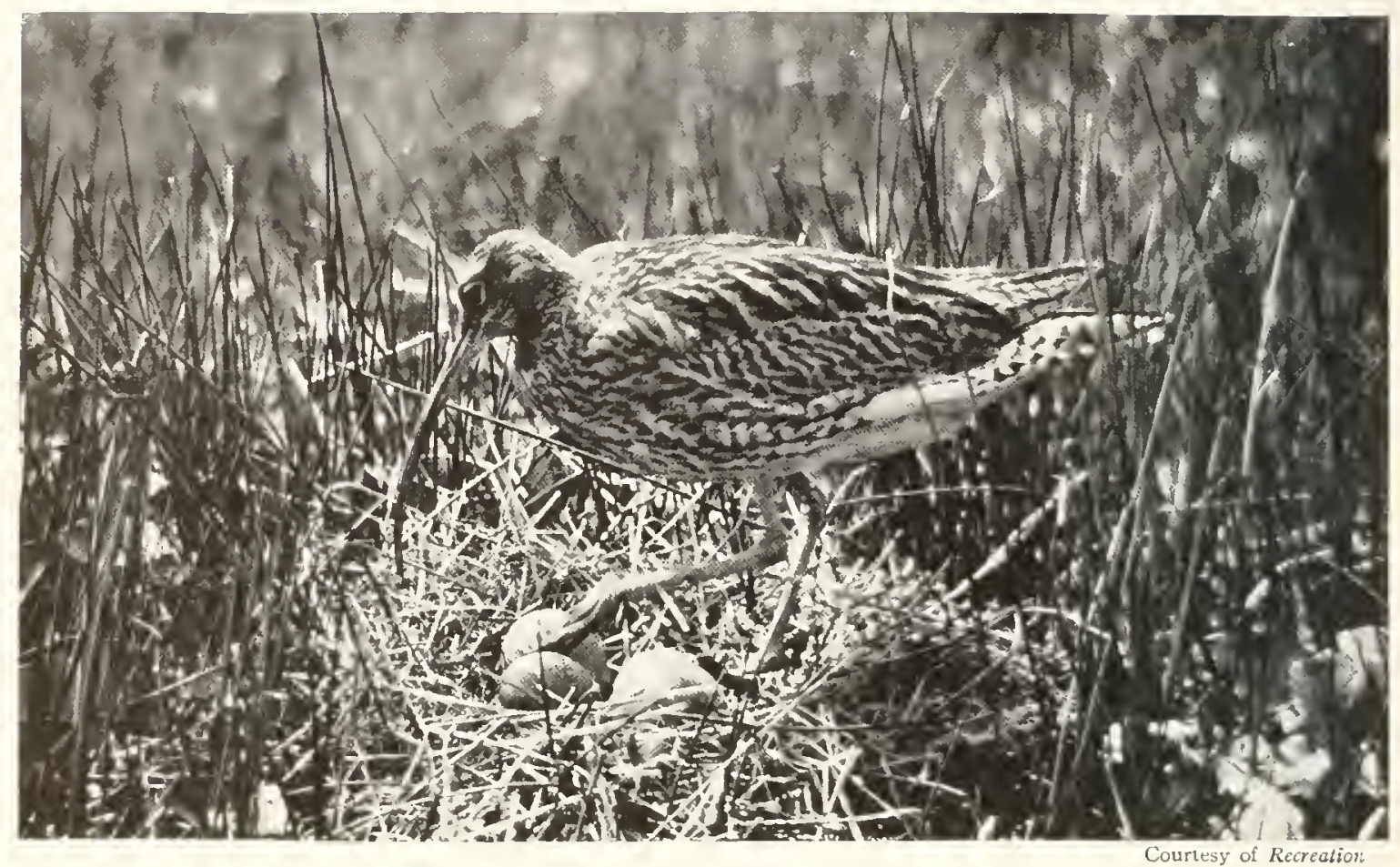

HUDSONIAN CURLEW

\section{ESKIMO CURLEW}

Numenius borealis ( $J$. R. Forster)

1. O U. Number 266 See Color l'late 38

Other Names.-Fute: Dough- or Doe-bird; Little Curlew; Prairic Pigeon.

General Description.-- Length, 15 inches. Color like that of the Hudsonian Curlew, but more reddish. Bill slender. curved, and about twice the length of head; toes, webbed at base.

Color-Upper parts, brownish-black variegated with pale cinnamon-brown; croa'n, atithout contral light line: streak over eye of whitish; under parts, tawny ocher to whitisl, marked everywhere with dusky streaks, bars, or arrowhead spots, these markings very numerous except on chin; bill, black, paler at base below; feet, lead-gray; iris, brown.

Nest and Eggs.- NEST: Usually on the open plains; a mere depression in the ground, lined with a few dry leaves or grass. Egos: \& ground color variable, from pale green, gray, or brown to olive-drab, with numerous bold markings of sepia and unber-brown. more crowded around large end.

Distribution... North and South America; breeds on the Barren Grounds of northern Mackenzie; winters in Argentina and Patagonia: now nearly extinct.
It is a great pity that we must speak of the Eskimo Curlew in the past tense. Its disaypearance is but another tribute to the effectiveness of modern fire-arms and the short-sighted selfishness of the average American hunter. In the seventies and early eighties Eskimo Curlews in countless numbers came annually to the coast of Massachusetts and earlier witers mention themas heing very plentiful in the Carolinas. Their summer lome was in the Barren frounds and other regions in the northern part of North America. In autumn they collected in Newfoundland in enormous flocks. One observer declares that they came in millions that darkened the sky. After following down the coast to Nova Scotia they launched out over the ocean for South America, and many of them never sighted land until they reached the West India Islands. Whether during this long journey they ever rested on the water, or whether they continued 
therr rorage without pause, is not known. Autumm sales, homever, diverted many of then from their conrse and they landed on the fiemunda lslands as well as alones the const of the northern sitites. Tens of thousands thus came to the islands and heaches of New England where, aconding to Forbush, they were merctlessly shot for foud. Because at this season they were always extremely fat they were hinown senerally as "Dough-birds."

- Ifter reaching Soutl inerica the Curlews proceeded southward, spreading out over the continent as far a Patagonia. llere they passed the winter. In March and April the sreat flights would appear on the shores of thone States horlering on the Gulf of Mexico. Passing a gantlet of gum-fire the survivos journeyed wp the Mlississippi valley to northern Camada, and so on to their breeling srounds. It will thus he seen that their migrations were among the most extensive of any undertaken by our North Imerican birds.
Since luoo perhape a dozen specimens have come to the attention of ornithologints - all clead hirds - and it is of course pussible that a few may still exist. Tiut the rreat fincks are gone and the species is doomed.

Like all the Curlews this bird was an inhabitant of regions where water abounds. Alung the coast they fed in the beach-pools and marshes but not generally on the andy beaches so commonly frequented ly. Sandpipers and some of the I'lovers.

In the spring and summer their ereat joy was to wade in the ponds, sloughs, and shallow, grassy lakes of the interior. They were of no special economic value to the farming interests of the comntry, for they did not ieed on insects injurious to crops, lut they were of mucli value as a food product, and with proper laws enforced for their conservation the areat flocks might lave been spared indefinitely for the pleasure and benefit of mankind.

T. Gilbert PEARson.

\section{PLOVERS}

\section{Order Limicolu; family Charadriide}

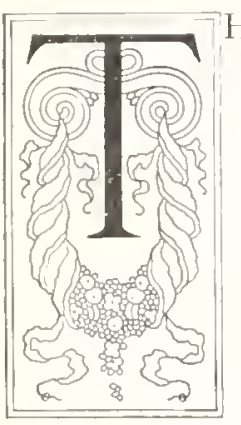

HE Plovers comprise the family (harudrida of the order of Shore Birds and include about serenty-five species of comparatively small birds, which, during the breeding seasnn, have a ensmospolitan distribution. The birds generally are migratory and they are likely to cover great distances in their journeys hetween their summer and winter homes, this being particularly true of the Golden Plover. Eight species occur in North America. Externally the Plovers differ markedly from the Snipes in having a comparatively short and pigeon-like bill, which is hardened and somewhat swollen at the end, and is ill-adapted for probing in mud or suft sand, and they must. of neeessity, feed from the surface. For this reason, also, Plovers are often found feeding in the dry uplands not frequented by the Snipe. Furthermore, in the Plovers the hody is relatively shorter and plumper than in the Snipes, and the neck is much shorter and thicker. Plovers' wings are long and pointed, and, except in a few species, when folded extend to or bevond the end of the tail, which is comparatively short, generally rounded, and consists of twelve feathers. Their plumage varies greatly, and in some species shows considerable seasonal changes.

They nest on the ground and lay ustally four eggs, which are marlied or spotted with dark colors in a manner that makes them hard to detect among the pebloles by which they are likety to be surrounded. But one brool is raised in a season. The young when hatehed are covered with soft buff or gravish down, spotted with blackisli. Whether or not the ehicks know that these colors are jrotective, it is certain that they lie very still anong the peblules and grass when an intruder approaches, and therefore may easily be overlooked.

Plovers' voices usually are mellow, piping whistles which have singular carrying power.

$$
\text { 1.11.. } 1-18
$$




\title{
BLACK-BELLIED PLOVER
}

\section{Squatarola squatarola (Linnaus)}

\author{
1. O. U. Number 270 See Color I'late 39
}

Other Names.- Black-breast; Black-breasted Plover ; Bull-head : Bull-head Pluver; Beetle-head ; Bottle-head; Chuckle-head; Hollow-head; Owl-head; Whistling Plover; Whistling Field Plover; Pilot; May Cock: Swiss Plover; Ox-eye; Four-toed Plover; Gump; Gray Plover (autumn); Mud Plover; Pale-belly (young).

General Description.- Length, 12 inches. In summer, upper parts black and white, lower parts black; in winter, whitish all over but tinged with brown above. Four toes, but hind toe very small; outer and middle toes webbed at base; bill rather short.

Color.-Adults in Summer: Forihad, crown, sides of head to upper lewel of eye, back of neck, and sides of same, pure white with a few dusky spots on nape and center of neck; rest of upper parts, including coverts, shoulders, and inner secondaries, white, each feather with a small exposed dusky area, these forming bars on the imer secondaries; tail and upper coverts, barred with dusky; bolow, including lores, chin, throat, part of side of head. breast, and abdomen, pure blackish-brown; nuder tail-coverts, white: primaries, dark brown blackening at ends zith large white arcas at base; bill and feet, dusky-gray; eye, remarkably large and lustrous, deep brown. Abults IN Winter: Ground color all over, whitish; upper parts, tinged with pale brown; crown, yellowish streaked with dusky; sides of head, back of neck, throat, and breast, finely streaked with brownish; feathers of back, of wing-coverts, and of inner secondaries, with wedgeshaped dusky centers; rest of under parts, unmarked, thus showing none of the black area so conspicuous in summer; bill, feet, and eye as in summer; intermediates between these two plumages, showing an admixture of black and white below, are very common. Young: Upper parts, lighter with a golden shade on each feather: under parts, whitish; breast, streaked with grayish.

Nest and Eggs.- Nest: A mere depression in the ground, lined with grass and leaves. EGGs: 4, light buffy-olive to deep olive-buff, heavily spotted with sepia or black.

Distribution.- Nearly cosmopolitan: breeds on the Arctic coast from Point Barrow to Boothia and Melville peninsulas, and also on the Arctic coast of Russia and Siberia: winters from the Mediterranean to South Africa, in India and Australia, and from California. Louisiana, and North Carolina to Brazil and Peru; in migration occurs throughout the United States and in Greenland and the Bermudas; accidental in the Hawaiian Islands.
The largest of our Plovers, the Black-bellied or Black-breast, is also the shyest. I recall that once, in boyhood, I was trying to creep up on a flat to get a sliot at a small flock - of course in vain. A fisherman said to me, as I returned: "Sonny, you night as well try to walk up to an old Black Duck in broad daylight as to them "ere I'lovers."

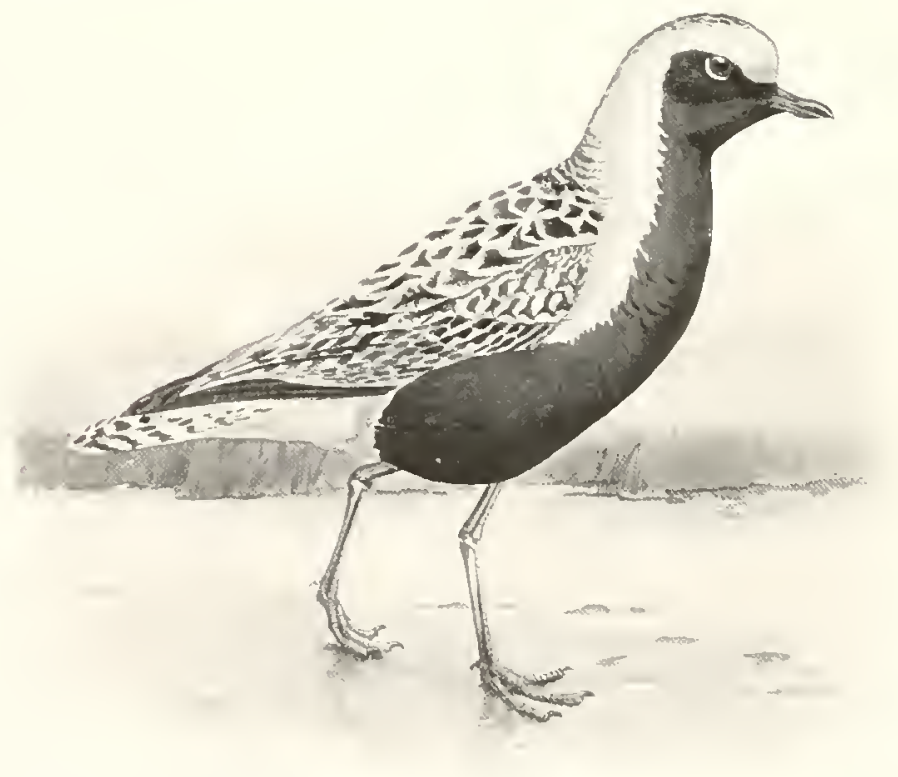

Drawing by R. I. Brasher

BLACK-BELIIED PLOVER ( $\frac{1}{3}$ nat. size)

The largest and shyest of the Plovers 
Thanks to their wariness, it is quite possible. eren at the present, to see mall parties or flocks uf these stout hirds standing well out on the flat, at the water"s edge. It the first alproach of danger. off they so. with their mellow call $n t$ tec-utrete. I"lump hodies and larese heads, as well as the white rump, white on the extended wings, and the conspicuous hlack patel under the wings against light feathers, make them easy of distinction from the darker fullen I'lovers. Unlike the latter, which resort to dry fields to secure grasshoppers and other insects, these "Beetle-heads," as they are smetimes callew hy fishermen and gunners, mostly confine themselyes to flats and beaches and to pook in the marsh.

Solid though they are, comparatively, I made the discovery one day that they could wa where I could not. I small flock were feerliner well out at the water"s edge, at low tide, on a muddy shore. in winter, on the coast of I.nuisiana. I nuanaged to wade out with my heary nutionpicture camera near enough to show them up with the telephoto lens. When I started to return, I thought I should have to stay there. When I pulled the tripod legs out of that tenacious mud, I sank down so that I could not extricate myself without putting down the tripod again and leaning on it till it was as a eep in mud as before. Theoretically this might have contimued forever, hut finally I managed to stagger to dry land without disaster.

Is with the Colden Plover, there is decided difference between the plumages of arlult and young, notably so in the case of this sjecies. These "pale-hellies" are readily distinguished. They arrive on the New England coast early in September. whereas the adults lesin to appear about Iuly 25. The young linger late in the tall, sometimes being noted well through November.

Even hack in the palmy days when the rolden l'lover was sometimes abundant, it seemed to me that the Black-breast did not hahitually Hy about in such lare flocks as its relitive, nor did these smaller flucks fly as high or perform such sight] evolutions in the air. They were, however, accustomed, in some localities, to concregate in a very large mass on some fiarorite dry sand-bar or flat, to seatter asain when they left the rendezvous.

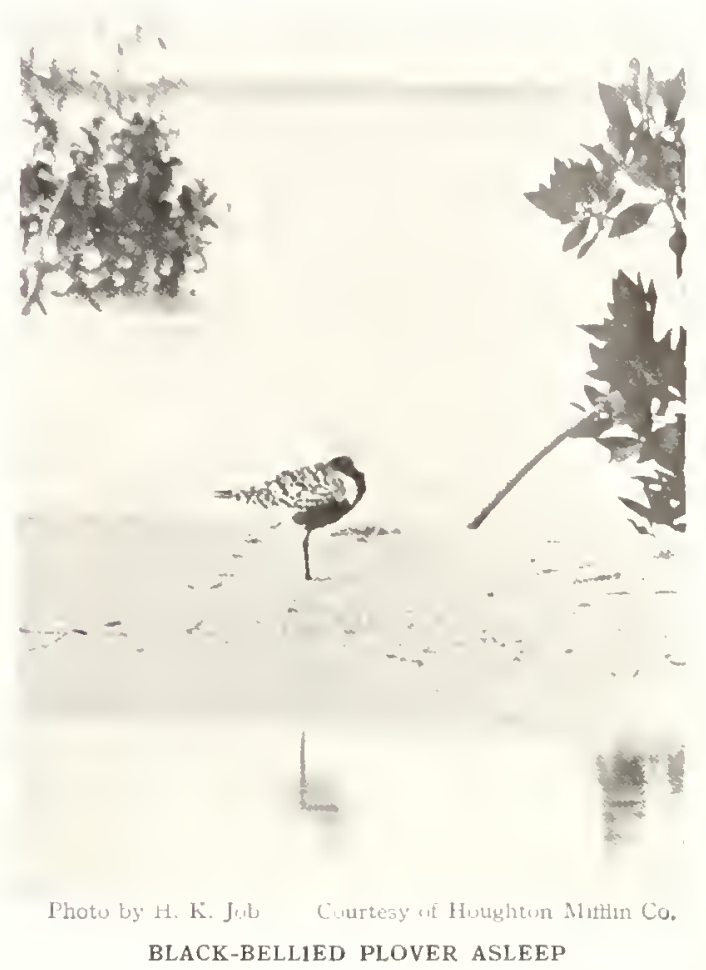

Nso like the Golden I'lover, they breed on the Aretic coast and penetrate on the southward migration as far as l'eru. But their routes are quite different, and smme of them winter on our fiulf and south Atlantic coasts.

llikiskt k. Jors.

\section{GOLDEN PLOVER}

\section{Charadrius dominicus dominicus ( Hiiller)}

1. O 1'. Number 272 see Color Plate 39

Other Names.-American Colden I'luver: Green Plover: Three-thed Plover; Whistling I'fover: "Threetoes: Common Plover: Spotted Plover; Ficld Plover: Grcen-back: Gulden-back: Brass-back: Greenhearl: Pale-breast; Muddy-breast: Muddy-belly: Bull-heacl: Toad-head; Hawk's eve: Squealer; Fiehl-hird; Pasture- hird: Frost-hird: Trout-hirrl: Prairite-bird: Prairie Pigeon: Pale-belly (yomng).

General Description,- Length, Il inchea, L'pper parts conspicunts spotted with ydlow, lower part black. Bill small and alender: no hind toc: wings long. Bohs its hearl very frequently. 
Plumage,--Adults in Summer: Forehead, broad stripe over and behind eye and continuing down side of neck and breast, pure white; croa'n, back of nock, back. and shoulders, blackish-bruan, streaked on crown and back of neck, and each feather of rest of upper parts sharply indented all around with golden yellow; wingcoverts and secondaries, more brownish, but showing some golden-yellow spotting; primaries, plain duskygray darkening at tips and whitening at hase, hut no pronounced white areas as in the Black-breasted Plover: tail, white with brownish hars; lores, throat, side of hear in front of white stripe, breast, and under parts, pure lorownish-black; bill, dusky ; feet, lead culor; eye, large and lustrous brown. ADCLTS in Minter: Above, sonewhat as in summer but colors less intense; more greenish-yellow and paler hrown; sides of head, neck, breast. and under parts in general, brownish or grayishwhite, narrowly streaked on sides of head and throat. mottled on neck, breast, and abdomen, with rlark grayish-brown; an obscure dusky stripe behind eye; bill, legs, and eye as in summer. loung: Above, dusky mottled with dull whitish spots, hecoming yellow on the rump; below, ashy, deeper on lower neck and breast.

Nest and Eggs.-NEST: A slight depression in the moss or ground. EGGs: 4 creany-white to buffybrown, spotted holdly with blotches of brown and hlack.

Distribution.- North and South America; breeds from Kotzebue Sonnd along the Arctic coast to mouth of the Mackenzie, and frum Melville Island, Wellington Channel, and Melville Peninsula south to northwestern Hudson Bay; winters on the pampas of Brazil and Argentina; migrates south across the Atlantic from Nova Scotia and New Brmswick; a few pass south through the Mississiupi vallev, and all nigrate north by this route; in migration to California. Greenland, and Permuda; formerly abundant, now becoming rare.
In the Golden Plover we have a noble and beattiful species which has woefully decreased in numbers and may even he in danger of extermination. Its wonder ful migrations have been much written about. Breeding along the Aretic consts of northwestern North America, the (iolden Plovers in August proceed eastward to Labrador, and down the coast to the peninsula of Nova Scotia. Thence they launch forth over the open Atlantic, straight south, passing several hundred miles off the New England coast, unless driven ashore by easterly gales. Continuing, they

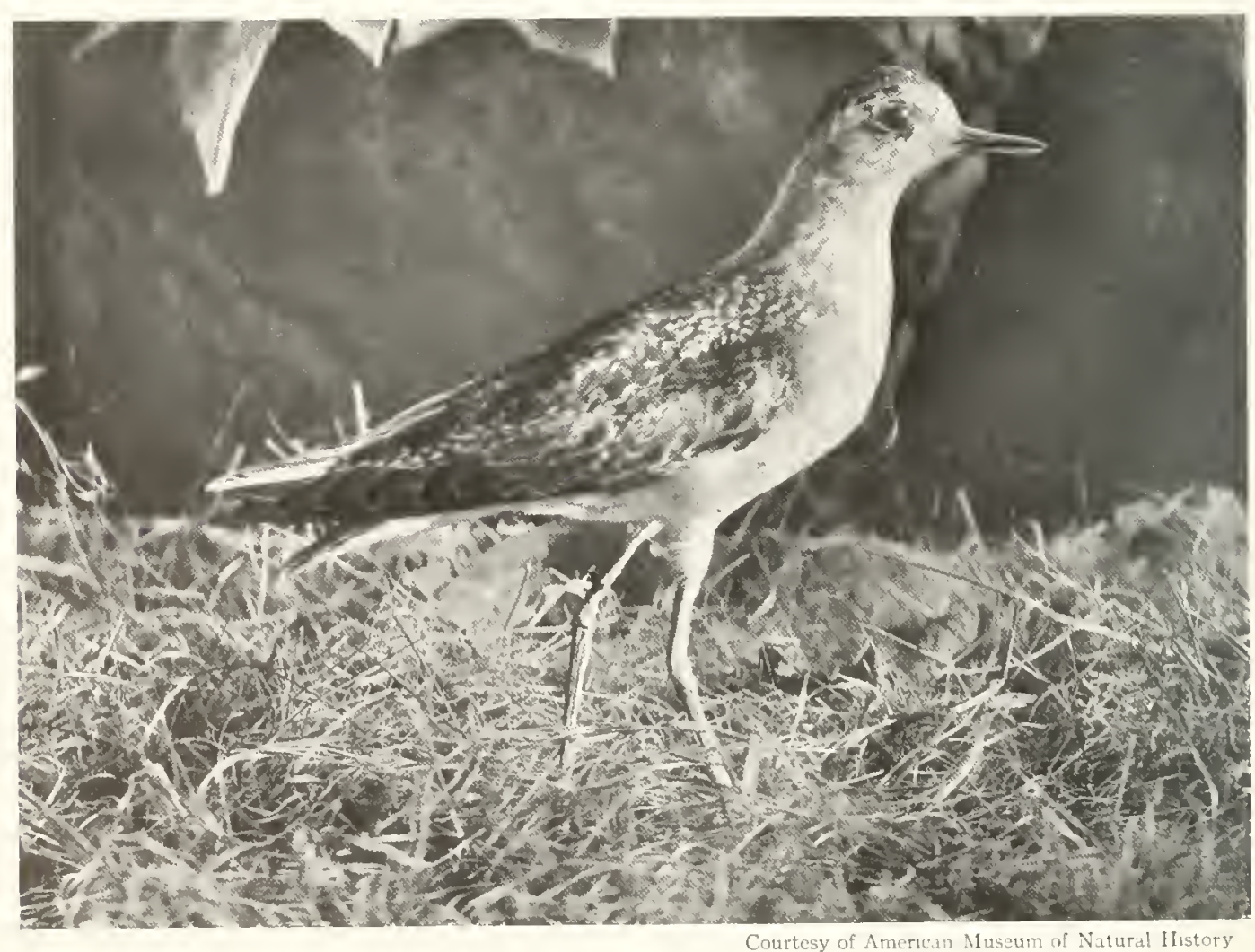

GOLDEN PLOVER

(Winter plumage)

A noble and beautiful species which has woefully decreased in numbers 
lass the Mest Indies, cross the full of Mexico and appear on the coast of lirazil. Beins able to alight on the water and feel among masses of drift-meed makes such a long journey possible. Reaching land, they keep on fown to the pampas of Irgentina. Returning north to breet, they pass, in April and May, up through the interior United States, especially the Mississippi valley, neglecting the Atlantic coast, and thus again reach the breeling grounds.

The antumnal Hight on the New England coast used to be a great event, watched for witl eagerness lyy the local gumers. If a tropical hurricane came up the coast between about lugunt 20 and the midclle of September, with its violent onshore gales from the northeast, there would le a wonderful infux of Golulen ]'overs, driven off their course, accompanied by equally great flocks of the Eskino Curlew, now, alas, probably extinct.

The last really great flight of hoth these species which I winessed was in late fugust, 183 , at Chatham, Mass., at the southern end of the projection of Cape Cod. The wind was shrieking, and I hardly could stand against it on the exposed headlands, where I watehed sreat compact masses of these wonclerful hirds, hish in air, blowing in from the sca. They alighted, as was their wont. m the whlund wassy pasturen as well as on the marshes, where they eagerly levied toll on their favorite grasthopler diet, while the gunners also trok toll of them. Thus early in the season all were in the changing arlult plumage, the pale-bellied young not arriving till about midSeptember.

In Nova Scotia, before they launched forth on their great voyge, ] have watched large flocks of them perform wonderful aerial evolutions wer the marshes, swinging high and low many times before alighting. They cante ytute rearily to tin or wooden decoys before a well-placed blind. During the spring fight, in Mlay, I have watched them on the North Dakota prairie, when they were in their exyluicite breeling plumage. Is they faced me, their coal-black breasts so hlended with the black loam soil that it was hard at first to make them out. Apparently realizing their concealing coloration, they would stand perfectly still till I cane within fifteen or twenty jaces, whereupon they would dat off together in their swift flight, piping their melomlinus calls.

IIRBERT K. JOI:

\section{KILLDEER}

\section{Oxyechus vociferus (Linneus)}

1. O I. Vumber 273 see color l"late in

Other Names.- Killdeer Plover: Anisy l'lover: Chattering Plover; Killdee.

General Description.- Length. In inches. Color above, olive-brown: below, pure white. A front view of the bird shows four black hands, two on head and two on breast. Wings, long and, in flight, showing a white $\mathrm{V}^{\top}$; tail long and rounded: bill slender.

Color.-AntLTs: Forehead. white from eye to eye, prolonged below: ahove this, a black hand; a hrownish-hlack patch from gape along lower sirle of head: a white collar around neck continuous with white throat: a broad diffuse stripe of the brownish-black back of eye; crown, back, shoulders, wing-coverts, and secondaries, plain olive-brown: mmp and uppor tailcorerts, orame-broan deepening to clestnut behind: several inner frairs of tail-feathers, olive-hrown slading into black, then lightening again and changing into rusty tips, whers with the orange-horn at rump, hlack subterminal hars, and pure white tips, the unter pair, mostly white, with several broken black lars on inner webs; primaries, dusky with a white space on onter webs and a longer one on inner wehs; secondaries, montly white, hut witl black areas increasing from within outward; a black breast-hand racircling neck: below this a white space, and bolna this aldain another black brast-band not crtinding around neck: rest of under parts, pure white; bill, duaky ; lewa, learlen gray ; iris, brown; eyelids, orange or red. lount, Plack of arlitits replaced by gray; feathers of upper parts marked with rusty-brown.

Nest and Eggs.- Euss: Depusited on the hare ground in fields, woulty ncar water: 4. dull buffy, thichly spotted and blutched with brown and sepia.

Distribution.-North and Sinth America; hreeds from central 13ritish Colmulia. whthern Mackenzie. central Keewatin, and central (Juchere sonth to the Gunf const and central Mexion; winter from California. Arizona, Tevas, Tndiana, New Joracy, and Permuda couth to Tenezuela and Peru; casual in New foundland, Paraguay, and Chile: accirlental in Creat Pritain.
The killdeer gets its name from its loud, strident, and frequently reiterated cry. which smmewhat resembles the works "Kill "leer" or" the syllables "Kill-dee." It is a true l'loyer, and a member of the important shore-hirel family which are usually to be foumd near the water or in moist places. Fut the Killdee's alco oecurs ftefuently on pertectly dry lame, nany miles from 


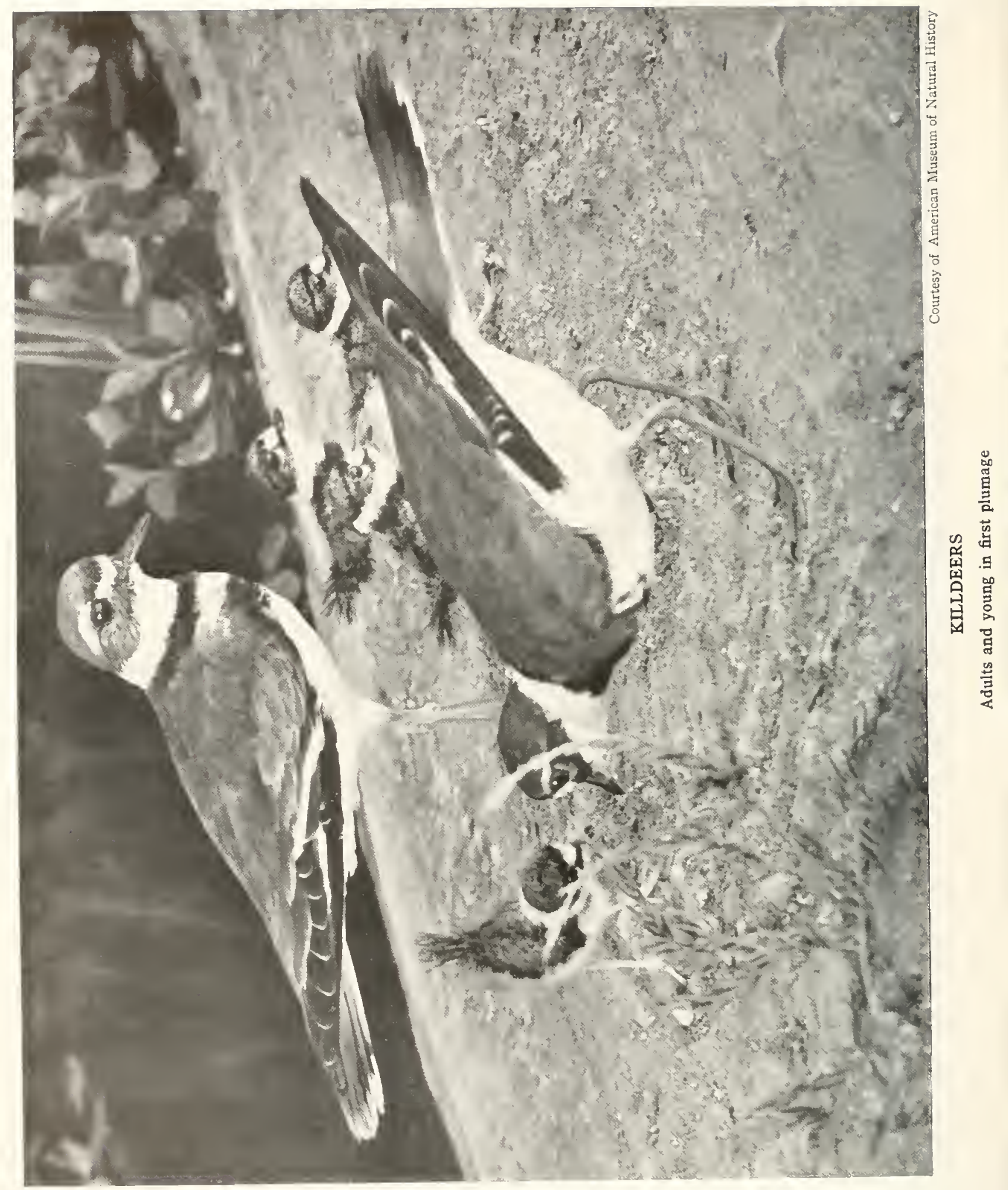


ponds, streams, or the ocean. It scems to be especially fond of freshly plowed fietes, where it feeds voraciously upon worms, gruhs, and bugs of various kinds. (On the ground it runs about rapilly and in a somewhat norvous manner, frequently uttering its somewhat petulant cry, which, under these conditions, is sonctines abbreviated to the last syllable, der.

The Killeeer is especially solicitous about its eggs or young. When the incubating bird is flushed from her nest, she resorts to all of the tactics of the ground-building birds, fluttering away with one or both wings dragging as if broken, sometimes almost rolling over, often stopping to gasp and prant as if totally exhausted. and keeping up meanwhile an incessant screaming. In the meantime the male bird circles around at a safe distance, adding his protests and denunciation, and the two continue the uproar until the intruder has withdrawn.

On the wing the bird is swift, graceful and somewhat erratic, for which reason it has been much pursued as "game" by antateur gumers and others who should have known hetter. This "sport" is forbidden by the Federal Migratory Bird Law, which prohilits the luunting of these birds until tols. The bird should, indeed, be protected at all times, not only because the shooting of it is killing for the mere sake of killing. since its flesh is not edible, but becaltse it makes itself exccedingly useful by destroying great quantities of noxious insects.

There can be no doubt as to the economic value of the Killdeer's feeding habits, for its regular diet is known to include mosquitoes, the fever tick, which spread she dreaded Texas fever annong cattle; crane flies ("leather-jackets"), which are destructive to wheat and grass: grasshoppers, the clover-poot curculio, various weevila which attack cotton, grapes and sugar bects; bill-

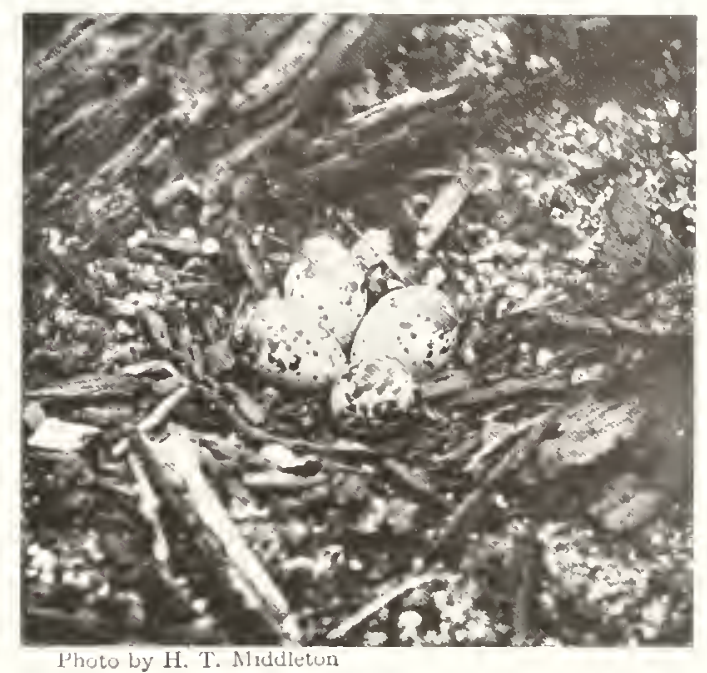

\section{EGGS OF KILLDEER}

Laid in a depression of the ground

bugs which often do much damage to corn; wireworms and their adult forms, the click beetles: the southern cornleaf beetle; horse flies; crawfishes; the diving beetles which are injurious in fish hatcheries; and the marine worms which prey upon oysters.

Geukge Gladden.

\title{
SEMIPALMATED PLOVER
}

\section{Egialitis semipalmata (Bonaparte)}

\author{
A. O. U. Number 274 Siee Color I'late 39
}

Other Names.- Semipalmated Ring Plover; Ringnecked Plower; Ring-neck; Ring Plover; Red-eye: Beach-hircl.

General Description.- Length, ; inches. Upper parts color of wet sand: lower parts white; one black ring around neck. libll short; outer and millle toes webbed to the second joint; hind toe missing.

Color.-Anuls: A narrow black lar extending from eye over top of bill to other eye with the white space ahove it, and this in turn borkered by another black stripe reaching from eye to eye across front of crown: below eye (narrowly) and behind it a dusky stripe; a white bar around back of neck continuous wuth white of chin and lower sides of head: below this, a broader bar of dusly encircling neck and upper breast: croa'n and upper parts, dark brozenish-tyray; tail, like back darkening toward end, white-tipped; primaries. Ausky; narrow, white spaces at base; secondaries. largely white excent long inner ones which are like the back; greater coverts, white tipped; entire under parta. white; hill, yellow, with hlack tip; feet, pale flesh color: eye-ring, bright orange: iris, hazel. Young: Plack of alults replaced ly hrownish-gray; feathers of upper parts with buffy edgings.

Nest and Eggs.- Nest: A mere depression in the ground, lined with leaves or grass. Eoris: 4. buffy to olive-buff, spotted and blotched with dark brown and black. 
Distribution.-Nortl and South America; breeds from Melville Island. Wellington Channel, and Cumberland Sound to the valley of the upyer Yukon, southern Mackenzie, southern Keewatin, and Gulf of St. Law- rence; winters from southern Lower California, Louisiana, and South Carolina to Patagonia. Chile, and the Galapagos; casual in Siberia, Greenland, and the Fiermudas.
The Semipalmated Plover is the common Plover of the Atlantic seaboard, for during the migrations there are probably more of them to he seen than of all the other Plovers combined, but even at that they are far from being numerous as they once were. In my boyhool I have seen flocks of hundreds, while now it is a matter of dozens. Tet we are fortunate in having them still with us to illustrate the Plover type on our bound in response. When they take to wing these notes are speeded up and reiterated as the flock circles out over the water and dashes past. They are with us in May, and again in August and September, being nore numerous in the latter period, reinforced by the new generation. Through August we see the adults, with theirdistinct black breast-bands, but it is not till September, usually, that the grayer young begin to

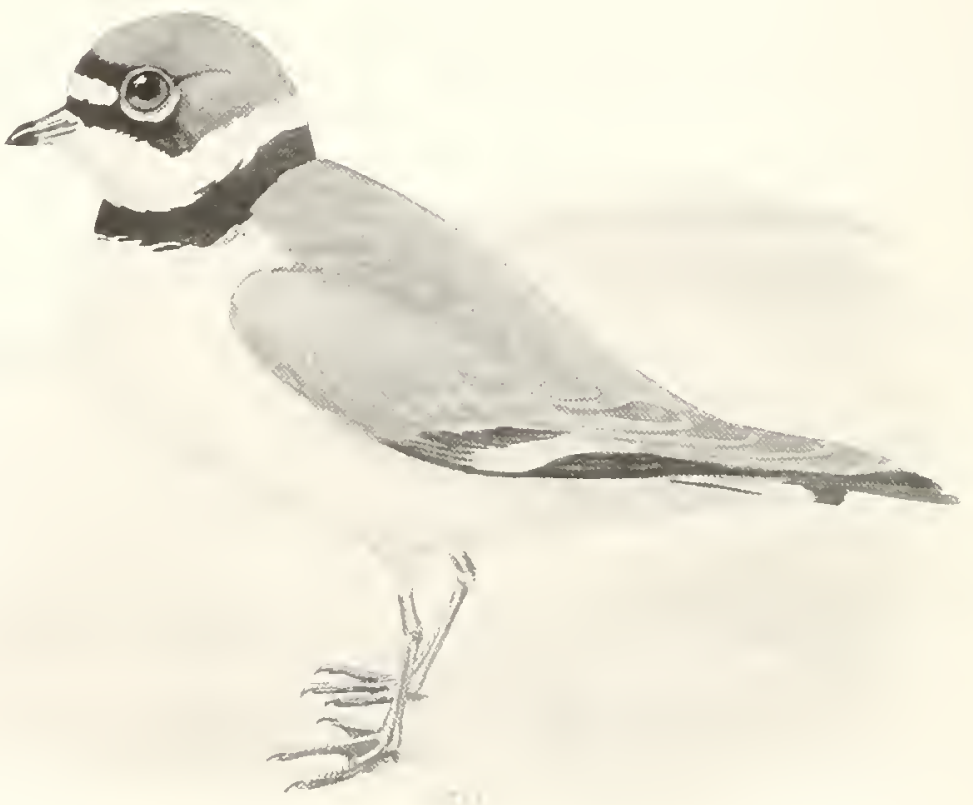

Drawing by R. I. Brasher

SEMIPALMATED PLOVER (产nat. size)

A graceful little Plover and skillful in the art of concealment

beaches and flats - birds with heads projortionately large, with robin-like actions in racing off for a few vards, then standing still to gaze and meditate, though with the body more horizontal than the Robin, then stooping to conquer the small marine life at their feet.

They frequent both beaches and flats, preferably the latter, and sometimes pools on the marsh. Ifere they scatter out in leeding but bunch together in flight. From the flats, before we discorer them, comes that singularly attractive characteristic call which always makes my pulses aprear, illustrating one of the strange phases of Jird habits, that in many cases the voung make the long untried journey southward after most of the parents have gone on before. They are found in the interior, as well as on the coast, but mostly along the larger bodies of water, or on marshes where there are shallow sloughs and mud-flats.

The brecling-grounds are mostly in the Far North, even beyond the Irctic Circle. The southermmost point where they are known to breed is the Gulf of St. Lawrence. There I have studied them, on the Magdalen Islands, finding a scattered 


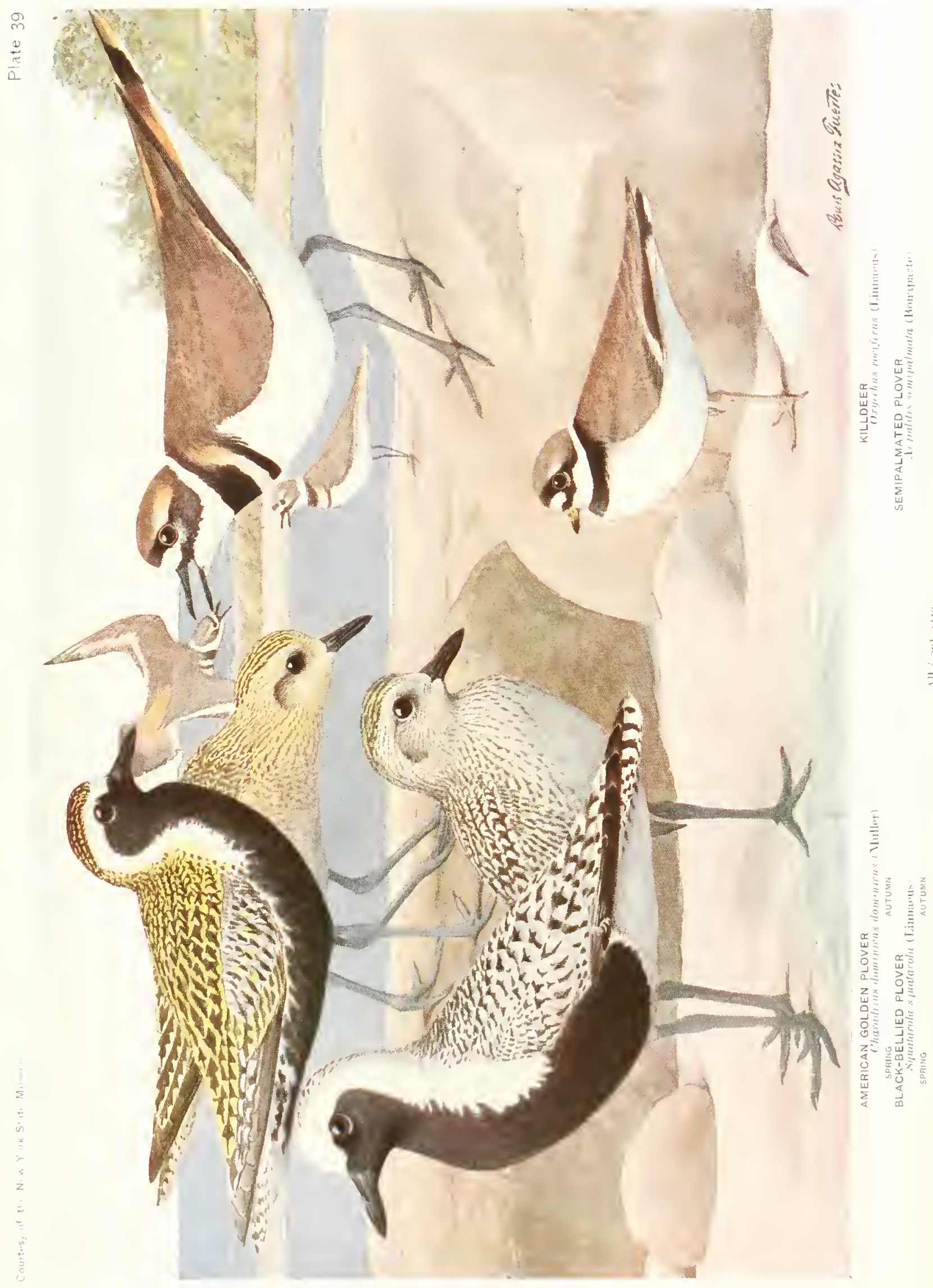



culony on a long sandflat, boudering a lagonn, that stretched for miles between two uf the lareer islands. The litule creatures would run ahead of me, piping plaintively. Careful looking finally revealed a number of their nests, hack from the laxoun, in the sand and froken wells above ligh-water mark, or further hack in the tracts where spare tufts of heach-grass wew from the sank. The nests were more than the mere scratched-out bollows of the F'iping l'lover, in having at least a few grass-stem or seraps of dried sea-weed surrounding the hollow, or even partly filling it. The egress were wsually fottr, sometimes only three, hanclsome, boldly martied, resembling. save for their priform shape. Terns' eggs more than those of Piping and Vilson's Plovers.

Breeding seemed to be at its height the tenth of June. By that time a very few young nere just hatched. They are darker than the P'iping Plover chicks, but have similar ways. I had quite an experience in catching and tethering one of them to a blade of grass. Sitting quietly on the sand near by, I watched the mother rim about anxiously, and finally venture up to snugse the baby, while I tuok snapshots of them with the reflecting camera.

IIERBERT K. Juli,
The Semipalmated Plover's diet moludes several species of injurious washoppers, as well as mosquitoes which suriously molest cattle and certain species of which it is now well known

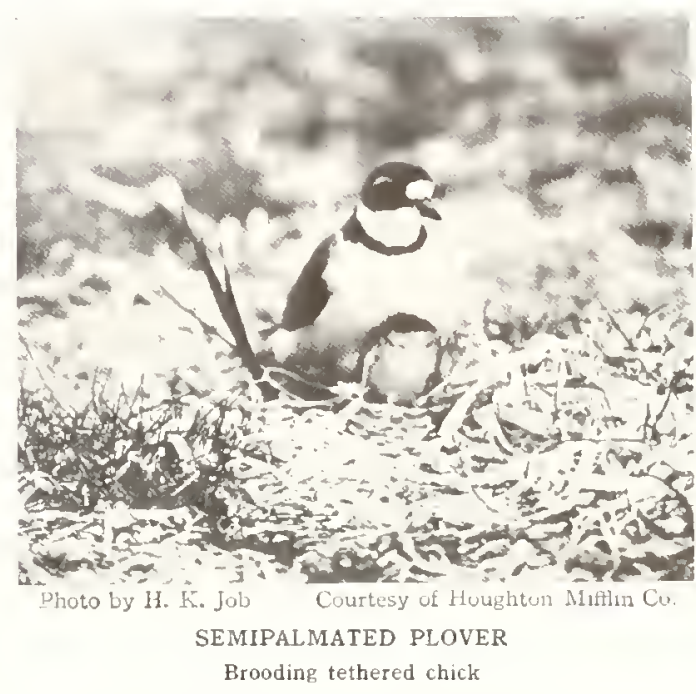

may be carriers of dangerous diseases. It is known also that the bircl feeds upon locusth. The usefulness of this l'luver is, therefore, leroud questiun.

\section{RINGED PLOVER}

\section{Egialitis hiaticula (Linnaus)}

A. O U. Number $2: 5$

Other Names.- Ringed Dotterel; Ring Flover.

General Description.- length, $7^{\mathrm{T}}$ inches. Coloration very similar to that of the Semipalmated Plover. but usually the white spots in the lower eyelids and a white patch behind the eve are better marker. No web between middle and inner toes; hind toe missing

Nest and Eggs.- XEST: A slight depression in the sand amirl broken shells. Eros: 4. pale buff or cream

The well-known Ring Plover of Europe was long supposed to be confined to that continent, but it is now known that the hird breeds freely in rireenland and there are definite recorls of its appearance in America, one specimen having been taken at Great siave lake. It resemliles the Semipalmated l'lover, thomgh it is somewhat larger, the black band on the lreast is wider and the white stripe on the forebead extends backward and rownward over the eye, while it lacks color. spotted with dark reddish-brown apprnaching hlack.

Distribution,- Eastern Arctic America and Old World: breeds from central Furope and Turkestan to Siberia. Spitzbergen, Iceland. Gremland, and Cumberland Sound; winters on shores of the Mediterranean and throughout Africa; acciclental in Barbadon. Chile. India, and Australia

the weh between the middle and inner toes of the Semipalmated. Its general habits are ploverlike.

This d'lover must be consinlered a very usetul hird hecause it persistently destroys several species of grassoppers which are known to be injurious to crous. It should, therefore, be protected against molestation which is at all likely to lesseu materially its numbers, or to change its normal habits. 


\section{PIPING PLOVER \\ Egialitis meloda ( $\mathrm{rd}$ ) \\ 1. O. U. Number 277}

Other Names.-Ringneck: Pale Ringneck: White Ringneck; Belted Piping Plover; Western Piping Plover; Clam Bird; Mourning Bird; Beach Plover; Sand Plover.

General Description.- Length, 7 inches. Upper parts, color of dry sand; under parts, snowy white. Tocs, not a'ebled; hind toe missing; bill short.

Color.-Forehead, white; a black band on front of crown from eyc to eye: lores, streak behind eye, chin, throat, sicles of head, a half collar around back of neck, and entire under parti, pure snowy white: crown and upfor parts, zory palo ashy-browen; a black band on upper breast tending to encircle neck but not meeting; an indistinct dusky streak behind eye; primaries, dusky with white spaces at base; secondaries and greater coverts, mostly white: long inner secondaries, similar to back; upper tail-coverts and base of tail white, latter blackening toward end, and onter pair of feathers, entircly white; an orange-red ring around eye : basal half of bill, orange yellow, front half, black; feet, yellowish; iris, brown. Adult Female: The crown bar is usually dark brown and the breastband much reduced and brownish. Young: No trace of dark color on head, and little, if any, on sides of neck; feathers of upper parts with pale or rusty edgings; bill, mainly black.

Nest and Eggs.-EgGs: Generally laid among stones on the beach; 4. clay color or creamy-white, thinly and uniformly marked with sepia specks, sometimes mere points.

Distribution.- Eastern North America; breeds locally from southern Saskatchewan, southern Ontario, Magdalen Islands, and Nova Scotia south to central Nebraska, northwestern Indiana, Lake Erie, New Jersey (formerly), and Virginia; winters on the coast of the United States from Texas to Georgia, and in northern Mexico; casual in migration to Newfoundland, the Bahamas. Greater Antilles, and Bermuda.
Truly a bird of the beach-sand is the Piping Plover. With propriety it might have been named the "Sand Plover." It looks the part, for it lives on the sand and so closely resembles the sand in color that it is rendered almost invisible till it moves. Then whoever it is that approaches may notice a whitish streak projecting itzelf ahead over the intensely bright dry sand so rapidly that it might more readily seem to be something flying than rumning. Its piping calls are plaintive and pretty, harmonizing finely with the general spirit of the extended beach, the dazzling sand, and the flowing sea with its monotonous undertone.

Somehow the sea-beach hardly seems fully genuine without it. None the less many of our beaches have lost this little gem of a resident. With the advent of increasing throngs of stmmer visitors, the eggs are stepped on or picked up. and the birds are shot by vandals or are forced to move on. At some times it has seemed that these birds would be exterminated, hut law and public sentiment have come to the rescue, and in some quarters they still cling tenaciously to their old haunts. They are found not only on the seacoast, lut on the sandy or pebbly shores of the larger inland lakes.

The eggs of this Plover generally number four and are laid in a rather deep. well-rounded cavity, in almost clear sand, when there is such, but otherwise on shingle or pebbly areas, at the top of beaches. They are laid in the latitude of southern New England during the latter part of
Nay or in early June. I have even found fresh eggs in July, but such cases are more likely second layings, after the first set is destroyed, as shore birls as a class seem to rear but one brood each season. The eggs are distinct from those of other allicd species in being finely speckled instead of coarsely marked.

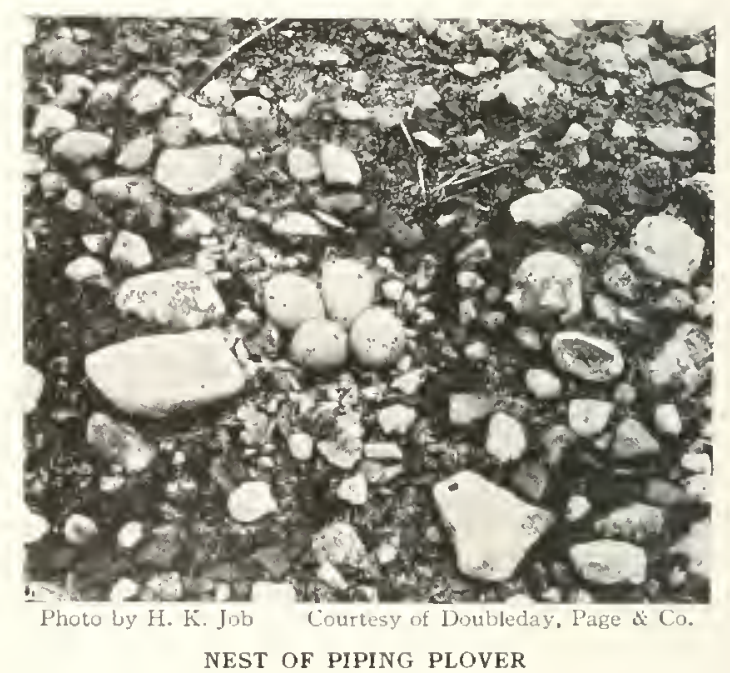

The roung look like little hunches of cottonbatting blowing over the sand. Though born out in the open glare of the sum on the hot sand, they cannot at first endure much heat, but are carefully brooded by their parents, or else hide under drift-weed or in the clumps of beach-grass.

The food of these little Plovers is the tiny 
marine life cast un ly the waves on the hroad white lieaches where they spend their imocent lives and beautify the impressive surmundings. The sight of a big man with a gun chasing the little things has always seemed to me an atrocity, happily now made a crimle, both by State enactments and be tle laws of the nation.

lleriart K. Joh.

\title{
SNOWY PLOVER
}

\section{Ægialitis nivosa Cassin}

\author{
1. () $[1$, Number 2,8
}

Other Name.- Snowy Ring Plover.

General Description.- Lengti, $>$ inches. Culor above, ashy-gray: betow, snowy-white; no complete white ring armul nick. bill slender, shorter than lead; hind toe misings.

Color.-Anelt Atme in Summer: Forehearl, tine wer eye, sides of head and whole under parts, snowy white; broal black bar from eye to eye: crown. pale urange-brown: narrow black streak from hack of eye tending to meet its fullow on nape; rest of upper parts. pale ashy-gray: several pairs of tail-feathers, like hack, darkening toward ends; two or three outside pairs, entirely white; primaries, dusky with a brownin central space: sretater coverts, ashy-gray, whitetipped: primary coverts, larker, also white-tipped: nuter secondaries, dark brown. long inner ones, onlor of hack: a briad black patch on each side of hreast, nut meeting on hack of neck or front of hreast; bill and twet, black; iris, brown. AnLli liemale IN SUMMeK: Band over eye and stripe back of it, with breast patch, dusky-inray: otherwise similar to male. Anults in WINTER: lilack parts replaced by grayish brown; otherwise simitar to summer plumage.

Nest and Eggs.--Nest: I depression in the sandy beach. Erits: 3. rate huff or clay color with ummerous scratchy markings of dark hrown and hack.

Distribution. - Western United States, to South Anterica: breeds from central Califormia, northern Ltah. and southern Kansas south to nuthern Lower California and sonthern Texas; winters from southern California and Texas south along hoth coasts of Central America. and on the west cuast to Chile: casual in Oregon. Iyoming, Ontario, Louisiana, Florida, Bahamas, Cuba, Venezuela, and Brazil.
Something like poetic license must be invoked as an excuse for calling this I'lover " snowy," since in point of fact only about half, ancl that the lower half, of the bird is white, while the upper parts grenerally are luffy-gray. It is essentially a bird of the western United states. Its note is smilar to that of the Piping l'lover and so are its halits, especially that of searching for marine crustacea and worms along the seashore. following the receding waves and retreating before them as they come sliding in.

The male and female take turns at incubating the eggs and the lird who is on the nest is fed by the other. lint for the tracks made by the birts in these visits, the eggs nsmally would be exceedingly hard to find, as their color often makes them blend perfectly with the sand and drift about them.

The breeding halits of the lirds were closely observed at Santa Barhara, California, by Henry IT. Henshaw, and the following graphic description of their conduct when their nest wat discovered is incluted by 1). Baird in North Americun Birds: "Great was the alarm of the colony as soon as his $\mid \mathrm{Mr}$. Henshaw's] presence was known. They gathered into little knots, following him at a distance with sorrowful cries. When her nest was seen to be really discovered, the female woukl fly close by him and make use of all the arts which birds of this kind know so well how to employ on like nccasions. With wings dropping and trailing on the sand, she woukl move in front till his attention was secured. and would then fall helplessly down, and, burying her hreast in the sand, present the very picture of destair and woe, while the mate bird and the other pairs expressed their sympathy ly loud cries." 


\section{WILSON'S PLOVER}

\section{Ochthodromus wilsonius $(\mathrm{Ord})$}

A. O U. Number 280

General Description.-Length, \& inches. Color above, ashy-gray: below, pure white. Head large: bill long and large; onter tues webled halfway.

Color,-ADUlt M.ile in Summer: Forehead, white, extending backwarl above eye; narrow black band across fore cruwn, not reaching eyes; lores, dusky; a white collar continuous with throat, around neck: upper parts, pale ashy-gray tinged with brown or ocher on back of head and neck, feathers of back and wingcoverta, with lighter edges; primaries and central tailfeathers, rlusky; the outer pair whitisln; others, colos of back, growing darker toward end. and white-tipped: a black half ring on fore-breast not completed around neck; rest of under parts, pure white; secondaries. except inner ones, mostly white on inner web. darker on outer; bill, biack; legs, flesh color; iris, dark brown: no colored ring around gle. ADELT MALE IN WINTER: Black replaced by dusky-gray. ADULT FEMALE: Black on breast of male replaced by dark gray, with a rusty tinge: otherwise similar to summer male. Young: Differ only from the adult female in having no black on crown or lores.

Nest and Eggs. - Eutis: Laid among the lonse pehbles of the open beaches: 3. pale olive or greenish-gray, spotted anl splashed all over with blackish-brown.

Distribution.-Southern North America; breeds from Texas eastward along the Gulf coast, and from southeastern Virginia (formerly New Jersey), south to the northern Bahamas; winters from southern Lower California, Texas, and Florida south to southern Guatemala and prohabiy to the West indies; casual in Nova Scotia and New England, and at San Diego, California.
Wilson's Plover looks like a bleached and farled copy of the Semipalmated, or else a more robust and darker type of the I'iping Plover. Its much larger and stouter bill, however, proclaims its identity, as does the fact that it is seen in summer on the southern coast, suuthward of the breeding range even of the Pijing Ilover, though these ranges may overlap occasionally on the coast of Virginia. Its favorite hannts are the more retired sand beaches an! hars from that State southward and on the Gulf coast, preieraljy on the acean front, though it feeds to some extent back on the flats or along inlets. Following the water-line, we meet it singly or in pairs, though there naty be several pairs along a good streteh of beach. later in the summer, from about July, when the young are on wing, there may be a semblance of flucking.

By keeping our eres well "peeted," carefully watching the sand as we walk along, we may spy the spotterl eggs lying in a light cavity of the sand, usually among scattered shells or bunches of weeds or urass, in the dry Hat area of white sand alwe high-water mark. The only nestluilding, aside from the scratching ont of the hollow, is to line it with a few chips of lroken shell. It is hard to see what particular purpose this may serve, mless possilly to make the exgs a little less comspicunns. At the best they are not readily found, and the birds themselves give little clue to the whereabouts of their treasures. They are not very shy, and patter along the sand ahead, uttering flute-like notes. For a while they keep Hying on ahead, and presently will circle out over the water to the rear.

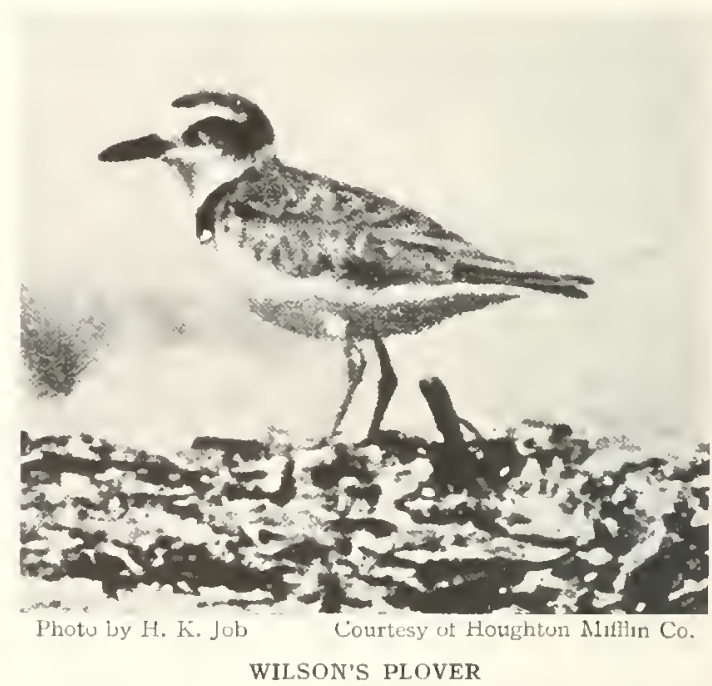

Its favorite haunts are the more retired sand beaches

I have found their egrgs in southern Florida in late April, and on the shores of South Carolina toward the middle of May.

Неквект K. Јов. 


\title{
MOUNTAIN PLOVER
}

\section{Podasocys montanus $(I . K$. Transend)}

$$
\text { 1. (1) 1. Vumber } 28 \mathrm{r}
$$

Other Name.-- Prairie Plover.

General Description.- Length, " inchen. Color above, srayich-brown; helow, white; bill vlemeler; tail short. less than hali the lenetlo of wine: himel tre missing; no web between midtle and inner toes.

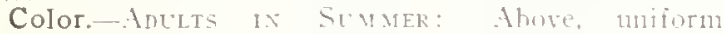
grayish-brown, usually fure but in some cares the ieathers edsed with tawny or ocher: a sharp black line from bill to cye: a black har acruss fore-ernw varving in width from a nutere line to a band nearly half the length of the crown in wilth; contral tailfeathers, color of lack, hlackening toward end, onter unes, rale, all white-tigped: hilws, pur white without bilt or patchis hut hreast sometimes shaded witl rusty or gray: primaries, blackish, sme of the inner mes

(on the central table-tand of the Rocky Mountains, near sweetwater, IVyoming, wis captured the first specimen of the Nountain l'lover to be described. From the altitude of this point, the bird receised its name. In reality, however, its unufficial name of I'rairie Phwer is more alpropriate. It freculents the barren prairies as well as the well-watered regions of the wetem C'niterl states hut not dhe marshes and beaches.
White toward base: hill. hack; lege, leat color: iris, lirown. Auliti in Mintek: Black crown bar and loral stripe, absent; plumage, more ruty; otherwise, as in summer. Youxis: No pure white or hlack markinge, and even more buffy than winter adults.

Nest and Eggs.- Nest: On the upen prairies: a tentesion in the sromml, lined with leaves and grass. Eisis: 3 or 4. cream to light olive. finely and thickly dotted with sepia, black, and lavender.

Distribution.-Westerm North Anerica: breeds from northern Montana and western Nebraska south tw northern New Alexico and northwestern Texas; winters from northern Califurnia an! southern Tevas to southern Lower California and central Mexico: accidental in Ilorida.
It is a quiet bird, attending consistently and constantly to its business of chasing and capturing inrects. It feeds freely upon loeusts, as is shown by the lact that sixteen stomachs of the bird which were exannined, contained an average of forty-five locusts each. Nlso included in its diet are rarious species of harmful grashoppers and it deserves, therefore, tw he convitered a useIul lird.

\section{SURF-BIRDS AND TURNSTONES}

\author{
Order Limicole: family Aphriatda
}

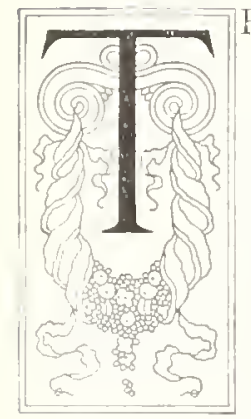

HE surl-birds and Turnstones constitute the family . I phrizide of the order of Shore Birds. There are hut three species, all of which occur in North America. The subfamily of Surf-birds seem to be more closely related to the Sandpipers than to the Plovers, and the only known species is the one rlich is found on the coasts and islands of the Pacific. The Turnstone subfamily includes two species. Structurally they are related to the Plovers and the SurfBircls. The bill is shorter than the head, and is curved slightly upward, a feculiarity which assists the bird in tuming over stmes in search of its food, and from which it derives its name. The legs are short and stout, the wings long and pointed, the tail short and slightly rounded, and the plumage particolored in summer and neutral in winter. The birds lay four eggs, unually on almost harren rocky coasts, and conceal them very cleverly by selecting a nesting site with which their varied colors harmonize very closely. 


\title{
SURF-BIRD
}

\section{Aphriza virgata (Gmelin)}

\author{
1. () U. Number 28
}

Other Name.- Plover-billed Turnstone.

General Description.- Length, ro inches. Color above, dark ashy-brown streaked and varied; below, dull white with dark markings: bill stout with rounded tip : tail, slightly notched.

Color-Adults in SUmmer: Above, dark ashybrown streaked with whitish on head and neck and varjed with chestnut and black on back and wingcoverts: upper tail-cua'erts and basal half of tail. pure white: "est of tail, llack tiphed with athite: primaries, dusky, tipped with white; greater coverts, white-tipped; large space on secondaries, also white; under parts, dull white or ashy variegated with hrownish-black marks; throat and fore-breast, narrowly streaked, these streaks changing on breast proper to crescentic bars; rest of under parts, sparsely spotted; bill, hlack; legs, greenishyellow; iris, brown. ADULTS IN WINTER: Head, neck. breast, and upper parts generally, uniform dusky-brown with darker shaft lines; no white or reddish; wings and tail, as in summer; beneath, dull white faintly spotted. Young: Above, brownish-gray with white edgings to feathers; helow, white streaked with dusky.

Nest and Eggs.- Unknown.

Distribution.- Pacific coast of North and South America; breeding range unknown, but probably in the interior of northwestern Alaska; winters in Chile to Straits of Magellan; occurs in migration from Kohuk River, Alaska, to southern South America.
Ornithologists have been divided as to whether the Surf-bird should be considered a Plover or a Turnstone, and after much argument have compromised by giving it distinct generic rank. Evidently the bird accurs frequently on the Hawaian and other islands in the Pacific Ocean, and it is known also to visit the Pacific coast of the United States, but nowhere is it abundant. Its breeding grounds are unknown. The bird frequents the outer beaches of the sea-coasts, where it permits the spray from the heavy surf to dash over it; hence the name given to it.

\section{RUDDY TURNSTONE}

\section{Arenaria interpres morinella (Linnaus)}

\author{
A. O. [. Number 2833 See Color I'late 33
}

Other Names.-Turnstone: Sca Dotterel: Sea Quail: Sand-runner: Stone-pecker; Horsefoot Snipe; Brantbird: Bead-bird; Checkered Snipe; Red-legs; Redlegged Plover; Chicken; Chicken Plover; Chickenbird: Calico-hack; Calico-bird; Calico-jacket; Sparkedback; Streaked-back; Cluuckatuck; Creddock; Jinny; Bishop Plover.

General Description.- Length, 9 inches. Upper parts chestnut, hlack, and white; lower parts black and white: bill with sharp tip inclined upward; tail slightly rounded.

Color.-Adult Male in SPRing And Summer: Forehead, cheeks, sides of hearl, and back of neck, white with a bar of hlack from side of neck to helow eye, continuing forward and meeting its mate over base of bill and enclosing a white loral patch; another black streak on side of neck; top of head, streaked with black and white: loace hind neck, lack and shoulders, raricgated with black and chestnut; rump and upper tailcozerts, snoz'y-rehite, the latter black in center; tail, white with a broad subterminal black band; center tail-feathers, white-tipped; wing-coverts and inner sec- ondaries, mixed black and chestnut: greater coverts, mostly white; middle secondarics, cutirely white becoming gradually more dusky outwardly, producing an oblique white wing bar; primaries, dusky, largely white at base; under parts, snoacy-rithe; breast and throat, jit-black. encircling a white patch; bill, black: foct, orangrered: iris, deep brown. Adult Female ti SpRing AND SUMMER: Less strongly colored; chestnut replaced by plain brown, especially on wing-coverts; darker parts restricted; black not glossy. ADults IN Winter: Chestnut ahsent, the blacks mostly replaced by browns or grays, the patch on chest smaller and much broken.

Nest and Eggs.-Nest: A hollow scratched in the ground and lined with hits of grass or seaweed. EGGs: 4. greenish-gray spotted and blotched heavily with yellowish and umber-brown.

Distribution.- North and South America; breeds on Arctic shores from Nackenzie River east, probahly to Melville Peninsula, and north to Melville Island; winters from central California, Texas, Louisiana. and South Carolina to southern Brazil and central Chile. 
Shore birds as a class are foremost among the earth's greatest travelers. The typical species of this class breed on the Iretic tundra, and, when winter approaches, migrate nealy to the further end of the South . Imerican continent. Such a wanderer is the Turnstone, a beautiful species, richly colored, and possessed of great powers of fliglit. The month of Mlay finds it rapidly passing across the United States, following both the Atlantic and Pacific coasts and also through the interior. In the latter it is found along the larger bodies of water, but also on the sloughs of the prairies, especially where alkaline conditions produce open muddy shores. Some flocks are seen as late as the first week of Imne. Returning one exceptional chance to watch. It was in late afternoon toward the midalle of September, on a sandy shore, slightly mudity, where shells and debris had been washed up. The select company was "one little Turnstone and I," the latter armed with binoculars, the former too busy to notice intruders. Hle was a fine gentleman. dressed in the gauliest "calicn " possible for the fall fashions, yet not too proud to work for his supper. His method was not unlike that of the proverbial hull in the china shop, for he troted alwut, "tossing" nearly everything that came in lis way. Inserting the "wedge" under a jebble, a shell, or what not, he would give a real toss of his imperious head, and flop over it

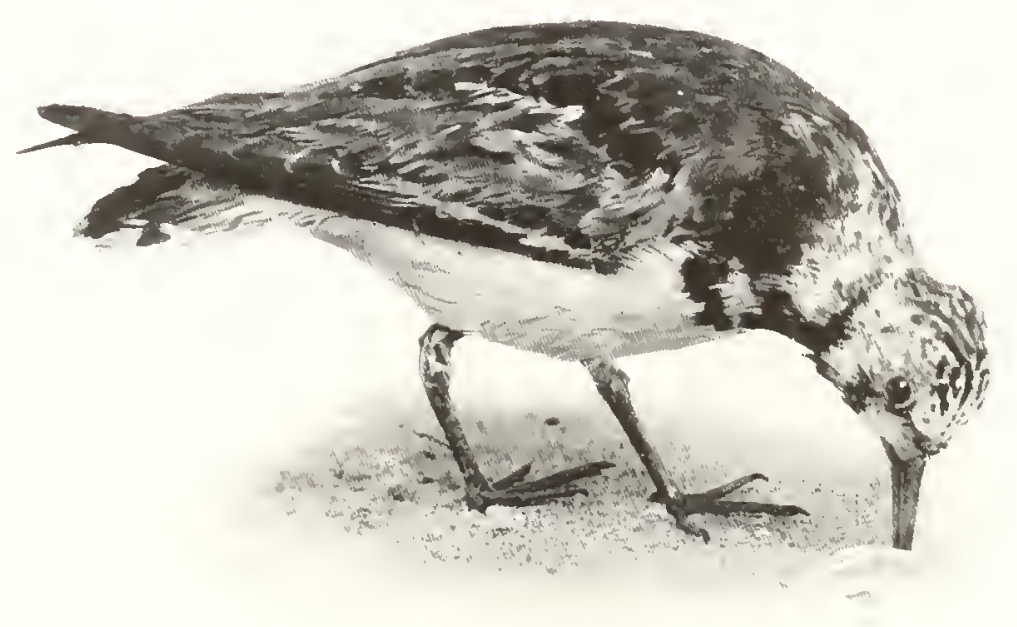

Currtesy ot Ant. Mlus. Nat. Hist.

TURNSTONE ( 3 nai, size)

His method was not unlike that of the proverbia! bull in the clina-shop

hands hegin to aprear as soon as the last of July, and during August the main southbound tide is on.

Their prevailing habit is to keep in compact flocks, more often alout a dozen, when often they fly in lines, as well as hunched up. None the less they are also found scattering, two or three, or even a lone one. They fly very fast, usually with a sort of trilling, rapidly reiterated series of notes. They are well known to hunters, frequently by the mames of Chicken Plover, Calicobirk, ind others.

Their favorite haunts are stony beaches on the open coast and also inlets with gravelly or partly muddy shores. For feeding purposes they carry no knife, like the Oyster-catcher, but liave an arrangement no less effective for their purpose - a wedge-shaped lill. Jlow they use this 1 had would go. I'renently he tackled a shingle, and had a hard time to holge it. He tried it on all sides, and then again, until at last he lifted and threw it over. His efforts seemed to be well rewarded, for he fed there some little time, as though many shigs and worms had taken refuge beneath it. It is in seateh of such prey that the turner of stones operates, a cog in the whecl of the system of nature. which decrees that every presible cornet and crevice of the great system shall have its guardian, even the tiny spot of ground beneath the pelble on the beach.

HERIERT K. Job.

The Turnstone's diet is not confined to the animal food mentioned, but includes grasshoppers of species which often menace serinusly various crops. Its service in kecping down these pests is 
undoubtedly very valuable, and for this reason alone the bird deserves careful protection at all times.

The Black, or Black-licaded, Turnstone (Arenaria molanocephata) averages a trifle smaller than the Ruddy Turnstone. In its summer plumage the crown and upper back are black with a greenish-bronzy gloss: the rest of the head, neck, throat, and chest are black, the forehead and sides of the head spotted with white, and a white spot in front of the eye; the rest of the under part of the body is white. lin the winter, the head, neck, and chest are sooty-black without spots. The nesting and other habits of this Turnstone duplicate those of the Ruddy Turnstone. It occurs on the Pacific coast of North America, breeding from Kotzebue Sound south to the valley of the lower Yukon, and wintering from British Columbia south to Lower California. Sometimes it wanders north to I'oint Barrow, Maska, and over to northeastern Siberia.

\title{
OYSTER-CATCHERS
}

\section{Order Limicola; family Hamatopodida}

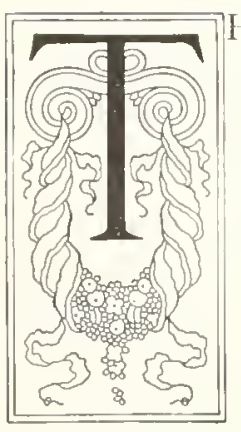

HE Oyster-catchers (Hamatopodida) inchude ten species, and are virtually cosmopolitan in their distribution. Three species occur in North America, and all are essentially maritime birds. They are found (excepting by accident.) only along the ocean fronts, where they get the principal parts of their diet, oysters, clans, mussels, and various shell-fish, whose shells they force apart with their strong, wedge-shaped bills. They also feed on marine worms and insects.

These birds have very stout legs and strong feet from which the hind toe is lacking. The plumage is chiefly black on the upper parts and white underneath. The bill of the living bird is bright red. On the ground Oystercatchers walk with a deliberate and dignified stride, or run with ease and considerable speed. Their flight also is swift and graceful, though when flushed when they are feeding they are not likely to fly far. They build no nest but lay in a slight depression in the sand usually three eggs, which are buffy white, blotched and speckled with dark hrown. Various observers have declared that incubation is performed entirely by the female, but that she covers the eggs only at night or on cloudy days and at other times leaves her work to the sum and the hot sands.

\section{OYSTER-CATCHER}

Hæmatopus palliatus Temminck

\author{
1. 01 . X゙umber 28 in
}

Other Names.-American Oyster-catcher: Nantled Oyster-catcher: Brown-backed Oyster-catcher: Sea Crow.

General Description.- Length. zi inches. Hearl black, hack brown, and under parts white.

Color. Futire hode and neck all around, ylossy bluish-black, frequently with a glaucous shade; back, shoulders, rump, and upper tail-coverts, dusky-brocn. the side and central coverts white: tail, aihite at base, then brownish shading to blackish at ends; inner secondaries, dusky-brown, outer ones, pure white; greater coverts, broadly tipped with white forming a conspicuous area in combination with the white of seconda- ries; primaries, lusky-blackish at ends; entire monder parts from the breast, pure white; bill, vermilion or coral-red, yellowish at end: legs, pale purplish flesh color: iris and eye-ring, red or orange.

Nest and Eggs.--NEst: A slight depression on sancly beaches. Elics: 2 or 3, white or cream, spotted and blotched with dark brown, black, or lavender.

Distribution,- Coasts of North and South America from Texas, Louisiana, and Virginia (formerly New Jersey), sunth on both coasts of Mexico to the West Indies, southern Brazil, and central Chile: casual north to New Brunswick: breeds probably throughout its range. 
Shonld we seeti ont the !oneliest of the harren beaches or bars of grlistering sand which are so characteristic of the coasts of the southern States, here and there at considerable intervals we are likely to meet scattered pairs of a rather large slume bird, very conspicuous from its black and white plumage. With high-power binoculars we can see their large hright-red bills. though they are so very sly that we coulu hardly distinguish this last feature without sucli aid. They are Oyster-catchers, lirds which literally carry about with them each its oyster-knife, in order to be able to feed upon the oysters, mussels. clams, or other shell-fish which they encomnter. Locally they are sometimes called "Sea-Crows" by the fishermen, which is not an inapt descriptive title, though their notes, which are charion flute-like calls, are certainly more melodious than crow-talk.

Though they are often seen upon the more retired beaches of the mainkand, the real type location is the little "sea island," of very small and low degree, which at high tide is a mere little strip of white sand, with areas of shell cast ap by the sea. This is where, the year around, we may find the curious birds and from April to June their nests. Really it seems almost like pleasantry to imply that they ever have a real nest. To provide such homes for its eggs, all the bird needs to do is to squat on the sand, turn around a few times, and there will be found as gond a halitation as it ever cares to nccupy. In more ways than one is this home insecure, for it recouires lout a sudeden leary syuall or storm to maise the water level and drive the waves over the low bar. The water may be over it lut a short time, yet the mischef is done. This and other birds of the sea never alpear to claim their eggs

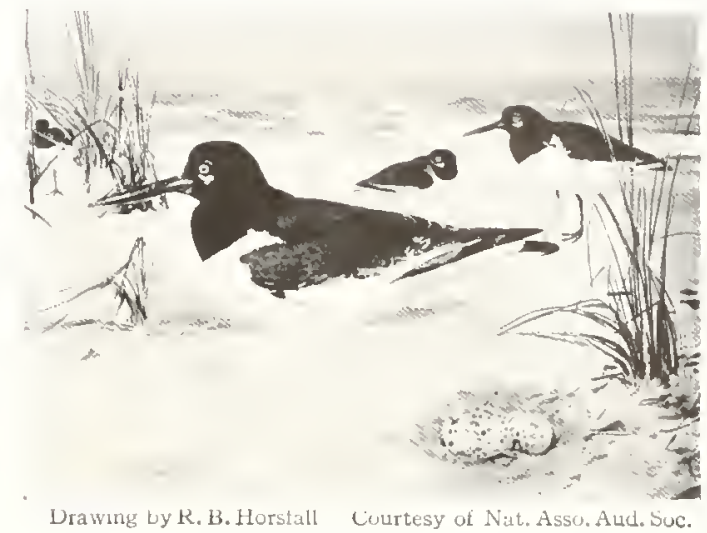

OYSTER-CATCHERS AT HOME

or to make any effort to save them after they have once been floated off even for a short distance.

Possibly the prodigal prarents may not think the eggs worth saving, so small is their number. Two eggs is the clutch I have always found, though sometimes they are said to have three. Where

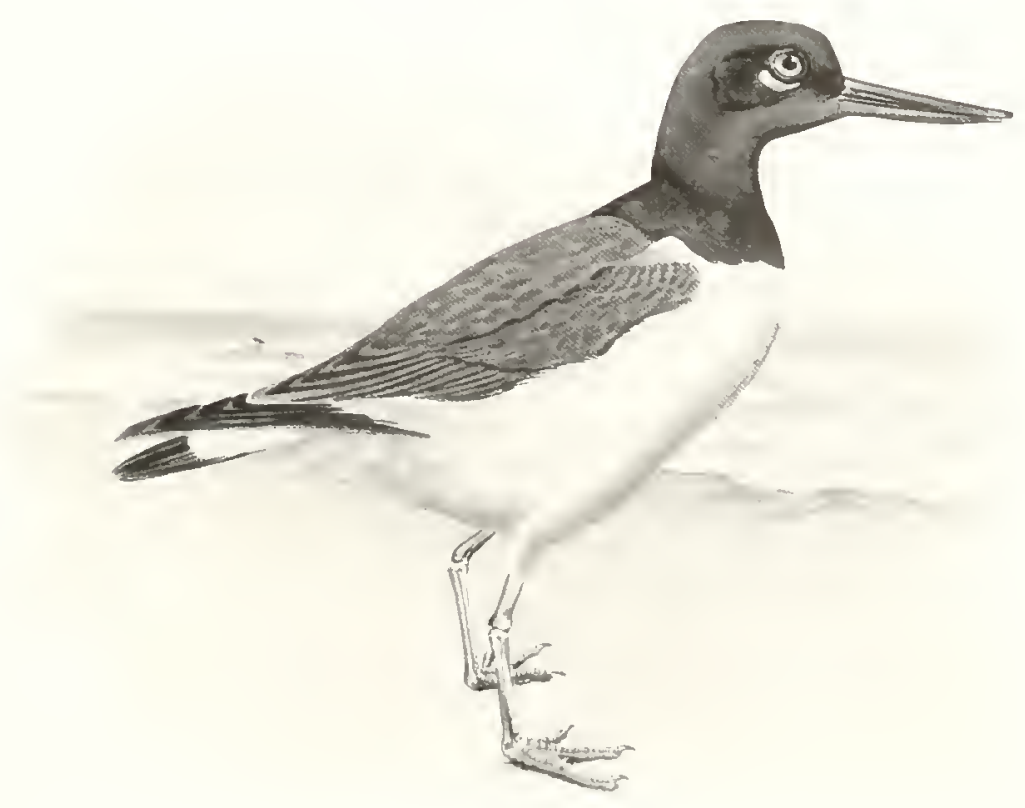


the ()yster-catchers are seen flying on ahead as one advances, and then returning in a circuit, it is likely that there are eggs or young not far off. The eggs are hard to find, though they lie right ont in the open, on the highest and driest part of

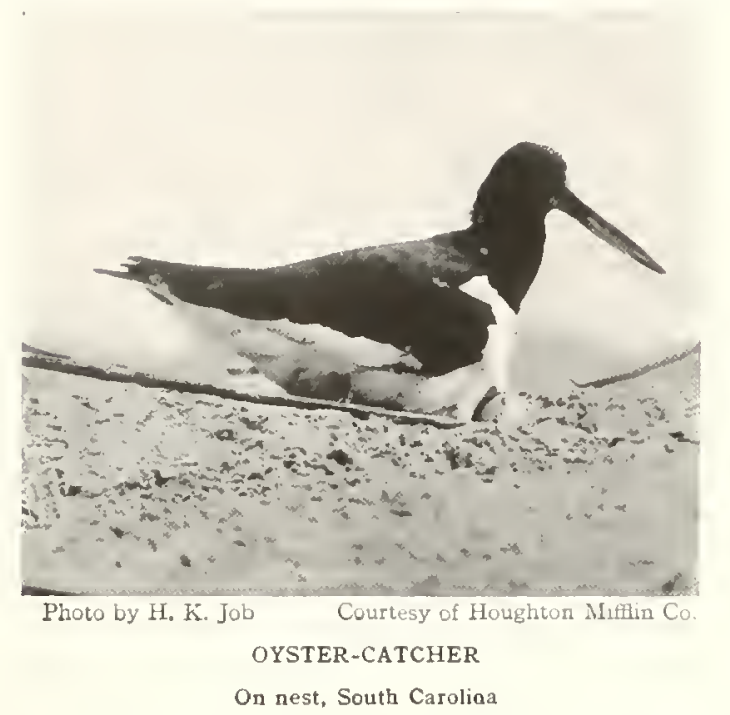

the bar, often among shells and bunches of drifted sea-weed, with which they aptly blend. The young are even harder to discover, unless they are seen to run. I have searched a bar, as it were, with a fine-tooth comb hefore detecting the little creatures - exactly the color of the sand - lying outstretched by some weed or bit of débris.

One very absorbing experience which I have had was in photographing an Oyster-catcher at her nest. The open sand-flat afforded no possible concealment. At night I placed a bunch of seaweed near the two eggs. In the morning I set the camera under this, and, attaching a spool of strong thread to the shutter, had my friends bury me in the sand, at the thread's end, all but head and arm. When the rest of the party left the island, the birds walked right past me, gazing without fear at the apparently disconnected head cast up by the waves. Soon the female was shielding her eggs from the blazing Carolina sun. Then excitedly I pulled the thread and the picture was mine! Herbert K. Јob.

The Black, or Bachman's, Oyster-catcher (Hamatopus bachmani) is peculiar to the Pacific coast of North America, breeding from Prince Villiam Sound, Alaska, west through the Aleutian Islands and south to central Lower California, and wintering from southern British Columbia to Lower California. It averages about two inches shorter than its eastern congener. Its head and neck are dull bluish-black, and the rest of its plunnage brownish-black. In habits it, also, is strictly a slore-bird.

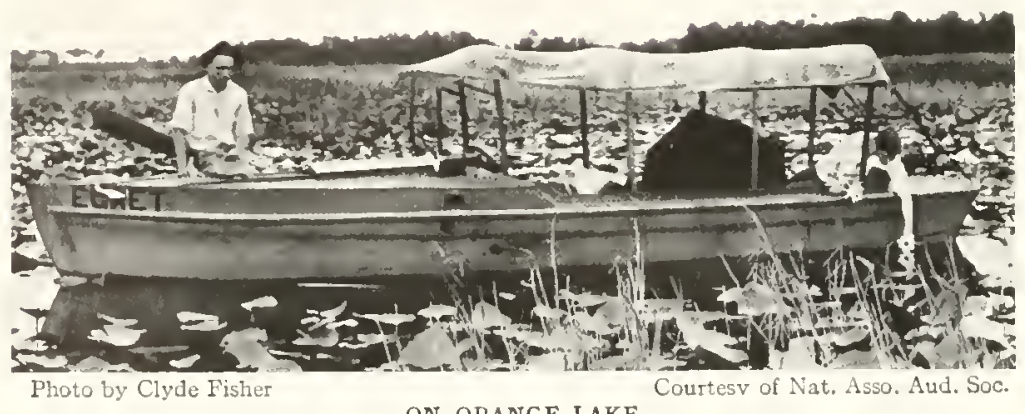

ON ORANGE LAKE

The Island, here shown, was purchased by the National Association of Audubon Societies for a bird reservation 





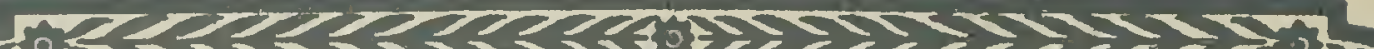

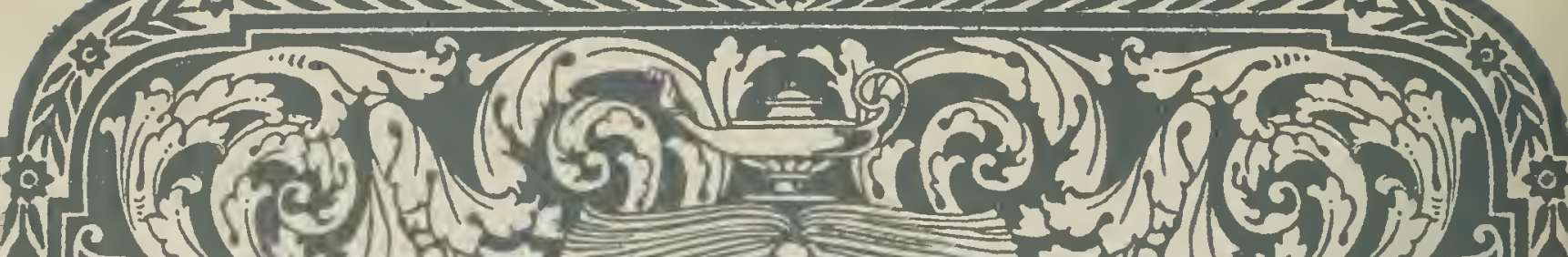
$\sqrt{\sqrt{3}(5)}$ مि:

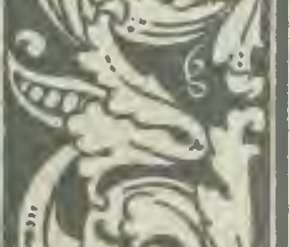

$(12)$

$(3)$

,

al $>$ ineo

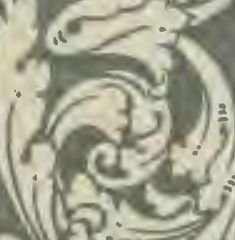

a $1 \mathrm{C}=$

toge - is

$\therefore$ हा.

(1) 59 )

$u^{2}-21$

(5) R.

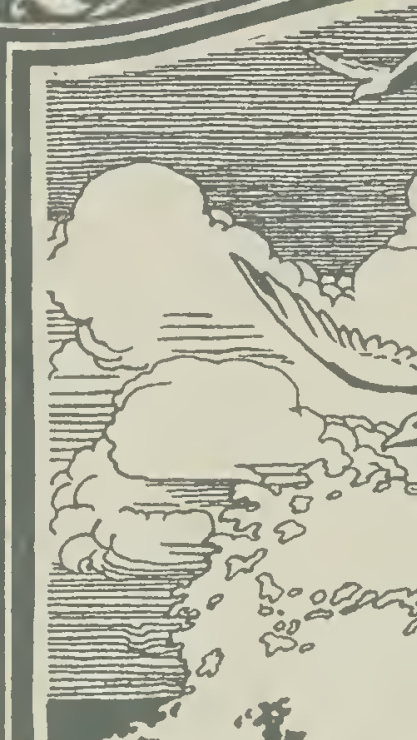




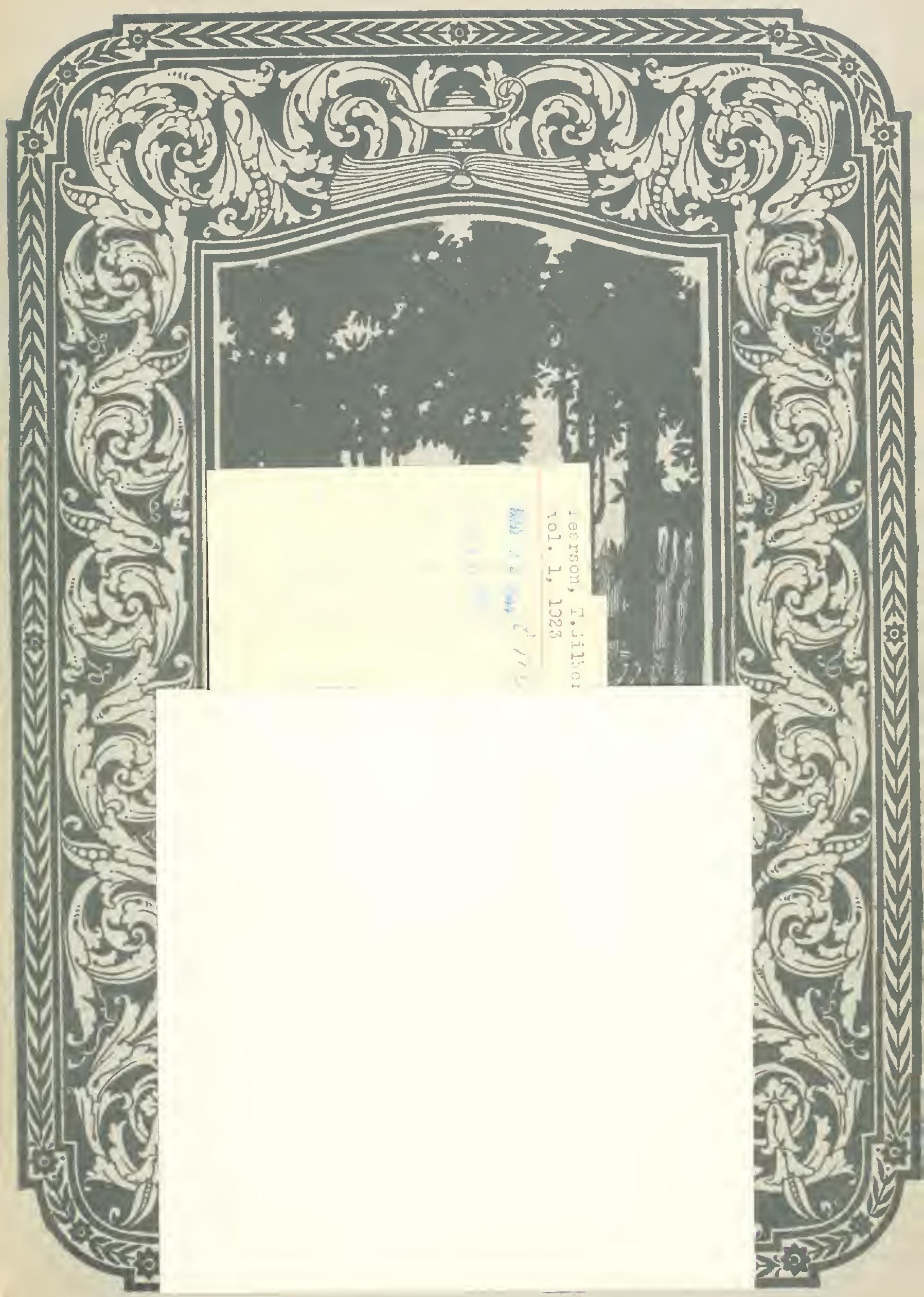


